UNIVERSIDADE DE SÃo PAULO

Faculdade de FILOSOFIA, Letras E CIÊNCIAS HUMANAS

Departamento de LeTRAS ClÁsSiCAS E VERNÁCULAS

\title{
NAS REDES DOS TELEJORNAIS: O TECIDO DISCURSIVO E A FORMAÇÃO DE MEMÓRIA SOCIAL
}

VALÉRIA PAZ DE ALMEIDA

Tese apresentada ao Programa de Pós-Graduação em Filologia e Língua Portuguesa, do Departamento de Letras Clássicas e Vernáculas da Faculdade de Filosofia, Letras e Ciências Humanas da Universidade de São Paulo, para obtenção do título de Doutor em Língua Portuguesa.

Orientadora: Profa. Dra. Lineide do Lago Salvador Mosca

SÃo PAULO 2006 
À minha filha Serena, para que se lembre de olhar o mundo com seus próprios olhos.

Ao Márcio, pelo passado, pelo presente e pelo futuro.

À memória de milhares de vítimas invisíveis para a mídia. 


\section{AgRADECIMENTOS}

Ao Márcio e à Serena, pelo apoio, pelo amor e pela infinita paciência.

À professora Lineide, pela confiança e pela longa acolhida.

À família e a todos os amigos, pelo carinho e pelo incentivo.

Ao Maurício Maia, pelo exemplo, pela interlocução generosa e pela leitura crítica.

À Cristina Piasentini e ao Jorge Zappia, pela imensa compreensão.

Ao Marco Aurélio Mello, pela ajuda na obtenção do material telejornalístico.

A todos os meus mestres, de um passado próximo ou distante, pela partilha do saber. 
A memória, na qual cresce a história, que por sua vez a alimenta, procura salvar o passado para servir ao presente e ao futuro. Devemos trabalhar de forma que a memória coletiva sirva para a libertação e não para a servidão dos homens. (Jacques Le Goff) 


\section{Resumo}

O objetivo desta tese é mostrar como o discurso dos telejornais pode construir determinada memória social de um acontecimento, pelo entrelaçamento de vozes, imagens e designações. Para isso, partimos da análise de elementos lingüísticos, argumentativos e enunciativos desse tipo de discurso, que tem papel fundamental na mediação dos demais discursos sociais. Procuramos mostrar como os telejornais articulam as várias vozes tornadas públicas no espaço da mídia e organizam as estratégias de referenciação dos fatos num processo de construção de um mundo textual homogêneo, que se tornará material simbólico a ser captado pela memória social.

Como se trata de um discurso verbo-visual, investigamos também a confluência de elementos lingüísticos e imagéticos na trama discursiva, que a nosso ver aumenta o poder de penetração na memória social pela via da memória eletrônica da televisão, que controla lembranças e esquecimentos por meio da seleção e da edição de acontecimentos, fixando-lhes determinados sentidos e construindo modos de recordação.

Empreendemos o exame do discurso de telejornais mediante um estudo de caso, o episódio dos ataques aos Estados Unidos em 11 de setembro de 2001, tendo como base teorias da argumentação, conceitos da análise do discurso, como o de polifonia, estudos sobre os processos de referenciação, concepções a respeito da imagem e teorias da memória social.

O corpus da tese é constituído pelas edições de 11 de setembro de 2001, 2002, 2003 e 2004 do Jornal Nacional e do Jornal da Record, o que possibilitou analisar a cobertura televisiva sob uma dupla perspectiva: uma dimensão sincrônica e sua extensão diacrônica. Assim pudemos avaliar as estratégias de manipulação cognitiva e afetiva pelas quais se construiu uma versão paradigmática dos fatos, com pouca reflexão sobre seu contexto ou suas implicações históricas, o que por si só pode ter resultado em significativos efeitos sobre a memória social dos eventos.

A análise resultou também na observação de muitos pontos de contato entre os dois telejornais, sobretudo no que se refere aos padrões de mediação da realidade e de distribuição dos conteúdos simbólicos, marcas inequívocas da poderosa máquina televisiva, que reinventa a esfera pública ao controlar o intercâmbio de signos e ideologias e posicionar-se como testemunha de um presente perpétuo.

Palavras-chave: discurso telejornalístico, memória social, imagem, polifonia, referenciação. 


\section{ABSTRACT}

The objective of this dissertation is to show how the discourse of television news programs may build a certain social memory of an event due to the interminglement of voices, images and designations. To this end, we based ourselves on the analysis of the linguistic, argumentative and enunciative elements of this type of discourse, which has a critical role in the mediation of other social discourses. We tried to show how television news programs articulate the many voices that are made public in the media space and organize the strategies of fact referentiation in a process of construction of a homogenous contextual world, which will become symbolic material to be captured by social memory.

As this is a verbal and visual discourse, we also investigated the confluence of linguistic and imagery elements in the contrived discourse, which, in our opinion, increases the power of penetration into social memory by way of television's electronic memory, which controls memories and forgetfulnesses by means of the selection and edition of events, giving them certain meanings and building ways to remember.

We undertook the examination of the discourse of television news programs by way of a case study, the episode of the attacks on the United States on September 11, 2001, based on argumentation theories, discourse analysis concepts, such as polyphony, studies on the referentiation processes, conceptions of image, and social memory theories.

The corpus of this dissertation is made up of the editions of September 11, 2001, 2002, 2003 and 2004 of the Jornal Nacional and Jornal da Record, which allowed us to analyze the television coverage under two perspectives: a synchronic dimension and its diachronic extension. Therefore, we could evaluate the strategies of cognitive and affective manipulation by way of which a paradigmatic version of the facts was built, with little reflection about their context or historical implications, which, alone, may have had a significant effect on the social memory of the events.

The analysis also resulted in the observation of many points of contact between the two television news programs, particularly with respect to the standards of mediation of reality and distribution of the symbolic contents, unmistakable hallmarks of the powerful television media, which reinvents the public sphere by controlling the exchange of signals and ideologies and standing as a witness of a perpetual present.

Key words: television news discourse, social memory, image, polyphony, referentiation. 


\section{SUMÁRIO}

\section{INTRODUÇÃO}

ESCOLHENDO OS FIOS

\section{CAPÍtULO 1}

NAS REDES DA MÍDIA - O TECIDO MUSCULAR

\section{Primeira parte - O fenômeno midiático}

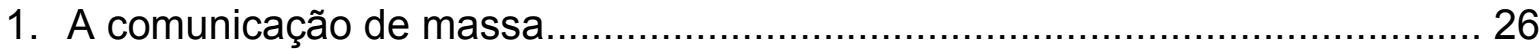

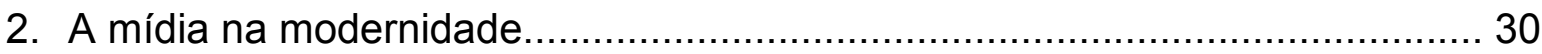

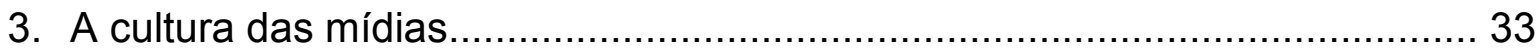

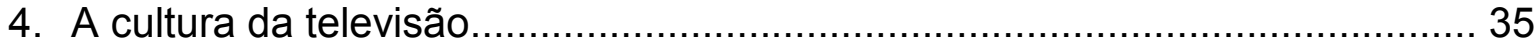

\section{Segunda parte - Televisão e jornalismo}

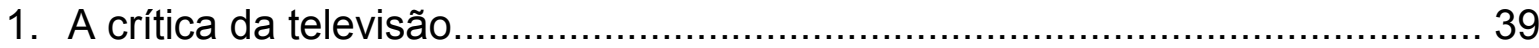

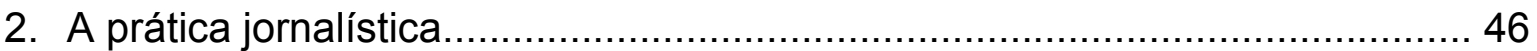

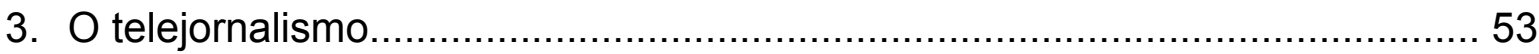

4. A palavra e a imagem no telejornal......................................................... 58

\section{Capítulo 2}

NAS REDES DA TEORIA - O TECIDO CONJUNTIVO

\section{Primeira parte - Teorias do discurso}

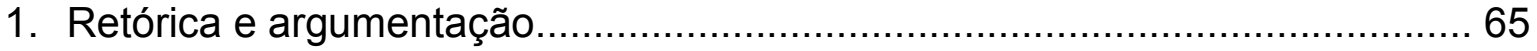

Argumentação ou manipulação? ........................................................... 73

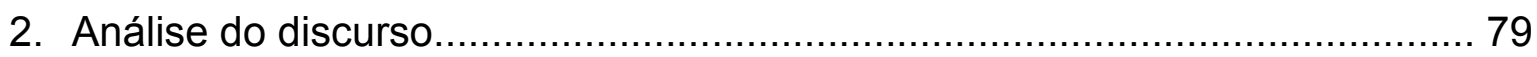

Heterogeneidade mostrada: o discurso do outro........................................ 84

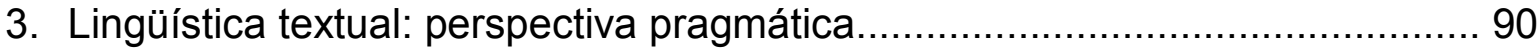

4. Teoria social do discurso: um ponto de conjunção......................................... 99 


\section{Segunda parte - Noções complementares}

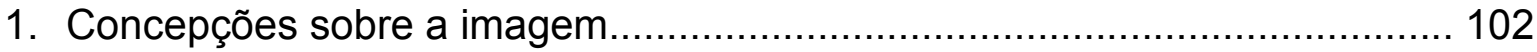

2. O discurso da informação e a encenação visual........................................ 108

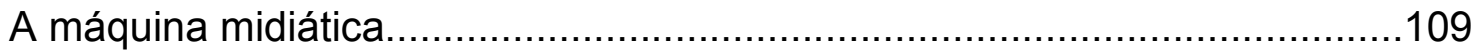

Uma enunciação fílmica......................................................................... 116

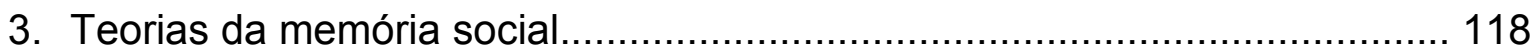

Discurso, mídia e memória social......................................................... 125

\section{Capítulo 3}

DES(A)FIANDO AS REDES - O TECIDO ÓSSEO

\section{Primeira parte - 0 contexto}

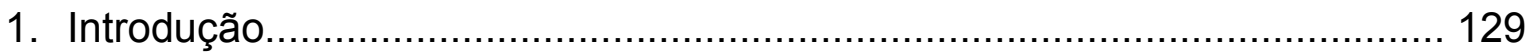

2. Considerações sobre 011 de setembro................................................. 133

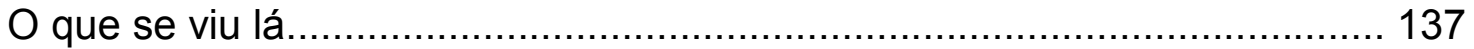

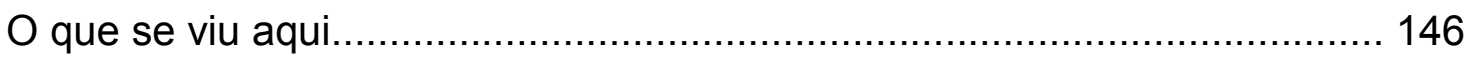

\section{Segunda parte - 0 objeto}

1. O 11 de setembro no Jornal Nacional....................................................... 158

2. 011 de setembro no Jornal da Record...................................................... 214

3. Os aniversários do 11 de setembro: 2002, 2003 e 2004 ........................... 259

\section{CONSIDERAÇÕES FINAIS}

\section{ENTRELAÇANDO AS REDES}

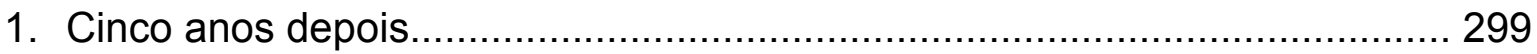

2. Discurso telejornalístico e memória social................................................. 303

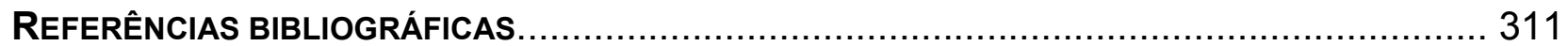

ANEXOS 


\section{NAS REDES DOS TELEJORNAIS: O TECIDO DISCURSIVO E A FORMAÇÃO DE MEMÓRIA SOCIAL}

O mundo que nos é trazido pelos relatos, que assim conhecemos e a partir do qual refletimos, é um mundo que nos chega editado, ou seja, ele é redesenhado

num trajeto que passa por centenas, às vezes milhares de mediações, até que se manifeste no rádio, na televisão, no jornal. (Maria Aparecida Baccega)

\section{INTRODUÇÃO}

\section{ESCOLHENDO OS FIOS}

O objetivo geral de nossa tese é mostrar como a mídia, especificamente o discurso dos telejornais, é potencialmente capaz - pelo entrelaçamento de vozes, imagens e designações - de criar determinada memória social. Para examinar o problema, é preciso retomar algumas das principais reflexões sobre a expansão da esfera pública e críticas à grande influência dos meios de comunicação de massa, estabelecendo o contexto que acolherá as hipóteses que apresentaremos a seguir.

Um dos pontos a considerar é que, apesar de haver concomitância entre a civilização do jornal e a civilização democrática oriunda das revoluções burguesas, há também o incontestável fato de que, nas últimas décadas, a indústria da comunicação e da cultura tem sido assumida como um sistema de condicionamentos, diante do qual o homem deve reformular seu comportamento e rever sua própria imagem (cf. Eco, 1998:14).

Habermas já vislumbrava esse cenário, ao falar da imprensa como a principal instituição na reestruturação da esfera pública: "Em comparação com a imprensa da era liberal, os meios de comunicação de massa alcançaram, por um lado, uma extensão e uma eficácia incomparavelmente superiores e, com isso, a própria esfera pública se expandiu. Por outro lado, também foram cada vez mais desalojados dessa esfera e reinseridos na esfera, outrora privada, do intercâmbio de mercadorias; quanto maior se tornou a sua eficácia jornalístico-publicitária, tanto mais vulneráveis se tornaram à 
pressão de determinados interesses privados, seja individuais, seja coletivos. Enquanto antigamente a imprensa só podia intermediar e reforçar o raciocínio das pessoas privadas reunidas em um público, este passa agora, pelo contrário, a ser cunhado primeiro através dos meios de comunicação de massa" (1984:221).

Da mesma forma, grande parte das teorias sobre ideologia - como a de Althusser (1974), que designava os meios de informação como aparelhos ideológicos de Estado, assim como o são os aparelhos religioso, escolar, jurídico, político, familiar, sindical e cultural - assinala como característica mais marcante da cultura de massa a oferta de produtos homogêneos para um público heterogêneo, que pode redundar em efeitos mais negativos do que positivos. Independentemente disso, com o advento da globalização, ainda que tenha aumentado a vulnerabilidade da mídia à pressão de interesses sobretudo econômicos, muitos teóricos propõem que se repense tanto o conceito de "esfera pública" quanto o de "comunicação de massa".

Num mundo em que toda informação é mediada, o que é de caráter público passa a ser ressignificado: "o uso dos meios de comunicação implica a criação de novas formas de ação e de interação no mundo social, novos tipos de relações sociais e novas maneiras de relacionamento do indivíduo com os outros e consigo mesmo" (Thompson, 1998:13), e também novas formas de poder. É preciso observar que, na sociedade contemporânea, ocorrem profundas mudanças nos sistemas de comunicação e que vivemos uma "crise de identificação de macrossujeitos" (Mattelart, 2004:167), da qual a mídia emerge como um novo e poderoso macrossujeito. Portanto é inconcebível falar de processos sócio-históricos sem considerar o fenômeno da comunicação mediada.

$\mathrm{Na}$ década de 70 , ficou célebre a dicotomia que caracterizava o grupo dos que se dedicavam à crítica dos mass media, cujos membros foram assim nomeados por Umberto Eco: de um lado, os integrados, que defendiam a cultura de massa; de outro, os apocalípticos, que denunciavam os malefícios do sistema. Entre as "peças de acusação" que sustentavam a tese dos apocalípticos contra os meios de comunicação de massa, destacamos as seguintes, que serão de certa forma consideradas ao longo deste estudo: "em vez de simbolizarem uma emoção, de representá-la, provocam-na; em vez de a sugerirem, entregam-na já confeccionada; encorajam uma imensa informação sobre o presente e assim entorpecem toda consciência histórica; trabalham sobre opiniões 
comuns, sobre endoxa, e assim funcionam como uma contínua reafirmação do que já pensamos" (Eco, 1998:40).

Eco afirmava que o erro dos integrados era afirmar que a indústria da cultura de massa fosse boa em si mesma e não devesse submeter-se a novas orientações, enquanto o erro dos apocalípticos era pensar que ela fosse radicalmente má e que ainda pudesse existir alguma cultura que não se condicionasse a esse inevitável fenômeno (1998:49). Hoje, assim como se propugna a revisão de outros conceitos, cabe rever o infrutífero embate entre "apocalípticos e integrados". De acordo com Martín-Barbero (1997), já em meados dos anos 70 as teorias da comunicação pararam com as denúncias ideológicas e passaram a se preocupar mais com a ciência. Percebeu-se que era preciso cessar a dispersão disciplinar e metodológica para ordenar o campo da comunicação e delimitar os objetos, do que surgiram as novas teorias críticas que hoje conhecemos e das quais falaremos no primeiro capítulo desta tese.

Independentemente de tantos esforços, as implicações, influências e efeitos dos meios de comunicação ainda não foram completamente compreendidos, como salientam DeFleur e Ball-Rokeach, para quem ainda estão longe do fim as controvérsias entre acusadores e defensores dos veículos de comunicação de massa, embora atenuadas por uma nova percepção do fenômeno: "A idéia mais antiga de serem os veículos forças formando e plasmando a sociedade conforme desejam é simplista e ultrapassada. A mídia é formada pelos acontecimentos da sociedade como um todo e é profundamente influenciada pelo processo dialético de conflito entre forças, idéias e acontecimentos opostos no âmbito do sistema da mídia, e entre os veículos e outras instituições da sociedade" (1993:139). De qualquer forma, esses autores chamam a atenção para a necessidade de se compreender como se dão tanto a persuasão premeditada quanto as influências involuntárias dos meios de comunicação.

Há pelo menos duas décadas vêm sendo discutidos temas ligados ao desafio de construir um cenário das relações entre comunicação, cultura e ideologia que comporte também as questões do imaginário social e da subjetividade. Boa parte das discussões gira em torno de um dos mais poderosos meios de comunicação da atualidade: a televisão. Muitos estudiosos têm tentado entender as bases de tantos julgamentos 
negativos em relação ao veículo e, principalmente, comprovar se os efeitos sobre o espectador são mesmo de acomodação, alienação ou redução do senso crítico.

Nossa preocupação recai sobre os efeitos que parecem corresponder à função geral da ideologia como mediadora na integração social. Segundo Ricoeur (1977), toda ideologia é simplificadora, esquemática e caracterizada pela resistência às modificações, motivo pelo qual reduz as possibilidades de interpretação dos acontecimentos. Nesse sentido, vale registrar a análise que a professora Maria Rita Kehl (1994:170) faz da cobertura televisiva de fatos recentes da história e sua relação com a produção de material simbólico, que necessariamente passa por processos ideológicos que limitam a compreensão das informações:

Nos anos 70, o impacto das imagens da Guerra do Vietnã, chegando ao vivo aos lares americanos, foi tão mobilizador que contribuiu para pôr fim à guerra. Já na Guerra do Golfo, nós assistimos a uma transformação das imagens da guerra em espetáculo, uma transformação da realidade em ficção e a produção, no público, de certa aceitação fascinada da destruição. 0 público norte-americano assistiu à Guerra do Golfo como se fosse uma partida de videogame, uma luta do bem contra o mal, em que a morte concreta foi substituída pelo espetáculo pirotécnico da destruição de um outro desumanizado, fictício. As mesmas informações que, num momento inaugural da história das transmissões internacionais de imagens pela TV, criaram um efeito de mobilização das consciências, num segundo momento produziram um efeito de alienação. Mas, é claro, não são as mesmas informações. A linguagem televisiva se sofisticou, as imagens se estetizaram. O fato concreto da morte e da destruição é sempre o mesmo, mas a versão é outra, o tratamento das imagens é outro e, portanto, o fato simbólico é outro também.

Veja-se também como, anos mais tardes, se deu a cobertura do ataque terrorista aos Estados Unidos em 11 setembro de 2001: as televisões de quase todo o mundo, inclusive a brasileira, criaram um clima de comoção geral, como se só nesse caso as vítimas merecessem compaixão e tamanha atenção da mídia. Esse episódio e o da Guerra do Golfo têm em comum o fato de terem sido noticiados, a nosso ver, de forma distorcida por uma televisão potencialmente capaz de orientar o público para sentir certas emoções e manipulá-lo para ver a realidade de uma forma paradigmática, sem refletir 
sobre o contexto e as implicações históricas ou de outra natureza. Apagou-se uma das faces do interdiscurso e criou-se certa memória daqueles fatos.

O episódio do ataque ao World Trade Center virou fato histórico, virou substantivo. Dizia-se que depois disso o mundo não seria mais o mesmo. Algumas coisas mudaram; outras, nem tanto. Algum tempo depois se ouvia que estava "fora de moda" falar no 11 de setembro, o que se desmentiu pela grande quantidade de estudos que foram e ainda são desenvolvidos sobre o tema. Muitos tentam entender as causas do evento, suas conseqüências na ordem mundial e o papel da mídia na inscrição desse fato na história.

Cumpre observar, no entanto, que a maioria dos estudos sobre meios de comunicação e suas implicações ideológicas ou comportamentais tem se desenvolvido, de forma independente, em áreas das ciências sociais e das ciências humanas, como antropologia, sociologia e psicologia, e em áreas ligadas à comunicação. Propomos, neste trabalho, um esforço interdisciplinar para chegar a bom termo na compreensão dos discursos que tecem o fenômeno da comunicação nas sociedades modernas.

As ciências da linguagem têm contribuído para avançar nessa direção, principalmente no que se refere aos estudos da análise do discurso em suas mais diferentes manifestações. Muitos são os pesquisadores que se dedicam a tentar entender, pelo estudo dos componentes lingüísticos e pragmáticos, as formas de construção do discurso midiático, e na maioria das vezes o fazem com base na análise de textos da imprensa escrita. Conseqüentemente, acabam por empreender também o exame das relações de poder e persuasão que há entre mídia e público, aspecto essencial para configurar o papel da comunicação no mundo contemporâneo, mas julgamos necessário estender o estudo desse tema tão abrangente e complexo aos discursos jornalísticos televisivos.

É muito importante que as novas gerações sejam preparadas para viver com maior lucidez a era da informação, o que se justifica pela afirmação de Melo: "Ao dominar efetivamente a gramática dos mass media, ao conhecer sua engrenagem produtiva e compreender sua inserção na sociedade, as novas gerações educadas pela escola se converteriam em leitores críticos desde o momento em que se incorporam, como usuários, ao mercado da indústria cultural" (1998:106). 
Maria Aparecida Baccega também aponta para os novos rumos da sociedade num mundo construído pela comunicação: "Se o mundo a que temos acesso é este, o editado, é nele, com ele e para ele que se impõe construir a cidadania. O desafio, então, é como trabalhar esse mundo editado, presente no cotidiano, que penetra ardilosamente em nossas decisões e que, pela persuasão que o caracteriza, assume o lugar de verdade única" (2001:22).

Martín-Barbero e Rey (2001) advertem para a premência de uma "segunda alfabetização" para ler esse novo mundo mediado, do qual emerge uma outra cultura. Segundo eles, há uma mudança nos protocolos e nos processos de leitura e um outro tipo de interação com o "ecossistema informacional e comunicativo", que exigem um novo olhar sobre o fenômeno da mediação.

Essas discussões nos fazem crer que, nesse cenário, se impõe seja investigado com muita atenção o discurso da televisão em suas múltiplas dimensões, dado o alcance desse veículo na sociedade contemporânea. Baccega define bem o atual papel dos meios de comunicação, que, segundo ela, se referenciam uns aos outros, num constante processo de mediação organizativa, "que leva em consideração seu público receptor, procurando selecionar o que há de mais conveniente tanto aos interesses da empresa a que pertence determinada mídia quanto ao perfil médio do público, levando ao senso comum, a uma repetição que procura travar o dinamismo da história" (2000:10).

À parte o questionamento sobre os diferentes interesses que movem a máquina de todas as mídias, em particular a televisiva - reflexão que passa pelo sério problema da democratização dos meios de comunicação, hoje nas mãos de pouquíssimos grupos, em sua maioria grupos privados -, é preciso, para fazer a crítica do discurso das mídias, desconstruir as linguagens que $o$ articulam.

Há, hoje em dia, um debate permanente sobre a atuação dos meios de comunicação, seja em seu próprio universo, por meio da figura do ombudsman nas mídias impressas ou de veículos destinados a criticar o papel da imprensa, seja em outras esferas públicas, em que se discute um código de ética para as televisões ou se investiga o impacto das novas tecnologias na formação da sociedade. Um dos principais protagonistas desse debate é o professor italiano Giovanni Sartori, que apresenta uma 
dimensão antropogenética do problema em relação à televisão: "o telever está a mudar a natureza do homem".

Segundo o autor, o vídeo está transformando o Homo sapiens, produto da cultura escrita, em Homo videns, o que implica a primazia da imagem, do visível sobre o inteligível, que leva a um ver sem compreender. Sartori também afirma: "É falso que a televisão se limita a refletir as mudanças em curso na sociedade e na sua cultura. $\mathrm{Na}$ verdade, a televisão reflete mudanças que em larga medida promove e inspira" (2000:63). Ele atribui esse movimento ao fato de que a televisão dá menos informação que quaisquer outros meios de comunicação, visto que seleciona primordialmente a informação "que melhor se pode filmar" (se não houver imagem, também não há notícia), além de muitas vezes produzir pseudo-acontecimentos (op.cit.:73).

Todas essas reflexões e o diálogo que delas possa resultar são indiscutivelmente pertinentes num momento em que a relação entre nós e a realidade, já mediada por todos os outros discursos que circulam na sociedade - o discurso da religião, o da escola, o da família, o do poder político -, é sobredeterminada pelo discurso dos meios de comunicação. É preciso que passemos a entender melhor como esses meios funcionam e agem sobre nós e sobre os demais discursos sociais. Mais do que tentar compreender como se engendram os mecanismos de manipulação da mídia - cujos efeitos mais conhecidos são emoções pré-fabricadas e pensamentos resumidos a fórmulas - e, com isso, apreender o alcance ideológico dos conteúdos, algo percebido desde há muito tempo, é premente investigar o conteúdo ideológico das formas, tarefa que vem sendo empreendida por muitos analistas do discurso.

Nesse sentido, "a aparente simplicidade das linguagens midiáticas - das imagens, das palavras e dos discursos colocados no ar - constitui o principal obstáculo a ser derrubado se se quer colocar em movimento um processo cognitivo, um processo de aprendizagem" desses códigos, diz Bechelloni (2000:64). Entendemos que esse autor define como "aparente" a simplicidade das linguagens midiáticas porque a pasteurização dessas linguagens, que se valem da repetição do senso comum por meio dos mais variados recursos, oculta sofisticados mecanismos discursivos de manipulação 
ideológica, intencional ou não, para cujo reconhecimento é preciso dotar a sociedade de eficazes instrumentos discursivos.

É preciso entender, acima de tudo, que a natureza dos veículos de comunicação é complexa e que não faz sentido dizer que eles retratam a realidade. O jornalista Eugênio Bucci observa com exatidão, especificamente sobre o discurso da informação na mídia: "A realidade não antecede o discurso. Os fatos jornalísticos não antecedem o discurso jornalístico. Ao contrário, ela mesma, realidade, é um discurso que se articula em signos lingüísticos, sobretudo em signos visuais. (...) Por isso, o que chamamos de realidade é sempre realidade discursiva"1. Isso significa que, independentemente da conduta da mídia no que se refere à informação, o fato já nasce como relato e só o relato dá ao fato o estatuto de realidade discursiva.

Dessa forma, só podemos pretender a observação da própria "máquina midiática", como a chama Charaudeau (2006), e a análise dos possíveis efeitos discursivos, embora saibamos que o discurso da mídia tem caráter intersubjetivo. Interessa-nos investigar o modo como o discurso ideológico da mídia organiza-se num sistema lógico e coerente de representações, a mediar o olhar das sociedades contemporâneas e a contribuir para a formação de determinada memória social.

Evidentemente não vamos empreender uma análise sociológica do fato de que tal discurso manipula o real na medida em que, intencionalmente ou não, omite, falseia, atenua ou seleciona ideologicamente elementos da realidade, retratando de forma enviesada uma visão de mundo. Objetivamos a análise e a compreensão desse fato no que tange à construção eminentemente discursiva de manifestações midiáticas, levando em conta elementos enunciativos, lingüísticos e argumentativos de seu engendramento. Dada a dimensão do papel da televisão na formação social e cultural do homem contemporâneo, elegemos o discurso da mídia televisiva, especificamente o discurso dos telejornais, como objeto de nossa pesquisa, a fim de verificar como se constrói a linguagem peculiar desse gênero².

\footnotetext{
${ }^{1}$ Prefácio do livro Poder no jornalismo, de Mayra Rodrigues Gomes (2003:11).

${ }^{2}$ Conforme Fairclough, hoje os estudiosos das várias áreas "começam a reconhecer os modos como as mudanças no uso lingüístico estão ligadas a processos sociais e culturais mais amplos e, conseqüentemente, a considerar a importância do uso da análise lingüística como um método para estudar
} 
Nossa hipótese é a de que a linguagem usada nos telejornais (a rigor, uma multilinguagem) tem características que a instituem como poderoso instrumento de construção e controle da memória social. Parece-nos que esse discurso, erigido sobre uma confluência de vozes, constitui-se fundamentalmente como monológico, a perpetuar ou apagar certas formações discursivas, certas imagens e os fatos simbólicos que representam. O discurso midiático televisivo faz crer numa aparente pluralidade, sob a qual haveria, segundo nossa hipótese, uma estrutura que orienta para determinada memória discursiva e social.

Sobre a mídia impressa, Beth Brait questiona se a polifonia enunciativa nela observada revela "um democrático processo dialógico ou unicamente uma cacofonia polienunciativa" (1994:26). Da mesma forma, Pierre Bourdieu pondera: "tenho no espírito que os produtos jornalísticos são muito mais homogêneos do que se acredita" (1997:30). Entendemos que essas reflexões também dizem respeito aos telejornais, que veiculam de forma mediativa e interpretativa várias vozes tornadas públicas no espaço da mídia.

O professor Arlindo Machado assim define o telejornal de modelo polifônico: "O apresentador é mais um condutor, em geral impessoal, cuja função principal é ler as notícias (visivelmente escrita por outros) e abrir passagem para os outros protagonistas. (...) O apresentador chama o repórter, que por sua vez chama o entrevistado e assim vamos encaixando uma voz dentro da outra, como no recurso lingüístico das citações" (2000:108).

Porém, a despeito de afirmar que esse processo leva a uma desmontagem dos discursos acerca dos acontecimentos, Machado analisa - a nosso ver, de modo equivocado - que "o telejornal é uma colagem de depoimentos e fontes numa seqüência sintagmática, mas essa colagem jamais chega a construir um discurso suficientemente unitário, lógico ou organizado a ponto de poder ser considerado 'legível' como alguma coisa 'verdadeira' ou 'falsa"' (op.cit.:110). Além disso, o autor diz que "não existem, nos telejornais, desinências, sinalizadores, dispositivos de emolduramento que orientem a leitura no sentido de como se deve 'ler' esses depoimentos e essas inserções de fontes,

a mudança social" (2001:19). Essa intersecção de perspectivas será fundamental no desenvolvimento desta tese. 
ou capazes de designar a voz 'doadora', sob a batuta da qual deveríamos reenquadrar todas as outras" (op.cit.:112).

Segundo nossas hipóteses, o telejornal de modelo polifônico não apresenta uma colagem aleatória de vozes, tampouco está isento de sinais que orientem uma interpretação. A polifonia revela-se num espaço de negociação, portanto num espaço eminentemente argumentativo, em que se mostram as fronteiras pelas quais 0 enunciador se delimita na pluralidade de outras vozes. Segundo Authier-Revuz (1982), trata-se de um jogo em que o sujeito detém o controle do que mostra ou oculta da presença do outro, costurando fissuras sob a unidade aparente de um discurso. O sujeito ora diz "esse sou eu falando", ora diz "esse não sou eu".

Ora, parece-nos que os telejornais não escapam a essa constituição intrínseca a qualquer discurso citante. Ao mediar outros discursos e estabelecer a tessitura de diversas vozes, o telejornal cria uma nova cena enunciativa, torna-se um outro acontecimento discursivo, a refletir a realidade. Mas a mídia não é um espelho fiel, como afirma Charaudeau: "Se são um espelho, as mídias não são mais do que um espelho deformante, ou mais ainda, são vários espelhos deformantes ao mesmo tempo, daqueles que se encontram nos parques de diversões e que, mesmo deformando, mostram, cada um à sua maneira, um fragmento amplificado, simplificado, estereotipado do mundo" (2006:20).

A polifonia discursiva certamente faz parte desse conjunto de espelhos, portanto sua análise é um dos temas centrais de nossa tese, juntamente com o exame dos recursos de linguagem que promovem a reiteração de determinadas imagens visuais e verbais, a partir das quais se estabelecerão novas formações e memórias discursivas. Alguns desses recursos são os mecanismos de referenciação e designação, que incluem eufemismos e expressões metafóricas. Privilegiaremos não só as questões referentes à representação do mundo pela mídia, mas sobretudo a problemática da referenciação, que hoje se coloca entre as principais preocupações da lingüística textual e da pragmática.

Segundo muitos estudiosos, mudou-se da perspectiva que privilegiava a relação entre as palavras e o mundo para a perspectiva da relação intersubjetiva e social da linguagem. Disso decorreu a substituição do termo referência por referenciação, "visto que passam a ser objeto de análise as atividades de linguagem realizadas por sujeitos 
históricos e sociais em interação, sujeitos que constroem mundos textuais cujos objetos não espelham fielmente 0 mundo real, mas são, isto sim, interativamente $\mathrm{e}$ discursivamente constituídos em meio a práticas sociais, ou seja, são objetos de discurso" (Koch, 2005:8). Tentaremos demonstrar, portanto, como os procedimentos de referenciação ajudam a construir um mundo textual homogêneo no discurso da mídia televisiva, que forja um espaço de formação de consenso e de aparente debate.

Assim como defende José Arbex Jr. (2001), entendemos que a televisão cria memórias e amnésias. Se é assim, certamente o faz em razão do poder da imagem, mas não sem o reforço da palavra, que contribui, como na tradição oral, para a elaboração do fato simbólico. Como diz Sartori, "não é de todo verdade que a imagem fala por si só": "Énos mostrado um morto. Quem o matou? A imagem não o diz; di-lo a voz de quem tem o microfone na mão" (2000:91).

Presumimos que haja componentes no discurso verbo-visual dos telejornais que nos permitam desvelar o modo como se instaura lingüística e imageticamente o poder que a memória da mídia tem de penetrar na memória social. Dada a extensão do trabalho, não trataremos especificamente do fenômeno da recepção, mas procuraremos mostrar como o produto jornalístico aparece na tela, com características potencialmente capazes de construir determinadas memórias. Supomos haver um modo de tessitura enunciativa e discursiva que crie esse efeito e evidencie o controle da formação da memória social pelas produções culturais e sua subordinação à memória eletrônica.

Nosso interesse pelo tema da memória social encontra justificativa em muitos estudos sobre o discurso jornalístico, que "funciona em várias dimensões temporais simultaneamente: capta, transforma e divulga acontecimentos, opiniões e idéias da atualidade - ou seja, lê o presente - ao mesmo tempo em que organiza um futuro - as possíveis conseqüências desses fatos presentes - e assim legitima, enquanto passado memória -, a leitura desses mesmos fatos do presente, no futuro" (Mariani, 2001:33). Em outras palavras, aponta-se o discurso jornalístico como um agente fundamental no processo de seleção dos acontecimentos que serão recordados no futuro, fixando-lhes determinados sentidos e construindo modos de recordação do passado. Em se tratando de jornalismo televisivo, isso parece acentuar-se. 
Uma vez que a mídia faz circular conteúdos que mobilizam o imaginário de bilhões de pessoas, trata-se, como bem aponta Arbex, de discutir questões muito novas nesse campo, tornando-se impossível pesquisar os domínios da memória social sem falar dos fenômenos midiáticos: "Como a televisão e a imprensa escrita criam metáforas que 'explicam' o mundo, transformando-as em convicções individuais? Até que ponto a mídia tem o poder de sedimentar como 'a' realidade (isto é, como 'fatos que realmente aconteceram'), na memória coletiva, as 'suas' imagens dos eventos (isto é, as imagens por ela selecionadas e editadas)?" (2001:37).

As hipóteses deste trabalho contêm essas indagações e serão fundamentadas em teorias que apresentam conceitos como os de heterogeneidade mostrada, polifonia enunciativa, formações discursivas, interdiscurso, memória discursiva e memória social, os quais exporemos no segundo capítulo. Ao examinarmos esse conjunto de elementos, pretendemos apreender, com base na materialidade lingüística do discurso, como se dá a ação de um destinador extremamente complexo e de difícil identificação.

Decerto não propomos uma generalização, tampouco queremos olhar para nosso objeto de estudo de forma dogmática, no entanto é preciso deixar claro que nossa tese observa a relação contratual estabelecida entre o telejornal e o telespectador médio. $O$ acordo básico desse tipo de comunicação pressupõe que o telejornal mostra os fatos com veracidade. As pessoas crêem nisso e é com essa disposição que recorrem ao telejornal para obter informação. No entanto, como veremos, a televisão insiste em perseguir uma descrição única de fatos complexos e multifacetados e, não raro, oculta, distorce, dissimula outros aspectos do que noticia, da história que é capturada pelas câmeras.

Mas não é por dons mágicos que a mídia modela ideologicamente a memória do público. Há muitos fatores em jogo nesse processo de construção de memória social. A televisão fala para um auditório ideal, mas a recepção se dá com base no conjunto de crenças e valores de um auditório real. Os modelos intelectuais e morais de cada coenunciador do discurso dos telejornais agirão sobre a interação, porém os componentes afetivos sofrerão constantes coerções.

Segundo Landowski, é possível dizer, a respeito da opinião pública, que ela pode se enganar devido à sua própria incompetência interpretativa ou pode ser enganada por um fazer persuasivo. Nesse caso, a desqualificação da opinião pública como instância 
cognitiva pressuporia o domínio de seus estados afetivos por bombardeio psicológico ou por condicionamento - comovendo, chocando, perturbando a opinião pública (1992:39). Isso parece se aplicar também ao processo de formação da memória social. Se o público não recebe todas as informações que deveria receber para formar um julgamento sobre determinado fato, o que fica do discurso midiático é o apelo do sensível, é a reiteração do senso comum, formado por uma conjuntura social e cultural influenciada por modos de referenciação do mundo presentes nos meios de comunicação.

Com base nas teorias, conceitos e críticas que apresentaremos, visamos compor um quadro integrado de disciplinas que possam nos auxiliar a articular os problemas aludidos e a desfiar a rede de complexas relações em que eles se situam. A forma como serão colhidos e analisados os dados para a pesquisa proposta é um ponto crucial em se tratando de tema tão abrangente, que focaliza um sistema complexo de produção de informações. Para atingir o objetivo geral do estudo, será preciso examinar um amplo conjunto de elementos que possibilitam a construção dos jornais televisivos. Não é fácil traçar uma linha divisória entre análise de processo e análise de produto, então nossa investigação tentará conciliar específicas condições de produção do discurso telejornalístico e o resultado que se vê, enfim, na tela.

Dada a enorme massa de informações com a qual trabalharemos, não seria factível constituir um corpus com todos os telejornais das principais emissoras de sinal aberto do país. Selecionamos então apenas dois - o Jornal Nacional, da TV Globo, e o Jornal da Record -, conforme os seguintes critérios: a) grau de inserção nos diferentes meios sociais, medido por índices de audiência ${ }^{3}$; b) concorrência direta, em razão do horário de exibição; c) importância e credibilidade, atestadas pela história de cada jornal.

Naturalmente, para viabilizar a análise da organização geral desse tipo de discurso, era preciso selecionar um fato de grande repercussão, cuja cobertura durasse algum tempo. Pretendíamos analisar notícias mais recentes, tendo em vista a preservação da atualidade do trabalho, mas gravamos, em setembro de 2004, algumas edições dos dois telejornais e iniciamos um percurso que nos fez deparar com material

${ }^{3}$ O Jornal Nacional é líder de audiência e tem sido seguido, nos últimos anos, pelo Jornal da Record e pelo Jornal do SBT, ambos com média de 5 pontos em maio de 2004, período em que o Jornal Nacional registrou 44 pontos, segundo o lbope. 
riquíssimo, decisivo para a escolha do corpus da tese. Na ocasião, o recorte temporal se deu sobretudo em razão de haver duas datas importantes no período: o nosso 7 de setembro e o 11 de setembro dos norte-americanos, eventos que pressupõem a construção de uma memória coletiva.

No entanto, como já havíamos demonstrado interesse pela cobertura do episódio do 11 de setembro em alguns trabalhos, ocorreu-nos a possibilidade de analisar o discurso da mídia televisiva no dia dos ataques ao World Trade Center e ao Pentágono e nos anos subseqüentes, na mesma data, a fim de entender melhor a construção da memória do fato. Já tínhamos gravadas as edições de 11 setembro de 2004, tanto do Jornal Nacional quanto do Jornal da Record, e empenhamo-nos em conseguir as edições de 11 de setembro de 2001, 2002 e 2003. Não havia como desprezar material tão significativo, tendo em vista sobretudo a dificuldade de acesso aos arquivos de televisão pelo público. Entendemos então que essa seria uma oportunidade de mostrar, com certo distanciamento temporal, as estratégias discursivas dos telejornais.

Dessa forma, mediante a análise comparativa desses dois telejornais brasileiros cujas edições foram transcritas e descritas segundo o recorte do corpus -, no que tange aos processos de referenciação e polifonia capazes de produzir memória, tentaremos identificar se há realmente homogeneização do discurso e de que forma ela se instaura, o que nos permitirá estudar os vínculos entre discurso midiático e formação de memória social em dois planos temporais: no calor do acontecimento e numa extensão diacrônica. Além disso, poderemos analisar como os noticiários da noite editaram os acontecimentos exibidos ao vivo durante o dia.

Em relação ao modo de construção do discurso, avaliaremos fatores de diversas naturezas, tendo em vista que se trata de discurso híbrido, composto de signos verbais e não-verbais. Entretanto nossa proposta não é fazer uma descrição completa dos sistemas lingüísticos, imagéticos e cênicos inerentes a esse discurso. Mostraremos as principais características do entorno em que se dá a enunciação e procuraremos nos concentrar nos elementos enunciativos capazes de dissimular um discurso que, segundo 
supomos, interpreta a realidade conforme determinados interesses ${ }^{4}$ e transmite essa representação ao público de forma unívoca.

Não poderemos nos furtar, em vista disso, ao delicado debate sobre a ética profissional e sobre as fronteiras entre o ethos da instituição jornal e a individualidade dos jornalistas que nela atuam. Por trás das câmeras há o intangível. Sabemos que muitos profissionais da área negam haver submissão a qualquer tipo de coerção em suas atividades e reafirmam não ser sua intenção produzir esse ou aquele efeito negativo apontado pela crítica. Ninguém duvida de que haja inúmeros jornalistas éticos, sérios e bem-intencionados, porém parece haver um código tácito nos veículos de comunicação que faz com que se produzam os efeitos visíveis das redes de manipulação da mídia ${ }^{5}$.

Bourdieu afirma, particularmente falando sobre os jornalistas, que "os que estão inscritos no objeto da análise [sociológica] tendem a pensar que o trabalho de enunciação, de desvelamento dos mecanismos, é um trabalho de denúncia, dirigido contra pessoas ou, como se diz, 'ataques', ataques pessoais, ad hominem". E prossegue: "Eles se sentem visados, alfinetados, quando, ao contrário, quanto mais se avança na análise de um meio, mais se é levado a isentar os indivíduos de sua responsabilidade - 0 que não quer dizer que se justifique tudo o que se passa ali -, e quanto melhor se compreende como ele funciona, mais se compreende também que aqueles que dele participam são tão manipulados quanto manipuladores" (1997:21).

A despeito de qualquer intencionalidade, o discurso da "máquina midiática" tem uma natureza singular, caracterizada por uma série de filtros que constroem sentidos e transformam o acontecimento, desde sua origem, em objeto de interpretação (cf. Charaudeau, 2006). Nenhuma produção de jornal ou telejornal escapa às pressões internas e externas dessa máquina, porém reiteramos que o interesse precípuo desta tese recai sobre a materialidade lingüística do discurso e o entorno visível do produto.

\footnotetext{
${ }^{4}$ Luiz Weis conta-nos que, "coisa de meio século atrás, o jornalista Cláudio Abramo ensinava aos focas do Estadão que a liberdade de imprensa é antes de mais nada a liberdade dos donos da imprensa" ("O abate sem debate do CFJ", artigo publicado no site do Observatório da Imprensa, agosto de 2004).

${ }^{5}$ Chomsky e Herman, na célebre análise que fazem da mídia norte-americana, são mais contundentes acerca disso: "A maioria das escolhas tendenciosas da mídia decorre da pré-seleção de pessoas de mentalidades coadunadas, pré-concepções internalizadas e da adaptação de pessoal às restrições impostas pelo poder da propriedade, da organização, de mercado e político. A censura é em grande parte autocensura" (2003:54).
} 
Tentaremos contornar o problema da diversidade de linguagens, buscando recortar de cada uma delas o que for essencial para definir um padrão de construção do discurso. Devemos observar, portanto, questões ligadas ao gênero telejornal, que se manifesta por discurso híbrido, com sobreposição de imagem e palavra, e questões ligadas à edição de texto e imagem ${ }^{6}$, processo fundamental na construção da versão dos fatos que se impõe ao público. Aliás, o exame das imagens é relevante no que concerne ao problema da memória, sobretudo se considerada sua característica eminentemente retórica de seduzir, porém analisaremos a imagem especialmente como contexto ou argumento do discurso telejornalístico.

No entanto, de todos os elementos passíveis de análise, os que nos parecem mais importantes são aqueles relativos à dimensão lingüística do discurso. Poderíamos examinar muitos aspectos discursivos, como as modalizações e os diversos tipos de argumento, mas nos deteremos nos seguintes elementos, cuja inter-relação não pode deixar de ser considerada para a consecução da pesquisa: 1) os elementos contextualizadores; 2) as formas de designação e referenciação; 3) as formas de discurso relatado, os verbos de opinião e o metadiscurso.

Um modelo que servirá aos nossos propósitos é aquele que propõe Charaudeau, ao lembrar que "todo acto comunicativo es un objeto de intercambio entre dos instancias, una de enunciación y otra de recepción, cuyo sentido depende de la relación de intencionalidad que se instaura entre ellas" (2003:22). Isso impõe que sejam examinadas, além da construção do discurso e das condições de produção, as condições de interpretação, que representam os três lugares básicos da "máquina midiática", segundo Charaudeau (2006:23). Tal modelo considera, nessas instâncias, a existência de efeitos visados, efeitos possíveis, efeitos supostos e efeitos produzidos.

\footnotetext{
${ }^{6}$ Parece-nos oportuno lembrar esta afirmação de Luiz Weis: "o poder de formar opinião está muito mais no conteúdo informativo de um jornal - desde o que nele se considera noticiável até o modo como a notícia é apurada, editada e publicada - do que nos editoriais e nos textos opinativos" (no artigo "O abate sem debate do CFJ", disponível no site do Observatório da Imprensa).
} 
Essa distinção nos interessa porque resolve, em grande parte, o problema da análise da recepção do discurso dos telejornais. Diante da dificuldade de medir qualitativamente a resposta do público à influência dos telejornais, enfatizamos nossa pretensão de avaliar o potencial desse meio para determinar algumas orientações e criar certas memórias e amnésias, portanto esse modelo avaliza que consideremos somente os efeitos possíveis e supostos desse discurso sobre o público.

Segundo Charaudeau, os efeitos possíveis são um eco dos efeitos visados e somente uma parte deles corresponderá às intenções do enunciador, sendo a outra parte construída pelo receptor (2003:26). Assim, avaliaremos o que emerge do discurso como marca dos efeitos possíveis e, por conseguinte, poderemos chegar aos efeitos supostos, sem necessariamente aferir os efeitos produzidos de fato, haja vista que o público tem características diversas a agir sobre o modo de interação com a mídia.

Em síntese, empreenderemos um exame do discurso dos telejornais mediante um estudo de caso, tendo como base um modelo de análise crítica do discurso e sustentado por conceitos relativos à polifonia, bem como por recentes estudos da lingüística textual sobre o fenômeno da referenciação. Objetivamos também uma análise interpretativa dos dados com suporte nas teorias da argumentação e nos trabalhos sobre memória social, conforme exposição teórica que faremos no segundo capítulo da tese. Antes, no primeiro capítulo, apresentaremos um dos tecidos da complexa rede que pretendemos desfiar: a revisão bibliográfica de algumas teorias da comunicação e de estudos sobre o discurso midiático. O terceiro capítulo consiste na análise do corpus, seguida das conclusões e considerações finais. 


\title{
CAPÍTULO 1
}

\section{NAS REDES DA MÍDIA - O TECIDO MUSCULAR}

\author{
PRIMEIRA PARTE - O FENÔMENO MIDIÁTICO \\ O telespectador de massa, no curso do tempo, só terá conhecido \\ a história falsificada e apenas um pequeno número de pessoas terá consciência \\ de que existe uma outra versão, mais autêntica, da história. (Ryszard Kapuscinski)
}

\section{A comunicação de massa}

A história da comunicação compreende várias etapas: a era dos símbolos e sinais; a era da fala e da linguagem; a era da escrita; a era da imprensa; a era da comunicação de massa, cuja transição se iniciou no século 19 e cuja saturação se deu em meados do século 20; e a era dos computadores (cf. DeFleur e Ball-Rokeach, 1993). Muito embora as sociedade contemporâneas estejam vivendo a era da informática, da tevê a cabo e da internet, adventos que mudaram sobremaneira as relações de comunicação, ainda é grande a influência dos veículos de massa, em especial da televisão, e incompleta nossa compreensão a respeito das formas de influência psicológica, social e cultural que esses meios exercem.

O mundo mudou muito desde que, no século 18 , os jornais impressos se consolidaram, lançando o germe da comunicação de massa. Segundo Thompson, houve três aspectos centrais no desenvolvimento das indústrias da mídia, observado desde o início do século 19: 1) a transformação das instituições da mídia em grandes conglomerados da comunicação, com interesses comerciais de grande escala (ou seja, grandes concentrações de poder econômico e simbólico); 2) a globalização da comunicação (desenvolvimento de agências internacionais, sediadas nas principais cidades comercias da Europa, e depois dos Estados Unidos); 3) o desenvolvimento das formas de comunicação eletronicamente mediadas (1998:73).

7 Escritor e jornalista polonês, especialista em reportagens de guerra (excerto do artigo "Les médias reflètent-ils la réalité du monde?", publicado em Le Monde Diplomatique, agosto de 1999). 
No século 20, quando os jornais passaram a ser difundidos por rádio e televisão e começaram a se desenvolver na mesma proporção em que aumentava a complexidade das sociedades, a cultura de massa emergiu e acabou submetendo as demais culturas a um processo de homogeneização. Desde então, inúmeras teorias têm sido elaboradas a fim de compreender a comunicação de massa e, em especial, os efeitos produzidos por ela na construção do tecido social.

DeFleur e Ball-Rokeach explicam bem por que é importante conhecer a máquina midiática: "A mídia é parte central dos processos de comunicação das sociedades modernas. Ela contribui em suas descrições e relatos com interpretações da realidade que suas audiências internalizam. As pessoas podem criar construções de significado subjetivas e compartilhadas, para as realidades físicas e sociais nas quais vivem, pelo que lêem, escutam ou vêem. Portanto, seu comportamento pessoal e social pode ser em parte modelado por interpretações dadas pela mídia a acontecimentos e temas em debate acerca dos quais as pessoas dispõem de poucas fontes de informação alternativas" (1993:54).

No entanto, segundo esses autores, a idéia de que os conteúdos veiculados pela mídia são recebidos de maneira uniforme pelo público é simplista e ultrapassada, visto que o a própria mídia está inserida num processo dialético que envolve forças, idéias e acontecimentos de todos os campos da sociedade, que resulta em contínuas e mútuas influências. Isso significa que é difícil produzir modelos e proclamar explicações definitivas em se tratando dos efeitos da comunicação de massa sobre o público, devido ao constante processo de mudanças a que se submetem as sociedades e suas mídias.

Entre as teorias acerca dos efeitos da comunicação de massa que já foram defendidas estão, conforme sintetizam DeFleur e Ball-Rokeach: 1) a teoria da influência seletiva, segundo a qual a mídia atinge indivíduos ou grupos que compartilham padrões de necessidades, hábitos, crenças, valores e atitudes ou se organizam conforme classe, religião, identidade étnica etc.; 2) a teoria de influência indireta, que vê maior importância nas influências sutis da mídia, observadas a longo prazo na cultura e na organização da vida social, do que nas influências imediatas, visto que aquelas podem determinar a modelagem, a previsibilidade e a continuidade de certos comportamentos sociais; 3 ) as 
teorias da construção social, que buscam na história os princípios de regularidade para compreender os atuais fenômenos de comunicação de massa.

A teoria da influência seletiva determinou a crescente preocupação da mídia com a segmentação de mercado, no entanto não vingou em termos científicos porque é muito complexo prever ou analisar o comportamento da audiência ou os efeitos que a comunicação de massa tem sobre ela, dado que atenção, percepção, lembrança e ação são processos seletivos também (cf. DeFleur e Ball-Rokeach, 1993:218). A teoria da influência indireta ainda tem sua validade, mas são as teorias da construção social que mais têm a contribuir para o entendimento do alcance dos veículos de massa, porque empreendem uma investigação sobre as constantes transições pelas quais passa a sociedade, inclusive no campo da comunicação.

Segundo DeFleur e Ball-Rokeach, que não são os únicos a fazer analogia entre o mito da caverna e a televisão, pode-se encontrar na análise de Platão sobre a relação entre linguagem, significado e realidade um princípio intemporal que pode ser estendido à comunicação de massa: "convenções de linguagem vinculam significados a palavras que têm influência poderosa no comportamento das pessoas" (op.cit.:271).

Grandes pensadores da Idade Moderna, como Hobbes e Locke, já apontavam a importância da linguagem na construção do pensamento - aí incluída a memória - e da sociedade. DeFleur e Ball-Rokeach sintetizam as questões postas pelo pensamento filosófico até o século 19 da seguinte forma: "1) há uma realidade em que vivemos; 2) seres humanos criam alguma forma de representações mentais que fornecem significados para a realidade; 3 ) há um processo interveniente por meio do qual os indivíduos constroem significados subjetivos para a realidade; 4) nossos significados e interpretações subjetivas orientam nossa conduta pessoal; 5) os padrões de conduta da humanidade são tais que se torna necessária uma ordem social controladora de regras justas; esta ordem, por sua vez, influencia a conduta" (op.cit.:265).

Daí adviriam as teorias da construção social, desenvolvidas em diferentes áreas, como a antropologia, a sociologia, a psicologia social e a lingüística, todas tentando entender, de uma forma ou de outra, a relação entre interação simbólica e concepções da realidade. Mais recentemente, essa preocupação estendeu-se aos estudos sobre o papel que a mídia desempenha na construção social do significado, na formação de opinião 
pública, no estabelecimento de agenda política, na criação de estereótipos e outros tantos aspectos. Da mesma forma, cresceu o interesse por questões ligadas às coerções sofridas pela mídia, que se manifestam por códigos éticos, por exigências técnicas de cada veículo, pela característica seletiva da notícia, pelo constrangimento de tempo e espaço, pela natureza capitalista da indústria midiática.

Como proposta para integrar todas essas idéias, DeFleur e Ball-Rokeach apresentam uma teoria da dependência do sistema de mídia, que leva em conta os relacionamentos entre a mídia, ou partes da mídia, e indivíduos, grupos, organizações ou outros sistemas sociais, tendo em vista o gerenciamento de recursos e metas: "A força da equação inclui não apenas como outros dependem dos recursos da mídia para alcançar suas metas, mas também como o sistema de mídia depende dos recursos controlados por outros" (op.cit.:322).

Assim, cada tipo de relacionamento teria uma dinâmica própria e teria de ser analisado particularmente, embora seja possível observar que há padrões repetitivos de interdependência, tais como os que existem na relação entre o sistema da mídia e o sistema político. No caso da relação com os indivíduos, há maior variação de padrões, mas se pode dizer que as metas são basicamente as mesmas: compreensão (de si, da comunidade e do mundo), orientação (das ações e da interação com os grupos) e diversão. As pessoas são, na maior parte do tempo, selecionadores ativos, e não observadores casuais da mídia, isto é, buscam os veículos com alguma dessas metas ou com todas elas (cf. DeFleur e Ball-Rokeach, 1993:330).

Não é sem razão, portanto, que muitos teóricos e filósofos da modernidade estão empenhados em aprofundar os estudos e debates sobre a televisão, haja vista a profunda relação que há entre meios de comunicação e processos históricos e sociais, sobretudo no que se refere à instauração de novas formas de ação, interação e poder no mundo social. 


\section{A mídia na modernidade}

$\mathrm{Na}$ organização da sociedade moderna, pode-se distinguir, segundo Thompson quatro tipos principais de poder: o econômico, o político, o coercitivo e o simbólico. $O$ poder coercitivo (uso real ou ameaça de força física ou armada) e o poder simbólico (cultivo e sustentação da crença na legitimidade do poder político) seriam formas de o Estado, que representa o poder político, exercer sua autoridade. Thompson usa também o termo "poder simbólico", conceito amplamente divulgado por Bourdieu, para se referir à "capacidade de intervir no curso dos acontecimentos, de influenciar as ações dos outros e produzir eventos por meio da produção e da transmissão de formas simbólicas"; e seus agentes seriam os meios de comunicação e informação, personificados por instituições culturais como a igreja, a escola e a mídia (1998:24).

$\mathrm{Na}$ produção e na transmissão das formas simbólicas, empregam-se meios técnicos cujas principais características são: 1) capacidade de fixação ou preservação dos conteúdos simbólicos (a informação armazenada pode servir de fonte para o exercício de diferentes formas de poder); 2) capacidade de reprodução, que transforma as formas simbólicas em produtos comerciais; 3) possibilidade de distanciamento espaçotemporal (a forma simbólica pode ser afastada de seu contexto e reimplantada em novos contextos; o poder pode se estender no espaço e no tempo, agindo de novas formas); 4) facilidade de decodificação da mensagem pelos receptores (cf. Thompson, 1998:26).

No entanto, esses fatores que tornam extenso o braço do poder simbólico não permitem pressupor que a interação se dê com uma vasta audiência de indivíduos passivos e indiferenciados. Não são poucos os autores que têm preferido, ao termo "comunicação de massa", o conceito de "comunicação mediada", pois, embora o fluxo de mensagens se dê em sentido único, o receptor faz o que quiser com a mensagem mediada. Segundo Thompson, "mesmo que os indivíduos tenham pequeno ou quase nenhum controle sobre os conteúdos das matérias simbólicas que the são oferecidas, eles os podem usar, trabalhar e reelaborar de maneiras totalmente alheias às intenções ou aos objetivos dos produtores" (1998: 42).

A tendência da cultura contemporânea de buscar processos de homogeneização e uniformização das mensagens em circulação tem sido observada por outro ângulo, desde 
que se percebeu que o problema da manipulação ideológica não está nos meios, mas na mediação e em sua profunda relação com questões históricas e culturais. Há pelo menos dez anos, Martín-Barbero, um dos principais estudiosos da comunicação da América Latina, mudou o foco de suas preocupações e passou a investigar os processos de massificação a partir das mediações e dos sujeitos, das articulações entre política, cultura e memória popular, da relação entre práticas de comunicação e movimentos sociais. A ele interessa sobretudo o fato de que, com o advento da sociedade de massa, aumentou a circulação cultural e também a comunicação entre os diferentes estratos da sociedade.

Nesse contexto, segundo Martín-Barbero, a cultura de massa tem cumprido a função da verdadeira mediação, a que se dá entre o real e o imaginário, uma vez que, diante da impotência política e do anonimato social, a maioria dos homens contemporâneos reclama uma porção maior de imaginário cotidiano para poder viver (1997:83). Além disso, com a crescente disponibilidade de formas simbólicas mediadas, foi sendo mais e mais alterado o modo como as pessoas compreendem o passado e o mundo além de seus contextos sociais imediatos.

Pode-se dizer, com Thompson, que o desenvolvimento dos meios de comunicação criou uma 'historicidade mediada" e também, a nosso ver, uma memória mediada. Reflete esse autor: "Nós estamos constantemente e ativamente nos modificando por meio de mensagens e de conteúdos significativos oferecidos pelos produtos da mídia. Este processo de transformação pessoal não é um acontecimento súbito e singular. Ele acontece lentamente, imperceptivelmente, dia após dia, ano após ano. É um processo no qual algumas mensagens são retidas e outras são esquecidas, no qual algumas se tornam fundamento de ação e de reflexão, tópico de conversação entre amigos, enquanto outras deslizam pelo dreno da memória e se perdem no fluxo e refluxo de imagens e idéias" (op.cit.:46).

Outro ponto importante a observar é o modo como a organização social do poder simbólico contribuiu para o processo de globalização da comunicação e como foi transformada por ele. $O$ fenômeno da difusão da informação se iniciou em meados do século 19, com o desenvolvimento de cabos submarinos pelas potências européias, com o estabelecimento de novas agências internacionais de notícias e a divisão do mundo em esferas de operação exclusivas e com a formação de organizações internacionais 
interessadas na distribuição do espectro eletromagnético. Desde a Segunda Guerra Mundial, as quatro maiores agências são a Reuters, a Associated Press United, a United Press International e a Agence France Press, que são também os atores principais na organização global da informação, dos quais dependem muitas organizações jornalísticas e radiotelevisivas do mundo (cf. Thompson, 1998; cf. Chomsky e Herman, 2003).

Diante disso, pode-se constatar que o modelo econômico e social do mundo contemporâneo afeta os problemas teróricos das ciências da comunicação, que vão transcender à reflexão sobre massificação, padronização e consumo passivo dos meios. Emergem assim questões relacionadas à interação dos sujeitos, aos processos de produção do sentido, à análise dos poderes sociais, à mediação da história e da memória coletiva, fazendo com que as pesquisas avancem na compreensão das condições materiais de funcionamento da comunicação, de sua história e de seus elos com outros sistemas de socialização.

De acordo com Armand e Michèle Mattelart, esse movimento de revisão nas ciências da informação e da comunicação se iniciou no final dos anos 70 e, desde então, é ininterrupta a produção de estudos que deixam entrever o declínio de certos paradigmas e o advento de novos. Evidentemente, se muda o mundo e mudam as formas de poder simbólico, mudam também as formas de compreensão do real e as teorias da comunicação.

Hoje a idéia corrente é que o processo de comunicação se constrói pela intervenção de atores sociais muito diversos e muitas disciplinas passaram a tratar dos fenômenos da interação, abandonando o mito da onipotência da mídia, que modelaria uma sociedade amorfa e inerte. A lingüística e a semiologia pragmáticas, por exemplo, têm mostrado a inscrição histórica dos atos de enunciação como atos de recepção e buscado entender como cada instituição midiática posiciona o espectador e regula certos aspectos da produção de sentido e de afetos (cf. Mattelart, 2004:123). Tem havido, enfim, enorme esforço interdisciplinar para a compreensão desse fenômeno tão importante na sociedade moderna, conforme veremos nas seções subseqüentes. 


\section{A cultura das mídias}

Hoje, na era dos computadores, coexistem os meios de comunicação de massa e os meios de comunicação individual e interativa, que transformaram a cultura contemporânea numa "cultura das mídias", expressão usada por Lúcia Santaella. A cultura das mídias é hoje, a despeito de promover a inter-relação de diversas formas de cultura, a cultura do efêmero e da proliferação das próprias mídias. Uma característica fundamental, portanto, é sua mobilidade, a capacidade de trânsito da informação, conforme explica Santaella: "Uma mesma informação passa de mídia a mídia, repetindose com algumas variações na aparência. É a cultura dos eventos em oposição aos processos. Cultura do descontínuo, do esquecimento, de aparições meteóricas, em oposição aos contextos mais amplos e à profundidade analítica. Quando absorvida pelas mídias, qualquer coisa, seja lá o que for, passa a ter caráter volátil: aparece para desaparecer" (2003:35).

Talvez por isso tantas teorias tenham sido revistas e tenham passado a considerar o público não como uma vítima da mídia, mas como um conjunto de usuários que interpretam os conteúdos conforme suas experiências, necessidades e desejos. Em conseqüência disso, como aponta Bertrand, "a principal influência da mídia faz-se por omissão: o que ela não diz tem mais influência do que o que ela diz", já que "não pode ditar às pessoas o que pensar, mas decide no que elas vão pensar" (1999:61). Esse fato tem levado à crescente preocupação com uma nova deontologia das mídias, que preveja a melhoria da qualidade da mídia como condição indispensável à sobrevivência da democracia e da civilização.

Bertrand faz uma análise essencial do que vem ocorrendo na mídia: "A maior parte dos meios de comunicação não leva em conta a complexidade do real. Acha-se na obrigação de fazer depressa e de entreter, logo, de simplificar. Donde o abuso de estereótipos, a divisão em bons e maus, a redução dos fenômenos a indivíduos pitorescos, de um discurso a uma frase. A mídia dá assim, da sociedade e do mundo, imagens incompletas, freqüentemente deformadas, que podem gerar sentimentos e comportamentos lamentáveis" (op.cit.:125). 
Não se deve dizer que todas as mudanças sociais e culturais decorrem da influência da mídia, mas é inegável que as mensagens da mídia, sobretudo da televisão, reforçam valores latentes na sociedade. Em contrapartida, acredita-se numa forte pressão social sobre a mídia pela adoção e naturalização da doxa. Nesse processo dialético, estaria a base da cultura midiática, cuja função ideológica se geraria no movimento de realimentação incessante das estruturas profundas de um inconsciente coletivo (cf. Mattelart, 2004:149). Dá-se como certo, portanto, que os sistemas de comunicação são sistemas de consenso e que a memória popular não tem mais o mesmo lugar no espaço público, tendo sido substituída pela cultura de massa e por arquivos audiovisuais, não raras vezes denominados de memória eletrônica.

A análise que se faz atualmente da cultura das mídias indica que o receptor ideal é aquele que tem acesso a múltiplas fontes e que, assim, vai formando gradualmente sua opinião sobre a realidade, sem que seu potencial de interpretação fique reduzido a uma só dimensão. Assim, se considerarmos como "público" o que pode ser visto e ouvido por todos, então os meios de comunicação são hoje instrumentos fundamentais da ampliação ou restrição do que é público: "Amplia-se o público ao fazer visíveis preocupações de atores que, de outro modo, não se notariam, ao estender os limites do reconhecimento dos outros, ao qualificar as compreensões que os cidadãos têm de seus problemas ou das orientações das decisões de seus governantes. Restringe-se, ao distorcer a informação, ao banalizar os processos, ao tirar a densidade da complexidade social" (Martín-Barbero e Ray, 2001:86).

No contexto da cultura das mídias, é fundamental discutir sua relação com a responsabilidade social, com a educação, com as permanências históricas e com a formação de memória social, num permanente diálogo com outras formas de discurso, a fim de ampliar os atuais domínios da esfera pública. É preciso ir além do universo metonímico construído pela mídia, sobretudo pela televisão, no qual os conteúdos escolhidos para se dar a conhecer valem pelo mundo todo. 


\section{A cultura da televisão}

Um dos mais importantes e hegemônicos meios de comunicação da sociedade do espetáculo é a televisão, não porque sustenta o que muitos acreditam ser a ditadura da imagem, mas porque representa bem o célebre conceito de Guy Debord, segundo o qual o espetáculo é uma relação social entre pessoas, mediatizada por imagens.

Num de seus livros mais importantes, Comentários sobre a sociedade do espetáculo, de 1988, Debord aprofunda sua análise sobre a mídia no mundo contemporâneo e declara que a oposição entre a forma concentrada do espetáculo, própria dos regimes comunistas, e a forma difusa, presente no capitalismo ocidental, seria superada pelo que se poderia chamar de "espetáculo integrado". Os traços característicos desse modelo seriam a inovação tecnológica permanente, a absorção do Estado pelo mercado, a inacessibilidade das verdadeiras decisões do poder, a aceitação sem réplica das representações midiáticas e a abolição de toda consciência histórica, que Debord chama de "presente perpétuo" (2003:12).

Esses traços estão permanentemente no centro das questões sobre a mídia, como veremos ao longo desta tese, em que se destaca o papel do espetáculo na mediação das atuais relações sociais. Segundo Thompson (1998), um dos aspectos mais característicos da era contemporânea é a crescente necessidade de visibilidade dos mais diferentes grupos, a ponto de muitos eventos serem especialmente planejados para exibição pela mídia ou, até mesmo, de algumas ações serem simuladas com o fim de criar acontecimentos televisivos.

Para Martín-Barbero e Ray, no entanto, "a visibilidade que mídias como a televisão oferecem é quase sempre paradoxal: não responde a um ideal de total transparência, mas é o resultado mais ou menos ambíguo da intersecção entre informação e desinformação, verdade e artifício, montagens ritualizadas e espontaneidade" (2001:100). Em muito casos, a informação substitui a experiência e a velocidade da informação se impõe sobre a "necessária densidade da memória". Em outros casos, a verdade relatada, ou verdade midiática, surpreende mais do que as mentiras da mídia ${ }^{8}$. O que se processa

\footnotetext{
${ }^{8}$ Trataremos das noções de verdade, verossimilhança e fato no capítulo referente às bases teóricas.
} 
é sempre a versão, a seleção e a edição de determinados acontecimentos, num constante jogo entre memória e esquecimento. Nesse caso, as mídias são mais do que simples observadores dos acontecimentos, são atores da história que se constrói pelas montagens intencionais de fiç̧ões e relatos.

Muitos autores vêem o problema por ângulo semelhante, como Muniz Sodré, que afirma que a mídia detém o monopólio da fala na sociedade contemporânea, na qual se erige o mito da informação: a mídia finge que informa para que as pessoas não busquem informação, ou, em outras palavras, em vez de informar, notifica de forma monológica, normativa e pedagógica. Segundo Sodré, a sintaxe da televisão opera com a simulação de modelos do mundo, seja documental ou ficcional o material a ser reproduzido. Tratase de um sistema de produção monopolístico cuja ideologia sustenta-se mais no controle da fala do que no poder econômico, não importando se há diversidade e multiplicidade de fontes, visto que o essencial não é o controle dos meios de produção, mas o domínio do código e do intercâmbio de signos (cf. Sodré, 1984:42).

Nesse contexto, ainda sob a ótica de Sodré, a linguagem da televisão atenderia a esse projeto de hegemonia ideológica articulando-se em três processos fundamentais: 1) individualização familiarizada (simulação de contato íntimo com cada um dos espectadores, naturalização da mensagem mediada, adaptação do mundo à ótica familiar); 2) repetição analógica do real (ritmo, ilusão referencial de tempo e espaço, planos, edição de imagens, repetição exaustiva do verbal e do visual); 3) reprodução do já existente e elaboração em espelho da fantasia (construção de realidades e de representações sociais, com base em estereótipos culturais - os valores e opiniões vêm e voltam, como num espelho; e homogeneização do real e do imaginário) (op.cit.:56).

Já na análise de Martín-Barbero e Ray, a mídia opera a substituição do elo entre o passado e o presente pela fragmentação exigida pelo espetáculo e, com isso, transforma o desejo de saber em mera "pulsão de ver". De acordo com esses autores, "a televisão constitui hoje, simultaneamente, o mais sofisticado dispositivo de moldagem e deformação do cotidiano e dos gostos populares e uma das mediações históricas mais expressivas de matrizes narrativas, gestuais e cenográficas do mundo cultural popular" (2001:26). 
Isso se dá, segundo Martín-Barbero e Ray, pela descontextualização e pela deshistoricização que caracterizam a contemporaneidade produzida pela mídia: "A percepção do tempo, no qual se instaura o sensorium audiovisual, está marcada pelas experiências da simultaneidade, do instantâneo e do fluxo. A perturbação do sentimento histórico se faz ainda mais evidente numa contemporaneidade que confunde os tempos e os achata na simultaneidade do atual, no culto ao presente alimentado pelos meios de comunicação em seu conjunto e, em especial, pela televisão. Porque uma tarefa-chave, hoje, da mídia, é fabricar presente: um presente concebido sob a forma de golpes sucessivos sem relação entre si. Um presente autista, que crê poder bastar-se a sim mesmo" (op.cit::35).

Com o desenvolvimento dos meios de comunicação, especialmente da televisão, houve mudanças na ancoragem da tradição e na natureza das relações com o tempo e a história, implicando mudanças no fornecimento de material simbólico e na formação das identidades individuais e coletivas. Só é possível entender essa capacidade de mediação e de influência sobre o público, se forem conhecidas as demandas sociais e culturais que as pessoas fazem à televisão, já que são essas demandas que "põem em jogo o contínuo desfazer-se e refazer-se das identidades coletivas e os modos como elas se alimentam de, e se projetam sobre, as representações da vida social oferecidas pela televisão" (Martín-Barbero e Ray, 2001:40).

Outro aspecto da cultura da televisão a ser mais profundamente discutido é a relação entre as representações nas mídias e a memória. Não raro a mídia se vale do que Lopes (2004) chama de "artefatos de memória" para enfocar temas de natureza histórica e social, isto é, ela constrói e reconstrói representações que se fixam nas manifestações midiáticas e são continuamente acionadas pela memória do público. Fatos, imagens, símbolos e discursos veiculados e reiterados pela mídia são artefatos que legitimam continuamente a história, produzindo, alterando e reforçando padrões da memória social, na qual circulam as representações do passado e do presente imediato.

Como aponta Lopes, as mídias detêm arquivos que podem ser usados e reutilizados indefinidamente: "Há sempre um olhar, uma seleção de idéias em textos, imagens e sons. A interpretação da fonte utilizada agrega novos valores ao que é exibido, transmitido, escrito etc. Por sua vez, os receptores das mensagens as lerão de acordo 
com suas percepções previamente definidas, em um processo contínuo ao mesmo tempo mimético e adaptativo, que inclui possibilidades de conservação e ruptura. (...) O nãoconhecimento, as omissões, as novas versões modificadas relativas ao passado não são casuais. Fazem parte do processo contínuo de reconstrução da memória, da alimentação das redes intersubjetivas, o que consiste na essência do processo de inculcamento ideológico" (2004:105).

Pela intertextualidade e pela interimagética recorrentes na mídias, as marcas discursivas sobrepõem-se aos fatos e aos processos em si mesmos, manifestando-se na forma de conceitos morais, preconceitos sociais e fragmentos de determinadas ideologias, que produzem conhecimento e memória comuns (cf. Lopes, 2004:107). O tecido social é permanentemente penetrado, esgarçado e reconstituído pelo discurso da mídia, sobretudo o da televisão, o que acaba por intervir no processo de formação da memória social. É o interesse por esse fenômeno que move esta tese, centrada na observação do discurso dos telejornais. 


\section{SEgUNDA PARTE - TELEVISÃo E JORNALISMO}

A TV é o buraco da agulha por onde passa a história da humanidade: passam as fotos, mas não passam as idéias, o pensamento. (Eugênio Bucci)

\section{A crítica da televisão}

Não é novo o interesse pelo funcionamento e pelas influências da televisão na sociedade contemporânea, nem é limitado o campo de investigação dos estudiosos, que têm se debruçado sobre o universo das novelas, dos debates políticos, dos programas infantis, dos reality shows e de tantos outros gêneros televisivos. No mundo inteiro, discutem-se questões como a formação e a manipulação da opinião pública, a imbricação entre ficção e realidade, a modelagem de comportamento e linguagem, a fragmentação dos fatos e a desinformação, as representações identitárias e a memória coletiva, o assujeitamento político e econômico, a espetacularização da vida na televisão, a fabricação de consenso.

Muitos pontos de vista são polêmicos, como os de Giovanni Sartori, Pierre Bourdieu e Martín-Barbero, aos quais já nos referimos e que apresentam importantes dimensões sociológicas e antropológicas desse veículo de comunicação. Já outros pesquisadores, como François Jost $^{9}$, investigam formas de descrever uma gramática das condições de produção televisual. Vejamos, quanto às possibilidades teóricas e metodológicas de estudo, como alguns pesquisadores brasileiros abordam o problema.

Quando a televisão brasileira comemorou seu cinqüentenário, Eugênio Bucci organizou uma série de artigos que pensavam o veículo sob as mais diversas perspectivas: televisão e violência do imaginário, democratização dos meios de comunicação de massa, política e novela, censura e autocensura, identidade nacional na televisão. Sem dúvida, todos esse temas são importantes, mas sublinhamos apenas a reflexão que abre os trabalhos e norteia o projeto, conforme o excerto a seguir.

\footnotetext{
${ }^{9}$ Diretor do Centre d'Etudes des Images et des Sons Médiatiques, da Universidade de Sorbonne.
} 
Num país como o Brasil, em que a TV redefiniu o espaço público e reconfigurou a própria face da nacionalidade, a presença dos meios de comunicação é um fator incontornável para os educadores. Em números aproximados, há cerca de 40 milhões de lares com televisão no Brasil, o que corresponde a quase $90 \%$ do total. Isso, para uma população que lê pouco, dá à TV uma condição de monopólio da informação, ou seja, a TV monologa sem que outros meios the façam contraponto. (...) Por tudo isso, criticar a televisão tem sido fundamental, um exercício de utilidade pública. Um exercício urgente e inadiável. Não se trata de fechar os olhos para os avanços estéticos e tecnológicos alcançados pela televisão no Brasil, nem de pretender descartar o seu êxito em lograr a integração da nacionalidade, mas se trata, isto sim, de se relacionar criticamente com a história da presença desse veículo entre nós. O pensamento crítico não deveria ser rechaçado como é, como se fosse uma argumentação inimiga e de má vontade. Ele é, ao contrário, parte indispensável de qualquer projeto cultural e democrático (Bucci, 2000:9).

O exercício da crítica foi se adensando. Alguns anos depois, o próprio Bucci e a psicanalista Maria Rita Kehl lançaram novos ensaios sobre a televisão, nos quais propõem e discutem o conceito de "videologia", que seria a forma contemporânea do mito: "Vivemos uma era em que tudo ocorre para a imagem, para a visibilidade e para a composição de sentidos no plano do olhar. (...) Os mitos, hoje, são mitos olhados. São pura videologia" (2004:16). Partindo da definição de Barthes de que "o mito é uma fala roubada", Bucci e Kehl descrevem o que a televisão faz: rouba falas (verbais, visuais, gestuais), todas falas naturais, e as devolve aos falantes, do que decorre seu poder de influência: "A TV não manda ninguém fazer o que faz; antes autoriza, como espelho premonitório, que seja feito o que já é feito. Autoriza e legitima práticas de linguagem que se tornam confortáveis e indiscutíveis para a sociedade, pelo efeito da enorme circulação e da constante repetição que ela promove. A TV sintetiza o mito" (op.cit::19).

Além disso, segundo Bucci e Kehl, a supremacia do espetáculo sobre outras atividades humanas é a nova forma do modo de produção capitalista ${ }^{10}$. O macrossujeito

\footnotetext{
${ }^{10}$ Como contraponto, citamos Dominique Wolton, especialista em comunicação conhecido por opiniões que vão na contramão do discurso crítico sobre os meios de comunicação de massa. Ele acredita no papel da mídia como fator de vínculo social e como importante vetor da democracia e tem outro ponto de vista sobre o problema da espetacularização. Apesar de julgar pertinente que muitas das idéias de Guy Debord sobre a sociedade do espetáculo sobrevivam na crítica atual, não concorda com o pessimismo que elas ainda suscitam. Wolton diz que, embora o espetáculo ocupe um lugar cada vez mais destacado na mídia, ele "não transforma tudo, não dirige toda a sociedade", pois há outros valores e dimensões sociais relevantes
} 
do processo midiático não seriam, portanto, nem os donos dos meios de comunicação, nem os Estados, nem grupos e partidos políticos, mas o próprio capital, que assujeita todos os outros poderes. Nesse contexto, muda também a conformação do espaço público e o modo de entender a televisão nesse espaço: "A televisão não mostra lugares, não traz lugares de longe para muito perto - a televisão é um lugar em si. Do mesmo modo, ela não supera os abismos de tempo entre os continentes com suas transmissões na velocidade da luz: ela encerra um outro tempo. O lugar da TV, ou melhor, a TV como lugar, nada mais é que o novo espaço público, ou uma esfera pública expandida" (Bucci, 2004:31).

Assim, o lugar da televisão é miticamente ubíquo. Pode até apresentar-se multifacetado e fragmentário, mas é totalizante, na medida em que não admite nada que ocorra fora dele, como se tudo o que não aparece na televisão não existisse fora dela. Bucci diz que o que não é captado pelas câmeras da televisão não faz parte do espaço público brasileiro, "é só escuridão". Da mesma forma, avalia Kehl: "Na sociedade do espetáculo toda imagem, mesmo a imagem jornalística, mesmo a informação mais essencial para a sociedade, tem o caráter de mercadoria, e todo acontecimento se reduz à dimensão do aparecimento. O imperativo da novidade, ao apagar a história dos acontecimentos e os jogos de força e de interesse que os determinam, não produz o novo: produz a repetição renovada do mesmo" (2004:156).

Esse processo de repetição renovada só é possível porque há, sobretudo na televisão, talvez a mais híbrida das mídias, mais do que uma redundância de códigos. Há uma cooperação entre códigos e linguagens que produz mensagens semioticamente diversificadas o tempo todo (cf. Santaella, 1996:46). Tais constatações contribuem para a mudança de foco dos estudos sobre televisão, que aos poucos vão reafirmando que "não há um cérebro maquiavélico por trás de cada emissora procurando doutrinar a massa acrítica" (Bucci, 2005:12) e vão procurando desvendar a estrutura e os mecanismos que permitem que a televisão exerça sua influência.

que interferem na recepção das mensagens midiáticas ("Wolton fala sobre o valor da mídia e da diversidade", entrevista concedida à revista Trópico, 13 de janeiro de 2002, disponível no site do Observatório da Imprensa.) 
Nesse sentido, é singular o trabalho de Elizabeth Duarte, que apresenta propostas metodológicas para a compreensão da gramática televisual que vão desde a relação entre os interlocutores e as configurações discursivas até os diferentes gêneros, subgêneros e níveis de realidade constitutivos da televisão. Segundo Duarte, para entender muitas das questões polêmicas atuais, é preciso levar em conta, antes de mais nada, o caráter eminentemente discursivo da televisão, que não apenas pauta o que deve ser conhecido da realidade, como também reduz essa realidade a manifestações discursivas oriundas da inter-relação de diferentes sistemas intersemióticos e intermidiáticos (2004:11). Toda realidade, enfim, é realidade discursiva; então, o que interessa, mais do que a lógica econômica e a lógica tecnológica, é a lógica simbólica que faz funcionar a "máquina midiática".

Conforme a autora, para entender o processo comunicativo televisivo, é preciso observá-lo em sua totalidade, nas instâncias de produção e recepção inseridas num contexto sócio-histórico, passando pelo emaranhado de linguagens verbais e visuais que constituem os produtos televisivos. Evidentemente, não se trata de tarefa fácil, devido à complexidade e à hibridação inerentes à televisão, e nem mesmo as instigantes propostas teórico-metodológicas de Duarte parecem conseguir abarcar o fenômeno em sua completude. Antes apontam direções que precisam ser exploradas pela pesquisa científica primeiro em sua especificidade, para depois serem entendidas no amplo espectro da comunicação televisual.

Uma direção interessante é a observação dos modos de enunciação da televisão, tendo em vista que os sujeitos envolvidos no processo nunca estão in presentia: os múltiplos sujeitos produtores estão por trás das câmeras e os milhões de receptores estão em frente ao vídeo. Isso, segundo Duarte, acarreta duas preocupações permanentes da gramática televisiva: 1) a contínua enunciação de sua enunciação, o permanente simulacro de seu ato comunicativo, por meio de estratégias como o deslocamento de fala para diversos atores; 2) a necessidade de apresentação reiterada do telespectador, cuja posição é presumida e com quem se estabelece um contrato potencial de caráter cognitivo e passional (2004:33).

Outro caminho que se pode seguir é a investigação dos princípios que permitem à televisão gerar diferentes níveis de realidade, quais sejam, segundo Duarte: a) meta- 
realidade (nível referencial); b) supra-realidade (nível ficcional) e para-realidade (nível artificial) (op.cit::82). A meta-realidade tem como referência o mundo exterior e natural (correspondência entre realidade e discurso) e manifesta-se nos subgêneros telejornal, documentário, reportagem, entrevista etc. Nesse tipo de realidade discursiva, o compromisso da televisão é com a veracidade do relato, portanto deve dotar seus textos de autenticidade e credibilidade, convocando testemunhas e fontes confiáveis para a construção do discurso. A supra-realidade não tem compromisso direto com o mundo natural, mas com a verossimilhança e com a coerência interna do discurso que produz, manifestando-se nos subgêneros ficcionais. A para-realidade tem como base acontecimentos provocados e controlados pela própria televisão. Seria um "real artificial", que se manifesta em produtos como os reality shows e os talk shows.

Nesse caso, como em toda relação mediada, há um contrato com o receptor: "Cabe ao telespectador o reconhecimento do tipo de realidade que the está sendo ofertada e do regime de crença que ela pressupõe, bem como a verificação da coerência entre essa proposta e o discurso disponibilizado. Mas, textualmente, essa coerência só pode ser pensada em termos de veridicção, verossimilhança ou plena visibilização; assim, o verdadeiro acaba por ser, na maioria das vezes, determinado pelo próprio texto" (Duarte, 2004:70). Dessa forma, vemo-nos diante da perda do sentido histórico dos acontecimentos reais, ocasionada pela máquina discursiva da mídia, que fabrica perpetuamente um presente a-histórico ou, o que é ainda pior, uma história sem passado ou futuro, fixada na memória social por fragmentos de um continuum irrecuperável.

Entre as muitas questões que apresenta ao discutir o conceito de videologia, Bucci dá lugar de destaque à relação entre história, memória e a era da reprodutibilidade técnica. Mais do que mediada pela televisão, a memória histórica passou a ser produzida por ela. Tudo que é veiculado pela tevê e, portanto, dado como existente, é retido em arquivos da memória eletrônica, porém não existem arquivos públicos e independentes e o acesso ao acervo das emissoras nem sempre é facilitado. Para Bucci, isso leva a questionar como se escreverá a história do Brasil a partir do período em que os fatos passaram a ser mediados pela televisão, uma vez que é difícil recuperar os modos de veiculação dos fatos e apreender a extensão de sua influência sobre o curso da história. 
Sua preocupação, que encontra eco em nossa tese, parece-nos bastante pertinente: "Como reavaliar a história que as novas gerações conseguem reter em suas retinas, em sua memória humana, se não há documentos que sirvam de comprovação dessa história para as gerações futuras? Se não temos cópias em vídeo de tudo o que os lares receberam de sinais da TV, cópias autênticas, gravadas nos núcleos de recepção, como faremos para documentar a nossa história? Poderão os historiadores do futuro saber aquilo que a televisão veiculava ou não veiculava, assim como os historiadores de hoje podem saber o que os periódicos do passado publicavam ou deixavam de publicar?" (Bucci, 2004:204).

É sabido que a história é um discurso inacabado e em permanente reelaboração, no entanto, segundo Bucci, o problema agora é que ela não tem se reproduzido pelos parâmetros da historiografia, mas sim submetida às leis que ordenam os modos de produção do espetáculo. Bucci relembra um slogan da televisão norte-americana CNN que indagava "Onde é que você vai estar da próxima vez que a história acontecer?". A resposta pretendida era "diante da tevê", pois, segundo a lógica das mídias, é na tevê que a história acontece e se reproduz (op.cit::206).

Bucci afirma também que não foram raras as vezes em que a televisão brasileira recondicionou a memória nacional, ao exibir imagens antes expurgadas e que se tornaram "iconografia oficial" da história. Ele dá como exemplo programas que exibiram, logo após a eleição do presidente Luiz Inácio Lula da Silva, em 2002, imagens das assembléias e das greves do $A B C$ paulista nos anos 80 , então sob as vestes de um novo discurso ${ }^{11}$. Fenômeno semelhante fora observado na série Contagem Regressiva, exibida em junho de 1995 pela TV Globo, em comemoração aos 30 anos da emissora. Segundo Bucci, o programa dramatizava a realidade e tornava liqüefeita a própria história, com um turbilhão de imagens sem o encadeamento lógico do relato histórico, a fim de ilustrar a retrospectiva não dos fatos mais determinantes da história, mas dos fatos que, por alguma razão, a televisão transformou em espetáculo (op.cit.:212).

${ }^{11}$ Curiosamente, esse foi o tema da monografia "Polifonia, interdiscurso e memória social - análise de um
programa jornalístico", que apresentamos no final de 2002, durante o curso de pós-graduação. O objeto de
análise foi o programa Globo Repórter exibido em 1 遖 de novembro de 2002 , sobre a trajetória de Luiz Inácio
Lula da Silva, eleito presidente da república alguns dias antes, em 27 de outubro. Nossa intenção foi 
A atual estética da televisão tende a dramatizar o real e a aproximar a ficção da estrutura do real, não permitindo que nenhum subgênero - mesmo os informativos, como telejornais, documentários e debates - escape à espetacularização, visto que há sempre uma fusão dos níveis de realidade discursiva a criar efeitos de ficção e de verdade. Para compreender a gramática televisiva, que também se funda numa estética da repetição, é preciso tentar desvelar que engrenagens da estrutura produtiva deixam vestígios nos produtos que editam o mundo para consumo. Com este trabalho, pretendemos dar alguma contribuição para esse necessário processo de revelação, sobretudo no que se refere às estratégias de produção do telejornal.

mostrar como certos elementos foram atenuados, ignorados ou apagados e outros ressoaram reiteradamente na enunciação, pela simulação de um discurso orientado para a alteridade interlocutiva. 


\section{A prática jornalística}

Para atingir os objetivos de análise do telejornal, é preciso antes percorrer os principais temas da discussão sobre a prática atual do jornalismo. Segundo Marcondes Filho (2002), pode-se dividir o jornalismo moderno em quatro fases: 1) a primeira se deu de 1789 à metade do século 19, com o jornalismo "da iluminação", um jornalismo político-literário, com fins pedagógicos e de formação política; 2) a segunda se iniciou na metade do século 19, época em que o jornal se fixou como grande empresa capitalista, em decorrência de inovações tecnológicas, e consagrou o jornalismo de massa; 3) a terceira fase é a do jornalismo que predominou no século 20 , o jornalismo dos monopólios, que busca menos a verdade, é menos engajado politicamente e não aposta tanto numa sociedade mais humana; 4) a quarta e última fase do jornalismo é a da era tecnológica, iniciada por volta dos anos 70. Para Marcondes, esse último tipo "é algo que hoje, com dificuldade, ainda se pode chamar de jornalismo" (2002:29).

Em relação ao jornalismo atual, Marcondes afirma que as novas tecnologias agem em dois planos: a) virtualizam o trabalho, fazem o profissional se submeter a uma lógica imaterial e definem novas relações e nova ética de trabalho; b) interferem nos conteúdos, favorecendo certas linguagens e desvalorizando outras. Especialmente quanto aos conteúdos, Marcondes analisa: "O fascínio da imagem, definido como critério principal dos meios visuais, passa a ditar a hierarquia da comunicação: primeiro, uma cena tecnicamente perfeita; depois, um texto, uma narrativa, uma notícia. A técnica viabiliza uma melhor montagem cênica de notícias e acontecimentos, com efeitos como se fossem reais. Os fatos fabricados concorrem em condições de superioridade (melhor técnica, mais dramaticidade, criação de cenas e situações vividas impossíveis de obter na realidade) com os fatos brutos ou reais" (op.cit.:31).

O jornalismo é, desde suas origens, um trabalho intermediário, mas o que tem havido hoje é que as análises, comentários e interpretações dos fatos têm se misturado com a enorme massa de dados do jornal e se tornado, em certa medida, inócuos e esquecidos. Segundo Marcondes, a produção informatizada e contínua de um jornal tende a triturar os fatos e análises, transformando-os num "produto insosso", apesar da aparência atraente, sem que se possa responsabilizar alguém por essa mudança na 
forma de fazer jornalismo, a não ser a própria tecnologização do mundo moderno (op.cit::37).

Essas novas condições de produção colocam o jornalista numa situação em que ele próprio precisa rever seus objetivos, sua formação e até sua ética. Como já vimos, a cultura das mídias transforma os veículos em máquinas, que se movem como motoperpétuos, causando a impressão de que o trabalho jornalístico funda-se mais na disputa de mercado do que num ideário profissional. Além disso, como aponta Marcondes, na tentativa de organizar de alguma forma o mundo complexo que descrevem, os jornalistas tendem a torná-lo mais caótico, na medida em que se satisfazem com as mesmas explicações e posições homogêneas diante dos fatos, repetindo os argumentos circulantes na mídia e agindo, não raro, como "porta-vozes da retórica do establishment" (op.cit::57).

Há mais de vinte anos, Nilson Lage já afirmava que a liberdade de imprensa é, na verdade, a liberdade do capital e que, de modo geral, a imprensa não falseia informações, mas procura revesti-las com a versão mais conveniente, por meio de técnicas de ocultam preconceitos e pontos de vista dos grupos sociais dominantes (2001:47-52). Do fato à versão, pode haver imensa distância, visto que, conforme Lage, não são os fatos que guiam os homens, mas os sistemas de crenças que se concretizam nas versões. Assim, derruba-se o mito da objetividade jornalística: "se contra fatos não há argumentos, é contra as versões que eles são cabíveis" (Lage, 1998:64). Portanto a crítica à imprensa não se resume hoje aos problemas de distorção das informações, de ocultamento da realidade ou de controle da opinião pública, mas avança na direção do caráter discursivo da prática jornalística, que está inserida num universo retórico, no qual se tem sempre em vista o comportamento resultante da persuasão.

Como a mídia faz parte do organismo social, não se pode deixar de considerar a co-responsabilidade do receptor na conformação da realidade visível, uma vez que as versões oferecidas pela mídia devem ser verossímeis e a seleção e a hierarquia dos assuntos devem coincidir com valores aceitáveis pelo público (cf. Lage, 1998:232), o que prova a natureza dialética do jornalismo. No entanto a balança não é tão equilibrada quanto deveria ser, já que os sujeitos produtores detêm o controle da circulação desses valores, selecionando e classificando fatos novos a partir de seus próprios estereótipos, 
num processo que os torna atores privilegiados na manutenção de idéias e na conservação da cultura. Lage afirma que grande parte dos jornalistas não sai pelo mundo para conhecê-lo, e sim para reconhecer e reforçar modelos já inculcados (op.cit.:109).

Outro aspecto desse contrato tácito entre mídia e público na construção da realidade é que, mesmo que se aceitem versões verossímeis no lugar de fatos reais, nem sempre ficam claros os processos dessa conversão discursiva. Lage observa que, à medida que as informações são transportadas para o texto, são sugeridas conexões, avaliações e teorias sobre o fato, muitas vezes aceitas em função do senso comum e de uma aparente unanimidade que apóia o sistema (2005:119). Raramente se constroem narrativas densas nas reportagens, preferindo-se a edição fragmentada de dados parciais de diferentes fontes, até por força da coerção temporal na produção da notícia.

Essa aglutinação de fragmentos dá ao texto jornalístico uma organização enciclopédica e redundante, em que não há espaço para a conexão com pensamentos anteriores e posteriores, a não ser pelo sugestivo jogo gráfico da diagramação de textos e fotos ou pelas sutilezas verbais das rubricas, manchetes e subtítulos, verdadeiros comentários dos fatos noticiados, que revelam, pela seleção lexical e pelas forma de relato, a escolha de alguns valores e a rejeição de outros. Segundo Marcondes, trata-se de repetições do mesmo sob diversos ângulos e a repetição substitui a demonstração: "No final, restam na memória do leitor apenas sinais, traços da informação que cada segmento porventura deixou. Ele não será capaz de recordar a matéria que acabou de ler e nem terá o conhecimento para aplicar essa informação adquirida em outros casos semelhantes. Foi-lhe negado o principal, o fio condutor" (2002:46).

Ressalvamos que não se pode afirmar o efeito produzido na memória do leitor, mas o procedimento usado pelos jornais parece gerar o que Serva (2001) chama de "desinformação funcional". Por mais abundantes que sejam as informações ou extensa a cobertura jornalística, é flagrante a ignorância dos leitores sobre as causas e conseqüências de determinados fatos. Poucos entendem realmente o que significaram acontecimentos como a guerra do Golfo, a guerra civil da ex-lugoslávia, a ocupação da Palestina por Israel, a intervenção dos Estados Unidos no Afeganistão e no Iraque, os ataques de 11 de setembro, sem falar de escândalos políticos e um sem-número de CPIs 
no Brasil. Serva tem procurado identificar no fazer jornalístico mecanismos que podem provocar a incompreensão do público nos casos em que há cobertura de longa duração.

No estudo que fez sobre a cobertura da guerra civil bósnia, dos anos 90 , o autor observou enorme falta de informação histórica sobre os conflitos. Um indicador disso foi o uso indiscriminado por todos os meios de comunicação do termo "limpeza étnica", empregado muitas vezes para descrever a expulsão de outras etnias pelas forças sérvias, sem dar a conhecer que essa prática sempre existiu nas guerras ocorridas nos Bálcãs. Outro traço marcante da cobertura era a constante troca de papéis, nos relatos da mídia, dos protagonistas do conflito: sérvios, croatas e muçulmanos eram tratados ora como vítimas, ora como algozes; ora croatas estavam massacrando muçulmanos, ora muçulmanos massacravam sérvios e croatas.

Da análise de diversos jornais e de extensa bibliografia histórica, Serva concluiu que "as diversas guerras" nos Bálcãs noticiadas pela imprensa eram partes de uma única guerra que vinha sendo travada ao longo dos séculos, portanto um único acontecimento histórico. Segundo Serva, tendo como base a lógica de que a imprensa deve vender novidades, as notícias não deixam ver a história, cuja lógica subjacente "parece ser compreensível apenas a quem observa os fatos por outra lente que não a do jornalismo" (2001:47). Essa obsessão pela novidade e a negligência para com a compreensão histórica dos acontecimentos caracterizam o conhecimento mediado pelos veículos de comunicação, que operam a desinformação por mecanismos que vão da omissão ou simplificação dos fatos à saturação das notícias, cujos efeitos mais importantes são um ponto de vista maniqueísta, como acontece provavelmente em todas as guerras, e a redução de fatos contemporâneos a arquétipos históricos (cf. Serva, op.cit::102).

Desviando-se da análise dos conflitos internacionais, em si bastante complexos para qualquer leitor, Serva dá um exemplo de como a imprensa trata os fatos como se fossem determinados por uma espécie de "geração espontânea": "Quando uma onda de criminalidade ocorre, sua lenta gestação se deu em anos ou décadas anteriores. Mas só quando explode é percebida como tal pela imprensa, e possivelmente pela opinião pública. $O$ fato novo se esgota em si então: o criminoso deve ser preso e condenado, o crime deve ser vingado. Mas as causas de longo prazo não são visíveis para o leitor" (op.cit.:109). Dessa forma, mesmo que os fatos dialoguem com outros fatos e por eles se 
expliquem ao longo da história, a mídia contemporânea os retrata como incoerentes e descabidos, portanto facilmente reorganizáveis segundo a lógica da espetacularização.

O poder paralelo do jornalismo de desinformar pode ser constatado não só nas grandes coberturas nacionais e internacionais, mas também na prática cotidiana das notícias locais. Há cerca de dez anos, Chaparro (1994) desenvolveu uma pesquisa sobre o modo como se manifestam, se escondem ou se simulam as intenções que controlam os textos da mídia impressa e apresentou propostas teóricas para uma descrição pragmática da ação jornalística, com vistas sobretudo à relação entre intencionalidade e ética. Ele acompanhou a realização de algumas reportagens e também rastreou a produção de outras por meio da reconstituição dos passos de pauteiros, editores, repórteres, fontes e entrevistados, a fim de comparar o processo com o produto final.

O pesquisador encontrou muitos problemas, que atribuiu ao desprezo pela ética e ao que chamou de "patologia de princípios" da prática jornalística: relatos equivocados, superficiais ou contraditórios, desvios de interpretação, omissão ou imprecisão de informações, opção ou desprezo por alguma versão, alteração de falas ou idéias, acusações apressadas e equívocos jamais retificados, reprodução de rumores mal investigados gerando informação falsa, manchetes tendenciosas, simulação jornalística da propaganda ou da argumentação partidária, distorção dos fatos por interesses diversos. Diante disso, Chaparro avalia que é necessário fazer uma abordagem pragmática do jornalismo, a fim de colocar no centro das questões a noção de "intenção" do fazer discursivo, que para ele é "a liga que funde ética, técnica e estética, tríade solidária e inseparável das ações jornalísticas" (1994:13), que devem sempre buscar o relato veraz em função do interesse público.

A proposta é bastante pertinente, mas deve ser complementada pela análise adequada do texto jornalístico como fundador de uma realidade discursiva, pois, como já foi dito, mesmo que os grandes veículos da imprensa se esforcem em ser objetivos e em buscar a verdade factual, eles jamais logram retratar a realidade. Nesse sentido, como observam Bucci e Charaudeau, não se trata apenas de criticar a conduta ética da imprensa, pois, por mais equilibrada e correta que ela seja, há algo na natureza do fato jornalístico que o torna sempre um fato discursivo. 
A notícia, diz Bucci, acontece sempre como elemento discursivo: "O MST sabe disso como Hollywood, Beatles ou Madonna sempre souberam. George Bush sabe disso ou alguém em seu nome sabe disso, pois a política americana vive disso, vive de gerar eventos, imagens, cenas, ícones. Os ativistas antiglobalização, que pipocam em todas as cidades do mundo, sabem disso quando atiram pedras contra as lanchonetes do McDonald's. Seus atos são atos de fala. Quebrando as vitrines da rede sanduicheira mundializada, interferem num signo da própria mundialização e, ao fazê-lo, interferem no discurso do mundo sobre o mundo. Assim alcançam a visibilidade - e a condição de ser notícia. (...) Entender os fatos é, quase sempre, entender o discurso que eles procuram articular por meio dos relatos jornalísticos" (2003:10). Volta-se assim à máxima que faz paráfrase do discurso do direito, que diz que "aquilo que não está nos autos não existe": "aquilo que não está na mídia não está no mundo".

Segundo Bucci, cada vez mais a mídia exerce uma função simbólica ordenadora de sentidos e valores, porém ele entende que o controle desse processo é mais da ordem do discurso do que propriamente da ordem das intenções. É no discurso que os fatos se tornam visíveis ou invisíveis, lembrados ou silenciados, e é nisso que reside o real poder do jornalismo. Na prática, isso se dá por um conjunto de estratégias que muitos já tentaram explicar, inclusive jornalistas comprometidos com a análise crítica da profissão. É o caso de Perseu Abramo, que há quase duas décadas propôs a descrição de padrões de manipulação observáveis na produção jornalística, sobretudo na imprensa escrita.

Num ensaio escrito em 1988 e inédito até 2003, Abramo explicita as operações normalmente utilizadas pela imprensa para produzir determinados efeitos, mas faz uma ressalva indispensável: "É importante notar que não é todo o material que toda a imprensa manipula sempre. Se fosse assim - se pudesse ser assim - o fenômeno seria autodesmistificador e autodestruidor por si mesmo, e sua importância seria extremamente reduzida ou quase insignificante. Também não é que o fenômeno ocorra uma vez ou outra, numa ou noutra matéria de um ou outro jornal; se fosse esse o caso, os efeitos seriam igualmente nulos ou insignificantes" (2003:25).

Segundo Abramo, os principais padrões de manipulação são os seguintes: 1) a ocultação, ou silêncio deliberado sobre determinados fatos da realidade, a partir da decisão de quais fatos são ou não jornalísticos; 2) a fragmentação, cujas duas operações 
básicas são a seleção de certos aspectos do fato e sua descontextualização; 3) a inversão, ou reordenamento das partes do fato e criação artificial de outra realidade (pode-se substituir o principal pelo secundário, a informação pela opinião, o fato pela versão oficial etc.); 4) a indução, que se manifesta pela recontextualização de fragmentos da realidade, pelo subtexto da diagramação, das manchetes, dos comentários, pela presença ou ausência de temas ou de grupos da sociedade.

Abramo conclui que a manipulação da informação é deliberada, pois os órgãos de comunicação estão submetidos à lógica econômica do capitalismo e à lógica do poder, recriando a realidade conforme diversos interesses. O sonho de Abramo era que a sociedade se organizasse e assumisse a tarefa de desmistificar a imprensa rumo a uma revisão dos conceitos de liberdade de imprensa e de expressão, que questionaria sobretudo o regime de propriedade privada dos órgãos de comunicação (op.cit.:50).

Como se vê, grande parte dos críticos do jornalismo contemporâneo é consoante sobre a dinâmica incontrolável da produção de notícias, mas insiste na necessidade premente da transformação dos jornalistas. Não basta limitar o debate à dicotomia dos que encaram a profissão como principal pilar da democracia e dos que a reduzem a mero instrumento do poder político e econômico. Há que se entender, como avalia Charaudeau, que a instância midiática é um "manipulador manipulado" em razão de suas próprias engrenagens, azeitadas por três fatores externos importantes: a agenda social, o poder político e a lógica comercial (2006:257). Por isso a análise estrutural da máquina midiática deve impor-se sobre as conjeturas ideológicas, sem no entanto desprezá-las.

Segundo Charaudeau, a verdade está presa numa armadilha: "o que acreditamos ser o visível do mundo é apenas um invisível, intocável, construído em visível pelo efeito conjunto da espetacularização e da projeção de nossa memória sobre o espetáculo" (op.cit::269), restando-nos desconstruir esse visível para compreendê-lo. Cabe às mídias ser mais responsável quanto à seleção dos acontecimentos, mais zelosa na identificação das fontes e na prática da citação, mais consciente dos efeitos que a encenação discursiva pode provocar. Não se deve concluir, como pondera Charaudeau, pela impossibilidade de as mídias servirem à democracia, mas é preciso que sua deontologia seja reconhecer as limitações da máquina midiática e rejeitar oferecer como realidade do mundo social aquilo que é apenas representação construída (op.cit.:276). 


\section{O telejornalismo}

Vejamos agora o jornalismo sob outra lente, que parece ampliar e multiplicar os problemas deontológicos, estruturais, éticos e discursivos. Como observa Marcondes, hoje em dia o que dá aos fatos jornalísticos o estatuto da existência é a televisão: "A condição de possibilidade da existência das coisas é entrarem no mundo da representação. E o que significa isso? Quer dizer que os fatos - todos eles - carecem de um tratamento midiático para efetivamente existirem. O novo sentido do ex-sistir (do 'sair de si') não está numa 'abertura do ser' (Heidegger), mas, ao contrário, num mascaramento, num representar o mundo de forma mais agradável, emocionante, espetacular" (2002:78).

Numa definição simplista, o telejornal é um jornal com imagens, que tenta capturar a realidade tal qual é: "Se o mundo é para nós colorido, a fotografia imediatamente virou cor. Se o mundo é dinâmico, o cinema tratou de processar as imagens num movimento fiel ao movimento das coisas tal como ocorre nas cenas da nossa percepção real. No entanto, faltava ainda vencer o descompasso do tempo. Veio, então, a televisão: o mundo flagrado no instante mesmo do seu ir existindo" (Santaella, 2003:61).

Ao lado de uma boa imagem, um texto curto e ágil, que persegue a exatidão da informação jornalística. Há quem diga que, no telejornal, o visual predomina sobre o verbal, mas entendemos que se trata de um processo de cooperação entre esses dois códigos, conforme mostra Rocco: "A imagem televisual não se basta a si própria, não se esgota em si mesma, já que não é auto-explicável. Se uma imagem pode valer por mil palavras, há momentos em que, talvez, nem dez mil imagens consigam expressar o poder polissêmico de uma única palavra" (1991: 240).

No entanto não é difícil compreender o mito da hegemonia da imagem se consideramos que muitas vezes, no exercício do telejornalismo, é dada prioridade ao componente imagético com o objetivo de magnetizar a atenção de um público bastante diversificado. Segundo Rezende, a produção telejornalística também tende ao formato espetacular, combinando o aproveitamento de imagens atraentes com um conjunto de 
notícias constituído essencialmente de fait divers ${ }^{12}$, do que decorre freqüentemente a desvalorização do poder expressivo das palavras (2000:25). Como essa relação entre imagem e palavra é essencial para a análise do telejornal, objeto desta tese, trataremos do tema na seção seguinte.

Há outras características que merecem atenção na descrição do subgênero informativo telejornal, entre elas a velocidade e a redundância. Se os meios impressos dispõem de tempo e espaço suficientes para mostrar os fatos em seus múltiplos aspectos - ainda que o façam de modo fragmentado -, a televisão tende a informar com o máximo de imediatismo, transformando-se num verdadeiro "documento do cotidiano", com um alto grau de veracidade (cf. Rezende, 2000:76), por isso um de seus traços mais notáveis é a redundância, que funciona como fator de inteligibilidade da mensagem. Não é demais reiterar, no entanto, que a redundância e a repetição podem ter outros efeitos, uma vez que toda enunciação é irrepetível e ganha novos significados e valores a cada realização.

$\mathrm{Na}$ televisão, por causa desse imediatismo, a organização anárquica que também caracteriza o jornal impresso parece ficar mais evidente. O telejornal precisa, ao mesmo tempo, dar conta do tempo do programa e manter a audiência. Nesse processo, são flagrantes a fragmentação e a personalização: os fatos são retirados de seu contexto e tratados como notícia isolada, da mesma forma que se coloca uma pessoa, ou personagem, no centro da notícia como vítima ou culpada de algo que muitas vezes é produto de um conjunto maior da sociedade (cf. Marcondes, 1988:54). O que hierarquiza esses fragmentos é o trabalho de edição, poderoso instrumento de reconstrução da realidade na dimensão multissensorial da mensagem televisiva.

O público não tem tempo de se deter em determinada cena, de contemplar os detalhes, de interpretar as conexões intertextuais, tampouco pode ver ou ouvir novamente a notícia, diferentemente do que se pode fazer com um jornal impresso ou, para citar uma mídia mais moderna, na internet. Aquilo que o público reterá da informação é sobretudo fruto das relações que a edição logra forjar pela disposição e pela redundância dos signos. Nesse sentido, Szpacenkopf (2003) diz que no processo de

\footnotetext{
${ }^{12}$ Trata-se de notícias gerais e variadas, sem muita profundidade. Pode-se dizer que são aquelas notícias baseadas no que Bourdieu chama de "fatos-ônibus", "que não devem chocar ninguém, que não envolvem
} 
escolha e de montagem da notícia usam-se estratégias que transformam o fato em acontecimento, este sim verdadeira matéria-prima da notícia televisiva.

A autora distingue então dois tipos de montagem: a técnica, que faz cortes e alinhava diferentes segmentos narrativos e visuais, e a "montagem branca", que provoca efeitos invisíveis: "O poder de olhar e de fazer olhar dá poder ao olhar que decide, seleciona, monta, corta, edita o que irá ao ar. O poder exercido pelas pessoas responsáveis pela produção e edição do telejornal obedece a regras e contratos que vão desde os de leitura até os que envolvem interesses políticos, econômicos e mesmo os das emissoras" (Szpacenkopf, 2003:16). Não há dúvida de que a atividade dos profissionais de jornalismo pressupõe mecanismos conscientes, ainda que camuflados pela rotina ou pelo hábito, e também inconscientes, como a pulsão do poder, mas interessam-nos mais os efeitos dessa montagem branca do que propriamente sua gênese, fincada numa multiplicidade de fatores já apontados.

A escolha das notícias e a definição da montagem mostram, por certo, a ingerência do poder de quem decide que versão dos fatos será adotada, mas é na materialidade discursiva dos telejornais que aflora o poder de fazer-ver, fazer-crer e, do ponto de vista desta tese, fazer-lembrar. Trata-se, portanto, de um potente discurso de autoridade, sobretudo por agregar a força das imagens ao poder ideacional das palavras. Se os efeitos da edição são invisíveis, não se pode dizer o mesmo dos recursos que os provocam: composição e repetição de imagens, chamadas e vinhetas, reiteradas formas de referenciação, confluência de vozes e comentários são alguns dos aspectos visíveis da montagem branca.

Da mesma forma que Chaparro acompanhou a produção de jornais impressos, Szpacenkopf pôde observar o trabalho de diferentes emissoras de televisão no Brasil, em Portugal e na França, desde a pauta até a edição das matérias, e diz ter se surpreendido ao constatar como os fatos podem ser empobrecidos ou superdimensionados (op.cit.:188). Além disso, chamou-lhe a atenção a uniformidade dos conteúdos 
internacionais distribuídos, na maior parte, por agências de notícias especializadas ${ }^{13}$. Segundo ela, uma conseqüência incontornável da supressão das fronteiras no mundo globalizado é que todos vêem as mesmas imagens nos telejornais.

É bastante conhecida a tese de Bourdieu de que os produtos jornalísticos são muito mais homogêneos do que se acredita, sobretudo porque a concorrência leva a isso e porque jornais e jornalistas estão sujeitos às mesmas restrições, às mesmas pesquisas de opinião, aos mesmos anunciantes (1997:31). Como notam Bistane e Bacellar, as pautas, os entrevistados e os especialistas consultados também são sempre os mesmos, "por comodismo ou falta de tempo para procurar outras fontes, e o resultado é que os telejornais, de maneira geral, não surpreendem" (2005:47). Isso caracteriza o círculo vicioso da informação e das idéias feitas, em que não há espaço - muito menos tempo para a reflexão.

O que resta é a mediação feita pelo telejornal entre o público e as fontes de informação, mediação extremamente poderosa, na medida em que a televisão é a única referência para grande parte da população e a verdade jornalística é sempre relativa, circunscrevendo-se ao que os profissionais conseguem ver, entender, organizar e divulgar para a audiência (cf. Curado, 2005:169). Cabe lembrar a definição de Charaudeau de que a mídia é um "espelho deformante" da realidade, o que compromete sobremaneira os fundamentos do jornalismo que ditam o equilíbrio entre os diversos pontos de vista sobre um acontecimento e a busca da verdade.

Barbeiro e Lima dizem que esse "jornalismo informacional", que se curva ao tempo dos eventos imediatos e simultâneos, "empurra os jornalistas em direção à perda da curiosidade, justificada pela falta de tempo em função da grande quantidade de dados disponíveis, colaborando decisivamente para a unanimidade de interpretação" (2005:47). Esse é um dos paradigmas que a produção dos telejornais apresenta desde o final do século 20: "a lógica da velocidade, a preferência do 'ao vivo', a substituição da verdade pela emoção, a popularização e o expurgo da reflexão" (Marcondes, 2002:80).

\footnotetext{
${ }^{13}$ Aronchi de Souza observa que as grandes agências internacionais são "donas" de cerca de $80 \%$ das informações que circulam no mundo, o que o leva a afirmar que "a crença plenamente compartilhada e claramente definida pelo Ocidente democrático é a de que uma imprensa livre é de origem privada, mantida pelo preceito econômico que define as nações capitalistas" (2005: 55).
} 
Não é sem razão, portanto, que Bucci afirma que, na televisão, "os cânones do jornalismo são anacrônicos" e que "a natureza da indústria cultural é incompatível com o projeto da verdade jornalística", uma vez que mistura espetáculo e informação num mesmo "balaio de imposturas éticas": "A busca da verdade era um projeto da razão e os conglomerados há muito se divorciaram da razão. Não porque seus gestores sejam pessoas mentirosas, mas pela própria natureza dos conglomerados e da comunicação tiranizada pela imagem. Onde quer que a notícia esteja a serviço do espetáculo, a busca da verdade é apenas um cadáver" (2004:129).

A indignada conclusão de Bucci é que tudo isso decorre de uma submissão econômica das emissoras: "O negócio do telejornalismo não é o jornalismo. Seu negócio é outro. Seu negócio não é sequer a veiculação de conteúdos. As grandes redes de televisão aberta têm como negócio a atração dos olhares da massa para depois vendêlos aos anunciantes" (op.cit.:130) ${ }^{14}$. A conformação da mídia, como a descreve Bucci, cristaliza em sua própria natureza padrões tecnológicos, ideológicos, lingüísticos, imaginários e éticos, cujos mecanismos e efeitos só nos resta tentar compreender.

\footnotetext{
${ }^{14}$ O programa Observatório da Imprensa exibido em 7 de março de 2006, pela TV Cultura, aproveitou o lançamento do filme Boa Noite, Boa Sorte no Brasil para traçar um paralelo entre o telejornalismo feito na década de 50 e o atual. O filme mostra como o idealista Edward Murrow, nos primórdios do noticiário televisivo, enfrentou o terror político imposto pelo senador Joseph McCarthy nos Estados Unidos. O professor de jornalismo Antônio Brasil, que participou do debate promovido pelo programa, lembrou que Murrow, num discurso de 1958, fez um aviso: "Nossa história será o que fizermos dela". Segundo Brasil, pelo que se vê cinqüenta anos depois, o telejornalismo tomou a direção errada.
} 


\section{A palavra e a imagem no telejornal}

O professor Nilson Lage diz que não existem radiojornalismo ou telejornalismo. Segundo ele, tudo é jornalismo, só que adaptado a diferentes meios tecnológicos (2005:161). Vejamos, pois, como tende a se manifestar o discurso jornalístico na televisão. Há os que avaliam que o telejornal se estabelece sob o império das imagens; outros julgam haver uma necessária intercooperação entre os códigos visual e verbal.

Segundo Rezende, na comunicação audiovisual as sensações predominam sobre a consciência, assim como os valores emocionais prevalecem sobre os valores racionais, por isso seria evidente a hegemonia das imagens sobre o conteúdo verbal, sobretudo quando há possíveis conflitos entre os códigos (2000:40). Num contexto em que prevalece a lógica do espetáculo, a palavra assumiria um lugar de submissão à imagem, cabendo-lhe o papel de enriquecer a informação visual.

No entanto Rezende não hesita em lembrar que há muitos profissionais de televisão que perseguem o equilíbrio entre o esmero da forma e a qualidade jornalística. Ele mesmo define, com precisão a nosso ver, a importância da palavra no telejornalismo: "A interveniência da palavra tem o poder de, em muitas circunstâncias, orientar até mesmo o público na interpretação das imagens. Quando bem escolhidas, as palavras podem determinar a reação do público, por exemplo, à imagem de um protesto. A impressão de sucesso ou fracasso da manifestação depende, muitas vezes, mais do que se diz do que das imagens mostradas" (Rezende, op.cit.:81).

Acreditamos que está na convergência do visual e do verbal toda a capacidade retórica do telejornal. Entenda-se "retórica" em todos os sentidos que a palavra tem acumulado desde a antigüidade clássica, que implicam sobretudo a controvérsia e a negociação, a persuasão e a ação que lhe corresponde, a influência recíproca entre forças sociais, a confluência entre razão e emoção. Mesmo sem o saber, muitos críticos aproximam suas análises do universo retórico, ao falar de traços da apresentação que dão significados complementares ao texto - como gestos, expressão facial, pausas, entonação, ênfase - ou de questões como a credibilidade e a inter-relação entre componentes racionais e afetivos, na qual por ora nos detemos. 
Diferentemente dos que cultivam o mito do império da imagem e dos que vislumbram a interdependência entre o verbal e o visual, Martín-Barbero apresenta uma análise que, em nosso entendimento, explica a genética retórica da televisão brasileira: "Durante muito tempo se criticou a predominância do verbal na televisão latino-americana como a melhor prova de seu subdesenvolvimento: era o rádio com imagens. Mas hoje, quando o desenvolvimento técnico e expressivo da televisão em boa parte de nossos países torna impossível essa explicação, começamos a suspeitar de que a predominância do verbal na televisão se inscreve na necessidade de subordinar a lógica visual à lógica do contato, dado que é esta que articula o discurso televisivo sobre o eixo da relação estreita e a preeminência da palavra em culturas tão fortemente orais" (1997:294).

Ainda segundo Martín-Barbero, pode-se observar essa característica também no telejornalismo, que recorre a dois elementos intermediários fundamentais na facilitação do trânsito entre a realidade cotidiana e o espetáculo ficcional: o "apresentador-animador" (presente em vários tipos de programa, inclusive no telejornal) e um certo tom que instaura um clima de familiaridade. Entendemos que esse contato necessário ao jogo da persuasão é construído por componentes imagéticos, cenográficos e sobretudo verbais, que instauram uma virtual interlocução com o público.

A televisão, como diz Sodré, pode mostrar qualquer coisa, mas tem de explicar o que mostra, e nessa operação o verbo se impõe ao elemento visual (1984:74). A reflexão que Curado faz sobre o exercício do telejornalismo vai na mesma direção. Ela defende que não se pode aceitar o jugo da imagem, sob pena de revogar a base sobre o qual o jornalismo de assenta, que é o princípio da informação: "O encantamento pelo vídeo pode produzir uma farsa, ainda que exiba um bom espetáculo. Ao afirmarmos que 'TV é imagem' nos esquecemos de que a imagem informativa pressupõe um contexto, ou será o fácil encadeamento de flagrantes" (Curado, 2002:11).

Curado critica a forma simplista como muitas vezes se pratica o jornalismo na televisão e que reduz o acontecimento àquele momento em que a câmera o captura. Com isso, reduz-se o jornalismo a uma coleção de cenas e impõe-se uma simplificação rude da história. Segundo Curado, "quando o fio condutor de uma reportagem é a seleção de imagens espetaculares, o material que resulta daí é um clipe jornalístico" (op.cit.:170). 
De seu ponto de vista, o jornalismo de televisão, ao supervalorizar a imagem, demonstra pouca compreensão do papel do pictórico e opera num limite que ameaça a missão de informar. Se "a imagem é a aparência do fato, mas não é o fato", em termos ideais o jornalismo precisa fornecer as referências do contexto e as conexões que demonstram como o fato aconteceu para que se entenda a dimensão da informação visual (Curado, op.cit.:173).

Não se pode supor, agora conforme Duarte, que a imagem do acontecimento seja suficiente para the conferir significação, estabelecendo a ilusão de que ver é compreender, nem se pode render à prática de informar somente o que tem uma face visível, "o que condena os fatos pobres em imagens à indiferença e ao silêncio" (2004:81). Segundo Duarte, hoje os jornais televisivos adotam uma concepção especial de informação, segundo a qual informar é "mostrar a história em-se-fazendo", daí a importância da imagem, que deve ser entendida como um recurso narrativo. A imagem que instaura o ato de mostrar revela o ponto de vista de quem mostra, mas o narrador produtor do telejornal - usa diversas estratégias para apagar esse olhar e criar o efeito de mera mostração, que é um dos procedimentos fundantes da meta-realidade ${ }^{15}$ (cf. Duarte, op.cit.:113).

Paralelamente a essa função de criar efeito de veracidade, a imagem tem importante papel afetivo e cognitivo, contribuindo para a formação de memória social: "Si la presse écrite est le lieu d'une multiplicité de modes de construction, la radio suit l'événement et définit le ton, tandis que la télévision fournit les images qui resteront dans la mémoire et assureront l'homogénéisation de l'imaginaire social" (Véron, 1979:170).

Essa capacidade da imagem, conforme nossa tese, é potencializada pelos componentes lingüísticos do discurso híbrido do telejornal, que é construído de modo singular. Diferentemente do jornalismo impresso, que faculta diversos modos de leitura do amplo espectro de notícias, a estrutura do telejornalismo impõe uma única forma de "leitura" das fatias de realidade que selecionou e editou em blocos lineares do programa. Numa instância mais pragmática, cabe a um grupo de editores "a decisão sobre o que irá

\footnotetext{
${ }^{15}$ Esse conceito foi apresentado no tópico "A crítica da televisão", neste capítulo.
} 
alimentar o imaginário popular"16 e a montagem das notícias que vai apresentar. Isso constitui um verdadeiro quebra-cabeça, pois é preciso articular as matérias no espaço e no tempo da televisão sem descuidar da inteligibilidade e da estética ou distrair-se dos objetivos jornalísticos e dos interesses econômicos da programação.

A resultante é uma estrutura em movimento, que tem de atender aos imperativos da instantaneidade, testemunhalidade, indivisibilidade de imagem e som, sintetização e objetividade do telejornal (cf. Barbeiro e Lima, 2005:97). Porém, mais do que isso, o processso resulta no que muitos críticos definem como uma estrutura melodramática. Segundo Bucci, a principal regra do melodrama que o telejornal segue é o permanente conflito entre o bem e o mal, com direito, se possível, a uma moral da história e a um happy end em cada bloco ou a cada dois blocos: "Se uma informação trata de uma guerra no exterior, a outra busca realçar a fraternidade que temos em nosso país; se uma frase conta que a inflação foi muito alta, a seguinte garante que o rendimento da poupança será um recorde" (2005:31). Por meio dessa estrutura mais dramática do que factual, o telejornal busca falar à razão e ao coração, sem o que não obteria sucesso.

Charaudeau explica que o discurso das mídias se caracteriza por uma finalidade ambígua, já que o organismo informador deve ao mesmo tempo atender a uma demanda social da informação e à necessidade de captar o público que divide com a concorrência, em razão do que tem de lançar mão de contínuas estratégias de sedução (2006:58). Portanto não é raro encontrar, nos telejornais, o cruzamento de reportagens e roteiros de filmes, sobretudo quando se trata de relatos de conflitos, guerras ou catástrofes naturais. Assim, no processo que Charaudeau chama de "roteirização visual entre ficção e realidade", anuncia-se o que desencadeou o conflito, exibem-se as imagens do drama e das vítimas, mostram-se as ações de socorro ou resolução do problema (op.cit.:244). Nesse roteiro, os atores são sempre os mesmos: vítimas, responsáveis e heróis.

O espetáculo visual, garantido por todo o aparato de edição de imagens, torna-se tão importante quando o acontecimento transmitido pela televisão. Assim o noticiário, como descreve Marcondes, "de um lado, funciona como lembrança, evocação, alusão a uma realidade ('infelizmente') existente fora das telas; de outro, é objeto de um trabalho

${ }^{16}$ Conforme artigo "O seletor de canais e a cidadania", de Paulo José Cunha, publicado no site do Observatório da Imprensa em 29 de agosto de 1999. 
intensivo, radical, reestruturante, com efeitos visuais, cores, tabelas, exatamente para minimizar o mal-estar desse 'retorno à realidade'" (2002:42). Dessa forma, ainda no dizer de Marcondes, o mundo deixa de ser uma realidade que precisa ser explicada e compreendida e torna-se algo a que se assiste como um "filme de aventura".

Por fim, ainda em relação ao problema da "verdade jornalística", cabe dizer que ela extrapola a não coincidência entre o fato e sua versão. Existe uma verdade que, segundo Lage, está disposta "no paradigma da escolha de palavras, da ordem e seleção dos acontecimentos, dos lapsos entre uma e outra informação e das sugestões que deixa ao consumidor sobre como preenchê-los", "é a verdade como adequação histórica" (2001:154). Nesse sentido, interessa-nos sobretudo o papel das palavras que constroem uma das faces do telejornal.

Há hoje, segundo Citelli, uma tendência à uniformização das referências lingüísticas que circulam na mídia e uma aparente redução do mundo das palavras no jornalismo. Ele observa que, nos jornais e telejornais, é comum o encurtamento de frases e textos, em certa medida porque há delimitação de espaço e de tempo e porque é preciso simplificar a mensagem para o público, mas não só por isso. Para Citelli, existe "uma tendência reificadora na utilização das palavras mediáticas", que as transforma em "palavras-mercadorias", separadas da história, sob pressão do mercado e da impaciência do mundo contemporâneo: "O preço a ser pago para se dizer tudo em quase nada é que praticamente nada pode ser dito, a não ser sob a forma do efêmero, do descontínuo e da simulação" (2001:35). Conforme esse ponto de vista, há menos palavras em circulação e elas parecem estar perdendo a capacidade de nomear as coisas devidamente. Da mesma forma, observa-se que não há mais compromisso ético com as palavras, que têm sido apartadas de suas raízes históricas, morais, culturais e emocionais, sendo ossificadas em lugares-comuns e passando a servir à cultura do espetáculo (cf. Citelli, op.cit.:37).

O fenômeno é captado em diferentes manifestações lingüísticas, que compreendem eufemismos, metonímias, metáforas de uso, expressões generalizantes ou subvertidas, escolhas lexicais que revelam juízo de valor e muitas outras formas. Tomemse como exemplos expressões como "intervenção cirúrgica" (para definir uma guerra em que "oficialmente" não há vítimas), "guerra preventiva" (para designar a ação militar 
arbitrária de determinados governos) e "processos de paz" (termo usado mesmo em casos em que se usa a força); ou a escolha que se faz entre "líder" e "governante", "guerrilheiro" e "combatente", "grupos de resistência" e "rebeldes".

Marcondes afirma que muitos jornalistas contribuem para a desinformação quando usam - tendenciosamente ou não - termos indevidos, que ele chama de "termos-engodo" (2002:113), para minimizar os problemas ou exagerar sua periculosidade. É semelhante a análise de Lage, que considera um desafio para o jornalista refletir, por meio do discurso, a realidade de maneira mais justa: "Por exemplo, como evidenciar que um suposto prisioneiro de guerra foi seviciado por seus captores, quando a nomeação previamente dada chama o prisioneiro de terrorista e os captores de força de paz?" (2001:149).

Tudo isso evidencia que não existe notícia neutra, assim como não existem efeitos inócuos. Como aponta Curado, no jornalismo de televisão, "não há cena aleatória ou palavra que não tenha significado ideologizado; pouco importa se o repórter ou o editor tenha absoluta consciência disso" (2002:170). Nesta tese, mostraremos uma face visível desse processo, por meio da análise do discurso verbo-visual de dois telejornais e de seus efeitos possíveis no que toca à formação de memória social. Passemos então ao capítulo das formulações teóricas que formam o tecido conjuntivo deste trabalho. 


\title{
CAPÍTULO 2
}

\section{NAS REDES DA TEORIA - O TECIDO CONJUNTIVO}

\author{
PRIMEIRA PARTE - TEORIAS DO dISCURSO
}

\begin{abstract}
A ideologia se produz justamente no ponto de encontro da materialidade da língua com a materialidade da história. Como o discurso é o lugar desse encontro, é no discurso (materialidade específica da ideologia) que melhor podemos observar esse ponto de articulação. (Eni Orlandi)
\end{abstract}

Apresentamos um quadro teórico em que se articulam conceitos afins e complementares e que nos guiará na investigação de importantes elementos argumentativos da estrutura discursiva do telejornal. Não fosse argumentativa a dimensão desse discurso, congregando razão e emoção, dificilmente lograria alcançar os efeitos sobre a memória social que supomos haver. Encontramos pontos de contato úteis para nossa análise nas teorias da argumentação e da enunciação, na análise do discurso e na pragmática textual, o que, a nosso ver, evidencia que essas abordagens não se excluem, mas contemplam sob perspectivas fronteiriças o amplo fenômeno da prática discursiva, colocando em relevo determinados aspectos do objeto de estudo.

Não é nova essa proposta - haja vista as pesquisas circunscritas ao que se chama de análise crítica do discurso, que incorpora elementos de natureza diversa -, mas pode ser problemática, como aponta Sírio Possenti ao especular sobre a possibilidade de conjunção entre pragmática e análise do discurso. Segundo o professor, "qualquer teoria do discurso deve tentar explicitar o papel dos fatores propriamente lingüísticos, dos fatores pragmáticos e dos fatores históricos, já que todos são relevantes para a análise dos textos ou discursos - embora, provavelmente, de maneira desigual"17. Entendemos que essa relevância desigual se refere menos a uma hierarquia entre os fatores do que ao ponto de vista do qual se olha o texto ou discurso.

\footnotetext{
17 "Pragmática na análise do discurso", texto xerocopiado e sem data, discutido no curso "Análise do discurso: enunciação, polifonia e construção do sentido", freqüentado no segundo semestre de 2002.
} 
Numa breve comparação entre análise do discurso e pragmática, Possenti destaca: "Ao falar de texto ou discurso, os analistas do discurso tematizam o interdiscurso, a polifonia, o processo histórico de produção; os pragmaticistas tematizam a coesão, a coerência, o processo interpessoal de produção e compreensão. Categorias relevantes para os analistas do discurso são o pré-construído, a memória discursiva; para os pragmaticistas, a memória de curto ou longo prazo, o conhecimento partilhado". Tal constatação serve, no entanto, como base do questionamento proposto pelo pesquisador: "Cada um desses programas pode, sem perdas relevantes, dispensar-se de considerar as propriedades do acontecimento discursivo que o outro campo considera constitutivas?"

Não temos a pretensão de esboçar uma teoria que conjugue as diversas disciplinas que cingem o objeto discurso, mas, assim como Possenti, julgamos que a análise discursiva e a pragmática - e aqui incluímos a análise da argumentação - não precisam ser excludentes, se bem delimitados os conceitos que se pretende examinar.

Diga-se até que muitas noções desta ou daquela linha teórica estão abrigadas sob o mesmo teto em importantes dicionários de análise do discurso, o que justifica a afirmação de Orlandi de que a análise do discurso é uma "ciência nômade", que redimensiona seu objeto, seus aspectos teóricos e métodos a cada passo, tornando-se por isso mesmo mais fecunda (1987:11). Isto posto, passamos à exposição das teorias que articularemos na análise do discurso telejornalístico, objeto em si mesmo sincrético.

\section{Retórica e argumentação}

As teorias do discurso atualmente conhecidas são tributárias, em grande medida, à retórica antiga, que desde sempre tratou do processo e do produto da atividade discursiva, compreendendo questões de que até hoje se ocupam os estudiosos dos mais diferentes domínios das ciências da linguagem. Da escolha dos melhores argumentos para cada situação comunicativa à organização estrutural e lingüística do discurso; das estratégias verbais e paraverbais usadas pelo enunciador aos efeitos de persuasão pretendidos; do jogo de imagens construído pelos sujeitos da comunicação à natureza dos saberes que constituem a prática discursiva; todos os aspectos fundadores da retórica têm sido continuamente investigados nos discursos contemporâneos à luz de 
novas perspectivas teóricas da análise do discurso, da pragmática, da lingüística textual, da sociossemiótica e de outras áreas correlatas.

Um ponto em que muitas dessas perspectivas se cruzam é o que concerne à natureza argumentativa da linguagem do homem como ser social, que a põe em prática numa infinidade de discursos, entre eles o político, o filosófico, o literário, o jurídico, o religioso, o científico, o midiático. Todo discurso, em maior ou menor grau, é argumentativo, portanto toda abordagem que se faz nas teorias do texto ou do discurso acaba por ao menos tangenciar aspectos ligados à persuasão, que objetiva a adesão dos ouvintes às teses que se lhes apresentam, tendo como pressuposto que todo espaço discursivo é um espaço polêmico.

Aristóteles, ao definir a retórica como um sistema em que a argumentação predomina quando a demonstração não é possível, repensará também o conceito de dialética, entendendo-a como um instrumento intelectual de argumentação, que se aliará a outros instrumentos afetivos. A dialética, em vez de orientada para a procura metódica da verdade, passa a funcionar num campo em que é possível raciocinar a partir do provável, mas de modo lógico e rigoroso. Alguns proponentes das novas retóricas, como Perelman e Meyer, desdobraram essa concepção no que se pode chamar de "racionalidade argumentativa", que se funda na lógica do verossímil, do possível e do preferível e numa noção alargada de razão, que não está apartada da vontade (cf. Grácio, 1993).

Trata-se de uma racionalidade que articula razão e vontade em nome do razoável e que não pode ser descontextualizada nem desumanizada, visto estar eminentemente ligada a discursos que não pretendem a evidência, mas a persuasão, isto é, a mudança de crenças, valores ou opiniões, que pode levar à transformação da ação num mundo que é ao mesmo tempo sensível e inteligível. A racionalidade argumentativa sintetiza, portanto, o eixo em torno do qual se articula todo discurso: a mobilização simultânea de ethos, logos e pathos, tríade que garante os efeitos retóricos de agradar, informar e comover, estudados desde a antigüidade.

Não sustentaremos este trabalho na retórica clássica ou nas novas retóricas, mas extrairemos delas concepções importantes que se vinculam ao objetivo da tese, sobretudo porque o discurso jornalístico representa um lugar social privilegiado das atuais 
práticas retórico-argumentativas. Um ponto fundamental a considerar é que toda argumentação pressupõe acordo do auditório ${ }^{18}$ com relação a determinados objetos, entre os quais as premissas do discurso, que podem se fundar em fatos, verdades, presunções, valores, hierarquias ou lugares do preferível.

Podem figurar como premissa fatos de observação ou fatos supostos, convencionais, possíveis ou prováveis. No entanto Perelman e Tyteca afirmam: "Só estamos em presença de um fato, do ponto de vista argumentativo, se podemos postular a seu respeito um acordo universal, não controverso. Mas, por conseguinte, a nenhum enunciado é assegurada a fruição definitiva desse estatuto, pois o acordo sempre é suscetível de ser questionado e uma das partes do debate pode recusar a qualidade de fato ao que afirma seu adversário" (1996:75). Assim, quando é preciso recorrer a um acordo acerca das condições de verificação de um fato, já se está em pleno território da atividade argumentativa.

As verdades são sistemas mais complexos, relativos a ligações entre os fatos, presentes em teorias científicas e em concepções filosóficas ou religiosas que transcendem a experiência. As presunções estão ligadas ao normal e ao verossímil, à sensatez das ações humanas, ao interesse do auditório e à sua credulidade natural, segundo a qual o que é dito é dado como verdadeiro, na medida em que não se tem motivo para desconfiança. Note-se que as noções de normalidade e sensatez também são objetos de acordo, uma vez que se referem a comportamentos presumidos. Fatos, verdades e presunções gozam do mesmo estatuto de premissa nas argumentações até que sejam postos em discussão.

Os valores, quando tomados como premissa, são usados para motivar o auditório a fazer certas escolhas e, sobretudo, para justificá-las. Assim como os fatos, os valores podem ser desqualificados, subordinados a outros valores ou interpretados pelo auditório conforme sua visão de mundo. Há os valores abstratos, como a justiça, a verdade e a lealdade, que estão ligados ao meio cultural, e os valores concretos, ligados a um

\footnotetext{
${ }^{18}$ No Tratado da Argumentação, Perelman e Tyteca definem "auditório" como "o conjunto daqueles que o orador quer influenciar com sua argumentação" (1996:22). De modo geral, a argumentação destina-se a auditórios particulares, determinados por contingências sociais, culturais e históricas, mas pressupõe sempre um auditório universal, que é construído idealmente pelo orador como aquele que pode aceitar com unanimidade suas teses.
} 
indivíduo, a um grupo ou a um objeto particular. As hierarquias estão estreitamente ligadas aos valores e também se dividem em concretas e abstratas. São exemplos de hierarquia a superioridade dos homens sobre os animais, a dos deuses sobre os homens, a do justo sobre o útil, a do fim sobre o meio, a do mais sobre o menos.

Os lugares (ou topoi) são premissas de ordem muito geral, que a retórica clássica definia como "depósitos de argumentos" ou "argumentos típicos", hoje conhecidos como "lugares-comuns". Em sentido amplo, lugar é uma premissa cujo alcance varia segundo as culturas e que possibilita encontrar os argumentos ou os contra-argumentos mais adequados para determinada tese. Na perspectiva da nova retórica, tem-se a seguinte classificação: a) lugares da quantidade; b) lugares da qualidade; c) outros lugares.

Lugares da quantidade são os lugares-comuns que afirmam que alguma coisa é melhor do que outra por razões quantitativas. Por exemplo, um mal duradouro é um mal maior do que um mal passageiro, o todo é melhor do que a parte, o provável é preferível ao improvável, o fácil ao difícil. Os lugares da qualidade aparecem na argumentação quando se contesta a virtude da quantidade e se quer valorizar o único, em oposição ao comum, ao corriqueiro, ao vulgar. Os outros lugares seriam: a) lugares da ordem (afirmam a superioridade do anterior sobre o posterior, ora da causa ou dos princípios, ora do fim ou do objetivo); b) lugares do existente (afirmam a superioridade do que existe, do que é atual, do que é real, sobre o possível, o eventual ou o impossível); c) lugares da essência (concedem um valor superior aos indivíduos que melhor representam sua espécie ou encarnam um padrão); d) lugares da pessoa (vinculados à sua dignidade, ao seu mérito, à sua autonomia).

Ao lado de noções como as de auditório, acordo e premissas, devemos considerar a forma de apresentação dos dados no discurso argumentativo. De acordo com Perelman e Tyteca, "o fato de selecionar certos elementos e de apresentá-los ao auditório já implica a importância e a pertinência deles no debate, porque semelhante escolha confere a esses elementos uma presença, que é um fator essencial da argumentação" (1996:132). Para melhor mover a vontade, recorre-se ao procedimento de tornar presentes certos componentes do discurso, mas essa presentificação não está ligada exclusivamente ao tempo e ao espaço em que se circunscreve determinado acontecimento. Afirmam Perelman e Tyteca: "Há que observar, aliás, que o esforço para tornar presente à 
consciência pode referir-se não só a um objeto real, mas também a um juízo ou a todo um desenvolvimento argumentativo. Esse esforço visa, na medida do possível, fazer que se ocupe, com essa presença, todo o campo da consciência e isolá-lo, por assim dizer, do conjunto mental do ouvinte" (op.cit::134). Segundo esses autores, tão marcante quanto a imposição da presença de determinada interpretação é a supressão deliberada de certos elementos, fenômeno que por si só mereceria estudos mais detalhados.

Esse processo que garante a presença de certos dados ou juízos, em detrimento de outros, interessa-nos sobretudo por mobilizar estratégias que interferem no modo de apresentar o mundo e classificar as coisas. O uso desse ou daquele epíteto, que resulta da seleção de uma qualidade que se quer enfatizar, é um bom exemplo disso. Escolher nomear um exército como "forças de paz", um bombardeio aéreo como "intervenção cirúrgica" ou qualificar alguém como "governante" ou "ditador" implica pontos de vista não raro tendenciosos. Perelman e Tyteca salientam que as qualificações são importantes figuras argumentativas e podem produzir efeitos surpreendentes.

Igualmente, noções como "justiça" e "liberdade" são passíveis de uso argumentativo: "Em geral, quando uma noção caracteriza sua posição pessoal, o orador a apresenta como sendo não confusa, mas flexível, rica, ou seja, como contendo grandes possibilidades de valorização e, sobretudo, como podendo resistir aos ataques de experiências novas. Em contrapartida, as noções vinculadas às teses do adversário serão congeladas, apresentadas como imutáveis" (Perelman e Tyteca, op.cit.:156).

A nova retórica propõe, então, o estudo das figuras de linguagem em estreita relação com a função que cumprem na argumentação, focalizando, na forma do discurso, "os meios que possibilitam a uma determinada apresentação dos dados situar o acordo num determinado nível, imprimi-lo com certa intensidade nas consciências, enfatizar alguns de seus aspectos" (Perelman e Tyteca, op.cit.:162). Nesse sentido, toda figura é considerada figura retórica e todo recurso lingüístico pode ser argumentativo, como as modalidades usadas na expressão do pensamento (certeza, dúvida, possibilidade, ordem etc.) ou a escolha entre subordinação e coordenação, que podem hierarquizar valores ou modificar consideravelmente as premissas do discurso.

Todos esses mecanismos são importantes, mas nos deteremos, para os fins desta tese, apenas em algumas figuras de retórica consideradas eminentemente 
argumentativas. De acordo com a nova retórica, a figura deixa de ser mero ornamento quando existe a percepção de seu pleno valor como argumento, o que só é possível quando seu emprego parece normal num determinado contexto, isto é, se a figura não chama a atenção sobre si mesma e se camufla na ordem natural do discurso. As figuras retóricas são divididas em figuras da escolha, da presença e da comunhão, conforme sua função de impor ou sugerir uma escolha, aumentar a presença ou realizar a comunhão com o auditório.

São figuras da escolha a definição oratória (que não define o sentido, mas põe em destaque certos aspectos de uma realidade), a perífrase e a antonomásia (que são expressões substitutas de um termo ou nome), a metonímia (que representa a escolha de um nome em lugar de outro para designar certa realidade), a prolepse ou antecipação (que insinua a substituição de uma qualificação que poderia levantar objeção por outra) e a retificação (que salienta a legitimidade de uma escolha).

São figuras de presença a repetição (técnicas das mais simples para criar presença, pois reside na insistência de imagens, palavras ou idéias), a amplificação (desenvolvimento oratório de um assunto), a sinonímia (também um tipo de repetição, que funciona como uma correção abreviada), o pseudodiscurso direto (atribuição fictícia de palavras a outros), a hipotipose (descrição detalhada) e a enálage de tempo (substituição de um tempo por outro para aumentar o efeito de presença).

Algumas figuras de comunhão, que facilitam a adesão do auditório por meio de referência a uma cultura, a uma tradição ou a um passado comum, são a alusão, a citação, os clichês, as máximas, os provérbios, as expressões estereotipadas, as fórmulas rituais, a interrogação oratória e a enálage de pessoa (substituição de "eu" por "nós", por exemplo).

Muitas dessas figuras de retórica são contempladas em outras linhas teóricas sob rótulos e definições diferentes, mas seu valor argumentativo não deixa de ser apontado qualquer que seja a perspectiva de análise. Essa função retórica será observada no exame do corpus, assim como argumentos bastante específicos, tendo em vista que não faz parte de nossos objetivos a descrição detalhada, segundo as definições da nova retórica, das estratégias argumentativas presentes no objeto analisado. Observaremos, portanto, se se mostrarem relevantes, argumentos incluídos em três tipos básicos de 
associação de noções, conforme a conceituação de Perelman e Tyteca: a) os argumentos quase-lógicos, b) os argumentos baseados na estrutura do real; c) as ligações que fundamentam a estrutura do real.

Estão na categoria dos argumentos quase-lógicos aqueles que têm aparência demonstrativa e apelam para raciocínios lógicos (contradição, identidade, comparação, transitividade) ou matemáticos (relação de parte com o todo, do menor com o maior, relação de freqüência). Os argumentos baseados na estrutura do real são aqueles que estabelecem uma ligação entre um fato e suas causas ou conseqüências, entre uma pessoa e seus atos, um grupo e seus membros ou, em síntese, entre uma essência e suas manifestações. Um bom exemplo desse tipo de argumento é o argumento de autoridade, em que se toma como válida a palavra de uma pessoa em razão do prestígio de que ela goza.

As ligações que fundamentam a estrutura do real são aquelas das quais derivam argumentos que operam pela particularização, como o exemplo, a ilustração, o modelo e o antimodelo, ou pelo raciocínio analógico, como a metáfora. A argumentação pelo exemplo permite generalizações e tende a fundamentar uma regra. Quando invocado numa argumentação, o exemplo deverá, visto que tem caráter empírico, ter estatuto de fato, do qual o auditório não duvidará. A ilustração, diferentemente do exemplo, não fundamenta uma regra, mas reforça a adesão a uma regra já conhecida e aceita pelo auditório. Esse tipo de argumento permite esclarecer um enunciado geral por meio de casos particulares, assumindo a função de figura de presença no discurso. Quando um comportamento particular tem como função não apenas fundamentar ou ilustrar uma regra geral mas estimular ou rejeitar uma ação, está-se diante, respectivamente, do modelo ou do antimodelo.

O raciocínio por analogia pode ser, além de um fator de invenção, um meio de prova. Se tomada como uma similitude de estruturas (A está para $B$ assim como $C$ está para D), a analogia terá, por evidente, seu valor argumentativo reconhecido. A analogia divide-se em tema, que encerra a conclusão, e foro, que sustenta o raciocínio analógico, esclarecendo o sentido do tema ou estabelecendo-lhe um valor. Entre os termos do tema e do foro, cujas naturezas devem ser diferentes - e aqui está a principal diferença entre 
analogia e comparação, na qual se cotejam elementos homogêneos -, há sempre uma relação assimétrica, que será posta em discurso com intenção argumentativa e para cuja interpretação se apelará ao raciocínio do auditório, o que, de modo geral, produz resultados eficazes. Segundo Reboul, "o foro é em geral retirado do domínio do sensível e concreto, apresentando uma relação que já se conhece por verificação; o tema é em geral abstrato, e deve ser provado" (1998:185).

A metáfora, figura de extrema importância na argumentação, é derivada do raciocínio analógico. Ela pode ser definida como uma analogia condensada, resultante da fusão de um elemento do foro com um elemento do tema. A metáfora não sugere, mas torna plausível a analogia, tornando visível ao auditório como é mostrado aquilo que é posto em discurso; daí sua força de convicção, seja a metáfora de invenção, seja a metáfora de uso, com estatuto de estereótipo e facilmente permeável à ideologia, por confirmar o "já-sabido" (cf. Mosca, 1997:39).

Segundo a visão cognitivista de Lakoff e Johnson (2002), a maior parte de nosso sistema conceptual ordinário é de natureza metafórica. A metáfora estrutura o modo de perceber, pensar e agir em determinada cultura, sendo possível afirmar que os conceitos, as atividades e a própria linguagem são estruturadas metaforicamente. Os autores postulam a existência de metáforas conceptuais, que definem os processos de pensamento e se manifestam por meio de diferentes expressões lingüísticas. Por exemplo, a metáfora conceptual "discussão é guerra" pode se atualizar em expressões como "seus argumentos são indefensáveis", "ele atacou os pontos fracos de minha argumentação" ou "eu venci o debate". Preferimos assim, no corpo deste trabalho, usar o termo "expressão metafórica" em lugar de metáfora, sobretudo na análise dos processos de referenciação, em que observaremos mais detidamente esse fenômeno. 


\section{Argumentação ou manipulação?}

A nova retórica, conforme a concepção de Perelman e Tyteca, revitalizou os estudos retóricos e derivou inúmeros trabalhos na área da argumentação. Uma obra recente que pretende contribuir para a renovação das pesquisas nesse âmbito é $A$ manipulação da palavra, de Philippe Breton, que sustenta a tese de que a manipulação se desenvolve hoje de forma maciça nas sociedades democráticas e midiáticas e que seus efeitos têm sido subestimados. Segundo Breton, é imperativo "refletir sobre a fronteira entre o que seria a argumentação, isto é, o respeito pelo outro, e a manipulação, que seria a privação da liberdade do público para obrigá-lo, por meio de uma restrição específica, a partilhar uma opinião ou a adotar determinado comportamento" (1999:10).

Breton afirma que a crítica da manipulação desapareceu a partir dos anos 80 sob os mais diversos pretextos, entre os quais o fim das grandes ideologias e a consolidação da sociedade de comunicação, em que os velhos procedimentos de influência e intervenção sobre as consciências não teriam mais lugar. $O$ autor rebate todos os argumentos de que não há mais causas a defender e de que a democracia, guardada pelos meios de comunicação, é refratária aos atos de manipulação. Para ele, as causas do passado foram substituídas por "verdades" que se apóiam num processo de naturalização da opinião, em si mesmo extremamente manipulatório, visto que "manipular consiste de fato em construir uma imagem do real que tenha a aparência de ser o real" (Breton, op.cit:15). Nesse sentido, a sociedade midiática é um universo em que são empregados habilmente métodos de argumentação, de debate e de livre circulação da palavra com fins manipulatórios.

Breton não acredita que o público tenha se tornado resistente aos efeitos da manipulação, mas supõe que esses efeitos tenham hoje outra dimensão, merecedora de estudos mais profundos. Segundo ele, numa sociedade perpassada pelos discursos midiáticos, reduz-se a liberdade do público de discutir ou resistir ao que lhe é proposto e essa é a estratégia central da manipulação. A palavra manipulatória estabelece, assim, uma paradoxal relação com o silêncio: "Onde a argumentação dispõe pausas que são o número de respirações existentes no diálogo e deixa ao interlocutor a possibilidade de refletir, de objetar, de aceitar ou de recusar, a manipulação parece ter como característica 
forçar o silêncio na interação a fim de aprisionar o outro numa seqüência contínua na qual ele não tem outra escolha senão se render" (Breton, op.cit.:22).

Esse ponto de vista coaduna-se com o que expusemos no primeiro capítulo desta tese, ao tratarmos das formas de existência da mídia na sociedade contemporânea. Ao mesmo tempo que se tem informação em abundância, tem-se menos possibilidade de refletir sobre os acontecimentos do mundo. Conhece-se mais do mesmo e o mesmo sempre se impõe pelas mesmas vozes e imagens. Os fatos são mediados, a interação é virtual, a manipulação é silenciosa. Em muitos aspectos, o público não é passivo na relação com a mídia, mas também não é infenso aos efeitos colaterais da máquina midiática. Como já foi dito, trataremos dos efeitos supostos e das estratégias visíveis no discurso dos telejornais, seja ele fundado em processos argumentativos legítimos, seja ele forjado por procedimentos de manipulação. Feita essa ressalva, importante para que não se julguem contraditórias as idéias aqui desenvolvidas, continuemos a ver os aspectos do estudo de Breton pertinentes a esta tese.

Os contextos sociais, econômicos e históricos podem ter mudado, entretanto os elementos que mobilizam sistemas de valores e redes de representações mentais, com vistas à convicção, continuam a existir. Os discursos religiosos e políticos sempre serão bons exemplos da prática retórica, ao lado dos discursos publicitários, que constituem o "novo império do convencer" no entender de Breton. Como se sabe, a publicidade informa, influencia e seduz, mas sobretudo "traz em si mesma a apologia da sociedade de consumo e da cultura de massas" (Breton, op.cit::44), persistindo em campos que estão além do mercadológico, tais como a política e a comunicação. É nessa extensa prática que Breton visualiza o que chama de "tecnicização da palavra" e dois tipos especiais de manipulação: a manipulação dos afetos e a manipulação cognitiva.

A tecnicização da palavra consiste no uso da palavra como instrumento para convencer e remonta à retórica clássica, estando ou não ligada ao exercício da ética, mas sempre vinculada à busca da eficácia. As técnicas de manipulação pela palavra hoje estão fortemente atreladas à propaganda e à desinformação, conceito este que entendemos no sentido de "desinformação funcional", conforme Serva (2001), e não no que pretende Breton: "ação que consiste em fazer validar, por um receptor que se quer intencionalmente enganar, certa descrição do real favorável ao emissor, fazendo-a passar 
por uma informação segura e verificada" (op.cit.:53). O desenvolvimento dessas técnicas no século 20 está, segundo Breton, paradoxalmente ligado à elevação do nível de informação e de conhecimento do público, que levou à busca de métodos capazes de tornar os indivíduos mais maleáveis à influência da palavra.

Tais métodos serão basicamente a manipulação dos afetos, que intervém sobre os sentimentos, e a manipulação cognitiva, que consiste em truque do raciocínio, podendo haver, em grande parte dos casos, o que Breton chama de manipulação global. Sem muita dificuldade, podemos associar esses procedimentos à racionalidade argumentativa propugnada pela nova retórica, que compreende as dimensões racional e afetiva do ato persuasório. Entretanto sempre é preciso distinguir argumentação de manipulação, já que o recurso aos sentimentos e às paixões é legítimo no exercício da retórica.

A manipulação pela sedução é, segundo Breton, aquela que inibe qualquer tipo de julgamento e visa obter privação de liberdade do público para que este aceite um conteúdo que de outro modo não seria aprovado. Uma possível tipologia compreende: 1) a sedução demagógica, fundada no vício da adulação; 2) a sedução pelo estilo, em que o bem falar toma o lugar do próprio argumento, tornando-se estética sem conteúdo; 3) a sedução pela autoridade, que mascara a força do medo e as ameaças veladas; 4) o amálgama afetivo, que consiste em transferir a carga afetiva de um elemento exterior ao discurso para a opinião que se quer manipular, processo de contaminação muito usado em publicidade; 5) a manipulação pela repetição, que cria, de modo artificial, um sentimento de evidência e plena aceitação da mensagem, com base no esquecimento de que nunca se explicou aquilo que se repete.

Parece-nos que esse último tipo de estratégia está bastante presente na estrutura circular da informação nas mídias, que acaba por gerar fraca resistência do público à versão construída pela repetição incessante de imagens e conteúdos, os quais tendem a fixar-se na memória individual e também na memória social. Como afirma Landowski, a mídia tem um perfil que a faz "uma figura social capaz de cristalizar duradouramente atitudes de atração ou de repulsa" (1992:118) e pressupomos que ela aja dessa forma sobretudo pela repetição sistemática de elementos discursivos atravessados por conteúdos ideológicos. 
Além dessas estratégias, Breton descreve os procedimentos de manipulação cognitiva, que vão além dos falsos silogismos e raciocínios distorcidos para os quais já alertava a retórica clássica. As duas grandes técnicas, nesse campo, seriam: 1) o enquadramento manipulatório, que consiste em reordenar elementos conhecidos e aceitos pelo público de tal forma que não seja possível opor-se ao discurso que os contém; e 2) o amálgama cognitivo, que propõe o enquadramento de um fato com o acréscimo de algum elemento em si mesmo convincente, em geral um lugar-comum.

O enquadramento manipulatório pode transformar o verdadeiro em falso ou viceversa, orientar os fatos a fim de deformar a realidade, mascarar parte dos fatos, de modo a ocultar as conseqüências da aceitação de determinado enquadramento. Nesse cenário se situam três espécies de enquadramento: o mentiroso, o abusivo e o restritivo. A base do mais elementar deles é a mentira sobre os fatos, que pode ser articulada por diversas instâncias sociais de poder, sobretudo por organismos oficiais e na defesa de interesses políticos, econômicos e bélicos. Entendemos que os discursos, tais como acontecem nos espaços do poder, jamais serão conhecidos. O que chega ao público são os fatos e os discursos visíveis para a mídia e reordenados como notícia. Se a mídia pode manipular, na mesma medida é permeável à manipulação pelas fontes oficiais, e esse é um ponto fraco da sociedade de informação. Breton dá como exemplo de desinformação exacerbada a cobertura da Guerra do Golfo, citada por muitos outros estudiosos nas críticas ao atual padrão de jornalismo mundial.

No enquadramento abusivo, apresenta-se o real de modo deformado, por meio de um trabalho que se dá principalmente no nível do sentido das palavras. Usa-se a manipulação lingüística para acionar uma espécie de reflexo condicionado a determinados vocábulos de conteúdo tendencioso, marcados ideologicamente. Um exemplo citado por Breton é a palavra "terrorista", que mobiliza o reflexo da indignação legítima ao terrorismo efetivo, mas que se torna, quando usada para qualificar indevidamente um indivíduo, mero instrumento de manipulação cognitiva. Pode-se recorrer ao uso de palavras enganosas, ou "termos-engodo" - expressão usada por Marcondes (2002) e já citada nesta tese -, para manipular o enquadramento da realidade no discurso conforme os mais diversos interesses. 
Em outra referência à Guerra do Golfo, que correspondeu a um período de intensa produção de reenquadramentos manipulatórios, Breton cita exemplos como "atingir o objetivo com alguns efeitos colaterais", para designar os bombardeios com vítimas civis, e "a força aérea lança mísseis", para salientar a ação e ocultar suas conseqüências. Há também termos que são usados com o fim de isentar da responsabilidade os verdadeiros agentes, o que pode ser observado no uso de "tragédia vietnamita", em lugar de Guerra do Vietnã, ou de "flagelo", nas referências a problemas como o desemprego em discursos políticos. Da mesma forma, pode-se reenquadrar a realidade fazendo passar por informação aquilo que não passa de opinião, juízo de valor ou preconceito, como em "um rapaz nordestino assaltou um banco". Entendemos que as formas de manifestação lingüística dessa manipulação cognitiva são múltiplas, incluindo expressões metafóricas, eufemismos e designações diversas, sobre as quais falaremos ainda neste capítulo.

O último tipo de enquadramento manipulatório apresentado por Breton é o restritivo, que funciona em dois tempos: primeiro se obtém do público o assentimento a uma opinião facilmente aceitável, depois se utiliza esse assentimento como ponto de apoio à aceitação quase automática de uma outra opinião, real objeto da manipulação. $O$ enquadramento restritivo tem muitas variantes, entre elas a proposição de algo cuja recusa do público ou do interlocutor é previsível, para então solicitar algo mais aceitável e, portanto, irrecusável.

A outra grande técnica de manipulação cognitiva é o amálgama, semelhante ao amálgama afetivo, em que se propõe uma associação sem fundamento entre um sentimento e uma opinião. No amálgama cognitivo, unem-se artificialmente alguns termos e sugere-se um vínculo aparente entre eles. Pode-se fazer aceitar pessoas, produtos ou idéias, associando-os a palavras ou símbolos tidos como positivos, como "liberdade", "justiça" e "solidariedade", ou, por outro lado, pode-se promover a rejeição pela associação a termos negativos, como "guerra", "corrupção" e "terrorismo". Da mesma forma, é possível obter efeitos análogos quando as associação são feitas com nomes de pessoas, que podem ser boas ou más referências, ou com aquilo que elas dizem. Observamos que essa técnica agrupa, sob o rótulo de manipulação cognitiva, diferentes argumentos descritos pela nova retórica, entre os quais o modelo, o antimodelo e o argumento de autoridade, desviados para uma finalidade manipulatória. 
Breton apresenta ainda em seu trabalho a análise de um trecho de um debate político, no qual encontra todo tipo de estratégia de manipulação, e especula os efeitos diretos e indiretos disso que chama de "manipulação global". Para ele, "em algumas situações, o público decodifica a intenção, decifra a mensagem e pode assim resistir à sua influência; em outras, não resiste, ou resiste pouco, e obtempera, na maioria das vezes sem sabê-lo, ao menos sem saber por que o faz" (Breton, op.cit.:113). Breton não se estende satisfatoriamente na explicação dos efeitos, mas afirma que, se eles não existissem, não haveria tantos exemplos de manipulação nos discursos que circulam na sociedade e tanto investimento em publicidade e comunicação política.

As pessoas aderem, em grande medida, aos discursos publicitários, políticos e midiáticos, não raro transformando idéias alheias em ações que refletem a ficção de liberdade em que vivem. Breton cita uma passagem do romance Ana Karenina, de Tolstoi, emblemática do que viria a ser o homem moderno (op.cit::122): "Ele não mudava de opinião, era a opinião que mudava nele, imperceptivelmente e sem que se apercebesse. Aliás, ele não escolhera suas opiniões políticas, elas tinham chegado a ele automaticamente, assim como, longe de escolher um chapéu ou uma roupa, ele envergava automaticamente o que todo mundo usava. Assim, o liberalismo se tornara para ele um hábito e amava seu jornal tanto quanto amava seu charuto depois do jantar por causa da ligeira névoa que produzia em seu cérebro".

Por tudo que expusemos até aqui, sabemos que nada se dá assim, "automaticamente". Pode-se não compreender com exatidão os procedimentos do que se pode chamar de manipulação, desinformação, orientação argumentativa, construção discursiva da realidade, "teledirecionamento da opinião" (Sartori, 2000) ou qualquer nome que as ciências venham a cunhar para designar o efeito dos discursos sobre o público, mas não há dúvida de que inúmeros procedimentos estratégicos subjazem aos discursos sociais. Está claro que podemos observar tais procedimentos e às suas conseqüências por diferentes lentes, ou por uma análise panóptica, contudo não vamos perder de vista o objetivo de examinar alguns mecanismos discursivos específicos no contexto da comunicação mediada. Vejamos então as contribuições de outro campo teórico, que também podem nos ajudar a entender como a palavra, aliada à imagem na televisão, mobiliza razão e emoção, que tramam o tecido da memória social. 


\section{Análise do discurso}

Acreditamos que não será suficiente apoiar a pesquisa apenas nas teorias da argumentação, pois o fenômeno midiático transcende os limites da prática argumentativa como a conhecemos: uma síntese de elementos racionais e afetivos. Segundo Sartori, "a cultura da imagem acaba com o delicado equilíbrio entre paixões e racionalidade" (2000:106), dado que muitas vezes o vídeo exacerba as emoções que envolvem determinados problemas, mas não dá nenhuma idéia de como resolvê-los, o que acaba por agravá-los.

Como afirma Mosca, "por melhor que seja a argumentação e suas escolhas, ela não pretende ser a manifestação da verdade mas do provável, do crível, cabendo à comunidade decidir a esse respeito" (1997:42). Ora, mais do que instaurar uma imagem daquilo que é provável ou crível no campo das relações sociais, políticas e econômicas, função básica da retórica do verossímil, inerente aos discursos sociais, o discurso da mídia televisiva se constrói, do ponto de vista ideológico, como o discurso da verdade, ou melhor, modaliza-se como o parecer-ser verdade, quando o que mostra são versões da verdade. Não é sem razão que Sartori diz que "a tecnologia está a produzir, à medida que avança, um homem mais crédulo do que o próprio homem medieval" (2000:127).

A nosso ver, apesar de lançar mão de estratégias tipicamente argumentativas, o discurso da televisão não o faz apenas para ser convincente e situar-se no quadro social das relações intersubjetivas. Se esse discurso assume uma forma argumentativa, isso se dá porque é próprio da mídia usar tecidos atraentes para revestir uma linguagem que cria modelos de pensamento, de conduta e de memória sócio-histórica, promovendo uma leitura homogênea do mundo. Dessa forma, além de investigar as operações argumentativas que esse discurso mobiliza, devemos examinar detidamente outros níveis da organização discursiva e estratégias diversas, tais como as formas de discurso relatado, explicadas pela teoria polifônica presente nos alicerces da análise do discurso, cujos princípios passamos a apresentar. 
A análise do discurso tem sido, desde sua gênese, influenciada pela filosofia e, em particular, por diversas concepções de ideologia, como as de Althusser e Paul Ricoeur. Pode-se dizer que o conceito de ideologia tem oscilado entre aquele que a determina como um mecanismo de dissimulação da realidade social e o que concebe a ideologia como uma visão de mundo determinada sócio-historicamente, que implica a afirmação de que não há um discurso ideológico, mas que todos os discurso o são. Helena Brandão sugere que essas duas concepções não se excluem e que se cruzam num ponto: o fato de toda ideologia poder ser produzida intencionalmente, fazendo-se um recorte da realidade e, mesmo de forma enviesada, retratando-se as relações sociais e uma visão de mundo (1996:27).

À noção de formações ideológicas, que governam o discursos, associam-se outros dois conceitos básicos nas formulações teóricas da análise do discurso: as formações discursivas, que pressupõem um discurso pré-construído ${ }^{19}$, continuamente parafraseado para ser perpetuado ou refutado, e as condições de produção, tais com as condições psicossociais dos interlocutores, a situação de enunciação e as determinações históricas. Em síntese, as formações ideológicas constituem conjuntos complexos de atitudes e de representações relacionadas a grupos sociais em conflito; e as formações discursivas determinam o que pode e deve ser dito a partir de um lugar social historicamente determinado (cf. Brandão, 1996:38).

É relevante apontar que, segundo Bakhtin, o verdadeiro lugar do ideológico é o material social de signos criados pelo homem e que o que determina a refração do ser no signo ideológico é a luta de classes. Bakhtin postula, então, que somente uma elaborada filosofia da linguagem poderia esclarecer certas unidades do discurso e em particular os problemas da enunciação, na qual se renova sem cessar, pela palavra, a dialética entre o sujeito e a sociedade, produzindo-se transformações sociais (1999:66).

A essas bases devem somar-se as noções fundamentais de sujeito e de interdiscursividade. Charaudeau e Maingueneau (2004) apresentam algumas definições

\footnotetext{
${ }^{19}$ A noção de pré-construído, desenvolvida por Pêcheux, está intimamente ligada à de interdiscurso. Citamos o dicionário de Charaudeau e Maingueneau: "O pré-construído pode ser entendido como a marca, no enunciado, de um discurso anterior; portanto, ele se opõe aquilo que é construído no momento da enunciação. Um sentimento de evidência se associa ao pré-construído, porque ele já foi dito e porque esquecemos quem foi seu enunciador" (2004:401).
} 
de sujeito, que se alteram conforma a posição teórica de seus autores: a) o sujeito emerge com o discurso que produz, sendo determinado pela formação discursiva que domina seu discurso e sobredeterminado por pré-construídos ideológicos (cf. Pêcheux); b) o sujeito é cindido em três instâncias: um ser empírico, um ser de discurso (locutor) e um ser de pura enunciação (o enunciador), que determina o ponto de vista do discurso (cf. Ducrot); c) o sujeito coloca-se no exterior e no interior do discurso em diferentes papéis: sujeito comunicante e sujeito interpretante, no nível situacional, e sujeito enunciador e sujeito destinatário, no nível discursivo (cf. Charaudeau). Conclui-se, então, que o sujeito do discurso é polifônico e sobredeterminado pela situação de comunicação, mas, simultaneamente, é livre para operar determinadas escolhas discursivas.

A interdiscursividade, que atravessa todo discurso, é a propriedade de estar em relação multiforme com outros discursos. Em sentido estrito, interdiscurso é um conjunto de discursos que mantêm relações de delimitação recíproca uns com os outros e difere do intertexto porque se refere a pontos de vista subjacentes a determinadas formações discursivas, não a fragmentos de textos inseridos em outro texto (cf. Charaudeau e Maingueneau, 2004).

É pertinente que a análise do discurso de linha francesa tenha feito, conforme afirma Maingueneau, do primado do interdiscurso sobre o discurso uma de suas teses principais, dado o caráter dialógico de todo discurso (2004:287). Os estudos sobre o dialogismo como princípio constitutivo da linguagem e condição do sentido de todo discurso vêm sendo desenvolvidos desde as primeiras décadas do século 20 , com base nas reflexões pioneiras de Bakhtin. Segundo ele, tanto nos gêneros primários (constituídos em circunstâncias de comunicação verbal espontânea) quanto nos gêneros secundários (constituídos em circunstâncias de comunicação cultural), nossos discursos são repletos de palavras do outro, de ecos e lembranças de outros enunciados: "nosso próprio pensamento nasce e forma-se em interação e em luta com o pensamento alheio, o que não pode deixar de refletir nas formas de expressão verbal", num movimento de ressonância dialógica (Bakhtin, 1992:317).

Essa e outras noções de discurso, como a de Ducrot, questionam a unicidade do sujeito falante, sendo fundadas nos pressupostos do dialogismo e da polifonia. A teoria polifônica da enunciação proposta por Ducrot afirma que "é o objeto próprio de uma 
concepção polifônica do sentido mostrar como o enunciado assinala, em sua enunciação, a superposição de diversas vozes" (1987:172). Assim, pode haver vários sujeitos na origem da enunciação, ficando pressuposta a pluralidade de responsáveis por certos enunciados e os pontos de vista correspondentes.

Distingue-se então dois tipos de dialogismo: o que se refere à heterogeneidade constitutiva da linguagem e o que remete à heterogeneidade da enunciação, aquela que é mostrada no discurso. Segundo Authier-Revuz, a primeira, que está inscrita na própria natureza da linguagem, é a instância em que estão em jogo o interdiscurso e o inconsciente; a segunda, verdadeiro espaço de negociação e lugar da polifonia, é a instância em que estão as fronteiras pelas quais "o um se delimita na pluralidade dos outros" (1990:32).

Essas instâncias têm sido tradicionalmente nomeadas de forma diferente: reservase o termo dialogismo para o princípio constitutivo da linguagem e de todo discurso e emprega-se o termo polifonia para o fenômeno pelo qual se deixam entrever muitas vozes num discurso, em oposição também a monofonia, efeito emergente de textos que escondem os diálogos que os constituem (cf. Barros, 1994:5). A heterogeneidade da enunciação, ou polifonia, é também denominada de "heterogeneidade mostrada" e revela-se por meio de marcas explícitas, recuperáveis a partir de uma diversidade de fontes de enunciação - tais como a pressuposição, a negação polêmica, as aspas, o discurso relatado e o metadiscurso.

No entanto, conforme aponta Barros, pode-se produzir textos monofônicos ou polifônicos mediante o acionamento de diferentes estratégias discursivas, que podem provocar efeitos de sentido de revelação ou de mascaramento das vozes que tecem polifonicamente os textos (1994:6). Essas vozes, que polemizam entre si ou se completam, podem ser abafadas e, então, uma só voz pode se fazer ouvir. Nesse caso, tem-se o discurso autoritário, o discurso da verdade única, absoluta, incontestável. De acordo com nossa hipótese, o discurso das mídias, que inclui o discurso dos telejornais, em lugar de abafar as vozes que o constituem, mostra-se como polifônico exatamente para ocultar, por meio de sofisticados recursos, sua condição de discurso que orienta para uma leitura homogênea da realidade. 
Retomemos aqui interessante reflexão de Brait sobre o discurso dos jornais: "Nada impede que, ao folhear um jornal hoje, o leitor perceba que o mesmo tema se multiplica em diferentes vozes. A essa percepção pode também corresponder uma pergunta: essa polifonia enunciativa revela um democrático processo dialógico ou unicamente uma cacofonia polienunciativa?" (1994:26). Essa indagação, como já dissemos, é a mesma que fazemos em relação ao discurso dos telejornais, cuja polifonia enunciativa pode camuflar um discurso monológico. Como afirma Brait, "é necessário observar no conjunto do enunciado, do discurso, de que forma a confluência de vozes significa muito mais uma interpretação do discurso alheio, ou a manipulação na direção da argumentação autoritária, ou mesmo a apropriação e subversão desse discurso" (op.cit.:25).

Entendemos que a polifonia presente do discurso dos telejornais representa exatamente essa interpretação e confirmação de discursos alheios que interessam ao sujeito enunciador, e maquia procedimentos de apagamento dos discursos que poderiam polemizar com aqueles outros, conformando o público a julgamentos de valor preestabelecidos, que conduzirão ao preenchimento de lacunas da memória social sobre determinado evento. Ao selecionar determinadas notícias ou versões dos fatos, a televisão, assim como outros meios, interfere na lógica de construção do mundo.

É dessa forma que os indivíduos vão sendo interpelados em sujeitos que perpetuam ou transformam as formações discursivas. Como explica Brandão, "todo falante faz uma operação de seleção lingüística entre o que é dito e o que deixa de ser dito, pela qual, no interior da formação discursiva que o domina, elege algumas seqüências que se encontram em relação de paráfrase e esquece, oculta outras. Essa operação dá ao sujeito a ilusão de que o discurso reflete o conhecimento objetivo que tem da realidade" (1996:66).

Pretendemos evidenciar que o público da mídia televisiva não passa por esse processo naturalmente, mas que é orientado a fazer apenas as paráfrases de um discurso que já se incumbiu de operar o apagamento de todas as vozes que com ele pudessem polemizar. Parece-nos que o discurso dos telejornais, como de resto o dos programas de televisão em seu conjunto, condiciona a memória discursiva ${ }^{20}$ do público,

${ }^{20}$ Conforme Charaudeau e Maingueneau (2004), o discurso tem relação com a memória em dois planos complementares, o da textualidade e o da história. Pode-se tomar memória discursiva como o lugar que 
impedindo-o de proceder por si só aos movimentos de escolha dos elementos que devem ser atualizados ou silenciados em determinada contingência histórica.

Vê-se nesse processo o que Foucault entendia como "ordem do discurso", marcada em muitos casos por procedimentos de controle e delimitação dos discursos que circulam em sociedade: "não se tem o direito de dizer tudo, não se pode falar de tudo em qualquer circunstância, não é qualquer um que pode falar de qualquer coisa" (2005:9). Isso implica também a rarefação dos sujeitos que falam, pois "ninguém entrará na ordem do discurso se não satisfizer a certas exigências ou se não for, de início, qualificado para fazê-lo" (Foucault, op.cit.:37).

Os mecanismos usados para o controle dos discursos incluem a seleção e a constante reiteração de fatos, imagens, relatos e designações que servirão à construção de um fato simbólico e de determinada memória social, conceito que explicaremos na segunda parte deste capítulo. Vamos concluir esta seção com a apresentação de estratégias enunciativas associadas ao discurso relatado, índice de polifonia que será analisado nesta tese.

\section{Heterogeneidade mostrada: o discurso do outro}

Uma das heranças que a análise do discurso recebeu de Bakhtin é a preocupação com o fenômeno de transmissão da palavra do outro e sua integração no processo de enunciação. Bakhtin temia que se deixasse de apreciar na justa medida o interesse metodológico que apresentam os esquemas lingüísticos e suas variantes na inscrição de enunciações alheias na produção discursiva. Ele forneceu então as bases para esse importante estudo, que encontra na obra recente de Authier-Revuz envergadura teórica suficiente para a compreensão de grande parte dos procedimentos de citação do discurso do outro.

guarda saberes compartilhados do contexto lingüístico e da situação extralingüística, entretanto, de modo geral o conceito refere-se à memória de outros discursos, tanto os que pertencem a formações discursivasa nteriores como os que se produzem no interior de uma mesma formação discursiva. Essa dupla memória permite que o discurse se apóie em determinada tradição e vá, aos poucos, criando sua própria tradição. 
O discurso relatado ou citado, uma das formas mais evidentes de manifestação da polifonia, é inserido na enunciação por meio de diversas estratégias e provoca efeitos múltiplos. Na definição de Bakhtin, "o discurso citado é o discurso no discurso, a enunciação na enunciação, mas é, ao mesmo tempo, um discurso sobre o discurso, uma enunciação sobre a enunciação" (1999:144). Devemos considerar, portanto, não só o conteúdo citado, mas sobretudo a forma como a fala citada é integrada ao discurso. Segundo Bakhtin, se nos limitarmos ao tema do discurso citado, podemos saber "do que" o outro falava, mas não entenderemos "o que" e "como" ele dizia em sua enunciação ${ }^{21}$.

É complexo o processo de apreensão e transmissão do discurso do outro e somente as formas de citação se apresentam como documento objetivo dessa operação. Bakhtin entende que "esse documento, quando sabemos lê-lo, dá-nos indicações, não sobre os processos subjetivo-psicológicos passageiros e fortuitos que se passam na alma do receptor [do discurso que será citado], mas sobre as tendências sociais estáveis características da apreensão ativa do discurso de outrem que se manifestam nas formas da língua" (op.cit:146).

Dessa forma, a fala do outro é apreendida de modo ativo e interpretativo e recolocada num contexto que é, de modo geral, um contexto de comentário efetivo, por mais que se vise à conservação da integridade e da autenticidade do discurso citado. Pode-se identificar nesse processo dois tipos de movimento: um determinado pelo esforço em manter nítidas e invioláveis as fronteiras entre o discurso citado e o discurso narrativo; e outro, de natureza oposta, caracterizado pelo uso dos meios mais sutis de inserção de comentários na apresentação do discurso do outro no contexto narrativo.

As formas básicas de discurso relatado são o discurso indireto, em que se reformula a fala do outro, e o discurso direto, que simula reconstruir fielmente as falas citadas, apenas visando a um efeito de sentido de autenticidade. A manutenção da autenticidade propriamente dita é improvável, visto que os entornos de uma descrição

\footnotetext{
${ }^{21}$ No dicionário de Charaudeau e Maingueneau (2004), encontram-se diversas concepções de enunciação, entre elas "a colocação em funcionamento da língua por um ato individual de utilização", processo que se opõe a enunciado, o produto (Benveniste); "o conjunto de atos que o sujeito falante efetua para construir, no enunciado, um conjunto de representações comunicáveis" (Relprend); "o evento constituído pela aparição de um enunciado", não importando se esse enunciado é de responsabilidade de um ou mais autores (Ducrot), o que pressupõe que a enunciação é sempre uma co-enunciação.
} 
necessariamente subjetiva do discurso relatado contribuem para a criação de uma nova cena enunciativa ${ }^{22}$, que condiciona toda a interpretação da fala citada.

Authier-Revuz, nos estudos que consagra à modalidade ou modalização autonímica, "forma que implica uma atividade linguageira de auto-representação do dizer pelo enunciador" (1998:177), trata das não-coincidências do dizer em várias dimensões da enunciação: a) na relação entre os interlocutores, que se reconhecem como nãoredutíveis ao mesmo; b) na relação entre as palavras e as coisas, isto é, no processo de nomear, quando as palavras empregadas não correspondem exatamente à realidade que deveriam designar; c) no discurso sobre si mesmo, reconhecido como atravessado pela presença de palavras ou sentidos provenientes de outros discursos; d) nas palavras, enfim, reconhecidas como atravessadas por outros sentidos ou outras palavras, configurando sua polissemia ou ambigüidade (op.cit.:84). Pela modalização autonímica, o enunciador desdobra seu discurso para comentar sua fala enquanto está sendo produzida, mecanismo que pode ser entendido como "metadiscurso" e que é acionado muitas vezes por expressões metaenunciativas (de uma certa forma, ou melhor, quer dizer, parece-me etc.) ou meramente tipográficas e entonativas.

Interessa-nos sobretudo, nos limites desta tese, a não-coincidência do discurso consigo mesmo, que resume a essência dialógica de todo discurso e que comporta o problema de incorporação do discurso do outro de diferentes modos. Fiquemos no âmbito da representação desse discurso, que pode se dar, segundo Authier-Revuz, de três maneiras: 1) por formas marcadas e unívocas (discurso direto, discurso indireto e modalização em discurso segundo); 2) por formas marcadas que exigem um trabalho interpretativo (aspas, itálico, entonação); 3) por formas puramente interpretativas (discurso direto livre, discurso indireto livre, alusões). Conforme nosso objetivo, vamos nos deter nas formas marcadas e unívocas.

Authier-Revuz chama o discurso direto de "citação-relíquia", introduzida por uma descrição feita em outro ato de enunciação pelo enunciador do discurso citante, e o discurso indireto de "reformulação-tradução" das palavras do outro (op.cit.:134). Trata-se,

\footnotetext{
${ }^{22}$ A cena enunciativa é um elemento constitutivo do discurso, é a representação que um discurso faz de sua própria situação de enunciação, permitindo reconhecer o gênero discursivo, os papéis dos enunciadores, as circunstâncias, o tempo, o espaço e a finalidade do discurso (cf. Maingueneau, 2004).
} 
em suma, de duas estratégias enunciativas diferentes - com efeitos de sentido diferentes - para relatar o discurso do outro (ver também Maingueneau, 1997). O discurso direto caracteriza-se pela clara dissociação entre discurso citado e discurso citante, que se dá por ruptura sintática. O fragmento citado no interior de um discurso direto é apresentado como um objeto extraído da cadeia enunciativa normal e remetido ao lugar de outro ato de enunciação, sempre em submissão ao enfoque do enunciador do discurso citante, que Ihe serve de moldura.

Cabe ao discurso citante indicar a fronteira que separa os dois discursos, o que é feito por meio de dois-pontos, travessões, aspas ou itálico (nos textos escritos) e pela introdução de verbos dicendi, que indicam atos de fala (dizer, negar, afirmar, responder), ou de opinião, que encerram pontos de vista (acusar, ironizar, confessar). Além disso, é o discurso citante que deve explicar a referência dos embreadores ${ }^{23}$ do discurso citado, devido à mudança do ambiente físico da enunciação. Pode-se recorrer ao discurso direto tanto para conseguir um efeito de objetividade e distanciamento quanto para sugerir uma opinião sem se responsabilizar diretamente por isso.

O discurso indireto é uma forma independente do discurso direto, não se podendo passar mecanicamente do discurso direto para o indireto. No discurso indireto, o discurso citado perde sua autonomia e é o verbo introdutor (normalmente inserido nas estruturas "verbo + que" ou "verbo + infinitivo") que marca a fronteira entre as falas no espaço de uma única situação enunciativa. Bakhtin já observava que "a tendência analítica do discurso indireto manifesta-se principalmente pelo fato de que os elementos emocionais e afetivos do discurso não são literalmente transpostos ao discurso indireto, na medida em que não são expressos no conteúdo mas nas formas da enunciação" (1999:159).

Não é possível transpor, por exemplo, a fala "Muito bem! Que grande realização!" para a forma indireta "Ele disse que muito bem e que grande realização", pois é preciso haver ajustes sintáticos e introdução de elementos descritivos da fala, o que necessariamente implicará interpretação das peculiaridades lingüísticas e paralingüísticas

\footnotetext{
${ }^{23}$ Trata-se de elementos que indicam que o discurso se ancora em determinados tempo e espaço e em relação a determinadas pessoas. Assim, quando há mudança de perspectiva, o "eu" torna-se "ele", o "aqui" torna-se "lá" e o "agora" pode tornar-se "ontem", "naquele dia" e assim por diante.
} 
(como pausas e entonação) do discurso citado. Portanto podem passar pelo crivo analítico do discurso indireto tanto o conteúdo como a expressão do discurso do outro.

Para Authier-Revuz, a dualidade do discurso direto (DD), em face da unidade do discurso indireto (DI), pode ser observada nos seguintes planos: a) o modo de citar é heterogêneo no DD e homogêneo no $\mathrm{DI}$; b) há ruptura sintática no $\mathrm{DD}$, mas não do $\mathrm{DI}$; c) a modalização e a embreagem atingem o discurso citado e o discurso citante no DD, mas afetam só o discurso citante no DI; d) a subjetividade é marcada em duas fontes enunciativas quando há DD e em uma só no Dl; e) há heterogeneidade no registro da língua e nos modos de dizer quando ocorre DD e homogeneidade em DI.

O modo de usar o discurso direto ou o discurso indireto, modalizado ou não pelo enunciador que os emprega, constitui em si mesmo estratégia de construção de um novo discurso, uma vez que instaura diversos locutores e enunciadores no discurso citante e estabelece alto grau de polifonia em certos gêneros, favorecendo a orientação interpretativa do discurso. Veja-se o caso de estratégias como a do uso de ilha textual em discurso indireto, freqüente em textos de imprensa, pela qual se marca com aspas um elemento "não traduzido" do discurso citado e para o qual se chama a atenção no dizer do outro (O ministro condenou as "agitações" daquele dia...). Ou ainda o caso das escolhas lexicais usadas nas descrições que emolduram o discurso direto ou servem de referência no discurso indireto (formas de designação, índices de avaliação etc.).

Outros problemas interessantes na constituição do discurso relatado são a tradução de uma fala e a escolha de trechos de uma fala, operações muito comuns na imprensa. No caso da tradução, decodifica-se e interpreta-se um enunciado para então recodificá-lo e produzir um novo enunciado considerado equivalente ao original segundo o ponto de vista do locutor. No caso da seleção da fala, o locutor mostra as palavras como resumo perfeito da mensagem original. Sem dúvida, isso não passa de estratégia, pois nem mesmo a citação textual pode ser considerada fiel e objetiva, dado o novo quadro de interpretação - sempre parcial e subjetivo - em que a fala é reconstruída.

A outra forma unívoca de representação do discurso do outro de que trata AuthierRevuz, a modalização em discurso segundo, é também uma estratégia discursiva. É o modo mais simples e discreto pelo qual o enunciador indica que não é o responsável por um enunciado, que está se apoiando em outro discurso. O efeito de mostrar as palavras 
do outro de forma tão clara pode ser tanto de distanciamento ("não sou eu que estou dizendo", "não concordo com isso") quanto de aproximação ("outra pessoa também pensa como eu"). Os modalizadores do discurso segundo são expressões como "conforme fulano", "para fulano" ou fórmulas que omitem o sujeito do discurso citado, como "segundo dizem", "parece" e verbos no condicional (teria dito, estaria envolvido).

Todas essas estratégias, bem como as que se referem às outras modalidades autonímicas, têm em comum a instauração de um metadiscurso do enunciador, isto é, uma glosa ou comentário sobre o discurso em construção. O metadiscurso pode se destinar a construir certa imagem do enunciador, a marcar uma inadequação do termo usado, a indicar uma autocorreção, a corrigir antecipadamente um possível erro de interpretação (cf. Maingueneau, 1997:93) ou, de modo geral, a orientar o modo de recepção do discurso, não sendo nunca uma operação gratuita ou neutra.

Podemos observar todos esses recursos na imprensa escrita, de forma mais clara, e nos telejornais, de modo menos visível por causa da realização oral. Vejamos alguns exemplos de títulos extraídos de jornal ${ }^{24}$, nos quais se reconhecem algumas das estratégias descritas: Serra liga para Lula e diz "boa sorte"; Genoíno: "Foi uma disputa de alto nível"; Eleito afirma que "esperança venceu o medo"; Expectativa é de "mercadinho paz e amor"; PSDB promete não ser oposição "do contra"; O operário Lula não gostava de política. Analisaremos nesta tese de que forma o discurso relatado se manifesta nos telejornais e que efeitos resultam da polifonia instaurada nesse tipo de discurso.

Acreditamos que, no caso do discurso jornalístico, classificado como gênero secundário segundo as concepções de Bakhtin, tem-se uma produção cultural a reproduzir discursos alheios e a criar novos efeitos simbólicos para fatos que serão armazenados não só na memória social, mas sobretudo nos arquivos da mídia, que podem ser acionados a qualquer tempo pelo sujeito enunciador para fortalecimento dessa memória, especialmente em se tratando de mídia eletrônica, na qual se inserem os telejornais. Essas são questões de que trataremos na segunda parte deste capítulo. Antes vejamos outros aspectos lingüísticos do discurso.

\footnotetext{
${ }^{24}$ Exemplos analisados em seminário que apresentamos durante o curso "Análise do discurso: enunciação, polifonia e construção do sentido", no segundo semestre de 2002. Fonte: Jornal da Tarde, Caderno de Eleições, 28 de outubro de 2002.
} 


\section{Lingüística textual: perspectiva pragmática}

Um importante pensamento de Bourdieu nos remete ao problema da designação e da referência, que também será observado em nossa pesquisa. Diz o sociólogo: "Acontece-me ter vontade de retomar cada palavra [grifo do autor] dos apresentadores que falam muitas vezes levianamente, sem ter a menor idéia da dificuldade e da gravidade do que evocam e das responsabilidades em que incorrem ao evocá-las diante de milhares de telespectadores, sem as compreender e sem compreender que não as compreendem. Porque essas palavras fazem coisas, criam fantasias, medos, fobias ou, simplesmente, representações falsas" (Bourdieu, 1997:26).

Para tratar desse aspecto, analisaremos questões ligadas à referenciação, que é uma atividade argumentativa que desencadeia múltiplas relações entre os objetos do mundo e os objetos do discurso. Segundo Ingedore Koch, "a interpretação de uma expressão anafórica consiste em estabelecer uma ligação com algum tipo de informação que se encontra na memória discursiva", aqui entendida como a memória que remete ao co-texto. Ela afirma que, "ao usar e manipular uma forma simbólica, usamos e manipulamos tanto o conteúdo como a estrutura dessa forma e, deste modo, também manipulamos a estrutura da realidade de maneira significativa" (Koch, 2002:81).

Será fundamental aos nossos propósitos o estudo dos mecanismos de designação e referência, bem como o exame de suas relações com a criação de determinados estereótipos. Isso completará o conjunto de perspectivas sob as quais analisaremos as formas de reiteração que levam à construção de determinada memória social, com base no pressuposto de que hoje a mídia persegue a descrição única dos fatos e priva o público de discutir outras interpretações, conforme análise do professor K. Rajagopalan ${ }^{25}$.

Segundo a definição de Charaudeau e Maingueneau (2004), a lingüística textual é o campo da lingüística que transcende a teoria da frase e explica a coesão e a coerência dos textos, apresentando-se como uma translingüística (cf. Bakhtin, Todorov, Benveniste), uma lingüística instrucional (cf. Weinrich) ou uma pragmática textual (cf. Beaugrande e Dressler). É vista muitas vezes como disciplina auxiliar da análise do

\footnotetext{
25 "Designação: a chave para desvendar o papel da mídia em conflitos internacionais", conferência proferida em 24 de maio de 2002, no Grupo de Estudos Lingüísticos realizado na USP, em São Paulo.
} 
discurso, mas apresenta um corpo de conceitos próprios, que compreendem os elementos ligados à micro e à macroestrutura do texto. De todo o vasto campo que a lingüística textual semeia, examinaremos a problemática da referenciação, que é eminentemente uma atividade discursiva e constitui um dos pontos centrais desta tese.

Muitos estudiosos entendem que a realidade é produto de uma percepção cultural, ou seja, "é fabricada por toda uma rede de estereótipos culturais, que condicionam a própria percepção e que, por sua vez, são garantidos e reforçados pela linguagem, de modo que o processo de conhecimento é regulado por uma interação contínua entre práxis, percepção e linguagem" (Koch, 2002:77). Pode-se dizer, e aqui Koch se apóia na tese de Blikstein ${ }^{26}$, que é a prática social o lugar do mecanismo gerador do sistema perceptual e cognitivo que fabricará o referente (a coisa extralingüística). Se o próprio referente é uma criação social, mais ainda o será, na concepção de Koch, a atividade sócio-cognitivo-discursiva de referenciação.

Nesse contexto, "a referência passa a ser considerada como o resultado da operação que realizamos quando, para designar, representar ou sugerir algo, usamos um termo ou criamos uma situação discursiva referencial com essa finalidade: as entidades designadas são vistas como objetos de discurso e não como objetos do mundo" (Koch, op.cit.:79). Se o processamento discursivo é estratégico e dinâmico, uma vez que implica escolha significativas entre as múltiplas possibilidades que a língua oferece, também serão dinâmicos os objetos de discurso, que podem ser modificados, desativados, reativados, transformados e recategorizados no curso da progressão textual, construindo e reconstruindo sentidos em novas configurações discursivas. Koch conclui, então, que "a discursivização ou textualização do mundo por via da linguagem não se dá como um simples processo de elaboração de informação, mas de (re)construção do próprio real" (op.cit::81).

Desse ponto de vista, tem-se preferido a noção de referenciação à noção de referência, tal como postulam Mondada e Dubois, que dizem que a construção de objetos cognitivos e discursivos se dá "na intersubjetividade das negociações, das modificações, das ratificações de concepções individuais e públicas do mundo", o que leva a vários

${ }^{26}$ Tese presente em Kaspar Hauser ou a fabricação da realidade, São Paulo, Cultrix, 1985. 
níveis de instabilidade das relações entre as palavras e as coisas (2003:20). A instabilidade também pode decorrer do fato de que as categorias usadas para descrever o mundo mudam sincrônica e diacronicamente (sincronicamente, uma pessoa pode ser tratada de "antieuropéia" ou "nacionalista", segundo o ponto de vista ideológico adotado; diacronicamente, quem era visto como "traidor" pode passar a ser visto como "herói"), mas em grande parte decorre de reenquadramento discursivo (ver ainda Flahault, 1978).

Assim, não se trata de avaliar se um rótulo é adequado ou não, mas de entender os procedimentos lingüísticos e sociocognitivos pelos quais os atores sociais se referem uns aos outros, afetando mais os objetos sociais do que os psíquicos e ligando-se a valores de verdade socialmente compartilhados. Normalmente, como apontam Mondada e Dubois, os deslizes entre referencialidade e negociação intersubjetiva dos processos de referenciação são marcados por comentários que pontuam o discurso, a evidenciar que há conflito entre diferentes convenções ${ }^{27}$ (op.cit::32).

A referenciação emerge dessa heterogeneidade, dado que determinada escolha lexical impõe um ponto de vista, um domínio semântico de referência que concorre com outras categorias possíveis. Nesse processo, não se pode deixar de considerar o trabalho de interpretação do interlocutor, que participa da co-construção dos objetos de discurso ao acionar suas estruturas cognitivas, notadamente memoriais, para ajustar as descrições do mundo ao contexto discursivo. Assim, não há como falar em literalidade das formas lingüísticas, como bem aponta Orlandi: "Não há um centro, que é o sentido literal, e suas margens, que são os efeitos de sentido. Só há margens. (...) O que existe é um sentido dominante que se institucionaliza como produto da história" (1987:144).

A outra face do procedimento discursivo da referenciação é a produção de estabilidade por meio de estratégias que criam efeitos de objetividade e de realidade, resultantes de processos simbólicos complexos. Pode-se, em outras palavras, utilizar representações estabilizadas que camuflem a heterogeneidade discursiva, isto é, apaguem do discurso a instabilidade entre as palavras e as coisas, impondo uma convenção dos significados das palavras, que facilmente evoluem para estereótipos. Vêse bem que este é um importante ponto de interseção entre retórica e análise do

${ }^{27}$ Reconhecemos aqui o fenômeno do metadiscurso, que anuncia as não-coincidências do dizer de que trata Authier-Revuz. 
discurso, na medida em que o estereótipo, como representação coletiva cristalizada, emerge da construção discursiva e abriga um conjunto de crenças e opiniões partilhadas, que por sua vez autorizam a interação verbal e naturalizam o discurso (cf. Charaudeau e Maingueneau, 2004:215).

Outro procedimento de estabilização discursiva é a anáfora, que pode "focalizar uma denominação particular, excluindo para isso outras possibilidades, mesmo se elas estiverem potencialmente disponíveis no texto" (Mondada e Dubois, 2003:43). A anáfora é um dos principais mecanismos de progressão referencial e consiste em usar um elemento para guiar a interpretação de outro num enunciado ou numa seqüência de enunciados, porém a interpretação da expressão anafórica depende, ao mesmo tempo, de seu antecedente. Há uma relação de interdependência tanto na anáfora (movimento retrospectivo) quanto na catáfora, cujo referente é enunciado depois do elemento catafórico (movimento projetivo). Diante da mudança de foco da referência para a referenciação, não se pode dizer que a anáfora simplesmente retoma, substitui ou se refere a um outro elemento do discurso.

Conforme Koch, "as formas de referenciação, bem como os processos de remissão textual que se realizam por meio delas, constituem escolhas do sujeito em função de um querer-dizer" (2005:35) $)^{28}$, portanto toda expressão referencial anafórica, sobretudo as nominais, localiza algum tipo de informação anteriormente alocada na memória discursiva. Assim, a referenciação pode compreender os princípios de ativação de um referente textual, de reativação do referente por meio de uma forma referencial e de desativação do referente por meio do deslocamento da atenção para um novo referente textual (cf. Koch, 2002:83), sendo todos esses princípios potencialmente argumentativos. Diga-se também que todo processo referencial é constitutivo de práticas simbólicas dos sujeitos em sociedade.

A referenciação pode se realizar pelo uso de pronomes ou elipses e pelo uso de expressões nominais definidas ou indefinidas. São as diversas formas das expressões nominais e seu uso argumentativo que nos interessam: as descrições definidas, as

\footnotetext{
${ }^{28} \mathrm{Em}$ "Referenciação e orientação argumentativa", artigo do livro Referenciação e discurso, organizado por Koch e citado na bibliografia.
} 
nomeações ${ }^{29}$, a remissão metadiscursiva, as expressões que funcionam como anáforas indiretas e os encapsulamentos anafóricos.

A descrição definida promove a ativação, dentre os conhecimentos supostamente partilhados com o interlocutor, de características ou traços do referente que o enunciador quer enfatizar, reforçando crenças e opiniões veiculadas pelo discurso em construção. Veja-se um exemplo apresentado por Koch: "Manipulando informações, agachando-se às ordens do psicopata travestido de presidente eleito de forma fraudulenta, vergonhosa e indecente, que se autodefine salvador do mundo, causa asco o exibicionismo desumano e narcisista com que a mídia americana mostra o genocídio praticado pelo governo norteamericano e seu escravo-mor, Tony Blair, contra o povo iraquiano" ${ }^{30}$ (2005:36). Está claro que as expressões que se referem ao presidente norte-americano George W. Bush, à guerra contra o Iraque e ao primeiro-ministro britânico não estão apenas no lugar desses referentes, mas ampliam seu sentido ao eleger elementos que mostram um ponto de vista que desqualifica as pessoas e os atos referidos no discurso.

Mesmo quando as descrições nominais são usadas para dar uma informação supostamente desconhecida do interlocutor, podem ter uma orientação argumentativa: "O prefeito é especialmente exigente para liberar novos empreendimentos imobiliários, principalmente quando estão localizados na franja da cidade ou em áreas rurais. (...) 'O crescimento urbano tem de ser em direção ao centro, ocupando os vazios urbanos e aproveitando a infra-estrutura, não na área rural que deve ser preservada', repete 0 urbanista que entrou no PT em 1981 como militante dos movimentos populares por moradia. ${ }^{31} \mathrm{~A}$ informação de que o prefeito petista era um urbanista tem como efeito fazer considerar como legítimo o argumento utilizado por ele, que ilustra a afirmação de o prefeito era exigente em relação a novos empreendimentos imobiliários.

\footnotetext{
${ }^{29}$ Apothelóz prefere empregar "nomeação", em lugar de "nominalização", para a operação discursiva que consiste em referir-se, por meio de um sintagma nominal, a um processo ou estado anteriormente expresso por uma proposição (2003:132).

${ }^{30}$ Carta enviada à seção "Caros leitores", da revista Caros Amigos, sem data.

31 "Quem matou Toninho do PT?", Caros Amigos, número 78, setembro de 2003, pág. 27 (exemplo também citado por Koch, 2005:37).
} 
Não raro a recategorização dos objetos de discurso é feita por meio de termos metafóricos, como em "No pântano jurídico, liminares eram fornecidas a empresas antes mesmo de sua constituição legal. Pouco se fez para pôr ordem na orgia." ${ }^{32}$ Pode-se acrescentar que a metáfora, freqüentemente usada em situações em que é preciso explicar conceitos complexos, cria determinada ilusão e presta-se bem ao papel de fazer uma leitura interpretativa dos fatos. Como postulam Lakoff e Johnson (2002), a metáfora tem a função de categorizar objetos e experiências, iluminando, atenuando ou escondendo certas propriedades, fato que se verificará em alguns casos encontrados no corpus desta tese.

Quanto ao processo de nomeação, de natureza anafórica, pode-se dizer que é um modo de condensar um conjunto de informações e explicitar seu estatuto. Pode-se nomear uma ação (a prisão, o fechamento, essa tarefa), um ato de fala (essa afirmação, esse aviso, o comentário), um sentimento (essa antipatia, o ódio), um processo cognitivo (essa avaliação, esse conceito), um julgamento (o embaraço, essa reverência). Em muitos casos, a nomeação comporta evidente conotação axiológica ou metadiscursiva, inclusive quando é feita por meio de expressão metafórica (essa orgia jurídica), é acompanhada de elementos qualificadores ou avaliativos (a brutal prisão, esse importante anúncio) ou representa uma modalização autonímica, isto é, quando o termo é posto entre aspas para reportar a denominação a outro enunciador.

Vemos aqui, portanto, um interessante ponto de contato entre a referenciação e a polifonia, dadas as marcas que revelam diferentes níveis de enunciação. Tanto os verbos introdutores de opinião, que citamos na seção anterior, quanto os nomes selecionados para qualificar metadiscursivamente algum a ação, processo mental ou atividade de linguagem podem produzir efeitos como os de ironia, contestação ou distanciamento sem que seja necessário fazer comentários explícitos, recorrendo-se para isso apenas a estratégicos instrumentos lingüísticos.

As formas nominais referenciais desempenham então, além das funções textuais, importantes funções discursivas, semânticas, pragmáticas e argumentativas. Elas organizam o texto, ativam e reativam informações dadas ou novas, focalizam e predicam

\footnotetext{
32 "Operação Ouro Negro", IstoÉ, 7 de julho de 2004 (exemplo encontrado em Koch, 2005:37).
} 
determinados referentes, veiculam valores e opiniões, assinalam direções argumentativas, agindo assim sobre a micro e a macroestrutura discursivas e orientando para determinados sentidos implicados no discurso. Todas as expressões referenciais têm uma dimensão representativa e intersubjetiva, logo constituem lugares em que "a manipulação é não só possível, como visível" (Koch, 2002:106). Os modos de referenciação são inúmeros, portanto substituiremos a exemplificação nesta seção por casos observados na análise do corpus da tese.

Trataremos agora de dois processos de referenciação que merecem destaque: a anáfora indireta e o encapsulamento anafórico. As expressões definidas anafóricas que não têm referente explícito, mas inferível a partir de elementos do co-texto precedente são chamadas de anáforas indiretas e fazem parte da estratégia referencial de associação. O elemento de relação, por vezes uma estrutura complexa, que permite a compreensão da anáfora indireta pode ser chamado de âncora. Temos um exemplo simples de anáfora indireta em "Ontem fomos a um restaurante. O garçom era gentil", em que "restaurante" funciona como âncora do termo anafórico "garçom".

As anáforas indiretas podem se basear em elementos lexicais, em modelos mentais ou em inferências. Também chamadas de associativas, essas anáforas têm papel fundamental na construção da coerência, uma vez que mobilizam tanto elementos co-textuais complexos quanto informações representadas na memória enciclopédica dos interlocutores do discurso, ativando novos referentes e, do ponto de vista desta tese, criando representações potencialmente capazes de ampliar as memórias discursiva e social, como o fazem todas as estratégias de referenciação, ao transformarem os objetos do mundo em objetos do discurso, que podem ser modificados no decorrer da atividade discursiva em função do ponto de vista do enunciador e da rede polifônica e argumentativa que se tece.

O encapsulamento anafórico, por sua vez, é "o uso de uma forma nominal para recategorizar segmentos precedentes ou subseqüentes do co-texto, sumarizando-os e encapsulando-os sob um determinado rótulo" (Koch, 2005:38). As formas anafóricas usadas nesse procedimento podem ser algumas das já citadas, como a descrição definida, a nomeação e a expressão metafórica, que estabelecerão, na maioria dos casos, rótulos avaliativos ou axiológicos para determinados segmentos do texto, 
funcionando como uma paráfrase resumidora de alto valor persuasivo no discurso ${ }^{33}$. Como não há um antecedente explícito do rótulo, chama-se o interlocutor a participar mais ativamente da interpretação da anáfora, o que em si já é uma estratégia retórica.

Conte considera o encapsulamento anafórico como uma anáfora pragmática, visto que põe em relevo, no discurso, operações cognitivas e emotivas (2003:182). Da mesma forma, vê esse procedimento como interessante estratégia de introdução de novos referentes, que podem se tornar argumentos de outras predicações ao longo do discurso, resultando em poderoso meio de manipulação. Em muitos casos, conforme aponta Conte, o encapsulamento anafórico permite atribuir uma força ilocucionária ${ }^{34}$ a algum enunciado, num movimento interpretativo de um ato de fala do outro, o que também constitui estratégia argumentativa.

Alguns autores chamam o encapsulamento de rotulação, que pode ocorrer em remissões anafóricas ou catafóricas. Nesse caso, pode-se falar em rótulos retrospectivos, quando há anáfora, e prospectivos, quando há catáfora (cf. Francis, 2003:191). O rótulo prospectivo, apresentado antes do conteúdo que resume e avalia, faz parte do foco da informação nova do enunciado e induz a determinada interpretação do que virá. O rótulo retrospectivo faz o interlocutor reavaliar o conteúdo anterior pela ótica do enunciador. Os dois movimentos são eficazes estratégias discursivas, visto que operam com referências difusas e com a mudança de direção assinalada pelo rótulo no ambiente discursivo. Não se pode esquecer também que os rótulos podem ser modificados por elementos axiológicos, o que potencializa sua força argumentativa.

Francis observa que esses recursos são muito comuns na imprensa e em todos os discursos de natureza argumentativa, não correspondendo a um processo aleatório de nomeação das coisas e dos fatos, mas sim à codificação de percepções partilhadas, ou partilháveis, do mundo (op.cit.:226). Com um olhar mais crítico, Rajagopalan vai além e afirma que "a mídia imprime certas interpretações pelo simples ato de designação de determinados acontecimentos, dos responsáveis por tais acontecimentos, dos atos

\footnotetext{
${ }^{33}$ Pode ocorrer encapsulamento anafórico por meio de pronomes neutros como "isso", mas vamos privilegiar na análise apenas os rótulos nominais.

34 "Força ilocucionária ou ilocutória" refere-se aos atos ilocutórios da linguagem, que são os atos realizados quando dizemos alguma coisa. Um ato de fala pode corresponder a uma ordem, um pedido, um agradecimento, uma promessa, ações enfim que só se realizam por meio do discurso.
} 
específicos praticados pelos lados em situações de conflito", fazendo assim uso político e ideológico das nomeações para influenciar a opinião pública (2003:82).

A mídia, ao escolher, por exemplo, os termos para designar as partes de um conflito, determina também quem vai desempenhar o papel de bandido e o de herói na encenação dramática do discurso midiático, aspecto discutido no primeiro capítulo desta tese. Segundo Rajagopalan, é por estarem camufladas como simples ato referencial que tais descrições acabam exercendo influência sobre o público, que vai se acostumando com os rótulos e deixa de perceber a avaliação que a descrição comporta, tomando a opinião como fato (op.cit.:87). Entendemos que isso ocorre também em relação às outras estratégias de manipulação que descrevemos neste capítulo, cuja reiteração naturaliza os componentes ideológicos do discurso e tem efeitos sobre a formação de memória social.

Assim como se pode identificar, no fenômeno da polifonia, uma tensão entre vozes e silêncios, tem-se nos procedimentos de referenciação um jogo entre dito e não-dito, que caracteriza uma outra face dos discursos: seu silêncio constitutivo, cujo significado é o de que "uma palavra apaga necessariamente as outras palavras". É assim que Orlandi subverte o senso comum, dizendo que o silêncio é a figura, não o fundo (1993:33). O silêncio constitutivo apaga outros sentidos possíveis, mas indesejáveis, em determinada situação discursiva, funcionando, segundo Orlandi, como um mecanismo de censura que impede a elaboração histórica dos sentidos ao selecionar e institucionalizar apenas alguns deles (op.cit:110).

A mídia, ao apropriar-se desses instrumentos lingüísticos, age como verdadeiro produtor e reprodutor de sistemas simbólicos que concorrem para a construção do sentido do mundo social. No entanto o poder simbólico de seu discurso emana, para usar as palavras de Bourdieu, da "crença na legitimidade das palavras e daquele que as pronuncia" (2005:14), crença cuja produção é, a nosso ver, da competência de toda a trama discursiva, cujos fios se entrelaçam na prática social do discurso midiático. Para finalizar esta parte relativa às teorias do discurso, é importante refletir sobre as contribuições da análise crítica do discurso, que discute todos os aspectos vistos até aqui numa perspectiva globalizante. 


\section{Teoria social do discurso: um ponto de conjunção}

As perspectivas teóricas que foram expostas mostram que é crescente o empenho em usar a análise lingüística para compreender fenômenos sociais, culturais e históricos mais amplos. No entanto o exame do objeto quase sempre se concentra num determinado aspecto do discurso em foco, sem que se apreendam suas relações com o universo social imediato. Isso decorre, decerto, da complexidade de aliar diferentes teorias a eficientes métodos analíticos. A fim de oferecer uma alternativa que torne viável essa junção, uma vertente denominada análise crítica do discurso propõe uma abordagem que reúne vários modelos de análise da lingüística, da pragmática e da análise do discurso, bem como estudos das ciências sociais.

Um dos postulantes dessa prática é Norman Fairclough, que desenvolve uma teoria social do discurso com base na convicção de que a linguagem tem desempenhado um papel central nos processos de transformação social. Sua concepção de análise do discurso é tridimensional e focaliza qualquer evento discursivo como um texto, uma prática discursiva, entendida como interação, e um exemplo de prática social, que envolve as circunstâncias institucionais e organizacionais do discurso. Fairclough concilia conceitos de diversas áreas e autores (Labov, Goffman, Halliday, Harris, Pêcheux, Foucault, Bakhtin, Authier-Revuz, Kristeva e outros) para formular uma teoria social do discurso, que conjuga a análise textual com a análise social do evento discursivo.

O principal objetivo desse pesquisador é constituir um quadro teóricometodológico que possa ser usado no estudo das mudanças sociais refletidas nos discursos e ao mesmo tempo produzidas por eles. Nesse aspecto, a visão de Fairclough não é diferente do que vimos até aqui: "O discurso é uma prática não apenas de representação do mundo, mas de significação do mundo, constituindo e construindo o mundo em significado" (2001:91). Segundo ele, os efeitos dos discursos contribuem para a construção de identidades sociais, das relações sociais e de sistemas de conhecimento e crença, o que corresponde às funções identitária, relacional e ideacional da linguagem. O quadro analítico comporta então elementos lingüísticos, interacionais e de estruturas sócio-ideológicas. 
O ponto de partida de um projeto de análise de discurso deve ser, segundo Fairclough, a proposição de questões sobre formas particulares de prática social e suas relações com a estrutura social, o que significa que as disciplinas que se ocupam do problema em foco deveriam ser postas em primeiro plano na definição da pesquisa, cabendo uma função metodológica à análise do discurso propriamente dita. Com base nesse conceito, Fairclough sugere um esquema flexível de análise de discurso como empreendimento interdisciplinar.

A análise textual e a análise da prática discursiva abrangem propriedades formais do texto e aspectos de sua produção e interpretação, focalizando sete itens: vocabulário (dimensão semântica), gramática, coesão, estrutura textual, atos de fala, coerência e intertextualidade. Nesse conjunto, são descritos e interpretados elementos como heterogeneidade manifesta, pressuposição, metadiscurso, coesão referencial, modalidade discursiva e metáfora. Por fim, analisam-se os efeitos ideológicos e políticos do discurso como prática social.

O projeto é ambicioso e conjuga diferentes ramificações teóricas para a consecução do que parece ser uma análise de discurso ideal. No entanto, como Fairclough mesmo admite, "em qualquer análise particular algumas das categorias são provavelmente mais relevantes e úteis que outras, e os analistas provavelmente desejam focalizar um número pequeno de categorias" (op.cit.:282). Neste trabalho, portanto, tomamos parte da teoria social do discurso como baliza metodológica, equacionando o mérito da análise interdisciplinar e a dificuldade operacional do modelo proposto.

Partimos de um problema inerente à prática social do discurso da mídia, em especial o do telejornalismo, e alinhamos algumas concepções teóricas que podem auxiliar a compreender em que medida a materialidade desse discurso se entretece com a materialidade sócio-histórica e investe-se de um duplo papel: fabricar o esquecimento pelo bombardeio de informações que promove e atualizar permanentemente a memória social. Para entender esse fenômeno, julgamos relativamente suficiente a análise dos aspectos já definidos nesta tese.

Lembramos que tentamos resolver o problema de avaliação da recepção do discurso, que não é devidamente considerado por Fairclough, recorrendo aos conceitos apresentados por Patrick Charaudeau em sua análise do discurso das mídias. Segundo 
ele, a máquina midiática pressupõe três lugares: o das condições de produção, o de construção do discurso e o das condições de interpretação. Entre os fatores envolvidos na produção do discurso está a intencionalidade dos efeitos visados; na construção material do discurso podemos ver marcas dos efeitos possíveis; e entre as condições de interpretação podemos considerar tanto os efeitos produzidos quanto os supostos. Como já dissemos, vamos avaliar somente os efeitos possíveis e supostos do discurso telejornalístico sobre o público, contornando a impossibilidade de afirmar quais são os efeitos visados intencionalmente pelo discurso e os efeitos realmente produzidos.

Neste passo, convém apresentar outras idéias de Charaudeau sobre o discurso da informação e também os estudos de Jean-Claude Soulages sobre a encenação visual da informação ${ }^{35}$. Como essas pesquisas sobre a mídia não constituem, em si, teorias do discurso, decidimos colocá-las na seção seguinte, ao lado de outros dois assuntos: as concepções relativas à imagem, elemento fundamental no discurso que nos propomos analisar, e as teorias sobre a memória social, ponto fulcral desta tese.

${ }^{35}$ O professor Charaudeau é diretor-fundador do Centro de Análise do Discurso da Universidade Paris-Nord (Paris 13) e o professor Soulages é pesquisador do Centre Universitaire d'Enseignement du Journalisme, em Strasbourg, França. 


\section{SEgUNDA PARTE - NoçõES COMPLEMENTARES}

Tornar-se senhores da memória e do esquecimento é uma das grandes preocupações das classes, dos grupos, dos indivíduos que dominaram e dominam as sociedades históricas. Os esquecimentos e os silêncios da história são reveladores destes mecanismos de manipulação da memória coletiva. (Jacques Le Goff)

\section{Concepções sobre a imagem}

Nossa pesquisa específica sobre as imagens de televisão não foi das mais frutíferas, mas colhemos conceitos e impressões genéricas sobre a representação visual que podem iluminar a análise desse elemento constitutivo do discurso telejornalístico. De modo geral, o interesse por esse universo, que ainda não conta com uma ciência da imagem (cf. Santaella e Nöth, 1999), traduz-se em estudos sobre a pintura e a fotografia. Acreditamos que certas concepções sobre a fotografia podem ser aplicadas, de alguma forma, às imagens do telejornal, em especial se levarmos em conta uma possível similaridade com o fotojornalismo.

Um ponto de vista interessante é o de Barthes, que situa a fotografia como simulacro sui generis da realidade, no qual há uma "teimosia do referente em estar sempre presente" (1984:15). A fotografia tem, no entanto, mais que a função dêitica de apontar para algo exterior. Segundo Barthes, ela transcende o tempo real, uma vez que repete mecanicamente e reproduz ao infinito "o que nunca mais poderá repetir-se existencialmente" (op.cit:13), sendo portanto, mais do que representação, verdadeira "emanação do real passado". Ela ratifica a certeza de que algo efetivamente aconteceu, ao contrário da linguagem, cujo infortúnio é não poder autenticar-se a si mesma, como observa Barthes. Entretanto, se a fotografia não mente quanto à existência de algo, pode mentir quanto ao seu sentido, na medida em que é por natureza tendenciosa (cf. Barthes, op.cit::128).

A natureza imóvel da fotografia favorece o processo de retenção de algum momento ou acontecimento, mas pode também funcionar, segundo Barthes, como uma "contralembrança", visto que bloqueia nossas lembranças naturais do evento 
(op.cit:136). Nesse sentido, pode-se dizer que a imagem visual acumula as funções de representação e apresentação, sendo capaz de reproduzir algo já presente na consciência ou de introduzir um novo referente (cf. Santaella e Nöth, 1999). É o que se vê na mídia, que de modo geral apresenta imagens de acontecimentos que a maioria do público não presenciou. A função de representação atingirá apenas os que assistiram aos eventos e mesmo assim poderá orientar e delimitar a lembrança de determinados elementos. Isso confirma a tendência de as imagens figurativas serem consideradas documentos de uma época, marcadas que são pela historicidade dos objetos e fatos que representam.

Outra discussão que se coloca entre os estudiosos da imagem e pulsa no interior desta tese é: "Será que as imagens podem ter significado autônomo como signos visuais ou o significado da imagem só se origina pela mediação da linguagem verbal?". Segundo Santaella e Nöth, há argumentos nas duas direções, mas parece prevalecer a idéia de que a linguagem verbal é sempre necessária à análise de uma imagem, uma vez que não existe uma metalinguagem visual que o faça. Em verdade, dizem eles, em contextos híbridos, há uma relação de interdependência e complementaridade dos códigos, já que, se há textos comentadores da imagens, há também imagens ilustrativas dos textos, que comentam o texto (Santaella e Nöth, 1999:43). Um código contextualiza o outro, controlando a particular polissemia de ambos, portanto a função da imagem extrapola a de mera redundância, predominante em alguns casos. Assim Santaella e Nöth concluem que "o código hegemônico deste século não está nem na imagem, nem na palavra oral ou escrita, mas nas suas interfaces, sobreposições e intercursos" (op.cit.:69).

Em comum com as palavras, as imagens têm a capacidade de se tornar símbolo ${ }^{36}$ e a propriedade de se disporem num diagrama sintático, não podendo ser compreendidas senão em seu conjunto. Barthes afirma que as imagens são, na maioria das vezes, conotativas ou simbólicas e que é difícil encontrar imagens literais ou denotativas em estado puro, visto que a sociedade dispõe de saberes que a fazem ver sempre além do literal (1986:39), e que quase sempre há uma mensagem lingüística a nortear a leitura da

\footnotetext{
${ }^{36} \mathrm{O}$ símbolo é, segundo a concepção clássica de Peirce, um signo associado ao objeto que representa, em virtude de uma convenção.
} 
imagem, obrigando-nos a evitar determinados sentidos e a aceitar outros. Assim, imagem e palavra formam um sistema retórico bastante particular.

No caso da imagem televisual, a complexidade sintática e retórica é ainda maior, visto tratar-se de imagem móvel, múltipla e seqüencial. Conforme apontam Santaella e Nöth, esse tipo de imagem trabalha concretamente com o movimento, que é a relação entre tempo e espaço, porém o tempo incidente é o tempo do discurso, não o da realidade. Assim, "o tempo mais característico da enunciação televisiva nasce do contraste entre o continuum do real que a câmera registra e os cortes nesse continuum que a produção e a edição executam" (Santaella e Nöth, op.cit::80).

Dessa forma, põe-se em relevo o sentido discursivo das imagens. Santaella e Nöth lembram que a imagem fotográfica é como um predicado ou um argumento em relação ao objeto representado e que, nesse contexto, as fotos de imprensa contêm traços conotativos adicionais, uma vez que são produzidas, escolhidas e editadas conforme normas profissionais, estéticas e ideológicas (op.cit:112). Desse processo podem surtir, além da manipulação de opinião, efeitos de orientação da memória, dado que a imagem fotográfica - e, por extensão, a imagem televisual - pode ser considerada "signo de um passado inatingível, irremediavelmente irrecuperável, mas imperturbável, perpétua e vicariamente presente" (Santaella e Nöth, op.cit:129).

A imagem veiculada em telejornais não tem o caráter de fixidez da fotografia, mas a possibilidade de repetição nos meios de comunicação, a qualquer tempo e em qualquer contexto, confere-lhe esse estatuto de signo de ausência e presença, que faz a mediação entre o homem e o mundo. Como qualquer modalidade de signo, a imagem reflete, interpreta e transforma a realidade, confirmando o descompasso que há entre o real e a capacidade de registro.

Santaella sintetiza, em outro estudo, uma marca inequívoca da cultura das mídias: "A profusão das misturas entre real e irreal, registro e manipulação, imagens referenciais, imagens sintéticas, intercambiadas ou sobrepostas, autonomia rítmica, que se desloca e desprende do tempo do referente, até a invenção de um universo próprio, são as características que afastam cada vez mais o vídeo de sua pretensa genealogia e vocação realista" (2003:180). 
Pode-se estabelecer uma correspondência com a análise que Sontag faz da função da fotografia, que é para ela uma modalidade de retórica, que simplifica e reitera o que retrata, criando uma ilusão de consenso (2003:12). A imagem televisual também é retórica, na medida em que se inscreve como argumento de autoridade no discurso midiático e, como qualquer argumento, serve aos propósitos da persuasão. Sontag observa que, na imprensa, toda foto pode ser explicada ou deturpada por suas legendas, assim como imagens de noticiários podem induzir a determinado sentimento conforme a moldura verbal que thes é dada. A isso pode-se acrescentar o fato de que as imagens, em si mesmas, têm dois níveis de sentido, explicitados na clássica análise de Barthes: um sentido óbvio e intencional, que se põe diante do destinatário da mensagem, e um sentido obtuso, valorativo, que não tem uma estrutura visível e que a intelecção não consegue absorver por completo (1986:51).

Esses dois sentidos podem ser observados no objeto de reflexão de Sontag, que são as fotos que retratam dor e sofrimento, como as fotos de guerra. Sobre elas, Sontag afirma: "Fotos de uma atrocidade podem suscitar reações opostas. Um apelo em favor da paz. Um clamor de vingança. Ou apenas a atordoada consciência, continuamente reabastecida por informações fotográficas, de que coisas terríveis acontecem" (op.cit:16). Sontag chama a atenção sobretudo para a evolução das coberturas de guerra: as fotos da Primeira Guerra Mundial eram de estilo épico e só mostravam as conseqüências; as da Guerra Civil Espanhola já eram tiradas nas linhas de frente; a Guerra do Vietnã foi a primeira a ser testemunhada pela câmeras de televisão e apresentou à população civil americana "a nova teleintimidade com a morte e a destruição".

Desde então, segundo Sontag, "criar, para determinado conflito, um nicho na consciência de espectadores expostos a dramas de toda parte do mundo demanda uma difusão e redifusão diária de imagens filmadas desse conflito" (op.cit.:22), de modo que a compreensão de uma guerra por pessoas que não a vivenciaram é sobretudo um produto do impacto dessas imagens. Sontag afirma, entretanto, que "a fotografia fere mais fundo" quando se trata de recordar, mesmo numa sociedade em que é incessante o fluxo de imagens em vídeo: "A memória congela o quadro; sua unidade básica é a imagem isolada. Numa era sobrecarregada de informação, a fotografia oferece um modo rápido 
de apreender algo e uma forma compacta de memorizá-la. A foto é como um citação ou uma máxima ou um provérbio" (op.cit.:23).

Entendemos que esse mesmo efeito pode ser obtido pela insistente repetição, e conseqüente presentificação, das imagens de determinado acontecimento, como ocorreu na cobertura dos ataques de 11 de setembro. Em casos assim, a imagem torna-se uma imagem "ultrafamiliar", "ultracelebrada", nos termos que Sontag para a fotografia, e isso age sobre a memória, sobretudo porque só algumas imagens alcançam esse estatuto na seleção operada pela edição: "Os produtores de programas jornalísticos na tevê e os editores de fotografia das revistas e dos jornais tomam, todos os dias, decisões que consolidam o instável consenso acerca dos limites do conhecimento do público" (op.cit.:59). Vamos nos deter nas reflexões sobre imagem e memória na seção seguinte.

Para finalizar este tópico, apresentamos algumas idéias de um repórter cinematográfico - o fotógrafo da contemporaneidade, segundo Sontag - sobre a comunicação visual na televisão. Segundo Zanlorezi ${ }^{37}$, o cinegrafista tem que se preocupar com o conteúdo informativo da imagem, mas deve antes de tudo cuidar da composição e da clareza da informação, que são fruto do olhar treinado do profissional. Esse olhar procura sempre algo especial na imagem, a fim de explicar a situação ou provocar emoção, no entanto esse olhar depende da bagagem cultural de cada um, assim como o olhar que receberá a informação visual.

Zanlorenzi tem plena consciência de que a imagem é carregada de subjetividade, muitas vezes manifesta na escolha dos planos e enquadramentos, e procura transmitir esse conceito aos profissionais mais novos. Ele aconselha que se analise o contexto e o conteúdo das imagens, que ajudarão a contar uma história de modo mais claro e compreensível para o telespectador. O objetivo do trabalho é, segundo ele, "escrever melhor com as imagens", transmitindo uma informação simples e consistente. De nada adianta, do ponto de vista desse cinegrafista, uma imagem tecnicamente bem feita, se ela não expressa simplicidade de raciocínio e não diz nada a ninguém. Nota-se aqui a busca da tradução e da síntese da informação por meio da imagem.

37 Jorge Zanlorenzi, repórter cinematográfico da TV Globo, coordenou um workshop sobre comunicação visual em abril de 2006, na sede de São Paulo, para público interno da emissora. 
Essa síntese é em si mesma retórica, pois ao lado da qualidade técnica da imagem, que envolve elementos como equilíbrio, linhas, dimensão, cor, plano, composição, está a sensibilidade do sujeito que filma, que fará com que o telespectador aprecie ou não a imagem, emocione-se ou não, apreenda ou não seu conteúdo informativo. Zanlorenzi enfatiza que, como o mundo é plano na fotografia e na imagem, é preciso usar todos os elementos com técnica e sensibilidade para construir um mundo tridimensional, que terá mais força, significado e até mesmo dramaticidade, dependendo da composição.

Vista dessa forma, no cotidiano do repórter cinematográfico, a imagem parece ser apenas mais um elemento da gramática televisiva. Não se pode deixar de considerar, entretanto, que ela é um poderoso argumento da construção discursiva dos telejornais. Quaisquer que sejam as intenções de quem as produz, as imagens serão selecionadas e enquadradas num contexto em que deixarão de representar objetos do mundo para tornar-se objetos de discurso, com todas as implicações já discutidas nesta tese. As imagens, óbvias ou obtusas, pertencem ao mundo do sensível e se ligarão às palavras, do universo inteligível, para compor uma realidade discursiva. A elas se sobreporão ou se subordinarão as múltiplas vozes que tecem o discurso telejornalístico e imagens e palavras se eternizarão na memória metálica ${ }^{38}$ da mídia, que por sua vez podem orientar nossa memória.

Como lembra Orlandi, a própria etimologia da palavra "televisão" explica o objeto: ela atinge, à distancia, o olhar, "produzindo o efeito documental, do testemunho". Por suas características, a televisão "historiciza seu instrumento e, no entanto, produz o efeito de des-historicização no espectador", pois o olho do espectador é o olhar do instrumento (Orlandi, 2005:179). Na próxima seção, procuraremos relacionar a essa reflexão algumas formulações sobre a constituição da memória social.

${ }^{38}$ Expressão usada por Eni Orlandi para se referir à memória que abrange conteúdos do ciberespaço e das mídias eletrônicas (2005:182). 


\section{O discurso da informação e a encenação visual}

$\mathrm{Na}$ obra em que propõe profundas reflexões sobre a sociedade plasmada em simulacros e simulação, Baudrillard afirma que "a informação devora seus próprios conteúdos", porque "em vez de fazer comunicar, esgota-se na encenação da comunicação e, em vez de produzir sentido, esgota-se na encenação do sentido" (1991:106). Com essa encenação exacerbada, os mass media promovem uma desestruturação do real e só o meio em si passa a constituir um acontecimento. Essa paráfrase da máxima de McLuhan de que "o meio é a mensagem" parece sintetizar a problemática de que vão se ocupar muitos estudos sobre a mídia. Os dois importantes trabalhos que ora apresentamos tratam, de diferentes perspectivas, das estratégias de encenação da informação no discurso midiático ${ }^{39}$.

Charaudeau (2006) focaliza o ato de informação em múltiplas dimensões: sua concepção como ato de comunicação e como discurso; o contrato de informação midiático; o acontecimento como visão social do mundo; os dispositivos de encenação; a transformação do acontecimento em notícia; os gêneros do discurso de informação. Depois avalia as relações entre mídia e democracia e as permanentes questões sobre a manipulação e a deontologia das mídias.

Soulages (1999) explora as inúmeras implicações de um objeto plural e complexo como a televisão: o espaço e o contrato midiáticos; os procedimentos de linguagem da informação televisiva; os dispositivos enunciativos de mediação; os modos de organização discursiva; os imaginários sociodiscursivos; os tipos de construção do acontecimento. Como faz um estudo comparativo entre televisões da França, da Espanha e dos Estados Unidos, em suas conclusões questiona se o jornal televisivo tem hoje um formato universal.

\footnotetext{
${ }^{39}$ Sobre o assunto, ver também a obra La noticia como discurso - compreensión, estructura y produción de la información, de Teun Van Dijk (Barcelona/Buenos Aires, Paidós, 1990). Por se tratar de trabalhos com perspectivas análogas, optamos por apresentar os dois mais recentes.
} 


\section{A máquina midiática}

Comecemos pelo estudo de Charaudeau, que parte das seguintes premissas: 1) as mídias não são uma instância de poder (pelo menos, segundo o autor, não um poder institucionalizado), mas fazem parte dos diferentes jogos do poder social; 2) as mídias manipulam tanto quanto manipulam a si mesmas; 3 ) as mídias são um espelho deformante da realidade; 4) as mídias de informação funcionam segundo uma lógica econômica e uma lógica simbólica, que as faz participar da construção da opinião pública.

A proposta de Charaudeau é observar a máquina midiática de modo interdisciplinar, distinguindo seus três lugares de construção do sentido, conforme o quadro a seguir (2003:23):

\section{OS TRÊS LUGARES DA MÁQUINA MIDIÁTICA}

\begin{tabular}{|c|c|c|}
\hline $\begin{array}{c}\text { PRODUÇÃo } \\
\text { Lugar das condições } \\
\text { de produção }\end{array}$ & $\begin{array}{c}\text { PRODUTO } \\
\text { Lugar de construção } \\
\text { do discurso }\end{array}$ & $\begin{array}{c}\text { RECEPÇÃo } \\
\text { Lugar das condições } \\
\text { de interpretação }\end{array}$ \\
\hline $\begin{array}{l}\text { 1. Práticas de organização } \\
\text { socioprofissionais } \\
\text { (intencionalidade dos } \\
\text { efeitos econômicos) } \\
\text { 2. Práticas de realização } \\
\text { do produto } \\
\text { (intencionalidade dos } \\
\text { efeitos visados) }\end{array}$ & $\begin{array}{c}\text { Organização estrutural } \\
\text { semiodiscursiva segundo } \\
\text { hipóteses sobre a } \\
\text { co-intencionalidade } \\
\text { (enunciador-enunciatário) } \\
\text { Efeitos possíveis }\end{array}$ & $\begin{array}{l}\text { 1. Alvo imaginado } \\
\text { pela instância midiática } \\
\text { (efeitos supostos) } \\
\text { 2. Público como instância } \\
\text { de consumo do produto } \\
\text { (efeitos produzidos) }\end{array}$ \\
\hline
\end{tabular}


Mesmo que a análise dessas instâncias não alcance os efeitos realmente visados e produzidos, dada a dificuldade de penetrar todas as camadas de produção do discurso midiático e avaliar objetivamente sua recepção, sempre se poderá avaliar seus efeitos possíveis, dos quais se pode inferir, pelo menos parcialmente, as intenções dos produtores e as operações de construção realizadas pelos receptores.

Essas distinções nos interessam porque resolvem, em grande parte, o problema da análise da recepção do discurso dos telejornais. Diante da dificuldade de medir qualitativamente a resposta do público à influência dos telejornais, enfatizamos nossa pretensão de avaliar o potencial desse meio para determinar algumas orientações e criar certas memórias e amnésias, portanto esse modelo avaliza que consideremos somente os efeitos possíveis e supostos desse discurso sobre o público.

Segundo Charaudeau, os efeitos possíveis são um eco dos efeitos propostos e somente uma parte deles corresponderá às intenções do enunciador, sendo a outra parte construída pelo receptor (op.cit.:26). Assim, avaliaremos o que emerge do discurso como marca dos efeitos propostos e possíveis; conseqüentemente, poderemos chegar aos efeitos supostos, sem necessariamente aferir os efeitos produzidos de fato, haja vista que o público tem características diversas a agir sobre o modo de interação com a mídia.

Como o discurso da informação, tomado como um ato de comunicação social que também põe valores em circulação, pressupõe uma reserva de mercado - apenas alguns grupos detêm o privilégio de informar -, a atividade midiática está constantemente na mira da crítica social. Diante disso, Charaudeau preocupa-se em definir o ato de informar e em esclarecer suas implicações. Segundo ele, "a informação é pura enunciação" (op.cit.:36), portanto cabem questões sobre seu valor de verdade, que diz respeito à autenticidade e à verossimilhança dos fatos e à pertinência da informação. Sempre será possível e necessário indagar que critérios e interesses determinam a seleção dos fatos a serem informados e que estratégias discursivas produzem esse ou aquele efeito de sentido.

A informação, tomada como evento discursivo, veicula saberes, crenças, opiniões e representações, portanto implica determinado grau de engajamento e credibilidade do informador, bem como a necessidade constante de provar e explicar o que é mostrado por meio de imagens, testemunhos, documentos, entrevistas, debates -, com vistas à construção de uma verdade consensual. Daí decorre a importância dos estudos que se 
destinam a entender o funcionamento da máquina midiática, cujas peças podem revelar como a mediação da informação estabelece versões de um acontecimento.

Charaudeau aponta como um dos problemas do discurso da informação a pretensão de vulgarizar ou simplificar eventos e explicações, com vistas à inteligibilidade da notícia. Na maioria das vezes, o que ocorre é que a informação é transformada ou deformada para parecer acessível, sobretudo no processo de vulgarização praticado pela televisão, que tenta traduzir fatos complexos por meio de estereótipos e raciocínios simplistas. Para Charaudeau, "pode-se dizer que as mídias trapaceiam cada vez que uma explicação é apresentada como a decodificação simplificada de uma verdade oculta, como acessível a todos e a mesma para todos graças ao efeito mágico da vulgarização" (op.cit:62). Outro característica desse discurso é a impossibilidade de controlar a inteligibilidade, o que leva a instância de produção a supor as condições de recepção tais como conhecimento lingüístico, motivação para se informar e reações emocionais para dotar seu discurso de elementos capazes de atingir o público-alvo intelectual e afetivamente. Essa não uma limitação exclusiva desse tipo de discurso, mas parece tornar-se um problema maior devido ao enorme público de mídias como a televisão.

Sobre essas e outras questões, paira o problema da relação com a verdade, visto que a instância midiática deverá empreender a atividade de reportar os fatos do mundo e a de esclarecer as causas e conseqüências desses fatos. Charaudeau trata das noções de verdadeiro e falso não de modo filosófico, mas do ponto de vista da linguagem, assim a verdade será avaliada com base nas atividades de descrição-narração e explicação: "o verdadeiro seria dizer o exato, o falso seria dizer o erro; o verdadeiro seria dizer o que aconteceu, o falso seria inventar o que não aconteceu; o verdadeiro seria dizer a intenção oculta, o falso seria mascarar a intenção; o verdadeiro seria fornecer a prova das explicações, o falso seria fornecer explicações sem prova" (op.cit.:88).

Portanto, no discurso da informação, a verdade está ligada ao modo de designar, relatar e explicar os fatos do mundo, seja por imagens, seja por palavras. Isso explica nosso interesse pelas formas de designação e referenciação e pelas formas de discurso relatado presentes nos discursos dos telejornais. Da análise desses elementos, poderemos verificar que verdade histórica esse discurso fornece ao arcabouço de nossa memória social. Teremos sempre em mente, no entanto, que essa encenação discursiva 
da verdade e dos fatos decorre da ambígua finalidade inscrita no contrato de informação: fazer saber e fazer sentir, esta ligada aos apelos da lógica econômica e aquela, às leis da lógica simbólica.

É da natureza do discurso midiático informar; é da natureza da cultura midiática impor a espetacularização. Por isso Charaudeau não hesita em afirmar que "uma mídia que só satisfizesse ao rigor sóbrio e ascético do fazer saber estaria condenada a desaparecer" (op.cit:93). Embora isso provavelmente seja verdade, não podemos deixar de indagar até que ponto o que se paga (ou se ganha) para não desaparecer desestabiliza o compromisso que a mídia tem com a sociedade e com a história. Pode tudo ser explicado pela genética da máquina midiática ou há que se considerar o abuso do poder econômico ou de outra natureza? Não nos antecipemos e deixemos essa questão para as considerações finais.

Retomamos as idéias de Charaudeau, que também partilha da convicção de que o acontecimento, tal como transmitido pela mídia, não passa de uma construção concebida a partir de uma visão social do mundo. Para que um acontecimento saia de seu estado bruto e adquira significação é preciso que um olhar o integre a um sistema de pensamento e o torne inteligível. Para realizar esse processo, cada mídia se valerá de determinados dispositivos ou suportes da encenação da informação.

O rádio, por exemplo, tem como principais dispositivos "a magia da voz", a transmissão no tempo presente, a interação verbal. Na televisão, é da solidariedade entre fala e imagem que nascem a significação, a estruturação do sentido, o efeito de autenticação do acontecimento, o efeito de fascinação pelo drama que é apresentado. Assim, conforme observa Charaudeau, a televisão proporciona dois tipos de olhar: "um olhar de transparência, mas de ilusão de transparência, quando pretende desvelar, descobrir o oculto, mostrar o outro lado do espelho; o outro de opacidade, quando impõe sua própria semiologização do mundo, sua própria intriga, sua própria dramatização" (op.cit.:112).

Ao lado dos dispositivos, estão as estratégias de encenação da informação ou de construção da notícia, que compreende a descrição, o relato e a análise dos fatos. Antes porém os fatos são submetidos a uma seleção, cujas principais diretrizes são a obsessão do tempo presente, o equilíbrio entre notícias locais e acontecimentos do mundo e a 
importância hierárquica dos eventos. Segundo Charaudeau, o critério da atualidade explica duas características do discurso da informação: sua efemeridade e sua ahistoricidade, uma vez que "as mídias nunca podem garantir que o que é relatado traga alguma marca de perenidade" (op.cit.:134). Eis mais uma questão que havemos de retomar ao fim deste trabalho, uma vez que sustentamos a tese de que o discurso midiático, ao mostrar a história em se fazendo sob uma ótica particular, pode inscrever duradouramente na memória social sua versão de determinados eventos.

Quanto às outras duas diretrizes, entendemos que ambas dependem da agenda que a mídia quer impor à sociedade: o que se deve ou não saber sobre nossa "aldeia" e o mundo e em que ordem de importância. Essa seleção se faz, segundo Charaudeau, em função do potencial de saliência dos fatos, que reside ora no notável, ora num estado de desordem do mundo, ora num estado de triunfo da ordem social. A composição dos recortes que o público verá influenciará sua forma de apreensão do mundo. Por outro lado, interferem nessa composição as fontes de informação a que as instâncias de produção recorrem e que devem ser verificadas e apresentadas com rigor.

Charaudeau classifica as fontes como internas aos organismos de informação (correspondentes, enviados especiais, arquivos próprios, agências de notícias e outras mídias) e externas a eles (órgãos governamentais, partidos políticos, movimentos sociais, sindicatos, especialistas, testemunhas etc.) (2006:148). É inegável a possibilidade de se instaurar um jogo de manipulação entre as mídias e as fontes, portanto faz parte do contrato de informação que as mídias consultem o máximo de fontes ou canais de difusão possível, verifiquem as informações e identifiquem sua origem - resguardado o direito de preservação da fonte em certos casos - para garantir a credibilidade da notícia.

No entanto, mesmo que isso seja feito, podem emergir da enunciação marcas que revelem a relação que a mídia mantém com a fonte, marcas como o modo de denominação e a modalização do dizer das fontes. Diferentes nomeações e modalizações ("o presidente Lula", "Lula", "o governo", "o Palácio do Planalto", "a oposição", "fontes oficiais", "a Casa Branca", "os especialistas"; "afirma", "acredita", "revela", "admite", "reagiu", "teria dito") podem produzir diferentes efeitos discursivos, como veremos na análise do corpus desta tese. 
Charaudeau apresenta ainda três modos possíveis do acontecimento midiático: o acontecimento relatado, o acontecimento comentado e o acontecimento provocado. Uma vez que o corpus desta tese não é formado por um acontecimento provocado, como um debate ou uma entrevista, deteremos nossa atenção nos dois primeiros modos. O acontecimento midiático relatado constitui-se de fatos e ditos relatados; o acontecimento comentado tenta explicar o acontecimento relatado, ou justificar o posicionamento adotado no relato, por meio de análises e pontos de vistas em geral dos chamados especialistas. A instância midiática impõe assim uma visão do mundo previamente articulada, que implica todas os traços de subjetividade e manipulação de que já tratamos neste capítulo.

As observações que Charaudeau faz sobre o acontecimento relatado contemplam muito do que já expusemos sobre o discurso relatado e as formas de referenciação. Um dado relativamente novo que podemos enfatizar é a distinção que ele aponta entre narrativa em simultaneidade e narrativa de reconstituição. Essa distinção básica funda os dois principais tipos de transmissão telejornalística dos acontecimentos: a cobertura ao vivo e a edição posterior ao event. Na narrativa reconstituída, o informador (sempre um informador coletivo) está liberado das restrições da simultaneidade e pode empreender um trabalho de roteirização, edição e dramatização do acontecimento, utilizando-se de diversas estratégias verbais e visuais. Pode-se recortar o continuum cronológico em muitas partes e montá-las do modo mais conveniente do ponto de vista discursivo; podese inserir comentários explicativos na reconstituição e recontextualizar ditos relatados; pode-se, enfim, conduzir a narrativa para quaisquer perspectivas ou questionamentos gerados pelo acontecimento midiático.

Especificamente sobre o fenômeno da fala relatada, Charaudeau afirma que se trata de um dos grandes desafios das mídias modernas, que acabam se enredando, de um modo ou de outro, nas armadilhas da seleção, da identificação e da reprodução das diversas falas sociais e revelando um posicionamento em relação a elas. Charaudeau avalia que o principal problema da seleção de falas é que as mídias, ao darem a palavra a notáveis e instâncias oficiais, podem mostrar-se como "organismos da informação institucional", portanto organismos suspeitos; por outro lado, ao darem a palavra aos anônimos, as mídias podem apresentar-se como "a imagem da democracia", mas serem 
acusadas de demagógicas (op.cit:168). Veremos como a mídia analisada nesta tese procede em relação à construção polifônica de seu discurso.

Simultaneamente, verificaremos em que medida o acontecimento relatado é transformado em acontecimento comentado e que recursos são usados pela mídia televisiva para realizar essas atividades discursivas inseparáveis, segundo Charaudeau: relatar e comentar. Os comentários jornalísticos comportam explicações, analogias, sínteses, opiniões, contraposições, clichês e as mais variadas formas de metadiscurso. Todos esses procedimentos podem provocar múltiplos efeitos discursivos e, se mal empregados, podem gerar desinformação e colocar em risco a credibilidade do veículo.

Os efeitos, entretanto, não cessam aí. Charaudeau afirma que a mídia televisiva "não pode se apresentar como máquina de fabricar ficção, mesmo que, afinal, seja isso que ela produza" (op.cit.:223). Pois bem, ao roteirizar, dramatizar ou "ficcionalizar" os acontecimentos do mundo, o discurso telejornalístico recria a história como fiç̧ão e estabelece uma memória artificial dos eventos, que será incorporada à nossa memória social. Nesse caso, é de menor importância se isso se dá porque as mídias manipulam ou porque são manipuladas, se a deformação é proposital ou não, se o público é ou não co-responsável pelo processo de espetacularização do mundo - questões de fundo na análise que Charaudeau faz da máquina midiática.

Como o próprio autor enfatiza, da combinação entre palavra e imagem "nasce um produto talvez mais apto do que os outros a fabricar imaginário para o grande público, isto é, um espelho que devolve ao público aquilo que é sua própria busca de descoberta do mundo" (op.cit::223). Sabendo disso, não nos cabe procurar culpados, tampouco nos resta aceitar placidamente que a máquina midiática é incontrolável. Devemos conhecer as engrenagens, entender os movimentos da máquina e aprender a controlar criticamente seus efeitos, sob pena de, se não o fizermos, vivermos apenas um mundo diegético ${ }^{40}$, do qual restará tão-somente a memória do espetáculo.

\footnotetext{
${ }^{40}$ O termo "diegese" recobre "a história contada como conteúdo e mais amplamente o mundo que propõe e constrói cada narrativa: o espaço e o tempo, os eventos, os atos, as palavras e os pensamentos das personagens"; assim "o universo diegético de uma narrativa é interpretativamente construído pelo leitor/ouvinte a partir do que está dito e do que está pressuposto pelo texto" (Charaudeau e Maingueneau, 2004:343).
} 


\section{Uma enunciação fílmica}

Soulages (1999) afirma que os estudos sobre as mídias constituem um saber mosaico e propõe, como os outros autores que citamos, uma aproximação entre diversas áreas do conhecimento a fim de compreender a natureza complexa, polimorfa e heterogênea das mídias, sobretudo no que concerne à pesquisa das formas significantes e dos efeitos do discurso midiático, visto como encenação em diferentes trabalhos. Em virtude de muitas das reflexões de Soulages sobre o contrato e o espaço midiáticos e também sobre a informação e os regimes de verdade serem semelhantes ao que já expusemos, vamos nos concentrar em aspectos específicos da encenação visual dos telejornais, pouco explorados no estudo de Charaudeau.

$\mathrm{Na}$ concepção de Soulages, é preciso considerar no jornal televisivo - além das estratégias argumentativas e dos procedimentos de dramatização - a construção de uma enunciação fílmica, cuja principal função é criar a ilusão de coincidência entre o universo diegético da informação e o universo real, como prova da pretensa ubiqüidade da mídia. Soulages afirma que a produção televisual engloba numerosas formas culturais preexistentes, como o filme de cinema, mas dá origem a novas atividades comunicacionais, como o telejornal, que se refere ao mundo exterior ao mesmo tempo em que obedece a uma lógica interna de narração verbo-visual.

A aproximação do telejornal com o cinema se justifica pelos dispositivos que são acionados para mostrar os acontecimentos: múltiplas câmeras a captar a ação, variação incessante de ângulos, pessoas reais investidas como personagens. Tudo isso constitui uma grande figura de presença, capaz de promover empatia e adesão ao discurso, e ao mesmo tempo cria um efeito de ausência da mediação instaurada: o sujeito que mostra não está em cena, as imagens (e também os sons captados) referenciam e autenticam o mundo por si sós. No entanto o olhar também é modalizado e mostra cenas, figuras e detalhes do acontecimento sob os ângulos e planos que convierem à narrativa visual, sempre pontuada por comentários verbais.

$\mathrm{Na}$ cena enunciativa do telejornal, a pluralidade de imagens é tão importante quanto a pluralidade de vozes na busca dos efeitos de realidade e abrangência dos fatos. Inserir, por exemplo, repórteres e correspondentes em espaços relacionados aos 
acontecimentos resulta em notáveis efeitos de co-presença e sincronização entre relato e exibição. Da mesma forma, mostrar uma autoridade, um especialista ou uma testemunha falando produzirá efeitos diferentes dos obtidos pelo relato das falas. As imagens, assim como as palavras, não têm função puramente estética e podem servir aos propósitos de descrever, narrar, ilustrar, explicar ou argumentar. A simbiose entre palavra e imagem ou até mesmo a redundância do conjunto reforçam a concepção dramática e potencializam a função retórica do jornal televisivo.

Segundo Soulages, ao operar num espaço de cognição e sedução, o discurso da informação televisual cria um imaginário sociodiscursivo, repleto de vozes e imagens reconstituídas diegeticamente e orientadas para determinada leitura do mundo, tomada como crível mediante o contrato de confiança que se estabelece entre mídia e público. Esse imaginário sociodiscursivo, no entanto, está claramente vinculado aos imaginários socioculturais de cada nação. Soulages concluiu, com base no estudo comparativo das estratégias enunciativas usadas por três emissoras de televisão de países diferentes, "que chaque rédaction, en se posant comme l'interlocuteur ratifié d'une collectivité nationale, introduit as perspective particularisante, interne et subjective et confère une identité narrative à la thématique événementielle" (1999:200).

O pesquisador observa, porém, que existe um risco real de padronização e uniformização das formas e conteúdos do discurso informativo, sobretudo porque o telejornal é um produto da indústria das mídias de massa. Isso significa um risco maior de homogeneização dos processos que reportam os acontecimentos do mundo, não apenas como efeito inevitável da globalização, mas pela subserviência da máquina midiática ao poder econômico. Como vimos no primeiro capítulo deste trabalho, esse mal não é só uma possibilidade. Há vários estudos sobre a influência da mídia norte-americana sobre a mídia de outros países e também sobre a concentração do privilégio da informação nas mãos de poucas e poderosas empresas privadas de comunicação ${ }^{41}$.

\footnotetext{
${ }^{41}$ Segundo dados apresentados por Chomsky (2003:13), em 1983, 50 empresas dominavam quase todas as mídias de massa nos Estados Unidos; em 1990, eram 23 empresas; desde então, a centralização se intensificou e hoje apenas nove conglomerados transnacionais detêm o controle da mídia (Disney, AOLTime Warner, Viacom, News Corporation, Bertelsmann, General Electric, Sony, AT\&T-Liberty Media e Vivendi Universal).
} 
Virando a lente para o objeto desta tese, podemos lamentar: não bastasse a subordinação da memória social à memória metálica das mídias, há também a conformação dessa memória à história contada por instâncias midiáticas que se curvam ao mundo dos negócios. Mas esse é um outro problema. Ajustemos a lente para examinar algumas concepções sobre memória social, última camada deste tecido conjuntivo teórico, e então passar à efetiva análise do corpus.

\section{Teorias da memória social}

Há diferentes modos de considerar a memória e sua relação com a linguagem, a sociedade e a história. Guimarães aponta alguns caminhos e diz que se pode tomar a memória como memória discursiva, estruturada pelo esquecimento; como memória institucionalizada, ou arquivo, estruturada pelo não esquecimento; como mecanismo psicológico e cognitivo, como base do conhecimento humano e da linguagem; como traço de identidade, fixado pelo discurso da história e da literatura; e como elemento do processo histórico e social de significar. Neste último caso, a memória seria um artefato construído pelas práticas histórico-sociais de organização e distribuição da informação e pelas normatizações do conhecimento (cf. Guimarães, 2005:7).

O escopo desta tese não é o funcionamento da memória cognitiva ou a constituição da memória como arquivo. Nosso olhar passeia pela memória discursiva e pela memória histórica, porém se detém mais ao longe, na construção da memória coletiva por meio de práticas sociais de organização e distribuição da informação. Objetivamos analisar o impacto da mídia televisiva no processo de formação da memória social e, para isso, precisamos entender algumas teorias e concepções sobre o que se pode chamar de memória coletiva ou memória social ${ }^{42}$. Comecemos pelo pioneiro Maurice Halbwachs, teórico que na primeira metade do século 20 desenvolveu

\footnotetext{
${ }^{42}$ Muitos teóricos desenvolveram trabalhos sobre a memória social, tais como Bartlett, Nora, Vigotsky e Durkheim, porém não julgamos necessário citá-los todos, uma vez que as premissas de Halbwachs, apresentadas a seguir, fornecem as bases para esses estudos posteriores.
} 
importantes estudos sobre os quadros sociais da memória e sobre a memória coletiva ${ }^{43}$, revolucionando o conceito de memória.

Halbwachs parte da afirmação de que não há lembrança que seja puramente interior, que possa se manter apenas na memória individual, portanto toda lembrança agrega uma percepção coletiva, sustentada no pensamento do grupo social de que o indivíduo faz parte, não sendo possível distinguir a observação interior da observação exterior. Como a sociedade se transforma conforme o tempo e as circunstâncias, modificam-se também as convenções a que se dobram seus membros, que mudam a orientação de suas lembranças no sentido para onde evolui a memória coletiva. Deve-se portanto, segundo Halbwachs, renunciar à idéia de que o passado se conserva da mesma maneira nas memórias individuais.

Essas mudanças nos quadros ou convenções sociais se refletem na linguagem, assim como as lembranças. Afirma Halbwachs que não há lembranças a que não possamos fazer corresponder palavras e que é a linguagem, e todo o sistema de convenções sociais que the são solidárias, que nos permite lembrar e reconstruir nosso passado. No entanto, mesmo as idéias da sociedade que correspondem ao presente e que o exprimem incorporam-se ao pensamento das pessoas ou dos grupos e deixam seus traços na memória. Nesse sentido, aponta Halbwachs, não há idéia social que não seja ao mesmo tempo uma lembrança da sociedade, que se esforçará em vão para resgatar uma figura ou evento puramente concretos, que não estejam impregnados nas memórias. Todo personagem e todo fato histórico que penetram nessa memória coletiva se transformam em ensinamento, em noção, em símbolo, isto é, recebem um sentido e se tornam elementos do sistema de ideologia da sociedade.

As impressões iniciais de Halbwachs sobre a formação da memória coletiva serão retomadas e desenvolvidas em seu trabalho seguinte, no qual precisará a distinção entre memória individual, memória coletiva e memória histórica. O autor reforça a convicção de que não existe uma memória estritamente individual, visto que nossas idéias e reflexões, paixões e sentimentos são freqüentemente inspirados pelo grupo social, embora os expressemos como se somente a nós pertencessem. $O$ teórico enfatiza que as

\footnotetext{
${ }^{43}$ Tomamos contato com as idéias que vamos expor a seguir consultando os livros Les cadres sociaux de la mémoire, edição de 1994 (original de 1925) e A memória coletiva, edição de 2004 (original de 1950).
} 
lembranças individuais não atendem imediatamente ao nosso apelo, ao contrário das lembranças que se conservam nos pensamentos coletivos com os quais mantemos estreitas relações. Segundo Halbwachs, "a sucessão de lembranças, mesmo daquelas que são mais pessoais, explica-se sempre pelas mudanças que se produzem em nossas relações com os diversos meios coletivos, isto é, em definitivo, pelas transformações desses meios" (2004:56).

Evidentemente, a memória de um indivíduo não se confunde com a de outro, pois é limitada no tempo e no espaço, porém as pessoas apelam continuamente às lembranças alheias para evocar seu próprio passado. Elas têm de se reportar a pontos de referência externos, fixados pela sociedade, e a palavras e idéias do meio social, que acabam por transformar o que realmente viram, fizeram, sentiram e pensaram num determinado momento de suas vidas. Por outro lado, a memória coletiva também tem limites no espaço e no tempo, porém eles podem ser mais restritos e mais remotos. Halbwachs testemunha que, apesar de muitas vezes ter dito se lembrar de determinados acontecimentos havidos em seu país, não os conhecera de fato a não ser por jornais ou depoimentos daquele que deles participaram diretamente. A única fonte de evocação, nesse caso, é uma memória emprestada, são lembranças que se tornaram símbolos e ocupam um lugar na memória da nação.

Entendemos que o autor se refere a uma memória histórica, que representa o passado de forma resumida e esquemática e na qual se apóia a memória autobiográfica, e julgamos ser possível relacioná-la ao fenômeno que se pode chamar de memória mediatizada, claramente observado nas sociedades modernas. Mais do que em qualquer outro tempo, nossa memória advém das inúmeras mediações que sofrem as informações que nos chegam de toda parte do mundo. A profusão de imagens repetidas pela mídia cola-se em nossa memória de modo semelhante ao que ocorre com imagens históricas que vemos na infância - mesmo que à distância - e atravessam nossas consciências.

Segundo Halbwachs, grande parte de nossas lembranças repousam no social e no histórico: "A lembrança é em larga medida uma reconstrução do passado com a ajuda de dados emprestados do presente e, além disso, preparada por outras reconstruções feitas em épocas anteriores e de onde a imagem de outrora manifestou-se já bem alterada" (op.cit.:76). Se há, no passado, lugares sociais em que a memória coletiva se formou, 
também os haverá no presente, que um dia se tornará passado. Um desses lugares é, sem dúvida, a mídia, que fomenta a construção de um presente histórico que, muito provavelmente, servirá de base à história que será lembrada.

Neste ponto convém refletir sobre a distinção entre memória histórica e memória coletiva, tal qual nos apresenta Halbwachs: "Se, por memória histórica, entendemos a seqüência dos acontecimentos dos quais a história nacional conserva a lembrança, não é ela, não são os seus quadros que representam o essencial daquilo que chamamos memória coletiva" (op.cit.:84). Para o teórico, a história só é escrita quando a memória coletiva começa a desvanecer e é preciso preservá-la de modo perene. Então se compilam os fatos que ocuparam maior espaço na memória dos homens e se registra a história. No entanto, Halbwachs afirma que, antes de povoarem os livros e serem ensinados na escola, "os acontecimentos passados são escolhidos, aproximados e classificados conforme as necessidades ou regras que não se impunham aos círculos de homens que deles guardaram por muito tempo a lembrança viva" (op.cit.:85).

Halbwachs afirma ser inútil, enquanto uma lembrança subsiste, querer fixá-la por escrito, portanto a história só começa quando acaba a tradição e quando surge a necessidade de salvar as lembranças de determinado período. A história não é uma memória, é o registro do passado; a memória coletiva é uma construção do presente e se estende no tempo até virar memória histórica. Se bastasse ler a história, indaga o teórico, como o sujeito poderia evocar suas lembranças, condição essencial da memória?

Em síntese, a memória é um movimento contínuo e retém aquilo que ainda está vivo na consciência do grupo; a história é uma ponte entre o passado e o presente, que tenta restabelecer a continuidade interrompida em algum ponto. Logo não há história no presente, pois só é possível recriar correntes de pensamento coletivo que tomam impulso no passado. Outro aspecto distintivo, segundo Halbwachs, é que pode haver várias memórias coletivas, pertencentes a grupos distintos, mas só uma história da nação, da mesma forma que pode haver uma história universal, mas não uma memória universal.

Como a memória está ligada às transformações sociais, hoje todas essas questões merecem ser revistas, em virtude dos avanços tecnológicos e da mediação imposta pela cultura das mídias. Há cerca de trinta anos, Le Goff já dizia que "as direções atuais da memória estão profundamente ligadas às novas técnicas de cálculo, de manipulação da 
informação, do uso de máquinas e instrumentos cada vez mais complexos" (2003:419). Tudo isso se amplifica no cenário de um mundo globalizado, informatizado e permanentemente reportado pelos meios de comunicação. Nesse mundo, as sociedades de memória oral e de memória escrita foram substituídas pelas sociedades de memória eletrônica, "um dos elementos mais espetaculares no desenvolvimento da memória no século 20", que provocou uma revolução na documentação da história, segundo Le Goff (op.cit.:462).

Se antes a história era escrita com base em textos oficiais, jornais de época e memórias de quem vivenciou os fatos, hoje ela é uma história imediata, em grande parte fabricada pela mídia. O processo de passagem da memória coletiva à memória histórica parece acompanhar a velocidade com que os acontecimentos entram e saem do círculo da mídia, deixando apenas ecos insistentes das imagens e das falas arquivadas e repetidas eletronicamente. Nunca a afirmação de Halbwachs foi tão apropriada: "São as repercussões, e não o acontecimento, que penetram a memória de um povo que as suporta, e somente a partir do momento em que elas o atingem" (2004:111).

No mundo mediatizado, somos atingidos instantaneamente pela repercussão dos fatos e imediatamente formamos uma memória do evento, que será reforçada pela superexposição a que a mídia submete determinados acontecimentos. Falamos especialmente da televisão, veículo de comunicação de maior penetração nas sociedades atuais, pois é ela que detém o poder de construir uma representação do mundo que se tornará comum a milhões de pessoas simultaneamente. É a televisão que concentra grande parte dos arquivos que produzem memória coletiva, o que é sem dúvida um instrumento de poder.

Como reflete Le Goff, a memória coletiva, ao longo da história do mundo, tem sido posta em jogo na luta das forças sociais pelo poder e é formada tanto de lembranças quanto de esquecimentos produzidos por diversas instâncias sociais. Por isso o autor alerta para os riscos do controle da memória coletiva, principalmente pelos governos, e propõe que pesquisadores da memória, antropólogos, historiadores, jornalistas e sociólogos façam da luta pela democratização da memória social um dos imperativos de sua atividade (cf. Le Goff, 2003:471). 
Entendemos que a democratização da memória social é hoje dificultada sobretudo pela tendência de homogeneidade do discurso da informação, como vimos em vários estudos apresentados. A concepção, os processos, as estratégias de encenação, os interesses econômicos que põem a máquina midiática em funcionamento parecem convergir em muitos pontos, portanto o produto tende a ser muito parecido em muitas partes do mundo. Os produtos midiáticos são verdadeiros documentos da história que é contada pelos meios de comunicação e resultam de escolhas feitas enquanto a história mesma se faz, escolhas do que se deve lembrar e do que se deve esquecer, ou nem ao menos conhecer.

Le Goff ensina que documentos e monumentos, materiais da memória coletiva e da história, não são um conjunto do que existiu no passado, "mas uma escolha efetuada quer pelas forças que operam no desenvolvimento temporal do mundo e da humanidade, quer pelos que se dedicam à ciência do passado e do tempo que passa, os historiadores" (op.cit:525). Ora, o que é a mídia senão uma dessas forças que operam no desenvolvimento temporal do mundo? Jornais e telejornais são então documentos verbovisuais que forjam a memória e a história, com todos os silêncios pressupostos nos vãos de seus discursos, e são, como todo documento, "resultado de uma montagem, consciente ou inconsciente, da história, da época, da sociedade que o produziram". Em sendo documentos, cabem-lhes estas outras palavras de Le Goff: "O documento não é inócuo. (...) Resulta do esforço das sociedades históricas para impor ao futuro - voluntária ou involuntariamente - determinada imagem de si próprias. No limite, não existe um documento-verdade" (op.cit.:537).

Os telejornais são documentos arquivados na memória eletrônica da televisão ou, na expressão de Orlandi, na imensa "memória metálica", que abrange o ciberespaço e as mídias eletrônicas. Segundo Orlandi, "a tevê trabalha para que a memória não trabalhe, para que já esteja sempre lá um conteúdo bloqueando o percurso dos sentidos, seu movimento, sua historicidade, seus deslocamentos" (2005:181). As formulações se repetem, seja nas novelas, seja nos telejornais, e produzem uma leitura unidirecionada, produzindo uma "memória achatada, horizontal", por onde os sentidos não deslizam, apenas se multiplicam. Paradoxalmente, afirma Orlandi, o homem aprende a se significar por meio dessa linguagem que apaga a memória histórica e a substitui por uma memória 
metálica: "nesse lugar o homem põe uma combinatória infindável de sinais à qual se liga e é isto afinal o que se historiciza" (op.cit.:182). A memória social que sedimenta a história é agora uma memória social mediada pela memória metálica.

Segundo Fentress e Wickham (1992), a memória não pode ser vista como mero mecanismo de cópia e armazenamento de informação, sobretudo por ter uma dimensão histórica fundamental. Mas a memória metálica, a nosso ver, tem saliente essa capacidade de copiar e armazenar informações para usá-las posteriormente em outros contextos e na formação de novas idéias. No caso dos telejornais, o acesso aos arquivos da memória metálica é restrito às emissoras; como já lembramos no primeiro capítulo desta tese, não há arquivos públicos de televisão. Não se pode, portanto, ter as imagens e as palavras a qualquer tempo, tampouco rever criticamente a informação contida no discurso dos telejornais. Ao público só cabe ver e rever aquilo que se the torna visível no tempo e no espaço definidos pela televisão. É isso que tende a instalar-se num amplo lugar da memória constituída socialmente.

Ainda que o indivíduo possa acionar componentes internos ao evocar e utilizar sua memória para a interpretação do mundo, num processo ativo de reconstrução dos acontecimentos, "o conteúdo e o modo da recordação são, muitas vezes, predominantemente determinados por influências sociais, que estabelecem o estado e dirigem a ação da recordação, assim como da percepção, da imaginação, do trabalho construtivo" (Braga, 2000:43). Se as memórias naturais "muitas vezes são dominadas por um processo de estereotipia e se dobram à memória institucional" (Bosi, 2003:17), parece-nos que a memória mediada sofrerá ainda mais essas coerções, sendo afetada pela interpretação simplificadora que a mídia fornece dos acontecimentos.

Em relação à memória de pequenas coletividades urbanas, Bosi observa que o distanciamento das pessoas a põe em risco e diz que, quando as vozes das testemunhas se dispersam ou se apagam, cabe às vozes oficiais conduzir as pessoas pelos caminhos da história mais recente: "em vez da envolvente trama tecida à nossa frente, só nos resta virar a página de um livro, unívoco testemunho do passado" (op.cit.:70). Essa imagem parece também adequada para descrever o que ocorre com a sociedade globalizada, em que a "envolvente trama tecida à nossa frente" é tão-somente a que assistimos pela televisão, que sobrepõe vozes distantes e imagens fragmentadas na tessitura do unívoco 
testemunho do presente, no qual presumidamente confiamos. Grande parte da matéria que constitui a memória serão fatos sociais exponencialmente decantados pela mídia.

De acordo com a teoria de Halbwachs, o passado que existe é apenas aquele que é reconstruído continuamente no presente. Logo, conforme aponta Santos, a memória do passado tem dois componentes fundamentais: a estrutura e a ação (2003:72). A estrutura é a parte objetiva da memória, que contém formas simbólicas e significados percebidos individualmente ou produzidos por agentes sociais. A ação é a parte subjetiva, que constrói ou reconstrói experiências por processos individuais também submetidos à influência social. Desse todo, interessa-nos a parte objetiva da memória, em especial o fornecimento de matéria pelas instâncias midiáticas para sua construção. Não sabemos como os indivíduos evocarão a memória que a mídia ajuda a construir, mas podemos identificar que tipo de estruturas e convenções lhes são dadas no presente.

No entanto, como lembra Santos, " é importante trazer sempre para o debate a noção de que a representação do passado, que aparece aos nossos olhos como igual à matriz, trazendo a ilusão de que o passado está sendo literalmente reproduzido, pode ser utilizada e manipulada para atender interesses de grupos diversos" (op.cit.:186). Os discursos do presente, segundo a autora, não podem controlar os significados construídos ao longo do tempo e dificilmente se esquivam de reproduzir arbitrariedades do passado, independentemente da vontade dos sujeitos. Assim temos de tentar flagrar o modo de construção da memória pela mídia bem perto do tempo em que se dá, e não nos embates com o devir, quando a história já tiver sido escrita.

\section{Discurso, mídia e memória social}

Um terreno fértil para a análise do discurso tem sido o das pesquisas sobre 0 estatuto da memória nos processos discursivos. Discute-se de que modo acontecimentos históricos, culturais e midiáticos são inscritos ou não na memória, de que forma as mudanças tecnológicas e os meios televisuais interferem nas práticas memoriais, como agem os operadores contemporâneos da memória social e, acima de tudo, como se estrutura o discurso para estabelecer determinadas memórias. 
Segundo Achard, a estruturação do discurso constitui a materialidade de uma certa memória social e a memorização das formulações discursivas repetidas regularmente repousa sobre um consenso. A memória está ligada mais à regularidade dos sentidos repetidos do que à própria repetição. Cada vez que se reenquadra uma unidade formal com o mesmo sentido em novos contextos, esse sentido memorizado emerge e permite a interpretação do discurso, que estabelecerá outras relações a serem assimiladas pela memória. Achard afirma que a memória discursiva "não restitui frases escutadas no passado mas julgamentos de verossimilhança sobre o que é reconstituído pelas operações de paráfrase" (1999:16). Dessa forma, a memória oscila entre o histórico e o lingüístico, sendo simultaneamente acionada e armazenada por uma série de operações que regulam a retomada e a circulação dos discursos.

Courtine observa que, na ordem do discurso, é comum que se divida em pedaços a lembrança dos eventos históricos, inscrita na memória coletiva de certos enunciados, e que se organize ora sua recorrência, ora sua anulação. Segundo ele, é no nível do enunciado que se articulam enunciações distintas e dispersas (citando-se, parafraseando-se, opondo-se entre si, transformando-se) e que pode ocorrer o processo de preenchimento da memória ou de esquecimento. É esse espaço interdiscursivo que se poderia denominar domínio de memória, no qual a enunciação se apropria de enunciados pré-construídos e estabelece novos construtos (cf. Courtine, 1999:18).

Relativamente aos estudos de Pêcheux sobre a memória, destacamos sua preocupação com as condições em que um acontecimento histórico, descontínuo e exterior, torna-se suscetível de se inscrever na continuidade interna da memória social. Deixando de lado o incontornável problema da interpretação, que acentua a complexidade do objeto, Pêcheux sugere que se procure entender os procedimentos de repetição e regularidade dos enunciados e dos implícitos, assim como os de designação e construção, antes de dirigir o olhar à significação dos discursos. Isso permitiria entender o funcionamento da memória como "um espaço de desdobramentos, réplicas, polêmicas e contra-discursos" (1999:56).

Além disso, Pêcheux faz considerações sobre o papel fundamental da imagem como operadora de memória social, numa época em que predominam os acontecimentos televisuais. Ele entende que a inscrição de um acontecimento histórico singular no 
complexo dispositivo da memória pode estar relacionada à passagem do visível ao nomeado, uma vez que a imagem comporta um programa de leitura, um discurso escrito em outro lugar, como se fosse a "recitação de um mito". Há algo na imagem, diz ele, que está sempre lá, "no retorno de um paradigma que se repete no interior de sua aparição instantânea" (Pêcheux, op.cit::55). Muitas imagens se tornam símbolos e são imediatamente associadas aos acontecimentos que representam e aos discursos que traduzem.

Davallon também faz importantes reflexões sobre o papel dos operadores de memória na sociedade contemporânea. $O$ autor pondera que "o desenvolvimento dos meios de registro da imagem e do som (...) parece hoje nos afastar definitivamente da necessidade de situar uma parte da memória social na 'cabeça' dos sujeitos sociais: a memória social estaria inteiramente e naturalmente presente nos arquivos das mídias" (Davallon, 1999:23). Assim, a formação da memória social passa a ser controlada pelas produções culturais, destinadas a produzir efeitos simbólicos, e se subordina à memória eletrônica.

À indagação que se faz sobre se o fato de registrar, descrever, representar a realidade é suficiente para produzir memória, Davallon responde afirmativamente, pois é o registro do acontecimento que o tira da insignificância e abre uma dimensão entre o passado originário e o futuro. A convergência de olhares sobre o mesmo objeto, o "acordo de olhares" que meios como a televisão facultam permite que o registro ganhe força de memória. Assim se instaura, por meio dos objetos culturais, o controle da memória social, que está estreitamente ligado, segundo Davallon, ao funcionamento formal e significante desses objetos. Disso decorre a importância dos estudos sobre a imagem e certos enunciados lingüisticos, que podem conservar a força das relações sociais pelas impressões que produzem no público.

Todas essas reflexões fazem perceber a proeminência do telejornal como formador e armazenador de memória social, como lugar de ancoragem da memória produzida e da história imediata. O discurso jornalístico sempre foi considerado agente construtor de memórias e esquecimentos, uma vez que participa ativamente do processo de seleção dos acontecimentos que se tornarão visíveis, fixando-lhes um sentido em detrimento de outros possíveis e impondo um modo de recordação do passado. Muitos 
estudos procuram investigar, sobretudo na imprensa escrita de importantes períodos históricos, as formas de inscrição da historicidade na linguagem e os processos que tecem e homogeneizam a memória de uma época ${ }^{44}$. Nosso objetivo é contribuir para que esse caminho seja trilhado na direção das produções telejornalísticas, que têm notável poder de abrangência e reiteração.

Evidentemente não trataremos de episódios que, no espetáculo do telejornal, "lutam contra o tempo para marcar presença", mesmo porque a memória não dá conta de tanta informação e muitas delas perecem depois de cada apresentação (cf. Szpacenkopf, 2003:175). Entre tantas escolhas possíveis, decidimos analisar um fato que imediatamente se tornou histórico, o ataque a alvos norte-americanos em $11 \mathrm{de}$ setembro de 2001, episódio analisado desde então sob múltiplas perspectivas, que vão das implicações políticas e sociológicas às questões que perpassam o universo da informação e do discurso. A escolha se deu especialmente porque a cobertura desse evento simboliza bem o processo de construção de uma história do presente pela mídia.

Conforme aponta Gregolin, nessa operação da mídia, "apagam-se as determinações da operação historiográfica produzida de um certo lugar, por sujeitos, por discursos e cria-se a aparência de uma história que se faz por si mesma, sem sujeito, sem determinação de ideologias, no cruzamento entre uma atualidade e domínios de memórias que não pertencem a ninguém" (2003:15). Acreditamos que o objeto de análise desta tese comporta um modelo de dramatização midiática que resulta em tais efeitos de ilusão. Pura ilusão, porque o discurso da informação está sempre a criar e recriar arquivos de imagens, inclusive imagens verbais, que "aprisionam a história em nossa mente" (cf. Sontag, 2003:73). Vamos finalmente tentar destecer alguns fios dessa rede discursiva.

\footnotetext{
${ }^{44}$ Nessa linha, são inspiradores os trabalhos de Mariani (2001) e Orlandi (2001).
} 


\section{CAPÍTULO 3 \\ DES(A)FIANDO AS REDES - O TECIDO ÓSSEO}

\section{PRIMEIRA PARTE - O CONTEXTO}

Naquela hora eu senti que tinha travado conhecimento com um engenhoso aparelho de aparições e eclipses, espécie complicada de tablado de mágica e espelho de prestidigitador, provocando ilusões, fantasmagorias, ressurgimentos, glorificações e apoteoses com pedacinhos de chumbo, uma máquina Marinoni e a estupidez das multidões. Era a Imprensa, a Onipotente Imprensa. (Lima Barreto ${ }^{45}$ )

\section{Introdução}

Pode-se dizer que os textos que vou apresentar ${ }^{46}$ me caíram nas mãos por uma conjunção de fatores, no mínimo, curiosos. Quando submeti meu projeto ao exame de seleção para o doutorado, em 2001, o fiz em setembro, poucos dias depois dos ataques ao World Trade Center. Imediatamente, ocorreu-me citar um aspecto do episódio para exemplificar o que pretendia pesquisar. Tive minhas impressões sobre o evento, mas, evidentemente, no calor dos acontecimentos e às vésperas de entregar o projeto, não poderia me aprofundar na questão.

Limitei-me a comentar que a mídia televisiva havia ajudado a criar um clima de comoção geral e a fazer ecoar o discurso do presidente George W. Bush conclamando o povo e todas as nações para uma guerra contra o terrorismo. Uma de suas falas foi: "A nação que não estiver conosco está com os terroristas." O discurso na íntegra foi transmitido por pelo menos uma emissora de televisão brasileira e trechos dele foram repetidos à exaustão nos telejornais de todos os canais de sinal aberto, reproduzindo a interpelação do público como "inimigos do terrorismo".

Naquele momento, tive a certeza de que queria pesquisar de que forma o universo midiático consegue silenciar ou propagar vozes, impedindo que o público conheça o contexto dos fatos e reflita sobre relações básicas, como a de causa e

\footnotetext{
${ }^{45}$ Em Recordações do Escrivão Isaías Caminha, de 1908.

${ }^{46}$ Conscientemente, neste breve relato do processo de escolha do corpus, tomamos a palavra na primeira pessoa do singular.
} 
conseqüência. O que me moveu, desde o início, foi um forte desejo de entender que tipo de discurso sustenta esse poder dos meios de comunicação de massa.

Como observa Chomsky, é "uma atitude absolutamente típica da grande mídia (...) alinhar-se em apoio ao poder num momento de crise e tentar mobilizar a população para essa causa" (2003:32). Essa constatação não é nova, como não é novo o fato de que a mídia mostra apenas versões de uma verdade nunca apreensível em sua totalidade. Por isso reitero minha intenção de fazer da análise desse tipo de discurso um instrumento para que se possa compreender a intrincada rede de relato dos fatos. Espero também que este trabalho contribua de alguma forma para que o público aprenda a guiar seus olhos para além da tela da televisão.

Relativamente ao corpus da tese, cogitei diversas coberturas telejornalísticas, mas acabei me dando conta de que o modo como a mídia tratava os conflitos internacionais - sem explicar o porquê dos fatos - me incomodava muito. Além disso, chocava-me a tendenciosidade das formas de designação em textos como este: "Acabou a paciência dos americanos com as duas rebeliões que enfrentam no Iraque. Os ocupantes decidiram usar a força bruta para esmagar os insurgentes." Sugeri aos editores dos telejornais da TV Globo, empresa a que presto serviços, que tomassem mais cuidado com as formas de expressão e observei que os termos "rebeliões" e "insurgentes" contrastavam com o eufemismo "ocupantes" e que a abertura do texto "acabou a paciência dos americanos" - era uma justificativa e um endosso ao uso da força pelos Estados Unidos.

É evidente que essa intervenção não mudou nada, mas o episódio fez aumentar meu interesse pela antiga questão das formas de designação usadas pela mídia e também por conflitos internacionais. Então, apesar de estar muito longe de ser uma conhecedora mediana de tema tão complexo, decidi tratar da cobertura de um acontecimento recente importantíssimo: os ataques de 11 de setembro de 2001. Obtive uma cópia da edição do Jornal Nacional (JN) nesse dia e fiz uma análise preliminar para o exame de qualificação. Posteriormente, consegui a edição do Jornal da Record (JR) e também as edições do dia 11 de setembro dos três anos seguintes dos dois telejornais, o que tornaria possível um exame comparativo sincrônico e diacrônico dos dois noticiários em relação ao acontecimento. 
Esse material constitui o corpus da tese, cuja transcrição está nos anexos abaixo nomeados, que são acompanhados de um DVD com a edição de 11 de setembro de 2001 dos dois telejornais:

Anexo $1-\mathrm{JN}$ de 11/9/2001

Anexo 2 - JN de 11/9/2002

Anexo 3 - JN de 11/9/2003

Anexo $4-\mathrm{JN}$ de 11/9/2004

Anexo 5 - JR de 11/9/2001

Anexo 6 - JR de 11/9/2002

Anexo 7 - JR de 11/9/2003

Anexo 8 - JR de 11/9/2004

As edições de 11 de setembro de 2001 dos dois telejornais estão transcritas na íntegra, porém as demais edições foram parcialmente descritas porque só nos interessavam as matérias sobre o aniversário do evento. Na edição de 11 de setembro de 2004 do Jornal Nacional, foi exibida a última reportagem de uma série especial sobre os 35 anos desse noticiário. A série abordou diversos assuntos, de política e economia a esporte e meio ambiente, e no último dia, não por acaso o dia 11 de setembro, o tema foi o terrorismo no mundo. Transcrevemos também o script dessa reportagem porque julgamos importante analisá-lo como intertexto das matérias sobre os ataques.

As transcrições foram feitas de modo simples, obedecendo tanto quanto possível à estrutura dos roteiros (scripts) de telejornais. Não seguimos o padrão do NURC ou qualquer outro sistema convencional, por não serem nosso alvo principal as marcas de oralidade ou os recursos suprassegmentais dos textos do corpus. Além disso, como sustenta Fairclough, "nenhum sistema [de transcrição] poderia mostrar tudo, e sua escolha é sempre um problema de julgamento, considerando-se a natureza do projeto e as questões de pesquisa, os tipos de característica que se quer mostrar e quais os detalhes" (2001:280). Para o que pretendemos demonstrar, julgamos suficientes a transcrição textual das falas de apresentadores, repórteres, testemunhas e especialistas e a descrição de imagens e de elementos contextualizadores como legendas e vinhetas. 
É fundamental observar também que, por se tratar de matérias da área internacional, o trabalho de rastreamento ${ }^{47}$ das fontes primárias não é factível. Sabemos que, de modo geral, os jornais se abastecem das mesmas notícias das agências internacionais e que esse componente pode obstar nosso propósito de chegar a alguma conclusão sobre outros fatores de homogeneização dos produtos telejornalísticos. No entanto entendemos que esse problema poderá ser parcialmente neutralizado, se nos concentrarmos na problemática da escolha e da intenção de uso das informações das agências, bem como nos processos de inserção das mesmas imagens em discursos aparentemente diferentes. Além disso, aquela limitação pode ser um forte argumento para mostrar como a mídia trabalha com canais extremamente reduzidos de difusão da informação na tessitura do relato dos acontecimentos.

Devido à importância do episódio e à profusão de artigos, livros e debates que se produziu deste então, vamos conjugar a esta tese algumas das principais discussões sobre o evento e, principalmente, sobre a cobertura da mídia, que poderão apoiar substancialmente a análise de determinados aspectos do objeto em foco.

\footnotetext{
${ }^{47}$ O professor Manuel Chaparro (1994), como já mencionamos, desenvolveu importante trabalho sobre a pragmática do jornalismo, para o qual os métodos utilizados foram o rastreamento por dissecaçãoreconstituição de reportagens publicadas e o rastreamento por observação direta dos fazeres jornalísticos, da decisão da pauta à reportagem. Infelizmente, a escolha do objeto de nossa pesquisa limita sobremaneira esse processo de investigação.
} 


\section{Considerações sobre o 11 de setembro}

No clima criado com o "quem não está conosco, está contra nós", será ainda possível manter a independência, o simples distanciamento cético e o olhar crítico próprios do melhor jornalismo?

Ou estaremos condenados a ser transformados em meros agentes de uma poderosa, tentacular e generosamente financiada máquina de propaganda que - sutilmente umas vezes, descarada e brutalmente outras - a todos nos tenta controlar ou iludir? (Carlos Fino, 2003:40)

No livro Deus é inocente: a imprensa, não, Carlos Dorneles analisa matérias publicadas nos mais importantes veículos de comunicação do Brasil e do mundo no final de 2001 e em 2002, depois dos ataques de 11 de setembro, e faz um levantamento impressionante sobre a parcialidade ${ }^{48}$ da mídia. Logo nas páginas iniciais, o jornalista é contundente e vai direto ao ponto central (2002:19):

Sempre foi assim. Para quem comanda exércitos, quanto menos a imprensa mostrar, melhor. Mas nunca se tinha chegado a tal estágio de controle de informações como na guerra dos Estados Unidos contra o Iraque. As imagens que ficaram registradas na memória são as luzinhas esverdeadas caindo sobre Bagdá. Sem sangue, sem horror. Até hoje não se conhece o número de vítimas. Quem poderia prever uma nova guerra com mais restrições ainda? Pois a cobertura pós-11 de setembro se transformaria no episódio mais censurado, autocensurado e distorcido de que se tem notícia na história da imprensa em frontes de guerra. Logo depois dos atentados, a imprensa americana - e toda a imprensa ocidental de roldão - pediu guerra, declarou-a antes do governo.

\footnotetext{
${ }^{48}$ Entendemos que, segundo os pressupostos da retórica, não há discursos neutros ou sujeitos que não se coloquem de determinado lugar social ou ideológico para formular seus discursos; no entanto é preciso observar que a imparcialidade pode ser compreendida como "um equilíbrio de forças, uma atenção máxima aos interesses em causa, mas repartida igualmente entre os pontos de vista" (Perelman e Tyteca, 1996:67). É tão-somente nesse sentido que falamos, vez por outra, em parcialidade ou imparcialidade jornalística.
} 
Sobre a autocensura que existe na mídia atual e que corrobora uma censura globalizada, Fábio Konder Comparato, no prefácio ao livro de Dorneles, analisa:

O poder estatal depende das grandes empresas de comunicação para assentar a sua legitimidade política junto à opinião pública, e essas empresas, por sua vez, dependem do Estado para a defesa do sistema capitalista, no qual elas se inserem como elemento-chave. A mútua dependência acaba por suscitar, naturalmente, um acordo, visando ao exercício conjunto do poder político, econômico e cultural sobre aquilo que é essencial para ambos os lados. Quem fica de fora do acordo é, obviamente, o povo, que no esquema constitucional clássico seria o grande beneficiário do sistema de garantias institucionais à liberdade de comunicação.

Acontece que, em tempos de globalização, o conluio entre o poder estatal e as grandes redes de comunicação de massa se estabelece, claramente, em níveis transnacionais. $O$ surgimento do primeiro império mundial da História, com sede nos Estados Unidos, ampliou o acordo de que se acaba de falar para todo o espaço do orbe terrestre. Doravante, as políticas de dominação imperial exigem uma cobertura ideológica sem fronteiras, por parte dos grandes veículos de imprensa, rádio, televisão e cinema.

Também Chomsky, Mattelart, Martín-Barbero, Arbex, Aronchi e muitos outros autores falam sobre como o poder político e econômico dos Estados Unidos influencia a mídia mundial. Esse é, inegavelmente, um ponto central na produção do velho e conhecido pensamento único. Por mais que a imprensa diga o contrário, sempre estará enredada nos fios dessa censura invisível. Foi assim na cobertura dos eventos que se seguiram aos ataques ao World Trade Center e ao Pentágono, foi e é assim no caso de tantas guerras envolvendo os Estados Unidos, foi assim no próprio 11 de setembro, marco zero de uma história que, diziam, começava a se escrever naquele dia, dia em que a única potência mundial se viu ameaçada.

Como enfatizam os editores do livro de Dorneles, o repórter descobriu, por trás da cobertura da mídia escrita, a guerra de interesses que determinou a censura à difusão de informações sobre os ataques ao Afeganistão, imposta pelo governo americano; a credulidade com que a versão oficial dos acontecimentos foi tratada; o tratamento do fato como evento isolado, sem causa ou contexto histórico, logo altamente manipulável; o islamismo e o fundamentalismo transformados em sinônimos. Dorneles pesquisou 
matérias de O Estado de S. Paulo, Folha de S.Paulo, O Globo, Jornal do Brasil, Veja, Época e IstoÉ e fez breve referência a emissoras de televisão americanas, em especial à $\mathrm{CNN}$, mas não mencionou a cobertura feita por televisões brasileiras, que provavelmente ocultou as mesmas censuras e distorções.

Em Jornal Nacional: a notícia faz história, do Projeto Memória Globo, são dedicadas oito páginas aos atentados ao World Trade Center e à guerra no Afeganistão. Segundo o projeto, o livro é "um relato de como o mais importante telejornal do país contou aos brasileiros os fatos que marcaram a história do Brasil e do mundo" num período de 35 anos, "idade" do Jornal Nacional em 2004. Mas o que se vê, pelo menos nas poucas páginas em que se fala sobre o 11 de setembro, é o relato das operações técnicas para mostrar as notícias. Esse é o sentido do advérbio "como" no livro, e não aquele que interessaria, relativo ao modo como o telejornal tratou as notícias. Segundo o livro, a emissora foi a primeira TV aberta brasileira a mostrar um flash do atentado, apenas sete minutos após o choque do primeiro avião contra uma das torres do WTC. A transmissão foi encerrada depois de quatro minutos e retomada logo em seguida por ordem do diretor de jornalismo.

A programação normal foi interrompida e a transmissão ao vivo dos eventos se estendeu das dez às catorze horas, tomando o lugar da edição do Jornal Hoje daquele dia, que programara como destaque uma matéria sobre a morte de Toninho do PT, prefeito de Campinas (SP), assassinado no dia anterior. O apresentador Carlos Nascimento sustentou a transmissão das imagens com as poucas e repetidas informações que chegavam de agências internacionais de notícias. Nascimento estranhou o acidente, pois o local não era rota de aviões e o tempo estava bom, e cogitou um possível ataque terrorista (cf. Bistane e Bacelar, 2005:75). De acordo com as memórias do Jornal Nacional, a TV Globo começou a falar nessa possibilidade antes mesmo da CNN e, segundo um vídeo institucional a que tivemos acesso, esse "furo" foi motivo de grande orgulho para os jornalistas envolvidos na transmissão.

A certa altura, como lembram Bistane e Bacelar, as imagens foram ficando repetitivas e não havia dados novos. Nascimento começou a improvisar comentários sobre os ataques, procurando não se deixar levar "pelo sensacionalismo ou pela emoção barata", conforme contou às autoras (op.cit.:77). Pouco antes do fim da 
transmissão, ganhou a companhia da jornalista Ana Paula Padrão, que já fizera reportagens no Afeganistão e podia contribuir com informações sobre a Al Qaeda, organização sediada naquele país e comandada por Osama Bin Laden, a quem "analistas americanos" atribuíam a autoria dos ataques.

Estava "comprada" a versão que seria reproduzida em outros jornais da emissora, inclusive o Jornal Nacional, cuja equipe começou a preparar cedo uma edição especial com uma hora de duração. O livro de memórias do telejornal destaca que, segundo William Bonner, a edição de 11 de setembro foi resultado de um "trabalho heróico": "Todo mundo se envolveu, aqui e no exterior, e o resultado foi uma riqueza de informações brutal. Essa equipe pequena conseguiu se mexer para fazer História".

Não sabemos em detalhes como se deu o processo de cobertura na TV Record ${ }^{49}$, mas um aspecto fundamental é partilhado pelo Jornal Nacional e pelo Jornal da Record: ambos apresentaram uma edição dos acontecimentos mostrados ao vivo na manhã daquele dia. O produto que foi ao ar nesses dois telejornais da noite certamente refez a história dos ataques de 11 de setembro e nosso propósito é descobrir que história foi essa, como ela foi contada e que memória ajudou a criar a partir desse processo. $O$ ambíguo subtítulo do livro sobre o Jornal Nacional - "a notícia faz história" - leva a uma pergunta que esperamos ver respondida ao fim desta tese: se a notícia editada faz uma história diferente, que memória ficará?

Duarte diz ter confirmado a hipótese da existência de uma gramática das condições de produção televisiva por ocasião dos ataques de 11 de setembro, que foram, segundo ela, "um espetáculo midiático dos mais competentes"50. A autora

\footnotetext{
${ }^{49}$ Numa entrevista à Folha de S.Paulo, em 23 de setembro de 2001, Luiz Gonzaga Mineiro, então diretor de jornalismo da Rede Record, conta: "Foi uma correria. Tivemos que decidir tirar a programação do ar, convocar os apresentadores, contatar todo mundo que podíamos nos Estados Unidos, deslocar repórteres, localizar autoridades, embaixadores, fazer plantão nos aeroportos, em Brasília." Segundo Cláudia Croitor, repórter da Folha, a Record cancelou toda a programação e transmitiu das $10 \mathrm{~h} 30$ às $17 \mathrm{~h} 20$, sem intervalos, com José Luiz Datena à frente da cobertura durante quase todo o tempo.

${ }^{50}$ Segundo Dominique Wolton, "fazer um espetáculo de morte e de medo" não era o único objetivo dos terroristas em 11 de setembro, "a intenção era claramente politica, antes de ser espetacular". Wolton afirma que "o tema da sociedade do espetáculo, com freqüência, simplifica as causas políticas, sociais ou culturais que explicam o sucesso do espetáculo", no entanto é preciso entender que "o espetáculo é uma conseqüência, não uma causa". (Em entrevista concedida à revista Trópico, de 13/1/02, encontrada no site do Observatório da Imprensa, sob o título "Wolton fala sobre o valor da mídia e da diversidade".)
} 
sustenta que "os atentados foram minuciosamente planejados por alguém que dominava suas regras de produção [da televisão] e utilizou esse conhecimento estrategicamente, acertando as ações empreendidas aos tempos e espaços da construção do simulacro televisivo, isto é, de forma a fazer com que os acontecimentos a eles correspondessem", e que especialmente nesse caso "não houve a necessidade de tratamento da matéria informativa, isto é, de transformação do acontecimento em notícia". Assim, segundo Duarte, "o real não precisava ser restituído: ele se dava por completo na e para a televisão, pronto para ser exibido, ao vivo, em tempo real" (2004:15).

Note-se que, mesmo em se tratando de espetáculo ao vivo, a autora emprega o termo "simulacro televisivo" para o que se vê retratado. No caso das edições posteriores ao acontecimento, o problema da representação se complica e é esse o ponto nodal da relação entre o discurso que nos propomos a analisar e a formação de memória social. As imagens transmitidas ao vivo têm grande impacto, porém as poucas informações e os comentários improvisados não têm força suficiente para dar significado àquilo que se vê. No entanto, quando a notícia é editada, a hierarquização das informações, o reenquadramento das imagens, a instauração orquestrada da polifonia, o uso estratégico de formas de designação dos fatos e pessoas, a orientação dos comentários garantem poder simbólico ao discurso, e é justamente o material simbólico que se inscreve na memória social.

\section{O que se viu lá}

Não encontramos, em nossa pesquisa, trabalhos sobre a cobertura do 11 de setembro ou de seus desdobramentos pelas televisões brasileiras, no entanto uma dissertação de mestrado nos chamou a atenção por ter propósitos similares aos nossos. Trata-se de uma análise da linguagem e de imagens usadas pela emissora norteamericana CNN na cobertura dos eventos posteriores ao 11 de setembro. Mizan, a autora, procurou mostrar como a versão construída pela mídia dificultava a penetração de discursos alternativos e apoiava a estabilidade do sistema ideológico e social dos Estados Unidos. Mizan enfatiza, no estudo, que os discursos da mídia podem mudar nossa percepção da verdade sobretudo pela credibilidade pressuposta no contrato de 
informação: "People who watch what is reported on channels like CNN tend to believe what they are told for the simple fact that those channels belong to the journalistic order of discourse; and thus are legitimized" (2004:15).

Para Mizan fica claro, depois da pesquisa, que o discurso da CNN é um discurso que reproduz o discurso oficial do governo norte-americano e ela tenta entender os códigos e as técnicas que a emissora usou para tentar convencer o público de sua versão dos fatos, uma vez que "CNN's representation of reality affects the essence of the events reported and the notion that is created in the spectators mind" (op.cit.:21).

A autora toca em questões que também discutimos, como a crescente tendência de a narração fragmentada do presente tornar-se imediatamente história, uma história parcial, que não mostra o lado do Outro. Nesse caso, o Outro era o Afeganistão, a que os Estados Unidos declararam guerra por suspeitaram que o regime do Talibã, milícia islâmica radical que controlava o país, escondia o terrorista saudita Osama Bin Laden, também alvo de suspeição em relação aos ataques de 11 de setembro.

Mizan discute então o problema das identidades em conflito durante a guerra, sempre a representar o "eu" e o "outro": heróis versus vilões; Estados Unidos, Ocidente, aliados versus Afeganistão, mundo islâmico, terroristas. Ninguém se esquece da conclamação de Bush para a formação de uma coalizão internacional de combate ao terrorismo emergente do mundo árabe, o novo inimigo da superpotência na era que finalmente sobrevinha à Guerra Fria. Seu discurso reverberou na mídia e obrigou que as nações se posicionassem na nova ordem contra um "eixo do mal", formado por países inimigos e terroristas dispostos a enfrentar os Estados Unidos tão-somente por instintos insanos, sem nenhuma razão política. A ausência de contexto histórico no discurso da mídia fomentava, segundo Mizan, um cego consenso sobre o que se passava: os ataques de 11 de setembro inauguraram uma forma de terrorismo que jamais se vira, o terrorismo contra os guardiães da democracia ocidental.

O poder das palavras da mídia contribuiu para a construção de uma realidade que serviria para justificar a retaliação que sobreveio aos ataques e confortar a população norte-americana com relação à justiça da resposta bélica. Segundo Mizan, tudo conduzia à reprodução do discurso oficial, a começar dos slogans mantidos na tela durante a narração das notícias na CNN: "America under attack", "War against terror", 
"America responds", "America strikes back", "Strike against terror", "Infinite justice" Havia ainda o uso de termos como "guerra santa" e "cruzada contra o terror", que tentavam investir os acontecimentos de uma natureza religiosa que nunca tiveram, e a dupla medida na consideração das fontes: as informações do governo americano eram sempre oficiais e as informações das autoridades do Talibã eram sempre manipuladas e não podiam ser verificadas com independência.

Além disso, a guerra ao terror acabou se tornando, na superfície, uma guerra pela liberdade do povo afegão, oprimido pelo regime radical do Talibã. Ao mesmo tempo que destruíam o miserável Afeganistão, os Estados Unidos apareciam na mídia como salvadores dos afegãos; uma das mãos lançava bombas e a outra, alimentos. Mizan procura mostrar todas as incoerências do conflito que se seguiu aos ataques de 11 de setembro e, principalmente, o papel de grande aliado do governo desempenhado pela CNN durante longo período.

Outro trabalho significativo sobre a rede CNN é o estudo de Aronchi a respeito da cobertura da guerra entre Estados Unidos e Iraque em 2003, um conflito também vinculado ao 11 de setembro na ótica deforma de George W. Bush ${ }^{52}$. O autor desenvolve a tese de que a CNN, o primeiro canal "all news" do mundo, é altamente comprometida com um projeto de dominação global por parte da nação norte-americana. Ele afirma que o megaconglomerado de mídia formado pela AOL Time-Warner, do qual

\footnotetext{
${ }^{51}$ Nesse sentido, é pertinente a observação de Arbex: "As primeiras imagens do atentado pela CNN já foram divulgadas com o selo 'America under attack', dando a entender que se tratava de um ataque ininterrupto, um fogo cerrado de grandes proporções, de uma guerra convencional, em que o inimigo fazia um fogo cerrado e contínuo contra os Estados Unidos. Nos dias seguintes, o selo mudou para 'América em guerra', em total sintonia com o discurso de George Bush júnior, que falava em 'guerra ao terror'" (2003:53).

${ }^{52}$ No discurso em que declara o fim da guerra contra o Iraque, em $1^{\circ}$ de maio de 2003 , com transmissão ao vivo pela $\mathrm{CNN}$, Bush cita várias vezes os ataques de 11 de setembro e insiste em vincular os fatos. Eis alguns trechos: "A batalha do Iraque é uma vitória numa guerra contra o terror que começou em 11 de setembro de 2001 e ainda prossegue. Naquela manhã terrível, dezenove homens cruéis, a tropa de choque de uma ideologia odiosa, mostraram aos Estados Unidos e ao mundo civilizado as suas ambições. Eles imaginaram, nas palavras de um dos terroristas, que o 11 de setembro seria o começo do fim dos Estados Unidos. Na tentativa de transformar nossas cidades em lugares de matança, os terroristas e seus aliados acreditaram que poderiam destruir a determinação desta nação e forçar nossa retirada do mundo. Eles fracassaram. (...) Com aqueles ataques os terroristas, e aqueles que os apóiam, declararam guerra aos Estados Unidos, e guerra foi o que tiveram. Nossa guerra contra o terror está prosseguindo de acordo com os princípios que deixei claros a todos. Qualquer pessoa que cometa ou planeje ataques contra o povo norte-americano torna-se inimigo deste país e alvo da justiça norte-americana."
} 
a CNN faz parte, é tão poderoso que desafia o conceito de que nem mesmo o processo incontornável de globalização pode fazer com que todos pensem da mesma maneira.

Segundo Aronchi, a transmissão de notícias da CNN para mais de duzentos países do mundo influencia sobremaneira "os critérios dos meios de comunicação de massa sobre o que deve ser revelado, destacado, sugerido, ocultado e até malversado" (2005:18), redundando no que o autor chama de "ceenenização do telejornalismo", em forma e conteúdo, o que reforça sua tese do imperialismo da mídia. Aronchi afirma que a CNN dissemina o ponto de vista dos Estados Unidos sobre assuntos de interesse mundial, ao fazer circularem signos e jogos de linguagem nas emissoras que utilizam as imagens da rede em seus telejornais, ou ao se impor como fonte freqüentemente citada por outros veículos.

O autor menciona ainda um relatório de 2001 da organização Repórteres sem Fronteiras, segundo o qual os Estados Unidos são uma das nações que mais prejudicam a liberdade de imprensa. Diz o relatório: "Desde o 11 de setembro se constata que a liberdade de imprensa está em perigo dentro dos Estados Unidos devido à censura oficial de imagens e opiniões e à autocensura motivada pelo patriotismo. Os Estados Unidos consideram que estão numa guerra declarada e que os jornalistas devem se converter em patriotas" (cf. Aronchi, 2005:59). Em relação ao que se seguiu imediatamente ao 11 de setembro, Aronchi aponta o que Dorneles já observara: "A imprensa passou a proclamar a guerra, veiculando acusações dos Estados Unidos contra os possíveis responsáveis, preparando o terreno para as decisões do presidente Bush. O clima de patriotismo tomou conta dos jornais e televisões norte-americanos, que publicaram editoriais e produziram reportagens de evidente apoio à guerra, sem ao menos saber quem era o inimigo, antes até de qualquer decisão do governo" (op.cit.:59).

Houve os ataques, o choque, a incompreensão, a indignação, o clamor, a guerra e outras guerras. Tudo acontecendo muito rápido, sem explicação, enquanto ainda estavam todos boquiabertos com o espetáculo da violência. Em 2002, Thierry Meyssan, jornalista e pesquisador francês ligado a associações internacionais em defesa das liberdades individuais, chegou a publicar um livro sobre o que chamou de "uma terrível farsa". Com base em documentos da Casa Branca e dos Departamento de Defesa dos Estados Unidos e em declarações de dirigentes civis e militares americanos à imprensa 
internaciona, Meyssan tenta mostrar que o maior beneficiário dos ataques de 11 de setembro foi o próprio governo norte-americano. Ele dizia que todos ficaram hipnotizados com a transmissão incessante das mesmas imagens da colisão dos aviões contra o World Trade Center e do desabamento das torres e que as informações limitadas sobre o acontecimento e as atitudes do governo impediram naquele momento a compreensão global do que ocorria.

Segundo o jornalista, dias depois a onda ininterrupta de notícias sobre as vítimas e as ações de resgate ainda era tão grande, que engolia as informações oficiais que começavam a surgir, mantendo distante o entendimento dos fatos. Isso se repetiu durante os meses seguintes e os acontecimentos continuaram envoltos em mistérios, incertezas e contradições. $\mathrm{Na}$ análise de Meyssan, a opinião pública contentava-se com a versão oficial, aceitando que os imperativos de segurança nacional não permitiam que as autoridades norte-americanas dissessem tudo à população (2003:7).

Em meio a essas ponderações, no entanto, o autor lançou a polêmica tese de que nenhum avião tinha caído sobre o Pentágono, com a alegação de que não se podia acreditar cegamente em que as mais poderosas forças armadas do mundo não tivessem sido capazes de proteger sua própria sede. Meyssan encontrou alguns indícios, como a ausência de imagens do avião ou de vestígios da fuselagem, e concluiu que se tratava de uma encenação montada por grupos militares e paramilitares de extrema-direita. Muitos consideraram a tese fantasiosa, pois não seria possível negar as evidências da queda do avião e a existência das vítimas cujos corpos foram encontrados. Mas o que importa, nesse caso, não é o lugar da verdade, e sim as nuvens que ainda a encobrem.

Veja-se, por exemplo, que só em 16 de maio de 2006 o Departamento de Defesa dos Estados Unidos liberou imagens inéditas, gravadas por câmeras de segurança, do momento em que o avião se chocou contra o Pentágono ${ }^{53}$, sem maiores explicações

53 Segundo a matéria "Governo dos EUA libera vídeo de ataque ao Pentágono", também de 16 de maio de
2006 , disponível no Portal do Estadão, as imagens foram liberadas em resposta a um Ato de Liberdade de
Informação requisitado pelo Observatório Judicial, um grupo de interesses públicos, e não é possível ver
mais do que uma "fina linha branca que se colide com o Pentágono próximo ao nível do chão" e depois
uma "grande bola de fogo laranja, seguida por uma nuvem de fumaça negra". Ainda segundo a matéria, a
irmã do piloto do vôo 77 , Debra Burlingame, disse que "as imagens não acrescentam nenhuma nova
informação sobre o que aconteceu naquele dia" e que não acreditava que a divulgação dos vídeos pudesse
dissipar "as várias teorias conspiratórias que rondam o episódio, inclusive a de que o Pentágono foi atingido 
sobre a demora da divulgação. Se o ataque ao Pentágono ainda gera controvérsias, outros aspectos do 11 de setembro são interpretados de modo semelhante por Meyssan e por críticos de sua tese, como Peter Franssen, jornalista da revista eletrônica Solidaire, e Pol De Vos, presidente da Liga Anti-Imperialista, que também em 2002 publicaram um livro sobre os atentados (11 Septembre: Pourquoi ils ont laissé faire les pirates de l'air).

Segundo os autores, os serviços de informação dos Estados Unidos sabiam que os atentados do 11 de setembro estavam sendo preparados, sabiam que edifícios eram visados, conheciam os quadros superiores e intermediários da rede de Osama Bin Laden e seguiam os passos de certo número de piratas do ar. Em síntese, a teoria é a de que o governo não quis detê-los porque os atentados serviriam muito bem à elite militar e política dos Estados Unidos, conquistando a opinião pública para uma guerra de longa duração contra países que barram o caminho da hegemonia norte-americana ${ }^{54}$. Meyssan também acredita que já se sabia do atentado e que houve intervenção prévia para que muitas pessoas não estivessem no WTC na hora dos ataques, motivo pelo qual o número de vítimas foi bem menor do que se imaginava. Teria havido até mesmo apoio logístico da inteligência americana para a implosão dos prédios, pois apenas o choque dos aviões não poderia ter feito as torres ruírem, como avaliaram muitos peritos.

Meyssan lembra que em poucos dias o FBI já tinha a versão oficial pronta para a imprensa internacional, que imediatamente passou a reproduzi-la, afinal a opinião pública clamava pela apresentação de culpados, que eram "definitivamente" os islamitas árabes comandados pelo terrorista Osama Bin Laden e a organização Al Qaeda. A explicação para os ataques já fora dada pelo presidente Bush, em mensagem televisionada na noite de 11 de setembro: "A América foi tomada como alvo porque é o mais brilhante farol da liberdade e do progresso em todo o mundo".

A definição do que acontecera e do que estava por vir também partiu de Bush, em declaração à imprensa no dia 12 , depois de receber relatórios do $\mathrm{FBI}$ sobre a interceptação de comunicados da Al Qaeda no dia anterior: "Os ataques deliberados e mortíferos perpetrados ontem contra nosso país não eram atos de terror. Eram atos de

por um míssil, e não por um avião". As imagens circularam na televisão e na internet no mesmo dia. Nós assistimos à transmissão da Bandnews no site da UOL e não é mesmo possível ver o avião.

${ }^{54}$ Dados da entrevista dos autores à revista Solidaire, 4/9/2002 (resistir.info/11set/article.phtml.html). 
guerra. Em conseqüência, nosso país deverá unir-se numa determinação e numa resolução sem falhas. A liberdade e a democracia foram atacadas. (...) Os Estados Unidos usarão todos os recursos que estão em seu poder para vencer esse inimigo. Nós juntaremos o mundo. Seremos pacientes. (...) Não vamos permitir que esse inimigo ganhe a guerra mudando nosso modo de vida e limitando nossas liberdades. (...) As nações do mundo que estão ávidas por liberdade estão do nosso lado. Esta luta do bem contra o mal será monumental, mas o bem vencerá" (cf. Meyssan, 2003:62).

Após inquérito e julgamento sumários, sem provas, estava declarada a guerra. Os atentados de 11 de setembro constituíram uma oportunidade única de os Estados Unidos atacarem inimigos estratégicos como o Afeganistão e o Iraque, sob o confuso pretexto de guerra simultânea ao terror, a religiões tidas como radicais e a opositores da democracia. Foi durante uma cerimônia na National Cathedral, em 14 de setembro, instituído como dia de luto nacional em homenagem às vítimas dos atentados, que Bush praticamente oficializou a declaração de guerra: "Nossa responsabilidade diante da história é clara: devemos responder a esses ataques e liberar o mundo do mal. Fizeramnos a guerra, através da esperteza, do embuste e do assassinato. Nossa nação é pacífica, mas, quando irritada, torna-se feroz" (cf. Meyssan, op.cit.:72).

A partir daí, afirma Meyssan, as informações à imprensa tornaram-se restritas. Independentemente de muitos dados terem se confirmado depois ou terem se mantido na sombra da dúvida, o que importa observar é que, em 11 de setembro e nos dias que se seguiram, a versão oficial dominou a mídia sem que nenhum questionamento fosse feito, virou dogma. Os céticos só foram se fazer ouvir mais tarde, mas por canais alternativos à grande imprensa. Teorias como as de Meyssan, Franssen e Pol De Vos foram revelando muitas informações imprecisas e numerosos fatos incompatíveis com a versão oficial, mas na época foram consideradas extravagantes.

Outras vozes, como as do lingüista Chomsky e do cineasta Michael Moore, se uniram a essas e denunciaram o uso do 11 de setembro como um grande álibi para a consecução de objetivos militares, econômicos, políticos e geopolíticos, a qual não seria possível sem o apoio das elites e da opinião pública, sobretudo nos Estados Unidos.

Como lembra Meyssan, houve adesão em massa à política de guerra ao terrorismo, mas com o passar do tempo a população começou a se desinteressar e a 
duvidar de novas ameaças ao território americano. Em outubro, então, começaram a ser divulgadas informações alarmantes sobre formas de bioterrorismo e o pânico voltou à cena. Além disso, os Estados Unidos se preocupavam em estender o período de luto e as cerimônias em homenagem às vítimas dos atentados para manter presente a tragédia na mente das pessoas. Mesmo com todo esse aparato para manter a memória e o medo do terror no país, o ceticismo avançava em outras partes do mundo e começava a contaminar o povo americano. Talvez por isso as conferências de Chomsky e o filme de Moore, o documentário de maior bilheteria da história do cinema e ganhador da Palma de Ouro em Cannes em 2004 (Fahrenheit 11 de setembro), tenham feito tanto sucesso.

Ambos denunciaram, assim como Meyssan, Franssen e Pol De Vos, o lobby do setor energético, da indústria bélica norte-americana e de grandes investidores, bem como uma possível farsa montada em torno de Bin Laden, antigo aliado dos Estados Unidos durante a Guerra Fria e membro de uma família cujos negócios (Saudi Bin Laden Group) estariam ligados a empresas que tinham a participação de George Bush (Carlyle Group). Não ficou de fora também a acusação de que os Estados Unidos sempre tiveram grande interesse no Afeganistão - antiga base de ataques contra a União Soviética e contra a China - por sua estratégica posição geográfica, que o torna um país de passagem para o petróleo e o gás provenientes das repúblicas da Ásia Central.

Chomsky sempre foi um crítico ferrenho da política e da mídia norte-americanas. Após o 11 de setembro, ele passou a defender com mais veemência a idéia de que não se pode falar de terrorismo unilateralmente, pois existe também o terrorismo dos poderosos contra os fracos. De seu ponto de vista, os ataques não foram exatamente uma novidade, tendo em vista o modo como as potências imperialistas têm tratado o resto do mundo há centenas de anos. O acontecimento seria rotulado como histórico não pela atrocidade, mas por ter como vítima os Estados Unidos (cf. Chomsky, 2005:15).

Segundo Chomsky, ninguém parou para pensar nas razões do que houve ou tentou buscar as raízes do problema. Muitos se apressaram em acusar o cientista de fazer apologia ao terrorismo, inclusive órgãos da imprensa brasileira ${ }^{55}$, mas Chomsky se ${ }^{55}$ A revista Veja, no artigo "Intelectuais em guerra" (edição de 10 de outubro de 2001), dizia haver uma
batalha entre os "rápidos", que perceberam imediatamente as mudanças provocadas pelos ataques, e os
"lentos", que continuaram a bater na mesma tecla de suas teorias. Sobre o lingüista Noam Chomsky e "sua 
defendeu dizendo que era apenas uma questão de "sanidade": "Se você não se importa com a possibilidade de haver outros ataques terroristas, ótimo, é só não prestar nenhuma atenção às razões. (...) Estão todos preocupados em deter o terrorismo. Bom, há uma maneira realmente fácil de fazê-lo: é parar de participar dele. Por si só, isso reduzirá enormemente a quantidade de terrorismo no mundo" (op.cit.:18,24).

A crítica aos Estados Unidos se estende a diversos países aliados que, segundo Chomsky, já teriam praticado terrorismo camuflado em ações de guerra, como Argélia, Turquia e Israel, e se estende também às intervenções bélicas norte-americanas, chamadas eufemisticamente pelo governo e pela mídia de "processos de paz", cujos sujeitos sempre integram "forças de paz". O professor sustenta que muitas das ações diretas ou indiretas dos Estados Unidos em países da América Central, do Oriente Médio e da África, praticadas em nome de interesses capitalistas, foram atos terroristas atrozes. Isso responderia, segundo Chomsky, à falsa ingênua pergunta feita por Bush depois do 11 de setembro: "Por que eles nos odeiam?" (2003:155).

Por si sós, todas essas perspectivas alheias ao discurso oficial que ecoou na mídia internacional por muito tempo depois dos atentados ao menos nos fazem pensar se poderia ter sido diferente a cobertura dos acontecimentos. Nos últimos cinco anos, o 11 de setembro foi tema de muitos debates, artigos, estudos, livros e - passado o período mais traumático - até de filmes produzidos por Hollywood, mas normalmente o foco é o drama das vítimas ou a compreensão da lógica do terror. Ainda que se tenha discutido, em alguma medida, o fato de os Estados Unidos terem se aproveitado politicamente da situação e tenham aumentado as manifestações contra a superpotência, isso não mudou nada. Bush se reelegeu e prosseguiu sua trajetória marcada por guerras. Mas, mais uma vez, essa é uma outra história.

turma", a revista avalia: "Ícone da esquerda e último refúgio dos preguiçosos (todo mundo bate à sua porta quando quer uma crítica invariável a qualquer iniciativa do governo americano), o veterano professor ficou patentemente do lado dos lentos. Não mudou seu discurso em nada, insistindo em equiparar os atentados suicidas que pulverizaram quase seis mil pessoas [sic] nos Estados Unidos ao bombardeio de uma fábrica de remédios do Sudão, desfechado em 1998 a mando do então presidente Bill Clinton, numa desastrada tentativa de punir colaboradores de Osama Bin Laden. Chomsky sustentou, delirantemente, que o bombardeio provocou 'milhões' de mortes (...). Para se ter idéia da discrepância, o ataque americano em si não matou ninguém." $\mathrm{O}$ artigo foi citado por Arbex, que defendeu a posição de Chomsky e disse que, sem dúvida, o bombardeio à única fábrica de remédios do miserável Sudão provocara imensa tragédia para dezenas de milhares de pessoas (2003:77). Arbex criticou também a revista por limitar-se a qualificar como "desastrado" "um ato de puro terror da mais potente máquina militar do planeta". 
Voltemos às reflexões sobre a mídia, que tem tornado muita gente descrente, até mesmo jornalistas como o inglês Robert Fisk, especialista em conflitos no Oriente Médio, para quem "o jornalismo está cada vez mais covarde depois do 11 de setembro": "Os jornais já não são uma fonte de informação confiável. Nos Estados Unidos, minhas palestras estão sempre cheias. E não é porque sou eu quem está falando, mas porque os norte-americanos estão percebendo que não podem confiar no que o New York Times ou o Los Angeles Times oferecem. Sabem que algo diferente do que estão vendo na CNN ou na Fox está acontecendo. E, para acessar outra versão, têm de buscar a mídia independente, ou estrangeira" ${ }^{56}$.

Segundo Fisk, foi muito positivo o aumento do interesse por notícias depois do 11 de setembro, mas a mídia continua a fugir da controvérsia e a abastecer o público com a versão dos governos para os fatos. O jornalista chama a atenção para o número de vezes que expressões como "segundo fontes oficiais" ou "as autoridades disseram" aparecem nos jornais e para o uso de termos que denunciam o medo, por parte dos veículos de comunicação, de descrever o que realmente acontece. Fisk afirma que dizer "território disputado", em vez de "território ocupado", ou "assentamento", em vez de "colônia", não é uma questão de eufemismo, mas uma prática de ocultamento dos fatos e de suas razões: "Isso é dessemantizar a história, é degradar a linguagem".

\section{O que se viu aqui}

A cobertura ao vivo que a rede CNN fez da Guerra do Golfo em 1991, como enfatiza Arbex, "consagrou definitivamente a espetacularização da notícia" (2001:31). Nesse episódio, ainda segundo esse autor, a televisão funcionou como veículo de propaganda e sustentação das ações dos Estados Unidos e teve início uma nova etapa das "relações promíscuas" entre Estado e mídia. A CNN ganhou o mundo, a notícia como espetáculo ganhou o mundo, a promiscuidade também: "Em cada uma das intervenções militares subseqüentes protagonizadas pelos Estados Unidos, a mídia teve um papel fundamental não apenas como propagadora de um discurso legitimador das ações de Tio

\footnotetext{
${ }^{56}$ Entrevista à Folha de S.Paulo, 14 de maio de 2006.
} 
Sam, como também na qualidade de arma psicossocial, componente fundamental da guerra de propaganda contra o inimigo" (Arbex, op.cit::37).

Segundo Arbex, após a queda do Muro de Berlim, os Estados Unidos se investiram do papel de "nação escolhida por Deus", para lutar contra o "Império do Mal", o que fez com que se multiplicassem suas intervenções militares em outras nações: no Golfo (1991), na Somália (1992), no Haiti (1994), na lugoslávia (1999), no Brasil (mais especificamente na Amazônia, na fronteira com a Colômbia, em 2000), no Afeganistão (2001), no Iraque novamente (2003). Arbex lembra que, em todos os casos, o discurso da Casa Branca foi a defesa dos direitos humanos e das liberdades democráticas contra as "forças do mal", como o terrorismo, o fanatismo islâmico e o narcotráfico: "Nunca, como se vê, os Estados Unidos agiram em defesa dos próprios interesses econômicos e/ou geoestratégicos. Jamais" (2003:32). Em todos os casos, a mídia reproduziu esse discurso maniqueísta.

A mídia brasileira não agiu diferente, sobretudo por motivos ligados à hegemonia do grande capital corporativo norte-americano e ao monopólio da informação de agências internacionais de notícias, cujas conseqüências já foram apontadas. Arbex e outros pesquisadores já analisaram muitos casos em que a imprensa brasileira acompanhou o discurso oficial ou dominante e cometeu grandes equívocos de informação, principalmente em relação a eventos internacionais, como os conflitos nos Bálcãs, os ataques de 11 de setembro, a ocupação do Afeganistão, a invasão do Iraque e as lutas entre Israel e Palestina.

A respeito da cobertura do 11 de setembro, Arbex lembra que âncoras de telejornal, correspondentes internacionais, professores universitários, "especialistas", ninguém - no Brasil e no mundo - hesitava em afirmar que "foi o maior atentado terrorista da história". A frase e as imagens do choque dos aviões contra as torres do World Trade Center eram repetidas incessantemente, mas ninguém esclarecia os critérios segundo os quais esse atentado podia ser considerado pior ou maior do que muitas outras ações terroristas nas quais morreram milhões de civis. Arbex e Chomsky compartilham a mesma visão, segundo a qual é muito longa a lista de atos candidatos a "maior atentado terrorista da história", especialmente se incluídos o terrorismo de Estado e o terrorismo econômico, que leva à fome, à miséria e à morte em todo o mundo. 
Também como Chomsky, Arbex era constantemente lembrado, nos debates de que participou logo após o 11 de setembro, de que era preciso distinguir atos de guerra, atos terroristas contra alvos civis e o funcionamento da ordem econômica, que a rigor não tem a intenção de matar ninguém. Arbex discordava e apresentava um argumento que servia também em sua defesa contra a acusação de que apoiava o atentado: "Do ponto de vista da vítima civil inocente, tanto faz se o sujeito que disparou a bomba foi Osama Bin Laden, estudantes da Brigada Vermelha, militantes do ETA basco ou algum burocrata confortavelmente instalado na Casa Branca" (2003:52). Mas nada convencia os debatedores, nem mesmo a convicção histórica - se admitida a distinção entre atos de terrorismo e atos de guerra - de que nenhum ato terrorista pode ser entendido como ato isolado, inesperado ou inexplicável.

Ao que parece, a mídia também não entendia essa premissa básica, pois foi exatamente assim que qualificou o atentado de 11 de setembro, como um ato incompreensível de um grupo de fanáticos. Em não havendo explicação, cresciam os sentimentos de medo e ódio, alimentados pela contínua exibição, por todas as televisões do mundo ocidental, das cenas de destruição e morte, cujo impacto se amplificava pelo simbolismo que elas continham: "era a sede do império que sofria, e não mais um país da periferia" (Arbex, op.cit.:53). A guerra contra o terror era urgente e inevitável, assim como a fabricação de um consenso em torno do discurso e das ações de George W. Bush, tarefa de que grande parte da mídia se incumbiu, sem exigir provas de nada.

O miserável Afeganistão foi atacado sem maiores explicações ${ }^{57}$, a despeito das reações internacionais que poderia provocar, e a mídia, segundo Arbex, limitava-se a apresentar Bush como "o ícone da civilização contra a barbárie", sem jamais cogitar as vantagens que o presidente americano, seu país e aliados obtiveram depois dos atentados, tais como: a oportunidade de legitimar um governo até então de pouca expressão; a possibilidade de intensificar programas repressivos a movimentos

\footnotetext{
${ }^{57}$ Carlos Fino, experiente jornalista da RTP, Rádio e Televisão Portuguesa, cobriu a ofensiva militar norteamericana no Afeganistão, em 2001, e conta que os jornalistas tiveram de se instalar a mais de quinhentos quilômetros do "teatro das operações". Segundo Fino, não havia reações por parte dos afegãos na região em que ele estava: as televisões foram destruídas, então muitos nem sequer estavam informados sobre o que se passou em Nova York no dia 11 de setembro (2003:72).
} 
considerados terroristas ou contrários à globalização ${ }^{58}$; os pretextos necessários para que os Estados Unidos interviessem em regiões produtoras de petróleo no Oriente Médio e na Ásia Central ${ }^{59}$; o apoio para que operações militares ocupassem regiões consideradas estratégicas na Eurásia, o que implicava maior controle geopolítico; a crescente sustentação da indústria armamentista, como conseqüência das ações bélicas do governo norte-americano (op.cit.:60-66).

No Brasil, dias depois dos atentados, a imprensa denunciava que a mídia dos Estados Unidos, embalada pelo clima de patriotismo e união nacional, maquiava os efeitos da destruição, não exibia imagens dos cadáveres, adiava a investigação de eventuais falhas no sistema de segurança do país e não se queixava da falta de informações, sob o pretexto de respeitar o momento de grande comoção, seguindo a política oficial ${ }^{60}$. Entretanto a cobertura feita por veículos brasileiros não foi muito diferente, conforme mostram trabalhos como o do jornalista Carlos Dorneles e numerosos artigos publicados no site do Observatório da Imprensa, com sérias críticas principalmente ao telejornalismo.

Não faltou quem comparasse, inclusive no universo midiático, as imagens dos atentados a cenas de cinema. Segundo o jornalista Paulo José Cunha ${ }^{61}$, entretanto, "o que a tela da tevê exibiu durante toda a terça-feira, 11 de setembro, não parecia cinema;

\footnotetext{
${ }^{58} \mathrm{Um}$ ano depois dos atentados, segundo análise de José Luís Fiori (artigo publicado no site da revista Carta Capital, com data de 10 de setembro de 2002), seria possível constatar que os Estados Unidos haviam adotado a paranóia como estratégia de defesa, uma vez que seu novo adversário não era uma religião, uma ideologia, uma civilização ou uma nação, mas as próprias vulnerabilidades do país, conforme discurso sustentado pelo governo para justificar suas ações depois de 11 de setembro. Fiori entendia que, numa batalha que vinha sendo travada desde o fim da Guerra Fria, os atentados "acabaram dando ganho de causa aos interesses e idéias consagrados pela nova Doutrina Bush, uma estratégia internacional que foi desenhada pela primeira vez em 1989" e cujo objetivo era "impedir o surgimento de qualquer nação ou aliança de nações que pudessem rivalizar com os Estados Unidos". A partir dos atentados, os Estados Unidos poderiam redefinir seus inimigos - invisíveis e onipresentes - como melhor conviesse e garantir seu direito exclusivo de fazer "ataques preventivos" a quem quer que fosse e de vigiar a tudo e a todos.

${ }^{59} \mathrm{O}$ jornalista Carlos Fino critica o fato de as coberturas internacionais, de modo geral, não terem explicado suficientemente determinados aspectos da invasão do Afeganistão: "Torna-se impossível não contextualizar a guerra no quadro geral da luta estratégica pela posse e controle das fontes de energia, especificamente 0 petróleo. Sabe-se como a descoberta de enormes jazidas no Mar Cáspio intensificou a luta de interesses na região, impondo a procura de vias de escoamento mais diretas e seguras. Controlando o Afeganistão e com bases militares em outros países da antiga Ásia Central soviética, os americanos criam, sem dúvida, melhores condições para o escoamento do petróleo do Cáspio de acordo com os seus próprios interesses" (2003:94).

60 "Mídia dos EUA maquia destruição e releva falhas do governo", Folha de S.Paulo, 15/9/2001.

61 "Não parecia cinema: era cinema", site do Observatório da Imprensa, 19/9/2001.
} 
era cinema e as imagens foram tratadas pelos narradores como cinema", obtendo-se um efeito paralisante de perplexidade. Cunha notou que o tom da narração dos âncoras das principais televisões do mundo, "inclusive as tupiniquins", era marcado por exclamações que "só atingiam o espetáculo, não a essência da tragédia", um tom que se justificava, pondera o jornalista, "pela lógica intrínseca dos próprios fatos, visivelmente produzidos tendo em vista seus efeitos midiáticos". Mais do que atingir um edifício símbolo do poder econômico americano, "aquele avião acertou o olho da câmera de tevê"; esse era o alvo, na análise de Cunha. Que fosse, mas a mídia também acertou em cheio, por sua intrínseca lógica do espetáculo e da audiência, ao explorar a encenação.

Em outro artigo, o jornalista Luiz Weis diz que pelo menos na primeira semana depois dos atentados, "parecia mais fácil achar uma vítima viva nos escombros do World Trade Center do que reportagens ou artigos que não ecoassem a 'linha justa' de Washington sobre os acontecimentos"62. Segundo Weis, embora a mídia norte-americana tenha cumprido sua missão e mostrado o que era preciso ser mostrado, "nenhum órgão de imprensa americano que vale o que pesa pôs em dúvida, por exemplo, a instantânea versão oficial de que o culpado pelas atrocidades" era Osama Bin Laden, não se pediu prova de nada, ninguém se importou de o governo deixar tantas perguntas sem resposta em relação ao que - segundo se afirmava - já havia sido descoberto pelo serviço de inteligência e à "tremenda vulnerabilidade da única superpotência mundial". Que seja, mas a mídia brasileira, também nos primeiros dias, reproduziu esse comportamento.

Aqui também se ouviu, onde menos se esperava, o eco do clamor por vingança. Alberto Dines censurou jornalistas brasileiros que criticaram a mídia americana por incentivar "o furor vindicativo contra os mandantes do genocídio": "Jornalistas brasileiros, em geral, não sabem fazer contas: são mais de cinco mil vítimas, no mínimo dez mil famílias chorando seus mortos e, considerando cinco pessoas por família, cinqüenta mil pessoas diretamente atingidas pela tragédia. Sem contar amigos, parceiros, vizinhos, famílias afins e ex-cônjuges. É um universo de cem mil pessoas numa cidade cuja imprensa costuma refletir diretamente aquilo que seus leitores sentem. Seria possível neste exato momento clamar por outra coisa que não a punição?" ${ }^{63}$ Que outro clamor

\footnotetext{
62 "White plates press", site do Observatório da Imprensa, 26 de setembro de 2001.

63 "Anotações de um observador atônito", site do Observatório da Imprensa, 26 de setembro de 2001.
} 
não fosse possível às famílias das vítimas é aceitável, mas não à mídia, não a um observador da imprensa.

Ao mesmo tempo, e no mesmo artigo, Dines punha em dúvida a capacidade do jornalismo brasileiro de sustentar por muito tempo a cobertura de um acontecimento com aquelas dimensões: "Quanto tempo agüentarão? Pouco: as editorias internacionais já começam a bater pino. Há muito tempo que estão espremidas em nesgas, subdimensionadas, sem apoio de correspondentes internacionais experimentados e com pessoal de retaguarda jovem, sem o devido treino. (...) O mundo sumiu dos nossos jornais e revistas justamente no auge da mundialização. Agora, a ferro e fogo, o mundo irrompe em nossas vidas e só sabemos reagir mandando buscar os cientistas sociais da esquina mais próxima para ouvir os seus palpites. Em lugar do jornalismo declaratório estamos desenvolvendo o jornalismo achista". Que as informações e interpretações dos fatos nos chegavam por uma espessa camada de filtros é inegável, mas se a fonte era o jornalismo americano - que naquele ano merecia o Prêmio Pulitzer por seu "pronto e instintivo espírito crítico", na opinião de Dines - que mal haveria em seguir-lhe os passos?

Haveria muitos males, uma vez que a cobertura dos atentados e seus desdobramentos estava fomentando, desde o primeiro dia, a intolerância e uma visão maniqueísta do mundo, que se estenderia por longo tempo depois de 11 de setembro e levaria a mais violência e a novas guerras. Duas semanas depois dos eventos, Paulo José Cunha ${ }^{64}$ alertava para o fato de que o foco da atenção deslocara-se da tragédia para o modo como a mídia vinha conduzindo um importante processo histórico. Não importava se tinha havido ou não sensacionalismo na transmissão dos fatos pela televisão ${ }^{65}$, mesmo porque a violência dos ataques por si só não pedia retoques, mas preocupava de que forma as notícias podiam intervir no imaginário da sociedade.

Segundo Cunha, a imprensa já não estava reportando os fatos de forma cristalina e pautava a cobertura por informes das agências e "sob o crivo da subjetividade de seus editores". Além disso, como há muito tempo as nações mais potentes tinham descoberto

\footnotetext{
64 "Precisamos mesmo ser ajudantes de xerife?", site do Observatório da Imprensa, 26/9/2001.

65 A Folha de S.Paulo divulgou uma pesquisa, no dia 23 de setembro, sobre a satisfação dos telespectadores com a cobertura ao vivo dos ataques realizada por emissoras brasileiras de televisão aberta. Responderam à pesquisa leitores do TV Folha e internautas que acessaram a Folha Online e a
} 
o caráter simbólico das guerras no mundo midiático, era fundamental para os governos construir a versão que desejavam fosse adotada como verdadeira, para o que tinham de manipular a mídia. E o que se viu foi mesmo, como afirma Cunha, "o alinhamento incondicional à versão adotada pelas grandes redes internacionais que vocalizam a ideologia dominante e a distribuem mundo afora", inclusive no Brasil, onde as redes de televisão, com pouquíssimas exceções, seguiram fielmente a cartilha oficial, "repetindo bovinamente um esquema de cobertura de conflitos internacionais bastante conhecido": "do lado de cá, a verdade, do lado de lá, a mentira; o Bem mora aqui, lá mora o Mal".

Era indiscutível, diz Cunha, que os ataques deviam ser repudiados e que os culpados não podiam ficar impunes, mas isso não significava que a "miopia da cobertura" tivesse o direito de criar a impressão de que os Estados Unidos deviam ser canonizados e que mais de um bilhão e trezentos milhões de muçulmanos mereciam ser satanizados. A história recente não credenciava os Estados Unidos a encarnarem o Bem, o que justificava a opinião de Cunha: "A explosão de irracionalidade e bestialismo que se abateu sobre a nação americana tem a ver com esse passado e essas práticas. E é essa faceta que exige cobertura, análise, esclarecimento, confrontação de pontos de vista em contraposição ao paiol de pólvora que vem sendo montado a partir do discurso de mão única." O 11 de setembro trouxe esse desafio para toda a mídia internacional, inclusive a brasileira, que não podia aceitar exercer o papel de "ajudante de xerife".

Alguns veículos brasileiros, porém, aceitaram prontamente o papel e tentaram explicar o que incomodava o terror, fazendo repercutir a ladainha de que o atentado tinha sido cometido contra "os mais caros e mais frágeis valores ocidentais: a democracia e a economia de mercado", contra um sistema social e econômico que, "mesmo longe da perfeição, é o mais justo e livre que a humanidade conseguiu fazer funcionar ininterruptamente até hoje", contra "uma sociedade em que os justos podem viver sem ser incomodados e os pobres têm possibilidades reais de atingir a prosperidade com o fruto de seu trabalho"66. Nem é preciso dizer que Arbex, ao citar esses trechos, ironizou a "visão idílica" de um sistema responsável por tantas desigualdades sociais no mundo

maioria $(77,3 \%)$ reprovou a cobertura, considerando-a sensacionalista, repetitiva, dramática, superficial e pouco esclarecedora.

66 "O que incomoda o terror", editorial da revista Veja, 19 de setembro de 2001. 
todo, mas sobretudo alertou para o grande problema desse discurso, que é a tentativa de "empulhar" o público, fomentando o preconceito contra o islamismo e o mundo muçulmano, imediatamente apontados como culpados do ataque e transformados em sinônimo de terrorismo nas inúmeras "explicações" que a mídia tentava fornecer ao público e que se entranhariam no imaginário social.

Arbex mostrou a fragilidade e a falácia dos argumentos: "não há como sustentar que se tratou de uma agressão ao capitalismo, pois não há, nem jamais houve, qualquer identidade entre 'Islã' e 'anticapitalismo"', da mesma forma que Bin Laden, se ficasse provada sua responsabilidade, não o teria feito por ser anticapitalista, já que sua fortuna pessoal é incalculável e ele lutou, durante a Guerra Fria, ao lado dos Estados Unidos" (2003:70). Da mesma forma, não se podia falar em guerra religiosa, choque de civilizações ou atentado à democracia, já que a história mostra que não foram poucas as vezes em que os Estados Unidos, por interesses diversos, apoiaram regimes repressores e violentos em outras partes do mundo.

Essas questões, no entanto, não se faziam presentes no discurso da mídia televisiva no calor dos acontecimentos, com exceção dos lugares de debate, como o programa Roda Vida, da TV Cultura, que constitui um gênero diferente de jornalismo. Quase uma semana depois dos ataques, o programa promoveu uma discussão entre intelectuais brasileiros sobre as inquietações que o episódio suscitava. $\mathrm{O}$ apresentador e mediador Paulo Markun menciona, logo no início, o espetáculo da mídia, mas o tema não será desenvolvido durante o debate: "Passada a perplexidade inicial, terminado o espetáculo dos ataques suicidas a Nova York e Washington, por mais que novos acontecimentos sejam apresentados e tratados outra vez como espetáculo, as incertezas criadas nos levam a pensar nas conseqüências disso tudo para o mundo"67. A despeito da cobertura pouco reflexiva que se via naqueles dias, ou até mesmo para preencher-lhe as lacunas, o programa espacial convidava à compreensão do fato e das mudanças que poderiam atingir sobretudo as relações internacionais.

Os debatedores fizeram ponderações bastante interessantes sobre as questões militares e econômicas e sobre a reordenação mundial, principalmente no que tangia à

\footnotetext{
${ }^{67}$ Especial Terror nos Estados Unidos, DVD Roda Viva, TV Cultura, setembro de 2001.
} 
oportunidade de os Estados Unidos reverem sua política externa, no entanto não tocaram profundamente nas causas daquela nova modalidade de ataque, o "terrorismocatástrofe", conforme denominação usada na narração dos fatos no início do programa. Alguns pontos para que se chamava a atenção eram: o conflito entre a necessidade de os Estados Unidos darem uma resposta imediata à opinião pública interna e o imperativo de se discutir internacionalmente o combate ao terrorismo, ou, em outras palavras, o conflito entre os objetivos retóricos dos Estados Unidos e os objetivos da comunidade internacional; o objetivo de criar um inimigo visível a qualquer preço e o perigo de transformar o mundo árabe nesse inimigo, sob uma operação de fumaça semelhante à que se viu na Guerra do Golfo; a pelo menos aparente fragilidade dos serviços de inteligência e segurança da superpotência; a falta de liderança mundial, constatada pelo rápido alinhamento de outras nações à posição dos Estados Unidos.

No rumo que o debate tomou, havia também algumas luzes. O coronel Geraldo Cavagnari, especialista em estudos estratégicos, alertava para a necessidade de o mundo aprender a conviver com o terrorismo, uma arma das minorias e dos países pobres, porque isso só teria fim quando se solucionassem os problemas da exclusão. $O$ cientista político Reginaldo Nasser insistia em que era preciso desfazer a confusão que se estava estabelecendo entre árabes e religiosos radicais, para evitar uma espiral de violência. Segundo ele, o melhor que os Estados Unidos poderiam fazer naquele momento era se aproximar do mundo árabe e avaliar a situação histórica em que podiam ser inseridos aqueles ataques praticados supostamente - até então - por fanáticos religiosos. O cientista político José Augusto Guilhon sugeria que era preciso entender o que diferenciava o terrorismo com objetivos políticos, como o que existe na Irlanda e na Espanha, daquele terrorismo que então se via, cujas conexões logísticas deveriam ser extremamente complexas.

Na mesma direção, a historiadora Maria Aparecida Aquino lembrava que não era possível tomar o terrorismo como um "rebelde sem causa". O terrorismo é uma ação injustificável, mas deve ter explicações, e um caminho, naquele caso, era procurá-las na história marcada pela prepotência dos Estados Unidos, em cujas mãos não se podia concentrar o poder de fazer justiça no mundo. Segundo Aquino, era necessário perguntar se queríamos manter o mundo "bom para poucos e mau para muitos". Também na 
perspectiva do economista Luís Carlos Mendonça de Barros, os objetivos daqueles atentados passavam pela questão da ordem econômica. Para o jornalista Roberto Godoy, o dedo apontado para Osama Bin Laden e as armas voltadas para o já destruído Afeganistão de nada adiantavam, porque a estrutura do terror independia dessa ação isolada. No entanto essas reflexões eram ofuscadas pela própria cobertura da mídia, que impedia ao público, naquele momento, separar as reações normais ao drama humano das reações ao espetáculo em que fora transformado o acontecimento, conforme ponderou o cientista político José Augusto Guilhon.

A preponderância do jornalismo espetacular suscitou até mesmo uma análise controversa do discurso da mídia. Houve quem achasse que, no episódio de 11 de setembro, a imprensa contribuiu para a propagação da mensagem dos terroristas. Mais do que isso até. Houve quem dissesse que as corporações jornalísticas fazem prevalecer a visão de mundo dos terroristas e que, de modo geral, não os apresentam como criminosos ou assassinos, mas como uma espécie de políticos, revolucionários, libertadores (cf. Wainberg, 2005:16) Houve quem dissesse até que, sem a mídia, provavelmente não haveria terror. E aqui voltamos à teoria da visibilidade, segundo a qual só tem existência o que aparece na televisão. Muitos fatos só têm existência midiática, mas certamente não é o caso da miséria, da violência, do terror.

Umberto Eco chegou a afirmar, logo depois do 11 de setembro, que a mídia foi o melhor aliado de Bin Laden, com o que muitos concordaram, inclusive estudiosos brasileiros $^{68}$. Em síntese, colocava-se em pauta a velha polêmica sobre a possibilidade de a divulgação de crimes incentivar ou não o crime. Eco deu razão ao Pentágono em pedir cautela aos jornais e às redes de televisão, afinal "nenhum exército que se encontra em guerra fica satisfeito quando seus planos são revelados ou os apelos de seus inimigos são difundidos"69. Para ele, o objetivo de Bin Laden era "criar o maior espetáculo da Terra e deixar a marca visível de uma agressão contra os símbolos do poderio ocidental", tudo o que contava era "a imagem criada" e a mídia se viu "obrigada" a divulgar o que evidentemente se tornou uma meganotícia.

\footnotetext{
${ }^{68}$ Tais como Jacques A. Wainberg (2005) e Elizabeth Bastos Duarte (2004:16).

69 "Mídia foi o melhor aliado de Bin Laden", Folha Online, 2 de dezembro de 2001.
} 
Pois bem, mas a grande questão para Eco era: "Será que a mídia era obrigada a repetir esses relatos diariamente e por mais de um mês a fio, com fotos, imagens em vídeo e os intermináveis relatos de testemunhas oculares, todos fazendo as pessoas reviverem e relembrarem os ataques?" Esse é um ponto importantíssimo para qualquer dos lados do debate: o lado dos que viram a mídia, de início, como "refém" do terror e, depois, como "cúmplice"; e o lado dos que leram o discurso da mídia como fio condutor da história oficial, que não queria apagar a tragédia das memórias.

Um lado acredita que o terror se beneficiou da "publicidade gratuita" da mídia e que Bin Laden venceu a primeira rodada, mas também não duvida de que os jornais aumentaram suas vendas e as emissoras de televisão aumentaram sua audiência com a exploração do acontecimento. $\mathrm{O}$ outro lado acredita que a mídia reforçou a imagem de "vítima" dos Estados Unidos ${ }^{70}$ e ajudou a propagar os slogans da guerra contra o terror, assim como, e contraditoriamente, uma política do pânico, pelo que pagou um preço maior do que qualquer lucro que possa ter tido: sua independência.

Eco, naquele momento, demonstrava-se cético: "Só o futuro nos dirá se o 'espetáculo' criado por Bin Laden - pelo fato de ter extrapolado o tolerável - desencadeou uma série de acontecimentos que marcarão o começo de sua derrocada. Se isso acontecer, então a vitória terá sido da mídia." Agora os céticos somos nós. Se os terroristas planejaram um ataque tão espetacular, e assim o fizeram porque conheciam a natureza espetacular da mídia, devem ter calculado as conseqüências de um ato intolerável pelo ocidente, portanto nos parece conflituoso falar em cumplicidade ou vitória da mídia. A mídia não poderia querer difundir ou derrotar o terrorismo pela precipitação de novos fatos. Ela representa um poder simbólico e age sobre elementos simbólicos, portanto sobre o imponderável.

É extremamente complicado avaliar tudo o que ocorreu depois de 11 de setembro e apontar vencedores e derrotados, como também não nos cabe investigar a verdade dos

\footnotetext{
${ }^{70}$ Jacques Wainberg, professor de jornalismo que defende a idéia de que a mídia divulga e apóia o terrorismo, afirma que o que se viu na mídia brasileira foi uma "tendência antiimperial", um "pesado rancor aos Estados Unidos", um "menosprezo aos símbolos do capitalismo e da sociedade de consumo", um "sutil afago ao terror" e o argumento preponderante de que os americanos fizeram por merecer (2005:139). Segundo Wainberg "o ódio antiamericano falou mais forte, não houve espaço no imaginário social para a vitimização dos norte-americanos" (op.cit.:142). Não sabemos a que segmentos da mídia o autor de refere, mas de qualquer forma nos parece uma total subversão do que se observou na maior parte da imprensa.
} 
fatos, mas é possível tentar analisar que imagem ou versão a mídia construiu disso tudo, como representou os dois lados ${ }^{71}$, a quem atribuiu o direito da fala, que símbolos recriou ou calou, como reorganizou fatos históricos segundo a lógica da espetacularização, que objetos de discurso forneceu como matéria da memória social.

A tarefa é gigantesca e nossa contribuição é o exame das edições históricas, em mais de um sentido, do Jornal Nacional e do Jornal da Record em 11 de setembro de 2001, e também das edições que apresentaram matérias relativas ao "aniversário" dos ataques em 2002, 2003 e 2004. Lembramos que a opção por telejornais que editaram os acontecimentos exibidos ao vivo durante aquele dia se deve ao fato de querermos observar como a montagem interfere na enunciação da notícia. Vejamos então se o germe da memória única ameaçou contaminar o tecido social desde o dia dos acontecimentos e como se mostrou sua evolução nos anos seguintes.

\footnotetext{
${ }^{71}$ Como vamos tratar do uso de certas formas de designação, mas não do complicado problema de sua recepção, gostaríamos ao menos de registrar um dado curioso com que nos deparamos durante a pesquisa. Jacques Wainberg diz num trecho de seu livro que "a mídia de esquerda fez ecoar símbolos adormecidos da rebeldia antiamericana da guerra fria, fazendo paralelo entre Che Guevara e Osama Bin Laden" (2005:138). Encontramos a referência a essa comparação também no livro de Arbex, que criticava a revista Veja pela forma desrespeitosa como tratava o mundo islâmico (povos fanáticos, atrasados e autoritários, "turma do turbante") e pelas "falsificações históricas" que apresentava (2003:74). Uma delas, segundo Arbex, estava implícita num texto em que a revista chamava Osama Bin Laden de "Che Guevara do Islã" (edição de 26 de setembro de 2001), indicando como único ponto de comparação o fato de que Bin Laden estava sendo considerado herói em vários países do Oriente Médio e tinha o rosto estampado em pôsteres e camisetas. O que Wainberg considerou panfletagem antiamericana de uma "mídia de esquerda" só podia ser, para Arbex, uma "provocação barata", típica de "uma imprensa marrom da pior espécie".
} 


\section{SEgUNDA PARTE - O OBJETO}

Os fatos, transformados em notícia, são descritos como eventos autônomos, completos em si mesmos.

Os telespectadores, embalados pelo estado hipnótico diante da tela de televisão, acreditam que aquilo que vêem é o mundo em estado natural, é o próprio mundo. (José Arbex Jr.)

\section{011 de setembro no Jornal Nacional}

No dia 11 de setembro de 2001, a edição do Jornal Nacional é especial ${ }^{72}$ e o telejornal faz um abertura diferente. Não é uma chamada para as principais notícias do dia. O assunto é um só e suplantou todos os outros.

"Onze de setembro de 2001.

Uma terça-feira que vai marcar a história da humanidade.

A maior potência do planeta é alvejada pelo terror.

World Trade Center, Nova York.

No mais importante centro financeiro do mundo,

uma torre queima - depois de ser atingida por um avião.

Enquanto o incêndio avança no arranha-céu,

um segundo avião é jogado contra a torre vizinha.

E em menos de duas horas dois dos prédios mais altos do mundo

se desfazem numa montanha de poeira e fumaça.

Na cidade sede do poder americano,

outra aeronave despenca sobre o Pentágono: o centro de inteligência militar.

E mais um boeing cai na Pensilvânia.

O planeta em alerta geral.

Chefes de estado condenam o banho de sangue e reforçam a segurança nas fronteiras.

Bolsas de valores e moedas internacionais são abaladas pelos atentados.

Nos territórios ocupados por Israel, palestinos comemoram

a maior ofensiva terrorista de todos os tempos.

E na madrugada, no mundo árabe, explosões.

${ }_{72}$ Foi uma edição com uma hora de duração, que fez o telejornal bater o recorde de audiência naquele ano, segundo o livro Jornal Nacional: a notícia faz história (2004:340). 
Mísseis riscam o céu de Cabul - a capital do Afeganistão.

O Jornal Nacional mostra a análise de especialistas sobre as conseqüências dos ataques.

O depoimento dos brasileiros que testemunharam a tragédia.

O apoio oficial aos que estão nos Estados Unidos.

O dia em que os americanos experimentaram o horror de uma grande guerra.

O Jornal Nacional está começando agora."

Os textos da escalada escalada ${ }^{73}$ e das passagens de bloco, as imagens editadas e as legendas que chamam a atenção para o assunto dos blocos seguintes são importantes elementos contextualizadores. Vejamos o que nos mostra a escalada, que é acompanhada pela rápida exibição de imagens que serão repetidas durante o jornal.

A cena enunciativa tem uma moldura lingüística que enquadrará todo o discurso: "Onze de setembro de 2001. Uma terça-feira que vai marcar a história da humanidade." A data é anunciada como a data de um fato histórico. A qualificação que acompanha a referência temporal prenuncia sua inscrição na história. O fato irrompe na mídia como a história em processo. O enunciado catafórico encapsulará todo o texto da escalada e o próprio discurso do telejornal, num movimento projetivo: tudo o que aconteceu naquele 11 de setembro, agora apresentado numa narrativa editada pelo noticiário da noite, será abrigado sob o rótulo de um dia "que vai marcar a história da humanidade".

A forma que aparece na seqüência, no enunciado que revela o que houve naquele dia, tem um referente exterior, cujo nome só aparecerá explicitamente no final da escalada. Nem é preciso dizer, todos sabem que se trata dos Estados Unidos, "a maior potência do planeta", à qual se referem todas as outras anáforas associativas: "World Trade Center, Nova York", "no mais importante centro financeiro do mundo" (cujo referente textual é Nova York), "na cidade sede do poder americano" (cujo referente extratextual é Washington). O que tornava o dia histórico "para a humanidade" era o fato de "a maior potência do planeta" ter sido "alvejada pelo terror". A referência a "terror"

\footnotetext{
${ }^{73}$ Termos que se referem a partes do telejornal e são usados na análise e nos anexos, que contêm os textos na íntegra: 1) escalada é a chamada, no início do jornal, das principais notícias do dia; 2) cabeça é o texto que o locutor lê na bancada; 3) VT é a matéria gravada; 4) off é o texto lido enquanto se exibem as imagens do VT; 5) passagem é a entrada do repórter gravada, diferentemente da entrada ao vivo; 6) sonora é a fala dos entrevistados, identificados com crédito ou não; 7) passagem de bloco é a chamada das
} 
sustenta-se provavelmente em conhecimento partilhado pelo telespectador, que ao longo do dia já deveria ter ouvido falar nos atentados por outros meios.

Os acontecimentos são descritos na seqüência, em torno da referência à importância dos alvos atingidos: "o mais importante centro financeiro do mundo", "a cidade sede do poder americano", "o centro de inteligência militar". As imagens mais marcantes são as que correspondem ao resumo do ataque ao World Trade Center: "No mais importante centro financeiro do mundo, uma torre queima - depois de ser atingida por um avião. Enquanto o incêndio avança no arranha-céu, um segundo avião é jogado contra a torre vizinha. E em menos de duas horas dois dos prédios mais altos do mundo se desfazem numa montanha de poeira e fumaça". Mostra-se o segundo avião se chocando contra uma das torres e, com um efeito de zoom, vemos a imagem mais de perto. Ouve-se uma pessoa gritando: "Oh, my God!". O ritmo da escalada é rápido, o das imagens também, o que provoca, desde o início do jornal, um efeito de dramaticidade e de simulação do que fora transmitido ao vivo, durante o dia, por outros telejornais.

É também na escalada que se começa a observar o uso das formas de designação que remetem à imagem de grandeza dos Estados Unidos e, na mesma medida, à dimensão dos ataques à superpotência: "uma terça-feira que vai marcar a história da humanidade", "a maior potência do planeta é alvejada pelo terror", "em menos de duas horas dois dos prédios mais altos do mundo se desfazem numa montanha de poeira e fumaça", "o planeta em alerta geral", "banho de sangue", "a maior ofensiva terrorista de todos os tempos", "o dia em que os americanos experimentaram o horror de uma grande guerra". O nome "planeta" será usado muitas vezes mais ao longo da edição para enfatizar a idéia de que o fato abalou o mundo todo - o substantivo "mundo" parece pequeno diante da grandiosa cena de horror.

A escalada anuncia que "o planeta" está em "alerta geral", o que pode ser confirmado, no discurso, pela informação seguinte: "Chefes de estado condenam o banho de sangue e reforçam a segurança nas fronteiras". Note-se que a expressão metafórica "banho de sangue" é um termo anafórico que vai além da referência ao conjunto dos ataques, concretizados pelo choque de dois aviões contra as torres do World Trade

notícias do bloco seguinte; 8) nota pé é o texto que fecha uma matéria, com alguma informação complementar. 
Center, pela queda de um avião sobre o Pentágono e de outro na Pensilvânia. A referência às vítimas é implícita. Não se mostra nenhum corpo. Não há sangue na tela, somente na expressão que designa a carnificina, o "ato de matar com selvageria, e em massa" (cf. dicionário Houaiss). É intensa a força de reenquadramento discursivo dessa anáfora, cuja imagem semântica é o estopim para que se acenda o imaginário sobre as mortes que o atentado provocou. Ativa-se um referente que estará oculto o tempo todo no telejornal, mas se instalará nos corações e nas mentes do telespectador, por meio de manipulação afetiva e cognitiva.

Paulo José Cunha lembra que, depois da Guerra do Vietnã, "quando a ampla liberdade de imprensa permitiu que os lares americanos fossem invadidos pelas explosões em que seus boys morriam diante de uma platéia estarrecida, precipitando o fim do conflito" ${ }^{74}$, os Estados Unidos intensificaram o controle sobre as informações em tempo de guerra, o que pode ser confirmado pelo que não se viu durante a Guerra do Golfo. Segundo ele, na cobertura das operações de rescaldo dos ataques de 11 de setembro, houve "todas as cores da tragédia, menos o vermelho do sangue", porque o "orgulho americano" não permitiria a exibição da imagem de seus mortos e feridos. Em lugar disso, diz Cunha, proliferaram imagens de bandeiras americanas.

Do ponto de vista de Susan Sontag, "permanecer dentro dos limites do bom gosto foi a razão primária apresentada para não exibir nenhuma das horripilantes imagens dos mortos colhidas no local do atentado contra o World Trade Center, logo após o ataque no dia 11 de setembro de 2001" (2003: 59). Já para José Arbex Jr., a questão era política. Assim como não se viu um só morto na cobertura da Guerra do Golfo, em que morreram pelo menos 140 mil pessoas, ninguém viu os corpos das vítimas dos atentados de 11 de setembro, segundo Arbex porque "não interessava mostrá-los quando George Bush júnior preparava a opinião pública de seu país para uma nova guerra"75.

Quaisquer que tenham sido os motivos da mídia para não mostrar a dor e a morte, do respeito à estética à aceitação dos limites impostos pelo orgulho ou pela estratégia americana, os efeitos parecem ter sido muito diferentes daqueles que resultaram do

\footnotetext{
74 "Precisamos mesmo ser ajudantes de xerife?", artigo de 26 de setembro de 2001, disponível no site do Observatório da Imprensa.

${ }^{75} \mathrm{Na}$ apresentação do livro Padrões de manipulação na grande imprensa, de Perseu Abramo (2003:9).
} 
apagamento deliberado, também na mídia, das vítimas da Guerra do Golfo, a guerra "de videogame". Como veremos na análise das edições dos telejornais nos anos seguintes, nos quais se mostram as homenagens às vítimas de 11 de setembro, o fato de não terem sido exibidas imagens do "banho de sangue" não impediu que se instaurasse um clima de comoção e indignação, diferentemente do que já se viu por ocasião de outros atentados ou conflitos em que também houve milhares de mortes.

Voltando ao texto da escalada, observamos uma interessante seqüência enunciativa: "O planeta em alerta geral. Chefes de estado condenam o banho de sangue e reforçam a segurança nas fronteiras. Bolsas de valores e moedas internacionais são abaladas pelos atentados. Nos territórios ocupados por Israel, palestinos comemoram a maior ofensiva terrorista de todos os tempos." As repercussões econômicas vinculam-se, de alguma forma, ao enunciado "o planeta em alerta geral", mas o mesmo não acontece com a informação de que o povo palestino comemora os ataques.

O enunciado "palestinos comemoram a maior ofensiva terrorista de todos os tempos" opõe-se a "chefes de estado condenam o banho de sangue", o que leva a inferir que os palestinos estão à margem desse planeta que está em alerta geral. Criam-se, dessa forma, relações de identidade e de alteridade, que fazem eco ao discurso americano oficial. Há os que estão em "alerta geral", chocados com o ataque à superpotência e a ela alinhados, e há os que não se comovem com a tragédia americana e são, portanto, inimigos.

$\mathrm{Na}$ inter-relação desses trechos, nota-se a substituição da expressão "banho de sangue" por outro termo anafórico, "maior ofensiva terrorista de todos os tempos", que atenua o que não está explícito. Dizer que "palestinos comemoram a maior ofensiva terrorista de todos os tempos" equivale a dizer, feita a transposição das anáforas que têm o mesmo referente, que os palestinos - que não têm chefe de estado, que não são uma nação - comemoram o banho de sangue. O termo "palestinos" não está definido, o que leva a entender que não se trata de todo o povo, mas a sutil diferença tende a passar despercebida no roldão das notícias. Da mesma forma, será necessário certo distanciamento crítico para perceber quão dispersa fica a explicação desse evento, ocorrido "nos territórios ocupados por Israel". 
Mais adiante concluiremos esta reflexão, ao analisarmos uma passagem de bloco em que o discurso se despoja do eufemismo. O locutor anuncia: "E, nos territórios ocupados por Israel, palestinos comemoram o banho de sangue". A imagem é a mesma nos dois trechos, uma imagem aliás bastante repetida na mídia durante a cobertura dos ataques. Ela mostra um pequeno grupo pulando nas ruas. Eram principalmente crianças. A legenda da imagem, na passagem de bloco, é "a celebração do ódio". Discutiremos os possíveis efeitos da exibição reiterada dessas imagens quando tratarmos desse segmento do telejornal.

Uma das informações finais da escalada sugere relações cujas explicações, dispersas no discurso, também deverão ser analisadas mais detidamente: "E na madrugada, no mundo árabe, explosões. Mísseis riscam o céu de Cabul - a capital do Afeganistão". Observe-se, por enquanto, a referência a "mundo árabe", que já sinaliza uma oposição, no discurso, entre dois mundos cujo choque se enfatizará. Há muito a analisar nos meandros desse discurso que mais insinua do que informa sobre a contextualização daquele fato aparentemente inexplicável, daquele fato que não poderia simplesmente nascer histórico.

"O dia em que os americanos experimentaram o horror de uma grande guerra", que ficaria conhecido como o 11 de setembro, conforme o vaticínio desse texto de abertura do jornal, haveria de ter uma gênese, mas ela não estaria inscrita nos discursos midiáticos que fizeram parte desse dia histórico, que seria assimilado como o dia de declaração de guerra à superpotência americana, segundo nosso entendimento. Essa anáfora final encapsula novamente tudo o que foi dito na escalada e ativa, em forma de alusão, o que se conhece sobre grandes guerras, preparando o telespectador para determinada orientação argumentativa, conforme mostraremos durante a análise.

Curiosamente, esse enunciado específico, "o dia em que os americanos experimentaram o horror de uma grande guerra", poderia soar irônico em outro contexto, em grande parte pelo uso do verbo "experimentar", que nos leva à associação com o dito "provar do próprio remédio" (ou do próprio veneno). Não nos parece, entretanto, que esse sentido se confirma na trama discursiva do telejornal, encimada pelo texto de abertura que acabamos de examinar. É mais coerente analisar o enunciado como uma expressão de perplexidade, que se coaduna com a cabeça que inicia o primeiro bloco do noticiário. 
O selo que paira no cenário é um mapa dos Estados Unidos, sobre o qual aparece a imagem de uma das torres em chamas após o choque do segundo avião e sobre o qual foi desenhada a mira de uma arma. O emblema aparecerá em todas as entradas em que os locutores chamarem notícias referentes aos atentados. Esse é um elemento contextualizador que simboliza o assunto em pauta e que contribui para a reiteração de uma das imagens mais espetaculares do ataque, flagrada ao vivo pelas televisões.

\section{Bloco 1}

$\mathrm{Na}$ abertura do bloco, o locutor diz: "Eram 8h45 em Nova York, 9h45 em Brasília. Um avião americano de passageiros batia em cheio numa das torres do World Trade Center. Um acidente tão inimaginável que imediatamente chamou a atenção de todo o planeta. Mas não era acidente. Para perplexidade do mundo inteiro, foram-se registrando acontecimentos que nenhum roteirista de Hollywood imaginou. E era tudo real. Estava começando o maior atentado terrorista de todos os tempos".

Nesse trecho, há uma interessante manifestação polifônica: "Um acidente tão inimaginável que imediatamente chamou a atenção de todo o planeta. Mas não era acidente". Uma voz diz que se tratava de acidente - foi o que todos pensaram inicialmente - e o discurso se apóia nesse senso comum para empregar a anáfora que retoma o choque do avião. O termo anafórico aparece hiperbolicamente qualificado ${ }^{76}$, "acidente tão inimaginável", e seguido de uma oração consecutiva, "que imediatamente chamou a atenção de todo o planeta". No entanto outra voz, a do jornal, afirma que não era acidente. Parte-se do que seria mais provável, nega-se imediatamente essa probabilidade e então se apresenta o fato. O texto jornalístico constrói-se como verdadeira narrativa de suspense e sucumbe ao emocional: o acidente era inimaginável, assim como os acontecimentos que se seguiram, e o planeta estava perplexo.

\footnotetext{
${ }^{76}$ No livro Jornal Nacional: a notícia faz história, afirma-se que, no momento da transmissão ao vivo, feita pela equipe do Jornal Hoje durante o dia, "tudo ali era superlativo", uma vez que o choque atingia quem assistia e tinha de trabalhar ao mesmo tempo (2004:340), o que não se aplicou à equipe do Jornal Nacional, que no entanto manteve o efeito de perplexidade na edição que se viu à noite.
} 
O locutor relata, antes da exibição da primeira matéria, que "estava começando o maior atentado terrorista de todos os tempos". O enunciado remete ao passado, mas também anuncia a reprodução dos acontecimentos que serão vistos no ambiente diegético do telejornal. $O$ intertexto com o universo do cinema e dos espetáculos é explícito. Faz-se alusão às centenas de filmes já produzidos sobre ataques fictícios, por parte dos mais diferentes inimigos, aos Estados Unidos. Apesar da negação de que se tratava de mais uma história de Hollywood, os enunciados remetem ao gênero. Era como se ouvíssemos uma versão moderna do bordão que divulgava companhias de circo: "estava começando o maior espetáculo da Terra", agora "do planeta" e "da mídia". E, era bom que se dissesse, um espetáculo real. A televisão estava, segundo o discurso, mostrando a realidade. O que se viu, e se veria novamente à semelhança de um filme, era "o maior atentado terrorista de todos os tempos", que ninguém duvidasse.

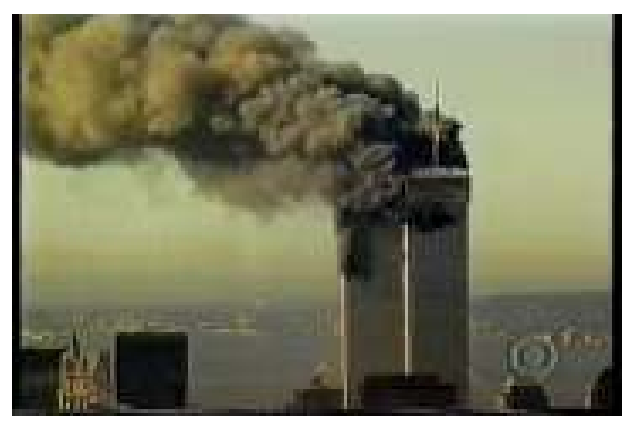

Figura 1

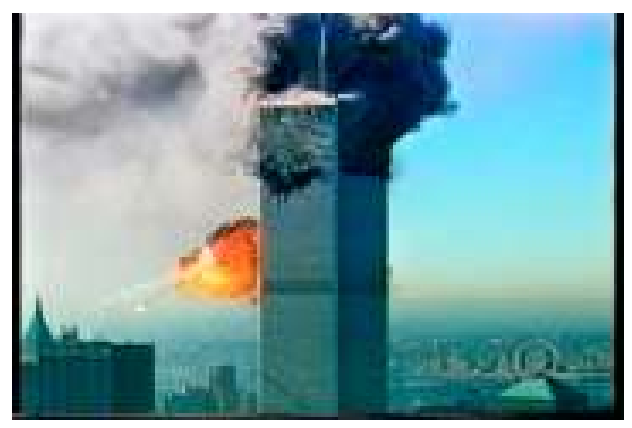

Figura 2

As imagens exibidas na seqüência comprovariam isso. O texto do repórter, que estava em Nova York, é mera legenda: "o edifício mais alto de Nova York está em chamas", "acenos, gritos de socorro nas janelas", "nas ruas próximas do atentado, correria e lágrimas". Eram cenas do horror provocado pelo "maior ataque terrorista da história da humanidade", designação que colocava os Estados Unidos no centro do mundo e ganhava força a cada emprego pelos atores discursivos. Os depoimentos das testemunhas só repetem o que se vê, como elemento de reforço da narração da tragédia: "Foi uma coisa horrível, horrível, horrível", diz um brasileiro; "As pessoas estão pulando das janelas", diz uma americana, cuja fala é traduzida pelo repórter, que acrescenta "Aumenta o desespero: a todo momento alguém se jogava lá de cima". 
A narração do repórter, a atribuição de voz às testemunhas, a seqüência de imagens dramáticas (figuras 1 e 2: as torres em chamas, o choque do segundo avião por vários ângulos) e a captação dos gritos e sirenes acentuam a dramaticidade dos acontecimentos. Então o repórter informa: "Os dois aviões que se chocaram contra o World Trade Center tinham sido seqüestrados. As torres, construídas para resistir até ao choque de um boeing 727, tinham sido atingidas por dois aviões maiores. Jatos 767 , seqüestrados em Boston. Os dois aviões levavam passageiros". Mostram-se novamente as imagens do segundo avião se lançando contra a torre, os prédios cobertos por fumaça negra (figura 3), a mesma cena do choque do avião à distância e mais de perto outra vez.

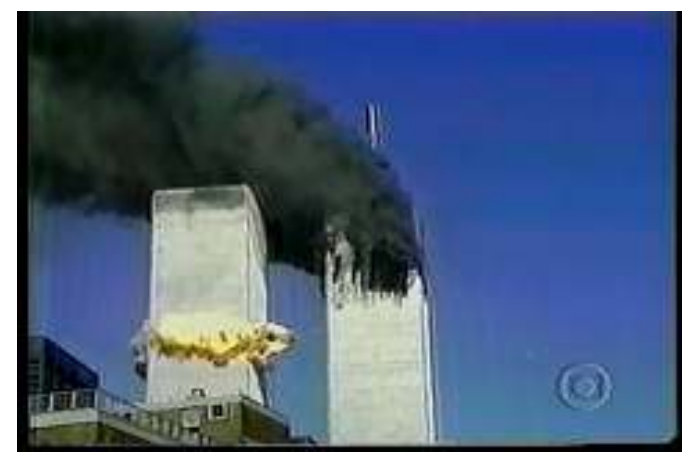

Figura 3

Na seqüência imediata, o repórter diz "O presidente dos Estados Unidos, George W. Bush, confirma: foi um atentado terrorista" e emenda "A brasileira Bruna Paixão trabalha num restaurante que fica perto do World Trade Center". Segue-se a sonora da estudante: "As pessoas estavam correndo na rua, desesperadas, sem saber o que fazer. Elas entravam no restaurante, pediam para usar o telefone, porque não conseguiam usar ao telefone público. lam ao banheiro vomitar. Era um desespero. Muita gente machucada chegou no restaurante também. Muita gente nervosa, chorando. Foi um caos. Eu nunca vi uma coisa como essa. Foi um caos".

Nesse trecho julgamos haver uma edição ruim das informações. Passa-se abruptamente da imagem do presidente Bush discursando, e da fala do repórter sobre o que ele teria dito, para a imagem da estudante brasileira dando seu depoimento, que tem por função descrever, em discurso direto, o "caos" que as câmeras não flagraram no momento, compondo a cena que o jornal apresenta nesse primeiro VT. No entanto a 
rápida informação sobre a manifestação do presidente americano perde-se nesse contexto. Há uma ruptura da cena. Lança-se uma idéia e nada se explica, como se ela fosse auto-suficiente. Bush, ou melhor, "o presidente dos Estados Unidos, George W. Bush", designação formal que parece mais adequada à gravidade da situação, confirmou que foi um atentado terrorista e pronto.

A fala foi apresentada como um tipo de discurso direto. $O$ repórter extraiu e traduziu a breve afirmação de um discurso do presidente Bush, sobre o qual não se dá maiores detalhes, e modulou-a com o verbo "confirmar", seguido de uma pausa que, na expressão oral, equivale a dois-pontos. Vemos a imagem de Bush falando, mas só ouvimos o que o repórter nos diz. O uso do verbo "confirmar" faz-nos pensar na já referida aceitação da mídia em relação a determinadas informações oficiais e no fato de que a informação, inserida no discurso midiático, que se sustenta num contrato de confiança, adquire imediata credibilidade. Nada é dito, naquele momento, para justificar a confirmação do presidente americano. Aceita-se e impõe-se ao público que a aceite.

Assistimos a um vídeo institucional sobre a cobertura jornalística do 11 de setembro, produzido por uma equipe da TV Globo, e descobrimos uma falha na edição no Jornal Nacional. Esse trecho que estamos analisando reproduzia o que entrara ao vivo em outro telejornal da emissora, o Jornal Hoje, na época apresentado por Carlos Nascimento. O correspondente Edney Silvestre informa que o presidente Bush dera declaração afirmando que se tratava de ações terroristas e fala para Carlos Nascimento, que dissera antes ser improvável se tratar de acidente ${ }^{77}$ : "Está confirmado o que você disse há pouco, foi uma atuação camicase".

Parece-nos, portanto, que o verbo "confirmar" foi usado fora do contexto no Jornal Nacional, criando outro efeito de sentido para o público que não acompanhara a transmissão ao vivo no Jornal Hoje. Mas em nenhum dos dois casos se explica que elementos levaram o presidente Bush a fazer tal afirmação, além do fato de que não se poderia tratar como coincidência os dois "acidentes"; tampouco se esclarece, no noticiário da noite, em que momento ele fez a declaração.

\footnotetext{
${ }^{77}$ No livro Jornal Nacional: a notícia faz história, relata-se que "a Rede Globo começou a falar em ataque terrorista antes mesmo da CNN" (2004:339).
} 
No mesmo VT, depois da sonora da estudante que testemunhara o "caos", o repórter informa que as torres desabaram. Ele faz uma passagem numa rua de onde ainda se podia ver a fumaça, o que garante um efeito de presença e veracidade: "Toda a área próxima do atentado foi fechada. Onde estava o World Trade Center, só fumaça. Os dois edifícios, de 110 andares, vieram abaixo após as explosões". Aos poucos vai sendo esclarecido o que se anunciou na escalada do jornal. Ainda não se falara em explosões ou desabamento e tais referências são introduzidas de forma associativa nesse preâmbulo à descrição do que se passou. Entram as primeiras imagens das torres desabando, repetidas por diversos ângulos, mostrando o que o repórter conta: "A primeira torre a cair foi a do norte. Pouco depois, às 10h25, os andares superiores da segunda torre começam a ceder. E vêm abaixo".

Mais uma voz, em discurso direto, se une à orquestração polifônica dos testemunhos do "caos". Um capelão brasileiro, que ajudou as equipes de socorro, conta: "Eu fui ajudar os bombeiros e tinha pessoas em choque. Eu também comecei a ficar muito nervoso, porque começou a vir muita fumaça. A gente não sabia se subia, pegava o elevador, se descia. Os bombeiros: calma, calma. Olha, foi terrível". A descrição reiterada pelas imagens continua, sempre no presente, transcendendo o tempo real: "As ambulâncias, ainda cobertas de pó, não param. Polícia, bombeiros e equipes de socorro aumenta a cada momento".

O repórter apresenta uma nova informação: "As fundações das torres são de aço. O engenheiro brasileiro Carlos Levy diz que é improvável que apenas o choque dos aviões pudesse levar os prédios abaixo" (durante essa fala, novamente se exibem as imagens das torres cobertas por fumaça e do choque do segundo avião). Segue-se o discurso direto do engenheiro: "Fica difícil acreditar que apenas o choque dos aviões e as explosões causassem o desabamento dos prédios de uma maneira tão rápida. As próprias imagens assustam com a velocidade que ocorreram". Repetem-se as imagens da segunda torre desabando, agora por três ângulos diferentes, e ouve-se o som local, com pessoas chorando e gritando "Oh, my God".

A voz do engenheiro brasileiro funcionará como uma espécie de argumento de autoridade e servirá de apoio à informação que se segue, dada pelo repórter: "Há suspeitas de que o prédio tenha sido implodido pelos terroristas". No entanto não se 
explica tal afirmação e o texto segue com outra versão: "Alguns especialistas acham que o WTC acabou ruindo por uma combinação de fatores. O choque dos aviões, as explosões que se seguiram, mais o fogo enfraqueceram a estrutura dos andares superiores, e o peso deles, ao cair, levou o resto".

Indiretamente, são introduzidas várias vozes no discurso, mas nenhuma informação é suficientemente esclarecida. $O$ engenheiro mostra-se descrente quanto aos motivos do desabamento, mas nada sugere; não se sabe de que "especialistas" o repórter fala; não se sabe de quem são as suspeitas ou em que se baseiam as suspeitas de que "os terroristas" tenham implodido o prédio ${ }^{78}$.

As informações são lançadas no mosaico da enunciação telejornalística e não se sabe como serão interpretadas pelo telespectador que se perde nos fios dessa rede. Mas, antes que se possa pensar nisso, as imagens que fecham essa parte do VT assomam em sua redundância.

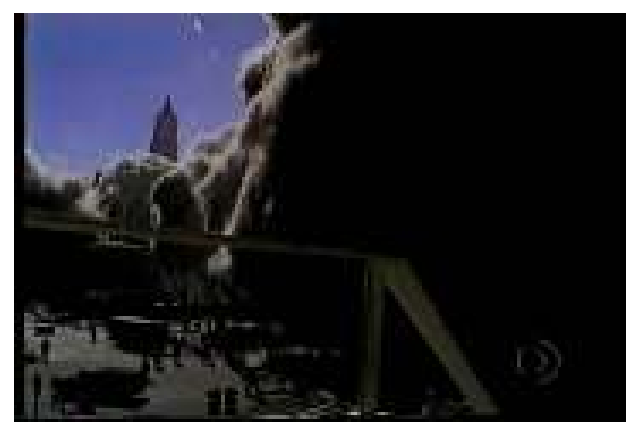

Figura 4

Vemos novamente as cenas do choque do segundo avião e as do desabamento das torres, agora mais longas, mostrando a fumaça e uma enorme nuvem de poeira negra se espalhando pelas ruas, "perseguindo" as pessoas e deixando tudo escuro (figura 4). É quase uma metáfora das imagens que perseguem o telespectador e turvam a compreensão dos fatos.

\footnotetext{
${ }^{78}$ Até hoje existem grupos que sustentam as chamadas "teorias da conspiração", segundo as quais teria havido participação do governo norte-americano nas ações de 11 de setembro, já que não seria possível que apenas o choque dos aviões fizesse as torres desabarem. Encontramos essa informação em vários sites indicados pelo Google e em vídeos inéditos divulgados recentemente pelo site Youtube.
} 
Na seqüência imediata da assustadora imagem, o repórter diz: "O ataque ao WTC é o maior já ocorrido em solo americano desde que os japoneses bombardearam Pearl Harbor. Lá foram mortos 2.280 soldados e 68 civis". As imagens vistas aqui não são de "lá", são as de algumas pessoas feridas no atentado, deitadas no chão ou sendo socorridas (figura 5). É uma seqüência breve, a única desse tipo no jornal todo.

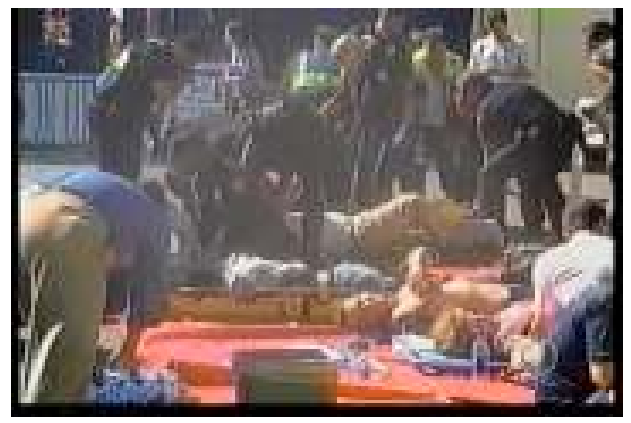

Figura 5

Não há coincidência entre o que se narra e o que se mostra, apenas a insinuação de que o ataque também provocou muitas mortes. $O$ repórter conclui, sugestivamente: "Foi o que levou os Estados Unidos a entrar na Segunda Guerra Mundial". A imagem que fecha o VT é, novamente, a dos prédios cobertos por fumaça, vistos ao longe, numa panorâmica do sul da ilha de Manhattan.

Segundo Chomsky (2003), muitos comentaristas tentaram fazer uma analogia entre os atentados e o episódio de Pearl Harbor, recorrendo a um conhecimento partilhado pelas pessoas, mas se tratava de um equívoco. Em 1941 foram atacadas bases militares em duas colônias americanas, e não em território nacional, que jamais chegou a ser ameaçado, porém esse dado histórico também não coube na trama discursiva do jornal. Restou o implícito, elemento mais significativo desse trecho, que remete a uma ameaçadora associação entre os eventos. Se o ataque a Pearl Harbor, que provocou cerca de duas mil mortes, levou os Estados Unidos à Segunda Guerra, o que não se poderia esperar depois daquele episódio, em que já se falava de "dezenas de milhares de mortos"? Mais do que sugerir essa pergunta, o enunciado parece justificar antecipadamente uma reação bélica dos Estados Unidos. 
O jornal prossegue e os locutores dão informações sobre os "prédios mais altos de Nova York", com o auxílio de desenhos para mostrar sua localização. Na seqüência da descrição, no mesmo texto em off, com imagens de arquivo, eles informam: "Em fevereiro de 1993, o World Trade Center foi alvo de um ataque à bomba que matou seis pessoas e deixou mais de mil feridos. A responsabilidade pelo atentado, há oito anos, foi assumida pelo terrorista mais procurado do mundo, Osama Bin Laden".

Essa é a primeira referência ao terrorista Osama Bin Laden, que não fora mencionado nem na escalada. A informação está inserida num trecho neutro, no qual se fala da construção do prédio, de quantas pessoas trabalhavam lá, da característica de ponto turístico do WTC. Lança-se uma ponta discreta do novelo que formará a imagem daquele que viria a ser tratado como o principal suspeito dos ataques, desde já designado como "o terrorista mais procurado do mundo", formulação que imediatamente remete aos famosos cartazes de "procura-se" de filmes americanos.

O locutor articula a essa informação a introdução do próximo VT: "Além da destruição em Nova York, o terror atacou o símbolo do poder militar dos Estados Unidos: o Pentágono". "O terror", nome que designa o agente sem face que provocou toda a destruição até então mostrada, nome que resume a causa daqueles acontecimentos inimagináveis e não tem sinônimo ou qualificação, atacou "o símbolo do poder militar dos Estados Unidos", forte e inequívoco epíteto do Pentágono. No dia que iria "marcar a história da humanidade", o inominável atacou o símbolo. Era isso que deixava o mundo perplexo e essa perplexidade contaminava o discurso telejornalístico.

No VT que se segue, o repórter ${ }^{79}$ descreve o ataque ao Pentágono: "Exatos quarenta minutos depois do segundo avião atingir o World Trade Center, em Nova York, os militares que trabalhavam na face oeste do Pentágono tiveram por breves momentos uma visão de pesadelo". O texto é coberto por uma seqüência de imagens: muita fumaça sobre o Pentágono, vista de vários ângulos, e pessoas deixando o prédio.

\footnotetext{
${ }^{79}$ Preferimos usar o termo geral "o(a) repórter" em lugar de nomear cada um dos profissionais que fizeram a cobertura dos ataques. Para tratar desse assunto, naquele dia, o Jornal Nacional dispôs de treze repórteres: seis nos Estados Unidos, cinco no Brasil e dois na Europa. Nos anexos, indicamos o nome de cada repórter.
} 
O repórter prossegue: "Um boeing 757 da companhia aérea United Airlines mergulhando diretamente contra o prédio. O impacto abriu uma cratera numa das faces dessa construção imensa, que é, na verdade, um sanduíche de cinco edifícios. Um dentro do outro, todos com seis andares de altura. Das dezenas de portas do Pentágono, milhares de funcionários foram retirados às pressas".

Tudo é grandioso nessa narração - "um boeing 757 mergulha contra o prédio", "o impacto abre uma cratera", "a construção é imensa", "há dezenas de portas e milhares de funcionários" -, mas nada que se aproxime de "uma visão de pesadelo", cujos "breves momentos" o discurso televisivo não consegue reproduzir. A imagem que se sobrepõe ao texto é a de pessoas saindo dos prédios andando, aparentemente sem pânico, e não "às pressas". Há uma contradição discursiva que se perde no conjunto, o qual repete as imagens mais chocantes ou, na falta delas, constrói imagens verbais de "caos" e "pesadelo".

A "visão de pesadelo" do boeing mergulhando contra o Pentágono é ainda hoje um objeto de discurso. Recentemente o site Youtube divulgou imagens inéditas dos ataques de 11 de setembro e reacendeu a polêmica sobre o choque do avião contra a sede militar. Vê-se o momento da explosão, mas não se vê nenhum boeing nem as marcas de suas asas na "cratera" aberta no prédio, que também não são vistas em momento algum nas imagens exibidas pela televisão. Qualquer que seja a verdade, a versão da mídia é uma só e não se sustenta no argumento das imagens, incontestável por definição.

Em seguida, no VT, o repórter analisa: "Não só a violência do ataque e a tragédia que ele provoca assustam os americanos. A simbologia é muito forte também. O coração das forças armadas foi atingido. A capital desse país é muito mais vulnerável do que os cidadãos podiam imaginar".

A referência à simbologia, feita antes pelo locutor, ressurge nesse trecho em que se apresenta um argumento quase-lógico, que apela para a necessária relação entre premissas dadas como verdadeiras. Os ataques atingiram símbolos americanos respeitados ou temidos pelo mundo todo, portanto o que esses ataques simbolizam é assustador. Eles revelam a vulnerabilidade do país, sobretudo porque atingiram um órgão vital, "o coração das forças armadas", outra forma de designação do temível Pentágono, agora humanizado pela desgastada expressão metafórica. 
O repórter continua a interpretar os sentimentos dos americanos, numa ruptura do ciclo de informações mais objetivas: "Os que trabalham em Washington e moram fora da cidade, nos subúrbios, saíram dos escritórios ouvindo informações de que uma outra explosão teria acontecido ao lado do departamento de Estado. E outra, ainda, próxima ao Capitólio. O clima na capital da maior potência do mundo era de medo e incerteza".

A incerteza também marca o discurso, modalizado como discurso segundo. A fonte da informação são pessoas que "ouviram falar" que outras explosões "teriam acontecido". A voz dos boatos também tem lugar no concerto polifônico. As imagens também desdizem a informação de que "o clima era de medo e incerteza". Pessoas e carros passam pelas ruas "na capital da maior potência do mundo" e não há sinal desse clima de tensão que se insiste em desenhar. Pode até ter havido no "mundo real", mas não é o que as imagens mostram, ao contrário da construção verbal, que remete reiteradamente à vitimização da superpotência.

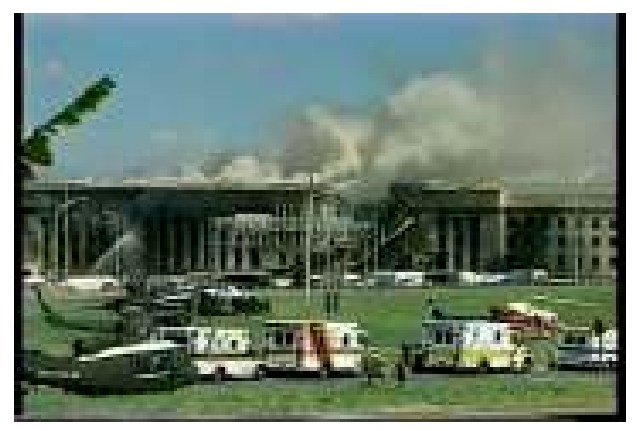

Figura 6

O repórter prossegue: "A possibilidade de novos ataques estava na mente de todos (repetem-se as imagens de fumaça sobre o Pentágono - figura 6). Em pouco tempo, Washington praticamente parou. Todo o pessoal foi retirado da Casa Branca e do Congresso. Funcionários federais foram dispensados em toda a cidade. Esse rapaz está surpreso. Diz que esperava que o Pentágono fosse mais seguro".

O discurso indireto traduz a fala do rapaz e não revela nenhuma novidade diante do que aconteceu. As outras falas que se seguem também não cumprem a função de confirmar o comentário inicial de que "a possibilidade de novos ataques estava na mente 
de todos": "Os terroristas estão enganados em achar que conseguiram o objetivo deles. Vão ser condenados por $99 \%$ da população do mundo, ele diz ${ }^{80}$. E esse outro diz que deve haver retribuição. É um crime. Tem que haver justiça". Os discursos citados representam vozes da população e vão se entrelaçando aqui e ali na costura de um amplo argumento que antecipa a justificação de uma reação armada americana.

Voltam as imagens da fumaça sobre o Pentágono e de parte do prédio destruída. $\mathrm{O}$ repórter informa que foi acionado um estado de alerta nas forças armadas americanas: "Dois porta-aviões nucleares e vários cruzadores foram dirigidos para a defesa dos litorais do país. A explicação do vice-almirante Steven Pretropaulin foi curta: Nós estamos ainda sob ataque. Até agora o Pentágono não está divulgando a lista dos funcionários atingidos no atentado. Sabe-se que 35 pessoas estão feridas e não há informação sobre mortes".

A explicação para o uso de equipamento nuclear é dada por um militar. Aparece a imagem do vice-almirante falando e o que ele diz é traduzido pelo repórter. Não se sabe se ele disse mais do que isso, mas o discurso citante nos faz crer que essa foi a única declaração do representante das forças armadas, direta e suficiente: "Nós ainda estamos sob ataque". As informações sobre as vítimas ainda não são oficiais, apenas "sabe-se" que há feridos. O discurso segundo mais uma vez ocultas fontes importantes.

O locutor chama um VT sobre o plano de emergência acionado pelo governo americano, com ênfase nas informações sobre o seqüestro dos aviões usados nos ataques: "Nunca, na história, tantos aviões foram seqüestrados ao mesmo tempo". O tom de perplexidade continua a tingir os fios do discurso. A repórter começa a matéria evocando outra testemunha: "Esta americana, uma nova-iorquina, ela conseguiu explicar como os americanos estão se sentindo hoje". Entra a fala da pessoa, traduzida pela repórter: "É horrível. Eu não podia imaginar que isso poderia acontecer, que somos tão vulneráveis assim". Outra vez se repete a idéia do "inimaginável" e da vulnerabilidade. Os americanos, mais do que nunca, precisam de proteção e o discurso oficial - cujos ecos já se percebem no discurso da mídia - será o de que a melhor defesa é o ataque.

${ }^{80}$ A maioria das sonoras em outra língua é traduzida pelos repórteres. A voz do repórter cobre a do entrevistado, enquanto aparece a imagem da pessoa falando, sem que seja possível entender o que é dito originalmente. 
Entra uma seqüência de imagens de muita fumaça nas ruas, carros e prédios destruídos, pessoas correndo. A repórter prossegue: "Os Estados Unidos, o país mais poderoso, o mais rico do mundo. Teve um momento hoje em que o Departamento de Aviação Americano perdeu o contato, não sabia onde estavam oito aviões. Quatro tinham sido seqüestrados".

A partir desse trecho são exibidas ilustrações mostrando a rota dos aviões, dois da American Airlines e dois da United Airlines. Fala-se também do número de passageiros e tripulantes, ao todo 285 pessoas. Não se fala dos outros quatro aviões com que o departamento de aviação perdera o contato. $O$ que chama a atenção nesse trecho é o início truncado da fala da repórter.

Pela edição, não é possível dizer com certeza se a primeira frase está ligada ao depoimento da nova-iorquina, o que parece mais coerente, ou se abre a seqüência seguinte, que fala do seqüestro dos aviões. A fala da repórter não apresenta pausas claras e a sintaxe também não dá muitas pistas. A frase "Os Estados Unidos, o país mais poderoso, o mais rico do mundo" pode referir-se tanto ao sentimento de perplexidade por esse país ter-se revelado tão vulnerável, quanto ao fato de não ter sido capaz de impedir as ações aéreas. De qualquer forma, a frase está meio solta nesse limbo, refletindo uma vez mais a manipulação dos afetos em relação ao acontecimento. Parece-nos que, mais do que a justificável dor pela tragédia humana, é esse ressentimento pela destruição dos símbolos americanos que permeia o discurso da mídia.

Sobre o avião da United Airlines que caiu na Pensilvânia, a repórter informa: "Uma das passageiras desse avião, com um celular, conseguiu avisar ao marido: Nós estamos sendo seqüestrados. Os seqüestradores estão com facas ou punhais." Não é a passageira quem fala, mas a opção pelo discurso indireto não levaria ao efeito de sentido que se obtém pela simulação do discurso direto. Não se dá a fonte, mas garante-se que as palavras de uma das vítimas foram essas ao citá-las em primeira pessoa, o que confirma a informação dos seqüestros.

Durante esse off, repetem-se as imagens das torres desabando e de muita fumaça e poeira nas ruas. A repórter conclui: "A United não informou se o avião caiu antes de atingir algum alvo terrorista [sic], ou se por uma outra razão. Todos os passageiros e tripulantes desses quatro aviões, 285 pessoas, morreram". 
Essa informação provoca certo estranhamento, pois coloca sob suspeita a afirmação de seqüestro, já que se sugere que poderia ter havido outra razão para a queda do avião. Além disso, como a companhia poderia saber se o avião caiu antes de atingir algum alvo dos supostos terroristas? Observamos alguns esgarçamentos como esse no tecido discursivo e julgamo-los semelhantes a pequenas falhas de roteiros ou de seqüências fílmicas, que não comprometem o todo, ao contrário da falta de contextualização histórica para os espetaculares acontecimentos.

A repórter fala então do plano de emergência dos Estados Unidos contra ataques terroristas. Ela ressalta: "Pela primeira vez na história americana, essa imagem, aeroportos supermovimentados, não foi vista. Todos os aeroportos do país foram fechados para pousos e decolagens. Quarenta mil vôos foram cancelados. Os outros, transferidos para o Canadá. O Departamento de Aviação Civil informou que eles só voltam a funcionar, talvez, a partir de amanhã, ao meio-dia".

Mais uma vez as imagens desmentem o texto. Não há imagens nem de aeroportos supermovimentados nem de aeroportos vazios. Mostram-se imagens normais de aviões nos aeroportos, talvez porque não houvesse outras para exibir, mas tendemos a ver aquilo que o discurso nos diz para ver. Pela observação desse detalhe menor, podemos constatar como o componente lingüístico é capaz de orientar o olhar sobre as imagens e o fará outras vezes.

No encerramento desse VT, a narração ganha um ritmo acelerado, que as imagens acompanham descritivamente: "A fronteira com o México foi e continua fechada. E alvos em potencial - prédios, monumentos, pontes, túneis -, tudo o que poderia ser atingindo por outros atentados foi isolado ou desocupado, inclusive o prédio das Nações Unidas, em Nova York. Na Flórida, a Nasa, Agência Espacial Americana, entrou em estado de emergência máxima. A Disney fechou os parques nas Flórida. Em Seatle, um dos principais pontos turísticos da cidade, essa torre, foi fechada. Eram os Estados Unidos tentando se proteger".

Mostram-se simples imagens dos lugares citados ou de pessoas desocupando os prédios, mas o efeito discursivo dessa fragmentação é o de corroborar a imagem de "alerta geral" e de quão o país mais poderoso do mundo se sente acuado. A imagem final 
do VT é a do Pentágono destruído, insistindo na lembrança de que o golpe foi além dos ataques a civis, próprios do terrorismo.

É o gancho para o locutor chamar a próxima matéria, que indicará de quem os Estados Unidos devem se proteger: "Na história recente, os americanos sofreram diversas ações terroristas, nem todas promovidas por estrangeiros, mas o maior de todos os suspeitos é árabe." Observamos um problema de coesão nesse trecho, já que a referência textual é "diversas ações terroristas" e a informação sobre o suspeito se refere ao atentado daquele dia.

No entanto, a despeito desse ruído, o segmento enfatiza que não é a primeira vez que os Estados Unidos sofrem ações terroristas e apresenta como pressuposto o fato de algumas dessas ações terem sido promovidas por americanos, para em seguida orientar a leitura - pela introdução da conjunção "mas" - para o que era relevante naquele caso, a informação de que "o maior de todos os suspeitos" era árabe, numa segunda referência, a ser explicitada no VT que se segue, a Osama Bin Laden. Não é o nome do suspeito que parece interessar, mas sua nacionalidade, o que contribui para a formação de uma imagem negativa de um povo contra o qual se levantará a bandeira de guerra americana, com base num suposto choque de civilizações.

O repórter informa, num longo off: "O primeiro nome da lista de suspeitos é o do saudita Osama Bin Laden, considerado o inimigo número 1 dos Estados Unidos. (Entram imagens de arquivo de Bin Laden e afegãos reunidos.) Ele vive no Afeganistão, protegido pelo governo Talibã. Em 1998, Bin Laden teria financiado os atentados às embaixadas americanas na África. Foram duas embaixadas, do Quênia e da Tanzânia, ao mesmo tempo. 224 pessoas morreram. (Imagens de arquivo: prédios destruídos, pessoas sendo socorridas.) Quatro terroristas ligados a Osama Bin Laden foram julgados e condenados à prisão perpétua nos Estados Unidos. Há menos de três semanas, Bin Laden teria ameaçado organizar um atentado como o de hoje. (Outras imagens de arquivo de Bin Laden falando.) Uma fonte do FBI disse à rede de televisão NBC que Osama Bin Laden deve estar por trás dos ataques. Ele é suspeito de outros ataques a bases militares americanas na Arábia Saudita em 95 e 96 e a um destroyer no ano passado. (Imagens de arquivo dos atentados citados.) Há anos o governo americano pede a extradição de Bin Laden, mas o Afeganistão nega o pedido. (Mais imagens de arquivo, figura 7: Bin Laden 
atirando e rindo.) Bush já tinha avisado: vai responsabilizar o Afeganistão por qualquer ataque de Bin Laden".

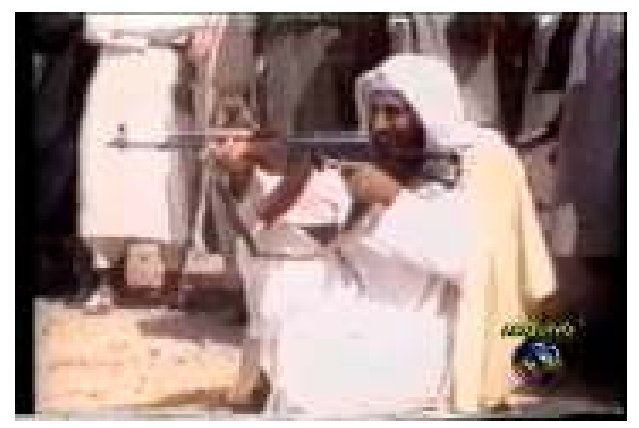

Figura 7

Destacam-se nesse trecho as suposições indicadas pelo tempo verbal no futuro do pretérito, uma marca do discurso segundo em que não se atribui identidade à voz inserida no relato: "ele teria financiado os atentados às embaixadas americanas na África", "Bin Laden teria ameaçado organizar um atentado como o de hoje". Note-se também como é vaga a informação "da fonte do FBl", outra voz modalizada pela incerteza: "Osama Bin Laden deve estar por trás dos ataques". Dos outros ataques a bases americanas, Bin Laden também é apenas "suspeito". Por todas essas suposições, ele é considerado embora não se diga por quem - "o inimigo número 1 dos Estados Unidos", outra forma de designação estereotipada que remete a vilões da ficção, reforçada pelas imagens de Bin Laden rindo e praticando tiro, reinseridas num contexto que sugere seu desdém pelas exigências americanas de sua extradição.

Por isso merecem atenção também os enunciados finais, quase um endosso às ameaças do presidente americano: "Há anos o governo americano pede a extradição de Bin Laden, mas o Afeganistão nega o pedido. Bush já tinha avisado: vai responsabilizar o Afeganistão por qualquer ataque de Bin Laden".

É interessante essa forma de citação, que tem marcas típicas de oralidade. Depois de informar que os Estados Unidos pedem "há anos" e sem sucesso a extradição de Bin Laden, o que justificaria a impaciência do governo americano, o texto articula dois enunciados marcados por tempos verbais distintos. Diz-se que a medida a ser tomada não será novidade para o Afeganistão, uma vez que "Bush já tinha avisado", e anuncia-se 
a medida no tempo futuro, mas não em discurso direto, como uma convicção - assumida pelo discurso citante - do que viria a acontecer. Os fios que conduzem a essa mensagem reincidente vão sendo urdidos gradualmente no telejornal.

No trecho seguinte, depois de arroladas tantas possíveis provas da implicação de Bin Laden, designado como "o maior de todos os suspeitos" e "o primeiro nome da lista de suspeitos", somos surpreendidos por uma flagrante contradição. O repórter afirma: "As autoridades americanas estão evitando falar em suspeitos". Então de quem eram todas as suspeitas mencionadas? Quais as fontes das informações que o discurso do jornal assume? De quem são as vozes camufladas pelo discurso segundo? Não se sabe, mas o que foi dito já ficou gravado na memória metálica, por mais que agora se afirme, inócua e vagamente, que "as autoridades americanas estão evitando falar em suspeitos" por razões que serão imediatamente explicadas pelo repórter: "O último atentado que os Estados Unidos sofreram em território americano aconteceu em 1995, em Oklahoma. O carro-bomba que destruiu o edifício do governo federal matou 168 pessoas. Os americanos logo suspeitaram de extremistas árabes. Depois o $\mathrm{FBI}$ pegou o verdadeiro culpado: um americano, Timothy McVeigh, que foi executado em junho deste ano".

"As autoridades", segundo o discurso, temiam um novo julgamento precipitado, já que o último atentado terrorista nos Estados Unidos não tinha sido cometido por "extremistas árabes", mas sim por "um americano", que já recebera seu exemplar castigo. Mas, em muitas passagens do jornal, não se evitará falar das suspeitas em relação a Bin Laden, à milícia talibã do Afeganistão e até a facções palestinas. Parece-nos que há aqui um recurso semelhante ao da preterição, figura pela qual se afirma que não se dirá o que já está sendo dito.

Em seguida, o repórter relata a reação do secretário de Estado americano: "Na hora em que aviões explodiam em prédios americanos, o secretário de estado Colin Powel estava no Peru. Ele interrompeu a visita oficial para voltar aos Estados Unidos. Antes de embarcar, o general da Guerra do Golfo mandou um recado aos terroristas: Eles podem destruir edifícios e matar pessoas, mas nunca matarão a democracia".

Aparece a imagem do secretário discursando e a tradução do repórter cobre a fala, mas no final do VT é possível ouvir as últimas palavras da frase em inglês, como a confirmar que aquilo foi dito. O recurso da simulação do discurso direto por meio da 
tradução é usado com a moldura de um interessante verbo de elocução ("mandar recado") e de uma sugestiva forma de referência anafórica ao secretário ("o general da Guerra do Golfo"). É muito provável que o secretário não tenha anunciado que sua fala seria "um recado", portanto a interpretação é feita pelo discurso citante, que usa uma expressão que não raro indica uma ameaça, um aviso de que o recado, tomado com o sentido de advertência severa, deve ser levado a sério.

O discurso enfatiza que o recado partiu do "general da Guerra do Golfo" e essa anáfora reenquadra todo o contexto, pois reativa o conhecimento partilhado acerca do homem que liderou os Estados Unidos naquele terrível conflito, um homem com o qual não se deve brincar e que pode levar o país a uma nova guerra sem hesitação. Trata-se de outras expressões que reforçam a idéia - tecida pelo discurso - de que será inevitável uma reação bélica americana aos ataques que representavam, segundo o discurso oficial reproduzido pela mídia, um atentado contra a democracia americana. Não se comenta por que haveria de ser essa a razão dos atos terroristas.

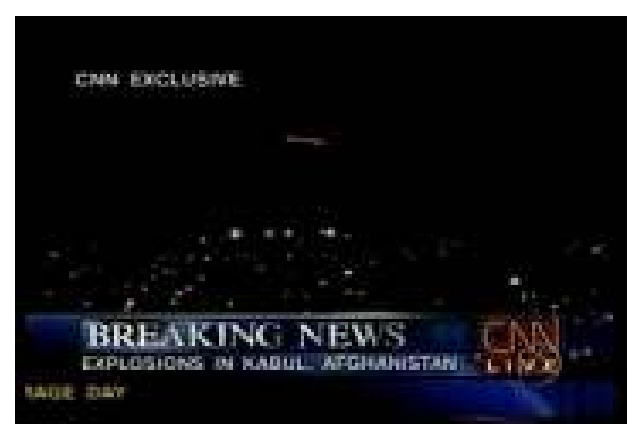

Figura 8

Depois o locutor anuncia, também sem nenhuma explicação do contexto: "Durante a madrugada, no Oriente, a capital do Afeganistão começou a ser bombardeada. As imagens da rede CNN mostram mísseis e armas antiaéreas em ação nos arredores de Cabul. As explosões começaram por volta das seis e meia da tarde, horário de Brasília. Assessores da presidência dos Estados Unidos disseram que não houve ataques americanos no Afeganistão e levantaram a hipótese de que o bombardeio tenha sido obra 
da oposição ao governo Talibã”. As imagens do que seriam mísseis e armas antiaéreas (figura 8), geradas pela $\mathrm{CNN}^{81}$, são exibidas durante toda a fala do locutor.

Uma repórter entra ao vivo e diz categoricamente: "Essa informação de que os Estados Unidos não têm nada a ver com os ataques em Cabul foi confirmada agora há pouco pelo secretário de Defesa americano". Na seqüência, dá o assunto por encerrado: "E aqui em Nova York, um terceiro prédio, que ficava ao lado das torres gêmeas caiu também. Foi no finalzinho da tarde. Ele tinha 47 andares. Esse prédio, as torres e outros cinco edifícios formavam o principal complexo econômico aqui de Nova York" (durante a fala, repete-se duas vezes a imagem do anexo desabando).

São breves e frias as informações sobre o ataque aéreo à capital do Afeganistão. Não se estabelece nenhuma relação explícita com o atentado nos Estados Unidos. O telespectador deve recuperar a memória do que já foi dito no telejornal sobre o fato de o Afeganistão proteger e abrigar Osama Bin Laden. Apesar de todas as suspeitas e de todos os "recados" ao Afeganistão, país que seria responsabilizado por Bush pelos ataques do terrorista saudita, o que importava afirmar e reafirmar é que os Estados Unidos "nada tinham a ver" com os ataques a Cabul, coincidentemente realizados nos dia 11 de setembro, mas não se cogita quem teria "mísseis" para atacar o país. Novamente não se questionam as fontes, que são enunciadas como vozes de autoridade no discurso indireto: "assessores da presidência dos Estados Unidos disseram", "a informação foi confirmada pelo secretário de Defesa americano".

O jornal volta ao que parece interessar, a queda de outro prédio em Nova York e as operações de resgate, relatadas pela repórter, ainda ao vivo: "Agora, sete e meia da noite aqui em Nova York, oito em meia aí no Brasil, um exército de dez mil pessoas está no local, vasculhando os escombros em busca de vítimas e sobreviventes. Segundo o prefeito de Nova York, pelo menos 2.100 pessoas ficaram feridas só aqui em Nova York e 600 foram hospitalizadas. Quase doze horas após o atentado, é impossível saber quantas

\footnotetext{
81 São as únicas imagens da CNN exibidas pelo Jornal Nacional, que utilizou material de agências internacionais (imagens que se repetem em outros noticiários) ou produzido pela equipe de correspondentes. Segundo o repórter Edney Silvestre, que dá um depoimento sobre a cobertura do 11 de setembro no livro Jornal Nacional: a notícia faz história, foi nesse momento que a emissora "mostrou que tem uma estrutura internacional que faz a diferença", pois "enquanto os outros mostravam imagens compradas, imagens de satélites, a TV Globo tinha suas próprias câmeras e seus próprios repórteres" (2004:342).
} 
pessoas morreram. Mas, pelo menos, como vinte mil estavam nos prédios, ou próximas a eles durante os atentados, o número de mortes pode chegar a dezenas de milhares".

Destaca-se que um "exército de dez mil pessoas" está procurando vítimas e sobreviventes e que "o número de mortes pode chegar a dezenas de milhares", mesmo contra toda a lógica matemática, já que havia cerca de vinte mil pessoas nos prédios (a despeito do uso da expressão "pelo menos", se pudesse haver mais, a projeção deveria ser informada). Parece não haver interesse em saber o que realmente houve em Cabul ou quantas mortes o ataque provocara. As vítimas que mereciam toda a atenção da mídia naquele momento eram tão-somente as americanas.

O locutor anuncia o que será visto no bloco seguinte: "O atendimento aos feridos numa cidade paralisada pelo terror". A legenda das imagens é neutra: "depois do ataque". As imagens mostram pessoas andando pelas ruas destruídas. Não há feridos, não há sangue. É o texto novamente que produz a principal imagem do discurso: depois do caos, a cidade está paralisada pelo terror.

É muito forte a construção, do ponto de vista discursivo, da imagem dos Estados Unidos como vítima do terrorismo. Evidentemente não se está dizendo que a tragédia que afetou inocentes não tenha sido enorme, apenas chamamos a atenção para a imagem forjada pela mídia naquele momento. Essa identidade de "vítima" será reforçada ao longo de toda a edição do Jornal Nacional, como o foi em quase toda a mídia ocidental. Como veremos, muito pouco se esclareceu em relação às possíveis causas dos ataques, ao que é terrorismo e às condições históricas em que ele aparece. Só se fez ecoar a versão de que aquele era o "maior ataque terrorista da história da humanidade".

A mídia agiu, pelo menos nesse dia, como se realmente devesse considerar retórica uma pergunta latente em muitas manifestações do presidente americano na época: "Por que será que nos odeiam?". Em reflexões que fez logo após os atentados, Chomsky qualificou como "patética" essa indagação de Bush sobre as razões do mundo árabe, já que não se tratava de um problema novo, e afirmou que não era difícil encontrar a resposta nos meandros da história política americana. Chomsky destacava o apoio dos Estados Unidos a governos brutais e corruptos e a opressão de tantas nações, por meio de atrocidades que resultaram num número colossal de vítimas (2003:156). 
Segundo Chomsky, e também Arbex, é longa a lista de atos candidatos a "maior atentado terrorista da história", incluídos aí atos de terrorismo de Estado e de terrorismo econômico. Da mesma forma, é longa a lista de vítimas desses atos, mas isso teve menos importância do que nunca naquele 11 de setembro, cuja memória em construção estava apartada de qualquer condição histórica.

\section{Bloco 2}

Nesse bloco, a primeira matéria é sobra a reação do presidente americano, que estava participando de um congresso sobre educação na Flórida quando recebeu a notícia. As imagens mostram o presidente numa sala de aula e alguém lhe dizendo algo ao ouvido. Há uma breve pausa na narração e a imagem presente na tela grava a indizível expressão de Bush (figura 9).

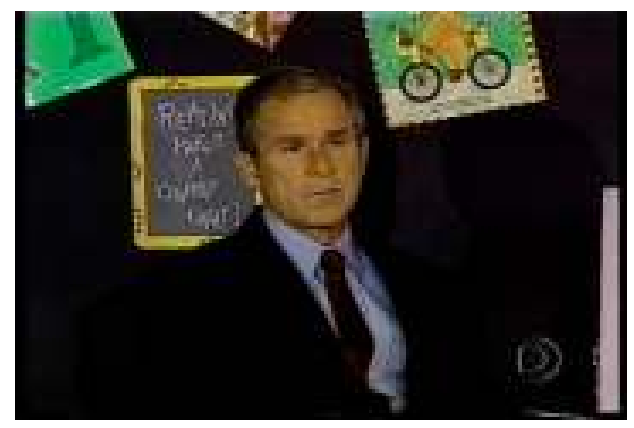

Figura 9

O repórter prossegue, em discurso indireto: "Bush pediu orações e um minuto de silêncio pelas vítimas. Depois, anunciou que estava voltando a Washington" ${ }^{22}$. Mostram-

\footnotetext{
${ }^{82} \mathrm{O}$ discurso feito na escola está registrado no site da Casa Branca. "Remarks by the President After Two Planes Crash Into World Trade Center", Emma Booker Elementary School: "Ladies and gentlemen, this is a difficult moment for America. I, unfortunately, will be going back to Washington after my remarks. Secretary Rod Paige and the Lt. Governor will take the podium and discuss education. I do want to thank the folks here at Booker Elementary School for their hospitality. Today we've had a national tragedy. Two airplanes have crashed into the World Trade Center in an apparent terrorist attack on our country. I have spoken to the Vice President, to the Governor of New York, to the Director of the FBI, and have ordered that the full resources of the federal government go to help the victims and their families, and to conduct a full-scale investigation to hunt down and to find those folks who committed this act. Terrorism against our nation will not stand. And now if you would join me in a moment of silence. May God bless the victims, their families, and America. Thank you very much."
} 
se as imagens do presidente falando, ainda na escola, e depois entrando num avião. Corta-se para a imagem de Bush chegando a outro lugar e iniciando um discurso.

O repórter diz: "Mais tarde, Bush apareceu num lugar mais distante da capital ainda: uma base aérea do estado de Louisiana. Bush disse que a liberdade foi atacada por covardes sem fé. E que ela seria defendida. O presidente prometeu caçar e punir os responsáveis. Garantiu que está sendo feito tudo o que é necessário para proteger a população. Há oito meses no poder, Bush enfrenta a primeira grande prova, o maior ataque terrorista já realizado em território americano. Ele diz que as forças do país estão sendo testadas e que vão passar no teste". Durante todo esse trecho, permanece a imagem de Bush discursando. Fragmentos das falas vão sendo traduzidos pelo repórter e transpostos para o discurso citante do jornal.

Assim como o "recado" de Colin Powel ("os terroristas nunca matarão a democracia"), o pronunciamento de Bush, segundo o telejornal, fala da liberdade como alvo dos ataques e, de viés, sugere um fator religioso ao referir-se aos terroristas como "covardes sem fé". O jornal não comenta essa referência ou a acusação de que os objetos do ódio dos terroristas fossem a democracia e a liberdade, mas continua a destacar nos recortes dos discursos citados a idéia da iminente e necessária reação dos Estados Unidos, que não podem permitir que suas forças sejam testadas.

O que convinha ao discurso oficial, como afirma Chomsky, era citar justificativas como essas. Segundo o crítico, "é sempre mais fácil personalizar o inimigo, identificar um símbolo do Grande Mal, do que buscar compreender o que está por trás das atrocidades cometidas" (2003:40). No entanto era uma escolha da mídia apagar, do discurso a que o público teria acesso, possíveis relações de causa e efeito no cenário dos acontecimentos.

Essa é a análise do que se apresenta no discurso do telejornal, porque no registro oficial do pronunciamento do presidente Bush $^{83}$ não encontramos referências

${ }^{83}$ O discurso feito na base militar está registado no site da Casa Branca. "Remarks by the President Upon
Arrival at Barksdale Air Force Base", Barksdale Air Force Base, Louisiana: "I want to reassure the American
people that the full resources of the federal government are working to assist local authorities to save lives
and to help the victims of these attacks. Make no mistake: The United States will hunt down and punish
those responsible for these cowardly acts. I've been in regular contact with the Vice President, the Secretary
of Defense, the national security team and my Cabinet. We have taken all appropriate security precautions
to protect the American people. Our military at home and around the world is on high alert status, and we
have taken the necessary security precautions to continue the functions of your government. We have been
in touch with the leaders of Congress and with world leaders to assure them that we will do whatever is 
correspondentes à fala "a liberdade foi atacada por covardes sem fé". Não sabemos dizer, portanto, qual a fonte usada pelo discurso citante.

$\mathrm{Na}$ citação feita pelo noticiário, notamos também que a escolha dos verbos de elocução é reveladora. O repórter diz que o presidente "prometeu caçar e punir os responsáveis" e "garantiu que está sendo feito tudo o que é necessário para proteger a população". Os verbos "prometer" e "garantir" são performativos quando enunciados em primeira pessoa, representam a própria ação a que seus significados remetem. Como a fala é traduzida e assumida pelo discurso citante, não ouvimos "eu prometo" e "eu garanto", mas a enunciação desses atos em terceira pessoa (ele prometeu e garantiu), o que demonstra que não se põe em dúvida as palavras de Bush, efeito de sentido que não se alcançaria se o verbo usado fosse um neutro "dizer" (ele disse que vai caçar e punir os responsáveis e que está sendo feito tudo o que é necessário para proteger a população).

Observa-se uma grande assimilação do discurso citado pelo discurso citante, ainda que não se use a estratégia de mostrar ipsis verbis a fala do outro. Aliás, ao consultar a fonte primária, encontramos uma fala bem diferente. O presidente Bush diz: "Make no mistake: The United States will hunt down and punish those responsible for these cowardly acts". Isso permite uma outra análise, a de que o discurso citante apresentou o presidente americano como um líder firme, que chamava para si a tarefa de punir os responsáveis por aqueles atos covardes. É esse o efeito que aparece na superfície do discurso construído pelo telejornal, em oposição ao espanto flagrado na expressão de Bush na escola da Flórica, ao ser informado dos ataques, e em direção oposta à conduta do presidente, que fisicamente se distanciava cada vez mais de Washington.

Na seqüência, a reportagem fala da reação de Laura Bush, primeira-dama dos Estados Unidos, que num pronunciamento no Senado "garantiu que as crianças do país estão protegidas". Novamente não se questiona a fala, tampouco há preocupação em informar - se é que se procurou saber - o que, e não quem, garantia a proteção das crianças americanas.

necessary to protect America and Americans. I ask the American people to join me in saying a thanks for all the folks who have been fighting hard to rescue our fellow citizens and to join me in saying a prayer for the victims and their families. The resolve of our great nation is being tested. But make no mistake: We will show the world that we will pass this test. God bless." 
Logo depois da fala de Laura Bush, o repórter informa: "A primeira-dama e as filhas foram levadas para um lugar não revelado. George Bush deixou a base aérea de Louisiana e foi para outra base aérea, no estado de Nebrasca, no centro dos Estados Unidos, bem longe de Washington. Mas já voltou à capital".

Não sabemos se houve a intenção, mas em duas seqüências bem próximas o telejornal deixa transparecer certa contradição entre o discurso e as ações de Bush, que anunciara estar voltando a Washington, mas "mais tarde apareceu num lugar mais distante da capital ainda" e depois foi para outra base "bem longe de Washington". Da mesma forma o texto aproxima as informações de que Laura Bush "garantia" proteção às crianças e logo foi levada com as filhas para "lugar não revelado". Em vez de evidenciar que o presidente e a família precisavam se proteger naquele momento, essa costura das informações parece demonstrar certa $\operatorname{covardia}^{84}$ do governante que enfrentava sua "primeira grande prova", mas dela não resultará nenhum outro efeito de sentido expressivo no conjunto discursivo do telejornal.

Outro dado relevante nesse trecho é que, pela primeira e única vez, a referência aos atentados muda. O repórter fala em "maior ataque terrorista já realizado em território americano", o que restringe a dimensão do ataque, na maior parte das vezes designado como "o maior da história da humanidade", sem que se justifique o motivo da denominação.

O locutor retoma a fala e analisa: "Os ataques terroristas surpreenderam também por derrubarem o que parecia uma verdade incontestável. Até hoje, o mundo considerava o sistema de segurança americano praticamente inviolável". A saliência dramática do discurso continua sendo o choque em relação à vulnerabilidade dos Estados Unidos.

O locutor prossegue: "Os inimigos mudaram - foi com esta frase que o presidente George Bush anunciou o início de um novo projeto antimísseis americano, em maio deste ano. Depois da Guerra Fria, o inimigo não era mais a Rússia. O terror poderia atacar do Irã, do Iraque, da Coréia do Norte. O sistema de US\$ 60 bilhões vai criar armas capazes

${ }^{84}$ Carlos Dorneles menciona essa imagem negativa de Bush e a rápida reação da mídia para desfazê-la: "O dia 11 de setembro de 2001 foi assustador também para o presidente George W. Bush. Ele recebeu a notícia dos atentados quando estava na Flórida. E procurou refúgio. Era muito difícil aceitar a imagem de um presidente em busca de abrigo quando o país sentia-se ameaçado. Mas a imprensa cumpriu um dever 
de derrubar mísseis inimigos logo após o lançamento. Só que o ataque não veio do espaço. Foi despachado por aviões civis e americanos" (repete-se a imagem do choque do segundo avião contra uma das torres).

Chamam a atenção nesse fragmento a mistura de focos e de vozes e o conflito temporal. Cita-se a frase de Bush sobre a mudança de inimigos e também o bilionário projeto antimísseis, que defenderia os Estados Unidos obviamente de quem os atacasse com mísseis, arma de guerra e não de terroristas, portanto não fica claro, nessa cena discursiva, por que o presidente disse que "o terror" poderia vir de outros países depois da Guerra Fria.

Como todo o discurso do anúncio do projeto está fora do contexto, e na manifestação oral não se podem ver as "aspas", é difícil dizer se as "explicações" foram mesmo de Bush ou se são interpretadas pelo discurso citante, numa alusão ao "Eixo do Mal" formado por aqueles países. De qualquer forma, reafirma-se a idéia de que o terror é o maior e mais terrível - por ser imprevisível - inimigo dos Estados Unidos. O enquadramento restritivo das informações, que se repetem mas não são devidamente explicadas, favorece a manipulação cognitiva do discurso.

Quanto ao conflito temporal ("o sistema vai criar armas" e "o ataque não veio do espaço"), parece-nos apenas um equívoco estrutural, um gancho mal colocado para reintroduzir a imagem do ataque ao World Trade Center e apresentar a opinião dos primeiros "especialistas" a falar no jornal, devidamente identificados por créditos no vídeo. As falas do cientista político Clóvis Brigagão e de João Roberto Martins Filhos, do Núcleo de Estudos Estratégicos da Unicamp, claramente extraídas de outro contexto, são inseridas sem nenhum anúncio.

Brigagão afirma: "Significa que nenhum sistema de segurança, por mais perfeito que seja, é infalível. E o terrorismo é exatamente isso, é a surpresa". Em seguida, Martins Filho diz: "Agora sim é que a gente vai poder dizer que isso era previsível. Mas até aí ninguém nunca imaginou que se poderia encontrar pilotos de avião a jato disponíveis a se suicidar, atacando um prédio. Quer dizer, era impossível prever isso".

patriótico desde o início. A imagem de Bush como um presidente vacilante não poderia continuar. A partir dali, ele seria um estadista em tempos de guerra" (2003:84). 
O recurso de inserir o próprio discurso dos especialistas visa a um efeito de sentido de legitimidade, porém a edição das falas deixa entrever que se trata de respostas que não se encaixam na seqüência do jornal que informava sobre o projeto de defesa americano. Isso é facilmente percebido pela frase do cientista político, que começa com "significa que" e não se liga a nenhum referente do texto anterior. Se ele estivesse falando do projeto antimísseis, também seria estranho o fato de relacioná-lo ao terrorismo. Além disso, há um paradoxo na afirmação de que "nenhum sistema de segurança, por mais perfeito que seja, é infalível".

A frase toda parece-nos incoerente e irrelevante, assim como a do especialista em assuntos estratégicos é contraditória e redundante. O que poderia ser um ponto a explorar na fala do especialista da Unicamp perde-se no contexto da redundância. É interessante que ele mencione "pilotos de avião a jato disponíveis a se suicidar", mas não os identifique como terroristas. O telejornal não se aterá a esses detalhes. Entendemos que tais fragmentos de entrevista apenas reforçaram a idéia recorrente do "inimaginável" e foram usados como parte da simulação polifônica do discurso telejornalístico.

Após essas sonoras, o locutor dá uma informação numérica e arrisca um comentário, mas a questão ficará sem resposta: "Todos os dias, mais de vinte mil aviões decolam e pousam nos Estados Unidos. A questão agora é saber como foi possível levar um boeing ao Pentágono sem que ele fosse interceptado muito antes de atingir um alvo tão estratégico".

Repetem-se as imagens do Pentágono sob fumaça e o locutor chama o VT seguinte: "Com a população em pânico e os transportes interrompidos, Nova York parou". O discurso continua a sustentar a imagem verbal do pânico, que agora se expandirá para uma imagem de guerra, conforme mostra o relato do repórter que fala em seguida e confirmam as dramáticas vozes das pessoas nas ruas de Nova York. Alguns falam em "terceira guerra mundial". Tudo parece corroborar a idéia de que o "planeta" tem motivos para se aterrorizar.

A narração é coberta, na maior parte do tempo, por imagens e sons locais que tentam mostrar o estado de pânico na cidade: policiais gritam para orientar o trânsito, ambulâncias e viaturas passam a todo momento, as pessoas correm e tentam se 
esconder, há muitos escombros nas ruas ${ }^{85}$. Texto e imagens são simbioticamente descritivos: "O clima em toda a cidade era de guerra, mesmo em lugares onde só se via de longe a fumaça do incêndio (figura 10). Todos os túneis e pontes que levam à ilha de Manhattan foram fechados. As bolsas e os bancos não chegaram a abrir. As escolas ficaram com as crianças, porque os pais não puderam buscá-las. Só as ambulâncias circulavam, levando feridos para todos os hospitais da cidade".

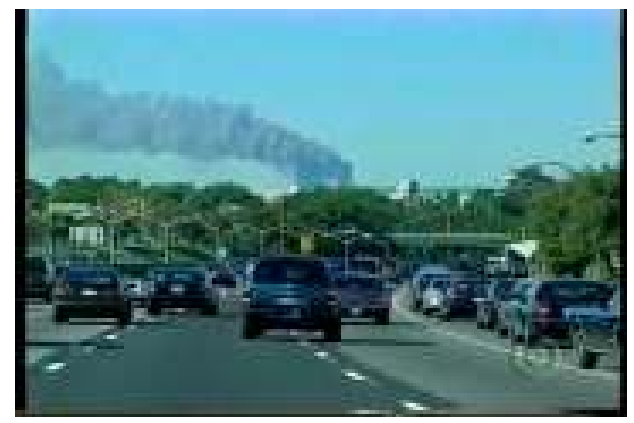

Figura 10

Na passagem que o repórter faz, novamente a redundância: "Times Square, o coração de Nova York, parou. As pessoas andam de um lado para outro, na rua, em estado de choque". Seguem-se falas de pessoas que passam nas ruas. São vítimas anônimas, reais, apavoradas, mas sobretudo patrióticas. Os fragmentos da voz americana comum, traduzidos pelo repórter, vão aderindo ao amálgama afetivo que o discurso molda: "'É uma guerra. É como Pearl Harbor, quando o Japão nos atacou de surpresa'. Esta não quer revide: 'Destruíram a minha casa', ela diz, 'o símbolo da minha cidade, mas a América tem que responder com amor'. 'Nova York vai dar a volta por cima', disse o policial. 'Nós sempre levantamos a cabeça'".

As vítimas são também heróis americanos, como mostram as imagens e o relato do repórter: "Os nova-iorquinos demonstraram solidariedade fazendo fila na porta dos bancos de sangue. Sem metrô nem ônibus, o jeito foi voltar a pé para casa ou sentar na calçada para ver no telão as notícias da tragédia. Esta se desesperou: 'Quero ir para

${ }^{85}$ Segundo o repórter Jorge Pontual e o cinegrafista Orlando Moreira, que dão depoimento no livro Jornal Nacional: a notícia faz história, eles foram os primeiros jornalistas a conseguir entrar no "marco zero" e fazer uma imagem da tragédia o mais perto possível dos escombros, essa imagem descrita acima. Eles 
casa', era tudo o que ela conseguia dizer. Muitos eram sobreviventes que andaram mais de 60 quarteirões, ainda surpresos por estarem vivos".

Num ritmo crescente, o repórter vai apresentando mais testemunhas do horror: "'Nós estávamos sendo retirados do segundo prédio quando o avião caiu. Tudo tremeu, parecia um terremoto. Meus amigos que estavam nos andares de cima devem ter tido uma morte horrível. Muitos pularam lá do alto'. Este estava ao lado do primeiro prédio quando ele desabou. Ainda levava a poeira nos sapatos. 'Saí correndo a toda, a nuvem dos escombros atrás. Muita gente caiu e morreu sob os destroços'. Este outro ficou encurralado entre o rio e o incêndio: 'Só escapei de morrer asfixiado porque alguém me deu uma toalha molhada'. Charles Moser trabalha em Wall Street e viu de perto o que aconteceu. 'Não havia visibilidade nenhuma e não havia como respirar fora dos prédios. $\mathrm{O}$ pessoal vinha correndo para Wall Street com uma parede de fumaça atrás'" (repete-se a imagem da poeira negra se espalhando pelas ruas).

O repórter destaca então uma manifestação de Rudolf Giuliani, na época prefeito da cidade: "'Nova York e a América', disse Giuliani, 'são mais fortes do que esses bárbaros terroristas'. 'A democracia vai prevalecer'". Repete-se a divulgação do argumento segundo o qual se tratava de uma guerra de "bárbaros" contra a democracia, cujo baluarte eram os Estados Unidos. São bárbaros porque cometeram terrível atrocidade, mas também o podem ser porque são o "outro", o "estranho". Fecha o VT a insistente imagem da fumaça cobrindo todo o sul da ilha de Manhattan, uma fumaça que não se apagará da memória.

Na seqüência são dadas informações sobre o cancelamento de vôos do Brasil para os Estados Unidos. Mostram-se diversas sonoras de pessoas nos aeroportos, nervosas e com medo, e imagens de gente tentando obter notícias de Nova York pelo telefone. As palavras mais ouvidas são "horror", "pânico", "desespero", "perigo", além da referência à idéia de uma "terceira guerra mundial". O Brasil também está em alerta geral: "A segurança nos aeroportos do país foi reforçada. Em Salvador, facas e tesouras identificadas pelo raio $\mathrm{X}$ foram retiradas das bagagens. Em Belo Horizonte, até veículos

dizem que até então "a única imagem que se tinha era daquelas câmeras fixas do governo norteamericano" (2004:342). 
foram revistado. A tragédia fez muita gente mudar os planos no balcão do aeroporto. Este grupo cancelou uma viagem para a Europa".

Antes da passagem para o bloco seguinte, o locutor chama a entrada de uma repórter ao vivo, para atualizar as informações. Ela diz que Manhattan "começa a tentar voltar ao normal" e que a situação é "um pouco mais normal", com linhas de metrô voltando a funcionar e túneis e pontes liberados para quem quer sair da cidade. A repórter informa que o prefeito fez um apelo para que as pessoas não fossem a Nova York no dia seguinte e que as escolas públicas e "as escolas católicas" não teriam aula.

Não parece haver algum efeito de sentido expressivo a analisar nesse trecho, a não ser que se possa considerar como efeito o contraste entre essa normalidade e o estado de pânico até então presentificado no discurso, que será imediatamente retomado na fala do locutor: "Em instantes. Especialistas analisam as conseqüências do terror para o futuro do planeta".

Nessa mesma passagem de bloco, o locutor anuncia: "E, nos territórios ocupados por Israel, palestinos comemoram o banho de sangue". A imagem que ilustra a chamada, que já fora exibida na escalada do telejornal e que se repetirá no VT, causou muita polêmica na época. Trata-se de um pequeno grupo, formado principalmente por mulheres e crianças, cantando e dançando na rua. A legenda da imagem, nessa passagem de bloco, é "a celebração do ódio" (figura 11).

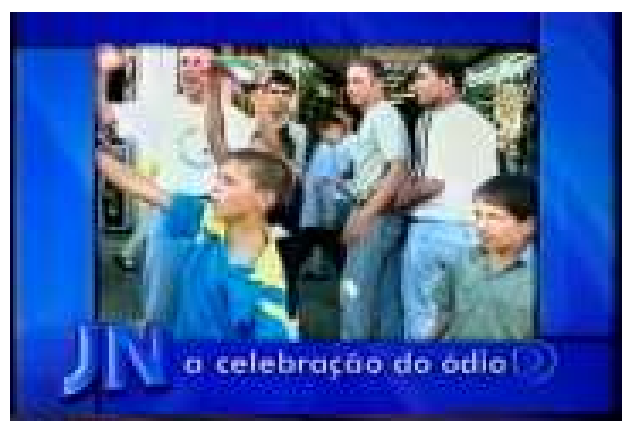

Figura 11

Houve muitas manifestações contra a exibição das imagens dessa suposta comemoração dos ataques. Falou-se em falsidade. A jornalista Beatriz Singer lembra que uma mensagem na internet chamou a atenção e foi noticiada por diversos meios de 
comunicação ${ }^{86}$. Ela partira de um mestrando da Unicamp e rodou o mundo sob o título de "a farsa da CNN", sendo traduzida do inglês para diversas línguas. Segundo o estudante, um professor da universidade tinha uma fita de vídeo que podia provar que as imagens haviam sido feitas em 1991 e mostravam palestinos comemorando a invasão do Kuwait, portanto teriam sido usadas por ocasião dos ataques aos Estados Unidos para manipular a opinião pública.

Beatriz Singer relata que em 17 de setembro a CNN divulgou nota repudiando as acusações do estudante e confirmando a legitimidade das imagens, filmadas no setor oriental de Jerusalém por cinegrafistas da agência de notícias Reuters no dia 11 de setembro, o que foi confirmado oficialmente pela agência em 20 de setembro. A CNN também apresentava um comunicado da Unicamp desfazendo o mal-entendido e apresentando as desculpas do aluno.

Verdadeiras ou não, as imagens não correspondiam à virulência dos enunciados interpretativos "comemoração do banho de sangue" e "celebração do ódio". Nada comprovava, no universo discursivo da mídia, que a manifestação daquela meia dúzia de crianças e mulheres significasse alegria pelas mortes ou fosse um rito de celebração de um ódio inexplicável. Aliás, é terrível pensar que alguém pudesse comemorar ou celebrar um banho de sangue. $O$ paradoxo entre os campos semânticos é muito forte e posto assim, sem contexto ou explicação, torna-se ainda mais chocante. As pessoas devem ter se perguntado que monstros eram aqueles.

Certamente a escolha da imagem se deu porque foi o que se conseguiu das agências internacionais, aliás fotos com o mesmo grupo de pessoas foram publicadas por toda a imprensa no dia seguinte. Era preciso falar da reação do "mundo árabe" e, evidentemente, mostrar alguma imagem comprobatória. $O$ que não era preciso é a intercorrência do verbo cruel e levianamente interpretativo, mesmo porque um pequeno grupo não pode ser tomado metonimicamente pelo povo palestino, muito menos pelo mundo árabe ${ }^{87}$. É flagrante a manipulação afetiva e cognitiva do discurso nesse ponto.

\footnotetext{
86 "Fragilidades da cobertura online", artigo de 26 de setembro de 2001, disponível no site do Observatório da Imprensa.

${ }^{87}$ Carlos Dorneles também aponta o disparate: "O pequeno grupo fotografado num campo de refugiados foi transformado pela imprensa em falta de sensibilidade dos palestinos com a tragédia que vitimou inocentes" (2003:239).
} 
Incita-se à indignação pelo enquadramento abusivo das palavras, que acionam um sentimento que, nesse caso, não afloraria pelo simples contato com a imagem quase ingênua que correu o mundo. A palavra torna a presunção em fato, um fato abominável.

\section{Bloco 3}

O bloco que mostrará a "celebração do ódio" começa com uma fraca tentativa de esboçar uma explicação para as ações terroristas. O locutor relata: "Há menos de uma semana, os Estados Unidos se retiraram da conferência da ONU sobre racismo e xenofobia, na África do Sul. Foi um protesto contra a decisão de se classificar Israel como um país racista. Posições como esta alimentaram, ao longo dos anos, o ódio de extremistas muçulmanos".

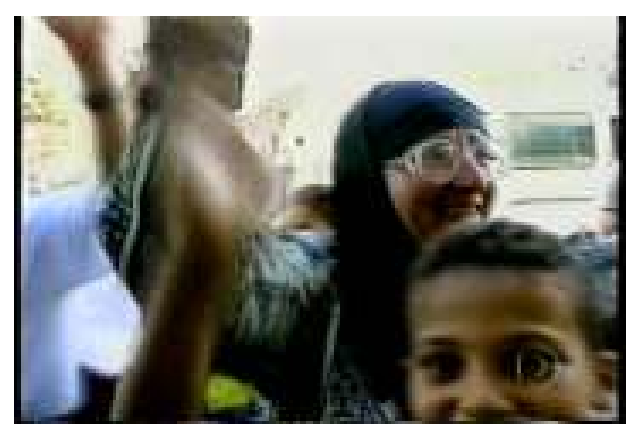

Figura 12

O repórter prossegue, no VT: "Terror na América, festa no Oriente Médio. Nas ruas dos territórios palestinos ocupados por Israel (imagem de um pequeno grupo dançando na rua), os americanos são vistos como amigos do inimigo israelense. Portanto, inimigos que merecem o pior. 'Alá é maior', grita esse grupo (repete-se a imagem já referida de uma mulher e algumas crianças dançando e gritando - figura 12). Para exibir felicidade, o dono da loja distribuiu doces" (imagem de um homem com um prato de bolo na mão, oferecendo às pessoas na rua).

E é só. Nada mais que esses tênues liames entre as ações terroristas, as ações americanas e as reações no Oriente Médio. Nada se esclarece pelo discurso ora sinuoso, ora simplista demais. Os Estados Unidos se retiraram de uma conferência sobre racismo e xenofobia em protesto a uma decisão contra Israel. A anáfora que rotula esse segmento é "posições como esta", que se pretende neutra e não avalia a extensão do ato 
americano. Cabe ao telespectador articular o sentido das relações que se sugerem por essa única informação de que os Estados Unidos apóiam Israel.

É preciso ativar - no exíguo espaço de tempo que se tem para refletir sobre notícias televisivas - conhecimentos profundos sobre a história e o cenário internacional para tentar entender por que o apoio a Israel "alimenta o ódio de extremistas muçulmanos". Sabe-se, e o texto do repórter lembrará essa informação, que Israel "ocupa" territórios palestinos, portanto quem odeia Israel e, por tabela, os Estados Unidos, são os palestinos, indiretamente designados no texto como "extremistas muçulmanos".

Essa complexa operação cognitiva tende a ser sobrepujada pela simplificação das imagens e de sínteses como "Terror na América, festa no Oriente Médio". Não importam o contexto histórico da ocupação israelense, o motivo do apoio americano a Israel, as razões da decisão da ONU de classificar Israel como "país racista". Os liames então vão sendo reforçados pela idéia de que a única coisa que pode explicar as ações terroristas é o inexplicável ódio de extremistas muçulmanos. As emoções são manipuladas para que não se perceba que ainda não se explicou nada sobre esse suposto choque de civilizações $^{88}$.

Há terror na "América", velha designação que superestima os Estados Unidos, e o planeta está em alerta geral, mas no Oriente Médio, que no discurso é posto à margem do planeta, festeja-se. Por quê? Simplesmente porque "os americanos são vistos como amigos do inimigo israelense, portanto, inimigos que merecem o pior". O discurso do telejornal afirma que é um argumento quase-lógico, baseado num raciocínio silogístico, que justifica a "comemoração" dos palestinos. Não são os palestinos que dizem isso, mas o discurso atribui a eles o argumento e, nesse movimento, simultaneamente o está desqualificando. Há um filete de ironia nessa interpretação das razões do Outro, o Outro

\footnotetext{
${ }^{88}$ Dominique Wolton, especialista em comunicação política, que logo após os atentados de 11 de setembro, intensificou seus estudos sobre mídia e terrorismo, dizia não acreditar em choque de civilizações ou em guerra de religiões. Segundo ele, a violência daqueles ataques refletia a violência da sociedade capitalista, as imensas desigualdades sociais e a dificuldade dos Estados Unidos de conviver com outras culturas. ("Wolton fala sobre o valor da mídia e da diversidade", entrevista concedida à revista Trópico em 13 de janeiro de 2002, disponível no site do Observatório da Imprensa.)
} 
que não é apenas o povo palestino, ao qual o trecho se refere, mas todo o Oriente Médio, expressão metonímica que contribui para a criação da imagem do "inimigo sem rosto" contra o qual é iminente uma guerra.

Chega a ser ingênuo o argumento que o discurso apresenta para comprovar que havia "festa no Oriente Médio": "'Alá é maior', grita um grupo. Para exibir felicidade, o dono de uma loja distribuiu doces". É marcante a antítese entre essas imagens e a referência a uma "celebração do ódio". O enquadramento restritivo do discurso presta-se a ocultar outros aspectos do fato, aquilo que restará invisível e silenciado e não penetrará as memórias.

Chomsky alertou, na época, para algo que a mídia internacional deixou de dizer: "Israel está escancaradamente exultante com a oportunidade que se apresentou, já que agora pode esmagar os palestinos com total impunidade" (2003:22). Verdade ou presunção, a televisão não mostrou. "Escancaradamente exultante", na mídia, somente o povo islâmico, disposto "a festejar a desgraça alheia diante das câmeras internacionais", supostamente por motivos religiosos.

É essa a fala do repórter: "Há muita gente disposta a festejar a desgraça alheia diante das câmeras internacionais (imagens de carros buzinando, gente cantando nas ruas). Mas os líderes do mundo islâmico querem se distanciar do terror. O embaixador do regime Talibã afegão, o mais radical entre os governos islâmicos, condenou o ataque. Com ar grave e preocupado, o palestino Yasser Arafat ofereceu os pêsames ao presidente Bush e ao povo americano. 'É um ataque terrível'", diz ele. 'Estou completamente chocado. É inacreditável'. (imagem do líder palestino falando e tradução do repórter.) A rápida condenação revela o medo que toma conta do mundo árabe e muçulmano, confirma do Oriente Médio o jornalista Mounir Safatli".

Por mais que se tente suavizar a parcialidade do discurso quanto às reações do Oriente Médio por meio da afirmação de que "os líderes do mundo islâmico querem se distanciar do terror", há indicações no trecho que conduzem ainda a uma imagem desfavorável do mundo islâmico. Pela leitura do enunciado "querem se distanciar do terror", pode-se pressupor que os líderes do mundo islâmico tinham alguma ligação com o terror e em seus discursos oficiais negam isso. 
Enunciados como "o mais radical governo islâmico condenou o ataque", "com ar grave e preocupado, o palestino Yasser Arafat ofereceu os pêsames" e "a rápida condenação revela o medo que toma conta do mundo árabe e muçulmano" parecem dizer que são dissimuladas as reações daqueles que representam os grupos acusados de proteger os terroristas (os talibãs) ou de tripudiar sobre a tragédia americana (os palestinos). Notamos que tais enunciados estão postos em relação de oposição a "muita gente estava disposta a festejar a desgraça alheia diante das câmeras internacionais", como se o discurso dos líderes camuflasse um sentimento oposto ao do choque manifestado diante das câmeras e a "rápida condenação" fosse um estratagema para livrar-se da retaliação americana.

O correspondente que está no Oriente Médio irá "confirmar" que essa atitude "revela o medo que toma conta do mundo árabe e muçulmano": "Líbano, Síria, Jordânia, Iraque, Irã e Líbia. Esses seis países colocaram suas forças armadas em estado de alerta máximo. Há um temor generalizado sobre qual será a reação americana diante das acusações de que extremistas muçulmanos estariam por trás dos atentados nos Estados Unidos. As facções palestinas, tidas como suspeitas, também estão em alerta nos acampamentos de refugiados na Jordânia, Síria e Líbano. Em quase todos os países árabes favoráveis à causa palestina, o clima é de tensão. Todos estão preocupados com a reação que já começou, vinda do ocidente. Aqui no Líbano, por exemplo, cinco companhias aéreas internacionais suspenderam seus vôos para Beirute, apesar do primeiro-ministro do Líbano se apressar em lamentar os atentados e encaminhar condolências ao povo americano, num sinal de que o Líbano nada tem a ver com o que aconteceu nos Estados Unidos".

A "confirmação" do repórter, que fala por telefone direto do Oriente Médio, pretende ser um argumento para demonstrar o medo de árabes e muçulmanos diante da possível reação belicosa dos Estados Unidos (reação que sobreviria ano após ano depois dos ataques e atingiria parte dos países citados nesse momento), mas não justifica que as manifestações de condenação tenham relação com esse medo. O medo se funda, como o próprio repórter diz, na incerteza sobre a reação americana diante das acusações de que os ataques partiram do mundo árabe, apesar de já ter sido dito que "as autoridades evitavam falar em suspeitos". 
Países em que, por pressuposição, deve haver extremistas muçulmanos, facções palestinas "tidas como suspeitas" e países árabes favoráveis à causa palestina estão em "alerta máximo", mas não pelos motivos do resto do "planeta". "Quem não deve não teme" (nem "se apressa em lamentar" para estampar inocência) é a voz proverbial que emana desse trecho, cujas únicas imagens são as de cenas normais de pessoas nas ruas de cidades do Oriente Médio. Aparentemente nenhuma delas devia ou temia alguma coisa, ao contrário do que dizia o discurso.

Aliás, é curioso observar que a afirmação de que todos estava preocupados com a reação que já tinha começado, "vinda do ocidente", nega inadvertidamente o que se reitera em outros trechos sobre o fato de os Estados Unidos não terem ligação com os ataques a Cabul naquele mesmo dia. Uma breve afonia no discurso predominante.

Na seqüência, tenta-se novamente atenuar a unilateralidade do discurso: "A festa nos campos de refugiados palestinos é inflamada por quase um ano de confrontos diários com a força de ocupação israelense. Mas a maioria dos habitantes do mundo árabe, que nada tem a ver com o terror, vai dormir hoje com medo de uma retaliação americana".

Apesar de os execráveis "refugiados palestinos" estarem em festa, cujo elemento de combustão é o já citado ódio por Israel, aliás pela "força de ocupação israelense", deve-se fazer concessão à "maioria dos habitantes do mundo árabe, que nada tem a ver com o terror". Os eufemismos constantemente empregados no discurso da mídia tendem a minimizar certos conflitos internacionais e silenciar suas razões, mas o jogo discursivo acaba por revelar julgamentos como o que se vê nesse trecho, que assimilará certos grupos do mundo árabe a terroristas.

O que é dito pelo repórter em seguida vai também nessa direção: "Mas quem teme sofrer o maior prejuízo de todos é a imensa e pacífica comunidade muçulmana que vive na Europa. Preocupado com uma onda de preconceito antiárabe, o especialista britânico alerta: 'Radicais terroristas não podem ser confundidos com a imensa população muçulmana que trabalha e respeita as leis pelo mundo afora'" (o repórter vai traduzindo a fala do "especialista", que não é identificado por nenhum crédito no vídeo).

Novamente se quer fazer crer que uma minoria árabe celebra o ódio, entretanto a voz que anunciara "festa no Oriente Médio" ainda ressoa no discurso que agora quer resguardar "a imensa e pacífica comunidade muçulmana" que vive numa parte civilizada 
do "planeta" e que "trabalha e respeita as leis pelo mundo afora". A fala do "especialista britânico" não identificado, mesmo em discurso direto traduzido, é inserida para garantir a legitimidade dessa preocupação com "uma onda de preconceito antiárabe", até então alimentada no discurso midiático ${ }^{89}$.

Depois se fala da reação de Israel e de líderes religiosos no Brasil: "O primeiroministro israelense, Ariel Sharon, decretou luto no país. As fronteiras com o Egito e a Jordânia foram fechadas, como medida de segurança. E o ministro da Defesa cancelou uma viagem que faria nos próximos dias aos Estados Unidos. Aqui no Brasil, lideranças islâmicas e judaicas condenaram os atentados. E fizeram um apelo a favor da paz".

Note-se o destaque para a informação de que Israel fechou as fronteiras com a Jordânia, um dos países citados como temerosos da retaliação americana e que, junto com o Egito, pressiona Israel por uma solução para a questão palestina, portanto um inimigo comum. Tais questões históricas evidentemente passam ao largo da construção discursiva e a informação perde-se na trama principal do roteiro telejornalístico.

Também nesse trecho, anuncia-se que o VT destacará a aproximação de islâmicos e judeus no apelo que fazem a favor da paz. Apresentam-se então as opiniões de figuras religiosas representativas: membros de comunidades muçulmanas, o rabino Henry Sobel, líderes pacifistas. Forma-se uma espessa camada de citações em discurso direto, cujo efeito de credibilidade é reforçado pela presença das pessoas que falam num contexto que abriga uma polifonia harmônica sobre a delicada questão. $O$ telejornal enfatiza que os atentados são considerados "uma ofensa à religião" e são condenados por todos.

O presidente da Sociedade Muçulmana de São Paulo diz: "Se nós matarmos uma pessoa é como se tivesse matado toda a humanidade. Então nós deploramos este ato criminoso". Dois líderes de uma entidade que prega a paz entre palestinos e judeus também se manifestam. O pacifista judeu diz: "Nós podemos tentar acabar com o terrorismo pela força ou podemos tentar acabar com o terrorismo pela paz". O pacifista

\footnotetext{
${ }^{89}$ Note-se a semelhança com o que ocorreu durante a Guerra do Golfo, que, segundo Arbex, "forneceu um magnífico e trágico exemplo de construção de uma metáfora interpretativa sobre um suposto choque civilizatório entre os Estados Unidos - portador dos valores cristãos, democráticos e pluralistas da civilização ocidental - e o Iraque - representante do Islã, uma religião intolerante, sustentada por fanáticos terroristas" (2001:116). Arbex lembra que "os árabes eram apresentados apenas como uma idéia, um conceito ameaçador", o que parece não ter mudado muito na cobertura de conflitos posteriores.
} 
palestino diz: "Porque não é possível que o mundo, que a ONU, que os governos mundiais deixem isso acontecer mais uma vez".

O repórter havia dito antes: "Para eles, o fato da maior potência do planeta não ter conseguido se defender do ataque de hoje mostra que a força não vai garantir a segurança mundial". Aqui o discurso segundo interpreta ou distorce os discursos citados, que não fazem menção ao fato "da maior potência do planeta não ter conseguido se defender do ataque".

Por se tratar de líderes pacifistas, infere-se que o conteúdo de suas falas seja uma mensagem de paz, porém o recorte das falas pode torná-las ambíguas ou desconexas. Note-se que a fala do homem palestino inicia-se com "porque", mas não se sabe a que enunciado a explicação se articula nem se conhece a referência inequívoca de "isso", em "não é possível que deixem isso acontecer mais uma vez". De qualquer forma, a inserção dessas vozes parece retomar o fio que costura a idéia de que o autor daquele "deplorável ato criminoso contra a humanidade", fosse quem fosse, não podia ficar impune.

Entretanto o discurso parece continuar a esticar a linha pelo caminho da insinuação que leva aos muçulmanos como principais suspeitos. O repórter dá a seguinte moldura à fala do vice-presidente de uma entidade islâmica: "No Rio, esse representante da Juventude Islâmica tem medo que o atentado estimule o preconceito contra os muçulmanos".

O rapaz diz: "Que se apure o atentado, que se veja realmente quem fez isso e que se condene quem praticou, não as demais pessoas. Generalizar isso é uma injustiça". O jovem líder não parecia estar com medo, como enunciara a expressão do repórter, mas indignado com a generalização que já se via nos discursos oficiais e na mídia. Só a generalização, em si preconceituosa, é que poderia estimular a aversão aos muçulmanos, já que assimilava islamismo e terrorismo por ignorância ou má-fé.

A fala que fecha o VT, sem comentário anterior ou posterior do discurso citante, é a manifestação de Henry Sobel, presidente da Congregação Israelita no Brasil: "As boas relações entre a comunidade judaica e a comunidade muçulmana no Brasil vão continuar sendo relações de respeito mútuo e cordialidade. Não vamos importar o terror para o Brasil". Pela fala do líder judeu, pode-se inferir que o terror tem ligação com o mundo 
muçulmano, mas não no Brasil, onde as relações entre as duas comunidades são cordiais.

Depois o telejornal fala das reações na Europa, com ênfase para o "clima tenso" que se estabeleceu na Grã-Bretanha, principal país aliado dos Estados Unidos. O locutor repete a informação sobre o choque contra o WTC e reitera a perplexidade de todos: "Na Grã-Bretanha, faltavam quinze minutos para as duas horas da tarde quando o primeiro avião se chocou contra uma das torres do WTC. A partir daquele momento, não só o país, como toda a Europa parou, atônita, para saber o que estava acontecendo".

O repórter descreve: "A tradicional pontualidade britânica hoje não funcionou. O país parou diante da TV para assistir às notícias que chegavam ao vivo dos Estados Unidos. No centro de Londres, ninguém esperou até as cinco da tarde para sair do trabalho. Lojas, bares e principalmente prédios públicos foram esvaziados". O estereótipo da pontualidade parece ter sido considerado adequado para mostrar quão grave foi considerada a situação na Grã-Bretanha.

O repórter deixa claros os motivos da preocupação na passagem que faz: "Esse clima tenso entre os britânicos encontra uma explicação principalmente no campo da diplomacia. A Grã-Bretanha é a principal aliada dos Estados Unidos. Costuma apoiar o governo americano em todas as decisões políticas. Hoje, essa amizade histórica deixou os cidadãos daqui com a sensação de que Londres poderia ser o próximo alvo".

Eufemisticamente, reduz-se a relação entre essas nações a uma questão de diplomacia, a apoio político, a uma amizade histórica, o que justificaria o medo, já que, na lógica do "outro", "os amigos dos inimigos merecem o pior". O repórter traduz a fala de pessoas na rua: "'Estou com muito medo', diz a moça. 'Também tenho pena das pessoas inocentes que morreram'. Este homem se diz apavorado: 'Meu receio é que isso provoque a terceira guerra mundial'".

Outra vez foram escolhidas como representativas falas que expressam o pânico no mundo e o temor de uma "terceira guerra mundial", idéia incongruente diante da imediata certeza do governo americano e da mídia de que se tratava de ataques terroristas.

O relato prossegue, apresentando as manifestações de líderes mundiais. Aparecem imagens das autoridades falando e fragmentos dos discursos são selecionados e traduzidos pelos repórter, numa simulação de discurso direto, chancelada pelas 
imagens: "O primeiro-ministro britânico, Tony Blair, cancelou uma reunião ministerial para fazer um pronunciamento: 'Estamos solidários com o povo americano. O mundo precisa se unir para erradicar o terrorismo'. De toda a Europa partiram manifestações no mesmo sentido. O presidente da França, Jaques Chirac, chamou de 'monstruoso' o que aconteceu na América. O presidente da Rússia, Vladimir Putin, disse que foi uma 'tragédia terrível' e convocou uma reunião ministerial para discutir a segurança. O chanceler alemão, Gerard Schoereder, classificou o ato terrorista de 'abominável'. O secretário-geral da OTAN, George Robinson, conclamou o mundo a formar uma frente comum para combater o terrorismo. A União Européia já convocou uma reunião de emergência para discutir um plano de ação. Todas as embaixadas americanas na Europa e na Ásia tiveram a segurança reforçada. Em Londres, diante das barreiras de isolamento, foram deixados buquês de flores. Uma homenagem às vítimas da violência que hoje abalou o mundo".

Agora é o mundo ocidental que fala, pela voz de seus líderes, da "terrível tragédia", do ato "monstruoso" e "abominável", denominações e qualificações ressaltadas pelo discurso citante. É o mundo que se solidariza com o povo americano e pede um "plano de ação", uma "frente comum para combater o terrorismo". É o mundo que se abalou e, apesar de toda a violência e clamor por resposta, pensa em flores para homenagear as vítimas. Não há ressalvas a essas manifestações como houve no trecho em que se fala das reações dos líderes do mundo árabe. O "planeta" está dividido também no discurso, que reflete a nova geopolítica que começa a se desenhar naquele dia: os aliados dos Estados Unidos, a quem o presidente Bush conclamou na época como "inimigos do terror", e os que, por exclusão, estariam do lado do "mal".

A propósito da manifestação dos aliados, Chomsky diz que "não é nenhuma surpresa que a Europa tenha se sentido absolutamente chocada pelos crimes terroristas praticados em11 de setembro" (2003:12), mas afirma que isso não se deveu, infelizmente, à dimensão do episódio. O crítico analisa que a preocupação decorreu do fato de que era a primeira vez que as armas se voltavam contra os Estados Unidos, que "nos últimos cinqüenta anos, particularmente, valeram-se da força para impor-se a boa parte do mundo". Da mesma forma, diz Chomsky, "as potências européias conquistaram grande parte do mundo usando sempre extrema brutalidade e, com raríssimas exceções, esses 
países jamais foram atacados por suas vítimas do exterior" ${ }^{\prime 00}$ (op.cit.:13). Essa inversão é que constituía uma mudança dramática, provocava pânico e fazia pensar que o mundo seria outro a partir dali.

É esse o destaque na chamada seguinte do locutor: "Os analistas políticos são unânimes em dizer que o mundo será outro depois desta terça-feira. O ministro das Relações Exteriores do Brasil, Celso Lafer, disse que a situação é de gravidade única, de conseqüências ainda imprevisíveis". Entram então as sonoras do ministro das Relações Exteriores e de professores de política internacional da PUC, vozes de autoridade que se colocam integralmente na tessitura no discurso.

São falas extensas e importantes, que garantem ao discurso citante a possibilidade de adensar um pouco o contexto em que os fatos vinham sendo apresentados. Entretanto, como as falas sobrevêm na linearidade do discurso telejornalístico, sem interlocução direta entre elas e como evento único na superfície discursiva, é possível que o conteúdo não tenha provocado o mesmo impacto da combinação de imagens e designações verbais reiteradas ao longo do telejornal e, portanto, seus fios se percam na malha que tende a envolver a memória dos fatos.

De todo modo, pode-se observar que a "unanimidade" em relação ao fato de que o mundo seria outro depois de 11 de setembro é representada por um ministro e por dois analistas que são até hoje, como diz Bourdieu, "habitués da mídia". A concessão do direito à visibilidade na mídia é seletiva e não raro é feita àqueles que tendem a não comprometer muito o senso comum.

Celso Lafer, por exemplo, só emprega frases genéricas para falar sobre as conseqüências dos ataques: "É um episódio decisivo. Ele muda o funcionamento do sistema internacional. Ele coloca as sombras da incompreensão no centro da vida mundial. E isso terá um efeito grande sobre tudo e sobre todos e mudará a maneira pela qual conduzimos a ação diplomática. Este evento é mais sério do que qualquer outro nos

\footnotetext{
${ }^{90}$ Ainda segundo Chomsky, as potências ocidentais tinham que falar de modo vago sobre declarar guerra ao terrorismo, pois, se assumissem suas próprias definições oficiais de "terrorismo", revelariam que "os Estados Unidos são um Estado líder do terrorismo, assim como os países que se constituem seus principais aliados" (2003:17), dadas suas nefastas ações ao longo da história. Os Estados Unidos e seus aliados estariam então conclamando uma luta contra o "terrorismo alheio".
} 
últimos tempos e ele tem um alcance maior do que foi o fim da Guerra Fria e a queda do Muro de Berlim".

Por outro lado, a edição parece comprometer a fala do especialista Reginaldo Nasser, que não explica por que o poder no mundo deverá ser descentralizado e sua fala termina com uma afirmação desvinculada da anterior: "Eu acho que os países europeus, os outros blocos do mundo, a América Latina, os vários organismos, como a Organização dos Estados Americanos, eles têm que tomar um papel mais ativo no mundo. Ou seja, o mundo deve ter uma descentralização do poder. Essa é uma questão que pode ser feita até a médio prazo. A curto prazo, os Estados Unidos vão mudar completamente o seu sistema de vigilância interna".

A fala menos evasiva e aparentemente menos editada é a do especialista Fernando Abrucio: "Eu acho que haverá pelo menos três respostas. Uma resposta militar muito forte, contra algum país. Eles vão tentar escolher, se não conseguirem descobrir quem foi, vão tentar escolher um país e os dois candidatos sérios a tomar um ataque maciço, que oxalá não seja nuclear, são Iraque e Afeganistão. A segunda resposta é uma resposta que vai obrigar o presidente Bush a sair do isolacionismo e, a partir de um relacionamento internacional com os seus aliados, com os países democráticos, ter uma política mais forte contra o terrorismo. E uma terceira reação fundamental é o problema do Oriente Médio. O presidente Clinton tentou fazer a paz. O presidente Bush esqueceu o Oriente Médio. Vai ser obrigado a relembrar o Oriente Médio".

Pelo menos três pontos podem ser destacados nessa fala autorizada pela mídia: ela se refere à inevitável resposta militar dos Estados Unidos, mesmo que não se descubra o responsável pelos ataques; coloca o terrorismo em oposição aos países democráticos; afirma que o presidente Bush será "obrigado a relembrar o Oriente Médio", o que sugere que é lá que está o inimigo. Intencionalmente ou não, essa fala reforça alguns estereótipos e idéias fixas presentes no discurso que germinava o conteúdo simbólico da memória daquele dia.

Segue-se outra entrada ao vivo, na qual a repórter informa que ainda não foi divulgada nenhuma lista com os nomes da vítimas e que não há notícias dos brasileiros que trabalhavam no WTC. O locutor faz a chamada do bloco seguinte, em que se falará das repercussões econômicas do atentado e de notícias do Brasil, que ficaram em 
segundo plano nessa edição. O destaque da passagem de bloco é o assassinato de Toninho do PT, que era prefeito de Campinas, em São Paulo.

\section{Bloco 4}

No mesmo exíguo espaço reservado a outras notícias do dia, o telejornal mantém a previsão do tempo, dá uma nota sobre a eliminação do tenista Gustavo Kuerten de um torneio, informa a morte do empresário José Hermínio de Moraes Filho, fala das investigações sobre a participação de Jader Barbalho na fraude no BanPará e, numa matéria de apenas dois minutos, trata do assassinato do prefeito de Campinas, ocorrido no dia anterior.

Muitos se indignaram com a falta de destaque, nos noticiários daquele dia, para esse caso de repercussão nacional. O Jornal Nacional nem menciona o fato na escalada da edição, toda ela dedicada aos ataques nos Estados Unidos, no topo da hierarquia das notícias do dia. Foi feita uma escolha. Escolheu-se o drama internacional, com suas imagens espetaculares, afinal, conforme se avaliou na época, "aquele avião acertou o olho da câmera de tevê".

Depois das notícias secundárias, o locutor chama nova entrada ao vivo de Nova York, com informações sobre as investigações. A repórter fala da sede da emissora na cidade e não é exibida nenhuma imagem relativa ao atentado: "O FBI acaba de abrir uma página na Internet pedindo para que as pessoas mandem informações que possam levar aos autores desses atentados. A CIA e o FBI não têm nenhuma pista concreta até agora. Esta é a informação oficial, mas funcionários do Pentágono disseram hoje cedo que tinham informações do envolvimento de Osama Bin Laden. Segundo eles, só o bilionário saudita teria ousadia e recursos suficientes para organizar uma série de atentados como esses. O Exército americano está em alerta máximo. E, se for necessário, pronto para agir".

Note-se nesse trecho a oposição articulada pelo operador "mas" entre "informação oficial" e as informações obtidas de fontes vagas. Pela noção de orientação argumentativa, prevalece o segundo enunciado como mais forte: as informações extraoficiais têm mais valor que as da Cia e do FBI e não são questionadas. Carlos Dorneles apurou, em sua pesquisa sobre a cobertura dos ataques e da guerra contra o 
Afeganistão, que os jornais publicavam com ressalvas as notícias que não eram favoráveis aos Estados Unidos, salientando que se tratava de informações "sem confirmação por fontes independentes" (2002:16). O contrário não ocorria, as fontes eram sempre seguras, e é isso que se observa no discurso do telejornal.

As informações dos "funcionários do Pentágono" não são discutidas, embora a justificativa apresentada para apontar o envolvimento de Osama Bin Laden fosse apenas uma suposição, conforme indica a modalização em discurso segundo: "Segundo eles, só o bilionário saudita teria ousadia e recursos suficientes para organizar uma série de atentados como esses".

O termo anafórico que reenquadra o referente "Osama Bin Laden" introduz a informação de que o terrorista saudita é "bilionário", o que justificaria o raciocínio de que "só" ele teria recursos suficientes para organizar um atentado como aquele. Não fora dito muito sobre Bin Laden no telejornal, a não ser que ele era suspeito de vários atentados terroristas e que era o "inimigo número 1 dos Estados Unidos". Agora se informa que ele é um "bilionário"91, mas não se explica por que um "bilionário saudita" é um terrorista sem objetivos políticos, que tivera a "ousadia" de atacar um símbolo do capitalismo.

O termo restritivo "só" impõe Bin Laden não como o principal suspeito, mas como o único capaz daquela "ousadia", termo que certamente se refere ao atrevimento de atacar a superpotência, mas que não explica por que essa seria uma característica exclusiva de Bin Laden, cuja antiga aliança com os Estados Unidos não é informada ou dada como relevante pela mídia.

A fragmentação, a descontextualização e a omissão de dados geram crescente desinformação, suplantada pelas imagens e versões construídas no discurso midiático. Fala-se em ataque à democracia, em choque entre civilizações, em ódio ao capitalismo, em fanatismo religioso. Os motivos da ação terrorista não são claros, mas são atos bárbaros e é para isso que o discurso chama a atenção. O governo americano precisava dar rapidamente um rosto ao inimigo, contra o qual o Exército estava "pronto para agir", e a mídia consente em exibi-lo sem hesitação.

${ }^{91}$ Segundo levantamento de Carlos Dorneles, a imprensa especulou muito a respeito da fortuna de Bin Laden, cujo valor variava "de oitenta milhões a trezentos milhões de dólares", conforme os cálculos sem apresentação de provas de cada veículo de informação (2003:185). 
A repórter continua a informar, ao vivo: "Agora há pouco a agência de notícias espanhola EFE diz que um grupo chamado Exército Vermelho Japonês teria assumido a autoria do atentado. Um integrante do grupo telefonou para um jornal da Jordânia dizendo que era uma retaliação aos ataques nucleares a Hiroshima e Nagasaki, em 1945. Apesar da sede do FBI ser em Washington, toda a investigação sobre essa série de atentados será conduzida pelo escritório do $\mathrm{FBI}$ aqui em Nova York. Esse escritório é muito mais eficiente. Foi ele que investigou e solucionou o atentado de 1993".

Nenhum comentário, nenhum crédito para a informação de que um grupo japonês teria assumido a autoria dos atentados. Esse silêncio parece desqualificar qualquer informação que não partisse do "eficiente escritório" do FBI em Nova York, que saberia conduzir as investigações na direção que interessasse. Como não se atribui a ninguém a voz que elogia a divisão de Nova York, resta concluir que se trata de julgamento de responsabilidade do telejornal.

Na seqüência, o locutor anuncia o VT que mostrará a repercussão dos atentados no mercado financeiro: "As explosões nos Estados Unidos provocaram uma onda que em segundos atingiu os principais mercados financeiros do mundo. Bolsas de valores interromperam os negócios e as que funcionaram tiveram quedas violentas". O repórter falará da reação das bolsas no mundo todo, mas o início do VT reacende a lembrança das imagens das torres desabando e das torres envoltas em muita fumaça (figura 13): "As torres gêmeas, arrasadas pelo atentado, abrigavam mesas de operadoras de mercado do mundo inteiro, no coração do capitalismo globalizado. O impacto imediato foi muito mais além do que transformar um símbolo em fumaça".

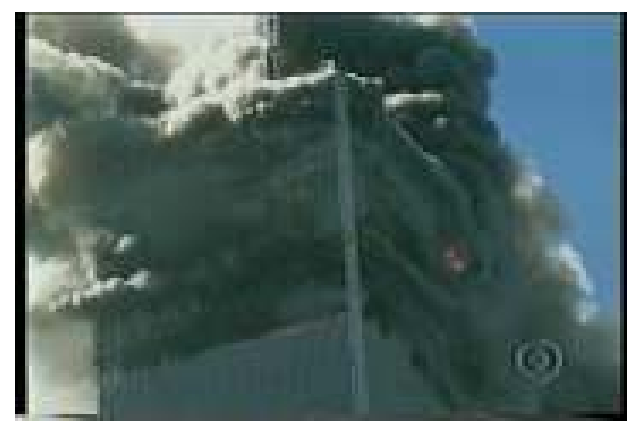

Figura 13 
As imagens e o texto reavivam a idéia de que o "coração do capitalismo globalizado" foi atacado, portanto se pode esperar conseqüências nas economias de todo o mundo. Essa notícia, de certa forma, tira os atentados de sob as luzes do espetáculo e os associa ao mundo concreto dos números e do dinheiro, sobre o qual o impacto é maior do que aquele que transformou "um símbolo em fumaça", na ótica subitamente realista do discurso. Segue-se uma profusão de índices de queda nas bolsas, para mostrar como "a onda de choque da explosão atingiu em cheio os mercados europeus" e também o brasileiro.

Aproveita-se mais uma vez para reiterar os componentes afetivos do discurso: "A paralisação dos negócios na bolsa de valores de São Paulo não foi apenas o resultado do horror e da emoção provocados pelas imagens vindas dos Estados Unidos, entre os operadores". E mais adiante, no mesmo VT: "Diante do clima de nervosismo, o governo preferiu cancelar três leilões de títulos públicos num total de 4,7 bilhões de reais em papéis. Refletindo temores de conflitos no Oriente Médio, o preço do barril de petróleo subiu $13 \%$ e chegou aos 31,05 dólares. Outro sintoma da insegurança: o ouro na bolsa de metais de Londres teve alta de $7 \% "$.

No entanto o VT se encerra com otimismo, em relação ao óbvio: "Mas economistas acham que o impacto imediato dos atentados em Nova York se desfaz também a curto prazo". Não é preciso ser especialista para saber que um impacto "imediato" não pode demorar muito tempo para se desfazer. De qualquer forma, entra uma única sonora a confirmar que essa é a opinião de "especialistas", voz de autoridade que todo telejornal deve inserir em seu discurso, de preferência em discurso direto.

Fala o economista Eduardo Gianetti: "Estamos sob o impacto de uma grande tragédia e é natural que, em um primeiro momento, a reação seja de uma certa histeria, movida pelo pânico de uns e pela especulação de outros, que tentam tirar proveito da situação, mas isso não é permanente. Isso vai durar alguns dias. A vida depois volta ao normal. A economia americana está em processo de desaceleração e isso pode até chegar a uma recessão, mas não será por causa dessa tragédia. Na verdade, a economia é muito mais robusta, e não é um acidente, um ataque terrorista que vai mudar grandes tendências e movimentos profundos que estão ocorrendo no mundo". 
É outra fala importante que tende a se perder no final de uma seqüência de imagens e informações que presentificam o pânico e a histeria, mas sua inserção provoca um grato acorde desafinado entre as vozes concertadas do discurso.

O locutor retoma imediatamente a sinfonia: "Veja a seguir. A aflição das famílias dos brasileiros que estão em Nova York. E as últimas informações sobre o dia que vai marcar a história". Entram imagens de pessoas correndo e policiais prestando socorro às vítimas. Como já dissemos, não há imagens chocantes de pessoas mortas ou feridas. $\mathrm{A}$ legenda da passagem de bloco é "escombros" e é somente isso que comporá a face visível da tragédia "que vai marcar a história" que começa a ser contada naquele dia.

\section{Bloco 5}

Nesse bloco, mostram-se algumas medidas de segurança tomadas no Brasil, o pronunciamento do então presidente Fernando Henrique Cardoso sobre os reflexos na economia brasileira e relatos de brasileiros que estavam em Nova York. A embaixada dos Estados Unidos e a de Israel foram fechadas. Reforçou-se a segurança nos aeroportos e nos consulados americanos de diversos estados.

O repórter relata a reação do governo brasileiro: "O Itamaraty divulgou uma nota condenando a violência e lamentando as mortes. O presidente Fernando Henrique Cardoso, se dizendo chocado e com uma preocupação extrema, acompanhou tudo pela televisão no Palácio da Alvorada. (Entra imagem do presidente diante da televisão e sobe o áudio de uma breve fala de FHC, a engrossar o coro do discurso citante: 'É uma guerra'.) O presidente mandou uma carta de solidariedade ao presidente dos Estados Unidos, George W. Bush, e repudiou o ato terrorista". Exibe-se imagem da carta de solidariedade e repúdio, com alguns trechos em destaque, para autenticar o discurso citante e também o citado.

Em seguida, Fernando Henrique fala de sua preocupação com os brasileiros que estão nos Estados Unidos, mas tranqüiliza o povo brasileiro: "Em Nova York, já existem no consulado telefones à disposição dos brasileiros para que eles possam acalmar suas famílias e mostrar que nada Ihes aconteceu. É provável que diante da virulência dos atos praticados haja conseqüências em todo mundo, principalmente econômicas. E o Brasil é parte do sistema mundial e pode vir a ser direta ou indiretamente afetado por essas 
turbulências. É inegável que se não houver uma ação atenta do governo as conseqüências podem ser maiores. E nós estamos atentos".

Para discutir as possíveis conseqüências, "principalmente econômicas", o presidente reúne-se com alguns ministros, "inclusive o da Fazenda", destaca o repórter, e convoca o Conselho de Defesa Nacional.

O locutor chama um VT que falará da apreensão das famílias de brasileiros que estavam em Nova York: "Até agora há pouco o Itamaraty ainda não tinha conseguido notícias sobre possíveis vítimas brasileiras. Entre os que sobreviveram aos atentados há relatos impressionantes".

O repórter passa a relatar "a angústia" dos parentes que tentam fazer contato com os Estados Unidos, mas não conseguem por causa do congestionamento das linhas. Usam-se três famílias para mostrar o drama. Mostram-se imagens das pessoas chorando e, em destaque, fotos dos parentes que estão sendo procurados. Duas famílias conseguem notícias. A outra, não. O rapaz trabalhava no World Trade Center. Os outros, não. Um deles, Fabrício Guimarães, desembarcara em Nova York naquele dia e fez contato com os irmãos por telefone.

A reportagem não mostra, portanto, "sobreviventes dos atentados", como anunciara o locutor. Apenas conseguiu falar com algumas pessoas que testemunharam o acontecimento, como Fabrício, cujo depoimento, por telefone, é divulgado pelo telejornal, que exibe a foto do rapaz como autenticação discursiva: "Eu cheguei acho que uns quinze ou vinte minutos antes da explosão. Eu cheguei a Nova York e o taxista me chamou a atenção. Eu estava na Long Island Express Highway e deu para ver muito bem a explosão em si. Quando eu estava chegando perto do meu objetivo, mais ou menos três ou quatro quadras do WTC, foi quando eu vi a queda da primeira torre. Foi uma coisa assim, muito, mas muito assustadora. Foi uma das coisas mais assustadoras que já vi na minha vida".

O jornal também falou por telefone com o advogado Paulo Lins e Silva, que "por pouco não tomou o vôo de Boston, justamente o avião que bateu na segunda torre", conta o repórter. Exibe-se a foto do advogado, enquanto se ouve seu depoimento: "Eu não entrei nesse vôo para Nova York porque era um vôo muito cedo e nós estávamos exaustos, voltando de Montreal para pegar um vôo que retardou demais. Eu estou muito 
nervoso aqui nos Estados Unidos, porque eu estou com minha família e nós não sabemos quando nós vamos sair".

Também não era um "sobrevivente dos atentados", mas sua voz é inserida no discurso para garantir um efeito de sentido de real. São pessoas de verdade, são brasileiros testemunhando, com seus "relatos impressionantes", o horror da tragédia, que não é somente diegética.

Apenas um dos entrevistados é um real sobrevivente. Larry Pinto de Faria Jr., funcionário de uma corretora, conseguiu sair a tempo do World Trade Center e conta, também por telefone: "Eu estava trabalhando. Nós ouvimos aquele estrondo, aquele barulho muito forte. Eu trabalhava no $25^{\circ}$ andar. Parecia a sensação de um terremoto. $O$ edifício balançou muito forte mesmo e nós fomos para a saída de emergência, para a saída de incêndio. O medo maior foram dois medos. O primeiro medo foi na escada de incêndio, porque não pode entrar em nenhum andar. Aquelas portas corta-fogo não têm acesso aos andares. E começou a subir fumaça e um cheiro muito forte de combustível. Deu medo para descer vinte e cinco andares de escada, com milhares de pessoas tentando descer ao mesmo tempo. Graças a Deus não teve pânico. O segundo avião se chocou contra a outra torre quando eu estava na escada. Eu não vi". Na ausência de imagens, essa voz vale como um fio de ouro na trama discursiva.

O locutor chama o repórter que estava em Brasília e tinha informações sobre o esquema de plantão do Itamaraty para atender os que procuravam notícias de brasileiros que moravam nos Estados Unidos. Ainda não se sabia se havia brasileiros entre as vítimas. Em seguida, o locutor chama um última entrada ao vivo de Nova York.

A repórter informa: "Daqui a pouco o presidente dos Estados Unidos, George Bush, faz um pronunciamento a nação. Ele já está na Casa Branca. E o tom do discurso vai ser de retaliação e impaciência. Ele vai dizer aos americanos: os Estados Unidos já foram testados várias vezes, sempre venceram, e agora, segundo ele, não vai ser diferente. Mas o presidente também vai fazer um apelo ao povo americano, para que o país volte ao normal. E os 170 hospitais de Nova York estão lotados. As vítimas estão sendo levadas para hospitais de outras cidades. A empresa aérea United Airlines acaba de informar que está liberando inicialmente 25 mil dólares para os parentes das vítimas. E um grupo de oposição ao Talibã assumiu a autoria das explosões em Cabul". 
O novelo final de informações só contém uma fonte explícita, a empresa aérea. As outras fontes são omitidas. Pode-se supor que tenha havido apuração para saber que os 170 hospitais de Nova York estavam lotados, o que leva a estimar o elevado número de vítimas, porém não se tem idéia de quem afirmou que um grupo de oposição ao Talibã assumiu a autoria das explosões em Cabul ou de quem informou com detalhes o conteúdo do discurso que o presidente Bush ainda faria.

A expressão "segundo ele", o presidente, está completamente deslocada, já que se trata de um termo característico de discursos relatados, feitos portanto no passado, apresentando a fala de um pronunciamento que ainda seria feito. São fontes ocultas, portanto vozes irreconhecíveis, que se dispõem no discurso telejornalístico, mas as informações que chegam ao vivo às mãos da repórter vibram nos momentos finais da edição especial do noticiário.

Ela continua: "Eu tenho mais uma informação aqui... A inteligência americana... Está difícil... A gente está recebendo essas informações ao vivo... (A repórter estava tendo dificuldade para ler um papel que acabaram de lhe entregar.) $A$ inteligência americana conseguiu interceptar mensagens de Osama Bin Laden sobre os ataques. Essa é a última informação que nós estamos acabando de receber aqui no escritório da Globo em Nova York".

A cena enunciativa flagra a notícia chegando. Há um suspense fortuito, que acaba fazendo incidir um efeito especial sobre o que se informará a respeito das mensagens interceptadas pela inteligência americana, a mesma que não detectara nenhum indício do seqüestro dos aviões ou do plano de ataque.

O tom do texto é enfático e peremptório e conduz à interpretação das últimas informações: não foram os Estados Unidos que atacaram Cabul, quem atacou os Estados Unidos foi Osama Bin Laden e vai ter guerra, afinal o "tom do discurso" do presidente Bush será de "retaliação e impaciência", conforme parece "profetizar" a repórter, ao antecipar um componente subjetivo do pronunciamento. Pode-se notar um movimento de manipulação cognitiva, pela qual se obtém o assentimento do público a uma opinião facilmente aceitável, que levará à aceitação quase automática de outra opinião. Os Estados Unidos são vítima e devem responder aos ataques. 
Era um prenúncio da cobertura que se seguiria, marcada por censura do governo americano e por distorções da própria mídia. Como afirma Dorneles, "não poderia existir episódio mais propício" para o início de um "bombardeamento ideológico", que se ampliaria na cobertura da mídia a partir dali: "Milhares tinham morrido nos atentados de 11 de setembro. Um ataque cruel, bárbaro. Quem poderia defender o assassinato de inocentes?" (2003:147). Quem poderia ser contrário à guerra depois de tudo o que se viu? Mas guerra contra quem? O rosto e o nome do terror já estão nos cartazes da televisão e ganharão as páginas dos jornais nos meses seguintes, ao contrário dos milhares de vítimas invisíveis que a guerra fará.

O jornal chega ao fim. A inflexão do locutor é grave: "O mundo assistiu hoje ao mais brutal de todos os ataques terroristas. Sem armas químicas, sem bombas atômicas. Aviões foram lançados contra símbolos do poderio americano. O pânico instalado no coração econômico do planeta. Imagens de filme, e que gostaríamos de ver tão-somente nas telas de cinema". Exibe-se então um videoclipe das imagens mais dramáticas dos atentados, incansavelmente repetidas pela mídia naquele dia e por muito tempo ainda.

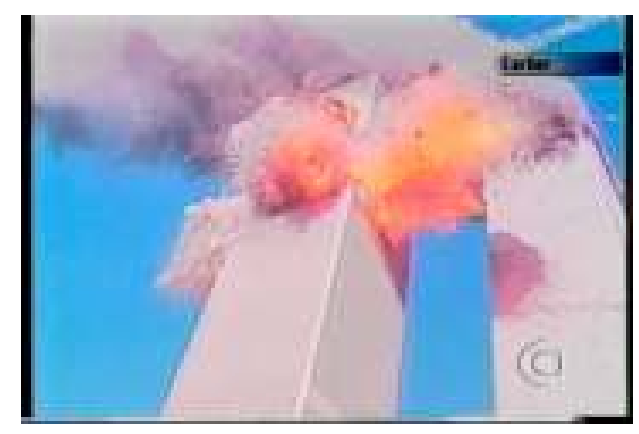

Figura 14

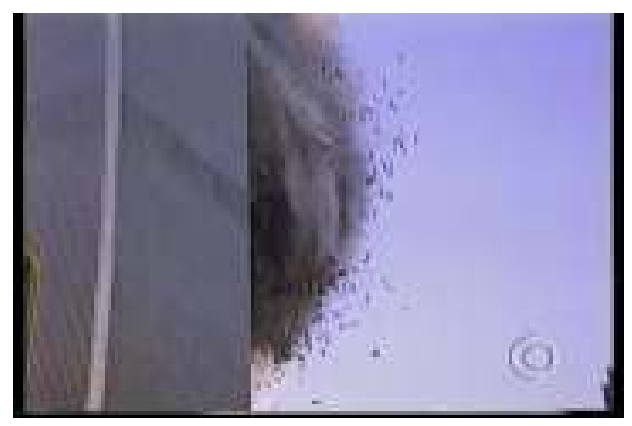

Figura 15 
Não há locução, apenas se ouvem gritos e sons do pânico. Vê-se novamente a fumaça sobre as torres, pessoas se jogando dos prédios, o choque do segundo avião (figura 14), pessoas gritando e correndo nas ruas, as torres desabando, a fumaça e a poeira negra tomando as ruas, mais pessoas correndo, outra vez o desabamento das torres (figura 15), outra vez a fumaça e a poeira negra sobre as ruas, pessoas feridas, escombros (figura 16) uma panorâmica da ilha de Manhattan sob espessa fumaça. Corta!

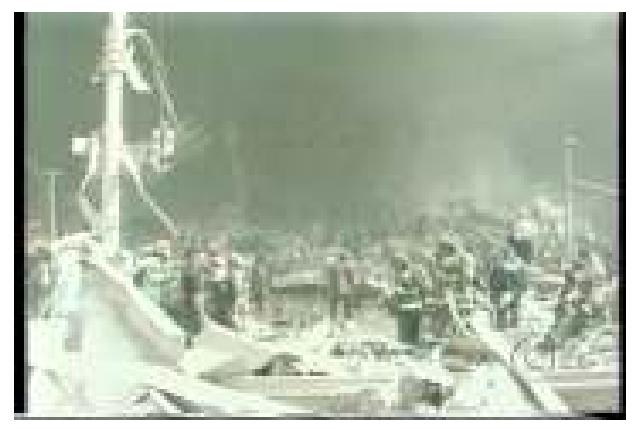

Figura 16

"Imagens de filme", que ninguém gostaria de ver, diz o discurso, mas a televisão precisa mostrar. É o que deve ficar na memória como aquilo que foi "o mais brutal de todos os ataques terroristas", sem que se explicite em nenhum momento os termos de comparação ou se procure explicar as possíveis causas do ataque. A referência a "bombas atômicas" chega a ser uma gafe, já que, ao que se sabe, terroristas não usam bombas atômicas, mas pelo menos uma nação já fez uso dessas armas em outro brutal ataque. No entanto a ação do filme desvia a atenção das falhas do roteiro.

O que vale é o efeito do discurso, que repete sem cessar - como o fazemos aqui deliberadamente - que o brutal ataque atingiu "símbolos do poderio americano", no "coração econômico do planeta". É o que deve ficar na memória do dia que mudaria a história, sem que se possa mudar a memória da história que contaram naquele dia. "Até amanhã", despedem-se muito sérios os locutores. E durante muitos amanhãs a mídia reprisará esse filme, favorecendo sua estabilidade referencial no domínio da memória. 


\section{011 de setembro no Jornal da Record}

Enquanto isso, na outra emissora, as imagens verbais e visuais reincidem, porém o contorno apresenta algumas variações. O que mais chama a atenção é a ausência de uma equipe da TV Record em Nova York. Não há um único repórter correspondente a dar informações sobre os atentados. O âncora Boris Casoy apresenta o telejornal e faz praticamente todas as narrações em off das notícias. Não há, portanto, imagens feitas pela emissora.

Muitas são imagens captadas pela televisão norte-americana CNN e reproduzidas pela Record, outras seguramente são de agências internacionais, pois podem ser vistas no outro telejornal. Especificamente em relação a essas imagens, é possível comparar os textos que as acompanham neste noticiário e no Jornal Nacional. Outras variações relevantes estão no modo de apresentação da escalada, na repetição de VTs inteiros ao longo da edição do telejornal e na inserção de comentários sobre os acontecimentos, marca registrada do âncora Boris Casoy ${ }^{92}$ em qualquer telejornal.

À primeira vista, os dois telejornais que ora analisamos podem ser considerados, devido à forma de apresentação, como produções de categorias diferentes quanto à objetividade. Há quem julgue que a presença de comentários torne um telejornal mais subjetivo e que sua ausência seja marca de neutralidade. Tal impressão não resiste a uma análise crítica, como já o provaram muitos estudiosos da comunicação, e pode ser subvertida diante da constatação de que existem inúmeras formas de comentar, interpretar e avaliar um acontecimento, seja pela própria voz de um sujeito enunciador aparente, seja por outras vozes subjacentes ao discurso.

Vejamos então em que pontos estratégicos se aproximam ou se distanciam as edições de 11 de setembro de 2001 do Jornal Nacional e do Jornal da Record, a começar pela escalada, segmento textual que revela muito sobre a estrutura do noticiário.

A escalada do Jornal da Record, diferentemente da do Jornal Nacional, não privilegia apenas a notícia dos atentados nos Estados Unidos. Como anuncia o apresentador, a que também chamamos "locutor", a escalada contém "as notícias mais

\footnotetext{
${ }^{92}$ Boris Casoy apresentou o Jornal de Record de junho de 1997 a dezembro de 2005.
} 
importantes do dia". Na época, o texto de abertura do telejornal não era acompanhado de imagens, portanto o telespectador não é imediatamente afetado pelo impacto do componente imagético, apenas entra em contato com o componente lingüístico do discurso, que aqui funciona como fio condutor. Eis o texto da escalada.

"Boa noite. Este é o Jornal da Record e estas são as notícias mais importantes do dia. Ataque terrorista destrói o World Trade Center em Nova York e atinge o Pentágono, em Washington. Há milhares de mortos e feridos.

As tropas americanas estão em alerta no mundo.

Bush promete caçar e punir os responsáveis pela agressão.

Explosões agora à noite na capital do Afeganistão podem indicar o início de uma retaliação. Nenhuma organização assume a autoria do atentado.

O milionário saudita Bin Laden encabeça a lista de suspeitos.

O primeiro-ministro de Israel diz que o ataque é uma declaração

de guerra aos Estados Unidos.

O líder da OLP, Yasser Arafat, condena a ação terrorista, mas palestinos comemoram nas ruas.

Os preços do ouro e do petróleo disparam.

No Brasil, o dólar bate novo recorde e a bolsa despenca.

Fernando Henrique prevê dificuldades na economia brasileira provocadas pela catástrofe.

O prefeito de Campinas, Toninho do PT, é assassinado ao sair de um shopping center.

O PMDB pressiona e adia a leitura do relatório que incrimina Jader.

Exausto, Guga é derrotado e está fora do Brasil Open."

Em comparação com a escalada do Jornal Nacional, pode-se notar que outros assuntos são considerados importantes, entre eles o assassinato do prefeito de Campinas, porém o tema predominante são os ataques. É importante observar, entretanto, que o tom do discurso não é exatamente o mesmo, é bem menos superlativo. Não se fala em "maior ofensiva terrorista de todos os tempos" ou em "banho de sangue", em "maior potência do planeta" ou em "horror de uma grande guerra".

De início, as informações são mais objetivas: "Ataque terrorista destrói o World Trade Center, em Nova York, e atinge o Pentágono, em Washington. Há milhares de 
mortos e feridos. As tropas americanas estão em alerta no mundo". Fala-se dos principais alvos dos atentados, não se descreve nem se mostra a imagem da explosão ou do desabamento das torres. Destaca-se que as tropas americanas estão em alerta "no mundo", e não que "o planeta" está em alerta geral. Fala-se em mortos e feridos, que não são mencionados na escalada do Jornal Nacional a não ser pela expressão metafórica "banho de sangue", que se refere muito mais ao ato do que ao efeito.

Mas eis que o discurso começa a enveredar pelo caminho das informações descontextualizadas e dos implícitos: "Bush promete caçar e punir os responsáveis pela agressão. Explosões agora à noite na capital do Afeganistão podem indicar o início de uma retaliação. Nenhuma organização assume a autoria do atentado. O milionário saudita Bin Laden encabeça a lista de suspeitos".

Ao contrário do outro telejornal, que apenas faz referência ao ataque ao Afeganistão, sem estabelecer relação de causalidade entre isso e os atentados nos Estados Unidos, aqui se indica essa ligação por meio da palavra "retaliação", imediatamente vinculada à informação anterior de que "Bush promete caçar e punir os responsáveis pela agressão". Observe-se que também nessa enunciação o discurso indireto repete o verbo performativo "prometer", que, como já vimos, não foi usado pelo presidente em sua fala. Com essa construção do discurso citado pelo citante, obtém-se o efeito de sentido de presença de uma firme atitude do presidente americano.

Além disso, nesse trecho já se implica o Afeganistão nos atentados e faz-se referência direta ao "milionário saudita Bin Laden", que não é citado na escalada do Jornal Nacional, como suspeito. O telespectador terá de acompanhar o telejornal para entender o motivo dessas relações, se é que ele se esclarecerá. O mesmo se espera quanto ao trecho seguinte: "O primeiro-ministro de Israel diz que o ataque é uma declaração de guerra aos Estados Unidos. O líder da OLP, Yasser Arafat, condena a ação terrorista, mas palestinos comemoram nas ruas".

O enunciado é menos direto que o do Jornal Nacional ("Nos territórios ocupados por Israel, palestinos comemoram a maior ofensiva terrorista de todos os tempos") e preocupa-se em informar primeiro que o líder palestino condena a ação terrorista, no entanto prepondera a idéia de que o povo palestino comemora o ataque. Também se 
destaca nesse trecho a referência a "declaração de guerra", que se repetirá em outros momentos do jornal.

Depois a escalada destaca a repercussão na área econômica e a manifestação do presidente brasileiro de forma mais dramática: "Os preços do ouro e do petróleo disparam. No Brasil, o dólar bate novo recorde e a bolsa despenca. Fernando Henrique prevê dificuldades na economia brasileira provocadas pela catástrofe". (A escalada do Jornal Nacional dissera apenas: "Bolsa de Valores e moedas internacionais são abaladas pelos atentados".) Diferentemente do outro noticiário, este não destaca a "análise de especialistas" nem o depoimento de "testemunhas da tragédia". Por enquanto a polifonia é discreta, assim como as formas de referenciação. Nesse trecho aparece a primeira anáfora avaliativa em relação aos atentados, retomados aqui pelo termo "catástrofe".

\section{Bloco 1}

Depois da escalada mais contida, o telejornal assume um tom parecido com o do Jornal Nacional. O locutor abre o bloco: "Foi o maior ataque terrorista da história. Três aviões comerciais americanos foram seqüestrados e lançados contra dois dos maiores símbolos do poderio militar e econômico dos Estados Unidos: o Pentágono, em Washington, e as torres gêmeas do World Trade Center, em Nova York. Ainda não é possível contar o número de vítimas, que deve chegar a milhares. Até agora os Estados Unidos e o mundo estão chocados".

Aqui já se usa a expressão "maior ataque terrorista da história", reincidente em toda a mídia, que decreta e dissemina a idéia de que nada se comparava àqueles ataques na história da humanidade. É importante notar que "história" vem sempre sem determinação. Não é a história dos Estados Unidos, da América, do Ocidente; logo é a história do mundo, desde sempre, o que, posto dessa forma, dá uma dimensão superlativa ao acontecimento.

Também se fala nesse trecho dos "maiores símbolos do poderio militar e econômico", afirma-se que o mundo está chocado e reitera-se a imagem verbal de que há milhares de vítimas. Vê-se portanto nesse discurso a mesma interpretação do evento, um ataque a símbolos americanos que abalou o mundo e deixou incontáveis vítimas. Há mudança na modalização do enunciado, mas a idéia geral permanece. Na escalada, 
afirmara-se que havia milhares de mortos e feridos; na abertura do bloco, diz-se que o número de vítimas "deve chegar a milhares". As poucas e imprecisas informações sustentam as edições dos telejornais daquele dia e ao mesmo tempo são transformadas em versão única dos fatos e sustentadas pelas imagens auto-suficientes que os noticiários documentam.

Nessa cabeça de matéria, notamos dois selos diferentes. O primeiro traz uma imagem do Pentágono antes do ataque e o segundo, a imagem de uma das torres em chamas, logo após o choque do segundo avião. Diferentemente da edição do Jornal Nacional, em que o selo é o mesmo em todas as chamadas do assunto, no Jornal da Record há diversos selos, alternado-se durante a edição, conforme o destaque de cada VT, porém o que aparece mais vezes é o que mostra uma das torres em chamas, a mesma imagem cristalizada no selo do outro telejornal.

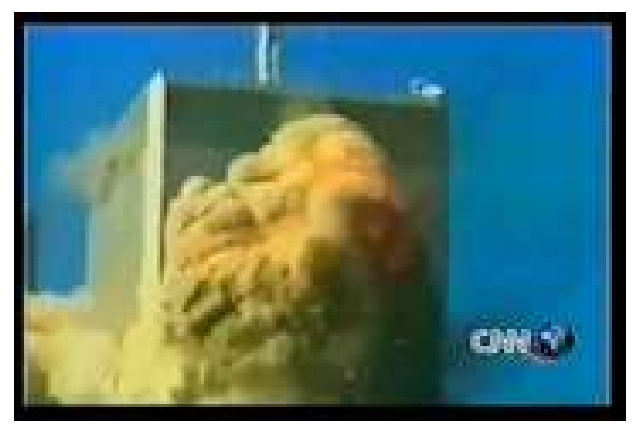

Figura 17

O locutor começa a narrar o primeiro VT: "A impressionante ação terrorista começou pela manhã (imagens das torres sob fumaça e das torres destruídas na parte superior). Num intervalo de apenas dezoito minutos dois boeings se chocaram contra as torres do WTC. (Aqui as imagens são da CNN, figura 17: o segundo avião se aproxima e se choca contra a torre.) Uma hora mais tarde o horror dos americanos se transformou em pânico (imagem do Pentágono sob fumaça). Um outro avião comercial se espatifou contra o Pentágono, a sede do comando militar dos Estados Unidos em Washington (imagem de parte do prédio em chamas, figura 18). Até então o enorme edifício parecia inexpugnável (novamente a imagem do prédio sob fumaça)". 
Observamos que as formas de designação do atentado começam a ganhar densidade dramática - "impressionante ação terrorista", "o horror dos americanos se transformou em pânico" - e as imagens emblemáticas, geradas pela CNN ou por agências internacionais, começam a reincidir.

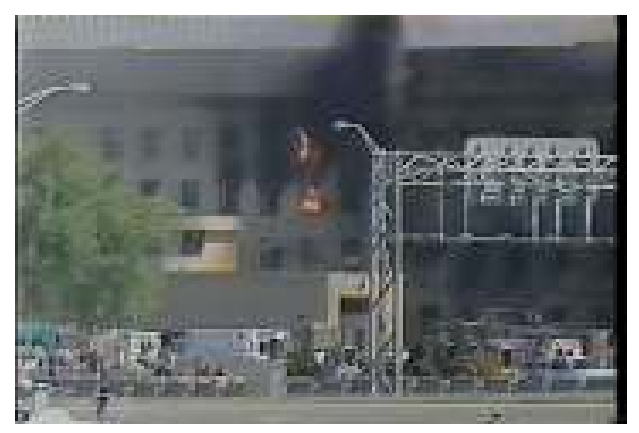

Figura 18

A narração prossegue: "A ação dos terroristas foi coordenada e quase perfeita (imagem de parte do Pentágono destruída). Quatro aviões de passageiros foram seqüestrados (imagem das torres sob muita fumaça, vista por novo ângulo). Dois deles, que tinham decolado em Boston, foram desviados para Nova York e lançados sobre o WTC. Um outro, que levantou vôo em Washington, foi forçado a dar meia volta e derrubado sobre o Pentágono. O quarto avião partiu de Newark, Nova Jersey, e caiu perto de Pittsburgh, na Pensilvânia (mapa e ilustrações dos aviões). Foi o único aparelho que os terroristas não conseguiram usar como arma de ataque" (novas imagens da CNN: floresta onde caiu o avião).

Destaca-se nesse trecho a versão dada como absolutamente certa de que se tratava de "ação terrorista coordenada", sem nenhum questionamento sobre a falha da segurança americana. A qualificação da ação como "quase perfeita", explicada pelo fato de que um dos aviões não pôde ser usado com "arma de ataque", soa como um misto de surpresa e admiração, mas não sabemos avaliar se tem efeito expressivo no conjunto discursivo.

No final do primeiro VT, cresce a dramaticidade da narração e das imagens: "A ação terrorista lançou os Estados Unidos num ambiente de grande confusão e pânico (imagens de pessoas correndo nas ruas, com máscaras - figura 19). Os americanos não conseguiam acreditar no que assistiam, ao vivo, pela televisão. No final da manhã esta 
era a imagem da América (as torres sob fumaça, ao longe, numa panorâmica da ilha). A estátua da Liberdade, solitária, pequena, coberta pela enorme nuvem do terrorismo (nova imagem da CNN: a ilha sob muita fumaça)".

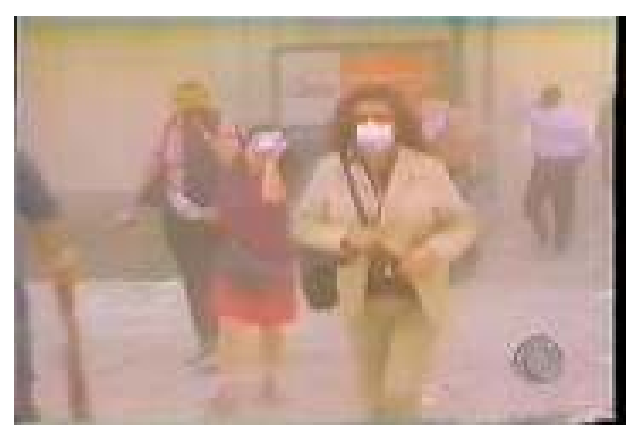

Figura 19

A palavra "pânico" também estende seus tentáculos por entre o discurso desse telejornal. Revê-se igualmente a idéia do inimaginável e do improvável. Reforça-se a idéia, no entanto, de que tudo era real, afinal pôde ser visto ao vivo, pela televisão, cavalo de Tróia da modernidade, pelo qual se infiltra toda e qualquer meta-realidade.

Põe-se em relevo a grande metáfora visual e interpretativa de que a América e a liberdade que ela representa - discurso dos Estados Unidos assumido pela voz do noticiário - estavam subjugadas naquele momento, submersas na "enorme nuvem do terrorismo" (figura 20), anáfora indireta que retoma os ataques e projeta um sentimento de que a ameaça ainda está no ar, em consonância com o que é sugerido também pela mensagem constante da CNN, "America under attack". Texto e imagem amplificam, poética e cinematograficamente, o discurso da vitimização americana.

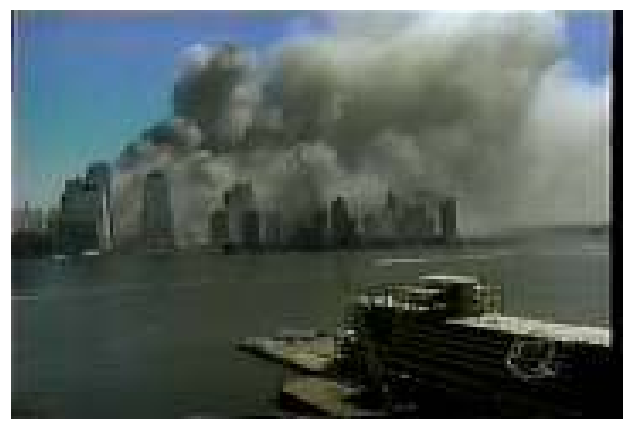

Figura 20 
Em seguida, o locutor chama o VT que mostrará o ataque ao World Trade Center: "As torres gêmeas do WTC desapareceram da paisagem de Nova York em duas horas". A narração é marcada pela redundância das imagens, pelos mesmos diversos ângulos disponíveis naquele dia: as torres sob fumaça, a parte superior das torres destruída, o choque do segundo avião e a explosão, pessoas em pânico.

Os olhos das câmeras e a voz do noticiário revivem o que é naturalmente irrepetível: "O terror em Nova York começou um pouco depois das 9 horas da manhã. Um avião comercial atingiu a torre norte do WTC. O prédio começou a pegar fogo. Dezoito minutos depois, quando as câmeras de televisão mostravam o incêndio e ainda não havia confirmação do que realmente havia acontecido, um segundo avião se chocou com a outra torre. $\mathrm{O}$ caos e o cenário de guerra se espalharam pelo sul da ilha de Manhattan, o distrito financeiro mais poderoso do mundo". Pelo universo diegético da mídia, espalhamse também o terror, o caos e o cenário de guerra.

O locutor prossegue, com pausas estratégicas para que sejam contempladas as imagens que o texto descreve: "As testemunhas contavam horrorizadas que viram muitas pessoas saltando do alto dos prédios em chamas. Os hospitais começaram a receber centenas de pessoas feridas e intoxicadas pela fumaça. Cerca de duas horas depois a primeira torre desabou".

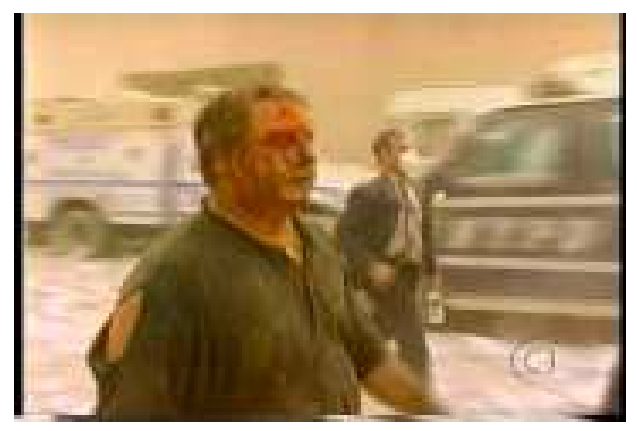

Figura 21

Nesse trecho, aparece a única imagem de uma pessoa ensangüentada andando pela rua (figura 21). É a mesma, aliás, exibida no "clipe" final de imagens do Jornal Nacional. No fim desse segmento, repetem-se imagens do desabamento das torres, de muita poeira e fumaça cobrindo as ruas e de pessoas correndo. Durante alguns 
segundos, suspende-se a narração e a meta-realidade preenche todo o espaço televisivo, como se inexistisse a mediação da instância midiática.

$O$ relato continua e informa-se sobre as medidas tomadas para esvaziar o sul da ilha de Manhattan. A moldura visual é iterativa: fumaça e poeira negra se espalhando pelas ruas, escombros, pessoas deixando o local, a ilha coberta por fumaça (figura 22). Mostra-se então o desabamento da segunda torre do "quinto prédio mais alto do mundo", com as mesmas incansáveis imagens, e informa-se que ainda não há balanço do número de vítimas. Fala-se também do desabamento de um outro bloco do complexo, o anexo 7 do World Trade Center, com a explicação prévia do locutor: "o WTC foi construído de forma a desabar para dentro no caso de um grande desastre como o que aconteceu hoje". Repete-se duas vezes, durante o off, a imagem do anexo desabando, o que também se observou no outro telejornal.

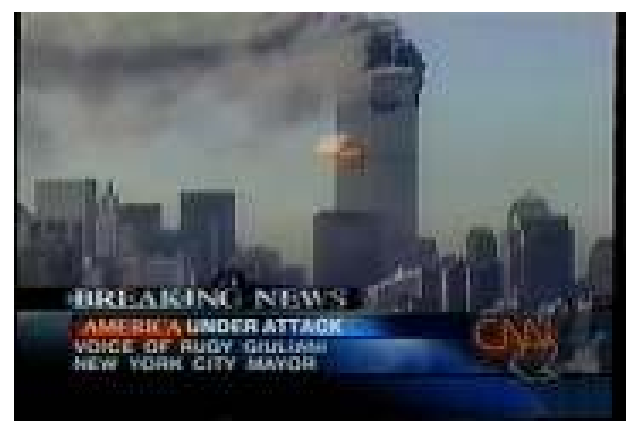

Figura 22

Em seguida, anuncia-se a primeira sonora da edição: "O economista brasileiro Raul Paulo Costa mora em Nova York há treze anos e trabalhava no WTC com o mercado financeiro. Ele contou por telefone como sobreviveu ao ataque".

A voz testemunhal presentifica o drama, enquanto novas imagens de prédios destruídos e escombros nas ruas se fixam na tela: "Eu tive a sensação da pancada, que foi muito, muito grande. O prédio balançou muito, várias vezes, e a sensação era que o prédio ia cair mesmo, então eu corri para a primeira escada de incêndio, que estava mais perto da minha mesa, e ela estava bloqueada. Eu desci até o $13^{\circ}$ andar e as portas travam automaticamente, aí ficou todo mundo preso dentro da escada de incêndio. Eu tentei sair por um outro lado do prédio, que provavelmente ia ter uma outra saída. Foi 
quando eu encontrei um bombeiro que tinha subido e ele falou pra mim que dava pra descer, mas que tinha muita água e muita fumaça. Por mim devem ter passado uns quinze bombeiros subindo e essas pessoas não conseguiram voltar".

Diferentemente do Jornal Nacional, o discurso não anuncia "relatos impressionantes de sobreviventes", mas seleciona uma fala que, ao final, introduz a imagem de um novo grupo de heróis no drama, os bombeiros que morreram em ação.

Eis que surge, na cabeça do VT seguinte, a palavra que melhor parecia traduzir, pelo menos segundo o discurso da mídia, a reação aos acontecimentos: "O mundo acompanhava, perplexo, as imagens de Nova York quando surgiu a notícia de que havia um terceiro atentado, desta vez na capital Washington. O alvo foi o Pentágono, o maior símbolo do poder militar americano".

Aqui também o mundo se afigura "perplexo" diante do ataque aos símbolos americanos. Exibem-se então novas imagens do prédio do Pentágono destruído, diferentes até das mostradas pelo Jornal Nacional, e relata-se o que sucedeu depois do choque do avião, do qual também não se vê sinais nas imagens.

Reforça-se a idéia de que nem o "prédio considerado o mais seguro dos Estados Unidos" escapou da ação terrorista e reitera-se a imagem - já transformada em verdadeiro símbolo - da "imensa nuvem de fumaça", formada também sobre a capital americana. $\mathrm{O}$ VT termina com uma seqüência descritiva, tanto no plano verbal quanto no visual, que enfatiza as conseqüências imediatas da tragédia: "Todos os prédios federais em Washington foram esvaziados. Jatos F16 passaram a sobrevoar a cidade. Toda a região foi tomada por carros de bombeiros e ambulâncias. Dezenas de pessoas foram hospitalizadas. O número de vítimas ainda não foi calculado".

Em seguida entra o VT com informações sobre o quarto avião seqüestrado, que caiu na Pensilvânia. O locutor antecipa que "há informações, ainda não confirmadas, de que ele teria sido abatido por caças da Força Aérea", mas não fornece as fontes do discurso citado nem se alonga em explicações que poderiam dar alguma pista de quanto a defesa americana sabia sobre a ação terrorista.

Depois de falar brevemente da queda do avião e mostrar imagens da CNN do lugar do acidente, que aliás não foram exibidas no Jornal Nacional, o telejornal volta a informar, com mais detalhes: "Havia 58 passageiros a bordo. A polícia informou que um deles 
conseguiu ligar do celular para o 911, número de chamada de emergência. O passageiro avisou do seqüestro e pediu ajuda. Há informações não confirmadas de que caças americanos derrubaram o boeing depois que o comandante não atendeu as ordens para aterrissar. Acredita-se que o boeing seria usado em mais um atentado".

O discurso relatado é todo marcado pela vaguidão - "a polícia informou", "há informações não confirmadas", "acredita-se" -, mas o discurso citante não hesita em passar as informações adiante, a despeito da falta de comprovação. Também não se questiona como as forças armadas poderiam ter tomado uma decisão dessa natureza tão rapidamente. Tudo se turva no redemoinho das informações e o telespectador tende a se quedar atônito diante da ação que se desenrola na tela, tentando entender as amarrações do roteiro do filme.

O tom do discurso volta a subir: "As tropas americanas entram em alerta no mundo inteiro. Declarada emergência em Washington, a capital dos Estados Unidos. E o presidente George W. Bush promete caçar e punir os terroristas que ousaram atacar o coração da América".

O discurso citante, em terceira pessoa, assimila o discurso citado com todas as letras, enfatizando a promessa de Bush e repudiando a "ousadia" dos terroristas que atacaram o "coração da América", forma de designação que revela o assentimento da mídia à imagem que os Estados Unidos têm de si mesmos.

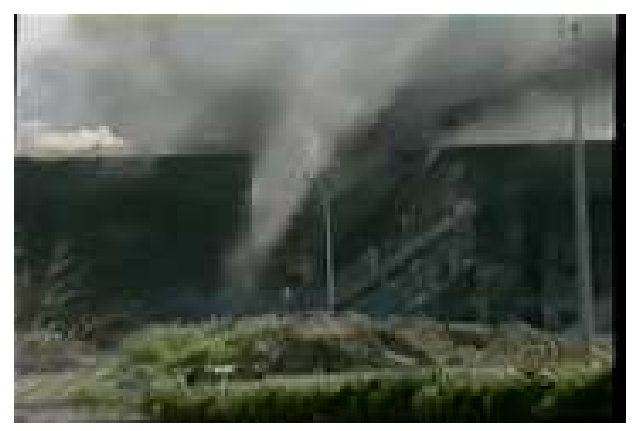

Figura 23

No início do VT, o locutor narra: "Em seu primeiro discurso aos americanos, de manhã, na Flórida, Bush falou duro, mas ainda pensava numa ação terrorista localizada (imagem de Bush discursando). Depois do ataque ao Pentágono, o governo americano 
entrou num ambiente de guerra (várias imagens repetidas do Pentágono sob fumaça, figura 23). O presidente sumiu. Ele foi levado para uma base militar em Louisiana e depois para uma outra base, em Nebrasca. Washington não era mais lugar seguro" (imagens da CNN: pessoas correndo e deixando os prédios).

Diferentemente do que se observou no Jornal Nacional, aqui não se sugere indício de covardia na atitude do presidente. Parece que o discurso trata seu "sumiço" como sinal de cautela e estratégia militar, já que o governo entrara "num ambiente de guerra" e que a capital "não era mais lugar seguro". De qualquer forma, também se reconhece nesse discurso uma história mal contada, em que se imiscuem referências a ações terroristas e a ações de guerra, sem que se expliquem as causas dessa relação estabelecida.

O telejornal continua a informar sobre as ações e o cenário de guerra, em que a figura principal é a ilha de Manhattan coberta por fumaça (figura 24), filmada por diversos ângulos: "A começar pela Casa Branca, os prédios públicos começaram a ser esvaziados na capital e nas principais cidades americanas. Todos os vôos foram cancelados e os aeroportos, fechados. A Força Aérea tinha ordem de derrubar qualquer avião suspeito. Vôos internacionais foram desviados para o Canadá. Os postos nas fronteiras entraram em alerta máximo. Navios de guerra patrulhavam a costa de Nova York".

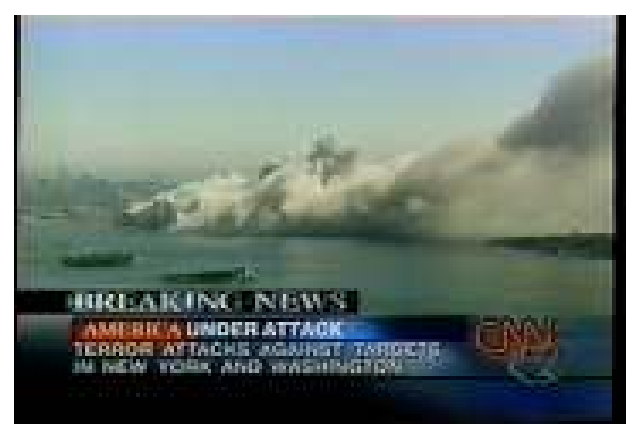

Figura 24

O locutor prossegue: "Por algumas horas, o pânico parecia dominar o país. (Entra uma seqüência de imagens da CNN: pessoas correndo e barulho de sirenes ao fundo.) Os boatos se sucediam. Notícias falsas de atentados e também de que haveria mais quatro aviões no ar controlados por terroristas. No meio da tarde, quando o governo parecia estar tomando pé da situação, Bush reapareceu numa base militar no Nebrasca 
(a mesma imagem de Bush chegando para discursar vista no Jornal Nacional). Foi quando prometeu caçar e punir os responsáveis pelo maior ataque terrorista da história americana".

Reitera-se a figura do pânico a dominar o país, porém acrescenta-se implicitamente que o clima se devia também a uma onda de boatos e notícias falsas ${ }^{93}$, no entanto o discurso citante não esclarece que voz determina quais notícias podem ser consideradas falsas ou verdadeiras.

Pela terceira vez, reproduz-se indiretamente a promessa do presidente americano e, pela primeira e única vez, a forma de referência "o maior ataque terrorista da história", que não foi usada pelo presidente em seu discurso, traz a especificação "história americana" (o off todo, com o mesmo texto, será repetido em outro bloco do jornal, por isso consideramos que a referência é feita uma só vez), que não foi vista nenhuma vez no outro telejornal, tampouco era a designação corrente durante a cobertura feita após os atentados. Vemos aqui outro exemplo de esgarçamento das tramas discursivas cujos fios se entrelaçam numa só direção.

Depois de informar que o presidente Bush faria um novo pronunciamento ainda naquela noite, o locutor assume seu papel de âncora e, rosto em close, tece o primeiro comentário da edição:

"Este foi o maior atentado terrorista já ocorrido em todo o planeta. E mais: grande parte dele foi transmitida, ao vivo, pela televisão, o que amplia muito a emoção já natural provocada na população americana que, perplexa, assistiu a ataques aos maiores símbolos do poder econômico e militar do país. Ainda não é possível saber de onde partiu o atentado. Pode ter sido realizado por terroristas de fora dos Estados Unidos ou até por grupos da extrema-direita americana, como no caso de Oklahoma. O fato de ser um atentado suicida aponta para um terrorismo internacional, como o do milionário saudita Bin Laden, protegido e escondido no Afeganistão, ou outros extremistas islâmicos. Há até gente que acha que traficantes de drogas podem ter sido os

\footnotetext{
${ }^{93}$ Após os atentados, instalou-se um clima de "alerta permanente" nos Estados Unidos, o que, segundo Dorneles, aumentava "o clima de medo e, é claro, o apoio a reações cada vez mais radicais" (2003:159), afirmação em consonância com a teoria de Michael Moore de que ao governo interessava manter a política do pânico, conforme mostra o filme Fahrenheit 11 de Setembro. Dorneles também destaca a cumplicidade da mídia nesse enredo: "O surgimento de 'ameaças' terríveis a cada momento de grande dificuldade para o governo americano foi uma constante desde o 11 de setembro. E, a cada nova história, a imprensa foi cúmplice passiva. Informações alarmantes eram passadas pelo governo, a imprensa publicava com
} 
patrocinadores desse atentado. Nenhuma hipótese pode ser descartada. A única coisa certa é que esse 11 de setembro marca o início de uma política inflexível contra o terrorismo, a partir de uma duríssima retaliação americana, até por pressão da opinião pública".

O hiperbólico termo "planeta" ganha seu lugar no enredo e o que era "o maior ataque terrorista da história americana" imediatamente se amplifica para "o maior atentado terrorista já ocorrido em todo o planeta". Curiosamente, o discurso comenta as conseqüências da transmissão ao vivo, que "amplia muito a emoção natural" provocada pelos acontecimentos, a qual se tenta reproduzir nos telejornais que tiveram de editar as notícias sobre os eventos. Retoma-se a idéia de perplexidade e de conspurcação dos símbolos americanos.

Outro ponto relevante é que, apesar de a escalada do telejornal ter alardeado que a lista de suspeitos era encabeçada por Osama Bin Laden, o âncora afirma que "ainda não é possível saber de onde partiu o atentado", porém dribla a contradição ao procurar explicar que aquele tipo de "atentado suicida" apontava para um "terrorismo internacional, como o do milionário saudita Bin Laden" (nesse noticiário ele não é "bilionário"). Não se esclarece, entretanto, o que se entende por "terrorismo internacional" e por que ele é praticado por "extremistas islâmicos".

$\mathrm{Na}$ contramão do discurso que propaga a suspeição em relação a Osama Bin Laden, esse comentário enfatiza que "nenhuma hipótese pode ser descartada", mas a contradição tornará a aparecer em outro bloco do telejornal. Por fim, há que se destacar a convicção de que sobreviria uma "duríssima retaliação americana", eufemismo para "guerra", e de que isso era inevitável, "até por pressão da opinião pública", que, salvo engano, estava em franco processo de formação, impulsionado pelo discurso da mídia.

O locutor retoma a meada das informações e convoca uma importante voz testemunhal: "Uma mulher que estava a bordo do avião que foi jogado sobre o Pentágono ligou do seu telefone celular para o marido quando começou o seqüestro. Barbara Olson contou ao marido que o avião estava sendo seqüestrado por mais de um homem, mas ela não sabia quantos eram. Barbara disse que os seqüestradores estavam armados apenas

destaque, criava-se o clima de histeria e, depois, ou aquele assunto era esquecido com o tempo ou vinha algum desmentido, sempre dado sem nenhum destaque" (op.cit.:160). 
com facas e canivetes. Eles empurraram todos os passageiros e tripulantes para o fundo do avião. Barbara ainda perguntou ao marido o que ela deveria fazer, mas não teve tempo de ouvir a resposta".

A imagem que permanece na tela durante todo o discurso indireto é uma foto de Barbara Olson, legendada com seu nome e as datas de nascimento e morte, 1955-2001. Sem dúvida é um relato que impressiona mais do que os dos "sobreviventes" invocados pelo Jornal Nacional, mas ambos os noticiários vão compondo seu dramático concerto polifônico com sucesso.

Entra em seguida um VT que mostra a reação de pessoas que tinham ido de Nova York para o Rio de Janeiro na manhã daquele dia, passageiros que, só quando desembarcaram, "souberam da tragédia que tinham deixado para trás". O recurso narrativo é o mesmo utilizado pelo outro telejornal. O repórter (a partir deste trecho começam a ser inseridas as vozes de outros profissionais da equipe de jornalismo, que fazem matérias no Brasil) costura breves falas de pessoas que tinham chegado dos Estados Unidos, ora traduzindo-as, ora interpretando-as, ora usando o discurso direto como ilustração.

Eis alguns trechos dessa sobreposição polifônica, que corrobora o medo, a perplexidade e a indignação das pessoas comuns, portanto tidas como neutras, diante do atentado: "'War?' (um rapaz fala somente essa palavra). 'Guerra?', perguntava esse americano perplexo. Esta outra estava transtornada porque o cunhado dela trabalhava no WTC. 'I'm very nervous and scare, because it's family' (a sonora não tem tradução nem crédito). Este jogador de basquete parecia não acreditar no que ouvia. Ele recebeu a notícia do amigo Charles Bird, que joga no Vasco e também é americano. As imagens foram descritas por Bird como cenas de um filme (o jogador fala em inglês, mas não há tradução). (...) O flautista Renato Axel tentou falar com os amigos que deixou em Nova York, mas não conseguiu. Os números para que ele ligou estavam ocupados. 'Isso envergonha a humanidade. Isso é uma declaração de guerra. Isso é uma ação de demente, loucos'." 
A seleção de vozes conseguiu reiterar algumas idéias correntes no discurso midiático naquele dia: a analogia entre as imagens dos ataques e cenas de cinema, a interpretação de que a "declaração de guerra" partira dos terroristas e a ausência de qualquer outra explicação para os ataques que não fosse a "insanidade" dos autores.

O próprio locutor reforça isso antes de chamar o bloco seguinte: "Uma ação que não tem qualquer justificativa". Justificativa e explicação são, equivocada ou convenientemente, tomados como sinônimos e o filme de ação continua, sem que se entenda satisfatoriamente o enredo. Nos dois telejornais se podem ver as marcas da manipulação cognitiva e afetiva. O locutor faz a passagem de bloco ${ }^{94}$ : "Veja a seguir. Líderes de todo o mundo reagem indignados contra o terrorismo. Os preços do petróleo e do ouro disparam e o mercado financeiro interrompe os negócios".

\section{Bloco 2}

O locutor anuncia o primeiro VT desse bloco: "Até o momento nenhuma organização terrorista assumiu a autoria dos atentados nos Estados Unidos. O terrorista saudita Osama Bin Laden encabeça a lista de suspeitos". A narração que se segue é completada por imagens de arquivo, que mostram Bin Laden (figura 25) e cenas de destruição referentes aos atentados que serão citados como sendo de autoria do terrorista saudita.

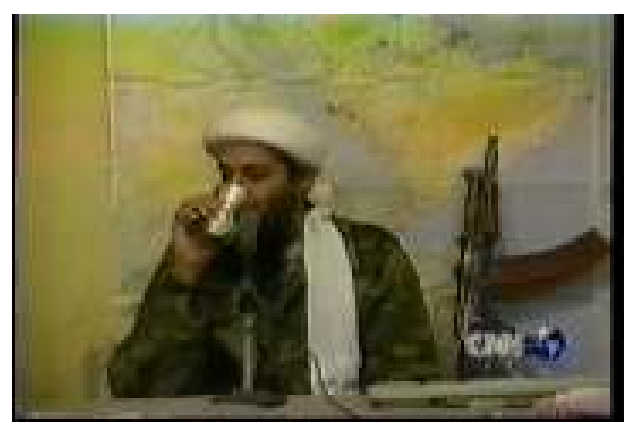

Figura 25

${ }^{94}$ Diferentemente do Jornal Nacional, as passagens de bloco nesse telejornal não apresentam imagens, portanto são um espaço a menos para a repetição de mensagens visuais. 
O texto, muito parecido com o do outro telejornal, também é marcado pelo discurso segundo sem explicitação das fontes: "Bin Laden é procurado pela Justiça americana, com recompensa de cinco milhões de dólares por sua captura. Ele é acusado de uma série de atentados: uma explosão na garagem no WTC em 1993 e as explosões nas embaixadas americanas no Quênia e na Tanzânia em 1998, que deixaram 257 mortos. Há informações na imprensa árabe de que ele teria anunciado, há três semanas, um ataque sem precedentes aos Estados Unidos. Bin Laden estaria escondido no Afeganistão, sob a proteção do Talibã, a milícia islâmica que controla o país. Hoje os líderes do Talibã negaram o envolvimento de Bin Laden e condenaram os atentados nos Estados Unidos".

O locutor continua: "Outros grupos extremistas islâmicos, como o Jihad, o Hamas, - Hezbollah e a Frente Democrática para a Libertação da Palestina, são hostis aos americanos (imagens de pessoas queimando a bandeira dos Estados Unidos), mas seus líderes também negaram o envolvimento e condenaram os atentados".

Em vez de designar-se os "grupos extremistas islâmicos" como suspeitos, preferese dizer que "são hostis aos americanos" e mostrar uma imagem que confirme isso, sem no entanto explicar os motivos desse sentimento. Por outro lado, não se dá nenhum exemplo de ação terrorista que esse grupos possam ter perpetrado contra os Estados Unidos, o que de certa forma demonstra que eles estão colocados em lugar de menor destaque na lista de suspeitos, assim como terroristas americanos que podem estar ligados ao grupo de Timothy McVeigh, responsável pelo atentado a um prédio federal em Oklahoma em 1995 e executado pela Justiça americana em junho de 2001. O governo americano aposta suas fichas em Bin Laden e a mídia banca a aposta.

O VT seguinte mostrará que "os principais líderes mundiais reagiram com indignação aos atentados nos Estados Unidos". O locutor destaca: "O presidente da Rússia e o chanceler alemão compararam os atos a uma declaração de guerra ao mundo civilizado. O presidente da China, Jiang Zenin, enviou um telegrama de solidariedade ao presidente Bush repudiando os violentos ataques terroristas".

A interpretação de que se trata de "uma declaração de guerra", referida antes por um rapaz no aeroporto, é legitimada nesse trecho pelas vozes de importantes líderes, que não hesitam em dizer que se trata de guerra "ao mundo civilizado", o que implica dizer 
que o mundo "bárbaro" está por trás dos atentados. Se o principal suspeito é árabe e é protegido por um país islâmico, é só somar dois mais dois e o resultado é uma grave acusação, reproduzida pela mídia.

O recurso usado para citar as falas dos líderes mundiais é o mesmo observado no outro telejornal. Exibem-se as mesmas imagens dos chefes de Estado discursando e o locutor seleciona e traduz, em discurso indireto, fragmentos das falas que reforçam o apoio aos Estados Unidos na guerra contra o terrorismo internacional: "O presidente da Rússia, Vladimir Putin, disse que os ataques terroristas ultrapassaram as fronteiras entre os países e são um desafio à humanidade. A mesma reação teve o chefe do governo alemão, Gerard Schoereder. Ele comparou os ataques a uma declaração de guerra a todo o mundo civilizado e afirmou que o povo alemão apóia o povo americano nesta hora difícil. O primeiro-ministro britânico, Tony Blair, convocou os chefes de segurança do país para uma reunião às pressas. Emocionado, disse que essa não é uma batalha entre os Estados Unidos e o terrorismo, mas entre o mundo democrático e o terrorismo. Afirmou ainda que não vai haver descanso enquanto o terrorismo não for varrido do mundo. $\mathrm{O}$ presidente da França, Jacques Chirac, reforçou a posição de que é preciso lutar contra o terrorismo". Como mencionamos na análise anterior, o alinhamento à única superpotência mundial é incondicional e nem se cogita a existência de outros tipos de terrorismo.

Em seguida, fala-se da reação de Israel, cujo ministro das relações exteriores também reputa os ataques como uma "declaração de guerra" e defende "uma resposta à altura do mal causado pelo terrorismo". A orquestra das vozes postas no discurso citante entoa um canto de guerra. O locutor também informa que Israel fechou o espaço aéreo para aviões estrangeiros e explica que "o temor do principal aliado dos Estados Unidos no Oriente Médio é também se tornar alvo dos atentados". O que não se explica é por que os aliados temeriam ser atacados se não fora aventado nenhum motivo político para os atentados contra os Estados Unidos.

Em todo caso, como informa o locutor, "tanques de Israel ocuparam a cidade de Jenin, na Cisjordânia, sob controle dos palestinos". (Note-se que o termo "tanques de Israel", que designa algo inanimado, é usado em lugar de "Israel", como a ocultar o verdadeiro agente da ocupação.) Tenta-se depois explicar a ação, mas não muito: "A 
medida, segundo o Exército, é preventiva, para evitar possíveis ataques de terroristas suicidas".

Assim os palestinos se afiguram como inimigos indiretos dos Estados Unidos e potenciais suspeitos dos ataques ao país e antecipadamente acusados de possíveis ataques a Israel. Ao contrário de Israel, que, segundo informa o locutor, decretara luto "em solidariedade ao povo americano" e colocara-se "à disposição dos Estados Unidos" para ajudar no que fosse necessário, "os palestinos estão divididos".

É com uma frase que revela uma oposição bastante subjetiva que o locutor chama o VT seguinte: "Enquanto as autoridades negavam participação nos atentados, a população festejava nas ruas" (figura 26). A notícia e as imagens distribuídas por agências internacionais também aparecem nesse telejornal, porém o discurso que as reproduz é bem menos virulento. Não se avalia a suposta comemoração como "celebração do ódio" nem se amplia o fato como "festa no Oriente Médio".

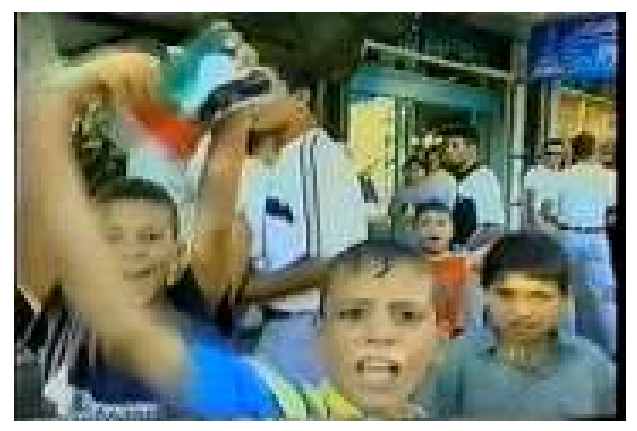

Figura 26

As imagens são exatamente as mesmas veiculadas por toda a imprensa na época e o locutor diz: "Pedaços de bolo distribuídos de mão em mão na cidade de Nablus, na Cisjordânia. Muitos palestinos foram às ruas comemorar os ataques suicidas nos Estados Unidos. O clima de festa, com tiros para o alto, chegou até os palestinos refugiados no Líbano. Cenas em contraste com as declarações oficiais. (Entram imagens de pessoas, principalmente crianças, dançando e cantando nas ruas, mas não se ouve o som de nenhum "tiro para alto".) O presidente da autoridade palestina, Yasser Arafat, condenou os atentados e mandou condolências ao povo americano e ao presidente Bush". 
A interpretação das imagens é menos subjetiva nesse telejornal, porém permanece a conotação geral de que palestinos comemoraram os ataques, muito embora se tratasse de um grupo pouco representativo, e não se explica por que eles haveriam de festejar o atentado $^{95}$. O registro dessa "festa" acabou sendo tomado como símbolo do contraste em relação às declarações oficiais, referido no discurso midiático como um sinal de que poderia haver dissimulação na reação das autoridades. Isso se observa nos dois telejornais, embora com menos contundência no Jornal da Record.

Em seguida, fala-se do ataque a Cabul e também nesse trecho se pode observar um empenho maior em esclarecer o contexto dos fatos: "Já era madrugada de quartafeira no Afeganistão quando as explosões começaram (são exibidas durante o off as mesmas imagens geradas pela CNN e vistas no outro telejornal). Os clarões podiam ser vistos ao longe em Cabul, a capital do país. As primeiras informações apontavam para uma retaliação dos Estados Unidos, já que o Afeganistão abriga o líder terrorista Osama Bin Laden, mas o governo americano negou qualquer envolvimento. Segundo a rede de televisão CNN, as explosões poderiam ser resultado de um ataque de rebeldes afegãos. Outra hipótese seria a explosão de um depósito de munições".

Esse texto contém mais dados, explicita uma possível relação entre as explosões em Cabul e os ataques nos Estados Unidos e é mais cauteloso em relação ao que se vê nas imagens da CNN, uma vez que não fala em "mísseis e armas antiaéreas" mas de "explosões", diferentemente do que se vê no Jornal Nacional. No entanto isso de certa forma desvia a atenção da suspeita de retaliação americana, pois a referência a "mísseis" não poderia se vincular às outras hipóteses.

\footnotetext{
${ }^{95}$ Pol De Vos, autor do livro 11 Septembre: Pourquoi ils ont laissé faire les pirates de l'air, relembra que muitas pessoas ficaram chocadas ao ver imagens de mulheres e crianças palestinas dançando nas ruas após os atentados. No entanto ele ressalta que ninguém se preocupou em explicar o ponto de vista da comunidade árabe, para quem era normal reagir com satisfação não ao deparar com a tragédia alheia, mas "ao descobrir que os Estados Unidos não são tão invencíveis como parecem", afinal se tratava do maior aliado de Israel, que faz guerra ao povo palestino há mais de cinqüenta anos. Pol De Vos também lembra que houve manifestações antiamericanas em outras partes do mundo, não mostradas pela mídia. Ele cita como exemplo uma faixa que se viu no Rio de Janeiro na época: "Um minuto de silêncio para as vítimas de Nova York. 59 para as vítimas da política americana" (entrevista à revista Solidaire, em 4 de setembro de 2002, disponível no endereço resistir.info/11set/article.phtml.html).
} 
Além disso, o discurso segundo sem esclarecimento das fontes deixa tudo muito vago ("as primeiras afirmações", "as explosões poderiam ser", "outra hipótese") e não há preocupação em desenvolver o assunto, que fica no ar como indício de que são fortes as suspeitas em relação a Bin Laden, caso contrário não haveria por que mencionar, no meio da matéria sobre os atentados, as explosões no país que abrigava o terrorista. Note-se também que a rede CNN ganha estatuto de fonte, mesmo sendo um veículo intermediário, o que comprova a já citada influência da mídia americana em grande parte do mundo ocidental.

Nesse segmento do telejornal, insere-se novo comentário do âncora, sempre enquadrado em close, aumentando o efeito de sentido de interlocução direta e franca com o telespectador:

"A CIA e o FBI são órgãos inteligentes americanos e certamente vão ser cobrados por não terem previsto o ataque. Previsão difícil porque o terrorismo é mesmo imprevisível e atinge de maneira cruel a população civil. A conseqüência política dos atentados de hoje é um fortalecimento da direita americana, especialmente dentro do partido republicano, o partido de Bush. Mesmo se ficar claro que o ataque veio de terroristas americanos, o exemplo basta para uma reação contra todo tipo de terrorismo, que na verdade só entende a linguagem da força e da violência. A reação americana dura, que ficou clara, extremamente clara, no pronunciamento do presidente Bush, será extensiva a países que recebem e protegem o terror. A saber: Afeganistão, Líbia, Síria, Iraque e Irã".

O âncora começa batendo e assoprando. Diz que o serviço de inteligência americano será cobrado por não ter previsto o ataque, mas imediatamente lembra que "o terrorismo é imprevisível". Entretanto o discurso tem o mérito de arriscar uma opinião sobre as conseqüências políticas dos atentados, o que não é pouco no contexto da interpretação fragmentada e superficial que se impunha na mídia. De qualquer forma, fica evidente a concordância com a reação bélica que se delineava no discurso do presidente Bush e cujos contornos eram reforçados pelas tintas do discurso midiático, afinal o terrorismo e os países que protegem o terror só entendem "a linguagem da força e da violência". 
Seguem-se informações sobre a repercussão dos atentados no mercado financeiro mundial e o locutor interpela a comentarista econômica Salete Lemos em tom alarmista: "Será que nós estamos à beira de uma recessão mundial?".

A jornalista sugere que o cenário de recessão é anterior aos ataques e faz uma reflexão sobre as conseqüências imediatas: "Ou já caímos nela, né, Boris? De certo até agora é que com os atentados de hoje no coração financeiro de Nova York muita coisa deve mudar nas relações dos Estados Unidos com o resto do mundo. Mudanças que certamente afetarão mais intensamente os países emergentes, destaque para Brasil e Argentina, hoje muito dependentes de recursos estrangeiros. Agora, as conseqüências econômicas dessa crise vão depender, claro, da intensidade da reação dos Estados Unidos aos atentados e também das origens dos atentados. Hoje suspeitas, apenas suspeitas de que os ataques partiram de grupos do Oriente Médio, por exemplo, já fizeram explodir os preços do petróleo".

Parece-nos uma voz ligeiramente dissonante no conjunto discursivo, uma vez que de certa forma alerta para o que poderia advir de um enfrentamento com o Oriente Médio, mesmo que a análise naquele momento se restringisse ao cenário econômico.

A comentarista conclui: "E as repercussões econômicas dos atentados sugerem desarranjos nas relações econômicas do mundo, FMI, Bird, BID inclusive, não temos a menor dúvida. Em tempo, o presidente do Banco Central americano, o Federal Reserve, Alan Greenspan, estava hoje na Suíça e, segundo agências internacionais, por enquanto vai continuar fora dos mercados. Na reabertura amanhã, dólar em queda frente ao euro, o iene e ao franco suíço. Na América Latina a reação foi contrária. $\mathrm{O}$ dólar fechou alto em relação às moedas locais. O resto, Boris, é expectativa".

Também aqui se nota um pouco mais de senso crítico, já que a analista pondera sobre o desequilíbrio nas relações econômicas internacionais - que fica evidente quando se percebe que o que afeta os Estados Unidos afeta ainda mais fortemente o resto do mundo - e desfaz a impressão de caos na economia mundial ao sugerir que as reações do mercado não foram surpreendentes e enfatizar que "o resto é expectativa".

Na seqüência, entram matérias do noticiário nacional: a morte do empresário José Hermínio de Moraes Filho, a eliminação do tenista Gustavo Kuerten do Brasil Open e a previsão do tempo. Depois o locutor dá uma nota sobre novas imagens do ataque: "Há 
poucos minutos a rede de televisão CNN divulgou essas imagens feitas por um cinegrafista amador. Elas mostram o segundo ataque ao WTC. O avião seqüestrado se aproxima e se choca com a segunda torre, provocando a explosão" (a seqüência de imagens é repetida duas vezes durante a narração). Chama-se o bloco seguinte: "Veja a seguir. Judeus e muçulmanos do Brasil condenam os atentados terroristas. E Fernando Henrique prevê efeitos negativos sobre a economia".

\section{Bloco 3}

O bloco começa com uma nota, sem imagens, sobre as idas e vindas do presidente americano naquele dia: "O presidente George W. Bush acaba de chegar a Washington a bordo do Air Force 1, o avião presidencial americano. Bush desembarcou na base aérea de Andrews e logo mais deve fazer um pronunciamento oficial pela televisão. Bush passou o dia fora de Washington por medida de segurança e esteve em duas bases aéreas: na Louisiana e no Nebrasca. Nas viagens, o boeing presidencial foi protegido por três caças da Força Aérea". Ressalta-se a idéia, já aludida no discurso, de que o presidente não estava fugindo, mas sendo protegido "por medida de segurança".

Depois o locutor chama o VT que falará sobre medidas de segurança tomadas no Brasil: "Tensão também em Brasília. Os Estados Unidos e Israel esvaziam embaixadas e reforçam a segurança. E os americanos que vivem no Brasil estão em alerta total". Palavras como "tensão" e "alerta" cumprem o destino da repetição. Imagens e texto descritivos mostram a mobilização da polícia militar e da polícia federal para proteger a embaixada americana em Brasília "à medida que crescia a gravidade dos atentados".

O repórter informa: "Em comunicado divulgado pela embaixada, os americanos no Brasil são aconselhados a permanecer no mais alto nível de alerta. Eles foram orientados a aumentar a segurança pessoal, evitar exposição desnecessária e não abrir qualquer correspondência cujo remetente seja desconhecido".

Divulga-se, pela inserção da voz da embaixada, a importação do pânico para os americanos que vivem no Brasil, que deviam seguir recomendações que criavam um clima de histeria, como se nenhuma parte do mundo fosse segura para os cidadãos dos Estados Unidos. 
O repórter continua: "Tensão também na sede da delegação especial da Palestina no Brasil. Ao longo do dia, passaram pelo local embaixadores e representantes de países árabes. Eles temem ser associados ao terrorismo. O representante da delegação palestina divulgou comunicado onde pede cautela à imprensa brasileira. Musa Amer Odeh condenou os atentados. Ele citou Jesus Cristo para pedir paz e amor ao mundo".

As vozes dos representantes de países árabes são genéricas e apresentadas em discurso indireto. A última fala não é traduzida. O repórter apenas afirma que 0 representante palestino "citou Jesus Cristo", mas não revela o contexto da alusão. É interessante observar nesse trecho que se dá espaço para o comunicado em que a delegação palestina pede cautela à imprensa e que se permite a inferência de que a imprensa poderia fazer a associação de países com o terrorismo. É tudo muito discreto e o acorde singular pode passar despercebido para o telespectador envolvido pelo andamento alegro do telejornal, mas ao menos ele está lá.

Falou-se da Palestina. Fala-se também de Israel: "A embaixada de Israel foi esvaziada ao meio-dia. O embaixador, os conselheiros e familiares foram levados para lugar seguro e não divulgado. O conselheiro da embaixada de Israel, Daniel Zuar, resumiu em uma frase o impacto da tragédia: Daqui pra frente, segundo ele, combater o terrorismo vai ter que ser prioridade mundial".

Como no outro telejornal, têm destaque tanto as reações da Palestina quanto as de Israel, mas não se explica suficientemente por que razão o conflito entre os dois povos parece ter estreita relação com os atentados nos Estados Unidos. Vai-se formando uma renitente imagem de quem é quem na iminente divisão do mundo entre bandidos e mocinhos, bárbaros e civilizados, inimigos do terror e inimigos dos Estados Unidos.

O locutor reforça a idéia de que árabes e muçulmanos (era constante a confusão entre nacionalidade e religião na mídia) festejaram os atentados: "Líderes da comunidade árabe em São Paulo, incluindo palestinos, condenaram o atentado aos Estados Unidos, mas nas ruas houve quem comemorasse".

Entretanto o VT mostrará a manifestação verbal de uma única pessoa alegre, e não exatamente pelo motivo apontado: "O Brás, bairro tradicional do centro da cidade, concentra comerciantes da comunidade árabe. Nas ruas muitos lojistas libaneses não quiseram falar sobre o assunto do dia. Já esta mulher muçulmana (figura 27) chega a 
dizer que o atentado pode chamar a atenção para o problema dos palestinos e resume o que sentiu quando soube do atentado: 'Alegria. A primeira coisa, alegria'".

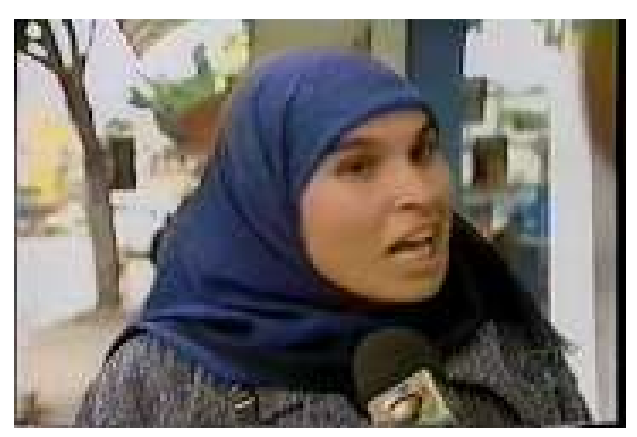

Figura 27

É preciso notar que não se trata de uma "comemoração" do atentado, mas da expressão de contentamento diante da possibilidade de os atentados chamarem a atenção para o problema dos palestinos, embora a mulher não explique, ou não tenha espaço para explicar, as razões de sua expectativa. Além disso, pode-se observar que sua opinião sobre o atentado é apresentada em discurso indireto, introduzida pela locução verbal "chega a dizer", enquadramento que predispõe a ouvir o que ela diz como algo ultrajante, em especial o que vem na seqüência e é estrategicamente mostrado em discurso direto: "Alegria. A primeira coisa, alegria". É o que basta para generalizar e ajudar a fixar a imagem de que o mundo árabe está em festa.

O discurso então, ambiguamente, se inclina para a atenuação dessa imagem: "Mas o sentimento da maioria é de repúdio ao terrorismo (entra a sonora de um comerciante). 'Eu acho isso muito ruim. Extremamente terrorista mesmo. O povo que fez também'".

O mundo metonímico da televisão fica outra vez evidente. Fala-se em "maioria" e mostra-se somente uma manifestação de repúdio ao terrorismo. A fala nada acrescenta em sua redundância (o ato terrorista é extremamente terrorista), mas fica uma pergunta curiosa: a que "povo terrorista" o rapaz da comunidade árabe poderia estar se referindo?

O repórter continua: "Representantes no Brasil de entidades islâmicas, incluindo os palestinos, também condenaram com veemência o atentado aos Estados Unidos". É a segunda vez que se tenta reforçar no discurso a idéia de que também havia palestinos entre os que condenavam o atentado. Nas duas vezes, usa-se a expressão "incluindo palestinos", como a enfatizar o contraponto com as imagens de comemoração mostradas. 
Não sabemos avaliar se o discurso busca demonstrar isenção, se é manifestamente ambíguo ou se inconscientemente revela um mea-culpa. O efeito de sentido que parece restar é que se faz necessário lembrar que a posição oficial dos palestinos é de condenação aos ataques, mas também não nos parece claro se isso tem conotação positiva ou negativa.

Como exemplos da condenação, entram sonoras de líderes palestinos devidamente identificados: "Não se justifica. Nenhum argumento político, nenhuma causa justifica um ato dessa natureza." (Hanna Yousef, secretário-geral da comunidade palestina na América Latina e Caribe) "Covarde. Não admito isso. Não ajuda nossa causa." (Hassan Emleh, presidente da Federação Palestina no Brasil)

São curiosas as falas desses líderes. Um afirma que nenhuma causa justifica o ato terrorista, como a pressupor que haja alguma causa por trás dos atentados. O outro reclama de que o ato covarde não ajuda a causa dos palestinos, como a insinuar que haja palestinos envolvidos. Como provavelmente se trata de fragmentos de falas mais amplas, não se dá a conhecer seu contexto, o que impossibilita uma interpretação mais precisa. Fica a impressão dos interditos.

Há mais uma sonora, a de um líder da Juventude Palestina, que representa trinta mil jovens palestinos e descendentes que vivem no Brasil, segundo informa o repórter. A fala é inserida em dois movimentos: uma parte por discurso indireto e outra por discurso direto. O repórter relata que o líder "diz que nada justifica a ação dos grupos terroristas" e o rapaz diz com as próprias palavras, sem implicar nenhum grupo explícita ou implicitamente: "Ficamos muito entristecidos e condenamos esses ataques de forma severa. Que sejam condenadas as pessoas que cometeram esses ataques". A inserção da fala cumpre a função de ratificar a idéia de veemente condenação aos ataques por parte da comunidade árabe, conforme se anunciara na chamada do VT.

A matéria prossegue, agora chamando a atenção para a reação da comunidade judaica, que, segundo o locutor, estava indignada e preocupada. O repórter volta a insistir na imagem da tensão: "O passo normalmente apressado, marca dos judeus moradores de São Paulo, hoje tinha um ritmo mais tenso. Escolas e sinagogas tiveram a segurança reforçada". Pelas imagens, não é possível reconhecer o "ritmo mais tenso" de que fala o 
repórter. Mostra-se judeus andando normalmente nas ruas. O texto orienta os olhos para o que se quer indicar discursivamente.

O repórter continua: "Como medida preventiva, a Federação Israelita de São Paulo determinou que as 54 entidades filiadas suspendessem as atividades no dia de hoje, incluindo aí clubes, hospitais, sinagogas e todas as escolas israelitas do estado de São Paulo. Cuidados de um povo que convive com atos terroristas desde a criação do estado de Israel".

O termo anafórico com que se designa os israelenses é "povo que convive com atos terroristas desde a criação do estado de Israel". Eis então que se apresenta Israel não só como o principal aliado dos Estados Unidos no Oriente Médio, mas também como grande vítima do terrorismo, por meio de um movimento de manipulação cognitiva.

Informa-se também que o consulado israelense em São Paulo foi fechado por medida de segurança. O consulado do Rio de Janeiro já recebera uma "ameaça de bomba". Insere-se a sonora do cônsul de Israel em São Paulo para confirmar a preocupação da comunidade judaica no Brasil, mesmo que ela fosse provocada apenas por boatos: "O consulado no Rio recebeu uma ameaça que o que está passando nos Estados Unidos vai passar também para o consulado no Rio, consulado em São Paulo e embaixada no Brasil".

A matéria sobre a reação dos judeus no Brasil convoca outras vozes. O repórter faz a introdução: "O atentado aos Estados Unidos provocou indignação geral entre os judeus de São Paulo, remetendo a colônia ao conflito no Oriente Médio". Um rapaz judeu avalia: "Quando existem pessoas que a vida deles, o propósito deles é matar outras pessoas, acabar com vidas, destruir famílias, e o mundo não condena, isso daqui nunca vai chegar a lugar nenhum". Uma mulher judia assim expressa sua expectativa: "Acho que agora virá uma pressão e vai haver então... um processo de paz deve estar chegando. Eu espero, acredito assim".

Mais uma vez o discurso opera por meio de metonímia. A "indignação geral" resume-se à fala se duas pessoas da comunidade judaica, mesmo assim só uma delas se mostra indignada e diz que é preciso condenar atos como aquele. A outra manifesta a esperança de que o atentado desperte para a necessidade de um processo de paz. A introdução do repórter indica que esses judeus também associam os ataques ao conflito 
no Oriente Médio. É a reiteração da imagem de que são obscuras as razões do atentado, mas tudo indica que tem alguma coisa a ver com o Oriente Médio. Resta ao público descobrir o que pode ser por outros meios.

Na seqüência, um VT fala da "aflição" de brasileiros que tinham parentes morando em cidades americana e que "passaram o dia pendurados no telefone", o que fez com que a Embratel registrasse um aumento de quarenta vezes no número de chamadas e impediu que se completasse mais do que $9 \%$ das ligações para os Estados Unidos naquela manhã.

A personagem que representa a "apreensão" dos brasileiros é Maria Braga, que tentava falar com a irmã que morava "a poucas quadras do World Trade Center", a atriz Sonia Braga. A mulher conta que conseguiu falar com a irmã, cuja foto aparece ao lado de sua imagem no vídeo: "Ela acordou com o barulho do avião e logo depois o estrondo, que foi a batida do avião. Aí depois ela me ligou da rua dizendo que continuava bem e que estava tudo bem, que estava tranqüilo. Agora estou aguardando que ela ligue novamente para dar notícias, porque só ela me ligando, porque a gente não consegue completar nenhuma ligação para lá".

O conteúdo da fala não é relevante, mas a inclusão de uma personagem ligada a uma atriz famosa tende a chamar a atenção do público para o drama vivido em Nova York e para o fato de que aquilo também atingia os brasileiros.

O VT termina com a imagem de pessoas parando para ver os jornais numa banca. O repórter conclui o texto: "No final do dia, diante das edições extras dos jornais cariocas, as pessoas ainda se mostravam perplexas com o que aconteceu". A falta de conexão com o assunto da busca por informações de brasileiros nos Estados Unidos parece indicar um problema de edição. A imagem foi encaixada em qualquer lugar do telejornal e aproveitou-se para falar mais uma vez do clima de perplexidade. O locutor aproveita o gancho para informar que "o medo se espalha" também em Miami, onde vivem milhares de brasileiros.

Ele chama o VT seguinte, gravado pelo único repórter da emissora nos Estados Unidos: "O clima de tensão se instalou nos Estados Unidos (imagens de policiais nas ruas). Os atentados que destruíram o WTC e atingiram o Pentágono só foram possíveis com o seqüestro de boeings comerciais, o que fez com que, de imediato, o governo 
americano suspendesse todo tráfego aéreo no país (imagens de aviões e de aeroportos vazios). A comunidade brasileira em Miami está perplexa. $O$ atentado que atingiu as cidades de Nova York e Washington também fez estragos no sentimento de segurança dos americanos. Aqui no Aeroporto Internacional de Miami todos os vôos foram cancelados e ainda não está prevista a normalização do tráfego aéreo da região".

Tanto ou mais do que as imagens, palavras como "tensão" e "perplexidade" vão se colando na memória, assim como a grande metáfora de que o atentado "fez estragos no sentimento de segurança dos americanos".

Fala-se novamente da "grande aflição" de famílias brasileiras em busca de informações, só que agora é a parentes e amigos residentes em Miami que o discurso dá voz. Duas moças falam atropeladamente, personificando a aflição: "A comunidade brasileira, está todo mundo junto, mas a gente não consegue falar com eles mais, desde às 11 horas agora não se fala mais." "Eu estou preocupada com minha amiga que foi para Nova York e a gente não tem notícia dela."

O repórter então diz que o cônsul brasileiro em Miami "não acredita que os atentados cheguem a essa cidade". A sonora do cônsul é usada como justificativa: "No condado de Miami, onde residem alguns milhares de brasileiros, não se registrou nenhum ato terrorista, nenhum incidente que seja do nosso conhecimento".

$\mathrm{Na}$ falta de informações sobre os brasileiros que vivem em Nova York, dá-se a boa notícia de que os brasileiros que moram em Miami parecem não correr risco. A propósito disso, o locutor dá uma nota: "O Itamaraty ainda não tem informações sobre brasileiros feridos no atentado nos Estados Unidos, mas colocou um serviço de atendimento 24 horas para receber ou prestar informações sobre possíveis vítimas brasileiras".

São informados os telefones do Itamaraty e do consulado brasileiro em Nova York e o locutor dá outra nota: "O governo americano informou agora há pouco que ainda não tem uma estimativa do número de mortos e feridos nos atentados de hoje. A polícia de Nova York fala em milhares de mortos, talvez dezenas de milhares". Continua a especulação sobre o número de vítimas e aqui também se fala, como no outro telejornal, em "dezenas de milhares" de mortos.

O número assustador parece acionar a necessidade de exibir novamente as imagens do "maior ataque terrorista da história", mas não só as imagens. No meio do 
terceiro bloco, o telejornal repete - não sabemos se por falta de material editado ou se por outro motivo qualquer - o primeiro VT do primeiro bloco. Tudo exatamente igual: texto e imagens. $O$ meta-real se baseia no real e agora se vê a cópia da meta-realidade. $O$ efeito da superexposição das imagens visuais e verbais atinge em cheio a memória.

O locutor muda um pouco a introdução, mas é honesto ao avisar que veremos novamente como foi a ação: "Foi o maior ataque terrorista da história. Aviões comerciais foram seqüestrados e lançados contra o Pentágono em Washington e as torres gêmeas do WTC, em Nova York. Veja novamente como foi a ação terrorista que deixou os Estados Unidos e o mundo em estado de choque".

O VT é aquele que se inicia com "A impressionante ação terrorista começou pela manhã" e termina com "No final da manhã esta era a imagem da América. A estátua da Liberdade, solitária, pequena, coberta pela enorme nuvem de terrorismo" (figura 28). E a memória do público vai sendo coberta pela enorme nuvem da repetição.

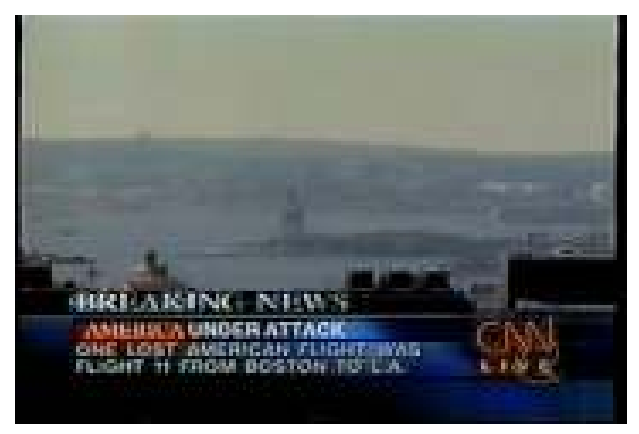

Figura 28

Arbex se refere aos efeitos da infinita repetição que se viu na cobertura do 11 de setembro da seguinte forma: "Tantas vezes foram repetidas as cenas dos aviões se chocando com as torres, que elas acabaram sendo metabolizadas, domesticadas pelo telespectador. Na enésima reapresentação da cena, não havia mais novidade alguma: o cadáver estava completamente dissecado. Já não víamos mais o registro do acontecimento: apenas confirmávamos aquilo que já estava inscrito na memória. Mal víamos o avião e já nos lembrávamos de tudo o que iria acontecer nos instantes seguintes. Em outros termos, o primeiro fotograma da seqüência disparava o gatilho da memória visual; dali para a frente, tudo se passava como um filme já visto; alguém 
poderia desligar o televisor e ainda veríamos o avião se chocando com a torre, a bola de fogo, o estremecimento do prédio, o pânico" (2003:54).

O mais impressionante é observar que esse processo se instaura numa edição de telejornal no mesmo dia dos acontecimentos. Diversos VTs serão repetidos a partir do trecho citado e até o final da edição do Jornal da Record naquele dia. Não só as imagens serão "metabolizadas", como também o contorno verbal que condiciona sua interpretação. O público vê e revê, ouve e ouve de novo o que já começa a se inscrever na memória que será confirmada em toda a cobertura posterior aos ataques. A formação da memória social daquele acontecimento é flagrante, com todas as lacunas e silenciamentos que o discurso da mídia promove enquanto registra a sua versão dos fatos.

Ainda no terceiro bloco, entra uma reportagem que mostra como foi a repercussão dos ataques entre os brasileiros. Entram diversas sonoras de pessoas anônimas, gravadas em várias cidades brasileiras e emoldurados por comentários do repórter, que iam ressaltando o clima de medo. O VT começa com a imagem de um homem vendo as notícias pela televisão. O repórter faz alusão ao fato de que não se tratava de cenas de filme: "Expressão de dor diante de cenas reais". O homem diz: "Eu não esperava acordar e ver uma coisa assim". De um outro, o repórter traduz o sentimento de forma redundante: "O paraense, mesmo distante, sentiu medo". O homem expressa o que capta de tudo aquilo: "Eu não sei direito, mas estou com medo". Um outro reforça: "É pra ficar com medo, né?".

Mas o coro tem vozes que surpreendem. Uma tem timbre político: "Esses ataques são um retorno dessa política neoliberal excludente que os Estados Unidos vêm lançando pelo mundo." Outra, timbre espiritual: "É devido à falta de Deus, né? Acho que o pessoal não tem Deus, a maioria". O repórter parece não ter ouvido a crítica à política americana $\mathrm{e}$ anuncia as sonoras seguintes dizendo que "ainda sobrou para os Estados Unidos", num tom de ligeira censura.

Uma voz implacável diz: "Eles devem estar sentindo agora o peso que o cidadão inocente sente. Eles também devem estar sentindo, jogando bomba em cima deles lá." Outra, um pouco mais branda, avalia: "Concentração de poder demais lá nos Estados Unidos está deixando muita gente doida." Julgamos que a presença dessas vozes tem o forte efeito de simular a democratização de opiniões no discurso, no entanto a 
reverberação de tais vozes críticas tende a se anular por se tratar da opinião de pessoas simples e anônimas. Nenhum "especialista" que tenha pensamentos semelhantes será chamado a participar desse coro.

Um repórter faz uma passagem numa importante avenida de São Paulo. Enquanto ele fala, mostra-se um telão no qual se vê a imagem das torres do World Trade Center sob muita fumaça. Num sofisticado recurso de metalinguagem, a câmera que mostra o telão (figura 29) vai se deslocando e se detém no repórter, que está dizendo: "Mais de dez horas de vôo, oito mil quilômetros nos separam de Nova York, mas não da tragédia. Mesmo de longe, quem acompanhou sabe que vai ser difícil não se lembrar desse atentado daqui pra frente".

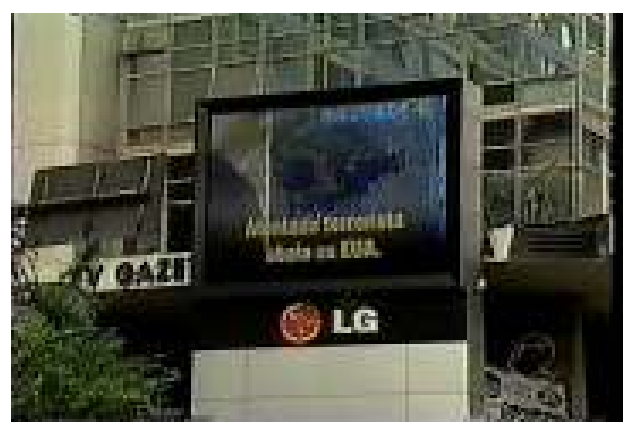

Figura 29

Provavelmente a intenção do repórter era evidenciar que tamanha tragédia não seria facilmente esquecida pelo que representava em si mesma, mas não podemos deixar de entrever um segundo sentido, acionado pela imagem do telão dentro da telinha: a mídia se encarregará de fazer com que ninguém esqueça da tragédia e de seu conteúdo simbólico.

Entram sonoras que remetem outra vez ao clima de medo. Surge a primeira e única referência externa a uma "terceira guerra mundial", figura recorrente no outro telejornal. Uma mulher diz o mesmo que se ouvira muito na mídia durante o dia: "O mundo vai ser outro a partir de hoje. Eu tenho medo do que vai vir". Um homem avalia: "Pode até vir uma terceira guerra mundial com essa brincadeira toda, envolvendo milhares de seres humanos que não têm nada a ver com essas políticas baratas, vamos 
dizer assim". A idéia de "terceira guerra mundial" será retomada pelo âncora em dois comentários ainda nesse bloco, mas sob uma ótica crítica.

O primeiro vem logo depois das sonoras: "Nada é impossível, mas terceira guerra mundial contra quem? Ninguém sabe quem fez o atentado. Se for algum estado, se for algum país, talvez. Nada indica que seja um estado organizado, um país, o autor ou o organizador ou o realizador desse atentado, portanto nada justifica um ataque contra uma população civil. Terrorismo é um horror e precisa ser banido da face da terra".

O âncora duvidava de que pudesse haver uma terceira guerra mundial, já que nada indicava que o ataque viera de alguma nação, apesar de ressaltar que ninguém sabia ainda quem cometera o atentado. Entretanto ele conclui enfaticamente que aquele ataque a uma população civil só podia ser uma ação terrorista, injustificável exatamente por não ser ação de um estado organizado.

O comentário tenta afastar a possibilidade de uma terceira guerra, mas deixa algumas perguntas sem resposta. Se o autor do atentado fosse uma nação, isso se justificaria, não seria um "horror"? Se não era a ação de um país, por que o discurso do telejornal apresenta tantas vezes a idéia de "declaração de guerra"? Por que se insiste na imagem, por meio de expressões como "cenário de guerra", "ambiente de guerra"? Por se mostram navios de guerra na costa de Manhattan? Talvez porque fosse latente o clamor por guerra ao terror, que precisava "ser banido da face da terra". Talvez porque não se avaliasse em que medida o reflexo do discurso do governo americano na mídia ocidental poderia ter conseqüências, como a de endossar ataques a outras populações civis, que viriam a acontecer ainda naquele ano e durante o mandato seguinte do presidente Bush.

A matéria seguinte mostra a reação do então presidente brasileiro, Fernando Henrique Cardoso, que, como tantos outros líderes, estava perplexo e condenava "com veemência" o terrorismo: "A perplexidade do presidente Fernando Henrique Cardoso diante das cenas do atentado nos Estados Unidos resumiu o sentimento que tomou conta das autoridades hoje em Brasília, no governo e no congresso" (imagem de FHC vendo as notícias pela televisão). Aliás, "perplexidade" é a palavra que sintetiza quase todas as reações mostradas pelos telejornais naquele dia. A mídia cai nas redes desse sentimento e com ele enlaça também seu discurso. 
O repórter informa, numa passagem: "Com a ajuda de ministros e auxiliares, o presidente tenta elaborar um quadro dos possíveis desdobramentos da crise e se declarou chocado diante das imagens do atentado. 'Eles perderam mais de cem mil no Vietnã e hoje podem ter perdido a metade disso'. 'É uma guerra', disse o presidente. Mais tarde, perguntado se temia pela paz mundial, o presidente declarou: Isso não".

Não há imagem do presidente falando, não há estrutura de discurso indireto, a não ser no segmento "se declarou chocado". Não é possível saber se o repórter realmente "abriu aspas" para citar as falas de Fernando Henrique, inclusive quanto à fala "Isso não", considerada inadequadamente pelo discurso citante como uma "declaração" do presidente brasileiro.

Independentemente dos recursos, instaura-se a polifonia e ouve-se a voz de uma autoridade a referir-se a uma "guerra", mas não uma terceira grande guerra, já que não se temia pela paz mundial. Podíamos ficar tranqüilos. O Vietnã não era aqui. O Oriente Médio também não. Mas também a referência a uma "guerra" pode ter sido apenas uma analogia em decorrência do número de vítimas superestimado pelo presidente brasileiro, única justificativa para que se mencionasse a guerra do Vietnã, deflagrada num contexto bem diferente.

O repórter prossegue: "Nesta carta ao presidente George Bush, Fernando Henrique fala da indignação e da tristeza dos brasileiros diante das vítimas perdidas no atentado e condena duramente o terrorismo". O conhecido recurso de mostrar a imagem da carta, aqui com destaque para a assinatura do presidente, confere credibilidade ao discurso citante. As palavras pinçadas da carta também não são novas no discurso citante: indignação, tristeza, condenação "dura" ao terrorismo.

Mais adiante o repórter informa sobre as providências do Itamaraty para obter informações sobre "possíveis vítimas brasileiras" e dá voz a um embaixador brasileiro, que atesta não haver até aquele momento "nem em Washington, nem em Nova York, nenhuma notícia de que houvesse vítimas de nacionalidade brasileira".

O repórter termina o VT forçando os acordes da comoção: "No pronunciamento feito no final desta tarde, a expressão e a voz do presidente tinham o peso da preocupação. Fernando Henrique declarou que pretende falar com o presidente Bush ainda hoje e deixou claro: teme pelos efeitos da crise sobre a economia brasileira". 
Mas o temor não fica tão claro na fala do presidente, que entra na seqüência: "Ainda esta manhã o governo determinou, através do Banco Central, uma intervenção para acalmar a situação financeira, posto que não há nenhuma razão para uma preocupação maior nesse momento". É mais uma das tantas cacofonias de um discurso que tem relativo controle das vozes que vai dispondo ao longo do concerto enunciativo.

O âncora está posto em close, interpela o telespectador e faz um longo comentário, que começa com o pretexto das preocupações econômicas e reincide sobre o tema da remota possibilidade de uma terceira guerra mundial. Vejamos o que se pode destacar:

"Olha, a economia só pode ser atingida pra valer se houver conseqüências, se houver fatos novos, se houver uma retaliação, um tipo de guerra, o que é absolutamente improvável a essa altura dos acontecimentos. Quando se fala em terceira guerra mundial - durante o dia hoje se ouviu falar muito nisso - não se sabe, não se leva em consideração que todas as grandes potências, antigas inimigas na Guerra Fria, por exemplo a antiga União Soviética, a Rússia, estão juntas nessa história do combate ao terrorismo, inclusive a China.

Não há razão para uma terceira guerra mundial. Não há nada neste momento em disputa, não há mercado, não há território, nada, nada, apenas conflitos regionais, pequenos e grandes conflitos regionais, nada que possa envolver as grandes potências atômicas. Pelo contrário, tudo converge, todas elas estão atravessando momentos difíceis, inclusive a China, que também, apesar de ter progredido muito, começa a sentir os efeitos da retração do comércio e das exportações e importações em todo o mundo. Por isso ninguém pode imaginar, nesta altura dos acontecimentos, que, finda a Guerra Fria, tenhamos uma terceira guerra mundial.

O que vai haver, no momento em que os americanos descobrirem exatamente quem são os autores desses atentados, vai ser uma retaliação fantástica, mesmo se os autores dos atentados forem de dentro dos Estados Unidos, terroristas americanos, mesmo assim o exemplo do que pode acontecer com os terroristas já foi demonstrado. Isso vai determinar uma guerra de extermínio contra o terror no mundo inteiro, porque extermínio, porque violência é a única linguagem que essa gente entende. Não há maneira, não há possibilidade de conviver, nem de negociar com o terrorismo".

No comentário, praticamente um editorial telejornalístico, o âncora coloca-se num papel diferente do de mero apresentador das notícias. É outra voz na composição polifônica do telejornal, portanto é natural que haja algumas dissonâncias entre os comentários e os demais segmentos enunciativos. 
Note-se, por exemplo, como o âncora comenta que naquele dia "se ouviu falar muito" em terceira guerra mundial, para então rejeitar novamente a hipótese, apresentada por outra voz num determinado trecho do telejornal e reapresentada agora numa menção a vozes exteriores ao discurso do noticiário. Segundo o âncora, a hipótese era "absolutamente improvável", tendo em vista que todas as grandes potências estavam alinhadas, naquele momento, no combate ao terrorismo.

Vê-se uma sintonia com o discurso americano oficial, segundo o qual "os inimigos agora eram outros", fala de Bush destacada no outro telejornal, e de certa forma também aqui presente. Ressoa também no comentário o discurso paralelo de que não havia razões lógicas para os atentados. Segundo o âncora, "não havia nada em disputa", "nada, nada, apenas conflitos regionais, pequenos e grandes conflitos regionais", retumba o forte eco. Mas são apagados desse discurso os milhares de vítimas desses conflitos e os interesses econômicos, políticos e geopolíticos de grandes potências por trás de tudo. Todo e qualquer contexto inconveniente é banido do discurso e da memória.

O âncora reitera, indiretamente, que não se sabia ainda quem eram os autores do atentado, mas assim que se soubesse haveria uma "retaliação fantástica". Mas ele afirmara no início que uma retaliação ou um "tipo de guerra" eram improváveis naquele momento. Afinal, haveria ou não retaliação? Retaliação contra quem, se não havia indícios de envolvimento de alguma nação? Se num contexto amplo, "retaliação" soa como eufemismo para "guerra" ou "ação armada", no contexto estrito do comentário e do discurso geral da mídia, "retaliação" nada mais é que um eufemismo para "vingança" e para o aforismo que representa: "olho por olho, dente por dente". Como então se aplicaria a pena de talião a terroristas? Como se revidaria a um grupo terrorista com igual dano o que a população civil dos Estados Unidos sofrera com aqueles ataques?

As palavras são traiçoeiras. O eufemismo apaga os sentidos mais recônditos e é mais fácil obter o assentimento do público a um movimento de "retaliação fantástica" por parte da superpotência. Aliás, o âncora já comentara no primeiro bloco: "A única coisa certa é que esse 11 de setembro marca o início de uma política inflexível contra o terrorismo, a partir de uma duríssima retaliação americana, até por pressão da opinião pública". E também afirmara num outro comentário: "A reação americana dura, que ficou 
clara, extremamente clara, no pronunciamento do presidente Bush, será extensiva a países que recebem e protegem o terror. A saber: Afeganistão, Líbia, Síria, Iraque e Irã".

A "retaliação fantástica" ao terror atingiria então, inevitavelmente, a população civil de países que estavam do lado do Mal. Olhos inocentes. Mas no discurso veloz, fragmentado, metonímico, espetacular da televisão, a compreensão dos fatos escapa ao telespectador. Não há tempo, não há como voltar a fita e ler nas entrelinhas. Lembramonos do que é insistente. $O$ resto são silêncios da memória.

A câmera muda o ângulo. O âncora sai de cena e entra o locutor: "Veja a seguir. Assassinado a tiros o prefeito de Campinas, Toninho do PT. E ainda nesta edição, mais informações sobre o ataque terrorista nos Estados Unidos".

\section{Bloco 4}

O telejornal retoma sua trajetória de discurso verbo-visual. As imagens mais marcantes dos atentados não tiveram grande destaque nos blocos dois e três, dando lugar às representações verbais que ressoaram polifonicamente no discurso. Nos dois últimos blocos do noticiário predominará a repetição de VTs inteiros, exibidos principalmente no início da edição. Com ou sem avisos do tipo "veja de novo como foi", tudo se repete.

As mesmíssimas seqüências de imagens e suas molduras verbais se tornarão presentes mais uma vez pela figura retórica da repetição, amplificada pelo efeito de sentido singular que assume a reapresentação de grandes porções do discurso. Nada se perde. Não são apenas imagens reincidentes. Todo o contexto interpretativo das seqüências imagéticas adere à memória. Imagens e palavras replicantes, que redundam dentro dos VTs e se duplicam na sua reexibição. Quadro por quadro, palavra por palavra.

O locutor dá uma nova informação, brevíssima, e com uma frase ligeiramente diferente da que usou no primeiro bloco chama um VT já visto: "O metrô e os ônibus voltaram a funcionar agora à noite em Nova York, mas os horários foram espaçados por razões de segurança. Os ataques de hoje mudaram a tradicional e conhecida paisagem da cidade. As torres gêmeas do WTC desapareceram em duas horas".

Trata-se do VT que começa com "o terror em Nova York começou pouco depois das nove horas da manhã", que mostra "o caos e o cenário de guerra", o prédio pegando 
fogo, as torres desabando, e fala das "testemunhas horrorizadas", das pessoas que saltavam do alto dos prédios, dos milhares de vítimas.

Em seguida, repete-se a informação de que um anexo do World Trade Center também desabou. Repete-se o VT, repetem-se as imagens da CNN, que já são mostradas duas vezes na matéria do primeiro bloco. Mais prédio em chamas. Mais cenas de desabamento. Mais perplexidade. O locutor muda de assunto e lança uma informação nova, sem citar fontes: "Agora há pouco grupos guerrilheiros do norte do Afeganistão se responsabilizaram pelos ataques à capital, Cabul". Então se repete o VT que mostra as explosões no Afeganistão naquela noite, o mesmo texto que diz que o governo americano negou "qualquer envolvimento" com um possível ataque ao país que protegia Bin Laden.

O locutor informa: "Depois de assumir a autoria dos atentados, os guerrilheiros afegãos declararam que vão realizar novos ataques de surpresa no país". Não há mais a cautela de dizer que o que se via eram "explosões". Agora fala-se abertamente em "ataques", em "atentados". Também não há menção das fontes, não se sabe a quem os guerrilheiros afegãos fizeram a "declaração", mas isso confirma o que disse o governo americano. Dá-se tudo como esclarecido e não se fala mais nisso.

O locutor informa, enquanto se exibe a imagem do secretário falando: "O secretário americano de Defesa, Donald Rumsfeld, fez um pronunciamento agora há pouco. Rumsfeld afirmou que o Pentágono está funcionando agora e vai trabalhar também amanhã. Rumsfeld disse que ainda é impossível fazer qualquer previsão sobre números. O general Shelton, chefe do estado maior conjunto das forças armadas americanas qualificou os ataques como atos bárbaros de terrorismo e afirmou que o exército americano está pronto para agir".

Reitera-se a imagem verbal de "atos bárbaros", indiscutível diante do que se vê, e da iminência de uma "retaliação" ou de um "tipo de guerra", uma vez que se fala em ações do exército americano.

Em seguida, volta-se a falar da reação do governo brasileiro, que convocou uma reunião "para discutir a crise provocada pelos ataques terroristas aos Estados Unidos", mas não se explica que crise seria essa. Passa-se então às principais notícias nacionais daquele dia, entre elas a do assassinato do prefeito de Campinas. No final do bloco, são dadas informações novas mas pouco relevantes sobre os atentados. 
O locutor faz a passagem de bloco: "Veja a seguir. A Otan garante que os responsáveis pelo atentado não sairão ilesos. E as imagens do presidente Bush chegando à Casa Branca". Como se verá no bloco seguinte, a notícia não é um fato, mas apenas uma vaga afirmação da aliança militar - tomada como "garantia" pelo discurso citante - de que os responsáveis seriam punidos.

\section{Bloco 5}

O locutor ratifica as informações sobre o ataque ao Pentágono: "Washington, a capital americana, continua em estado de emergência. O Pentágono, que foi um dos alvos do ataque terrorista de hoje, ainda não informou o número de vítimas no interior do prédio. Veja de novo como foi o ataque ao maior símbolo do poder militar americano".

Reforçam-se as idéias de "estado de emergência" e de "ataque a símbolos americanos". E vemos de novo como foi o ataque ao Pentágono, no VT que já fora exibido no primeiro bloco. Mais prédio em chamas (figura 30), a mesma "imensa nuvem de fumaça sobre a capital americana", a região "tomada por carros de bombeiros e ambulâncias", a mesma ausência de imagens das vítimas "cujo número ainda não foi calculado", mas que são milhares sob aqueles escombros, como nosso imaginário já deve ter registrado.

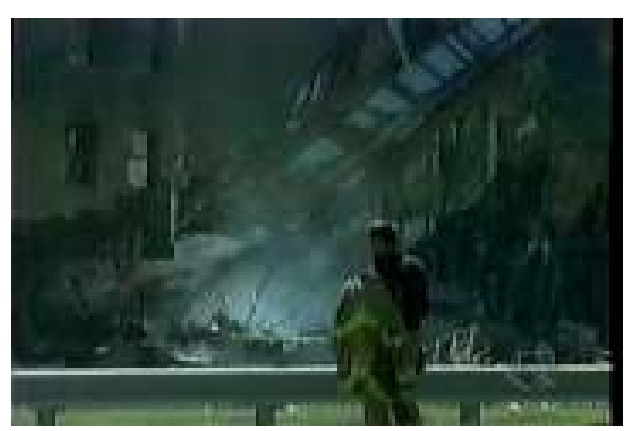

Figura 30

As medidas tomadas logo depois dos ataques e mostradas no VT, como o esvaziamento dos prédios federais e "jatos F16 sobrevoando a cidade", servem de pretexto para que o âncora encaixe mais um comentário: "Você vê que contra o terrorismo não há defesa. $O$ terrorismo é imprevisível e usa recursos muito diferentes dos recursos 
da guerra. Portanto não adianta proteger contra a guerra, não adianta nenhum projeto de defesa atômica, que ele pode ser facilmente penetrado por terroristas que agem de maneira totalmente diferente do que uma guerra normal, se é que guerra pode ser chamada de normal".

O público é interpelado mais uma vez pelo discurso, que pretende fazê-lo concordar com o argumento de que contra o terrorismo não há defesa. Isso levaria a aceitar que não é culpa da inteligência americana não ter previsto os ataques, já que nenhum sistema é invulnerável diante do terrorismo. No entanto o comentário não explica que "projeto de defesa atômica" foi "penetrado" pelos terroristas. O discurso polifônico não explica isso, como também não esclarece que as constantes referências a um clima de guerra ligam-se mais às ações do governo americano, difundidas nos noticiários, do que aos ataques propriamente ditos.

Muitas outras vozes falam em guerra e, apesar do metadiscurso, que marca a inadequação do termo e nega polifonicamente que uma guerra seja considerada uma coisa "normal", o discurso trata com naturalidade o cenário de guerra que se afigura diante da inevitável retaliação americana, plenamente justificável, na construção discursiva, pela tragédia que o país sofria.

O locutor repete então o texto com as informações sobre o seqüestro dos quatro aviões usados nos ataques. O VT também é o mesmo do primeiro bloco. Seja por falta de matéria nova, seja por opção editorial, o fato é que essas repetições todas produzem importante efeito de sentido no discurso. Se "ninguém cruza duas vezes o mesmo rio", como dizia Heráclito, também ninguém vê as mesmas imagens ou ouve as mesmas palavras duas vezes, sobretudo quando elas se entrelaçam num discurso complexo, continuamente reinterpretado e reenquadrado afetiva e cognitivamente por meio de diversos recursos, como o que se observa na inserção de novos comentários do âncora a cada repetição.

O comentário posto nesse trecho da rede discursiva é o seguinte: "Olha, hoje eu ouvi até gente ilustrada falando em ataque guerrilheiro, se é que esse ataque teve um fundo político. A diferença é simples: o ataque guerrilheiro é contra um quartel, contra uma tropa, contra um exército, nunca contra a população civil. Ataque contra a população 
civil, como esse ataque realizado hoje nos Estados Unidos, é ataque terrorista. Fomenta a intranqüilidade, fomenta o desequilíbrio. Esse é o objetivo do terrorismo".

O âncora desqualifica mais uma hipótese da qual ele "ouvira falar" naquele dia e, didaticamente, explica a diferença entre "ataque guerrilheiro" e "terrorismo", sem considerar, entretanto, que mesmo as definições menos técnicas e mais simplistas apresentam o terrorismo como "o emprego sistemático da violência para fins políticos" (cf. Houaiss). Como se viu por toda a mídia à época dos acontecimentos, e muito depois também, não há interesse em esclarecer contextos políticos ou históricos. Não dizemos que a mídia devesse justificar as mortes e a destruição, mas que deveria garantir o direito do público à informação irrestrita e honesta.

No entanto, quanto mais se falava, mais obscuro se tornava o conceito de terrorismo. Por que seu objetivo seria "fomentar a intranqüilidade e o desequilíbrio"? Parte da resposta também está no dicionário: terrorismo é "a prática de atentados e destruições por grupos cujo objetivo é a desorganização da sociedade existente e a tomada do poder". Mas por que terroristas - provavelmente terroristas árabes - almejariam tomar o poder nos Estados Unidos ou apenas deixar o país intranqüilo? E por que os que "declararam" ter atacado Cabul, a capital do Afeganistão, foram designados no telejornal como "grupos guerrilheiros" e "guerrilheiros afegãos"? A população civil não foi atingida nos ataques? A propósito, se foi, por que a mídia não demonstrava a mesma preocupação com as possíveis vítimas? Não sabemos a resposta nem podemos dizer com certeza como o público interpretou o discurso da mídia naquele dia, mas esta análise revela que os silêncios dizem tanto quanto palavras e imagens.

O selo que aparece no vídeo é, como em tantas outras chamadas, o que traz a imagem das torres sob fumaça, um dos símbolos que nos lembram que a "enorme nuvem do terrorismo" cobre os Estados Unidos. O locutor repete o que já fora dito no segundo bloco: "Até o momento nenhuma organização terrorista assumiu a autoria do atentado. $\mathrm{O}$ terrorista saudita Osama Bin Laden encabeça a lista de suspeitos".

O VT que fala sobre Bin Laden, o terrorista com a cabeça a prêmio, e outros possíveis suspeitos é o mesmo do outro bloco. O público vê tudo de novo e o âncora lança outro comentário, que é mais uma conjectura: "A grande pergunta que se faz agora é a seguinte: Será que o ataque já terminou ou será que nas próximas horas, amanhã, 
teremos surpresas? Essa deve ser a interrogação neste momento que preside a ação do governo americano".

Não há como não se lembrar da tarja exibida continuamente na CNN: "America under attack". É o clima que se estabelece com o reforço da mídia, juntamente com a imagem de grande vítima construída para os Estados Unidos.

O locutor dá uma breve nota, cujo conteúdo no entanto fora destacado na passagem de bloco: "A Otan, Organização do Tratado do Atlântico Norte, disse que os responsáveis pelo ataque não sairão ilesos. Os embaixadores da aliança militar discutiram o assunto numa reunião extraordinária, em Bruxelas. O secretário-geral George Robertson prometeu aos Estados Unidos total apoio dos aliados, mas disse que a Otan ainda não discutiu uma ação militar de retaliação".

O âncora descartara a hipótese de uma terceira guerra mundial e até de uma "guerra normal", mas as vozes que têm lugar no discurso midiático continuam executando a protofonia da guerra.

Na seqüência, mais uma cabeça de matéria repetida e também o VT inteiro sobre a reação dos líderes mundiais ao atentado. Novamente a indignação, a comoção, a solidariedade, as manifestações de repúdio aos violentos ataques terroristas. Novamente a referência a uma "declaração de guerra a todo o mundo civilizado". Novamente as importantes vozes, em uníssono, dizem que "não haverá descanso enquanto o terrorismo não for varrido do mundo".

O âncora não se furta a mais um comentário, só para reforçar: "Você vê que as grandes potências têm todas a mesma posição contra o terrorismo, até porque elas podem ser vítimas de terroristas. A França está sendo, a Rússia está sendo, a Alemanha já foi e isso é insuportável num país que queira manter o seu equilíbrio, a sua segurança e a sua segurança em termos de economia".

As grandes potências temem o terrorismo, que ameaça o equilíbrio, a segurança e a economia, mas evidentemente, como o discurso já deixara claro, não tem nenhum "fundo político". O público só vê e ouve o que o discurso da mídia apresenta - a não ser, é claro, que vá buscar outras fontes. O resto não tem visibilidade, fica sob a enorme nuvem da desinformação. 
Segue-se a repetição de outra cabeça de matéria e do VT sobre a reação de Israel, cujos líderes também consideraram o ataque como uma "declaração de guerra" e defenderam "uma resposta à altura do mal causado pelo terrorismo". O país também tomara "medidas preventivas" contra "possíveis ataques de terroristas suicidas", ocupando imediatamente, com tanques, a cidade de Jenin, na Cisjordânia, sob controle dos palestinos.

O âncora faz um breve comentário após a repetição da matéria: "Talvez tenha chegado o momento de as grandes potências intermediarem, até forçando um pouco, uma ação de paz entre israelenses e palestinos". Uma efêmera brisa de bom senso sopra no tecido discursivo. Fala-se em paz, no meio de tantas referências à guerra. Uma voz sem eco. Meses mais tarde, em abril de 2002, a cidade de Jenin seria massacrada por tropas de Israel. Não se tomara medidas preventivas a esse respeito e a mídia se calou ${ }^{96}$.

Em seguida, repete-se uma nota, uma cabeça de matéria e um VT, todos já exibidos no segundo bloco do noticiário. A nota informa que Israel decretou luto em "solidariedade ao povo americano" e se colocou à disposição para ajudar no que fosse necessário. Em contraposição, informa-se no outro texto que os palestinos estavam "divididos" quanto ao ataque: "as autoridades negaram participação nos atentados, mas nas ruas a população festejou". Retornam ao vídeo as polêmicas imagens do pequeno grupo de palestinos dançando nas ruas. Reavivam-se as cenas de "festa", presumidamente em comemoração aos ataques. Reitera-se a construção de uma imagem metonímica e negativa do povo árabe.

\footnotetext{
${ }^{96}$ Arbex afirma que "poucas vezes o silêncio conivente da mídia em face da atitude autoritária e brutal do governo israelense foi tão claramente explicitado quanto no episódio que se tornou mundialmente conhecido como 'massacre de Jenin'" (2003:97). Dorneles também fala do episódio: "Nenhuma cobertura jornalística deixou tão clara a atuação da imprensa nos conflitos do Oriente Médio como a ocupação de Jenin" (2003:252). Ambos denunciam a omissão da mídia diante do fato de Israel proibir a entrada de organizações independentes, observadores da ONU e repórteres na região em conflito e não permitir investigação nenhuma após inúmeras denúncias de crime de guerra, execuções e massacres, decisão apoiada pelo governo dos Estados Unidos. Segundo Dorneles, "a imprensa continuou fazendo seus relatos baseada nas informações do governo israelense" (op.cit::254). Mesmo mais tarde, quando órgãos como a Anistia Internacional comprovaram que houve assassinato em massa em Jenin, a imprensa se omitiu. Dorneles conta que por quase noventa dias o episódio foi esquecido e só voltou à mídia por ocasião da divulgação de um relatório da ONU, que foi elaborado "sem que nenhuma equipe tivesse visitado o local" e afirmava que não tinha havido massacre em Jenin. Para Dorneles, "era a pá de cal, Jenin sumia do mapa" (op.cit::258).
} 
O locutor repete a informação de que todos os vôos comerciais nos Estados Unidos estão suspensos e acrescenta: "As forças armadas americanas continuam em alerta, mas o governo demorou algumas horas para reagir contra a escalada terrorista". Em seguida, repete-se o VT que mostra o "ambiente de guerra" e as medidas tomadas pelo governo americano depois dos atentados, como esvaziar prédios públicos, fechar aeroportos e desviar vôos internacionais, dar ordens à Força Aérea para derrubar qualquer avião suspeito, patrulhar a costa de Nova York com navios de guerra e fazer o presidente sumir.

Nesse VT se destaca que o presidente Bush, quando reapareceu numa base militar no Nebrasca, "prometeu caçar e punir os responsáveis pelo maior ataque terrorista da história americana", mas não há nada no VT que indique "reação contra a escalada terrorista", ao contrário do que o locutor afirmara. Ou seria uma questão de ponto de vista? O que no Jornal Nacional foi resumido pela frase "eram os Estados Unidos tentando se proteger" aqui é visto como "reação contra a escalada terrorista". De qualquer forma, as vítimas são também mostradas como heróis nesse filme.

Por fim, repete-se a informação de que o presidente Bush tinha chegado no fim da noite a Washington e logo mais faria um pronunciamento oficial pela televisão. O locutor encerra o telejornal com o mesmo texto da escalada, agora com uma remissão ao passado: "Este foi o Jornal da Record e estas foram as notícias mais importantes do dia". Essa fórmula era uma marca do noticiário na época, mas não será observada nas edições dos anos seguintes que também serão analisadas.

$\mathrm{Na}$ edição de 11 de setembro, portanto, a repetição do texto de abertura não pode ser considerada como um recurso especial, embora seu efeito de síntese e lembrança não possa ser desprezado. No entanto o efeito é bem menor do que o produzido pelo encerramento da edição do Jornal Nacional, que exibiu um "clipe" das imagens mais dramáticas dos ataques sem narração. Também de modo diferente o locutor se despede. Seu "até amanhã" não é sério ou grave. Ele sorri e diz: "Boa noite. Muito obrigado por sua atenção. Até amanhã e paz". 
Sem dúvida, telespectadores da Globo e da Record não viram exatamente o mesmo filme, mas leram roteiros bem parecidos quanto aos principais nós dramáticos. A versão dos fatos apresentada pelos dois telejornais, que soaram na mesma freqüência, seria contada mil vezes na mídia a partir dali, até ser conhecida de cor. A lembrança ficaria nos corações e nas mentes. Imagens e palavras a nos perseguir.

Conforme diz Sontag, a respeito da fotografia, "o problema não é que as pessoas lembrem por meio de fotos, mas que só se lembrem das fotos", uma vez que "essa lembrança ofusca outras formas de compreensão e de recordação" (2003:75). Isso vale também, a nosso ver, para as palavras e imagens que se repetem na mídia. O problema é que as pessoas se acostumem a lembrar somente por meio do que a memória metálica da mídia registra. 


\section{Os aniversários do 11 de setembro: 2002, 2003 e 2004}

\section{1 de setembro de 2002}

Um ano depois dos atentados, o Afeganistão é um país destruído, mais miserável ainda. A guerra ao terror já fez milhares de vítimas, inclusive civis, mas a mídia ocidental diz que a culpa é dos próprios afegãos e risca o país do mapa de notícias. Os Estados Unidos são aclamados pela mídia como vitoriosos nessa guerra e não há espaço para outras versões, afinal, como enfatiza Dorneles, "o derrotado nunca conta sua história para a História" (2003:41). No entanto não há notícia da prisão ou morte de nenhum líder da Al Qaeda. Ninguém sabe onde está Osama Bin Laden, nem se está vivo ou morto.

Durante um ano, segundo afirma Dorneles com base em sua pesquisa, "em todos os momentos, depois do 11 de setembro, a imprensa passou a dar destaque às declarações de Bush, mesmo quando eram acusações ou declarações alarmistas sem nenhuma comprovação" (op.cit.:85). Nunca foi provado que houvesse armas químicas ou atômicas nas mãos de Bin Laden e da Al Qaeda, mas a mídia não se preocupava em desmentir o que antes alardeara, nem no caso do famoso antraz, que, soube-se depois, nada tinha a ver com grupos terroristas ou com Saddam Hussein, a quem os Estados Unidos queriam também declarar guerra, mas precisavam de um pretexto ${ }^{97}$.

Além disso, nesse período houve denúncias de que o governo americano sabia de um ataque ao país e que tinha planejado usar isso como pretexto para invadir o Afeganistão, por causa de seu interesse no petróleo da região. Surgem as chamadas "teorias da conspiração", que reforçam as suspeitas de que o governo Bush tenha se beneficiado dos atentados para legitimar-se e poder implantar livremente sua política externa. Há investigações por parte do congresso americano, mas a mídia demonstra total desinteresse pelo assunto ${ }^{98}$.

${ }^{97}$ Dorneles conta que não teve destaque na mídia a notícia de que o $\mathrm{FBI}$ mantivera em segredo por muito
tempo a descoberta de que o responsável pelos atentados com antraz era um cientista americano que
trabalhara no laboratório militar de Fort Detrick, no estado de Maryland (2003:128).
${ }_{98}$ Segundo Sérgio Davila, correspondente do jornal Folha de S.Paulo, somente às vésperas dos cinco anos
dos atentados o governo Bush resolveu responder às acusações das teorias conspiratórias sobre motivos,
meios, ações e reações relacionados ao ataque de 11 de setembro. Segundo o repórter, a preocupação se
deve ao fato de tais teorias terem ganhado força com a publicação de livros e vídeos sobre o tema e à
divulgação de pesquisas que mostram que pelo menos um terço da população americana acha que é 
Também um ano depois, conforme aponta Dorneles, continuava "um mistério" o número de pessoas presas nos Estados Unidos, acusadas, sem provas, de envolvimento nos atentados. Permanecia o clima de pânico e de alerta permanente. $O$ governo alardeava que novos ataques eram iminentes e a mídia divulgava isso com "estardalhaço", segundo a pesquisa de Dorneles. A política do medo garantia que o governo continuasse sua guerra contra o terror e contra o que mais se the afigurasse como inimigo. Aliás, Bush dissera, em 11 de setembro de 2001, que os inimigos tinham mudado, mas um ano depois ele voltava as armas contra um velho inimigo, o Iraque, alegando, entre outras coisas, que Saddam Hussein tinha ligações com Bin Laden e que seu país tinha um arsenal de armas químicas. Não há provas, mas outra guerra é deflagrada, sob a complacência da mídia ocidental.

Um ano depois, o mundo árabe ainda é visto como inimigo dos Estados Unidos e - Islã, como uma ameaça concreta aos valores democráticos. A mídia reforça o consenso, embora pensadores como Dominique Wolton apontem como causa dos principais conflitos com o Oriente Médio, e até como causa do 11 de setembro, a incompetência dos Estados Unidos em aceitar e respeitar a diversidade cultural ${ }^{99}$. Nesse período também a guerra entre Israel e Palestina recrudesce. Segundo Dorneles, no círculo da mídia, as ações dos palestinos eram vistas como ataques terroristas, ao passo que as ações dos israelenses eram sempre uma resposta à violência sofrida (op.cit.:243).

Um ano depois dos atentados, os milhares de vítimas de todas essas guerras são invisíveis para o mundo, porque não aparecem na mídia. Honrosas são as exceções. $O$ jornal britânico The Guardian, por exemplo, fez uma investigação sobre o número de pessoas mortas em conseqüência da intervenção dos Estados Unidos no Afeganistão e chegou a uma estimativa de vinte mil. Os que não morreram vitimados pelos bombardeios sucumbiram devido à suspensão da ajuda internacional ao miserável país imediatamente após os ataques de 11 de setembro.

\footnotetext{
"muito provável" ou "algo provável" que o governo tenha permitido que o atentado acontecesse ou mesmo que tenha sido o autor do atentado (Folha Online, 5 de setembro de 2006).

99 Entrevista concedida à revista Trópico, encontrada no site do Observatório da Imprensa, sob o título "Wolton fala sobre o valor da mídia e da diversidade", de 13 de janeiro de 2002.
} 
Segundo o jornalista Jonathan Steele, que comentou a pesquisa, jamais se saberá ao certo o custo total de vidas humanas e "os túmulos sem nomes das colinas do Afeganistão, em locais no deserto e em cantos obscuros dos campos de refugiados serão lentamente esquecidos"100.

O mesmo não aconteceria com as vítimas do 11 de setembro. Como observa Meyssan, "nenhuma das vítimas de genocídios recentes teve direito a tanta homenagem" (2003:74). Nem tanto espaço na mídia, ano após ano. Passada a fase do bombardeio de imagens, que antecedeu o tom da cobertura que sobreviria e lançou o germe da memória que se estabeleceria dos atentados, o que se viu na imprensa, sobretudo escrita, foi o que expusemos em linhas gerais, com base no levantamento feito pelo jornalista Carlos Dorneles (2003).

Mais difícil é dizer o que se viu na televisão, uma vez que não há arquivos públicos de telejornais para que se possa rever e examinar toda a cobertura. Para entender parcialmente o que se passou, podemos contribuir com a análise das edições de 11 de setembro de 2002, 2003 e 2004 do Jornal Nacional e do Jornal da Record, que exibiram matérias sobre "o aniversário" dos atentados. Vamos a ela.

\footnotetext{
100 "As vítimas invisíveis", artigo publicado no The Guardian, em 20 de maio de 2002.
} 
Em 11 de setembro de 2002, a lembrança dos ataques tem grande destaque nos dois telejornais. Fala-se com muita emoção da dor das famílias das vítimas e das cerimônias de adeus, mas há diferenças importantes nas duas edições, a começar pela escalada.

\section{JORNAL NACIONAL}

11 de setembro de 2002. Nova York.

Homenagens às vítimas do World Trade Center.

(Entram imagens da cerimônia e a repórter fala:

"Foram lidos, um a um, os nomes das quase 3.000 pessoas que morreram no ataque às torres, entre elas três brasileiros.")

11 de setembro. Um ano de solidão.

(Um repórter fala: "Uma brasileira ainda sonha reencontrar o marido." Breve sonora da mulher: "Eu penso que ele ainda vai bater na porta, e eu vou abrir, e vai ser ele.")

Nossos repórteres mostram como o mundo lembrou o aniversário da maior ação terrorista da história. (Entram breves imagens das homenagens.)

11 de setembro no Brasil.

Rio de Janeiro. Traficantes assumem o comando do presídio em Bangu. E quadrilhas rivais travam registradas a partir de maio. batalhas mortais dentro da cadeia.

11 de setembro no Vaticano. João Paulo II participa da missa de corpo presente de Dom Lucas.

11 de setembro de 2002.

O Jornal Nacional está começando agora.

\section{JORNAL DA RECORD}

Boa noite. Este é o Jornal da Record e estas são as notícias mais importantes do dia.

Levante de presos em Bangu 1, no Rio. Beira Mar estaria no comando. Seis rivais teriam sido mortos e ainda haveria oito reféns.

Após telefonar para Fernando Henrique, a governadora Benedita da Silva autoriza a polícia a reforçar o presídio, mas o impasse continua.

Emocionados e temerosos de novos atentados, os americanos homenageiam as vítimas de 11 de setembro. (Não há imagens na escalada.)

O presidente Bush promete vencer a guerra contra o terrorismo e vingar os mortos durante os ataques.

Tony Blair convoca o parlamento britânico para discutir uma eventual ação militar contra o Iraque.

Uma decisão polêmica pode anular multas de radar

A estrutura da abertura do Jornal Nacional usa o recurso não da anáfora referencial, mas da anáfora poética, para dar relevo à data de 11 de setembro. A repetição dramática ocorre cinco vezes e chega a ser usada para fazer remissão a um importante fato havido no Brasil naquele dia, uma grande rebelião num presídio do Rio de 
Janeiro. Entretanto a analogia entre os acontecimentos parece-nos exagerada e injustificável, como soa disparatada a associação da data com a missa no Vaticano.

As duas primeiras referências e a última repetição ajudam a estabelecer uma memória dos atentados, assim como as frases curtas, ditas com inflexão grave pelos locutores: "11 de setembro de 2002. Nova York. Homenagem às vítimas do World Trade Center"; "11 de setembro. Um ano de solidão"; "11 de setembro de 2002." As outras duas repetições soam como pobre recurso de estilo, mas resultam em figura de presença em relação à data da "maior ação terrorista da história", termo de designação que não se perdeu no espaço de um ano. Aliadas a isso estão a exibição de imagens das cerimônias de homenagem e a inserção de uma voz que expressa o inconformismo da perda, voz que se repetirá na matéria mostrada no noticiário.

A escalada do Jornal da Record não dá o mesmo destaque à data e inclui a notícia entre as principais do dia, mas localizando-a depois da rebelião no presídio. Entretanto o telejornal acrescenta a informação de que os americanos continuam "temerosos de novos atentados" e que o presidente Bush continua firme em seu propósito de "vencer a guerra contra o terrorismo e vingar os mortos durante os ataques".

Não há imagens, não há repetições, não há hiperbólicas formas de referenciação. Em vez de presentificar a emoção das homenagens às vítimas, o discurso reitera a idéia de guerra e de vingança, tão evidente na edição de 11 de setembro de 2001 e recorrente na mídia em todo o ano seguinte.

Essa é a principal diferença na inflexão do discurso dos dois telejornais em 2002. Um utiliza em grande escala recursos de manipulação dos afetos e de exacerbação da emoção; o outro coloca freio nesse ímpeto, mas não poupa recursos de manipulação cognitiva ao fazer lembrar de cenas da tragédia cujos autores não poderiam ficar impunes. Há estratégias dramáticas e ecos do clamor de guerra nos dois noticiários, mas as inclinações de cada um são reveladas logo na abertura e confirmadas ao longo das edições. Ambas dedicam espaço significativo à matéria, que ocupa quase todo o segundo bloco nos dois telejornais.

Na passagem de bloco, o locutor do Jornal Nacional anuncia: "Daqui a pouco, o 11 de setembro no mundo. Nossos repórteres mostram como o planeta lembrou o aniversário da maior ação terrorista da história". Entram imagens das cerimônias, com a 
seguinte legenda: "cicatrizes". A expressão metafórica funciona como um termo de retomada dos vestígios da destruição provocada pelos atentados e sobretudo dos sentimentos que perduram e não devem ser apagados da memória do "planeta", que é reativada por cenas de grande emoção e pela indefectível anáfora "a maior ação terrorista da história", relativa a "o 11 de setembro".

Quando o segundo bloco começa, o locutor repete a expressão e o discurso enfatiza a comoção mundial: "Os olhos do mundo se voltaram hoje para o local onde 2.801 pessoas foram mortas há um ano. No sul da ilha de Manhattan, onde ficavam as torres do WTC, uma cerimônia abriu as homenagens às vítimas da maior ação terrorista da história". Não podemos deixar de observar que "os olhos do mundo", lírica figura metonímica, se voltaram para o local da tragédia por meio dos olhos das câmeras de televisão sobretudo do mundo ocidental.

As imagens, o texto, a música de fundo do VT, tudo condiciona o telespectador a um clima de consternação. Na multidão, pessoas seguram fotos das vítimas e bandeiras americanas. Closes e mais closes de olhos e lágrimas. Imagens do World Trade Center antes da tragédia e do terreno então vazio, lugar da cerimônia.

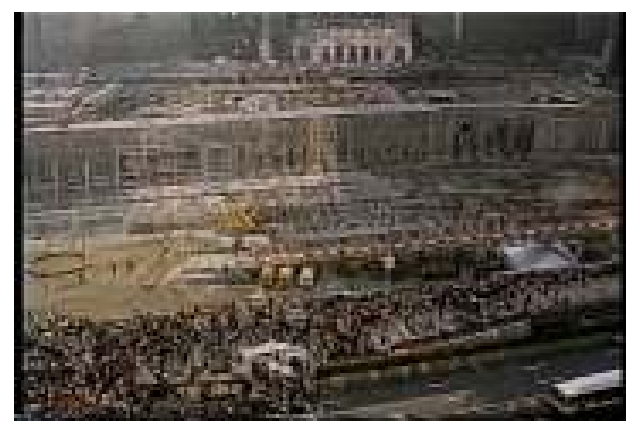

Figura 31

Narração sentimentalista, emoção pré-fabricada: "Pareciam procissões, pareciam peregrinos. Eram filhos, mães, pais, irmãos, amigos. Gente de todas as raças e gerações. Juntos para homenagear os seus mortos. Retratos na multidão. O lugar, que foi um símbolo do poder econômico americano e hoje é um imenso espaço vazio (figura 31), foi sendo lentamente ocupado pelas famílias das vítimas mortas no ataque que feriu o 
coração de Nova York". A homenagem aos mortos do 11 de setembro une "gente de todas as raças". Nenhuma palavra sobre os povos que entraram em guerra depois.

Reporta-se o minuto de silêncio feito no mesmo horário em que o primeiro avião atingiu as torres e a leitura dos nomes, "um a um" (como enfatiza desnecessariamente a repórter que está no local da cerimônia), "de todos os que morreram no ataque às torres, entre eles três brasileiros". Esse foi, segundo o texto, "o momento mais emocionante da cerimônia". Mostra-se as pessoas lendo os nomes, compungidas, e outras chorando e se abraçando. Sobe o som da leitura e se pode ouvir o nome dos brasileiros: Ivan Kyrillos Barbosa, Sandra Fajardo Smith, Anne Marie Ferreira.

Os sinos lembrando o desabamento da segunda torre e a repetição da imagem da queda a reforçar a lembrança. A tradução de um trecho emocionado da fala de uma menina que fez uma homenagem em nome dos "órfãos de 11 de setembro" tem seu lugar no discurso. Nenhuma palavra sobre os milhares de mortos e órfãos do Afeganistão.

O sentimentalismo domina a narração: "As famílias compartilharam a dor, depositaram flores numa longa cerimônia de adeus. Puderam finalmente enxugar as suas lágrimas (figura 32) e enterrar simbolicamente os seus mortos, numa manhã de sol tão bonita quanto a de 11 de setembro de 2001, um dia que elas nunca vão esquecer".

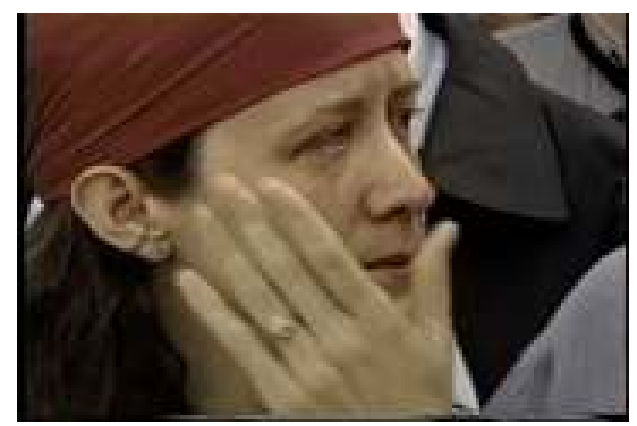

Figura 32

O texto tropeça na emoção e na coerência. Não se sabe por quê, acaba relacionando paradoxalmente o dia da tragédia a uma bonita "manhã de sol". O VT se encerra com imagens de mais gente chorando e de uma enorme faixa em que se lia "We will never forget". O filme de 2002 carrega nas tintas do drama. 
O locutor chama a matéria seguinte: "O presidente George Bush aproveitou o 11 de setembro para mandar um recado para Saddam Hussein". Exatamente a mesma estrutura usada no ano anterior para citar uma fala do general Colin Powel ("antes de embarcar, o general da Guerra do Golfo mandou um recado aos terroristas"), a mesma locução verbal, o mesmo movimento de catáfora, o mesmo tom ameaçador, mas um destinatário diferente.

Antes de dizer qual era o "recado" de Bush, o repórter fala da cerimônia no Pentágono: "A tristeza se misturou com o orgulho. Passados 365 dias, a ala que sofreu o impacto está totalmente reconstruída". Uma enorme bandeira americana aparece pendurada numa das paredes do prédio. Apesar da tristeza, o país reconstrói seus símbolos e seu "orgulho", a mídia é testemunha disso. Nenhuma palavra sobre o Afeganistão destruído.

O repórter continua: "Mas o presidente deu ainda um outro tom a essa cerimônia: o de preparação para a batalha. Num recado claro a Saddam Hussein, George Bush disse que a guerra atual não é só contra terroristas (entra a imagem de Bush discursando). Segundo ele, ditadores que conspiram contra os Estados Unidos estão na mira das forças armadas americanas. Ele prometeu derrotar os inimigos". Sobe o som da fala enfática de Bush, sem tradução: "But I will stop it".

O discurso interpreta a fala do presidente e associa os referentes "ditadores que conspiram contra os Estados Unidos" e "Saddam Hussein". Não se explica de que conspirações se trata nem se questionam os meios que deverão ser empregados na "batalha", apenas se dá espaço na teia discursiva às afirmações e promessas do presidente vingador, que irá parar os inimigos.

Mas há outros protagonistas na história que o telejornal conta: "Do Pentágono, George Bush foi à Pensilvânia, onde se emocionou ao conhecer as famílias dos heróis do vôo 93 , os passageiros que lutaram contra os seqüestradores, forçaram a derrubada do avião e impediram um outro atentado no dia 11 de setembro". O discurso interpreta não só falas relatadas, mas também gestos. Não há imagens que mostrem o presidente "se emocionando", mas apenas abraçando pessoas, inclusive crianças, e tirando fotos, como numa campanha eleitoral. 
Há ainda imagens de bandeiras americanas, de uma placa com o nome das vítimas e de outra placa em que se lia: "To the first citizen heroes of the $21^{\text {st }}$ century. The passengers and crew of flight 93. Let's roll." Mais que vítimas, os americanos são mostrados agora como heróis. Nenhuma palavra sobre uma das teorias da conspiração, segundo a qual o avião que caiu na Pensilvânia teria sido derrubado por uma ação da defesa americana.

Por fim o repórter informa: "Daqui a pouco, Bush fala ao povo americano. Além de fazer um balanço dos últimos doze meses, ele prepara o país para o que vai acontecer a partir de agora, incluindo a urgência que a Casa Branca tem em combater o que é definido como o maior perigo potencial no momento: o Iraque".

O telejornal não explica por que o Iraque é o "maior perigo potencial" naquele momento, muito menos faz um balanço dos fatos que marcaram aquele ano de guerra contra o terror. Mais silêncios no discurso que alimenta a memória do público tão-somente com imagens da dor americana e da justa vingança.

Depois são mostradas as homenagens que as vítimas receberam "no mundo inteiro". Imagens comoventes, música solene e triste de fundo, as manifestações de "compaixão e condolências" e a repetição da idéia fixa de Bush, agora citada não como discurso relatado, mas como o resumo de uma formação discursiva que subjaz ao discurso do telejornal: "Os inimigos agora são outros". O repórter explica: "A embaixada dos Estados Unidos na Dinamarca recebeu um envelope contendo o perigoso antraz".

Segundo Dorneles, em fevereiro de 2002 já se tinha informações de que o antraz fora desenvolvido em laboratórios do exército americano e que o governo ocultara isso para manter a suspeita de que Saddam Hussein estava por trás do terror biológico (2003:128). Nenhuma palavra sobre isso na edição de 11de setembro de 2002.

Em vez disso, volta-se a dar lugar aos tambores de guerra: "O mundo olhou para trás e prestou uma homenagem aos que morreram no 11 de setembro. Agora espera. Amanhã, na ONU, em Nova York, o presidente Bush vai fazer um discurso. Quer convencer a comunidade internacional que uma guerra, agora contra o Iraque, é necessária". O discurso é reticente.

O mundo espera olhar para frente e ver o quê? O mundo já fez o que tinha de fazer e agora espera qual decisão da comunidade internacional? Paz ou guerra? Esse mundo 
metonímico que a mídia mostra terá realmente olhado para trás naquele dia e visto somente as vítimas do 11 de setembro? As outras vítimas realmente não importavam ou não ocupavam a memória do mundo porque eram invisíveis na mídia? Os silêncios podem ser reveladores se soubermos ouvi-los.

O bloco de notícias sobre o aniversário dos ataques termina com mais imagens, vozes e músicas editadas com efeitos de pungência. O locutor quase lamenta: "Nas ruas de Nova York, hoje, o repórter Luiz Carlos Azenha encontrou inconformismo e tristeza entre os sentimentos de americanos e de estrangeiros".

O texto do repórter é a mais pura expressão do sentimentalismo, redundante nas imagens e no ininterrupto som de gaitas de fole ouvido ao fundo: "Uma lágrima na calçada. Outra, na esquina. Flores. Orações. Uma bandeira. Uma bandeira na camisa. Uma bandeira na pele (figura 33). (Uma mulher tatuada com a bandeira diz, conforme a tradução do repórter: 'Foi como se arrancassem meu coração'.) 'Ainda sinto raiva', diz o homem que ajudou a procurar sobreviventes. Foi um daqueles dias em que todos se perguntaram: onde é que eu estava há um ano?".

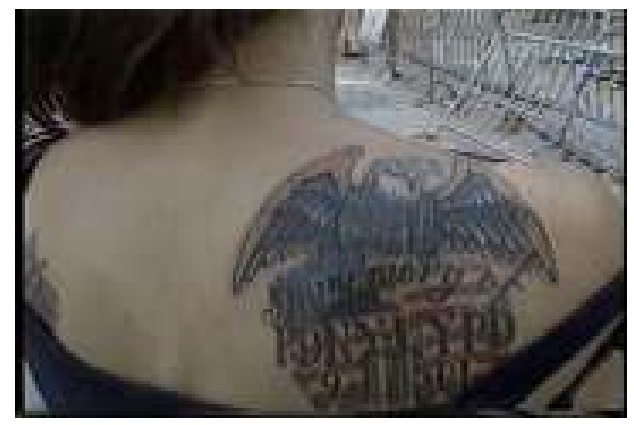

Figura 33

A câmera mostra mais e mais pessoas chorando. As bandeiras não deixam esquecer do orgulho e do patriotismo americano. As vozes de dor e raiva não deixam esquecer a tragédia que vitimou a única superpotência mundial.

O repórter conta que a cerimônia fez um homem, apenas identificado como José, lembrar-se das "cenas de guerra" que fotografou (figura 34) e filmou em 11 de setembro. A voz do homem é coberta por fotos e imagens de vídeo do World Trade Center destruído, de telefones tocando no meio dos escombros numa sala de recepção: "Eu 
lembro bem da hora em que eu entrei no prédio, pelo lado da passarela, e os telefones estavam tocando insistentemente. Com certeza eram os familiares procurando notícia das pessoas que estavam lá dentro". É grande o efeito de presença das cenas, assim como sua contribuição à densidade dramática do discurso.

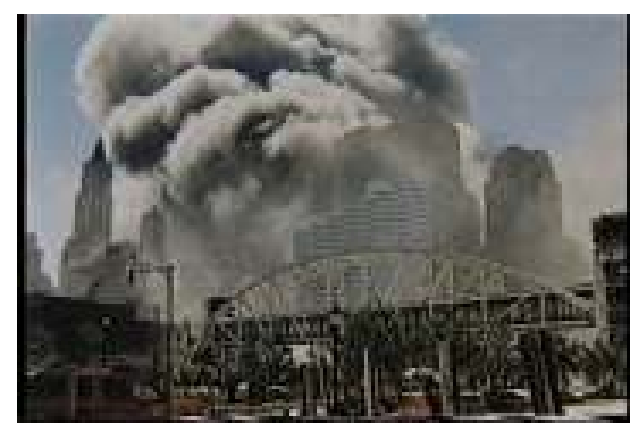

Figura 34

Uma última voz é inserida no discurso que persegue a comoção e que agora fala da "dor maior" dos que "nem mesmo conseguiram fazer o enterro dos parentes e amigos que perderam na tragédia". Entre as 1.331 pessoas desaparecidas, um bombeiro por quem a mulher ainda espera: "Às vezes eu penso que ele está num hospital, sem memória, perdido, querendo voltar pra casa. Isso que eu penso. Eu penso que ele ainda vai bater na porta, e eu vou abrir, e vai ser ele".

O som das gaitas de fole ecoa como um lamento e a matéria se encerra, com a imagem da ausência calando na memória. Nem era preciso repetir as cenas dos ataques, bastava reconhecê-las por trás das lágrimas que o telejornal mostrava agora sem nenhuma parcimônia. O discurso da perplexidade, que retumbou na edição de 2001 e atingiu mais a superfície do espetáculo do que a essência da tragédia, se transformou em rito de reverência.

O enfoque do Jornal da Record foi diferente do privilegiado pelo Jornal Nacional. Como fez na escalada, o locutor destaca na passagem de bloco não só as cicatrizes dos atentados: "Veja a seguir. Os americanos se emocionam no primeiro aniversário do maior atentado da história. Bush promete vencer a guerra contra o terror e vingar os mortos". Mais do que a emoção das homenagens, o discurso enfatiza a promessa de vingança de Bush e não deixa de lembrar o motivo da guerra, reiteradamente identificado como "o maior atentado da história". 
A chamada da matéria, no início do bloco, é redundante: "Tristeza, medo de novos ataques terroristas e promessas de vingança. Assim foi o primeiro aniversário dos atentados de 11 de setembro nos Estados Unidos. As cerimônias emocionaram os americanos". O VT começa com imagens bem parecidas com as do outro telejornal: uma multidão na cerimônia em Nova York, pessoas chorando e segurando fotos (figura 35), a leitura dos nomes das vítimas, a emoção das gaitas de fole, mas o texto é bem menos emotivo e não há nenhum trecho que se destaque nesse sentido.

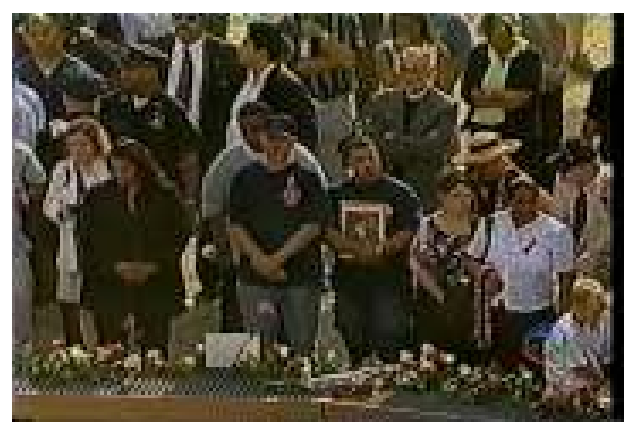

Figura 35

Em seguida, mostram-se as cerimônias no Pentágono e na Pensilvânia (figura 36), repete-se a informação de que Bush prometera "vencer a guerra contra o terror e vingar todos os americanos mortos nos atentados" e exibe-se a imagem da mesma placa de homenagem aos "heróis do vôo 93". O texto consegue dominar a emoção das imagens, do que resulta um conjunto discursivo mais sóbrio.

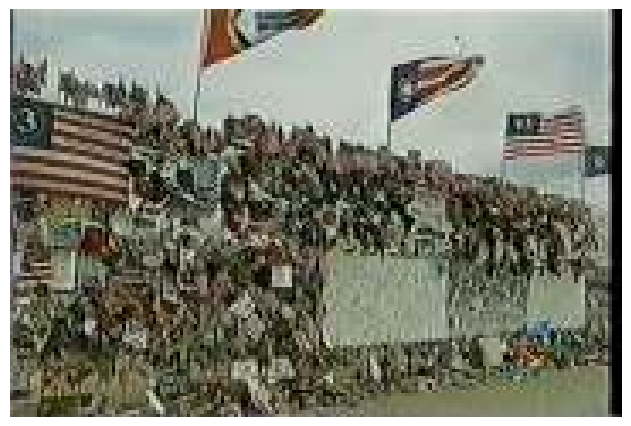

Figura 36 
No trecho seguinte, porém, a temperatura sobe. Começa o flashback dos atentados: "Há um ano, o mundo parava atônito para acompanhar ao vivo o ataque terrorista mais ousado e devastador da história. Os Estados Unidos, maior potência do planeta, foram golpeados em seu próprio território e seus símbolos de poderio financeiro e militar, reduzidos a escombros".

Curiosamente, o que não se vira na edição de 2001 agora transborda no discurso por meio de expressões grandiosas: "o mundo parava atônito", "o ataque terrorista mais ousado e devastador da história", "maior potência do planeta", "símbolos reduzidos a escombros". Os objetos de discurso, cuja lembrança é reavivada com mais ardor, parecem ser outros. Fomenta-se a memória de quanto a potência foi aviltada com aqueles ataques. Nenhuma palavra sobre outros ataques devastadores da história recente.

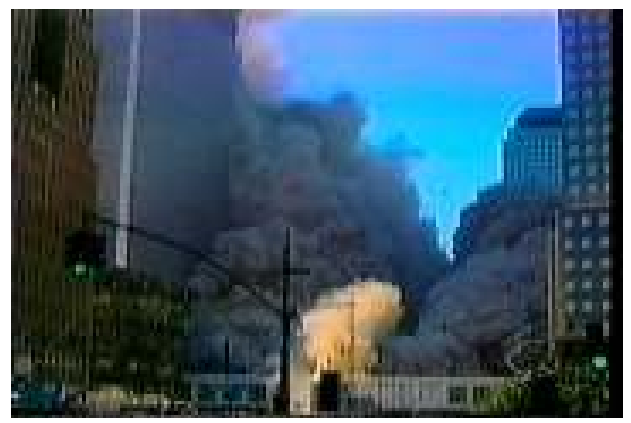

Figura 37

A memória eletrônica não deixa esquecer: "Manhã de 11 de setembro de 2001. A famosa silhueta de Nova York está prestes a mudar para sempre (imagem do WTC antes do ataque). O primeiro impacto foi registrado por um documentarista que estava por acaso nas imediações do WTC. (Entram imagens do choque do primeiro avião e da explosão, imagens não vistas na edição de 2001.) Dezoito minutos mais tarde, o mundo inteiro viu a segunda torre ser atingida. (Entra uma seqüência de imagens: o choque do segundo avião, as torres em chamas, fumaça e poeira - figura 37.) Foi o início do mais devastador e ousado ataque terrorista na história dos Estados Unidos. Uma chuva de aviões de passageiros seqüestrados por um obscuro grupo de terroristas suicidas". 
O drama todo ressurge na tela e as explosões acendem centelhas na memória do público. O recurso de mostrar "o antes e o depois" das torres, a exibição de imagens inéditas, a repetição de referências como "o mais devastador e ousado ataque terrorista da história" - dessa vez limitada pela adequada especificação "dos Estados Unidos" -, a hiperbólica expressão metafórica "chuva de aviões", tudo recompõe o cenário de 11 de setembro de modo intenso.

A matéria prossegue mostrando a destruição no Pentágono, "símbolo do poderio militar americano", o local em que "se espatifou" o quarto avião, "o único que não atingiu seu objetivo, provavelmente a Casa Branca", o presidente Bush recebendo a notícia naquela escola primária na Flórida.

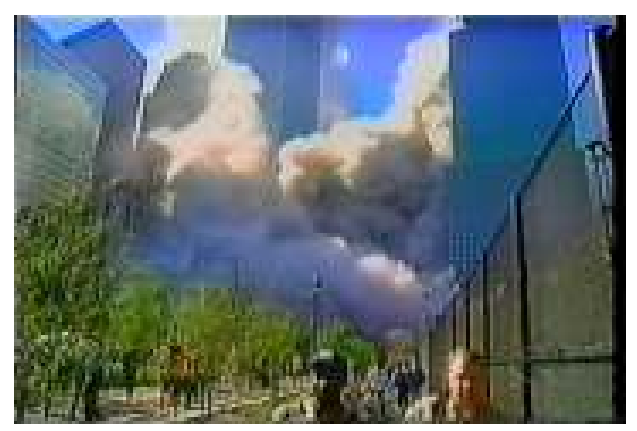

Figura 38

O locutor atiça a memória: "O clima era de guerra. Na capital, Washington, a Casa Branca, o Congresso e outros prédios públicos foram esvaziados. A América parecia sem governo, aterrorizada, mas o pior ainda estava por vir. (Entra mais uma seqüência de imagens: pessoas nas janelas, o desabamento das torres, pessoas correndo nas ruas, muita fumaça - figura 38.) No alto das torres gêmeas, em Nova York, os acenos desesperados de quem já não tinha como escapar. Foi quando a primeira torre veio abaixo. Mais meia hora e a segunda torre desabou. A estrutura derreteu em meio de toneladas de combustível em chamas. O dia virou noite. Nova York estava mergulhada no caos e na tragédia. Quando a poeira baixou, 2.800 pessoas tinham sido pulverizadas debaixo de um milhão e meio de toneladas de aço e concreto". 
Imagens e texto vão se sucedendo dramaticamente. Parece trailer de filme, só que exibido um ano depois do lançamento: clima de guerra, a América sem governo e aterrorizada, acenos desesperados, o dia virando noite, Nova York mergulhada no caos e na tragédia. Como diria o locutor do Jornal Nacional em 2001, "acontecimentos que nenhum roteirista de Hollywood imaginou", agora emanando da memória metálica reenquadrados pela narração grandiloqüente.

O mais curioso nesse trecho é a informação do número de vítimas, desconhecido em 11 de setembro, dia que está sendo lembrado na seqüência fílmica. No universo diegético do telejornal, era possível fundir os tempos e entrelaçar informações: "quando a poeira baixou, 2.800 pessoas tinham sido pulverizadas" (figura 39). Na época, se falava em "dezenas de milhares de vítimas", das quais nunca se viu nenhuma imagem.

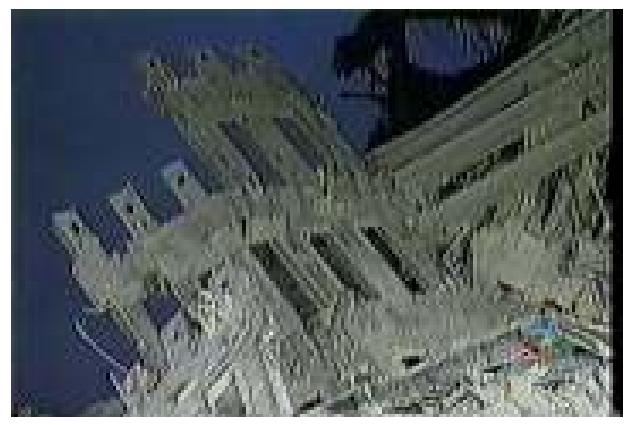

Figura 39

O discurso avança e volta no tempo: "O resgate durou sete meses. A identificação dos corpos, com amostras de DNA, continua até hoje. Quando a noite de 11 de setembro chegou, milhares de nova-iorquinos estavam em vigília esperando notícias de familiares e amigos desaparecidos. No ar, a pergunta era: Quem tinha feito aquilo? Quem odiava tanto os Estados Unidos? Feridos e assustados, os americanos choraram seus mortos (imagens de pessoas chorando) e os vivos não se sentiam mais seguros na sua pátria, a América (imagens da ilha sob fumaça e da Estátua da Liberdade)".

No final do VT, um longo trecho sem narração, sob o som de uma música melancólica. Na tela, uma arte em que se lê: 11 de setembro - World Trade Center, NY 2.801 mortos - Pentágono, Washington - 184 mortos - Pensilvânia - 40 mortos. 
A pergunta que estava "no ar" era, na verdade, uma pergunta feita pelo próprio presidente Bush. Já apresentamos, neste capítulo, um comentário de Chomsky a respeito dessa indagação, assumida também, ao que parece, pelo discurso do telejornal. Não se tratava de ódio, mas havia muitos motivos políticos, econômicos, sociais e culturais para um sentimento de antiamericanismo. Só os Estados Unidos, seus aliados e a mídia ocidental pareciam não enxergar isso ou simulavam ignorância, o que explicaria a absoluta falta de contextualização histórica dos fatos que iam se inserindo numa nova história, sempre contada de modo unilateral pela mídia. No trecho acima também se observa o súbito sentimentalismo que assoma no discurso, numa manobra manipulativa bastante semelhante à adotada pelo Jornal Nacional.

Na seqüência, o âncora Boris Casoy faz praticamente um editorial:

"A barbárie humilhou o gigante americano, barbárie que ceifou milhares de vidas e que só pode ser explicada pelo radicalismo religioso, levado as últimas conseqüências políticas. Depois do atentado, depois da humilhação, o mundo nunca mais foi o mesmo e talvez não o seja. Com uma liderança débil, os Estados Unidos elegeram como sua principal atividade no setor político e internacional o combate ao terrorismo, relegando a plano secundário vários problemas do mundo. O que se espera é que os autores intelectuais dessa barbárie sejam realmente punidos. Não há explicação e não há justificativa. O gigante foi humilhado e não vai sossegar enquanto não for buscar os autores nas suas cavernas e nos seus esconderijos. Entretanto o mundo não pode se calar quando vê que o radicalismo religioso ganha degraus, conquista juventudes, sacrifica vidas de um lado e de outro. O mundo precisa caminhar para a paz, o mundo precisa combater, infelizmente, com todos os instrumentos os radicalismos, especialmente aqueles com fundamento religioso, que só encontram explicação na obscuridade, obscuridade que precisa ser iluminada por todos nós".

O atentado ganha o epíteto de "barbárie"; os Estados Unidos, o de "gigante americano". Apenas novas formas de designação no mesmo contexto - oficial e midiático que opunha os bárbaros aos civilizados desde o 11 de setembro. O discurso corrobora o consenso fabricado de que os Estados Unidos foram "humilhados", mas esquece de dizer que a humilhação, naquele caso, era um sentimento decorrente do fato de o país sentir-se superior em relação a todas as nações do mundo. De resto, as mesmas explicações jamais questionadas pela mídia. Aliás, a confusão parecia sempre aumentar: o que 
significaria "radicalismo religioso levado às últimas conseqüências políticas"? Talvez fosse apenas uma expressão de efeito.

Mas, no meio do discurso inclinado às razões dos Estados Unidos, aparece uma censura ao governo Bush - que relegara "a plano secundário vários problemas do mundo" para combater o terrorismo -, logo abandonada para que se continue o desagravo. $O$ sentimento de vingança ainda ecoa um ano depois, a despeito de tantas outras mortes havidas na guerra contra o terror - principalmente no Afeganistão, ao qual se faz clara alusão no trecho "buscar os autores nas suas cavernas" - e a despeito de tantas outras barbáries cometidas em nome da civilização. Como então se caminharia para a paz? Como a obscuridade seria iluminada, se grande parte dela se devia às sombras do discurso oficial e da mídia? Temos a impressão de que a voz do âncora na polifonia discursiva do telejornal passaria pela voz de qualquer líder americano naquele momento.

Em seguida, fala-se da preocupação com a segurança em "várias partes do mundo". Uma "suspeita" de material radioativo a bordo de um navio na costa dos Estados Unidos; um pouso de emergência de um avião americano porque "o piloto considerou suspeitos três passageiros que haviam se trancado no banheiro" (os passageiros "foram retirados do avião, sem incidentes"); um avião que retornou a Huston por que os passageiros "desconfiaram que uma pessoa a bordo tinha uma arma" ("nenhuma arma foi encontrada"); um prédio esvaziado em Ohio "depois que cães do esquadrão antibombas reagiram a uma van estacionada" ("o alerta não foi confirmado").

Além desses fatos ocorridos nos Estados Unidos, cuja natureza alarmante é desmentida no próprio discurso que os noticia, são citadas medidas de segurança tomadas em países como a Inglaterra, a Alemanha e a Itália, mas nenhum fato concreto que sustentasse o alerta permanente em que o governo americano e a mídia insistiam em manter o mundo.

O telejornal continua seu exercício de excitar a memória: "Feridos e humilhados, os americanos declararam guerra, mas uma guerra diferente, a um inimigo de face invisível, o terrorismo". E recomeça o flashback, meio impreciso, como não deveria ser em se tratando de uma memória metálica: "Os Estados Unidos ainda estavam de luto quando os tambores da guerra começaram a tocar (imagem de uma enorme bandeira americana pendurada no prédio do Pentágono logo após o ataque). No meio das ruínas do WTC, o 
presidente Bush prometeu caçar os responsáveis pelo atentado contra as torres" (imagem de Bush falando num megafone, no meio de equipes de resgate).

O presidente não havia feito a promessa de "caça aos responsáveis" no meio das ruínas do WTC, mas em discurso numa base militar no dia 11 de setembro mesmo. 0 país ainda não tivera tempo para entrar de luto, no meio do cenário de caos e guerra. $O$ discurso desconsidera essas imprecisões e continua a articular o sentimento de luto com a idéia de que Bush tocara os tambores de guerra - no que foi acompanhado pela sinfonia da mídia - em nome da justiça.

O memorial prossegue falando de Osama Bin Laden e de sua ligação com a Al Qaeda. Mostram-se imagens de Bin Laden e do que parece ser um grupo terrorista em treinamento. Não se identificam as imagens, mas elas reforçam a história que se conta. Lembra-se ainda que Bin Laden, "um saudita de família milionária que colocou sua fortuna e habilidades a serviço do extremismo islâmico", foi apontado como o "principal suspeito" dos ataques de 11 de setembro, mas não se fala em prova alguma.

As lembranças avançam: "A postura das alianças e os preparativos militares duraram menos de um mês. Uma onda patriótica cobriu os Estados Unidos de bandeiras e símbolos. E no primeiro domingo de outubro, a guerra contra o terrorismo começou" (entram imagens de aviões e de explosões numa cidade não identificada). Nem se pronuncia a palavra "Afeganistão". Como alertara Dorneles, o miserável país sumiu do mapa e da mídia ocidental. A face invisível do terror tinha endereço e milhares de rostos, mas isso nunca se tornou visível na mídia.

Mas não era só isso. A desinformação continuava: "Mal iniciada a ofensiva, os americanos foram golpeados por um novo ataque terrorista, biológico. Cartas com pó branco, contaminados pela bactéria antraz, chegaram a jornais, redes de TV, Congresso, Casa Branca e outros prédios oficiais. E com elas, mais pânico. Se os aviões de carreira já não eram seguros, o gesto banal de abrir a correspondência podia levar à morte. Dezoito pessoas foram contaminadas e cinco morreram. Os funcionários dos correios foram as grandes vítimas. $O$ autor das cartas contaminadas não foi descoberto, mas dois meses de bombardeios demoliram o regime do Talibã, no Afeganistão" (imagens de tanques e de outras explosões). 
Já se sabia que os ataques com antraz não tinham ligação com o terrorista Bin Laden ou com Saddam Hussein, mas o telejornal oculta isso e afirma que "o autor das cartas contaminadas não foi descoberto", embora continue a insinuar suspeições. O que mais chama a atenção, no entanto, é o fato de o discurso praticamente endossar que meras suspeitas já justificariam o bombardeio ao Afeganistão.

O final da matéria relembra com pesar: "Procurado vivo ou morto pelos americanos, Bin Laden sumiu nas montanhas e cavernas afegãs (imagem de um cartaz com foto: "Bin Laden - Wanted dead or alive", figura 40). Deixou para trás fitas de vídeo em que comemora os atentados e reafirma seu ódio à América"101. A divulgação de um cartaz à boa e velha moda dos faroestes americanos tem o efeito de sedimentar a simbólica dicotomia entre bandidos e mocinhos.

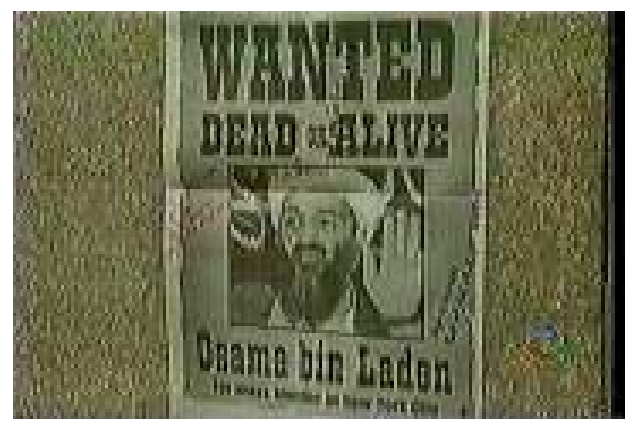

Figura 40

Por fim, o telejornal fala de alguns "sobreviventes da tragédia", para quem "é impossível esquecer a data que mudou a vida de cada um". Seria estranho se não fosse assim, mas o discurso insiste em reforçar o sentimento. O tom da locução volta a ser melodramático e o texto, cheio de lugares-comuns: "Sobreviver é desafiar o destino. Isso

\footnotetext{
101 Em dezembro de 2001 foi divulgada uma fita de vídeo em que Bin Laden assumia a autoria dos atentados de 11 de setembro. No artigo "A verdade, ora, e seus fiadores", (Jornal do Brasil, 20/12/01), Eugênio Bucci conta que a autenticidade do vídeo dividia opiniões, sobretudo entre os árabes. O governo americano garantia que era uma "prova arrasadora", mas havia quem afirmasse ser uma falsificação. Bucci fez sua análise: "É esquisito que Bush precise de um vídeo como esse para que o mundo creia no que ele diz, e é igualmente estranho que o mundo precise do atestado do governo Bush para crer no vídeo que ele mostra. A garantia da veracidade da fita magnética é a palavra de Bush. A garantia de Bush é a fita magnética. Não há como sair dessa sinuca." Depois ainda haveria muita especulação sobre a autoria dos atentados, muitas fitas supostamente atribuídas a Bin Laden e à Al Qaeda, muitos presos em Guantánamo sem provas, muitos boatos sobre a morte de Bin Laden.
} 
nunca foi tão verdadeiro como na tragédia do WTC. O empresário Tomas Canavan estava no $47^{\circ}$ andar quando o ataque começou (imagem do homem ensangüentado). A duras penas conseguiu descer até o térreo e foi soterrado pelo desabamento de uma das torres (repetem-se as imagens do desabamento). Milagrosamente sobreviveu (outras imagens do homem ensangüentado). Um ano depois, Canavan é um homem que tenta conviver com seus fantasmas (imagens do homem dando entrevista em 2002). Não consegue dormir mais que quatro horas por noite e ainda toma remédios". Curiosamente, o homem é o mesmo mostrado na única imagem exibida em 2001 de uma pessoa ensangüentada.

Depois, consta-se a história de um guarda de segurança que sofreu queimaduras graves em $40 \%$ do corpo - as imagens das cicatrizes enchem a tela - e que hoje "tem o coração cheio de ódio". Fala-se também de um bombeiro que "sente culpa de ser um dos sobreviventes" e sempre se lembra do "pesadelo" e do drama das famílias dos desaparecidos, como a de Martin, por cujos "restos mortais" a mãe e a irmã ainda esperam. O discurso não despreza a grande imagem da ausência, que parece ideal para um desfecho ao qual subjaz outra alusão ao dia que mudou o mundo: "Elas contam que outro dia compraram flores para ele, mas não sabiam onde colocá-las, onde levá-las. Dizem que não tinham percebido como a vida era boa antes de 11 de setembro".

\section{1 de setembro de 2003}

Dois anos depois, conforme análise de Emir Sader, a despeito do fortalecimento militar obtido com as campanhas no Afeganistão e no Iraque, os Estados Unidos estão mais isolados politicamente do que antes dos atentados de 2001, sobretudo por terem negligenciado até mesmo o papel da ONU ao tomarem decisões arbitrárias em relação aos conflitos que protagonizaram ${ }^{102}$.

Naquele momento, segundo Sader, tomados no seu conjunto, "com potência imperial, com força econômica, política, militar, tecnológica, ideológica e propagandística, os Estados Unidos não encontram nenhum adversário à altura". Naquele momento, a previsão de Sader era desoladora, em vista de não haver propostas concretas de aglutinação de forças com vistas à construção de uma hegemonia alternativa: "Podemos

${ }^{102}$ No artigo "Isolados, EUA sofrem revés na guerra da política mundial", publicado sob o chapéu editorial
"O império balança", em 8 de setembro de 2003, Agência Carta Maior. 
esperar então um mundo mais desordenado, violento, caótico, conforme os Estados Unidos percam capacidade de consenso e a substituam pelo uso da força e por um discurso militarizado".

Enquanto isso, também dois anos depois dos atentados, diversas organizações de direitos humanos dos Estados Unidos entram em campanha contra a ostensiva segurança interna que punha em risco direitos civis e liberdades individuais no país que se proclama guardião da democracia e da liberdade.

Segundo análise de Ottoni Fernandes Jr., os norte-americanos tinham de enfrentar naquele momento, principalmente nos aeroportos, restrições resultantes de "uma poderosa combinação da mais moderna tecnologia com a histeria antiterrorista"103. O clima de alerta permanente continuava a sustentar as investidas militares do governo Bush e a escalada do racismo e do preconceito religioso, mas já começava a dar sinais de cansaço.

Muitas organizações não-governamentais começam a denunciar violações aos direitos humanos e até às leis federais dos Estados Unidos, que não permitem que pessoas sejam investigadas apenas por sua nacionalidade, raça, gênero ou religião. Volta à tona o caso dos mais de quinhentos suspeitos de pertencerem à $\mathrm{Al}$ Qaeda presos na base militar norte-americana em Guantánamo, em Cuba, mantidos incomunicáveis e em condições desumanas fazia mais de dois anos. Não havia acusação formal, assistência jurídica nem julgamento oficial. Também não havia grande interesse da mídia pelo caso, que já sumira dos noticiários em 2002, segundo levantamento de Dorneles (2003:83).

No início de 2004, a situação de "ilegalidade total" ainda será a mesma, segundo matéria do Le Monde Diplomatique, e membros de alguns meios de comunicação se aliarão às organizações humanitárias que denunciam as violações ao direito internacional cometidas pelo governo Bush e as condições deploráveis dos presos, verificadas assim que o Pentágono permite a visita de jornalistas à base militar, decisão que pretendia melhorar a imagem dos Estados Unidos naquele momento ${ }^{104}$. Mas nada mudará. Em abril de 2006 o Pentágono divulgará, pela primeira vez, uma lista de nomes e nacionalidades

${ }_{103}^{103}$ No artigo "Movimentos civis reagem à histeria antiterror nos EUA", publicado na revista Carta Capital de 13 de setembro de 2003.

${ }^{104}$ "Guantánamo, a ilegalidade total", janeiro de 2004, disponível no site do Le Monde Diplomatique. 
dos 558 prisioneiros detidos em Guantánamo, "com base na guerra contra o terrorismo" ${ }^{105}$, e é só isso.

Dois anos depois dos atentados, o Afeganistão é um país devastado e ainda sem governo central definitivo ${ }^{106}$. Os Estados Unidos ainda discursam em nome da "reconstrução nacional" do país invadido, que continua a receber menos da metade da ajuda internacional prometida. Conforme reportagem de Julien Bousac, teme-se que a instabilidade crescente deságüe no renascimento de um "movimento neotalibã", portanto "o novo Afeganistão não está, visivelmente, livre dos espectros do antigo país"107. No entanto, no mundo que tem visibilidade na mídia ocidental, continua-se a chorar apenas pelas vítimas de 11 de setembro.

No Brasil, os telejornais que examinamos continuavam a enfatizar, no segundo aniversário dos atentados, as homenagens às vítimas e a preocupação dos americanos com o terror, mas o destaque é bem menor. No Jornal da Record, a matéria entra no final do primeiro bloco; no Jornal Nacional, entra só no meio do terceiro bloco. O assunto perde espaço e todo o contorno emotivo na escalada ${ }^{108}$ do Jornal Nacional; no Jornal da Record, tem o mesmo espaço mínimo de 2002 e o foco ainda é o alerta permanente.

No Jornal Nacional, uma chamada simples e objetiva, com breves imagens de pessoas chorando durante a cerimônia: "11 de setembro de 2003. Nova York homenageia os três mil mortos do World Trade Center". Não se salienta mais a comoção mundial. No Jornal da Record, uma simples frase sintetiza o sentimento dos americanos: "Em alerta antiterror, americanos lembram os dois anos do atentado de 11 de setembro".

Entretanto, no interior da edição do Jornal Nacional, observa-se outro movimento enunciativo. Na passagem de bloco, anuncia-se: "Daqui a pouco. Nova York homenageia os mortos do terror". Quando o locutor chama a matéria, o discurso é mais ferino: "O mundo inteiro lembrou nesta quinta-feira os atentados terroristas de 11 de setembro de 2001. Dois anos depois, o homem apontado pelo Estados Unidos como responsável pelos ataques continua vivo, em liberdade e fazendo novos desafios". O selo que identifica o

${ }^{105}$ Folha Online, 19 de abril de 2006.

${ }^{106}$ Hamid Karzai foi o presidente interino da administração transitória afegã. Só seria eleito em 9 de outubro de 2004 e tomaria posse em 7 de dezembro de 2004.

107 "Os impasses do Afeganistão", dezembro de 2003, disponível no site do Le Monde Diplomatique. ${ }^{108} \mathrm{O}$ texto integral da escalada dos dois telejornais pode ser consultado nos anexos. 
assunto é o mesmo do ano anterior: 11 de setembro, escrito sobre a imagem das duas torres em chamas.

Apesar de o discurso limitar bem a fronteira com o discurso do outro, ao enfatizar que Osama Bin Laden - referente externo ao texto e invocado pela forma de designação indireta - é apontado "pelos Estados Unidos" como responsável pelos ataques, imediatamente deixa entrever a solidária indignação diante da informação de que o terrorista continuava vivo e desafiando a superpotência.

Em seguida, a correspondente que está em Nova York dá informações ao vivo sobre as homenagens daquele dia. Fala das colunas de luz que foram acesas no local para simbolizar as duas torres do World Trade Center e destaca a leitura dos nomes das vítimas, com um texto incrivelmente parecido com o do ano anterior, dito pela mesma repórter. A emoção em déjà vu: "Na cerimônia de hoje, no marco zero, onde ficavam os prédios, crianças que perderam parentes nos atentados leram os nomes das quase três mil vítimas. Foi o momento mais emocionante de um dia que começou muito cedo".

Esse é o gancho para o VT que entra na seqüência: "A vigília começou de madrugada. Orações judaicas, cristãs, budistas. Ficou claro que a perda foi de todos. No memorial, o homem se esforça para tocar o nome de alguém que perdeu na tragédia (o texto descreve a imagem). Luzes azuis ocuparam o lugar das torres gêmeas. Até o nascer do sol. Nova York acordou com a música das gaitas de fole que abriu a cerimônia". Durante o off, mostram-se imagens das cerimônias e muitas pessoas chorando. $\mathrm{O}$ som das gaitas fecha a emotiva descrição, que privilegia as ausências.

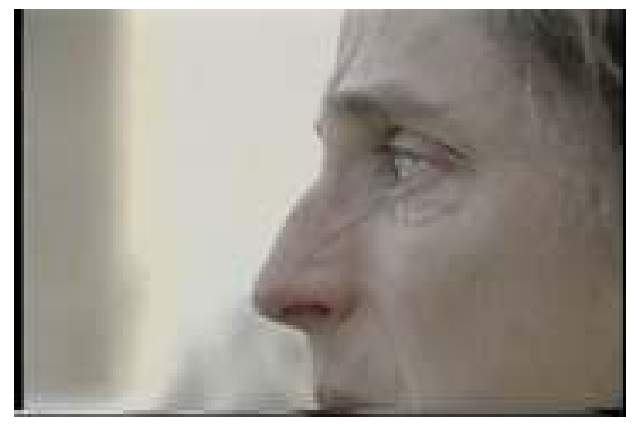

Figura 41 
Depois de informar que o presidente Bush e o vice-presidente Cheney não participaram das cerimônias, o repórter continua a descrever a cerimônia com emoção ainda mais estudada, enquanto se exibem imagens de mais pessoas chorando. Diz frases como: "A voz da órfã tremeu quando ela disse que a luz do pai ainda brilha. O homem recolheu areia do chão, como se estivesse resgatando o corpo do parente que deixou aqui. Os nomes dos três brasileiros mortos na tragédia foram lidos. (...) Para todos os que estiveram aqui, ficou um vazio do tamanho das torres que viraram pó" (figura 41). À medida que a memória dos atentados vai se afastando no tempo, percebe-se mais e mais a emoção como simulacro discursivo.

A correspondente dá outras informações ao vivo: "Um alerta emitido pelo Departamento de Estado pede que cidadãos americanos no mundo inteiro fiquem mais vigilantes. Há indícios de que a Al Qaeda estaria planejando um novo atentado. Apesar do medo, os americanos pararam hoje para homenagear as vítimas do 11 de setembro".

O telejornal dá espaço para mais declarações alarmistas do governo americano, mesmo que somente baseadas em "indícios", mas nem sequer comenta as manifestações contrárias ao clima de histeria que se instalara no país. Depois a repórter fala de outras cerimônias nos Estados Unidos e informa que o presidente Bush decidiu não fazer discursos, dizendo apenas que aquele era um dia "de reflexão e orações". Nenhuma palavra do telejornal sobre a situação de isolamento em que o país e o presidente se encontravam.

Na seqüência, a repórter repete a informação: "Foi um dia de luto, mas também de preocupação. O Departamento de Estado emitiu um alerta pedindo que os americanos no mundo inteiro, principalmente na Europa e na Ásia, redobrem os cuidados com a segurança, porque há indícios de que a Al Qaeda está planejando um atentado ainda mais devastador que os de 11 de setembro. Desta vez, a rede terrorista poderia atacar com armas químicas e biológicas".

A reiteração daquilo que representa somente suposições e suspeitas mostra como, muitas vezes, a mídia deixou de questionar as fontes oficiais, segundo as quais os Estados Unidos estavam sempre na iminência de serem atacados novamente por terroristas. Nenhuma palavra há, no entanto, sobre a situação dos países atacados pela assustada nação nos dois últimos anos. 
A repórter tenta explicar o alarme: "A tensão das últimas horas se deve à fita de áudio e vídeo de Osama Bin Laden e Ayman Al-Zawahiri divulgados ontem. A CIA confirmou a autenticidade da voz de Al-Zawahiri, mas ainda não concluiu o exame da voz atribuída a Bin Laden. Os analistas também tentam identificar o lugar onde a gravação foi feita examinando atentamente a paisagem e a vegetação. A CIA acredita que eles estão em algum lugar da fronteira do Afeganistão com o Paquistão. Para o FBI, a dificuldade para desmantelar a Al Qaeda não é menor. Em entrevista ao jornal USA Today, autoridades reconhecem que é muito mais difícil investigar a Al Qaeda do que a máfia e que talvez o FBI nunca consiga se infiltrar na máquina do terror de Osama Bin Laden".

No meio de tanta informação, o telejornal deixa de mencionar o conteúdo da fita, o que pode se dever à censura imposta pelo governo americano em relação à divulgação de mensagens dos inimigos. No entanto o trecho serve para explicar por que os Estados Unidos não tinham ainda derrotado Bin Laden e a Al Qaeda, mesmo depois de terem destruído o país que abrigava o terrorismo e contra o qual fora declarada guerra fazia quase dois anos.

Nesse contexto de reprodução do discurso oficial, surpreende a informação que a correspondente dá em seguida: "Uma pesquisa feita em vários países e publicada hoje nos Estados Unidos mostra que cresceu o sentimento antiamericano no mundo. Há dois anos, os Estados Unidos eram vistos como vítimas do terror. Agora, depois a guerra contra o Iraque, é visto [sic] como uma nação arrogante. Hoje houve homenagens às vítimas do 11 de setembro em vários lugares do mundo, mas também houve protestos".

Permite-se que uma voz dissonante, a do resultado da pesquisa, penetre o discurso telejornalístico. Dá-se a informação, porém não se entra em detalhes. A indeterminação do referente de "vários países" e o uso da voz passiva ("eram visto", "é visto") contribuem para que se informe o menos possível sobre aqueles que cultivam o "sentimento antiamericano". Também não se fala dos números da pesquisa, contrariando o que é típico na mídia, nem se explica por que isso pode ter acontecido, apenas se diz ligeira e superficialmente que isso se deu depois da guerra contra o Iraque.

Nenhuma palavra sobre o fato de nenhuma das alegações dadas pelos Estados Unidos para invadir o Iraque e depor Saddam Hussein ter se confirmado, tal como a existência de armas de destruição de massa. Nenhuma palavra sobre as novas tensões 
mundiais. Nenhuma palavra sobre os Estados Unidos ainda serem vistos (talvez por assim serem mostrados pela mídia) como vítima.

Da mesma forma, a repórter anuncia que houve homenagens e protestos no mundo, mas o que se vê na matéria é um grande destaque às homenagens. São quatro referências, entre elas a que salienta que a homenagem feita pelas tropas americanas no Iraque "foi num antigo palácio de Saddam Hussein". De resto, menciona-se que religiosos muçulmanos, na Indonésia, "pediram mudanças na política da Casa Branca em relação aos países islâmicos para evitar novos ataques", o que soa mais como ameaça do que como protesto.

Aliás, a palavra "protesto" só é usada uma vez no VT e em relação a um fato descrito ambiguamente: "Nas Filipinas, protestos contra e a favor dos Estados Unidos. Manifestantes incendiaram uma réplica das torres gêmeas para que o mundo nunca se esqueça do que aconteceu nos Estados Unidos" (figura 42). Além da estranha expressão "protestos a favor", pode-se notar que só se fala de "protestos contra" nas Filipinas, país de pouca expressão internacional, e mesmo assim o texto deixa obscura a interpretação das imagens.

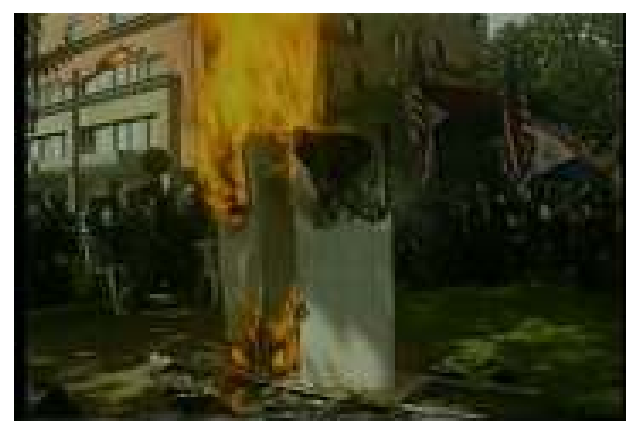

Figura 42

Não se saber ao certo se o ato de queimar uma réplica das torres era pró ou contra os Estados Unidos, mas palavras como "manifestantes" e "incendiaram" dão pistas de que se trata mesmo de um protesto, não a favor evidentemente, embora o discurso exima-se de esclarecer o objetivo da manifestação. Ao contrário, o discurso parece valerse do enunciado "para que o mundo nunca se esqueça do que aconteceu nos Estados 
Unidos" para deixar a impressão de que se tratava de algo positivo. Outra manobra de desinformação.

A matéria termina e entra uma charge (figura 43) de gosto duvidoso e com efeito de sentido imprevisível no conjunto discursivo. Uma voz diz: "11 de setembro, dois anos". $\mathrm{Na}$ tela, o desenho de fumaça - não de chamas - saindo das duas torres. A imagem de Bin Laden vem aparecendo do lado esquerdo do vídeo, como se viesse do céu. Ele sopra a fumaça que sai das duas torres, numa clara alusão ao ato de "apagar as velinhas". As torres somem com o sopro.

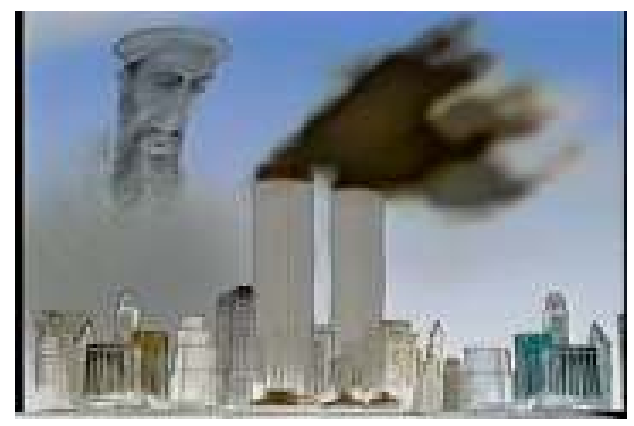

Figura 43

Parece-nos que a crítica subjacente à charge refere-se ao fato de Bin Laden ainda estar vivo e, provavelmente, comemorando o sucesso do ataque e o insucesso dos Estados Unidos em capturá-lo. Ele comemora e sopra as simbólicas velas do bolo. Certamente uma análise semiótica profunda extrairia mais elementos da charge televisiva, uma novidade do Jornal Nacional, mas o que mais nos chama a atenção é que, no contexto discursivo, a charge soa como um cacófato.

O sopro que apaga as torres é suave, os ataques foram violentos e a mídia insiste nessa memória. O sopro apaga as torres, mas as homenagens reiteradamente divulgadas pela mídia não deixam que elas se apaguem da memória. O sopro que apaga as torres reforça a imagem de poder de Bin Laden, ao contrário do discurso midiático, que ainda toca acordes da sinfonia de guerra contra o terrorista. Enfim, quem de certa forma vai apagando a imagem das torres não é Bin Laden, mas o próprio empalidecimento das imagens dos ataques no discurso do telejornal, observado ano após ano, ainda que a versão dos fatos se mantenha. 
No Jornal da Record, a palidez é menos acentuada. Ainda resistem as imagens que simbolizam os atentados desde que foram geradas para o mundo em 11 de setembro, embora o destaque para a matéria seja bem menor, diferentemente de 2002, quando se observou grande empenho em lembrar os ataques por meio de toda sorte de recursos. A principal mudança se dá na moldura verbal das imagens, essa sim mais descolorida.

O telejornal ainda fala do clima de alerta contra o terrorismo, mas com menos entusiasmo, e noticia as homenagens de dois anos com certo tédio: "A principal cerimônia foi em Nova York, no buraco onde se erguiam as torres gêmeas do WTC. Fotos, fotos, fotos e mais fotos. Para mostrar que eles não foram esquecidos". Parece que todos, principalmente a mídia, cumprem a obrigação de lembrar os que morreram "no maior ataque terrorista da história", forma de designação que resiste ao tempo.

O locutor vai descrevendo a cerimônia em Nova York e remetendo às cenas dos ataques, que ressurgem pela repetição das imagens: "Exatamente às 8h46 da manhã todos fizeram um minuto de silêncio para marcar o momento em que o primeiro avião de passageiros atingiu a torre norte do WTC (imagem do choque e da explosão). Em seguida, começou a leitura dos nomes das quase três mil vítimas. Às 9h03, outro minuto de silêncio para lembrar o ataque à torre sul (imagem do segundo choque, figura 44, e da explosão). Um minuto de silêncio também para lembrar os mortos do Pentágono, atingido pelo terceiro avião seqüestrado" (imagem do Pentágono em chamas).

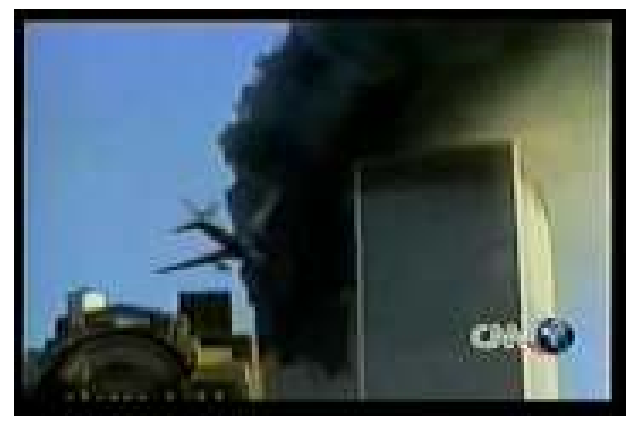

Figura 44 
Fala-se ainda de outras cerimônias nos Estados Unidos, que aconteceram todas "sob forte esquema de segurança, devido ao temor de um novo ataque terrorista", mas não se menciona nenhuma homenagem realizada em outra parte do mundo. Também não se noticia a pesquisa que revelava a evolução do sentimento antiamericano, tampouco são mostradas manifestações de protesto. $O$ discurso não retorna à cantilena de que o mundo nunca mais seria o mesmo, embora dois anos depois houvesse muitos motivos para enfatizar isso. Limita-se a lamentar a mudança na vida dos americanos: "Desde que os terroristas transformaram aviões de passageiros em armas de destruição em massa, a vida jamais voltou ao normal para os americanos. E talvez nunca volte".

Curiosamente, o texto que segue resume o movimento da memória e da história num mundo mediatizado e editado pela mídia: "Todo um modo de vida desabou junto com essas torres (imagem da queda das torres). Para o resto do mundo, essas imagens já começaram a fazer parte da história, dando lugar a cenas como o bombardeio de Bagdá e a ocupação do Iraque de Saddam Hussein (imagens dos conflitos). Mas para os americanos o pesadelo ainda não terminou, por mais que eles tentem deixar o horror dos atentados para trás" (mais imagens dos desabamentos e de pessoas correndo nas ruas, figura 45).

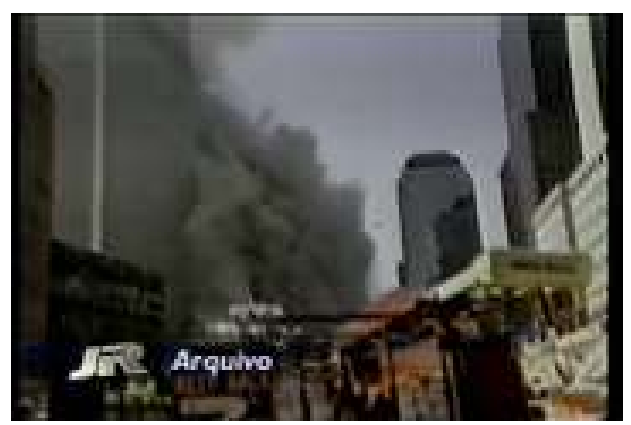

Figura 45

A memória coletiva dos americanos ainda pulsa e está longe da fronteira da história. A memória coletiva do resto do mundo, alimentada esparsamente pela mídia com fragmentos da realidade, agoniza e está à beira de virar história, à imagem e semelhança da história contada por essa mesma mídia, tecida de vozes e silêncios. 
Vozes que desnudam o comovente e surreal drama dos americanos: "Nos laboratórios, dezenas de milhares de exames já foram realizados e mesmo assim centenas de famílias ainda não têm o que sepultar, nem mesmo uma amostra de DNA. Todos os dias parentes de desaparecidos rondam o terreno do WTC como se procurassem fantasmas, mas o pior de tudo ainda é o medo, que não vai mais embora". (Enquanto o locutor diz isso, vê-se a providencial imagem de uma menina se agarrando à saia da mãe.) Silêncios que escondem com tarjas invisíveis outras guerras, outros dramas, outros cadáveres insepultos, outros fantasmas, outros medos, outros mundos.

Antes de mudar de assunto, o âncora do Jornal da Record faz um comentário que mostra bem o que a grande mídia insiste em tornar visível: "O terrorismo continua vivo e matando. Não faltam radicais, fanáticos religiosos e autoritários para atingir inocentes, civis inocentes no mundo inteiro, sob qualquer pretexto. $O$ ataque de 11 de setembro foi uma ação abominável, embora alguns pretendam justificá-la por razões ideológicas. $\mathrm{O}$ terrorismo precisa ser combatido com inteligência e com a força da democracia, democracia que esse mesmo terrorismo busca aniquilar".

Os argumentos dissonantes, fossem bons ou não, foram alijados das edições dos dois telejornais que ora analisamos, quiçá o tenham sido de toda a cobertura televisiva ou deixados à sombra do discurso monocórdio. Não se observou o desejado equilíbrio entre diferentes pontos de vista, essencial para que a liberdade de expressão não seja prerrogativa apenas de determinados grupos.

\section{1 de setembro de 2004}

Três anos depois dos atentados nos Estados Unidos, cresce a onda de ataques terroristas no mundo. Madri, Beslan, os casos se multiplicam e as faces do terror também, embora Bin Laden e a Al Qaeda ainda sejam considerados "os supostos responsáveis por quase todos os tipos de ações violentas em diferentes partes do mundo"109. Então a guerra contra o Afeganistão havia acabado sem a consecução do principal objetivo do governo americano, que continuava sua guerra contra o terrorismo internacional, deixando mais mortos pelo caminho. Da guerra contra o Iraque, país agora livre de

${ }^{109}$ No comentário "Após três anos do 11/9, terrorismo mantém Bin Laden 'vivo'", da editoria Mundo da Folha de S.Paulo, 11 de setembro de 2004, disponível na internet. 
Saddam Hussein e também carente de serviços essenciais, resta a vergonha das imagens de presos iraquianos vítimas de abusos por parte de soldados americanos. $\mathrm{O}$ mundo definitivamente não é mais o mesmo.

Três anos depois dos atentados, Maria Aparecida de Aquino indaga se as análises de historiadores contemporâneos aos fatos têm validade ou se é preciso perseguir uma objetividade científica por meio de certo distanciamento temporal. Ela mesma responde: "Os eventos contemporâneos, mais do que nunca, derrubam essas preocupações. Não há objetividade possível. Somos sempre movidos por paixões" ${ }^{110}$. Então a historiadora analisa a conveniente aliança entre capitalismo e comunismo depois da Guerra Fria e conclui que "estamos em tempos em que os jogos de cena encontram-se, apesar do ilusionismo, claramente delineados" e somente são enganados pelas artimanhas do poder aqueles que querem ser enganados.

Aquino afirma que "o jogo escancarado assusta pela ousadia" e que isso facilita a análise dos que se debatem com os dilemas contemporâneos. O problema, segundo ela, é saber "até quando será permitido a esses audazes jogadores prosseguir no seu louco intento de construir um mundo (pela destruição) alimentando-se do novo inimigo visível de ocasião: o 'terrorismo internacional'".

Três anos depois, e até hoje, muitas análises são apaixonadas. Algumas viraram filmes. Em 2004, estréia o documentário Fahrenheit 11 de Setembro, de Michael Moore, assumidamente feito para tentar evitar a reeleição de Bush para a presidência dos Estados Unidos. O filme, que documenta os desastres do governo Bush, palidamente visíveis na grande mídia, é um sucesso de crítica e de público.

Agora tudo parece tão óbvio, que até especialistas em cinema arriscam uma análise política: "Talvez para os mais bem informados o filme não traga tanta novidade, porque já se sabia que os Bush tinham ligações perigosas com os sauditas, com a família de Bin Laden, que protegeram descaradamente na época do ataque ao WTC. Também é evidente que, seguindo os preceitos de 1984, de George Orwell, o governo Bush sobreviveu pelo medo que provocou na população, que a cada momento acreditava que

110 "Dilemas da contemporaneidade", análise publicada em 11 de setembro de 2004, especial para a Folha Online e disponível na internet. 
haveria outro atentado. E a imprensa e a opinião pública foram tão manipuladas que a maioria apoiou a invasão do Iraque, mesmo estando claro que não havia provas para isso, a não ser a óbvia vontade de ficar com o petróleo local para si próprio"111.

Era tudo evidente, claro, óbvio, mas mesmo assim a imprensa e a opinião pública $^{112}$ se deixaram manipular. Como diz Aquino, só é enganado quem quer ser enganado. A opinião pública é, muitas vezes, um "artefato de linguagem" e pode ser invocada para contestar ou legitimar um discurso, numa clara estratégia de manipulação discursiva (cf. Landowski, 1992:43). Quem produz a opinião pública como um artefato é o poder político e também o poder midiático, portanto parece que a manipulação consentida diz muito mais respeito à imprensa, o que podemos corroborar pelas análises que apresentamos ora com relativa objetividade, ora com ímpeto apaixonado.

Segundo a crítica de Rubens Ewald Filho, o filme de Michael Moore tinha tudo para ser uma arma de propaganda muito eficiente. Não foi. Três anos depois dos atentados, depois de tantas guerras, mortes e pânico, o presidente Bush seria reeleito. Alguns estudiosos anteviram isso, afirmando que a memória da tragédia de 11 de setembro, ainda viva para a sociedade americana, seria explorada nas eleições daquele ano. Para o professor de relações internacionais Williams Gonçalves, "os cidadãos gostariam de esquecer tudo, gostariam de voltar a se sentir seguros", porém o 11 de setembro iria se impor "durante muito e muito tempo ainda para a sociedade americana, até mesmo depois das eleições" ${ }^{\prime 13}$.

A exploração eleitoreira deu resultado, a despeito das perspectivas de ver reforçada a Doutrina Bush, que garantia aos Estados Unidos fazerem "guerras preventivas" sempre que se sentissem ameaçados e fomentava crescente instabilidade mundial. A vitória foi dessa doutrina gestada, segundo Gonçalves, muito antes dos ataques, os quais providencialmente criaram "as condições necessárias para que essas idéias extremadas fossem alçadas à condição de diretriz da política externa dos EUA".

111 "Farenheit 9/11" é eficiente arma de propaganda anti-Bush", crítica de Rubens Ewald Filho, especial para o site da UOL, 17 de maio de 2004.

${ }^{112}$ De acordo com Landowski, "público" é diferente de "opinião pública", um ator coletivo que pode simultaneamente manipular e ser manipulado, conforme a vontade daqueles que se instauram como seus porta-vozes, do que decorrem estratégias distintas (1992:26).

${ }^{113}$ Entrevista concedida à Folha Online, em 11 de setembro de 2004. 
Não era isso, porém, que o 11 de setembro simbolizava para os americanos que viveram o lado humano da espetacular tragédia e tinham de continuar chorando diante das câmeras. Uma reportagem da Folha de S.Paulo traz o depoimento de uma mulher que participava das homenagens em Nova York três anos depois: "É impossível esquecer. A televisão não deixa. Todo ano, perto do 11 de setembro, eles ficam reprisando as imagens do ataque. Cada vez que vejo aquela torre ser atingida, fico pensando no que minha irmã estaria fazendo quando morreu. Se sofreu, se correu, se morreu rápido"114. A televisão não permite a privacidade da dor nem o natural apaziguamento das lembranças.

Myrian dos Santos afirma que uma das atuais preocupações dos estudiosos da memória social é uma possível redução da memória a "abusos da história e cultivo de comemorações". Segundo ela, as tentativas de recuperar situações traumáticas "têm criado o efeito perturbador de esvaziar o sentido de tragédia que esses eventos catastróficos implicaram no passado" (2003:31). É o que se pode observar nos telejornais em relação ao 11 de setembro.

No terceiro aniversário dos atentados, o assunto ainda é obrigatório, mas o destaque é bem menor. No Jornal Nacional, a matéria que ocupou praticamente o noticiário todo em 2001 tem agora menos de dois minutos. No Jornal da Record, que até 2002 falou longamente do tema, o tempo é inferior a um minuto. O acontecimento que mudaria o mundo não merece a mesma atenção da mídia e a dimensão pessoal da tragédia, que dera o tom das reportagens sobre as cerimônias nos dois primeiros anos, não é retratada com a mesma emoção. Tudo parece esvaziar-se de sentido pelo excesso da repetição de imagens e palavras.

Na escalada do Jornal Nacional, o locutor lembra: "Onze de setembro. Emoção nos Estados Unidos, três anos depois do pior atentado da história". Na cabeça da matéria, diz simplesmente: "Em Nova York, no local onde desabaram as torres gêmeas, uma cerimônia lembrou o atentado que matou quase três mil pessoas há três anos".

114 "Dor de familiares marca terceiro aniversário do 11/9", 12 de setembro de 2004. 
Na matéria, predominam imagens de pessoas chorando, mas o texto da repórter é enxuto: "Pais e avós que perderam filhos e netos no atentado leram os nomes das vítimas, entre elas, três brasileiros. O sino interrompeu a leitura em quatro momentos para lembrar a hora em que os aviões atingiram as torres e quando elas desabaram". É curioso notar que, nos três aniversários, o discurso desse telejornal reforça a lembrança dos três brasileiros mortos e, assim, também o vínculo com o sentimento de dor dos americanos.

A repórter prossegue: "Três anos se passaram, mas o trauma ainda está longe de ser superado. A dor é maior para quem perdeu um parente, um amigo. Mas há um sentimento de perda coletivo, na cidade que parou mais uma vez para lembrar a tragédia. 'Ainda dói muito', diz essa escritora".

A televisão não deixa esquecer, mesmo que seu discurso seja agora só um lampejo da imensa memória metálica que subordinou a memória social do acontecimento. As três mil mortes, que já foram "dezenas de milhares" no discurso inflamado da mídia e foram usadas para justificar tantas guerras, são agora, no texto pouco original, como o som dos sinos que o embala, apenas "uma ausência que vai ecoar para sempre no coração dos americanos" (figura 46).

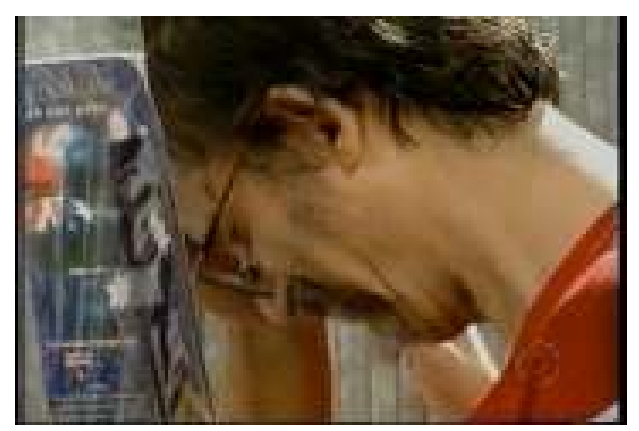

Figura 46

O que marca a edição de 11 de setembro de 2004 do Jornal Nacional é o intertexto com uma matéria especial sobre o terrorismo no mundo. Naquela semana, o telejornal exibia uma série temática para comemorar seus 35 anos e relembrava as grandes matérias que, segundo o próprio noticiário, ajudaram a construir a história. Naquele dia, não por acaso, o tema era "a marca violenta do terrorismo". A reportagem exibe imagens de arquivo de diversos atentados e pretende mostrar como o terrorismo se transformou 
desde o fim dos anos 60 e "ganhou a dimensão de um conflito mundial". O grande destaque daquelas memórias são os atentados de 11 de setembro.

O repórter narra o ápice da evolução do terrorismo no mundo: "O terrorismo, sempre uma ação desprezível e cruel, rompeu no fim do século 20 todas as barreiras até então conhecidas e ganhou dimensão de um conflito mundial. Ataques a duas embaixadas americanas na África foram o primeiro sinal. Era como se a Al Qaeda estivesse treinando para o maior de todos os atentados. Bin Laden apelou aos dois bilhões de muçulmanos que vivem em mais de cem países do mundo. Recrutou fanáticos e montou a primeira rede de terrorismo de alcance global".

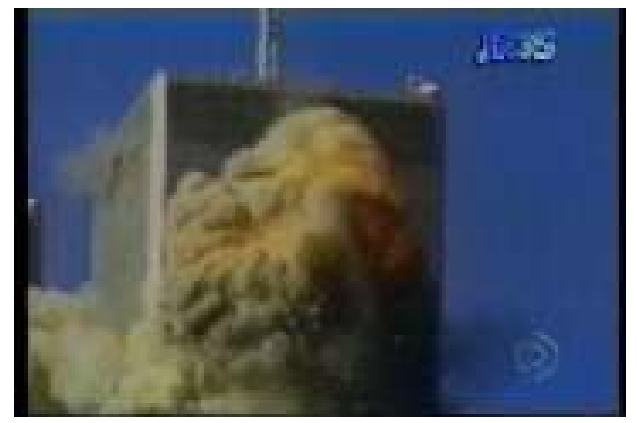

Figura 47

A voz de um outro repórter, em matéria de arquivo, lembra os primeiros movimentos do espetáculo do 11 de setembro: "A câmera aponta para o céu e registra o momento em que começou o horror". Revive-se a também espetacular escalada do Jornal Nacional naquele dia: "11 de setembro de 2001. Uma terça-feira que vai marcar a história da humanidade. No mais importante centro financeiro do mundo, uma torre queima depois de ser atingida por um avião. Enquanto o incêndio avança no arranha-céu, um segundo avião é jogado contra a torre vizinha (figura 47). E em menos de duas horas dois dos prédios mais altos do mundo se desfazem em uma montanha de poeira e fumaça. $\mathrm{Na}$ cidade sede do poder americano, outra aeronave despenca sobre o Pentágono - o centro de inteligência militar. E mais um boeing cai na Pensilvânia. O planeta em alerta geral". A televisão não deixa esquecer aquilo que seleciona para que não se esqueça. $O$ resto é silêncio e escuridão. 
O repórter que faz a narração da matéria especial está em Nova York e diz, numa passagem: "O que aconteceu aqui mudou este país. Tornou-se o marco zero de uma nova era política, militar e diplomática para o mundo. Ninguém imaginava que um grupo baseado em cavernas do Afeganistão conseguisse atacar no coração econômico da única superpotência". Nenhuma palavra, nenhum esclarecimento sobre a real "nova era, militar e diplomática" que se iniciara no mundo.

A reportagem prossegue e lembra o envolvimento de Osama Bin $\operatorname{Laden}^{115}$ e da $\mathrm{Al}$ Qaeda naquele e em outros atentados ocorridos depois. Especificamente sobre a ação terrorista em Madri, afirma-se que "ficou provado que era mais uma ação de terroristas islâmicos". No encerramento da matéria, o repórter avalia: "A ameaça dos grupos ligados à Al Qaeda continua um desafio para todo o planeta. Militantes muçulmanos estão usando o terror com novas táticas e objetivos. Para forçar a retirada de tropas no Iraque, degolaram e fuzilaram reféns estrangeiros. No massacre em uma escola da Rússia na semana passada, há suspeitas da ligação de militantes árabes com os rebeldes separatistas da Chechênia. O mundo debate se a ocupação americana do Iraque reduziu o terrorismo ou estimulou o recrutamento de suicidas".

O "planeta" volta a aparecer no discurso, que sempre toma a parte pelo todo. Os terroristas são definitivamente "militantes muçulmanos", que ampliaram seus objetivos (como, se antes não havia nenhum objetivo e o que movia suas ações eram a loucura e o fanatismo?). O mundo debate as relações entre a "ocupação americana do Iraque" (famigerado eufemismo para "invasão") e a evolução do terrorismo, a imprensa escrita dá mais espaço a esse debate, mas a televisão se mantém distante de qualquer esclarecimento sobre o assunto.

\footnotetext{
${ }^{115}$ Em outubro de 2004, a rede de TV Al-Jazeera divulgou um vídeo "com o que aparenta ser uma nova mensagem gravada" de Bin Laden, segundo matéria do site da BBC Brasil, que também informa: "na mensagem, o suposto Bin Laden admite da forma mais clara até hoje a responsabilidade pelos ataques de 11 de setembro de 2001". A matéria afirma: "Se de fato [a fita] for verdadeira, ela é a primeira com imagens de Osama Bin Laden falando que é divulgada desde a ofensiva militar americana no Afeganistão, em 2001. Várias outras mensagens de áudio atribuídas a Bin Laden, entretanto, surgiram desde então". Ainda hoje pairam dúvidas sobre a autoria dos atentados e continuam surgindo fitas. Em 23 maio de 2006, o Portal do Estadão informava que, em uma nova fita de áudio divulgada na internet, Bin Laden assumia que havia autorizado pessoalmente a ação dos seqüestradores em 11 de setembro e eximia o único condenado até então de qualquer responsabilidade, dizendo que Zacarias Moussaoui tinha confessado por causa das pressões a que teria sido submetido durante quatro anos e meio nas prisões americanas. A matéria ressalta que "a autenticidade da fita não pôde ser verificada".
} 
Para não dizer que não se ouviram algumas vozes dissonantes no telejornal nessa época, podemos citar um solitário comentário de Arnaldo Jabor na edição do dia anterior, 10 de setembro de 2004. A manifestação se dá logo após uma reportagem que informava que o medo de outros ataques tinha aumentado nos Estados Unidos em razão da divulgação de um fita de terroristas da Al Qaeda com novas ameaças e que isso estava sendo explorado pelos republicanos na campanha eleitoral americana. A informação, sem fontes citadas, era a de que $70 \%$ da população temia um novo atentado e que o mesmo percentual considerava o presidente Bush o mais preparado para combater o terror.

Surpreendentemente, a nosso ver, o telejornal concede espaço para o apaixonado e profético comentário de Jabor: "Quem caiu no 11 de setembro não foram as torres. Foi o Ocidente. Mas não se pode separar essa tragédia do Bush. Ele e sua gangue erraram em tudo. Eles aproveitaram a desgraça para iniciar uma política imperial, transformando a América na nação mais odiada do mundo. O Osama é louco. E o Bush diz agir em nome da liberdade, mas quer cerceá-la dentro e fora da América. Pela primeira vez a grande democracia americana pode ser destruída. Pelo medo, pode surgir um pré-fascismo nos Estados Unidos. Se Bush for reeleito, a cada 11 de setembro o mundo estará pior".

Na escalada do Jornal da Record, uma frase chama a atenção para o assunto: "Americanos lembram os três anos do maior ataque terrorista da história". O destaque para o clima de alarme permanente desaparece na edição de 2004. Na cabeça da matéria, o locutor diz simplesmente: "Os americanos marcam com cerimônias discretas o terceiro aniversário dos atentados de 11 de setembro". A discrição contamina o discurso do telejornal, que nesse dia não se desdobra em nenhum comentário político, talvez por não ser sido apresentado pelo âncora Boris Casoy.

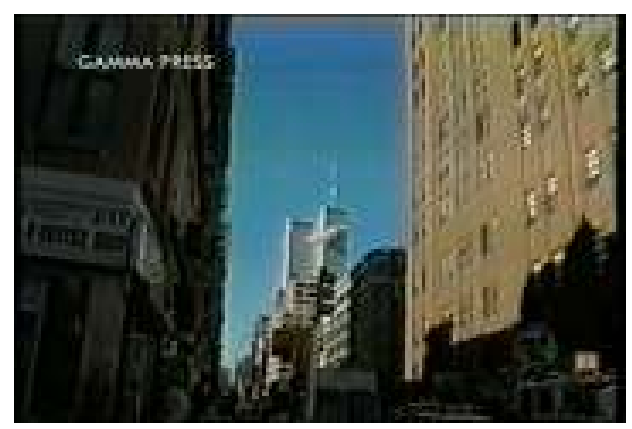

Figura 48 
Salete Lemos, que o substituía naquele dia, narra sobriamente: "Em Nova York, no lugar onde ficava o WTC, pais e avós leram os nomes das 2.749 vítimas (imagens de pessoas chorando). A leitura foi interrompida quatro vezes, cada uma delas por um minuto de silêncio, marcando as horas exatas dos choques dos aviões contra as torres e os dasabamentos (imagens dos ataques, figura 48 , e da queda das torres). $O$ presidente George W. Bush e o vice, Dick Cheney, lideraram [sic] um minuto de silêncio no jardim da Casa Branca. O pronunciamento semanal de rádio do presidente hoje foi transmitido também pela televisão. Bush, em campanha para reeleição, reafirmou que a guerra contra o terrorismo continua. No cemitério de Arlington, na Virgínia, um minuto de silêncio marcou a hora em que o terceiro avião foi jogado contra o Pentágono, matando 184 pessoas. Na Pensilvânia, a cerimônia foi realizada no local onde caiu o quarto avião, matando as 40 pessoas a bordo" (outras imagens de pessoas chorando).

Uma lembrança totalmente empalidecida e sem emoção tomou o lugar do discurso grandiloqüente dos anos anteriores. (Misteriosamente, até o número de vítimas, sempre apontado como 2.801, diminuíra.) A tragédia em si vai sendo esvaziada e despida de sua roupagem espetacular. Não sabemos se foi apenas a passagem do tempo que motivou essa nova configuração discursiva, mas o fato é que também não houve, para o bem ou para o mal, a inserção de notícias ou comentários relativos à situação do mundo, dos Estados Unidos e de Bush naquele momento. Um desconfortável silêncio diante de tudo o que se passava, quebrado tão-só pela recordação obrigatória do terceiro aniversário do 11 de setembro. 
Nossa análise acaba aqui e, provavelmente, alguns desejos jamais serão saciados. Gostaríamos de ter acompanhado, dia após dia, a cobertura das televisões brasileiras no período que se seguiu aos atentados, abrangeu as guerras contra o Afeganistão e contra o Iraque, estendeu-se até a reeleição de Bush e fechou um ciclo no quinto aniversário do 11 de setembro, pouco antes da conclusão desta tese. Isso nos parece impossível, sobretudo pela restrição de acesso aos arquivos de televisão. Além disso, mesmo que tal obstáculo não existisse, a massa de informações e a complexa estrutura do discurso televisivo seriam motivos suficientes para desencorajar uma pesquisa desse porte.

Por outro lado, a consecução deste trabalho, que contempla intervalos significativos da memória televisiva sobre o 11 de setembro, atesta a possibilidade real de ampliar as investigações sobre esse importante veículo de comunicação de massa, o que por si só justifica nosso contentamento nesta hora. É preciso lembrar, no entanto, que a pesquisa não seria possível sem os muitos estudos que tratam da cobertura dos atentados pela imprensa escrita, nos quais pudemos nos basear para preencher as lacunas desta análise no que se refere às informações e aos contextos históricos, políticos e ideológicos que não aparecem nas edições dos telejornais analisados, sobretudo no dia em que os fatos se desenrolaram.

O cotejo entre diversas fontes, que, assim como nossas escolhas, nunca são neutras, permitiu-nos avaliar se estávamos fazendo uma análise coerente dos discursos telejornalísticos ou se a interpretação emergia de um viés subjetivo. Ficamos aliviados ao constatar que outros pesquisadores tinham chegado a conclusões semelhantes quanto ao direcionamento da cobertura pela mídia impressa, mas isso também nos preocupou, já que poderia indicar uma possível redundância de nosso estudo. Afinal, não são poucos os que já falaram do quanto a informação foi vítima da própria mídia nas reportagens sobre os atentados.

Citamos aqui, além das obras que consultamos, o livro Imprensa histérica, informação prejudicada: uma análise da cobertura carioca no 11 de setembro, do jornalista Alexandre Monteiro Barboza, lançado em 13 de setembro de 2005, quatro anos depois dos atentados. $O$ autor pesquisou as edições extras publicadas por $O$ Globo e pelo Jornal do Brasil e incluiu depoimentos inéditos de jornalistas como Ricardo Boechat, Eliane Cantanhêde, Nilson Lage e Bernardo Ajzenberg. 
O livro questiona o fato de a imprensa ter preferido as informações oficiais e de agências de notícias, que refletiam clara campanha ideológica dos Estados Unidos, invariavelmente representados como vítima, em vez de contextualizar e analisar os fatos, e não sua reprodução espetacularizada ${ }^{116}$. Barboza concluiu que os jornais se mostraram influenciados pela mídia americana e que assumiram, em seus editoriais, uma posição ideológica favorável à retaliação dos países supostamente envolvidos no atentado, num claro grito de guerra.

Diante disso, pusemo-nos a refletir sobre a contribuição desta tese e podemos dizer que encontramos uma resposta que satisfez nossas aflições mais imediatas. Entendemos que nossa pesquisa permite entender parte do engendramento, pela televisão, da reprodução espetacularizada dos fatos em 11 de setembro, cuja análise seria feita depois pela mídia impressa e colocada à disposição dos que buscavam informações que iam além dos limites da telinha. Da mesma forma, permite reconhecer alguns mecanismos pelos quais os telejornais, a despeito de não comportarem editoriais formais em sua estrutura, acabam por revelar ou dissimular sua posição ideológica.

Além disso, propusemos uma reflexão sobre as possíveis relações entre esses elementos do tecido discursivo e a formação de memória social. É sobretudo em torno dessa reflexão que se articulam as considerações finais desta tese, que retomarão também as conclusões semeadas ao longo da análise.

${ }^{116}$ Conforme release divulgado pelo site do Observatório da Imprensa em 6 de setembro de 2005. 


\title{
CONSIDERAÇÕES FINAIS
}

\section{ENTRELAÇANDO AS REDES}

\author{
"O que acreditamos ser o visível do mundo é apenas um invisível, \\ intocável, construído em visível pelo efeito conjunto da espetacularização \\ e da projeção de nossa memória sobre o espetáculo." (Patrick Charaudeau)
}

\section{Cinco anos depois}

Cinco anos depois dos atentados de 11 de setembro, o jornal britânico The Independent divulga um estudo que avalia que 103 mil pessoas foram mortas na guerra contra o terror, liderada pelos Estados Unidos. Segundo o Instituto Nacional de Memória para a Prevenção do Terrorismo, milhares de civis morreram em guerras deflagradas depois dos atentados nos Estados Unidos, nas ações terroristas que se multiplicaram e em ações de contra-insurgência por parte dos Estados Unidos ou seus aliados ${ }^{117}$.

Cinco anos depois, segundo um relatório divulgado pela Casa Branca, os Estados Unidos são um país "mais seguro", mas ainda sob ameaça de novos ataques da Al Qaeda. O documento, no entanto, considera menores as possibilidades de ação de Osama Bin Laden - cuja captura, vivo ou morto, vale agora $R \$ 25$ milhões - e da rede terrorista, apesar de sustentar que eles mantêm a intenção de adquirir e utilizar armas de destruição de massas contra os Estados Unidos e seus aliados, e faz um alerta sobre novos inimigos, o Irã (com suas ambições nucleares) e a Síria, ambos acusados de apoiar grupos terroristas ${ }^{118}$.

Entretanto, em 10 de setembro, segundo matéria da Folha de S.Paulo, o vicepresidente americano Dick Cheney afirmara que o interesse do governo na captura de Bin Laden não havia diminuído e que as buscas continuavam a ser uma "alta prioridade"119.

\footnotetext{
117 "Conflitos desde 11/9 deixaram 103 mil mortos", matéria do The Independent, publicada na Folha Online em 5 de setembro de 2006. No dia anterior, outra matéria do jornal britânico falava em 72 mil mortos: "Guerra ao terror já matou 72 mil, diz Independent", disponível no mesmo site.

118 "Relatório dos EUA minimiza Bin Laden e foca ameaça de Irã e Síria", matéria publicada na Folha Online em 5 de setembro de 2006.

119 "EUA lembram 5 anos do 11/9; Al Qaeda faz novas ameaças", 11 de setembro de 2006.
} 
Em 11 de setembro, dia do quinto aniversário dos atentados, o diretor da CIA declara que "a cúpula operacional da Al Qaeda foi dizimada"120. No mesmo dia é divulgado um vídeo em que um líder da Al Qaeda faz novas ameaças ao Estados Unidos. Cinco anos depois, algumas informações continuam desencontradas e outras, nebulosas ${ }^{121}$.

Por outro lado, alguns analistas dizem que a aparência de tranqüilidade dos americanos deve-se mais à resistência em admitir que o 11 de setembro mudou suas vidas, o que significaria uma vitória do terrorismo. Os constantes alertas do governo sobre possíveis ataques terroristas também não surtem os mesmos efeitos. Segundo o sociólogo David Altheide, mais do que o medo, aumentou a desconfiança da população em relação a pessoas de outras religiões e etnias ${ }^{122}$. O tema dos ataques começa a perder a importância entre os próprios americanos, mas a sensação de que "o mundo agora é mais perigoso" perdura, conforme avalia Altheide.

Apesar disso, tem-se a impressão de que o trunfo "11 de setembro" não será tão grande nas eleições de novembro de 2006. Na análise de Caio Blinder, a opinião pública mostra mais desencanto "à medida que a guerra no Iraque fica mais sangrenta" e menos confiança em Bush "como o timoneiro da segurança nacional"123. Infelizmente não haverá tempo de registrar neste trabalho os desdobramentos eleitorais desse cenário.

O fato é que, cinco anos depois, continuam a proliferar análises sobre a "guerra infinita" em várias partes do mundo, com seus mortos, tribunais de exceção, tortura e prisões secretas, bem como balanços sobre o preço que todos tiveram de pagar, inclusive com restrições da liberdade, em nome da liberdade prometida pelos autoproclamados guardiães da democracia, o que prova a imensa relatividade do conceito.

\footnotetext{
120 "Cinco anos após o 11/9, CIA afirma que Al Qaeda foi 'dizimada"', 11 de setembro de 2006.

${ }^{121}$ No artigo "Encalacrados na teia", de Pascal Lardellier, discute-se a multiplicação, no ciberespaço, e a credibilidade de documentários que contestam a versão oficial sobre os atentados de 11 de setembro, criticando-se desde "bobagens digitais" até o enorme destaque que se deu ao livro lançado por Thierry Meyssan em março 2002 (citado nesta tese). Feita a análise, o articulista conclui que, cinco anos após a "catástrofe", casos como esses são dados como encerrados, "contudo são cada vez mais numerosos os jornalistas, pesquisadores, professores e até mesmo políticos que questionam, não sem razões, a falta de transparência do governo norte-americano e que pedem a reabertura do inquérito" (Dossiê "Guerra Infinita", Le Monde Diplomatique, setembro de 2006).

122 "Os EUA cinco anos após o 11 de setembro", matéria publicada no Deutsche Welle World, em 5 de setembro de 2006, e disponível na Folha Online.

${ }_{123}$ "Bush perde cartas no jogo eleitoral da segurança nacional", artigo publicado na Folha Online, em 5 de setembro de 2006.
} 
Segundo o professor e jornalista Philip S. Golub, "poucas vezes a distância entre democracia real e democracia formal foi tão grande" em países considerados avançados, sobretudo nos Estados Unidos, onde "a amplitude do recuo democrático é espantosa" ${ }^{124}$. Golub afirma que o país vive um "estado de exceção não-declarado" e que o governo se arroga poderes extrajurídicos no âmbito do direito internacional, "agindo por trás de uma cortina de segredos" e reduzindo vozes dissidentes ao silêncio "pela mobilização do sentimento nacionalista". Ao mesmo tempo, segundo Golub, esse jogo atiçou o ódio de outros povos e culturas, reduzidos à designação de "o outro, o bárbaro, o inimigo". Dessa forma, conclui o professor, "o 'choque de civilizações' torna-se pouco a pouco uma profecia auto-realizável".

O escritor inglês Jonathan Raban também faz uma análise contundente no aniversário de cinco anos dos atentados e se pergunta se é realmente o 11 de setembro que merece ser lembrado, pois, segundo ele, o mundo só começaria a mudar de verdade sete dias mais tarde ${ }^{125}$. As cenas vistas em 11 de setembro provocaram o mesmo sentimento de horror e solidariedade em grande parte do mundo, a ponto de o jornal Le Monde publicar a manchete "Somos todos americanos agora". Segundo Raban, "hoje essa manchete é lembrada apenas como um lembrete amargamente irônico da distância enorme que percorremos nos cinco anos desde aquele dia".

Raban diz que a data que deve ser lembrada para sempre é 18 de setembro, dia em que o congresso americano "aprovou às pressas uma autorização de uso de força militar que autorizava o presidente a 'usar de toda a força necessária e apropriada' contra 'as nações, organizações ou pessoas' que 'ele determinar' que foram responsáveis pelas atrocidades do 11 de setembro", o que permitiu toda a sorte de ações militares que sobrevieram e lançaram o mundo numa "guerra infinita". Cinco anos depois, é possível finalmente entender por que se trata de um "aniversário tão sombrio", diz o escritor.

Enquanto isso, telejornais brasileiros continuam a privilegiar, como notícia, as cerimônias de homenagem às vítimas do 11 de setembro, porém com uma sutil diferença: o acontecimento agora é designado como "o pior atentado da história americana", e não

\footnotetext{
${ }^{124}$ Dossiê "Guerra infinita", publicado pelo Le Monde Diplomatique em setembro de 2006.

125 "O preço que pagamos pelo 11/9", escrito para o The Independent e publicado na Folha Online em 10 de setembro de 2006.
} 
mais como "o maior atentado terrorista da história". Em 11 de setembro de 2006 não acompanhamos os telejornais que foram analisados nesta tese, mas notamos, por exemplo, que ao menos um noticiário da TV Globo deu algum destaque às informações sobre pesquisas que mostravam que metade da população americana condenava a guerra contra o Iraque, ainda que a alegação apresentada pelo telejornal para essa avaliação tenha sido a de que "o número de americanos mortos no Iraque já é quase igual ao das vítimas do 11 de setembro de $2001^{\text {"126 }}$.

De modo geral, o que se viu foi uma reprise da cobertura das homenagens em outros anos: gaitas de fole, sinos, minuto de silêncio, leitura dos nomes das vítimas. $\mathrm{Na}$ matéria do Jornal Nacional, cujo texto lemos na página da TV Globo na internet, houve destaque para as novas ameaças da Al Qaeda e para o discurso que Bush faria naquele 11 de setembro sobre o terrorismo. Uma frase se perde no meio do texto, sem que se dê mais detalhes da notícia: "Numa pesquisa publicada hoje, $45 \%$ dos americanos responsabilizam o presidente Bush pelos atentados de cinco anos atrás".

Cinco anos depois do 11 de setembro, discute-se a construção social e retórica da verdade. O professor de filosofia Simon Blackburn, ao resenhar cinco livros lançados em 2006, reflete sobre possíveis mudanças em torno das noções de razão e verdade ${ }^{127}$. Ele mostra que tais obras indicam que a visão de que a verdade não é mais do que uma construção social está sucumbindo diante dos últimos acontecimentos mundiais. Assim, parecem dizer que os fatos hoje nos levam a ver que "precisamos da verdade, da razão e da objetividade, e precisamos que elas estejam do nosso lado", sobretudo no mundo pósmoderno, em que nem sempre a ação de não dissimular é vista como virtude e em que são fartos os exemplos de manipulação da informação e da emoção.

Blackburn pergunta-se então "se o mundo está novamente em condições de ouvir a verdade com segurança". Sua resposta merece atenção: "Nossas opiniões são falíveis e nossos julgamentos estão longe de serem perfeitos, mas o remédio para qualquer uso imperfeito deles consiste em usá-los ainda mais. Se nossa política for suficientemente boa para que se possa conservar a manipulação, a ignorância, o medo e o ódio fora dela, então somos animais que se corrigem a si mesmos. Ou, pelo menos, assim esperamos".

\footnotetext{
126 Jornal Hoje, edição de 11 de setembro de 2006.

127 "O jogo da verdade", publicado no Caderno Mais!, da Folha de S.Paulo, em 3 de setembro de 2006.
} 


\section{Discurso telejornalístico e memória social}

Cinco anos depois de termos passado pelo processo de seleção para o doutorado, sentimos o espírito mais leve pela conclusão da tarefa, mas também o sentimos inquieto pelas reflexões suscitadas. Comecemos pela afirmação de Blackburn, que acabamos de citar. Ainda que possa existir um sentimento crescente de que precisamos da verdade, ela será sempre inapreensível. Parece-nos que entender a verdade como uma construção social não é mera abstração ou opção intelectual. É uma realidade.

Por isso não se trata de perguntar se o mundo está preparado para ouvir a verdade. Trata-se de aceitar que o mundo em que vivem os seres sociais é o mundo do verossímil, da opinião, do julgamento, da negociação, da argumentação e da manipulação. Logo é bastante adequada a proposição de Blackburn, diante do fato de que só o constante e livre exercício de nossas opiniões e julgamentos poderá levar à correção dos erros e a uma sociedade menos refratária ao medo, ao ódio e à ignorância. É cada vez mais imperativo que não nos deixemos seduzir por estratégias de manipulação que embotam a compreensão do mundo, o arbítrio das ações e até as memórias individual, social e histórica. É preciso ficar atento a tais estratégias, que ainda disputam lugar com o legítimo domínio da argumentação.

A retórica vive hoje nas teorias da argumentação e continua tendo como principal característica a capacidade de "conduzir a uma posição de dialogicidade, que não anularia as subjetividades, mas dialeticamente as incorporaria em sua trajetória, valendose delas para chegar à construção de novos saberes, novas atitudes, na construção de uma sociedade mais democrática" (Mosca, 2005).

No entanto é preciso considerar, como afirma Mosca, que o acordo que a prática argumentativa estabelece é sempre uma "relação assimétrica" e que, "por mais que se fale hoje em interatividade, em concessões, em avanços e recuos, não se pode esquecer a relação de poder que envolve os papéis sociais, a noção de prestígio, a voz de autoridade, a força do modelo e do estereótipo que entram no jogo" (op.cit.).

É sob essa perspectiva que observamos o papel da mídia na sociedade contemporânea, como um novo e poderoso macrossujeito a agir nos processos sóciohistóricos em relação assimétrica com os demais sujeitos sociais. A emergência de 
empresas de comunicação com grande poder econômico e simbólico e a globalização da informação fizeram da mídia uma máquina que processa incessantemente a interpretação da realidade e a dispõe para um público que, apesar de capaz de construir significados para o que lê, ouve ou vê, só poderá fazê-lo diante do que the é dado a conhecer do mundo, por meio de palavras e imagens impregnados dos sentidos que se colam às paredes dos filtros por que passam os fatos até se tornarem visíveis.

Mesmo que a recepção das mensagens midiáticas se dê individualmente, portanto sujeita a fatores imponderáveis, há padrões que se repetem no processo de mediação da realidade e de distribuição dos conteúdos simbólicos que tingirão o tecido social sob a estampa de produtos comerciais. Esses conteúdos são plantados e reimplantados em qualquer continuum espacial ou temporal e vão modificando lenta e imperceptivelmente a sociedade, num ciclo de lembrança ou de esquecimento de alguns deles. Porém o que não é mostrado ou dito tem, muitas vezes, mais conseqüências do que aquilo que se reflete pelo espelho multifacetado e deformado da mídia.

Vazios, amnésias e memórias podem resultar da interação com a máquina midiática, sobretudo a máquina televisiva, que reinventa a esfera pública ao determinar o que deve ou não se tornar público e ao definir quem pode ou não ter voz na ordem dos discursos que alimenta e aos quais subtrai, não raras vezes, a densidade da complexidade social. Ao deter o monopólio da fala e da visibilidade, a televisão controla também o intercâmbio dos signos e das ideologias. E tanto mais terá esse domínio o discurso da informação, que edita e reedita versões do mundo num movimento de repetição analógica do real e de abolição da consciência histórica, a que Debord chama de "presente perpétuo".

Dessa forma vai também construindo e fixando representações, imagens, símbolos e discursos, que se tornarão artefatos de inculcamento ideológico e de memória, além de legitimar ou fabricar consensos. Obra de um cérebro maquiavélico? Talvez sim, se se considerar que a máquina midiática não é movida por inteligência artificial. Talvez não, se se considerar que o discurso midiático é engendrado por múltiplos enunciadores, entre os quais, como em qualquer área de atividade humana, há os bem-intencionados e os malintencionados, com os mais diferentes pontos de vista. Porém o que importa e se mostra mais factível diante de máquina tão complexa é a desmontagem do produto visível e a 
análise dos possíveis efeitos do discurso midiático, o que nos remete ao objetivo central desta tese e à avaliação dos resultados da pesquisa.

Nossa proposta foi mostrar de que modo o discurso dos telejornais pode, pelo entrelaçamento de vozes, imagens e designações, produzir material simbólico e, por conseguinte, criar determinada memória social de um acontecimento, independentemente de esse processo se realizar de forma premeditada ou involuntária no contexto das condições de produção discursiva. Assim houve empenho em investigar, além do alcance ideológico dos conteúdos veiculados, o conteúdo ideológico das formas que sustentam aquele discurso.

A hipótese de que partimos nos fez procurar, na composição do telejornal, elementos que indicassem se haveria ou não uma tendência monológica, cujos efeitos seriam a perpetuação ou o apagamento de conteúdos simbólicos no tecido discursivo e também na memória social, sabidamente permeável tanto aos produtos da realidade quanto aos forjados culturalmente. Buscamos então verificar se o telejornal de modelo polifônico era mais que uma superposição de vozes e se dava sinais, na materialidade discursiva, de que orientava para determinada interpretação dos fatos, bem como se fixava sentidos e modos de recordação para o que se inscreveria na memória do público.

Tentamos responder, pelo menos parcialmente, a uma das novas questões sobre a influência da mídia, tal como proposta por Arbex: "Até que ponto a mídia tem o poder de sedimentar como 'a' realidade (isto é, como 'fatos que realmente aconteceram'), na memória coletiva, as 'suas' imagens dos eventos (isto é, as imagens por ela selecionadas e editadas)?" (2001:37).

Não sabemos dizer qual é o grau desse poder, mas podemos reafirmar que, se o público não recebe todas as informações que deveria receber para formar um julgamento sobre determinado fato, o que fica do discurso midiático é o apelo do sensível, é a reiteração do senso comum, formado por uma conjuntura social e cultural influenciada por modos de referenciação do mundo presentes nos meios de comunicação e por vozes legitimadas por esses meios.

Que matéria melhor para formar a memória senão a emoção, a repetição, o consenso, a representação dos acontecimentos num palco de primeira grandeza como a televisão? Que matéria melhor para sedimentar uma versão da realidade na memória 
coletiva senão a combinação entre razão e a emoção, temperada por sofisticadas estratégias de manipulação cognitiva e afetiva? Que matéria melhor que o simulacro televisivo, sobretudo aquele que é forjado pelos telejornais que têm a possibilidade de editar os eventos da realidade? Que matéria melhor do que a matéria simbólica produzida por esse simulacro que reporta, semantiza ou dessemantiza a história segundo a lógica da espetacularização?

Como fomos gradualmente mostrando na análise do corpus, os telejornais examinados, cada um à sua maneira, construíram uma meta-realidade, uma dramatização, uma enunciação fílmica que deu origem a um acontecimento discursivo apresentado como o acontecimento "real", a despeito de estarem sugeridas na teia discursiva conexões e interpretações por definição alheias aos fatos.

Muito daquilo que apresentamos como hipótese ou sublinhamos na exposição teórica pôde ser observado nas redes dos telejornais: as formas de designação que constroem objetos de discurso e, por extensão, recategorizam o referente real; os elementos contextualizadores e avaliativos que impõem uma leitura homogênea do discurso; os termos-engodo; a reconstituição interpretativa de vozes públicas e anônimas; a constituição de um modelo polifônico que ao fim soa como monológico; a profusão de figuras retóricas de escolha e de presença, como a metonímia e a repetição; as imagens que funcionam como argumento e documento histórico; a contextualização, a redundância e o controle recíprocos entre palavra e imagem; os sentidos óbvios e os sentidos obtusos dessa inter-relação; a estrutura melodramática; a desinformação funcional; a negligência para com a compreensão histórica dos acontecimentos; os enquadramentos manipulatórios do universo do sensível e do inteligível.

Relativamente ao episódio do 11 de setembro, pudemos constatar que o germe da memória única hospedou-se na memória metálica no mesmo dia dos acontecimentos e evoluiu nos anos seguintes, pela insistente repetição que favoreceria a estabilidade referencial de uma versão no domínio da memória social. Certamente, como já apontamos, o público não viu o mesmo filme nos dois telejornais, mas leu roteiros bem parecidos quanto às principais células dramáticas. Os efeitos possíveis dos discursos que analisamos - ainda que possa ter havido uma recepção crítica - emanam do imbricamento das reações ao drama e das reações ao espetáculo. Assim o mundo deveria se 
estarrecer, se comover, se apavorar, se indignar e ser persuadido de que a guerra contra o terror, liderada pela "grande vítima", era imperativa e inevitável.

Chomsky e Herman, em seu estudo sobre a manipulação do público pela grande mídia norte-americana, mostram diversos casos em que é evidente a adoção de um duplo padrão no que se refere ao tratamento jornalístico que recebem as vítimas de conflitos, atentados ou genocídios. Segundo Chomsky e Herman, a atenção que é dada às vítimas de países inimigos da nação americana é diferente da que recebem as vítimas dos Estados Unidos e de países aliados ou clientes: "as vítimas de Estados inimigos serão consideradas 'merecedoras' [de atenção] e serão sujeitas a uma cobertura mais intensa e indignada do que os vitimados pelos Estados Unidos ou por seus clientes, que são implicitamente 'não-merecedores"' (2003:20).

No caso de vítimas merecedoras, afirmam Chomsky e Herman, há sempre "ênfase na indignação, no choque, na busca dos responsáveis e no clamor por justiça", além do acompanhamento do caso e da "repetição diária de raiva e indignação" (op.cit::101). Não podemos deixar de apontar a semelhança no padrão adotado por telejornais brasileiros, que reproduziram muito do discurso oficial dos Estados Unidos e suas versões instantâneas, ou de reduzidas fontes de informação, e deixaram marcas inequívocas de seu posicionamento ideológico no que toca tanto às três mil vítimas do 11 de setembro quanto a um sem-número de vítimas de guerras como as do Afeganistão e do Iraque ${ }^{128}$.

Até mesmo críticos como Dominique Wolton, intelectual que acredita no papel da mídia como importante vetor de integração social, não deixaram de observar a fábrica de estereótipos em que a mídia globalizada se transformou sobretudo a partir do 11 de setembro. Para Wolton, é preciso rever o papel da mídia, que "é frágil e pertence ao patrimônio da democracia", não permitindo que ela fique entregue somente às leis do

\footnotetext{
128 Segundo pesquisa da revista médica britânica The Lancet, divulgada por diversos veículos de comunicação em outubro de 2006, o número de civis mortos no Iraque desde o início do conflito, em março de 2003, pode ser de pelo menos 650 mil. Segundo matéria do dia 17 de outubro do Jornal da Ciência, órgão da SBPC (Sociedade Brasileira para o Progresso da Ciência), "o número é vinte vezes maior do que as 30 mil mortes de civis que o presidente americano, George W. Bush, citou em dezembro de 2005 e mais de dez vezes superior aos 50 mil contabilizados pelo grupo britânico Iraq Body Count, que faz sua apuração com base em informações da mídia e do Exército americano". Segundo editorial da Folha de S.Paulo em 16 de outubro, que comenta os resultados da pesquisa sob o título "Morte em massa", "Bush conseguiu apanhar um país castigado por quatro décadas de uma das mais selvagens ditaduras do planeta para lançá-lo num inferno ainda mais sangrento de terrorismo e guerra civil".
} 
mercado e da globalização ${ }^{129}$. Fica claro que o poder da máquina midiática não decorre apenas de sua genética particular, que cruza o dever de informar e a necessidade de impor a espetacularização. O poder econômico e outros poderes estão por trás das engrenagens, portanto a mídia, na mesma medida que manipula, é suscetível de manipulação, o que se revela como o calcanhar-de-aquiles da sociedade da informação.

Mosca, ao lembrar o importante papel da retórica "na administração dos conflitos, com a aceitação das diferenças e do respeito ao outro", assim justifica o crescente interesse pelo exercício da argumentação: "As questões éticas com as quais a sociedade se depara na atualidade são inseparáveis de uma teoria da ação e exigem mudanças e novas posturas. Há disputas que são de cunho simbólico e que se apresentam de modo bastante intrincado. Acresce, ainda, uma crise de credibilidade e de confiabilidade nos poderes públicos e no tratamento da informação" (2005).

É preciso, portanto, que se reveja a relação assimétrica de poder entre mídia e público, para que a liberdade de expressão não seja um monopólio nem um álibi para a construção de "verdades" mais convenientes. O público deve ser sempre o maior beneficiário do sistema que garante a liberdade de comunicação. Quando o poder da mídia transcende o poder de formar opinião pública ou o de erigir-se como porta-voz dessa instância social, muitas vezes embaraçando esses papéis, e lança suas teias nos recônditos da memória, uma luz vermelha se acende. Opiniões vergam-se com certa facilidade, mas a memória resiste e é às vezes irreversível.

Segundo Bucci, é cada vez maior o controle da mídia sobre o processo de ordenação de sentidos e valores, um controle que é mais da ordem do discurso do que propriamente da ordem das intenções, e é nisso que reside o real poder das instâncias que detêm a informação, talvez mais até do que na submissão econômica dos meios de comunicação, "incompatível com o projeto da verdade jornalística" (2004:129). Portanto é necessário que a mídia se torne mais consciente dos efeitos que a encenação discursiva pode provocar e que reveja sua deontologia e sua práxis, a fim de melhor servir aos ideais democráticos que defende, desempenhando da forma mais equilibrada possível seu papel de testemunha do presente.

${ }^{129}$ Entrevista concedida à revista Trópico, disponível no site do Observatório da Imprensa, sob o título "Wolton fala sobre o valor da mídia e da diversidade", em 13 de janeiro de 2002. 
Como afirma Arbex, "a mídia é um componente-chave desse momento da história contemporânea, por ser o palco em que se dá o embate entre os campos em luta; é ela que dá visibilidade ao debate, constrói as narrativas, fabrica consensos" (2003:188), o que Ihe confere um enorme poder, que só será minimizado se o público souber ler o manual da máquina midiática, sobretudo o capítulo dos telejornais, que transformam em história imediata muitos fatos que são des-historicizados em suas narrativas diegéticas.

Charaudeau afirma que "as mídias nunca podem garantir que o que é relatado traga alguma marca de perenidade" (2006:134), o que justificaria duas características do discurso da informação, sua efemeridade e sua a-historicidade. Entendemos que isso cabe perfeitamente aos fait divers ou às notícias que, apesar de relevantes, não têm tanto peso para permanecer no foco de atenção da mídia ou não são escolhidas para isso. No entanto, no caso de acontecimentos de grande repercussão nacional ou internacional seja a repercussão legítima, seja fabricada -, a perenidade estará garantida na memória metálica e também na memória coletiva. Tem sido assim em relação a guerras e conflitos internacionais; tem sido assim no acompanhamento de crimes, de denúncias de corrupção, de manifestações sociais, de campanhas eleitorais nacionais.

O problema então será que as pessoas só lembrem por meio do que a memória eletrônica da mídia registra e só olhem o mundo pelos olhos do instrumento de registro. A parte objetiva da memória, correspondente à sua estrutura, não pode ser predominantemente a matéria simbólica fornecida pelas instâncias midiáticas, portanto é preciso saber identificar que estruturas e convenções são impostas no presente pelo discurso e pela regularidade das formulações discursivas, pois é esse movimento que oscila entre o lingüístico e o histórico que contribuirá para a formação da memória social.

Também é necessário ter em mente, conforme apontam Chomsky e Herman, que "o fato de a mídia oferecer alguns elementos sobre determinada questão não prova absolutamente nada sobre a adequação ou a precisão da cobertura" (2003:57), uma vez que pode haver a supressão de informações e de contextos importantes para a análise e compreensão dos fatos. Foi isso que observamos nos telejornais examinados, que apesar do volume de elementos noticiosos revelaram fragilidade óssea quando postos em relação com outros discursos tecidos acerca do 11 de setembro. Porém o processo de formação de memória do acontecimento já fora desencadeado, já que, conforme 
Davallon, o registro televisivo tem força suficiente para tornar-se memória social pela capacidade de fazer convergir olhares sobre o mesmo objeto (1999:31).

Perseu Abramo ressalvou, em seu estudo sobre os padrões de manipulação da imprensa escrita, que "não é todo o material que toda a imprensa manipula sempre", mas também não se pode dizer que isso ocorra uma vez ou outra (2003:25). Acreditamos que isso valha também para o jornalismo televisivo, em relação ao engendramento de estruturas e fatos simbólicos que repousarão na memória social. Entendemos que aquilo que se verificou por meio de um estudo de caso pode ser encontrado em outras coberturas telejornalísticas, desde que empreendidas as mesmas estratégias de análise crítica do discurso, pela qual é possível não só desmontar o discurso do telejornal como também revisitar as ruínas do mito da objetividade jornalística: "se contra fatos não há argumentos, é contra as versões que eles são cabíveis" (Lage, 1998:64).

Esperamos que pesquisas futuras possam ajudar a compreender como se poderá escrever, ou já se está escrevendo, a história do Brasil e do mundo a partir do período em que os fatos passaram a ser mediados pela televisão, uma preocupação manifestada por Eugênio Bucci e da qual compartilhamos. Na era do "telever", porém sem arquivos públicos de televisão, como proceder à documentação da história contada pelo mais influente dos meios de comunicação e legá-la às gerações futuras?

Como reavaliar a história tal qual nos foi contada pela televisão e analogamente retida na memória social? Como preencher as lacunas dessa história imediata com as interpretações amadurecidas pelo tempo? É evidente que a história não bebe apenas na fonte da televisão, mas parece-nos fundamental registrar como esse olhar mediador deflagra determinadas transformações sociais.

Por fim, uma última inquietação: e se nos perguntarem um dia de que matéria somos feitos? Será que ainda poderemos responder que "somos da matéria de que são feitos os sonhos"130? Ou diremos que somos da matéria de que é feita a memória, de espectros da realidade, de aparições e eclipses do universo midiático? Esperamos que não, então só assim a memória coletiva servirá para a libertação dos homens.

130 "We are such stuff as dreams are made of", frase da peça A tempestade, de William Shakespeare. 


\section{REFERÊNCIAS BIBLIOGRÁFICAS}

Abramo, Perseu. Padrões de manipulação na grande imprensa. São Paulo, Fundação Perseu Abramo, 2003.

ACHARD, Pierre. "Memória e produção discursiva do sentido", In: ACHARD, Pierre et alii. Papel da memória. Campinas, Pontes,1999.

AlthUSSer, L. Ideologia e aparelhos ideológicos de Estado. Lisboa, Presença, 1974.

APOTHÉLOZ, D. "Papel e funcionamento da anáfora na dinâmica textual", In: CAVALCANTE, M. M. et al. (orgs.). Referenciação. São Paulo, Contexto, 2003.

e ChANET, C. "Definido e demonstrativo nas nomeações", In: CavalCANTE, M. M. et al. (orgs.). Referenciação. São Paulo, Contexto, 2003.

ARBEX JR., José. Showrnalismo: a notícia como espetáculo. São Paulo, Editora Casa Amarela, 2001.

. O jornalismo canalha: a promíscua relação entre a mídia e o poder. São Paulo, Editora Casa Amarela, 2003.

ARONCHI DE SouzA, José Carlos. Seja o primeiro a saber - A CNN e a globalização da informação. São Paulo, Summus, 2005.

AuthIER-ReVuz, J. "Hétérogénéité montreé et hétérogénéité constitutive: élements pour une approche de l'autre dans le discours", In: Revue de linguistique, n 26, 1982. . "Heterogeneidade(s) enunciativa(s)", In: Caderno de estudos lingüísticos, n 19. Campinas, Unicamp, 1990.

- Palavras incertas. As não-coincidências do dizer. Campinas, Editora da Unicamp, 1998.

BACCEGA, Maria A. "Mediação organizativa: o campo da produção", In: Comunicação e educação, São Paulo, ECA-USP, n 17, 2000.

. "A construção do campo comunicação/educação: alguns caminhos", In: Revista USP - Comunicação, São Paulo, USP, n 48, 2001.

BAKHTIN, M. Estética da criação verbal. São Paulo, Martins Fontes, 1992. . Marxismo e filosofia da linguagem. São Paulo, Hucitec, 1999 [original de 1929].

BARBEIRo, Heródoto e LiMA, Paulo Rodolfo. Manual de telejornalismo: os segredos da notícia na TV. $2^{\mathrm{a}}$ ed. Rio de Janeiro, Elsevier, 2005. 
BARRETO, Lima. Recordações do escrivão Isaías Caminha (1908). Edição do Círculo do Livro, São Paulo, 1987.

BARROS, Diana L. P. e FIORIN, José Luiz. (orgs.) Dialogismo, polifonia, intertextualidade. São Paulo, Edusp, 1994.

BARTHES, Roland. A câmara clara. Rio de Janeiro, Nova Fronteira, 1984. . Lo obvio y lo obtuso: imágenes, gestos, voces. Barcelona, Paidós, 1986.

BAUDRILLARD, Jean. Simulacros e simulação. Lisboa, Relógio d'Água, 1991.

BECHELLONI, Giovanni. "Audiência: uma abordagem sociológica da comunicação", In: Comunicação e educação, São Paulo, ECA-USP, n 17, 2000.

Bertrand, Claude-Jean. A deontologia das mídias. Bauru, Edusc, 1999.

BISTANe, L. e BACELAR, L. Jornalismo de TV. São Paulo, Contexto, 2005.

BLIKSTEIN, Izidoro. "Intertextualidade e polifonia: o discurso do plano Brasil Novo", In: BARRos, Diana e FIORIN, J. L. (orgs.) Dialogismo, polifonia, intertextualidade. São Paulo, Edusp, 1994.

Bosı, Ecléa. O tempo vivo da memória: ensaios de psicologia social. São Paulo, Ateliê Editorial, 2003.

BouRdieu, Pierre. Sobre a televisão. Rio de Janeiro, Jorge Zahar Editor, 1997. . O poder simbólico. $8^{\text {a }}$ ed. Rio de Janeiro, Bertrand Brasil, 2005.

BRAGA, Elizabeth dos Santos. A constituição social da memória: uma perspectiva histórico-cultural. ljuí, Ed. Unijuí, 2000.

BRAIT, Beth. "As vozes bakhtinianas e o diálogo inconcluso", In: BARROS, D. e FIORIN, J. L. (orgs.) Dialogismo, polifonia, intertextualidade. São Paulo, Edusp, 1994.

. "Bakhtin e a natureza constitutivamente dialógica da linguagem", In: BRAIT, Beth (org.). Bakhtin, dialogismo e construção do sentido. Campinas,Ed.Unicamp, 1997.

Brandão, Helena H. N. Introdução à análise do discurso. Campinas, Ed. Unicamp, 1996. . Subjetividade, argumentação e polifonia. São Paulo, Unesp, 1997.

BRETON, Philippe. A manipulação da palavra. São Paulo, Ed. Loyola, 1999. . A argumentação na comunicação. Bauru, Edusc, 2003. 
Buccl, Eugênio. Prefácio a Poder no jornalismo. Mayra Rodrigues Gomes. São Paulo, Edusp, 2003.

. Brasil em tempo de TV. São Paulo, Boitempo, 2005.

e Hamburger, Esther. (orgs.) A TV aos 50 anos. São Paulo. Fundação Perseu Abramo, 2003.

e KEHL, Maria Rita. Videologias: ensaios sobre televisão. São Paulo, Editora Boitempo, 2004.

ChaPARRo, Manuel C. Pragmática do jornalismo. São Paulo, Summus, 1994.

Charaudeau, Patrick. El discurso de la información: la construcción del espejo social.

Barcelona, Gedisa Editorial, 2003.

. Discurso das mídias. São Paulo, Contexto, 2006.

e Maingueneau, Dominique. Dicionário de análise do discurso. São

Paulo, Contexto, 2004.

Chomsky, Noam. 11 de setembro. Rio de Janeiro, Bertrand Brasil, 2003.

. Poder e terrorismo: entrevistas e conferências pós-11 de setembro. Rio de Janeiro, Record, 2005.

e Herman, E. S. A manipulação do público. Política e poder econômico no uso da mídia. São Paulo, Futura, 2003.

CITELLI, Adilson. "Linguagem verbal e meios de comunicação: sobre palavras e (inter)ditos", In: Revista USP - Comunicação, São Paulo, USP, nº 48, 2001.

Conte, Maria-Elisabeth. "Encapsulamento anafórico", In: Cavalcante, M. M. et alii. (orgs.). Referenciação. São Paulo, Contexto, 2003.

Courtine, J-J. "O chapéu de Clémentis", In: INDURSky, F e FERREIRA, M. C. L. (orgs.) Os múltiplos territórios da análise do discurso. Porto Alegre, Sagra Luzzatto, 1999.

CURADo, Olga. A notícia na TV: o dia-a-dia de quem faz telejornalismo. São Paulo, Alegro, 2002.

Davallon, J. "A imagem, uma arte de memória?", In: ACHARD, Pierre et al. Papel da memória. Campinas, Pontes, 1999.

Debord, Guy. Comentários sobre a sociedade do espetáculo. Versão para ebook, ebooksbrasil.com, 2003. 
Defleur, Melvin L. e Ball-RokeAch, Sandra. Teorias da comunicação de massa. Rio de Janeiro, Jorge Zahar Ed., 1993.

Dorneles, Carlos. Deus é inocente. A imprensa, não. São Paulo, Globo, 2002.

DUARTE, Elizabeth Bastos. Televisão: ensaios metodológicos. Porto Alegre, Sulina, 2004.

Ducrot, Oswald. O dizer e o dito. Campinas, Pontes, 1987.

Eco, Umberto. Apocalípticos e integrados. $6^{\text {a }}$ ed. São Paulo, Perspectiva, 1998.

ENNE, Ana Lúcia. "Memória, identidade e discurso midiático: uma revisão bibliográfica", In: Revista eletrônica Novo Enfoque, $\mathrm{n}^{0} 1$, junho de 2004, site da Universidade Castelo Branco, Rio de Janeiro.

FAIRCLOUGH, Norman. Language and power. Londres e Nova York, Longman, 1991. . Discurso e mudança social. Brasília, Editora UnB, 2001.

FEnTRESS, James e WiCKHAM, Chris. Memória social. Lisboa, Teorema, 1992.

FINO, Carlos. A guerra ao vivo. São Paulo, Verbo, 2003.

FIORIN, José L. Elementos de análise do discurso. São Paulo, Contexto/Edusp, 1989.

FLAHAULT, François. La parole intermédiaire. Paris, Seuil, 1978.

Foucault, Michel. A ordem do discurso. São Paulo, Ed. Loyola, 2005 [original de 1970].

FRANCIS, Gill. "Rotulação do discurso: um aspecto da coesão lexical de grupos nominais", In: Cavalcante, M. M. et al. (orgs.). Referenciação. São Paulo, Contexto, 2003.

GRÁCIO, Rui A. Racionalidade argumentativa. Porto, Edições Asa, 1993.

GREGOLIN, Maria do Rosário. "A mídia e a espetacularização da cultura", In: GREGOLIN, M.

R. (org.) Discurso e mídia: a cultura do espetáculo. São Carlos, Claraluz, 2003.

GuimarÃes, Eduardo e BRUM de PaUla, M. R. (orgs.) Sentido e memória. Campinas, Pontes, 2005.

HABERmas, J. Mudança estrutural da esfera pública. Rio de Janeiro, Tempo Brasileiro, 1984 [original de 1962].

HALBWACHS, Maurice. Les cadres sociaux de la mémoire. Paris, Albin Michel, 1994 [original de 1925]. . A memória coletiva. São Paulo, Centauro, 2004 [original de 1949].

HeRnANDES, Nilton. Semiótica dos jornais. Tese de doutorado, FFLCH/USP, 2005. 
KEHL, Maria Rita. "Imaginário e pensamento", In: Sujeito, o lado oculto do receptor. São Paulo, Brasiliense, 1994.

KoCH, Ingedore V. Argumentação e linguagem. $4^{a}$ ed. São Paulo, Cortez, 1996.

. O texto e a construção dos sentidos. São Paulo, Contexto, 1997a.

. A inter-ação pela linguagem. São Paulo, Contexto, 1997b.

. Desvendando os segredos do texto. São Paulo, Cortez, 2002.

et alii. (orgs.) Referenciação e discurso. São Paulo, Contexto, 2005.

LAGE, Nilson. Controle de opinião pública: um ensaio sobre a verdade conveniente.

Petrópolis, Vozes, 1998.

. Ideologia e técnica da notícia. $3^{\mathrm{a}}$ ed. Florianópolis, Insular e Ed. da UFSC, 2001.

. Teoria e técnica do texto jornalístico. Rio de Janeiro, Elsevier Editora, 2005.

LAKOFF, G. e JoHnson, M. Metáforas da vida cotidiana. Campinas/São Paulo, Mercado das Letras/Educ, 2002 [original de 1980].

LANDOWSKI, Eric. A sociedade refletida. São Paulo, Educ/Pontes, 1992.

LE Goff, Jacques. História e memória. Campinas, Ed. Unicamp, 2003 [original de 1977].

LOPES, Luís Carlos. O culto às mídias: interpretação, cultura e contratos. São Carlos, EdUFSCar, 2004.

. "Televisão e argumentação: episteme e métodos", In: Revista Ciberlegenda, $\mathrm{n}^{\circ}$ 15, site da Universidade Federal Fluminense, 2005.

MAchado, Arlindo. A televisão levada a sério. São Paulo, Ed. Senac, 2001.

Maingueneau, D. Novas tendências em análise do discurso. Campinas, Pontes, 1997.

. Termos-chave da análise do discurso. Belo Horizonte, Ed. UFMG, 2000.

. Análise de textos de comunicação. São Paulo, Cortez, 2002.

MARCondes FiLHo, Ciro. Televisão: a vida pelo vídeo. São Paulo, Moderna, 1988.

. Comunicação e jornalismo: a saga dos cães perdidos. São Paulo, Hacker Editores, 2002.

MARIANI, Bethania Sampaio C. "De como o discurso jornalístico constrói memória", In: ORLANDI, Eni P. (org.) Discurso fundador. Campinas, Pontes, 2001. 
MARTín-BARBERo, Jesús. Dos meios às mediações: comunicação, cultura e hegemonia. Rio de Janeiro, Editora UFRJ, 1997.

e REY, G. Os exercícios do ver: hegemonia audiovisual e ficção televisiva. São Paulo, Ed. Senac, 2001.

Mattelart, Armand \& Michèle. Pensar as mídias. São Paulo, Edições Loyola, 2004 [original de 1986].

Melo, J. M. "Comunicação social: da leitura à leitura crítica", In: Leitura: perspectivas interdisciplinares. São Paulo, Ática, 1998.

MemóRIA Globo. Jornal Nacional: A notícia faz história. Rio de Janeiro, Editora Jorge Zahar, 2004.

MeYER, M. Questões de retórica: linguagem, razão e sedução. Lisboa, Edições 70, 1998.

MEYSSAN, Thierry. 11 de Setembro de 2001: uma terrível farsa. São Paulo, Usina do Livro, 2003.

MIZAN, Souzana. CNN TV News of September 11 ${ }^{\text {th }}$ : a representation of reality or the reality of representation. Dissertação de mestrado, FFLCH/USP, 2004.

MondADA, L. e DuBoIS, D. "Construção dos objetos de discurso e categorização: uma abordagem dos processos de referenciação", In: CAVALCANTE, Mônica M. et al. (orgs.). Referenciação. São Paulo, Contexto, 2003.

MOORE, Michael. O livro oficial do filme Fahrenheit 11 de Setembro. São Paulo, Francis/W11 Editores, 2004.

MoscA, Lineide L. S. "Velhas e novas retóricas: convergências e desdobramentos", In: MoscA, L. (org.) Retóricas de ontem e de hoje. São Paulo, Humanitas, 1997.

. "Subjetividade e formação de opinião na mídia impressa", In: GUILARDI, M. I. e BARzotto, V. H. (orgs.) Nas telas da mídia. Campinas, Alínea, 2002.

. "A atualidade da retórica e seus estudos: encontros e desencontros". Primeiro

Congresso Virtual do Departamento de Literaturas Românicas da Universidade de Lisboa, CD-ROM, 2005. (org.). Discurso, argumentação e produção de sentido. São Paulo, Associação Editoral Humanitas, 2006. 
ORLANDI, Eni. A linguagem e seu funcionamento: as formas do discurso. Campinas, Editora Pontes, 1987.

- As formas do silêncio: no movimento dos sentidos. Campinas, Editora da Unicamp, 1993.

- (org.). Discurso fundador. A formação do país e a construção da identidade nacional. Campinas, Pontes, 2001.

- Interpretação: autoria, leitura e efeitos do trabalho simbólico. $4^{\mathrm{a}}$ ed. Campinas, Editora Pontes, 2004.

. Discurso e texto: formulação e circulação dos sentidos. Campinas, Pontes, 2005.

PÊCHEUX, M. O discurso: estrutura ou acontecimento. Campinas, Pontes, 1997.

. "Papel da memória?", In: ACHARD, P. et al. Papel da memória. Campinas, Editora Pontes, 1999.

Perelman, C. (1993) O império retórico: retórica e argumentação. Porto, Ed. Asa, 1993.

e OLBRECHTS-TYTECA, L. Tratado da argumentação: a nova retórica. São Paulo, Martins Fontes, 1996 [original de 1958].

RAJAgopalan, K. Por uma lingüística crítica: linguagem, identidade e a questão ética. São Paulo, Parábola Editorial, 2003.

. "A construção de identidades e a política de representação", In: FERREIRA, L. M.

A. e ORRICo, E. G. D. (orgs.). Linguagem, identidade, memória social: novas fronteiras, novas articulações. Rio de Janeiro, D.P.\&A., 2002.

Reboul, O. Introdução à retórica. São Paulo, Martins Fontes, 1998.

Rezende, G. J. de. Telejornalismo no Brasil: um perfil editorial. São Paulo, Summus Editorial, 2000.

RIBEIRO, Raimundo D. P. "Memória e contemporaneidade: as tecnologias da informação como construção histórica", In: Revista eletrônica Com Ciência, março de 2004.

Ricoeur, Paul. Interpretação e ideologias. Rio de Janeiro, Francisco Alves, 1977. . A metáfora viva. São Paulo, Edições Loyola, 2000 [original de 1975].

Rocco, Maria Teresa Fraga. "As palavras na TV: um exercício autoritário?", In: NovAES, Adauto (org.). A rede imaginária. São Paulo, Cia das Letras, 1991.

SANTAELLA, Lúcia. Cultura das mídias. $3^{\mathrm{a}}$ ed. São Paulo, Experimento, 2003. e WiNfRIED, N. Imagem: cognição, semiótica, mídia. São Paulo, lluminuras, 1999. 
SANTOS, Myrian S. Memória coletiva e teoria social. São Paulo, Annablume, 2003.

SARTORI, Giovanni. Homo videns: televisão e pós-pensamento. Lisboa, Terramar, 2000.

SERVA, Leão. Jornalismo e desinformação. São Paulo, Ed. Senac, 2001.

SODRÉ, Muniz. O monopólio da fala: função e linguagem da televisão no Brasil. $7^{\mathrm{a}}$ ed. Petrópolis, Vozes, 1984.

SontAG, Susan. Diante da dor dos outros. São Paulo, Companhia das Letras, 2003.

SOULAGES, Jean-Claude. Les mises en scène visuelles de l'information: étude comparée France, Espagne, États-Unis. Paris, Nathan, 1999.

Strohschoen, A. M. Mídia e memórias coletivas. Santa Cruz do Sul, Edunisc, 2004.

SZPACENKOPF, Maria Izabel Oliveira. O olhar do poder. A montagem branca e a violência no espetáculo telejornal. Rio de Janeiro, Civilização Brasileira, 2003.

Thompson, John. B. A mídia e a modernidade: uma teoria social da mídia. Petrópolis, Editora Vozes, 2001.

Toulmin, S. Os usos do argumento. São Paulo, Martins Fontes, 2001 [original de 1958].

VAN DIJK, Teun A. La noticia como discurso - compreensión, estructura y produción de la información. Barcelona/Buenos Aires, Paidós, 1990. . Cognição, discurso e interação. São Paulo, Contexto, 1996.

VÉRON, Eliseo. Construire l'événement. Paris, Les Editions de Minuit, 1981.

VIZEU, Alfredo. O lado oculto do telejornalismo. Florianópolis, Calandra, 2005.

WAINBERg, Jacques A. Mídia e terror: comunicação e violência política. São Paulo, Editora Paulus, 2005.

\section{Programas e sites:}

Roda VIVA EsPeCIAL. "Terror nos EUA", TV Cultura, setembro de 2001.

OBSERVATÓRIO DA IMPRENSA. www.observatoriodaimprensa.com.br

UOL JORNAIS. www.uol.com.br 
ANEXOS 


\section{ANEXOS}

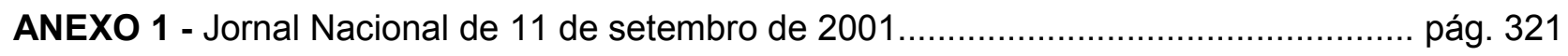

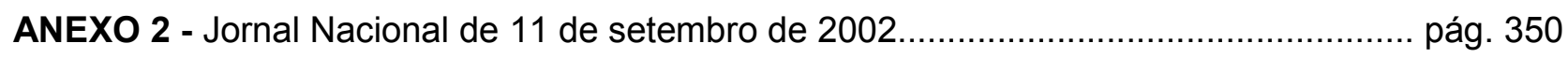

ANEXO 3 - Jornal Nacional de 11 de setembro de 2003............................................... pág. 355

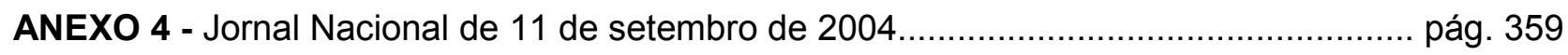

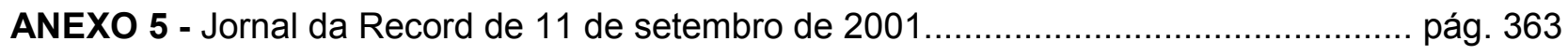

ANEXO 6 - Jornal da Record de 11 de setembro de 2002 ........................................... pág. 396

ANEXO 7 - Jornal da Record de 11 de setembro de 2003........................................... pág. 402

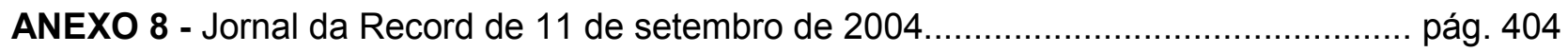

\section{Termos que indicam as partes dos telejornais:}

1) escalada é a chamada, no início do jornal, das principais notícias do dia;

2) cabeça é o texto que o locutor lê na bancada;

3) off é o texto lido enquanto se exibem as imagens;

4) passagem é a entrada do repórter gravada, em oposição à entrada ao vivo;

5) sonora é a fala dos entrevistados, identificados com crédito ou não;

6) passagem de bloco é a chamada das notícias do bloco seguinte;

7) nota pé é o texto que fecha uma matéria, com alguma informação complementar. 


\section{ANEXO 1}

\section{Jornal Nacional de 11 de setembro de 2001}

\section{Escalada (com as principais imagens do acontecimento):}

Onze de setembro de 2001.

Uma terça-feira que vai marcar a história da humanidade.

A maior potência do planeta é alvejada pelo terror.

World Trade Center, Nova York.

No mais importante centro financeiro do mundo,

uma torre queima - depois de ser atingida por um avião.

Enquanto o incêndio avança no arranha-céu, um segundo avião é jogado contra a torre vizinha. (Imagem do segundo avião se chocando contra uma das torres. Há um efeito de zoom, a imagem se aproxima rapidamente. Uma pessoa grita: "Oh, my God!")

$\mathrm{E}$ em menos de duas horas dois dos prédios mais altos do mundo se desfazem numa montanha de poeira e fumaça.

$\mathrm{Na}$ cidade sede do poder americano,

outra aeronave despenca sobre o Pentágono: o centro de inteligência militar.

E mais um boeing cai na Pensilvânia.

O planeta em alerta geral.

Chefes de estado condenam o banho de sangue e reforçam a segurança nas fronteiras.

Bolsas de valores e moedas internacionais são abaladas pelos atentados.

Nos territórios ocupados por Israel, palestinos comemoram a maior ofensiva terrorista de todos os tempos. (Imagem bastante repetida de uma suposta comemoração dos palestinos.)

E na madrugada, no mundo árabe, explosões.

Mísseis riscam o céu de Cabul - a capital do Afeganistão. (Imagens da CNN.)

O Jornal Nacional mostra a análise de especialistas

sobre as conseqüências dos ataques.

O depoimento dos brasileiros que testemunharam a tragédia.

O apoio oficial aos que estão nos Estados Unidos.

O dia em que os americanos experimentaram o horror de uma grande guerra.

O Jornal Nacional está começando agora. 


\section{Bloco 1}

\section{Locutor $1^{131}$ (cabeça) $^{132}$ :}

Boa noite. Eram 8h45 em Nova York, 9h45 em Brasília. Um avião americano de passageiros batia em cheio numa das torres do World Trade Center. Um acidente tão inimaginável que imediatamente chamou a atenção de todo o planeta. Mas não era acidente. Para perplexidade do mundo inteiro, foram-se registrando acontecimentos que nenhum roteirista de Hollywood imaginou. E era tudo real. Estava começando o maior atentado terrorista de todos os tempos.

\section{Repórter $1^{133}$ (off):}

O edifício mais alto de Nova York em chamas (com a imagem correspondente). Angústia, acenos, gritos de socorro nas janelas (com a imagem correspondente). O maior ataque terrorista da história da humanidade começou com o choque de um avião, seqüestrado pouco antes. As imagens estavam sendo transmitidas pela TV, ao vivo, quando, 18 minutos depois, um outro avião se aproxima, pela direita do quadro, e bate na outra torre. (Entram imagens das torres cobertas por fumaça e do momento em que o segundo avião se choca contra uma das torres, visto por dois ângulos diferentes. Sobe áudio local e entra uma breve sonora de um brasileiro, Luciano Fabello, comerciário: "Foi uma coisa horrível, horrível, horrível.")

$\mathrm{Na}$ ruas próximas do atentado, correria. Lágrimas (Entra seqüência de imagens: pessoas correndo e chorando nas ruas, policiais orientando o trânsito.) "As pessoas estão pulando das janelas", ela diz (a imagem é de uma americana, cuja fala é traduzida pelo repórter, exceto a interjeição "Oh, my God!"). Aumenta o desespero: a todo momento alguém se jogava lá de cima (imagens de pessoas se jogando).

Os dois aviões que se chocaram contra o World Trade Center tinham sido seqüestrados. As torres, construídas para resistir até ao choque de um boeing 727 , tinham sido atingidas por dois aviões maiores. (Entra seqüência de imagens: o segundo avião se lançando contra uma das torres, as torres cobertas por fumaça, a mesma cena vista à distância, com um panorama da ilha, e depois mais de perto novamente.)

${ }^{131}$ O locutor 1 é a apresentadora Fátima Bernardes e o locutor 2 é o apresentador William Bonner, também editor-chefe do Jornal Nacional.

${ }^{132}$ O selo que aparecerá ao fundo nas entradas dos locutores é um mapa dos Estados Unidos vazado, com a imagem de uma das torres em chamas, após o choque do segundo avião. 
Jatos 767, seqüestrados em Boston. Os dois aviões levavam passageiros. O presidente dos Estados Unidos, George Bush, confirma: foi um atentado terrorista (imagem de Bush falando). A brasileira Bruna Paixão trabalha num restaurante que fica perto do World Trade Center.

Sonora da estudante: "As pessoas estavam correndo na rua, desesperadas, sem saber o que fazer. Elas entravam no restaurante, pediam para usar o telefone, porque não conseguiam usar ao telefone público. lam ao banheiro vomitar. Era um desespero. Muita gente machucada chegou no restaurante também. Muita gente nervosa, chorando. Foi um caos. Eu nunca vi uma coisa como essa. Foi um caos."

\section{Repórter 1 (passagem, de um lugar em que se via a fumaça dos prédios):}

Toda a área próxima do atentado foi fechada. Onde estava o World Trade Center, só fumaça. Os dois edifícios, de 110 andares, vieram abaixo após as explosões.

\section{Repórter 1 (off):}

A primeira torre a cair foi a do norte (imagem correspondente). Pouco depois, às $10 \mathrm{~h} 25$, os andares superiores da segunda torre começam a ceder. E vêm abaixo. (Entram imagens da segunda torre caindo, de dois ângulos diferentes, e de pessoas nas ruas olhando a queda. As imagens são cobertas por áudio local.)

O capelão brasileiro Hélio dos Anjos foi ajudar as vítimas: "Eu fui ajudar os bombeiros e tinha pessoas em choque. Eu também comecei a ficar muito nervoso, porque começou a vir muita fumaça. A gente não sabia se subia, pegava o elevador, se descia. Os bombeiros: calma, calma. Olha, foi terrível."

As ambulâncias, ainda cobertas do pó, não param. Polícia, bombeiros e equipes de socorro aumentam a cada momento (imagens correspondentes). As fundações das torres são de aço (novamente a imagem das torres cobertas por fumaça). O engenheiro brasileiro Carlos Levy diz que é improvável que apenas o choque dos aviões pudesse levar os prédios abaixo (de novo a imagem do choque do segundo avião).

\footnotetext{
${ }^{133}$ Fala Edney Silvestre, de Nova York.
} 
Sonora do engenheiro: "Fica difícil acreditar que apenas o choque dos aviões e as explosões causassem o desabamento dos prédios de uma maneira tão rápida. As próprias imagens assustam com a velocidade que ocorreram." (Novamente as imagens da segunda torre desabando, agora por três ângulos diferentes. Sobe áudio local, com pessoas chorando e gritando "Oh, my God!")

\section{Repórter 1 (off):}

Há suspeitas de que o prédio tenha sido implodido pelos terroristas. Alguns especialistas acham que o WTC acabou ruindo por uma combinação de fatores. O choque dos aviões, as explosões que se seguiram, mais o fogo enfraqueceram a estrutura dos andares superiores, e o peso deles, ao cair, levou o resto. (Novamente as imagens do choque do segundo avião e as do desabamento das torres, agora mais longas, mostrando a fumaça e uma enorme nuvem de poeira negra se espalhando pelas ruas, "perseguindo" as pessoas e deixando tudo escuro.)

$\mathrm{O}$ ataque ao WTC é o maior já ocorrido em solo americano desde que os japoneses bombardearam Pearl Harbor. Lá foram mortos 2.280 soldados e 68 civis. (A imagem aqui é de pessoas feridas no atentado, deitadas no chão ou sendo socorridas. É uma imagem breve, a única desse tipo no jornal todo.) Foi o que levou os Estados Unidos a entrar na Segunda Guerra Mundial. (Aqui a imagem é, novamente, a dos prédios cobertos por fumaça, vistos ao longe, numa panorâmica da ilha.)

\section{Locutor 2 (cabeça):}

Com 110 andares e 417 metros de altura, as torres gêmeas do World Trade Center eram os prédios mais altos de Nova York.

\section{Locutor 2 (off):}

O edifício abrigava lojas e escritórios de 430 empresas, onde trabalhavam 50 mil pessoas. (Imagens de arquivo do WTC, pessoas nas ruas, ilha de Manhattan.) Começou a ser construído em 1970, numa tentativa do governo do estado de Nova York de revitalizar o sul da ilha de Manhattan. Desde então, o prédio - o quinto mais alto do mundo e o segundo dos Estados Unidos - virou ponto turístico. Dos dois terraços do edifício era possível ver a Estátua da Liberdade ao sul. O bairro do Brooklyn a leste. E a cidade de Nova Jersey a oeste. (Entra ilustração, mostrando a localização do WTC na ilha.) 
Em fevereiro de 1993, o World Trade Center foi alvo de um ataque à bomba que matou seis pessoas e deixou mais de mil feridos. A responsabilidade pelo atentado, há oito anos, foi assumida pelo terrorista mais procurado do mundo, Osama Bin Laden. (Imagens de arquivo do atentado e de Osama Bin Laden.)

\section{Locutor 1 (cabeça):}

Além da destruição em Nova York, o terror atacou o símbolo do poder militar dos Estados Unidos: o Pentágono.

\section{Repórter $2^{134}$ (off):}

Exatos 40 minutos depois do segundo avião atingir o World Trade Center, em Nova York, os militares que trabalhavam na face oeste do Pentágono tiveram por breves momentos uma visão de pesadelo. (Entra uma seqüência de imagens: fumaça sobre o Pentágono, pessoas andando por perto, muita fumaça, de vários ângulos, e pessoas deixando o prédio andando.)

Um boeing 757 da companhia aérea United Airlines mergulhando diretamente contra o prédio. $\mathrm{O}$ impacto abriu uma cratera numa das faces dessa construção imensa, que é, na verdade, um sanduíche de cinco edifícios. Um dentro do outro, todos com seis andares de altura. Das dezenas de portas do Pentágono, milhares de funcionários foram retirados às pressas. (A narração aqui coincide com a imagem das pessoas saindo do prédio andando, sem pânico.)

\section{Repórter 2 (passagem, da frente do prédio do Pentágono):}

Não só a violência do ataque e a tragédia que ele provoca assustam os americanos. A simbologia é muito forte também. $O$ coração das forças armadas foi atingido. A capital desse país é muito mais vulnerável do que os cidadãos podiam imaginar.

\section{Repórter 2 (off):}

Os que trabalham em Washington e moram fora da cidade, nos subúrbios, saíram dos escritórios ouvindo informações de que uma outra explosão teria acontecido ao lado do departamento de Estado. E outra, ainda, próxima ao Capitólio. O clima na capital da maior potência do mundo era de medo e incerteza. (Imagens de pessoas e carros andando nas ruas, nada indica medo.)

\footnotetext{
${ }^{134}$ Fala Fernando Silva Pinto, de Washington.
} 
A possibilidade de novos ataques estava na mente de todos (imagens do Pentágono sob fumaça). Em pouco tempo, Washington praticamente parou. Todo o pessoal foi retirado da Casa Branca e do Congresso. Funcionários federais foram dispensados em toda a cidade. Esse rapaz está surpreso. Diz que esperava que o Pentágono fosse mais seguro (não há crédito e o repórter traduz o que o rapaz fala).

"Os terroristas estão enganados em achar que conseguiram o objetivo deles. Vão ser condenados por 99\% da população do mundo", ele diz. (Aqui também o repórter traduz a fala de um senhor.) E esse outro diz que deve haver retribuição. É um crime. Tem que haver justiça. ${ }^{135}$

Um estado de alerta nas forças armadas americanas (ainda imagens de fumaça sobre o Pentágono) foi acionado logo depois do atentado contra o Pentágono. Dois porta-aviões nucleares e vários cruzadores foram dirigidos para a defesa dos litorais do país. A explicação do vice-almirante Steven Pretropaulin foi curta: "Nós estamos ainda sob ataque" (também tradução do repórter). Até agora o Pentágono (ainda as imagens de fumaça sobre o prédio e do prédio destruído) não está divulgando a lista dos funcionários atingidos no atentado. Sabe-se que 35 pessoas estão feridas e não há informação sobre mortes.

\section{Locutor 2 (cabeça):}

A seqüência dos acontecimentos levou o governo americano a acionar o plano de emergência. Nunca, na história, tantos aviões foram seqüestrados ao mesmo tempo.

\section{Repórter $3^{136}$ (off):}

Esta americana, uma nova-iorquina, ela conseguiu explicar como os americanos estão se sentindo hoje. "É horrível. Eu não podia imaginar que isso poderia acontecer, que somos tão vulneráveis assim". (Também aqui a tradução do repórter cobre a fala da pessoa.) Os Estados Unidos (entra uma seqüência de imagens: muita fumaça, carros e prédios destruídos, pessoas correndo), o país mais poderoso, o mais rico do mundo.

${ }^{135}$ A maioria das sonoras em outra língua é traduzida pelos repórteres. A voz do repórter cobre a do entrevistado, enquanto aparece a imagem da pessoa falando, sem que seja possível entender o que é dito originalmente.

${ }^{136}$ Fala Zileide Silva, de Nova York. 
Teve um momento hoje em que o Departamento de Aviação Americano (entra ilustração mostrando a rota dos aviões) perdeu o contato, não sabia onde estavam oito aviões. Quatro tinham sido seqüestrados. Dois da American Airlines. O que se chocou com a primeira torre ia de Boston para Los Angeles. O outro, que atingiu o Pentágono, ia de Washington também para Los Angeles. Segundo a empresa, os aviões levavam 158 passageiros e 17 tripulantes. Os outros dois aviões eram da United Airlines. O que atingiu a segunda torre fazia a rota Boston-Los Angeles, com nove tripulantes e 56 passageiros. E o que caiu na Pensilvânia, um avião com 38 passageiros e sete tripulantes. (A ilustração fica na tela durante todo esse trecho narrativo.)

Uma das passageiras desse avião, com um celular, conseguiu avisar ao marido: "Nós estamos sendo seqüestrados. Os seqüestradores estão com facas ou punhais" (é a repórter quem simula a fala). (Repetem-se as imagens das torres desabando, muita fumaça e poeira nas ruas, as torres sob fumaça.) A United não informou se o avião caiu antes de atingir algum alvo terrorista, ou se por uma outra razão. Todos os passageiros e tripulantes desses quatro aviões, 285 pessoas, morreram.

Logo após o primeiro choque na torre do World Trade Center, o plano de emergência dos Estados Unidos contra ataques terroristas foi acionado. E pela primeira vez na história americana, essa imagem, aeroportos supermovimentados, não foi vista. (Imagens de aeroportos, nem tão movimentados assim.) Todos os aeroportos do país foram fechados para pousos e decolagens. Quarenta mil vôos foram cancelados. Os outros, transferidos para o Canadá. O Departamento de Aviação Civil informou que eles só voltam a funcionar, talvez, a partir de amanhã, ao meio-dia. (Mais imagens de aviões, tudo normal.)

A fronteira com o México foi e continua fechada. E alvos em potencial - prédios, monumentos, pontes, túneis -, tudo o que poderia ser atingindo por outros atentados foi isolado ou desocupado, inclusive o prédio das Nações Unidas, em Nova York. (As imagens mostram o que a repórter vai citando.) Na Flórida, a Nasa, Agência Espacial Americana, entrou em estado de emergência máxima. A Disney fechou os parques nas Flórida. Em Seatle, um dos principais pontos turísticos da cidade, essa torre, foi fechada. (As imagens correspondem à descrição.) Eram os Estados Unidos tentando se proteger. (Imagem do Pentágono destruído.) 


\section{Locutor 1 (cabeça):}

$\mathrm{Na}$ história recente, os americanos sofreram diversas ações terroristas. Nem todas promovidas por estrangeiros. Mas o maior de todos os suspeitos é árabe.

\section{Repórter $4^{137}$ (off):}

O primeiro nome da lista de suspeitos é o do saudita Osama Bin Laden, considerado o inimigo $\mathrm{n}^{\circ} 1$ dos Estados Unidos. (Imagens de arquivo: Bin Laden e afegãos reunidos.) Ele vive no Afeganistão, protegido pelo governo Talibã. Em 1998 Bin Laden teria financiado os atentados às embaixadas americanas na África. Foram duas embaixadas, do Quênia e da Tanzânia, ao mesmo tempo. 224 pessoas morreram. (Imagens de arquivo: prédios destruídos, pessoas sendo socorridas.)

Quatro terroristas ligados a Osama Bin Laden foram julgados e condenados à prisão perpétua nos Estados Unidos. Há menos de três semanas, Bin Laden teria ameaçado organizar um atentado como o de hoje. (Imagens de arquivo: Bin Laden falando.) Uma fonte do FBI disse à rede de televisão NBC que Osama Bin Laden deve estar por trás dos ataques. Ele é suspeito de outros ataques a bases militares americanas na Arábia Saudita em 95 e 96 e a um destroyer no ano passado. (Imagens de arquivo dos atentados citados.) Há anos o governo americano pede a extradição de Bin Laden, mas o Afeganistão nega o pedido. (Imagens de arquivo: Bin Laden atirando e rindo.) Bush já tinha avisado: vai responsabilizar o Afeganistão por qualquer ataque de Bin Laden.

\section{Repórter 4 (passagem):}

As autoridades americanas estão evitando falar em suspeitos. O último atentado que os Estados Unidos sofreram em território americano aconteceu em 1995, em Oklahoma.

\section{Repórter 4 (off):}

O carro-bomba que destruiu o edifício do governo federal matou 168 pessoas (imagens de arquivo). Os americanos logo suspeitaram de extremistas árabes. Depois o $\mathrm{FBI}$ pegou o verdadeiro culpado: um americano, Timothy McVeigh, que foi executado em junho deste ano (imagens de arquivo do rapaz preso).

\footnotetext{
${ }^{137}$ Fala Heloísa Villela, de Nova York.
} 
Na hora em que aviões explodiam em prédios americanos, o secretário de estado Colin Powel estava no Peru. Ele interrompeu a visita oficial para voltar aos Estados Unidos (imagens do general no Peru e depois discursando). Antes de embarcar, o general da Guerra do Golfo mandou um recado aos terroristas: "Eles podem destruir edifícios e matar pessoas, mas nunca matarão a democracia". (A fala é traduzida pela repórter, mas no final é possível ouvir as últimas palavras da frase em inglês.)

\section{Locutor 2 (cabeça):}

Durante a madrugada, no Oriente, a capital do Afeganistão começou a ser bombardeada.

\section{Locutor 2 (off):}

As imagens da rede CNN mostram mísseis e armas antiaéreas em ação nos arredores de Cabul. As explosões começaram por volta das seis e meia da tarde, horário de Brasília. Assessores da Presidência dos Estados Unidos disseram que não houve ataques americanos no Afeganistão e levantaram a hipótese de que o bombardeio tenha sido obra da oposição ao governo Talibã. (As imagens da CNN - mísseis e explosões - permanecem durante todo o off.)

\section{Locutor 1 (chamada):}

E vamos agora, ao vivo, a Nova York. A repórter Zileide Silva tem novas informações.

\section{Entrada ao vivo:}

Fátima, essa informação de que os Estados Unidos não têm nada a ver com os ataques em Cabul foi confirmada agora há pouco pelo secretário de Defesa americano. E aqui em Nova York, um terceiro prédio, que ficava ao lado das torres gêmeas caiu também. Foi no finalzinho da tarde. Ele tinha 47 andares. (Repete-se duas vezes a imagem do anexo desabando.) Esse prédio, as torres e outros cinco edifícios formavam o principal complexo econômico aqui de Nova York.

Agora, sete e meia da noite aqui em Nova York, oito em meia aí no Brasil, um exército de dez mil pessoas está no local, vasculhando os escombros em busca de vítimas e sobreviventes. Segundo o prefeito de Nova York, pelo menos 2.100 pessoas ficaram feridas só aqui em Nova York e 600 foram hospitalizadas. Quase doze horas após o atentado, é impossível saber quantas pessoas morreram. Mas, pelo menos, como vinte mil estavam nos prédios, ou próximas a eles durante os atentados, o número de mortes pode chegar a dezenas de milhares. Bonner. 


\section{Locutor 2 (passagem de bloco):}

Em instantes. O país que se preparava para a guerra nas estrelas é vítima de seus aviões de passageiros.

\section{Locutor 1 (mesma passagem):}

E $O$ atendimento aos feridos numa cidade paralisada pelo terror. (Entra imagem de pessoas andando nas ruas destruídas, com a seguinte legenda: "depois do ataque".)

\section{Bloco 2}

\section{Locutor 2 (cabeça):}

O presidente americano George Bush estava fora de Washington quando aconteceram os atentados.

\section{Repórter $5^{138}$ (off):}

Quando os ataques começaram, o presidente Bush participava de um congresso sobre educação na Flórida. Foi na sala de aula que ele recebeu a notícia. (Aqui há uma breve pausa, sem narração, e aparece a imagem de Bush no momento em que recebeu a notícia, com uma expressão aparvalhada.) Bush pediu orações e um minuto de silêncio pelas vítimas. Depois, anunciou que estava voltando a Washington. (Imagens de Bush falando e entrando num avião.)

Mais tarde, Bush apareceu num lugar mais distante da capital ainda: uma base aérea do estado de Louisiana. Bush disse que a liberdade foi atacada por covardes sem fé. E que ela seria defendida. O presidente prometeu caçar e punir os responsáveis. Garantiu que está sendo feito tudo o que é necessário para proteger a população. Há oito meses no poder, Bush enfrenta a primeira grande prova, o maior ataque terrorista já realizado em território americano. Ele diz que as forças do país estão sendo testadas e que vão passar no teste. (Durante todo esse trecho, permanece a imagem de Bush discursando.)

A primeira-dama, Laura Bush, faria um pronunciamento no Senado sobre educação. Ao lado do senador Edward Kennedy, ela garantiu que as crianças do país estão protegidas. (Imagem de Laura Bush falando do Senado. No final, sobe áudio da fala dela, em inglês.)

\footnotetext{
${ }^{138}$ Fala Arnaldo Duran, de Nova York.
} 


\section{Repórter 5 (passagem):}

A primeira-dama e as filhas foram levadas para um lugar não revelado. George Bush deixou a base aérea de Louisiana e foi para outra base aérea, no estado de Nebrasca, no centro dos Estados Unidos, bem longe de Washington. Mas já voltou à capital. A Casa Branca anunciou que ele fará um pronunciamento logo mais, às nove horas, dez da noite em Brasília.

\section{Locutor 1 (cabeça):}

Os ataques terroristas surpreenderam também por derrubarem o que parecia uma verdade incontestável. Até hoje, o mundo considerava o sistema de segurança americano praticamente inviolável.

\section{Locutor 1 (off):}

"Os inimigos mudaram" - foi com esta frase que o presidente George Bush (imagem dele discursando) anunciou o início de um novo projeto antimísseis americano, em maio deste ano. Depois da Guerra Fria, o inimigo não era mais a Rússia. O terror poderia atacar do Irã, do Iraque, da Coréia do Norte (ilustração e mapas). O sistema de US\$ 60 bilhões vai criar armas capazes de derrubar mísseis inimigos (imagem de satélites) logo após o lançamento. Só que o ataque não veio do espaço (repete-se a imagem do choque do segundo avião contra uma das torres). Foi despachado por aviões civis e americanos.

\section{Sonoras (sem nenhum anúncio, na seqüência do off):}

"Significa que nenhum sistema de segurança, por mais perfeito que seja, é infalível. E o terrorismo é exatamente isso, é a surpresa." (Clóvis Brigagão, cientista político)

"Agora sim é que a gente vai poder dizer que isso era previsível. Mas até aí ninguém nunca imaginou que se poderia encontrar pilotos de avião a jato disponíveis a se suicidar, atacando um prédio. Quer dizer, era impossível prever isso." (João Roberto Martins Filho, do Núcleo de Estudos Estratégicos da Unicamp)

\section{Locutor 1 (off):}

Todos os dias, mais de vinte mil aviões decolam e pousam nos Estados Unidos (imagens de aviões). A questão agora é saber como foi possível levar um boeing ao Pentágono sem que ele fosse interceptado muito antes de atingir um alvo tão estratégico. (Outra vez as imagens do Pentágono sob fumaça. Não dá para ver o avião que atingiu o prédio.) 


\section{Locutor 2 (cabeça):}

Com a população em pânico e os transportes interrompidos, Nova York parou.

\section{Repórter $6^{139}$ (off):}

O clima em toda a cidade era de guerra, mesmo em lugares onde só se via de longe a fumaça do incêndio. (Aqui as imagens não correspondem à descrição: carros andando normalmente nas avenidas.) Todos os túneis e pontes que levam à ilha de Manhattan foram fechados. As bolsas e os bancos não chegaram a abrir. (Aqui entra uma seqüência mais adequada: policiais gritando para orientar o trânsito, muitos escombros nas ruas, ambulâncias passando.) As escolas ficaram com as crianças, porque os pais não puderam buscá-las. Só as ambulâncias circulavam, levando feridos para todos os hospitais da cidade. (Áudio local e imagens do estado de pânico atravessam essa narração: pessoas gritando e correndo nas ruas, se escondendo, carros de polícia passando.)

\section{Repórter 6 (passagem):}

Times Square, o coração de Nova York, parou. As pessoas andam de um lado para outro, na rua, em estado de choque.

\section{Repórter 6 (off):}

"É uma guerra. É como Pearl Harbor, quando o Japão nos atacou de surpresa" (tradução de uma sonora, sem identificação do senhor que fala). Esta não quer revide: "Destruíram a minha casa", ela diz, "o símbolo da minha cidade. Mas a América tem que responder com amor." (Outra tradução do repórter, sem identificação da moça que fala.) "Nova York vai dar a volta por cima", disse o policial. "Nós sempre levantamos a cabeça." (Também tradução da sonora, sem identificação do falante.)

Os nova-iorquinos demonstraram solidariedade fazendo fila na porta dos bancos de sangue. Sem metrô nem ônibus, o jeito foi voltar a pé para casa ou sentar na calçada para ver no telão as notícias da tragédia. (Imagens correspondentes à descrição.)

\footnotetext{
${ }^{139}$ Fala Jorge Pontual, de Nova York.
} 
Esta se desesperou: "Quero ir para casa", era tudo o que ela conseguia dizer. (Outra tradução de sonora, sem identificação da pessoa.) Muitos eram sobreviventes que andaram mais de 60 quarteirões, ainda surpresos por estarem vivos (Imagem: muita gente andando rápido nas ruas).

"Nós estávamos sendo retirados do segundo prédio quando o avião caiu. Tudo tremeu, parecia um terremoto. Meus amigos que estavam nos andares de cima devem ter tido uma morte horrível. Muitos pularam lá do alto." (Tradução da fala de um rapaz.) Este estava ao lado do primeiro prédio quando ele desabou. Ainda levava a poeira nos sapatos. "Saí correndo a toda, a nuvem dos escombros atrás. Muita gente caiu e morreu sob os destroços." (Tradução da fala de um senhor.) Este outro ficou encurralado entre o rio e o incêndio: "Só escapei de morrer asfixiado porque alguém me deu uma toalha molhada". (Também uma tradução, sem identificação do rapaz.) Charles Moser trabalha em Wall Street e viu de perto o que aconteceu.

\section{Sonora de Moser:}

"Não havia visibilidade nenhuma e não havia como respirar fora dos prédios. O pessoal vinha correndo para Wall Street com uma parede de fumaça atrás (breve imagem da fumaça e da poeira se espalhando pelas ruas). Todos cobrindo suas caras com lenços com água e indo em direção oposta ao World Trade Center. Todo mundo foi para a parte leste da cidade para poder subir andando até o norte. Nos primeiro dez blocos, não dava para avançar muito, não tinha trânsito, só veículos de emergência." (O rapaz fala em português.)

\section{Repórter 6 (off):}

O prefeito de Nova York, Rudolf Giuliani, estava num prédio ao lado do World Trade Center (mais imagens da fumaça e da poeira pelas ruas). Chegou a ficar preso nos escombros, mas conseguiu sair pelo subsolo (imagem do prefeito andando de máscara pelas ruas). "Nova York e a América", disse Giuliani, "são mais fortes do que esses bárbaros terroristas". "A democracia vai prevalecer." (Imagem do prefeito falando e tradução do repórter. Novamente a imagem de fumaça cobrindo os prédios, vistos de longe, com panorâmica da ilha.)

\section{Locutor 1 (cabeça):}

No Brasil, 30 vôos para os Estados Unidos foram cancelados. Dois aviões que já estavam no ar tiveram que voltar. 


\section{Repórter $7^{140}$ (off):}

Pouco depois do atentado o painel do aeroporto informava: todos os vôos previstos para os Estados Unidos foram cancelados (imagens de aviões e aeroportos). Aviões que já estavam no ar receberam ordens de interromper a viagem. "A companhia me informou que era para retornar, devido ao ataque terrorista, e que eu não ia conseguir pousar lá." (breve sonora do comandante Luiz Francisco Postigo) Os passageiros deste vôo da TAM, que ia de São Paulo para Miami, ficaram assustados (imagens de pessoas no aeroporto).

\section{Sonoras:}

"A tripulação ajudou a gente a se acalmar. A gente não sabia o que estava acontecendo, só via avião voltando. Depois que o comandante informou pra gente." (Nelson Moreira, estudante) "Eu estou nervosa porque tenho minha filha lá, com os meus netos e o meu genro, lógico. E eu ia visitá-los." (Diva Pedrosa, aposentada)

\section{Repórter 7 (off):}

Outro vôo da TAM, que ia de Brasília para Miami, fez escala em Manaus e não seguiu viagem (imagens de aviões). Por telefone pessoas tentavam saber notícias de Nova York (imagens de pessoas falando ao telefone). Dois aviões da Varig, que saíram de São Paulo, foram desviados para duas cidades no México (imagens de pessoas nos balcões de companhias aéreas). Por precaução, a United Airlines decidiu interromper vários vôos (mais imagens de aviões). Inclusive o deste grupo (imagem correspondente), que saiu de Boston ontem à noite, mesma cidade onde um dos aviões foi seqüestrado. Os passageiros foram obrigados a trocar de companhia em São Paulo para conseguir chegar ao Rio de Janeiro.

Sonoras: "Eu fiquei horrorizada. Porque podia ter sido comigo. Foi uma questão de horas." (Priscila Antonello, estudante) "Eu entrei em pânico e pensei logo na terceira guerra mundial." (Não há crédito da mulher que fala.)

\section{Continua o off:}

Esta estudante esperava a chegada da mãe, que vinha de Nova York (imagem de mãe e filha se abraçando). Quando soube que vários aviões foram seqüestrados, entrou em pânico.

\footnotetext{
${ }^{140}$ Fala Flávio Fachel, do Rio de Janeiro.
} 


\section{Sonora:}

"O cara ainda falou que cinco estavam sumidos, não tinha informação. Comecei a chorar. Falei: putz, minha mãe que estava vindo de lá. Só desespero, não pensei em nada." (Renata Teixeira)

\section{Repórter 7 (passagem):}

Nos aeroportos, pouca informação. Durante o dia, nem a Infraero nem as companhias aéreas sabiam dizer o que vai acontecer com os vôos entre Brasil e Estados Unidos previstos para os próximos dias.

\section{Repórter 7 (off):}

A segurança nos aeroportos do país foi reforçada (outras imagens de pessoas nos aeroportos). Em Salvador, facas e tesouras identificadas pelo raio $X$ foram retiradas das bagagens (imagens correspondentes à descrição). Em Belo Horizonte, até veículos foram revistados (imagens correspondentes). A tragédia fez muita gente mudar os planos no balcão do aeroporto. Este grupo cancelou uma viagem para a Europa.

\section{Sonoras:}

"Nós estamos muito preocupados com essa evolução do que houve nos Estados Unidos." (Gilberto da Silva, aposentado)

"A situação está muito perigosa, muito difícil. Os aviões estão sendo seqüestrados. Prefiro voltar para casa." (Maria de Lourdes, aposentada)

\section{Locutor 2 (chamada):}

E voltamos, ao vivo, aos Estados Unidos. Zileide, qual é a situação no momento, em Nova York?

\section{Entrada ao vivo (sem imagens):}

Bonner, Manhattan começa a tentar voltar ao normal. Hoje cedo as comunicações na cidade praticamente pararam. Os celulares não funcionavam. Completar uma ligação para outro país era praticamente impossível. Uma situação difícil, mas é o que está previsto, é o que deve acontecer quando um plano de emergência é acionado. Agora a situação é um pouco mais normal. Algumas linhas do metrô já estão funcionando. Túneis e pontes foram liberados, mas apenas para quem quer deixar a cidade. E o prefeito de Nova York fez um apelo. Pediu para que as 
pessoas não venham para Nova York amanhã, já que as investigações continuam. As escolas públicas e as escolas católicas não vão ter aulas amanhã. Fátima.

\section{Locutor 1 (passagem de bloco):}

Em instantes. Especialistas analisam as conseqüências do terror para o futuro do planeta.

\section{Locutor 2 (mesma passagem):}

E, nos territórios ocupados por Israel, palestinos comemoram o banho de sangue.

(Entra imagem de algumas pessoas, principalmente crianças, cantando e dançando nas ruas, com a seguinte legenda: "a celebração do ódio".)

\section{Bloco 3}

\section{Locutor 1 (cabeça):}

Há menos de uma semana, os Estados Unidos se retiraram da conferência da ONU sobre racismo e xenofobia, na África do Sul. Foi um protesto contra a decisão de se classificar Israel como um país racista. Posições como esta alimentaram, ao longo dos anos, o ódio de extremistas muçulmanos.

\section{Repórter $8^{141}$ (off):}

Terror na América, festa no Oriente Médio. Nas ruas dos territórios palestinos ocupados por Israel (imagem de pessoas, muitas delas crianças, dançando nas ruas), os americanos são vistos como amigos do inimigo israelense. Portanto, inimigos que merecem o pior.

"Alá é maior", grita esse grupo (imagem de uma mulher e algumas crianças dançando e gritando). Para exibir felicidade, o dono da loja distribuiu doces (imagem de um homem com um prato de bolo na mão, oferecendo às pessoas). Há muita gente disposta a festejar a desgraça alheia diante das câmeras internacionais (imagens de carros buzinando, gente cantando nas ruas). Mas os líderes do mundo islâmico querem se distanciar do terror.

O embaixador do regime Talibã afegão (imagem do embaixador), o mais radical entre os governos islâmicos, condenou o ataque. Com ar grave e preocupado, o palestino Yasser Arafat

\footnotetext{
${ }^{141}$ Fala Ernesto Paglia, de Londres.
} 
ofereceu os pêsames ao presidente Bush e ao povo americano. "É um ataque terrível", diz ele. "Estou completamente chocado. É inacreditável". (Imagem de Arafat falando e tradução do repórter.) A rápida condenação revela o medo que toma conta do mundo árabe e muçulmano, confirma do Oriente Médio o jornalista Mounir Safatli.

\section{Informações por telefone:}

Líbano, Síria, Jordânia, Iraque, Irã e Líbia (um mapa permanece na tela enquanto se ouve a voz do repórter). Esses seis países colocaram suas forças armadas em estado de alerta máximo. Há um temor generalizado sobre qual será a reação americana diante das acusações de que extremistas muçulmanos estariam por trás dos atentados nos Estados Unidos. As facções palestinas, tidas como suspeitas, também estão em alerta nos acampamentos de refugiados na Jordânia, Síria e Líbano.

Em quase todos os países árabes favoráveis à causa palestina, o clima é de tensão. (Entram imagens aparentemente normais de pessoas nas ruas de cidades do Oriente Médio.) Todos estão preocupados com a reação que já começou, vinda do ocidente. Aqui no Líbano, por exemplo, cinco companhias aéreas internacionais suspenderam seus vôos para Beirute, apesar do primeiro-ministro do Líbano se apressar em lamentar os atentados e encaminhar condolências ao povo americano, num sinal de que o Líbano nada tem a ver com o que aconteceu nos Estados Unidos.

\section{Repórter 8 (off):}

A festa nos campos de refugiados palestinos é inflamada por quase um ano de confrontos diários com a força de ocupação israelense (imagens de conflitos no Oriente Médio). Mas a maioria dos habitantes do mundo árabe (imagens de pessoas com bandeiras), que nada tem a ver com o terror, vai dormir hoje com medo de uma retaliação americana.

\section{Repórter 8 (passagem):}

Mas quem teme sofrer o maior prejuízo de todos é a imensa e pacífica comunidade muçulmana que vive aqui na Europa. 


\section{Repórter 8 (off):}

Preocupado com uma onda de preconceito antiárabe, o especialista britânico alerta: "Radicais terroristas não podem ser confundidos com a imensa população muçulmana que trabalha e respeita as leis pelo mundo afora." (Tradução da fala do "especialista", que não é identificado por nenhum crédito.)

\section{Locutor 1 (cabeça):}

O primeiro-ministro israelense, Ariel Sharon, decretou luto no país. As fronteiras com o Egito e a Jordânia foram fechadas, como medida de segurança. E o ministro da Defesa cancelou uma viagem que faria nos próximos dias aos Estados Unidos.

\section{Locutor 2 (cabeça):}

Aqui no Brasil, lideranças islâmicas e judaicas condenaram os atentados. E fizeram um apelo a favor da paz.

\section{Repórter $9^{142}$ (off):}

$\mathrm{Na}$ Mesquita do bairro paulistano do Cambuci, uma oração pela paz, citando o Alcorão, livro sagrado do islamismo (imagem de uma mesquita e de um homem rezando).

Sonora: "Se nós matarmos uma pessoa é como se tivesse matado toda a humanidade. Então nós deploramos este ato criminoso." (Mohamed Murad, presidente da Sociedade Muçulmana de São Paulo)

\section{Repórter 9 (passagem, da frente de uma mesquita):}

Uma ofensa à religião, os atentados de hoje nos Estados Unidos são condenados também por entidades muçulmanas de caráter mais político que atuam em São Paulo.

\section{Repórter 9 (off):}

"Abaixo a ocupação." A frase cobre as paredes da casa onde encontramos um militante palestino (desenhos de conflitos nas paredes). Ao lado dele, um judeu. Juntos, eles lideram uma entidade que prega a paz entre os dois povos (imagem dos dois, lado a lado, e um desenho de uma pomba coberta pelas bandeiras dos dois povos). Para eles, o fato da maior potência do planeta

\footnotetext{
${ }^{142}$ Fala Alberto Gaspar, de São Paulo.
} 
não ter conseguido se defender do ataque de hoje mostra que a força não vai garantir a segurança mundial.

\section{Sonoras:}

"Nós podemos tentar acabar com o terrorismo pela força ou podemos tentar acabar com o terrorismo pela paz." (Michael Haradom, líder pacifista)

"Porque não é possível que o mundo, que a ONU, que os governos mundiais deixem isso acontecer mais uma vez." (Emir Murad, líder pacifista)

\section{Repórter 9 (off):}

No Rio, esse representante da Juventude Islâmica tem medo que o atentado estimule o preconceito contra os muçulmanos.

\section{Sonoras:}

"Que se apure o atentado, que se veja realmente quem fez isso e que se condene quem praticou, não as demais pessoas. Generalizar isso é uma injustiça." (Jihad Hammadeh, vice-presidente da Juventude Islâmica)

"As boas relações entre a comunidade judaica e a comunidade muçulmana no Brasil vão continuar sendo relações de respeito mútuo e cordialidade. Não vamos importar o terror para o Brasil." (Henry Sobel, presidente da Congregação Israelita)

\section{Locutor 1 (cabeça):}

Na Grã-Bretanha, faltavam quinze minutos para as duas horas da tarde quando o primeiro avião se chocou contra uma das torres do World Trade Center. A partir daquele momento, não só o país, como toda a Europa parou, atônita, para saber o que estava acontecendo.

\section{Repórter $10^{143}$ (off):}

A tradicional pontualidade britânica hoje não funcionou. O país parou diante da TV para assistir às notícias que chegavam ao vivo dos Estados Unidos (imagens correspondentes à descrição). No centro de Londres, ninguém esperou até as cinco da tarde para sair do trabalho. Lojas, bares e principalmente prédios públicos foram esvaziados (imagens correspondentes).

\footnotetext{
${ }^{143}$ Fala Marcos Losekann, de Londres.
} 
A bolsa de valores fechou o pregão duas horas antes do horário normal. As linhas de metrô chegaram a ser interrompidas. Todos os vôos sobre a capital da Grã-Bretanha foram proibidos e os vôos para os Estados Unidos, suspensos. O Canary Wharf - o prédio mais alto de Londres também ficou vazio. (Imagens correspondentes ao que vai sendo descrito.)

\section{Repórter 10 (passagem):}

Esse clima tenso entre os britânicos encontra uma explicação principalmente no campo da diplomacia. A Grã-Bretanha é a principal aliada dos Estados Unidos. Costuma apoiar o governo americano em todas as decisões políticas. Hoje, essa amizade histórica deixou os cidadãos daqui com a sensação de que Londres poderia ser o próximo alvo.

\section{Repórter 10 (off):}

"Estou com muito medo", diz a moça. "Também tenho pena das pessoas inocentes que morreram." Este homem se diz apavorado: "Meu receio é que isso provoque a terceira guerra mundial". (Traduções, sem identificação dos falantes.)

O primeiro-ministro britânico, Tony Blair, cancelou uma reunião ministerial para fazer um pronunciamento: "Estamos solidários com o povo americano. O mundo precisa se unir para erradicar o terrorismo". De toda a Europa, partiram manifestações no mesmo sentido. O presidente da França, Jacques Chirac, chamou de "monstruoso" o que aconteceu na América.

O presidente da Rússia, Vladimir Putin, disse que foi uma tragédia terrível e convocou uma reunião ministerial para discutir a segurança. O chanceler federal alemão, Gerard Schoereder, classificou o ato terrorista de "abominável". O secretário-geral da OTAN, George Robinson, conclamou o mundo a formar uma frente comum para combater o terrorismo. (Aqui a fala do repórter, muitas vezes traduzindo os pronunciamentos, cobria imagens dos líderes citados.)

A União Européia já convocou uma reunião de emergência para discutir um plano de ação. Todas as embaixadas americanas na Europa e na Ásia tiveram a segurança reforçada (imagem correspondente). Em Londres, diante das barreiras de isolamento, foram deixados buquês de flores (imagem correspondente). Uma homenagem às vítimas da violência que hoje abalou o mundo. 


\section{Locutor 2 (cabeça):}

Os analistas políticos são unânimes em dizer que o mundo será outro depois desta terça-feira. O ministro das Relações Exteriores do Brasil, Celso Lafer, disse que a situação é de gravidade única, de conseqüências ainda imprevisíveis.

\section{Sonoras:}

"É um episódio decisivo. Ele muda o funcionamento do sistema internacional. Ele coloca as sombras da incompreensão no centro da vida mundial. $E$ isso terá um efeito grande sobre tudo e sobre todos e mudará a maneira pela qual conduzimos a ação diplomática. Este evento é mais sério do que qualquer outro nos últimos tempos e ele tem um alcance maior do que foi o fim da Guerra Fria e a queda do Muro de Berlim." (Celso Lafer, ministro das Relações Exteriores)

"Eu acho que os países europeus, os outros blocos do mundo, a América Latina, os vários organismos, como a Organização dos Estados Americanos, eles têm que tomar um papel mais ativo no mundo. Ou seja, o mundo deve ter uma descentralização do poder. Essa é uma questão que pode ser feita até a médio prazo. A curto prazo, os Estados Unidos vão mudar completamente o seu sistema de vigilância interna." (Reginaldo Nasser, prof. de Política Internacional da PUC-SP)

"Eu acho que haverá pelo menos três respostas. Uma resposta militar muito forte, contra algum país. Eles vão tentar escolher, se não conseguirem descobrir quem foi, vão tentar escolher um país e os dois candidatos sérios a tomar um ataque maciço, que oxalá não seja nuclear, são Iraque e Afeganistão. A segunda resposta é uma resposta que vai obrigar o presidente Bush a sair do isolacionismo e, a partir de um relacionamento internacional com os seus aliados, com os países democráticos, ter uma política mais forte contra o terrorismo. E uma terceira reação fundamental é o problema do Oriente Médio. O presidente Clinton tentou fazer a paz. O presidente Bush esqueceu o Oriente Médio. Vai ser obrigado a relembrar o Oriente Médio." (Fernando Abrucio, prof. de Política Internacional da PUC-SP)

\section{Locutor 1 (chamada):}

E voltamos, ao vivo, dos Estados Unidos, com a repórter Zileide Silva. Zileide, que informações nós temos sobre os brasileiros em Nova York? 


\section{Entrada ao vivo:}

Fátima, o governo brasileiro informou que dez empresas brasileiras tinham escritórios nas torres do WTC. Muitos brasileiros eram funcionários de corretoras. Essas imagens são de Nova York agora à noite, imagens ao vivo. (Entram imagens de uma rua quase deserta, sem nenhuma informação.) E esses funcionários brasileiros se concentravam principalmente no $25^{\circ}$ e no $107^{\circ}$ andar das torres. Brasileiros que não conseguiram chegar ao trabalho ligaram para a redação da Rede Globo aqui em Nova York. Assustados, diziam não ter informações sobre os colegas que estavam no prédio. Além desses funcionários, um outro grupo de brasileiros trabalhava ali. Engraxates, no subsolo do prédio, onde funcionava um shopping center e operavam várias linhas de metrô e trem. (A imagem da rua permaneceu na tela até este trecho.) Até agora, o consulado brasileiro não divulgou a lista com as vítimas. Segundo o consulado, porque ainda não se sabe a nacionalidade deles [sic]. E não é só o consulado brasileiro. Até agora, nenhuma lista foi divulgada com essa relação [sic]. Bonner.

\section{Locutor 2 (passagem de bloco):}

Daqui a pouco. Bolsas de valores e moedas internacionais são abaladas pelos atentados.

\section{Locutor 1 (mesma passagem):}

E veja também. A polícia suspeita que o assassinato do prefeito de Campinas foi crime político. (Entra imagem do carro em que estava o prefeito, com a seguinte legenda: "barbárie".)

\section{Bloco 4}

(O início deste bloco, que traz notícias do Brasil, não está gravado no DVD.)

\section{Entram outras matérias:}

Adiamento da entrega do relatório da Comissão de Ética que incriminava o senador Jader Barbalho no caso de desvio de dinheiro do BanPará; assassinato de Toninho do PT, prefeito de Campinas; morte do empresário José Hermínio de Moraes Filho, do grupo Votorantim; previsão do tempo; eliminação do tenista Gustavo Kuerten do Brasil Open.

\section{Locutor 1 (chamada):}

Voltamos com novas informações sobre os atentados terroristas nos Estados Unidos. Ao vivo, de Nova York, Zileide Silva diz como estão as investigações. 


\section{Entrada ao vivo:}

Fátima, o FBI acaba de abrir uma página na Internet pedindo para que as pessoas mandem informações que possam levar aos autores desses atentados. A CIA e o FBI não têm nenhuma pista concreta até agora. Esta é a informação oficial, mas funcionários do Pentágono disseram hoje cedo que tinham informações do envolvimento de Osama Bin Laden. Segundo eles, só o bilionário saudita teria ousadia e recursos suficientes para organizar uma série de atentados como esses. O Exército americano está em alerta máximo. E, se for necessário, pronto para agir. (Outra vez entra imagem da rua parada, sem informação nenhuma.)

Agora há pouco a agência de notícias espanhola EFE diz que um grupo chamado Exército Vermelho Japonês teria assumido a autoria do atentado. Um integrante do grupo telefonou para um jornal da Jordânia dizendo que era uma retaliação aos ataques nucleares a Hiroshima e Nagasaki, em 1945. Apesar da sede do FBI ser em Washington, toda a investigação sobre essa série de atentados será conduzida pelo escritório do FBI aqui em Nova York. (A imagem da rua permaneceu na tela até este trecho.) Esse escritório é muito mais eficiente. Foi ele que investigou e solucionou o atentado de 1993. E agora há pouco a empresa aérea American Airlines informou que todos os aviões dela que estavam desaparecidos já foram localizados. Bonner.

\section{Locutor 2 (cabeça):}

As explosões nos Estados Unidos provocaram uma onda que em segundos atingiu os principais mercados financeiros do mundo. Bolsas de valores interromperam os negócios e as que funcionaram tiveram quedas violentas.

\section{Repórter $11^{144}$ (off):}

As torres gêmeas, arrasadas pelo atentado, abrigavam mesas de operadoras de mercado do mundo inteiro, no coração do capitalismo globalizado. (Aqui há repetição das imagens das torres desabando, vistas por dois ângulos diferentes.) O impacto imediato foi muito mais além do que transformar um símbolo em fumaça (imagem das torres sob fumaça). As bolsas de Nova York, ali perto, e a bolsa eletrônica da Nasdaq, pelas quais pulsa a economia mundial, nem chegaram a abrir. A onda de choque da explosão atingiu em cheio os mercados europeus. (Entram ilustrações e mapas, com os índices que serão citados.)

\footnotetext{
${ }^{144}$ Fala William Waack, de São Paulo.
} 
A bolsa de Londres fechou em baixa de 5,72\%, a maior queda dos últimos 35 meses. Na de Paris, baixa de $7,39 \%$. Há dois anos não caía tanto. Frankfurt, queda de 8,49\%. Maior baixa dos últimos 32 meses. Bolsa de Milão, baixa de 7,79\%. México, as ações caíram 5,55\%. Na Argentina, o pregão foi interrompido quando a queda bateu $5,02 \%$.

Pela primeira vez, nos últimos 10 anos, na Bolsa de Valores de São Paulo os negócios foram suspensos. Às $11 \mathrm{~h} 15$ da manhã, o pregão já acumulava queda de 9,18\%, a maior desde janeiro de 1999, quando houve a desvalorização do Real. Com o resultado de hoje, a Bovespa já contabiliza baixa de 29,04\% este ano. (Neste trecho, imagem da Bolsa de São Paulo vazia.)

\section{Repórter 11 (passagem):}

A paralisação dos negócios na bolsa de valores de São Paulo não foi apenas o resultado do horror e da emoção provocados pelas imagens vindas dos Estados Unidos, entre os operadores. A bolsa simplesmente não tinha mais condições de fixar preços.

Sonora: "O motivo de nós fecharmos foi extremamente técnico. Informações desencontradas em todos os cantos, quando achamos por bem dos investidores em geral encerrar as atividades do pregão no dia de hoje." (Eduardo Brener, presidente em exercício da Bovespa)

\section{Repórter 11 (off):}

Houve poucos negócios nas mesas de câmbio (imagem correspondente) com o dólar batendo novo recorde: $\mathrm{R} \$ 2,66$, alta de 2,03\%, apesar de intervenção do Banco Central. Diante do clima de nervosismo, o governo preferiu cancelar três leilões de títulos públicos num total de 4,7 bilhões de reais em papéis (imagens de prédios públicos). Refletindo temores de conflitos no Oriente Médio, o preço do barril de petróleo subiu 13\% e chegou aos 31,05 dólares (imagens de plataformas de petróleo). Outro sintoma da insegurança: o ouro na bolsa de metais de Londres teve alta de $7 \%$ (imagens da Bolsa). Mas economistas acham que o impacto imediato dos atentados em Nova York se desfaz também a curto prazo.

Sonora: "Estamos sob o impacto de uma grande tragédia e é natural que, em um primeiro momento, a reação seja de uma certa histeria, movida pelo pânico de uns e pela especulação de outros, que tentam tirar proveito da situação, mas isso não é permanente. Isso vai durar alguns dias. A vida depois volta ao normal. A economia americana está em processo de desaceleração 
e isso pode até chegar a uma recessão, mas não será por causa dessa tragédia. Na verdade, a economia é muito mais robusta, e não é um acidente, um ataque terrorista que vai mudar grandes tendências e movimentos profundos que estão ocorrendo no mundo." (Eduardo Gianetti, economista)

\section{Locutor 1 (passagem de bloco):}

Veja a seguir. A aflição das famílias dos brasileiros que estão em Nova York.

\section{Locutor 2 (mesma passagem):}

$E$ as últimas informações sobre o dia que vai marcar a história.

(Entra imagem de pessoas correndo e policiais prestando socorro, com a seguinte legenda: "escombros". É bom notar que não há imagens chocantes de pessoas mortas ou feridas.)

\section{Bloco 5}

\section{Locutor 1 (cabeça):}

O presidente Fernando Henrique convocou uma reunião de emergência para discutir os reflexos que os atentados terroristas podem ter na economia brasileira. A segurança foi reforçada nos consulados e na embaixada americana.

\section{Repórter $12^{145}$ (off):}

A embaixada americana em Brasília liberou todos os funcionários e ficou fechada. Na porta, reforço no policiamento. Um comunicado pedia que os americanos que vivem no Brasil redobrem a segurança. Quem trabalha na embaixada de Israel também teve que sair e a polícia aumentou a vigilância. No Rio, o esquadrão antibombas fez uma revista no consulado americano. Os funcionários tiveram que deixar o prédio. Os consulados de São Paulo e do Recife também foram desocupados. O comando da Aeronáutica liberou os aeroportos nacionais aos aviões que não puderem descer nos Estados Unidos, além de recomendar maior fiscalização no embarque de passageiros. O Itamaraty divulgou uma nota condenando a violência e lamentando as mortes. (As imagens neste off são todas descritivas.)

\footnotetext{
${ }^{145}$ Fala Heraldo Pereira, de Brasília.
} 
O presidente Fernando Henrique Cardoso, se dizendo chocado e com uma preocupação extrema, acompanhou tudo pela televisão no Palácio da Alvorada. (Imagem do presidente vendo as notícias na televisão. Sobe som de fala breve: "É uma guerra", diz FHC.) O presidente mandou uma carta de solidariedade ao presidente dos Estados Unidos, George W. Bush, e repudiou o ato terrorista (imagem da carta, com trechos destacados). Num pronunciamento, o presidente se demonstrou preocupado também com os brasileiros que estão nos Estados Unidos e determinou que eles recebam toda a assistência do consulado (imagem de FHC falando).

\section{Sonora:}

"Em Nova York, já existem no consulado telefones à disposição dos brasileiros para que eles possam acalmar suas famílias e mostrar que nada lhes aconteceu. É provável que diante da virulência dos atos praticados haja conseqüências em todo mundo, principalmente econômicas. $E$ o Brasil é parte do sistema mundial e pode vir a ser direta ou indiretamente afetado por essas turbulências. É inegável que se não houver uma ação atenta do governo as conseqüências podem ser maiores. E nós estamos atentos." (Fernando Henrique Cardoso, presidente do Brasil)

\section{Repórter 12 (passagem):}

Para se antecipar às conseqüências deste episódio e tentar fazer uma avaliação, principalmente dos desdobramentos na economia brasileira, o presidente Fernando Henrique Cardoso chamou quatro ministros, inclusive o da Fazenda, Pedro Malan. A reunião foi a portas fechadas. Depois o presidente convocou o Conselho de Defesa Nacional.

\section{Repórter 12 (off):}

O governo vai fazer uma analise dos reflexos da situação nos Estados Unidos aqui no Brasil. O conselho foi comunicado das medidas para proteger os cidadãos americanos. $\mathrm{E}$ o presidente FHC tranqüilizou o encarregado de negócios dos Estados Unidos, que está respondendo pela embaixada americana em Brasília (imagem de FHC reunido com o conselho).

\section{Locutor 2 (cabeça):}

Até agora há pouco o Itamaraty ainda não tinha conseguido notícias sobre possíveis vítimas brasileiras. Entre os que sobreviveram aos atentados há relatos impressionantes. 


\section{Repórter $13^{146}$ (off):}

Apreensão em São Paulo. Dona Cecília passou a manhã tentando contato com o filho Cleiton, que mora em Nova York (imagem da mulher chorando e foto do filho). Não conseguiu. (Imagem do repórter falando ao telefone: "Is he fine?") As primeiras notícias vieram só à tarde. Um amigo confirma que Cleiton está bem. Só então ela se acalma. (Breve sonora: "Só queria agradecer a Deus, só isso. Muito obrigada, meu Deus.")

O congestionamento das linhas aumentou a angústia de quem procurava informações sobre os parentes nos Estados Unidos (imagem de pessoas falando ao telefone). Em uma das operadoras, as ligações aumentaram quarenta vezes (imagem de uma operadora). Um número de serviço foi posto à disposição dos usuários: 0800-7032111.

Em Uberaba, dona Nilda (novamente, imagem da mulher chorando e foto do filho) ainda espera alguma notícia sobre o filho Tiago. Há quatro meses em Nova York, ele servia café em três andares do WTC. Em Goiânia, os irmãos de Fabrício Guimarães ouviram incrédulos o relato dele (imagem dos irmãos e foto do rapaz). Fabrício embarcou ontem à noite e chegou hoje cedo a Nova York.

\section{Sonora (por telefone, com foto do rapaz e transcrição da fala no vídeo):}

"Eu cheguei acho que uns quinze ou vinte minutos antes da explosão. Eu cheguei a Nova York e o taxista me chamou a atenção. Eu estava na Long Island Express Highway e deu para ver muito bem a explosão em si. Quando eu estava chegando perto do meu objetivo, mais ou menos três ou quatro quadras do WTC, foi quando eu vi a queda da primeira torre. Foi uma coisa assim, muito, mas muito assustadora. Foi uma das coisas mais assustadoras que já vi na minha vida."

\section{Repórter 13 (off):}

Por pouco o advogado Paulo Lins e Silva (imagem dele) não tomou o vôo de Boston, justamente o avião que bateu na segunda torre.

\section{Sonora (por telefone, com foto e transcrição da fala no vídeo):}

"Eu não entrei nesse vôo para Nova York porque era um vôo muito cedo e nós estávamos exaustos, voltando de Montreal para pegar um vôo que retardou demais. Eu estou muito nervoso

\footnotetext{
${ }^{146}$ Fala José Roberto Burnier, de São Paulo.
} 
aqui nos Estados Unidos, porque eu estou com minha família e nós não sabemos quando nós vamos sair."

\section{Repórter 13 (off):}

Funcionário de uma corretora, Larry Pinto de Faria Jr. (imagem dele) conseguiu sair do World Trade Center a tempo.

\section{Sonora (por telefone, com foto e transcrição da fala no vídeo):}

"Eu estava trabalhando. Nós ouvimos aquele estrondo, aquele barulho muito forte. Eu trabalhava no $25^{\circ}$ andar. Parecia a sensação de um terremoto. O edifício balançou muito forte mesmo e nós fomos para a saída de emergência, para a saída de incêndio. O medo maior foram dois medos. O primeiro medo foi na escada de incêndio, porque não pode entrar em nenhum andar. Aquelas portas corta-fogo não têm acesso aos andares. E começou a subir fumaça e um cheiro muito forte de combustível. Deu medo para descer vinte e cinco andares de escada, com milhares de pessoas tentando descer ao mesmo tempo. Graças a Deus não teve pânico. O segundo avião se chocou contra a outra torre quando eu estava na escada. Eu não vi."

\section{Locutor 1 (chamada):}

O Itamaraty montou um esquema de plantão para dar informações sobre parentes de brasileiros que moram nos Estados Unidos. O repórter Roberto Kovalick tem as informações.

\section{Entrada ao vivo, de Brasília:}

O consulado brasileiro em Nova York recebeu a informação da polícia americana de que só em dois dias, no mínimo, será possível saber se há brasileiros entre as vítimas. Segundo o Itamaraty, o prédio onde funciona o consulado foi desocupado, mas uma pequena equipe permanece lá para dar informações. De acordo com o Itamaraty, 800 mil brasileiros estão nos Estados Unidos: 300 mil em Nova York. Para dar informações às famílias no Brasil o Itamaraty criou um serviço de informações que vai funcionar 24 horas por dia. O telefone é o seguinte: (61) 411-6456. Bonner.

\section{Locutor 2 (chamada):}

E agora as últimas informações, ao vivo, de Nova York, com a correspondente Zileide Silva. 


\section{Entrada ao vivo:}

Bonner, daqui a pouco o presidente dos Estados Unidos, George Bush, faz um pronunciamento a nação. Ele já está na Casa Branca. E o tom do discurso vai ser de retaliação e impaciência (imagem de Bush descendo de um avião). Ele vai dizer aos americanos: os Estados Unidos já foram testados várias vezes, sempre venceram, e agora, segundo ele, não vai ser diferente (volta imagem da repórter). Mas o presidente também vai fazer um apelo ao povo americano, para que o país volte ao normal. E os 170 hospitais de Nova York estão lotados. As vítimas estão sendo levadas para hospitais de outras cidades. A empresa aérea United Airlines acaba de informar que está liberando inicialmente 25 mil dólares para os parentes das vítimas. $E$ um grupo de oposição ao Talibã assumiu a autoria das explosões em Cabul.

Eu tenho mais uma informação aqui... A inteligência americana... Está difícil... A gente está recebendo essas informações ao vivo... (A repórter estava tendo dificuldade para ler um papel.) A inteligência americana conseguiu interceptar mensagens de Osama Bin Laden sobre os ataques. Essa é a última informação que nós estamos acabando de receber aqui no escritório da Globo em Nova York. Fátima.

\section{Locutor 1 (encerramento):}

O mundo assistiu hoje ao mais brutal de todos os ataques terroristas. Sem armas químicas, sem bombas atômicas. Aviões foram lançados contra símbolos do poderio americano. O pânico instalado no coração econômico do planeta. Imagens de filme, e que gostaríamos de ver tão somente nas telas de cinema. (Entram as imagens finais. Repetição das imagens mais dramáticas, sem locução e com o áudio dos gritos da população: a fumaça sobre as torres, pessoas se jogando, o choque do segundo avião, pessoas gritando e correndo nas ruas, as torres desabando, fumaça e poeira tomando as ruas, mais pessoas correndo, novamente o desabamento das torres, novamente a fumaça e a poeira nas ruas, pessoas feridas, panorâmica da ilha de Manhattan com muita fumaça.)

Locutor 1: Nós voltaremos a qualquer momento com outras informações sobre os atentados terroristas nos Estados Unidos e com o pronunciamento ao vivo do presidente George Bush. E ainda novos detalhes dos ataques, o socorro às vítimas, a reação do governo americano, você vai ver no Jornal da Globo. Até amanhã.

Locutor 2 (muito sério): Até amanhã. 


\section{ANEXO 2}

\section{Jornal Nacional de 11 de setembro de 2002}

\section{Escalada:}

11 de setembro de 2002.

Nova York.

Homenagens às vítimas do World Trade Center.

(Entram imagens da cerimônia e a repórter fala: "Foram lidos, um a um, os nomes das quase 3.000 pessoas que morreram no ataque às torres, entre elas três brasileiros.")

11 de setembro.

Um ano de solidão.

(Entra outro repórter: "Uma brasileira ainda sonha reencontrar o marido." Breve sonora da mulher: "Eu penso que ele ainda vai bater na porta, e eu vou abrir, e vai ser ele.")

Nossos repórteres mostram como o mundo lembrou o aniversário da maior ação terrorista da história. (Entram breves imagens das homenagens.)

11 de setembro no Brasil.

Rio de Janeiro. Traficantes assumem o comando do presídio em Bangu.

E quadrilha rivais travam batalhas mortais dentro da cadeia.

11 de setembro no Vaticano.

João Paulo II participa da missa de corpo presente de Dom Lucas.

11 de setembro de 2002.

O Jornal Nacional está começando agora.

\section{Bloco 1}

Cobertura da rebelião no presídio Bangu 1, no Rio de Janeiro.

\section{Locutor 1 (passagem de bloco):}

Outras informações sobre a rebelião ainda nesta edição. E, daqui a pouco, o 11 de setembro no mundo.

\section{Locutor 2 (mesma passagem):}

Nossos repórteres mostram como o planeta lembrou o aniversário da maior ação terrorista da história. (Entram imagens das cerimônias, com a seguinte legenda: "cicatrizes".) 


\section{Bloco 2 (inteiro)}

\section{Locutor 2 (cabeça):}

Os olhos do mundo se voltaram hoje para o local onde 2.801 pessoas foram mortas há um ano. No sul da ilha de Manhattan, onde ficavam as torres do WTC, uma cerimônia abriu as homenagens às vítimas da maior ação terrorista da história. (Um selo identifica a matéria: 11 de setembro, escrito sobre a imagem das torres atingidas, o 11 bem no lugar das torres.)

\section{Repórter $1^{147}$ (off):}

Pareciam procissões, pareciam peregrinos. Eram filhos, mães, pais, irmãos, amigos. Gente de todas as raças e gerações. Juntos para homenagear os seus mortos. Retratos na multidão. (As imagens vão mostrando a multidão, pessoas chorando e segurando fotos das vítimas, closes dos olhos e das lágrimas.) O lugar, que foi um símbolo do poder econômico americano e hoje é um imenso espaço vazio (imagens do WTC intacto e depois do terreno vazio), foi sendo lentamente ocupado pelas famílias das vítimas mortas no ataque que feriu o coração de Nova York (mais pessoas com fotos e bandeiras nas mãos). Às 8h46 da manhã, exatamente o horário em que o primeiro avião atingiu uma das torres, um minuto de silêncio.

\section{Repórter 1 (passagem, em frente ao local da cerimônia):}

O momento mais emocionante da cerimônia: foram lidos, um a um, os nomes de todos os que morreram no ataque às torres, entre eles, três brasileiros. (Som da leitura: Ivan Kyrillos Barbosa, Sandra Fajardo Smith, Anne Marie Ferreira... As imagens vão mostrando pessoas chorando e se abraçando.) Cento e noventa e sete pessoas, famosas e anônimas, leram os 2.801 nomes das vítimas. Às $10 \mathrm{~h} 29$ da manhã, o sino lembrou o momento em que a última torre caiu. (Toque do sino e imagem da queda das torres.) Esta filha fez uma homenagem em nome dos órfãos de 11 de setembro. "Você foi o melhor pai que eu poderia ter tido" (tradução da repórter, enquanto a menina fala). As famílias compartilharam a dor, depositaram flores numa longa cerimônia de adeus. Puderam finalmente enxugar as suas lágrimas e enterrar simbolicamente os seus mortos, numa manhã de sol tão bonita quanto a de 11 de setembro de 2001, um dia que elas nunca vão esquecer. (As imagens são descritivas. Mostra-se muita gente chorando. A imagem final mostra uma enorme faixa: "We will never forget".)

\footnotetext{
${ }^{147}$ Fala Cristina Serra, de Nova York.
} 


\section{Locutor 1 (cabeça):}

O presidente George Bush aproveitou o 11 de setembro para mandar um recado para Saddan Hussein.

\section{Repórter $2^{148}$ (off):}

No Pentágono, a bandeira que as equipes de salvamento penduraram naquele dia foi usada novamente hoje. A tristeza se misturou com o orgulho. Passados 365 dias, a ala que sofreu o impacto está totalmente reconstruída. (Imagens de uma enorme bandeira americana pendurada no prédio do Pentágono e de uma multidão de militares na cerimônia.)

\section{Repórter 2 (breve passagem, na frente do Pentágono):}

Mas o presidente deu ainda um outro tom a essa cerimônia: o de preparação para a batalha. (Continua em off.) Num recado claro a Saddan Hussein, George Bush disse que a guerra atual não é só contra terroristas (imagem de Bush discursando). Segundo ele, ditadores que conspiram contra os Estados Unidos estão na mira das forças armadas americanas. Ele prometeu derrotar os inimigos. (Sobe som da voz de Bush falando, sem tradução: "But I will stop it.")

\section{Repórter 2 (continua em off):}

Do Pentágono, George Bush foi à Pensilvânia, onde se emocionou ao conhecer as famílias dos heróis do vôo 93 (imagem de Bush abraçando pessoas, inclusive crianças, e tirando fotos), os passageiros que lutaram contra os seqüestradores, forçaram a derrubada do avião e impediram um outro atentado no dia 11 de setembro. (Imagens de bandeiras americanas, de placa com o nome das vítimas e de uma placa em que se lia: "To the first citizen heroes of the $21^{\text {st }}$ century. The passengers and crew of flight 93. Let's roll.")

O presidente Bush terminou o dia em Nova York, o lugar onde foram destruídas as torres do WTC. Daqui a pouco, George Bush fala ao povo americano (imagens de Bush cumprimentando pessoas no local da cerimônia). Além de fazer um balanço dos últimos doze meses, ele prepara o país para o que vai acontecer a partir de agora, incluindo a urgência que a Casa Branca tem em combater o que é definido como o maior perigo potencial no momento: o Iraque.

\section{Locutor 2 (cabeça):}

As vítimas receberam homenagens no mundo inteiro, como mostra, de Londres, o repórter Marcos Uchoa.

\footnotetext{
${ }^{148}$ Fala Luiz Fernando Silva Pinto, de Washington.
} 


\section{Repórter $3^{149}$ (off):}

Uma bandeira americana feita por centenas de pessoas em uma praia da Austrália. A homenagem nas gôndolas que divertem os turistas em Veneza. Um minuto de silêncio na bolsa de valores de Tóquio. (As imagens são todas descritivas.) Uma mensagem do presidente da Argélia, em nome de toda a África. Lisboa puxava o coro (som de música religiosa). Por toda a Europa, missas com as autoridades de praxe marcavam presença, num coral de compaixão e condolências. Até Belgrado, na lugoslávia, que há apenas três anos estava sendo bombardeada pelos americanos, se juntou às homenagens (imagens de coro e orquestra executando música solene). Os inimigos agora são outros. A embaixada dos Estados Unidos na Dinamarca recebeu um envelope contendo o perigoso antraz (imagens de agentes com roupas especiais entrando na embaixada). O Papa João Paulo II, no Vaticano, condenou a violência, que leva ao ódio e à destruição (imagem do papa falando a uma multidão).

\section{Repórter 3 (passagem):}

O mundo olhou para trás e prestou uma homenagem aos que morreram no 11 de setembro. Agora espera. Amanhã, na ONU, em Nova York, o presidente Bush vai fazer um discurso. Quer convencer a comunidade internacional que uma guerra, agora contra o Iraque, é necessária.

\section{Locutor 1 (cabeça):}

No Brasil também houve homenagens. (Continua em off.) Em Porto Alegre, por exemplo, as torres gêmeas eram simbolizadas por duas escadas, que foram recolhidas pelos bombeiros na hora dos atentados de um ano atrás (as imagens são descritivas).

\section{Locutor 2 (cabeça):}

Nas ruas de Nova York, hoje, o repórter Luiz Carlos Azenha encontrou inconformismo e tristeza entre os sentimentos de americanos e de estrangeiros.

\section{Repórter $4^{150}$ (off):}

(Texto e imagem se descrevem reciprocamente.) Uma lágrima na calçada. Outra, na esquina. Flores. Orações. Uma bandeira. Uma bandeira na camisa. Uma bandeira na pele. (Breve sonora, traduzida, de uma mulher com a tatuagem da bandeira: "Foi como se arrancassem meu coração", diz ela. Na seqüência, outra breve sonora: "Ainda sinto raiva", diz o homem que ajudou

\footnotetext{
${ }^{149}$ Fala Marcos Uchoa, de Londres.
} 
a procurar sobreviventes.) Foi um daqueles dias em que todos se perguntaram: onde é que eu estava há um ano? (Mais imagens de pessoas chorando. Ouve-se o som de gaitas de fole durante todo o VT.) A leitura dos nomes das vítimas fez José lembrar-se da cena de guerra que fotografou e filmou.

\section{Voz em off de José, sem crédito:}

"Eu lembro bem da hora em que eu entrei no prédio, pelo lado da passarela, e os telefones estavam tocando insistentemente. Com certeza eram os familiares procurando notícia das pessoas que estavam lá dentro." (A fala cobre fotos e imagens que o homem fez no dia dos atentados: o prédio destruído, os escombros no hall, onde se ouviam telefone tocando.)

\section{Repórter 4 (passagem):}

A dor foi maior para aquelas pessoas que nem mesmo conseguiram fazer o enterro dos parentes e amigos que perderam na tragédia. 1.331 pessoas simplesmente desapareceram aqui, no 11 de setembro do ano passado.

\section{Repórter 4 (off):}

Um ano depois, nenhum sinal do corpo do marido de Heloísa, um bombeiro que nunca mais foi visto depois que a primeira torre desabou (a mulher usa um bottom com a foto do marido). Hoje não foi preciso nem chamar. A construção parou. A multidão se formou diante do quartel para um minuto de silêncio. A brasileira voltou a sonhar desde que soube que um desaparecido foi encontrado vivo, sofrendo de amnésia.

\section{Sonora da mulher, sem crédito:}

"Às vezes penso que ele está num hospital, sem memória, perdido, querendo voltar pra casa. Isso que eu penso. Eu penso que ele ainda vai bater na porta, e eu vou abrir, e vai ser ele." (Mostra-se novamente a foto do bombeiro. O som das gaitas de fole sobe e fecha o VT.)

\section{Passagem para outro bloco.}

\section{Seguem-se outras notícias.}

\footnotetext{
${ }^{150}$ Fala o repórter Luiz Carlos Azenha, de Nova York.
} 


\section{ANEXO 3}

\section{Jornal Nacional de 11 de setembro de 2003}

\section{Escalada:}

Uma centena de policiais civis, militares e federais unidos numa missão: proteger o maior contrabandista de cigarros do Brasil. É a conclusão do Ministério Público.

11 de setembro de 2003. Nova York homenageia os três mil mortos do World Trade Center (breves imagens de pessoas chorando durante uma cerimônia).

Israel decide expulsar Yasser Arafat da Cisjordânia. E ele diz que não sai.

Nossos repórteres vão ao sudeste da Ásia e mostram uma ilha minúscula, que exporta o dobro do Brasil.

O Brasil se torna o maior exportador mundial de carne.

O presidente Lula diz que é hora de cumprir promessas.

Apresentada a cédula de um real com relevo, para os cegos.

Anunciadas as novidades para a Fórmula 12004.

E jogando o mínimo necessário, a seleção vira líder das eliminatórias para a Copa 2006.

Agora, no Jornal Nacional.

\section{Blocos 1 e 2}

Diversas notícias.

\section{Passagem de bloco:}

Daqui a pouco. Israel decide expulsar Yasser Arafat de territórios palestinos.

Nova York homenageia os mortos do terror. (Entram imagens das homenagens, com a seguinte legenda: 2 anos.)

\section{Bloco 3 (junto com outras notícias)}

\section{Locutor 2:}

O mundo inteiro lembrou nesta quinta-feira os atentados terroristas de 11 de setembro de 2001. Dois anos depois, o homem apontado pelos Estados Unidos como responsável pelos ataques continua vivo, em liberdade e fazendo novos desafios. (O selo que identifica a matéria é o mesmo usado no ano anterior: 11 de setembro, escrito sobre a imagem das torres em chamas.) Vamos à 
redação da TV Globo em Nova York, ao vivo, com a correspondente Cristina Serra. Cristina, o que é que está acontecendo neste momento na cidade?

\section{Entrada ao vivo:}

Bonner, começou agora há pouco a última homenagem do dia às vítimas dos atentados de 11 de setembro. Ali naquele lugar, bem perto de onde ficavam as torres, onde há aquele quadrado iluminado, foram acesas duas colunas de luz (a câmera mostra o lugar e volta para a repórter). Ainda há um pouco de claridade no céu, então a iluminação ainda está fraca. Mas essas duas colunas de luz vão representar simbolicamente as duas torres do WTC e vão ficar acesas até amanhã de manhã. E na cerimônia de hoje, no marco zero, onde ficavam os prédios, crianças que perderam parentes nos atentados leram os nomes das quase três mil vítimas. Foi o momento mais emocionante de um dia que começou muito cedo.

\section{Repórter Luiz Carlos Azenha (off):}

A vigília começou de madrugada. Orações judaicas, cristãs, budistas. Ficou claro que a perda foi de todos. No memorial, o homem se esforça para tocar o nome de alguém que perdeu na tragédia. Luzes azuis ocuparam o lugar das torres gêmeas. Até o nascer do sol. Nova York acordou com a música das gaitas de fole que abriu a cerimônia. (Durante o off, mostram-se imagens das cerimônias e muita gente chorando. $\mathrm{O}$ som das gaitas de fole fecham o trecho.)

\section{Mesmo repórter (passagem):}

O presidente George Bush não veio. O vice-presidente Dick Cheney desistiu de última hora. Não foi uma cerimônia política, mas nesta grade uma família deixou um protesto: "Não construam no túmulo de nossa irmã" (o repórter mostra a faixa e traduz os dizeres).

\section{Mesmo repórter (off):}

(As imagens são descritivas e mostram muita gente chorando.) A emoção de pessoas comuns. $O$ bombeiro manteve a continência durante mais de duas horas, enquanto crianças liam os nomes das vítimas. A voz da órfã tremeu quando ela disse que a luz do pai ainda brilha. O homem recolheu areia do chão, como se estivesse resgatando o corpo do parente que deixou aqui. Os nomes dos três brasileiros mortos na tragédia foram lidos. A brasileira Renata Macedo saiu da cerimônia com um pedaço de uma das torres que ganhou de presente. Procurou na bandeira o nome da amiga, uma garçonete americana que conheceu na "noite brasileira", tradição das 
quartas-feiras do restaurante que ocupava o topo da torre norte. $10 \mathrm{~h} 29$ da manhã. Os sinos marcam a queda da torre onde trabalhava a amiga de Renata (som dos sinos). (Sonora: "Eu vi o prédio caindo do terraço do meu apartamento. Então eu fecho os olhos assim, eu escuto esses barulhos, eu fecho os olhos e só vejo os ferros retorcendo.") Para todos que estiveram aqui, ficou um vazio do tamanho das torres que viraram pó. (Mais closes de gente chorando.)

\section{Cristina Serra, ao vivo:}

Um alerta emitido pelo Departamento de Estado pede que cidadãos americanos no mundo inteiro fiquem mais vigilantes. Há indícios de que a Al Qaeda estaria planejando um novo atentado. Apesar do medo, os americanos pararam hoje para homenagear as vítimas do 11 de setembro.

\section{Mesma repórter (off):}

Um minuto de silêncio na bolsa de valores de Nova York, no Congresso e na Casa Branca em homenagem às vítimas do 11 de Setembro. O presidente George Bush decidiu não fazer discursos este ano. Disse apenas que este é um dia de reflexão e orações (imagem de Bush falando). No cemitério de Arlington, na Virgínia, o secretário de defesa, Donald Rumsfeld, lembrou as vítimas do atentado ao Pentágono. Na Pensilvânia, onde caiu o quarto avião, o sino marcou a leitura dos nomes de todas as vítimas. (As imagens são descritivas.)

\section{Mesma repórter (passagem, na frente de um lugar cheio de bandeiras americanas):}

Foi um dia de luto, mas também de preocupação. O Departamento de Estado emitiu um alerta pedindo que os americanos no mundo inteiro, principalmente na Europa e na Ásia, redobrem os cuidados com a segurança, porque há indícios de que a Al Qaeda está planejando um atentado ainda mais devastador que os de 11 de setembro. Desta vez, a rede terrorista poderia atacar com armas químicas e biológicas.

\section{Mesma repórter (off):}

A tensão das últimas horas se deve à fita de áudio e ao vídeo de Osama Bin Laden e Ayman AlZawahiri divulgados ontem (imagens do vídeo: Bin Laden nas montanhas). A CIA confirmou a autenticidade da voz de Al-Zawahiri, mas ainda não concluiu o exame da voz atribuída a Bin Laden. Os analistas também tentam identificar o lugar onde a gravação foi feita examinando atentamente a paisagem e a vegetação. A CIA acredita que eles estão em algum lugar da fronteira do Afeganistão com o Paquistão. Para o FBI, a dificuldade para desmantelar a Al Qaeda 
não é menor (imagens de grupos aparentemente em treinamento). Em entrevista ao jornal "USA Today", autoridades reconhecem que é muito mais difícil investigar a Al Qaeda do que a máfia e que talvez o FBI nunca consiga se infiltrar na máquina do terror de Osama Bin Laden.

\section{Mesma repórter (ao vivo):}

Bem, nos continuamos aqui, no terraço do prédio onde fica a redação da TV Globo, aqui em Nova York, acompanhando as homenagens. E uma pesquisa feita em vários países e publicada hoje aqui, nos Estados Unidos, mostra que cresceu o sentimento antiamericano no mundo. Há dois anos, os Estados Unidos eram vistos como vítimas do terror. Agora, depois da guerra contra o Iraque, o país é visto como uma nação arrogante. Hoje houve homenagens às vítimas do 11 de Setembro em vários lugares do mundo, mas também houve protestos.

\section{Mesma repórter (off):}

Nesta mesquita, na Indonésia, país com a maior população muçulmana do mundo, religiosos pediram mudanças na política da Casa Branca em relação aos países islâmicos para evitar novos ataques. Nas Filipinas, protestos contra e a favor dos Estados Unidos. Manifestantes incendiaram uma réplica das torres gêmeas para que o mundo nunca se esqueça do que aconteceu nos Estados Unidos. Na Austrália, foram plantadas três mil árvores em homenagem aos mortos nos ataques. Em Londres, a princesa Anne lembrou os 67 britânicos que morreram nos Estados Unidos dois anos atrás. Os atentados também foram lembrados pelas tropas americanas no Afeganistão e no Iraque. Em Tikrit, a homenagem foi num antigo palácio de Saddam Hussein. (As imagens são das manifestações relatadas.)

\section{Charge (na seqüência):}

11 de setembro: 2 anos

A imagem de Bin Laden (um desenho) vem surgindo do lado esquerdo do vídeo, como se viesse do céu, e sopra a fumaça que sai duas torres. A fumaça e as torres somem.

Locutor 1: Um outro 11 de setembro também foi lembrado hoje. Há 30 anos, um golpe militar marcou a história do Chile. O presidente socialista Salvador Allende foi deposto e se matou quando aviões bombardearam o Palácio La Moneda. (...)

\section{Seguem-se outras notícias.}




\section{ANEXO 4}

\section{Jornal Nacional de 11 de setembro de 2004}

\section{Escalada:}

Está na cadeia o homem acusado de matar motoristas de táxi em três estados.

Madrugada de horror em Maceió. Três jovens entram atirando numa boate lotada.

Onze de setembro. Emoção nos Estados Unidos, três anos depois do pior atentado da história.

$\mathrm{Na}$ série especial do JN, os 35 anos das ações terroristas no mundo.

E a Fórmula 1. Rubinho larga em primeiro, na luta pelo vice-campeonato.

Agora, no Jornal Nacional.

\section{Bloco 1}

Diversas notícias. O assunto entra no final do bloco.

Locutor: Em Nova York, no local onde desabaram as torres gêmeas, uma cerimônia lembrou o atentado que matou quase três mil pessoas há três anos. (O mesmo selo das outras edições identifica a matéria.)

\section{Repórter Cristina Serra (off):}

Pais e avós que perderam filhos e netos no atentado leram os nomes das vítimas, entre elas, três brasileiros. O sino interrompeu a leitura em quatro momentos para lembrar a hora em que os aviões atingiram as torres e quando elas desabaram. (Muitas imagens de pessoas chorando.)

\section{Mesma repórter (passagem):}

Três anos se passaram, mas o trauma ainda está longe de ser superado. A dor é maior para quem perdeu um parente, um amigo. Mas há um sentimento de perda coletivo, na cidade que parou mais uma vez para lembrar a tragédia. "Ainda dói muito", diz essa escritora.

\section{Mesma repórter (off):}

Em Washington, homenagem às vítimas do Pentágono. Na Pensilvânia, aos que morreram no quarto avião. O presidente George Bush e o oponente John Kerry participaram de orações. Quase três mil pessoas morreram nos atentados de 2001. Uma ausência que vai ecoar para sempre no coração dos americanos. (Mais imagens de pessoas chorando e o som dos sinos.) 
Entram outras notícias.

Passagem de bloco:

Daqui a pouco. 35 anos de história. A marca violenta do terrorismo.

\section{Bloco 2}

\section{Locutor:}

Na última reportagem da série dos 35 anos do Jornal Nacional, o correspondente em Nova York, Luiz Carlos Azenha, mostra como o terrorismo se transformou e ganhou a dimensão de um conflito mundial.

\section{Repórter (off, com imagens de arquivo dos atentados):}

Atingir civis para espalhar o medo. Na Espanha, desde o fim dos anos 60, o ETA mata pela independência do País Basco, que inclui o norte da Espanha e o sudoeste da França. Na Irlanda, o IRA - Exército Republicano Irlandês - recorreu ao terrorismo durante quase três décadas para tentar reunificar a Irlanda do Norte, de maioria protestante, à República da Irlanda, de maioria católica. Nem o esporte escapou do terror. Nos Jogos Olímpicos de Munique, na Alemanha, palestinos do grupo Setembro Negro invadiram a Vila Olímpica. Onze atletas israelenses foram mortos. "Terroristas seqüestram o mais influente líder político da Itália. Aldo Moro, chefe do partido democrata-cristão foi seqüestrado hoje de manhã, em Roma." (Cid Moreira, março de 1978) O grupo Brigadas Vermelhas, de extrema-esquerda, exigia a libertação de presos políticos. "O corpo do ex-primeiro-ministro italiano, seqüestrado há 55 dias, foi achado hoje de manhã. Aldo Moro levou onze tiros no peito." (Cid Moreira, maio 1978)

Os homens-bomba surgiram no Líbano, depois que o país foi ocupado por Israel. O Hezbollah foi o primeiro a usar suicidas. Serviu de inspiração para os grupos Jihad Islâmica e Hamas, dedicados a combater a ocupação israelense da Cisjordânia e da Faixa de Gaza. Nos anos 80, o terror também atacou no ar e no mar. "Um comando palestino tomou o transatlântico italiano Achille Lauro no meio de um cruzeiro no mar mediterrâneo." (Jornal Nacional, outubro de 1985) Três anos depois, um avião da Pan-Am foi explodido sobre a cidade escocesa de Lockerbie. A Líbia foi acusada pelo ataque e submetida a um boicote econômico até este ano, quando concordou em indenizar as famílias das vítimas. Na América Latina, o maior atentado aconteceu na Argentina. Um carro-bomba destruiu a sede da Associação Israelita. Os responsáveis ainda nunca foram punidos. 
O primeiro grande ataque nos Estados Unidos destruiu um edifício público na cidade de Oklahoma. Autoridades desconfiaram de terroristas estrangeiros. Mas as investigações concluíram que eram americanos que se opunham ao poder federal. "Timothy McVeigh, de 27 anos, o primeiro suspeito preso ontem, foi acusado pelo atentado." (JN, abril de 1995)

Lima, capital do Peru. Os 500 convidados de uma festa na embaixada japonesa não imaginavam que, para 72 deles, a recepção só iria terminar quatro meses depois. Homens do movimento Tupac Amaru tomaram a representação diplomática. Militares invadiram a embaixada e mataram os seqüestradores. O terrorismo, sempre uma ação desprezível e cruel, rompeu no fim do século 20 todas as barreiras até então conhecidas e ganhou dimensão de um conflito mundial. Ataques a duas embaixadas americanas na África foram o primeiro sinal.

Era como se a Al Qaeda estivesse treinando para o maior de todos os atentados. Bin Laden apelou aos dois bilhões de muçulmanos que vivem em mais de 100 países do mundo. Recrutou fanáticos e montou a primeira rede de terrorismo de alcance global. "A câmera aponta para o céu e registra o momento em que começou o horror." (setembro de 2001) "11 de setembro de 2001. Uma terça-feira que vai marcar a história da humanidade. No mais importante centro financeiro do mundo, uma torre queima - depois de ser atingida por um avião. Enquanto o incêndio avança no arranha-céu, um segundo avião é jogado contra a torre vizinha. E em menos de duas horas dois dos prédios mais altos do mundo se desfazem em uma montanha de poeira e fumaça. $\mathrm{Na}$ cidade sede do poder americano, outra aeronave despenca sobre o Pentágono - o centro de inteligência militar. E mais um boeing cai na Pensilvânia. O planeta em alerta geral." (parte da escalada do JN em 2001)

\section{Repórter Luiz Carlos Azenha (passagem):}

O que aconteceu aqui mudou este país. Tornou-se o marco zero de uma nova era política, militar e diplomática para o mundo. Ninguém imaginava que um grupo baseado em cavernas do Afeganistão conseguisse atacar no coração econômico da única superpotência. (Imagem do imenso terreno vazio, onde ficavam as torres.)

\section{Mesmo repórter (off):}

A rede de Osama Bin Laden estava por trás dos ataques que deixaram mais de dois mil e oitocentos mortos (imagens do choque do segundo avião e do pânico nas ruas). Grupos islâmicos se aliaram à Al Qaeda. 


\section{Entram trechos de diversas matérias sobre ações terroristas:}

"11 de março de 2004. Atentado terrorista em estações de trem de Madri paralisa toda a Espanha. Mais de 190 mortos e mil e quatrocentas pessoas feridas. O governo da Espanha acusa o grupo terrorista ETA."

"Às 7h30 da manhã, quando milhares de espanhóis iam de trem para o trabalho, dez explosões ocorreram em três estações. À noite a polícia espanhola encontrou uma van abandonada com detonadores e fitas com gravações em árabe de trechos do alcorão."

\section{Repórter (finaliza em off):}

Ficou provado que era mais uma ação de terroristas islâmicos. A ameaça dos grupos ligados à Al Qaeda continua um desafio para todo o planeta. Militantes muçulmanos estão usando o terror com novas táticas e objetivos. Para forçar a retirada de tropas no Iraque, degolaram e fuzilaram reféns estrangeiros. No massacre em uma escola da Rússia na semana passada, há suspeitas da ligação de militantes árabes com os rebeldes separatistas da Chechênia. O mundo debate se a ocupação americana do Iraque reduziu o terrorismo ou estimulou o recrutamento de suicidas.

\section{Observação importante:}

No dia 10 de setembro, o JN noticiou que o medo de outros ataques tinha aumentado nos Estados Unidos em razão da divulgação de um fita de terroristas da Al Qaeda com novas ameaças. Depois de falar do conteúdo das fitas, a repórter diz: "O medo de novos ataques tornou-se o tema central da campanha eleitoral americana e tem sido explorado pelos republicanos. $70 \%$ da população teme um novo atentado. $O$ mesmo percentual considera que o presidente Bush é o mais preparado para combater o terror."

Na seqüência, entra o comentário de Arnaldo Jabor: "Quem caiu no 11 de setembro não foram as torres. Foi o Ocidente. Mas não se pode separar essa tragédia do Bush. Ele e sua gangue erraram em tudo. Eles aproveitaram a desgraça para iniciar uma política imperial, transformando a América na nação mais odiada do mundo. O Osama é louco. E o Bush diz agir em nome da liberdade, mas quer cerceá-la dentro e fora da América. Pela primeira vez a grande democracia americana pode ser destruída. Pelo medo, pode surgir um pré-fascismo nos Estados Unidos. Se Bush for reeleito, a cada 11 de setembro o mundo estará pior." 


\section{ANEXO 5}

\section{Jornal da Record de 11 de setembro de 2001}

\section{Escalada (sem imagens):}

Boa noite. Este é o Jornal da Record e estas são as notícias mais importantes do dia.

Ataque terrorista destrói o World Trade Center em Nova York e atinge o Pentágono, em Washington. Há milhares de mortos e feridos.

As tropas americanas estão em alerta no mundo. Bush promete caçar e punir os responsáveis pela agressão.

Explosões agora à noite na capital do Afeganistão podem indicar o início de uma retaliação. Nenhuma organização assume a autoria do atentado.

O milionário saudita Bin Laden encabeça a lista de suspeitos.

O primeiro-ministro de Israel diz que o ataque é uma declaração de guerra aos Estados Unidos.

O líder da OLP, Yasser Arafat, condena a ação terrorista, mas palestinos comemoram nas ruas.

Os preços do ouro e do petróleo disparam.

No Brasil, o dólar bate novo recorde e a bolsa despenca.

Fernando Henrique prevê dificuldades na economia brasileira provocadas pela catástrofe.

O prefeito de Campinas, Toninho do PT, é assassinado ao sair de um shopping center.

O PMDB pressiona e adia a leitura do relatório que incrimina Jader.

Exausto, Guga é derrotado e está fora do Brasil Open.

\section{Bloco 1}

\section{Locutor $^{151}$ (cabeça) $^{152}$ :}

Foi o maior ataque terrorista da história. Três aviões comerciais americanos foram seqüestrados e lançados contra dois dos maiores símbolos do poderio militar e econômico dos Estados Unidos: o Pentágono, em Washington, e as torres gêmeas do WTC, em Nova York (aqui o selo muda e exibe uma torre em chamas, logo após o choque do segundo avião). Ainda não é possível contar o número de vítimas, que deve chegar a milhares. Até agora os Estados Unidos e o mundo estão chocados.

\footnotetext{
${ }^{151}$ O locutor é o âncora do telejornal, Boris Casoy, que fará também grande parte das narrações em off.

152 Diferentemente da edição do Jornal Nacional, em que o selo é o mesmo em todas as entradas dos locutores, no Jornal da Record haverá diversos selos, alternando-se durante a edição. O primeiro traz uma imagem do Pentágono antes do ataque.
} 


\section{Locutor (off):}

A impressionante ação terrorista começou pela manhã (imagens das torres sob fumaça e das torres destruídas na parte superior). Num intervalo de apenas 18 minutos dois boeings se chocaram contra as torres do WTC. (Aqui as imagens são da CNN: o segundo avião se aproxima e se choca contra a torre.) Uma hora mais tarde o horror dos americanos se transformou em pânico (imagem do Pentágono sob fumaça). Um outro avião comercial se espatifou contra o Pentágono, a sede do comando militar dos Estados Unidos em Washington (imagem de parte do prédio em chamas). Até então o enorme edifício parecia inexpugnável (novamente a imagem do prédio sob fumaça). A ação dos terroristas foi coordenada e quase perfeita (imagem de parte do prédio destruída).

Quatro aviões de passageiros foram seqüestrados (imagem das torres sob muita fumaça, novo ângulo). Dois deles, que tinham decolado em Boston, foram desviados para Nova York e lançados sobre o WTC. Um outro, que levantou vôo em Washington, foi forçado a dar meia volta e derrubado sobre o Pentágono. O quarto avião partiu de Newark, Nova Jersey, e caiu perto de Pittsburgh, na Pensilvânia. (Mapa e ilustrações dos aviões.) Foi o único aparelho que os terroristas não conseguiram usar como arma de ataque. (Novas imagens da CNN: floresta onde caiu o avião.)

A ação terrorista lançou os Estados Unidos num ambiente de grande confusão e pânico (imagens de pessoas correndo nas ruas, com máscaras). Os americanos não conseguiam acreditar no que assistiam, ao vivo, pela televisão. No final da manhã esta era a imagem da América (torres sob fumaça, ao longe, numa panorâmica da ilha). A estátua da Liberdade, solitária, pequena, coberta pela enorme nuvem do terrorismo. (Nova imagem da CNN: a ilha sob muita fumaça.)

\section{Locutor (cabeça):}

As torres gêmeas do WTC desapareceram da paisagem de Nova York em duas horas (selo da torre em chamas).

\section{Locutor (off):}

O terror em Nova York começou um pouco depois das 9 horas da manhã (repetição das imagens das torres sob fumaça e da parte superior das torres destruída). Um avião comercial atingiu a torre norte do WTC (imagens da CNN: torres sob fumaça de novo, por diversos ângulos). O 
prédio começou a pegar fogo. Dezoito minutos depois, quando as câmeras de televisão mostravam o incêndio e ainda não havia confirmação do que realmente havia acontecido, um segundo avião se chocou com a outra torre (repete-se imagem do choque e da explosão). 0 caos e o cenário de guerra se espalharam pelo sul da ilha de Manhattan, o distrito financeiro mais poderoso do mundo (imagens da CNN: pessoas correndo).

As testemunhas contavam horrorizadas que viram muitas pessoas saltando do alto dos prédios em chamas. (Imagens das pessoas se jogando, sem narração durante alguns segundos.) Os hospitais começaram a receber centenas de pessoas feridas e intoxicadas pela fumaça. (Aqui aparece um homem todo ensangüentado, o mesmo que aparece no final do Jornal Nacional.) Cerca de duas horas depois a primeira torre desabou. (Imagens do desabamento, muita poeira e fumaça cobrindo as ruas, pessoas correndo, sem narração durante alguns segundos.)

O prefeito de Nova York, Rudolf Giuliani, pediu para a população permanecer em casa (imagem da poeira e da fumaça se espalhando pelas ruas) e ordenou que a região sul da ilha fosse esvaziada para facilitar o transporte das vítimas (imagem de pessoas deixando o local). Todas as pontes e túneis de acesso a Manhattan foram interditados (imagem de muita fumaça sobre a ilha). O metrô, que tinha estação no subsolo dos prédios, deixou de circular em toda linha (imagens dos escombros e de bombeiros trabalhando). Todos os prédios públicos foram esvaziados, assim como a sede da ONU.

Meia hora depois a segunda torre foi ao chão (novamente imagens do desabamento das torres e de muita fumaça e poeira cobrindo as ruas). Em pouco tempo, só havia destroços das duas torres gêmeas, com 417 metros de altura, 110 andares e 99 elevadores cada uma. O WTC era o quinto prédio mais alto do mundo. (Imagens das torres sob fumaça e em chamas, por ângulos diferentes, e de fumaça sobre os prédios ao redor.) Por ali passavam diariamente 50 mil funcionários, de 600 escritórios, e 70 mil turistas. Um primeiro balanço do número de vítimas só deverá sair amanhã (novas imagens da CNN: escombros nas ruas).

\section{Locutor (cabeça):}

O WTC foi construído de forma a desabar para dentro no caso de um grande desastre como o que aconteceu hoje. No final da tarde o terceiro bloco do complexo desabou (selo: torre em chamas). 


\section{Locutor (off):}

Veja o desabamento à direita do vídeo. Este bloco, bem menor do que as torres gêmeas, é conhecido como anexo 7 do WTC. (Imagens da CNN repetidas duas vezes durante o off: anexo desabando.) O desabamento foi resultado da queda das duas torres e do incêndio que tomou conta de todo o complexo. $\mathrm{O}$ anexo 7 tem 47 andares e ficou em chamas durante todo o dia.

\section{Locutor (cabeça):}

O economista brasileiro Raul Paulo Costa mora em Nova York há 13 anos e trabalhava no WTC com o mercado financeiro. Ele contou por telefone como sobreviveu ao ataque (selo: torre em chamas).

\section{Sonora (por telefone):}

"Eu tive a sensação da pancada, que foi muito, muito grande. O prédio balançou muito, várias vezes, e a sensação era que o prédio ia cair mesmo, então eu corri para a primeira escada de incêndio, que estava mais perto da minha mesa, e ela estava bloqueada. Eu desci até o $13^{\circ}$ andar e as portas travam automaticamente, aí ficou todo mundo preso dentro da escada de incêndio. Eu tentei sair por um outro lado do prédio, que provavelmente ia ter uma outra saída. Foi quando eu encontrei um bombeiro que tinha subido e ele falou pra mim que dava pra descer, mas que tinha muita água e muita fumaça. Por mim devem ter passado uns quinze bombeiros subindo e essas pessoas não conseguiram voltar." (A sonora cobre novas imagens dos escombros nas ruas, de prédios destruídos, de bombeiros trabalhando.)

\section{Locutor (cabeça):}

O mundo acompanhava, perplexo, as imagens de Nova York quando surgiu a notícia de que havia um terceiro atentado, desta vez na capital Washington. $O$ alvo foi o Pentágono, o maior símbolo do poder militar americano (selo: Pentágono).

\section{Locutor (off):}

O boeing 757 da American Airlines atingiu o Pentágono por volta das nove e meia. (Seqüência de imagens diferentes das exibidas no Jornal Nacional: prédio sob fumaça, fogo no interior do prédio, lateral do prédio destruída, muita fumaça se espalhando. Também não dá para ver sinais do avião.) O choque provocou uma explosão. A base do prédio pegou fogo e desabou. Uma imensa nuvem de fumaça se formou também na capital americana. $A$ área atingida abrigava o 
setor de logística do Exército. O secretário americano de defesa, Donald Rumsfeld, estava em outra ala. Vinte mil civis e militares trabalham no Complexo de cinco andares, sede do departamento de defesa e considerado o prédio mais seguro dos Estados Unidos (imagem do Pentágono antes do ataque).

Todos os prédios federais em Washington foram esvaziados (imagens da destruição no Pentágono e muita fumaça). Jatos F16 passaram a sobrevoar a cidade (imagem descritiva). Toda a região foi tomada por carros de bombeiros e ambulâncias (imagem descritiva). Dezenas de pessoas foram hospitalizadas (novas imagens da CNN: pessoas sendo socorridas). O número de vítimas ainda não foi calculado.

\section{Locutor (cabeça):}

Nos quatro aviões seqüestrados nos Estados Unidos havia, ao todo, 266 pessoas a bordo. Os jatos eram de companhias americanas: dois da American Airlines e dois da United Airlines. Um dos aviões da United caiu em Pittsburgh e há informações, ainda não confirmadas, de que ele teria sido abatido por caças da Força Aérea (selo: avião no céu).

\section{Locutor (off):}

O boeing 747 da United Airlines saiu de Newark, em Nova Jersey, com destino a São Francisco, na Califórnia (repete-se imagem da CNN: floresta onde caiu o avião). O aparelho caiu a poucos quilômetros de Pittsburgh, na Pensilvânia (mapa e ilustrações também da CNN). Os destroços ficaram espalhados numa área rural (imagem da CNN). Havia 58 passageiros a bordo. A polícia informou que um deles conseguiu ligar do celular para o 911, número de chamada de emergência. O passageiro avisou do seqüestro e pediu ajuda. Há informações não confirmadas de que caças americanos derrubaram o boeing depois que o comandante não atendeu as ordens para aterrissar. Acredita-se que o boeing seria usado em mais um atentado. (Imagens da CNN durante o off todo: helicópteros e local da queda do avião.)

\section{Locutor (cabeça):}

As tropas americanas entram em alerta no mundo inteiro. Declarada emergência em Washington, a capital dos Estados Unidos (selo: bandeira dos Estados Unidos). E o presidente George W. Bush promete caçar e punir os terroristas que ousaram atacar o coração da América (outro selo: imagens superpostas da bandeira, da Casa Branca e do presidente Bush). 


\section{Locutor (off):}

Em seu primeiro discurso aos americanos, de manhã, na Flórida, Bush falou duro, mas ainda pensava numa ação terrorista localizada (imagem de Bush discursando). Depois do ataque ao Pentágono, o governo americano entrou num ambiente de guerra (várias imagens repetidas do Pentágono sob fumaça). O presidente sumiu. Ele foi levado para uma base militar em Louisiana e depois para uma outra base, em Nebrasca. Washington não era mais lugar seguro (imagens da CNN: pessoas correndo e deixando os prédios). A começar pela Casa Branca, os prédios públicos começaram a ser esvaziados na capital e nas principais cidades americanas.

Todos os vôos foram cancelados e os aeroportos, fechados (imagens de aviões e aeroportos). A Força Aérea tinha ordem de derrubar qualquer avião suspeito. Vôos internacionais foram desviados para o Canadá (imagem repetida da ilha sob fumaça). Os postos nas fronteiras entraram em alerta máximo. Navios de guerra patrulhavam a costa de Nova York (outras imagens da ilha sob fumaça, novos ângulos).

Por algumas horas, o pânico parecia dominar o país. (Seqüência de imagens da CNN: pessoas correndo e barulho de sirenes ao fundo.) Os boatos se sucediam. Notícias falsas de atentados e também de que haveria mais quatro aviões no ar controlados por terroristas. No meio da tarde, quando o governo parecia estar tomando pé da situação, Bush reapareceu numa base militar no Nebrasca (imagem de Bush chegando para discursar). Foi quando prometeu caçar e punir os responsáveis pelo maior ataque terrorista da história americana.

\section{Locutor (nota pé):}

O presidente George W. Bush está voltando para Washington e deve fazer um novo pronunciamento ainda esta noite.

\section{Locutor (comentário, em close):}

Este foi o maior atentado terrorista já ocorrido em todo o planeta. E mais: grande parte dele foi transmitida, ao vivo, pela televisão, o que amplia muito a emoção já natural provocada na população americana que, perplexa, assistiu a ataques aos maiores símbolos do poder econômico e militar do país. Ainda não é possível saber de onde partiu o atentado. Pode ter sido realizado por terroristas de fora dos Estados Unidos ou até por grupos da extrema-direita americana, como no caso de Oklahoma. 
O fato de ser um atentado suicida aponta para um terrorismo internacional, como o do milionário saudita Bin Laden, protegido e escondido no Afeganistão, ou outros extremistas islâmicos. Há até gente que acha que traficantes de drogas podem ter sido os patrocinadores desse atentado. Nenhuma hipótese pode ser descartada. A única coisa certa é que esse 11 de setembro marca o início de uma política inflexível contra o terrorismo, a partir de uma duríssima retaliação americana, até por pressão da opinião pública.

\section{Locutor (cabeça):}

Uma mulher que estava a bordo do avião que foi jogado sobre o Pentágono ligou do seu telefone celular para o marido quando começou o seqüestro (selo: Pentágono).

\section{Locutor (off):}

Barbara Olson contou ao marido que o avião estava sendo seqüestrado por mais de um homem, mas ela não sabia quantos eram. Barbara disse que os seqüestradores estavam armados apenas com facas e canivetes. Eles empurraram todos os passageiros e tripulantes para o fundo do avião. Barbara ainda perguntou ao marido o que ela deveria fazer, mas não teve tempo de ouvir a resposta. (Imagem da CNN o tempo todo na tela, durante a narração: foto de Barbara Olson e as datas 1955-2001.)

\section{Locutor (cabeça):}

O último vôo que deixou Nova York com direção ao Brasil chegou ao Rio no final da manhã. Só quando desembarcaram, os passageiros souberam da tragédia que tinham deixado para trás (selo: avião no céu).

\section{Repórter $1^{153}$ (off):}

Um vôo da TAM que havia decolado às $10 \mathrm{~h} 20$ do Aeroporto Internacional de São Paulo foi obrigado a retornar 40 minutos depois. Os passageiros foram avisados no ar do ataque terrorista, mas desembarcaram com tranqüilidade. No Rio, o vôo 973 da American Airlines, que chegou por volta das onze e meia da manhã, foi o último a aterrissar depois do ataque a Nova York. A empresa era a mesma dos dois aviões seqüestrados e lançados pelos terroristas contra as duas torres do WTC. (Imagens meramente descritivas durante o off.)

\footnotetext{
${ }^{153}$ Fala Antônio Castello Branco, do Rio de Janeiro.
} 


\section{Repórter 1 (passagem):}

Os passageiros, entre eles muitos americanos, não foram informados durante o vôo sobre o que estava acontecendo em Nova York. Eles souberam da notícia assim que desembarcaram aqui no Aeroporto Internacional Tom Jobim.

\section{Repórter 1 (off):}

"War?" (Um rapaz fala somente essa palavra.) Guerra?, perguntava esse americano perplexo. Esta outra estava transtornada porque o cunhado dela trabalhava no WTC. "I'm very nervous and scare, because it's family." (Sonora sem tradução e sem crédito.)

Este jogador de basquete parecia não acreditar no que ouvia. Ele recebeu a notícia do amigo Charles Bird, que joga no Vasco e também é americano (imagem dos jogadores conversando). As imagens foram descritas por Bird como cenas de um filme. (O jogador fala em inglês, mas não há tradução.)

Integrantes da Orquestra Sinfônica Brasileira também estavam no avião (imagem do grupo). Eles fizeram um concerto no último domingo em Nova York e alguns aproveitaram para conhecer o WTC, como o trompetista Vinícius. "A gente estava exatamente onde aconteceu o problema. Ontem eu passei nas torres gêmeas". (Sonora sem crédito.)

Assim que tomavam conhecimento do que estava acontecendo, os passageiros corriam para o telefone. (Imagens de várias pessoas ao telefone. Um rapaz fala: "Pô, acabei de chegar aqui. Ficaram uns colegas nossos lá.")

O flautista Renato Axel tentou falar com os amigos que deixou em Nova York, mas não conseguiu. Os números para que ele ligou estavam ocupados. "Isso envergonha a humanidade. Isso é uma declaração de guerra. Isso é uma ação de demente, loucos." (Sonora do flautista. Dá para ler os lábios do homem falando, no fim da frase, "fanáticos", mas o som foi cortado.)

\section{Locutor:}

Uma ação que não tem qualquer justificativa 


\section{Locutor (passagem de bloco):}

Veja a seguir. Líderes de todo o mundo reagem indignados contra o terrorismo (sem imagens).

Os preços do petróleo e do ouro disparam e o mercado financeiro interrompe os negócios.

\section{Bloco 2}

\section{Locutor (cabeça):}

Até o momento nenhuma organização terrorista assumiu a autoria dos atentados nos Estados Unidos. O terrorista saudita Osama Bin Laden encabeça a lista de suspeitos (selo: torres sob muita fumaça).

\section{Locutor (off):}

Bin Laden é procurado pela Justiça americana, com recompensa de cinco milhões de dólares por sua captura (imagens de arquivo: Bin Laden falando). Ele é acusado de uma série de atentados: uma explosão na garagem no WTC em 1993 e as explosões nas embaixadas americanas no Quênia e na Tanzânia em 1998, que deixaram 257 mortos (imagens de arquivo da destruição e de pessoas feridas). Há informações na imprensa árabe de que ele teria anunciado, há três semanas, um ataque sem precedentes aos Estados Unidos (imagens de arquivo: Bin Laden falando). Bin Laden estaria escondido no Afeganistão, sob a proteção do Talibã, a milícia islâmica que controla o país (imagens de afegãos nas ruas). Hoje os líderes do Talibã negaram o envolvimento de Bin Laden e condenaram os atentados nos Estados Unidos (imagem de um embaixador talibã falando).

Outros grupos extremistas islâmicos, como o Jihad, o Hamas, o Hezbollah e a Frente Democrática para a Libertação da Palestina, são hostis aos americanos, mas seus líderes também negaram o envolvimento e condenaram os atentados. (Imagens de pessoas queimando a bandeira dos Estados Unidos.)

Existe ainda a possibilidade de que os terroristas sejam americanos ligados ao grupo de Timothy McVeigh (imagem do rapaz preso). Ele explodiu um prédio federal em Oklahoma em 1995. Morreram 168 pessoas (imagens de arquivo: prédio destruído, pessoas feridas). McVeigh, que dizia combater o autoritarismo no governo americano, foi executado com uma injeção letal em junho último (imagem de uma sala de execução). 


\section{Locutor (cabeça):}

Os principais líderes mundiais reagiram com indignação aos atentados nos Estados Unidos. O presidente da Rússia e o chanceler alemão compararam os atos a uma declaração de guerra ao mundo civilizado. O presidente da China, Jiang Zenin, enviou um telegrama de solidariedade ao presidente Bush repudiando os violentos ataques terroristas (selo: torre em chamas).

\section{Locutor (off, com imagens dos líderes mundiais discursando):}

O presidente da Rússia, Vladimir Putin, disse que os ataques terroristas ultrapassaram as fronteiras entre os países e são um desafio à humanidade. A mesma reação teve o chefe do governo alemão, Gerard Schoereder. Ele comparou os ataques a uma declaração de guerra a todo o mundo civilizado e afirmou que o povo alemão apóia o povo americano nesta hora difícil.

O primeiro-ministro britânico, Tony Blair, convocou os chefes de segurança do país para uma reunião às pressas. Emocionado, disse que essa não é uma batalha entre os Estados Unidos e o terrorismo, mas entre o mundo democrático e o terrorismo. Afirmou ainda que não vai haver descanso enquanto o terrorismo não for varrido do mundo.

O presidente da França, Jacques Chirac, reforçou a posição de que é preciso lutar contra o terrorismo. A exemplo de Tony Blair, o primeiro-ministro francês, Leonel Jospin, mobilizou todos os esquemas de segurança para proteger o país de possíveis ataques terroristas.

\section{Locutor (cabeça):}

A reação de Israel. O ministro das relações exteriores de Israel, Simon Peres, disse que o ataque aos Estados Unidos é uma declaração de guerra. Ele defendeu uma resposta à altura do mal causado pelo terrorismo. Hoje Israel decretou estado de emergência no país e fechou o espaço aéreo para aviões estrangeiros (selo: bandeira de Israel).

\section{Locutor (off):}

O governo israelense informou que o Aeroporto Internacional Ben Gurion ficará fechado pelo menos por 24 horas para vôos de companhias estrangeiras (imagens do aeroporto). O temor do principal aliado dos Estados Unidos no Oriente Médio é também se tornar alvo dos atentados (imagens de pessoas nas ruas). 
O ministro da defesa, Benjamin Ben Eliezer, cancelou a viagem que faria aos Estados Unidos e vai manter o gabinete em reunião de emergência (imagem do ministro). Tanques de Israel ocuparam a cidade de Jenin, na Cisjordânia, sob controle dos palestinos (imagens de soldados nas ruas). A medida, segundo o Exército, é preventiva, para evitar possíveis ataques de terroristas suicidas.

\section{Locutor (nota pé):}

Amanhã será dia de luto em Israel em solidariedade ao povo americano. $O$ anúncio foi feito pelo primeiro-ministro, Ariel Sharon, que condenou o terrorismo. Ele se colocou à disposição dos Estados Unidos para ajudar no que for necessário.

\section{Locutor (cabeça):}

Os palestinos divididos. Enquanto as autoridades negavam participação nos atentados, a população festejava nas ruas (selo: bandeira palestina).

\section{Locutor (off):}

Pedaços de bolo distribuídos de mão em mão na cidade de Nablus, na Cisjordânia (imagens de um homem distribuindo bolo). Muitos palestinos foram às ruas comemorar os ataques suicidas nos Estados Unidos (imagens de pessoas dançando nas ruas, carros buzinando). O clima de festa, com tiros para o alto, chegou até os palestinos refugiados no Líbano. Cenas em contraste com as declarações oficiais. (Entram imagens de pessoas, principalmente crianças, dançando e cantando nas ruas, mas não se ouve nenhum "tiro para o alto".) O presidente da autoridade palestina, Yasser Arafat, condenou os atentados e mandou condolências ao povo americano e ao presidente George W. Bush (imagem de Arafat falando). (Todas as imagens são as mesmas que foram exibidas no Jornal Nacional.)

\section{Locutor (cabeça):}

No início da noite, horário brasileiro, a capital do Afeganistão, Cabul, foi sacudida por várias explosões (selo: bandeira do Afeganistão).

\section{Locutor (off):}

Já era madrugada de quarta-feira no Afeganistão quando as explosões começaram. Os clarões podiam ser vistos ao longe em Cabul, a capital do país. As primeiras informações apontavam 
para uma retaliação dos Estados Unidos, já que o Afeganistão abriga o líder terrorista Osama Bin Laden, mas o governo americano negou qualquer envolvimento. Segundo a rede de televisão $\mathrm{CNN}$, as explosões poderiam ser resultado de um ataque de rebeldes afegãos. Outra hipótese seria a explosão de um depósito de munições. (Imagens da CNN durante todo o off: mísseis cortando o céu de Cabul e explosões.)

\section{Locutor (comentário, em close):}

A CIA e o FBI são órgãos inteligentes americanos e certamente vão ser cobrados por não terem previsto o ataque. Previsão difícil porque o terrorismo é mesmo imprevisível e atinge de maneira cruel a população civil. A conseqüência política dos atentados de hoje é um fortalecimento da direita americana, especialmente dentro do partido republicano, o partido de Bush. Mesmo se ficar claro que o ataque veio de terroristas americanos, o exemplo basta para uma reação contra todo tipo de terrorismo, que, na verdade, só entende a linguagem da força e da violência. A reação americana dura, que ficou clara, extremamente clara, no pronunciamento do presidente Bush, será extensiva a países que recebem e protegem o terror. A saber: Afeganistão, Líbia, Síria, Iraque e Irã.

\section{Locutor (cabeça):}

Os preços do ouro e do petróleo dispararam hoje. No mercado de Londres a onça do ouro subiu 20 dólares. O barril do petróleo atingiu a maior cotação desde dezembro do ano passado. Chegou a ser negociado a 31 dólares, mas recuou para 29 dólares com as declarações do presidente da Opep, garantindo o abastecimento. Os mercados de ações ficaram praticamente paralisados. As bolsas de Nova York não operaram. No resto do mundo, os negócios foram interrompidos depois de fortes quedas (sem selo).

\section{Locutor (off):}

Na Europa, a bolsa de Frankfurt chegou a ser esvaziada por receio de bombas. O pregão foi suspenso em queda de $8,5 \%$. Londres encerrou os negócios quando as principais ações caíam $5,7 \%$. Na América Latina, também foram registradas quedas recordes. A bolsa de São Paulo paralisou suas atividades uma hora depois de iniciar o pregão, com queda de mais de $9 \%$. (Imagens das bolsas em diversos países.) 


\section{Locutor (nota):}

As bolsas de valores de Nova York não vão operar amanhã. Em São Paulo, a assessoria da bolsa anunciou que o pregão deverá ser normal. Já o mercado do dólar deverá ter outro dia tumultuado. O dólar explodiu hoje e bateu novo recorde no plano real. O comercial pulou de $\mathrm{R} \$ 2,60$ para $\mathrm{R} \$ 2,66$, com alta de $2 \%$. O grama do ouro na Bolsa Mercantil e de Futuros foi negociado a $\mathrm{R} \$ 24$, com alta de $8 \%$.

\section{Locutor (chama comentarista):}

Salete, será que nós estamos à beira de uma recessão mundial?

\section{Salete Lemos (comentarista):}

Ou já caímos nela, né, Boris? De certo até agora é que com os atentados de hoje no coração financeiro de Nova York muita coisa deve mudar nas relações dos Estados Unidos com o resto do mundo. Mudanças que certamente afetarão mais intensamente os países emergentes, destaque para Brasil e Argentina, hoje muito dependentes de recursos estrangeiros. Agora, as conseqüências econômicas dessa crise vão depender, claro, da intensidade da reação dos Estados Unidos aos atentados e também das origens dos atentados. Hoje suspeitas, apenas suspeitas de que os ataques partiram de grupos do Oriente Médio, por exemplo, já fizeram explodir os preços do petróleo.

$E$ as repercussões econômicas dos atentados sugerem desarranjos nas relações econômicas do mundo, FMI, Bird, BID inclusive, não temos a menor dúvida. Em tempo, o presidente do Banco Central americano, o Federal Reserve, Alan Greenspan, estava hoje na Suíça e, segundo agências internacionais, por enquanto vai continuar fora dos mercados. Na reabertura amanhã, dólar em queda frente ao euro, o iene e ao franco suíço. Na América Latina a reação foi contrária. O dólar fechou alto em relação às moedas locais. O resto, Boris, é expectativa.

\section{Locutor:}

Obrigada, Salete. Daqui a pouco, mais notícias sobre os atentados nos Estados Unidos.

\section{No mesmo bloco, entram outras matérias:}

Morte do empresário José Hermínio de Moraes Filho, previsão do tempo e eliminação do tenista Gustavo Kuerten do Brasil Open. 


\section{Locutor (nota, em off):}

Começam a surgir novas imagens do atentado terrorista nos Estados Unidos. Há poucos minutos a rede de televisão CNN divulgou essas imagens feitas por um cinegrafista amador. Elas mostram o segundo ataque ao WTC. O avião seqüestrado se aproxima e se choca com a segunda torre, provocando a explosão. (A imagem é repetida duas vezes durante a narração.)

\section{Locutor (passagem de bloco):}

Veja a seguir. Judeus e muçulmanos do Brasil condenam os atentados terroristas (sem imagem). E Fernando Henrique prevê efeitos negativos sobre a economia.

\section{Bloco 3}

\section{Locutor (nota):}

O presidente George W. Bush acaba de chegar a Washington a bordo do Air Force 1, o avião presidencial americano. Bush desembarcou na base aérea de Andrews e logo mais deve fazer um pronunciamento oficial pela televisão. Bush passou o dia fora de Washington por medida de segurança e esteve em duas bases aéreas: na Louisiana e no Nebrasca. Nas viagens, o boeing presidencial foi protegido por três caças da Força Aérea (selo: imagens superpostas da bandeira americana, da Casa Branca e do presidente Bush).

\section{Locutor (cabeça):}

Tensão também em Brasília. Os Estados Unidos e Israel esvaziam embaixadas e reforçam a segurança. E os americanos que vivem no Brasil estão em alerta total (sem selo).

\section{Repórter $2^{154}$ (off):}

A polícia militar de Brasília desencadeou operação especial para proteger a embaixada americana pouco depois que as primeiras imagens da tragédia chegaram ao Brasil. À medida que crescia a gravidade dos atentados, o policiamento recebia reforço. A polícia federal também ficou de prontidão enquanto os funcionários deixavam o prédio. Só carros conhecidos, que depois de minuciosa varredura tinham acesso ao local. (Imagens meramente descritivas durante a narração.)

\footnotetext{
${ }^{154}$ Fala Júlio Mosquera, de Brasília.
} 


\section{Repórter 2 (passagem):}

A embaixada em Brasília e os consulados do Rio de Janeiro, São Paulo e Recife suspenderam por tempo indeterminado o atendimento ao público. Em comunicado divulgado pela embaixada, os americanos no Brasil são aconselhados a permanecer no mais alto nível de alerta. Eles foram orientados a aumentar a segurança pessoal, evitar exposição desnecessária e não abrir qualquer correspondência cujo remetente seja desconhecido.

\section{Repórter 2 (off):}

Tensão também na sede da delegação especial da Palestina no Brasil. Ao longo do dia, passaram pelo local embaixadores e representantes de países árabes. Eles temem ser associados ao terrorismo. O representante da delegação palestina divulgou comunicado onde pede cautela à imprensa brasileira. Musa Amer Odeh condenou os atentados. Ele citou Jesus Cristo para pedir paz e amor ao mundo (entra sonora sem tradução). A embaixada de Israel foi esvaziada ao meio-dia. O embaixador, os conselheiros e familiares foram levados para lugar seguro e não divulgado. (Imagens meramente descritivas.)

\section{Repórter 2 (passagem):}

O conselheiro da embaixada de Israel, Daniel Zuar, resumiu em uma frase o impacto da tragédia: Daqui pra frente, segundo ele, combater o terrorismo vai ter que ser prioridade mundial.

\section{Locutor (cabeça):}

Líderes da comunidade árabe em São Paulo, incluindo palestinos, condenaram o atentado aos Estados Unidos, mas nas ruas houve quem comemorasse (selo: imagem de São Paulo).

\section{Repórter $3^{155}$ (off):}

O Brás, bairro tradicional do centro da cidade, concentra comerciantes da comunidade árabe (imagens das ruas do bairro durante o off). Nas ruas muitos lojistas libaneses não quiseram falar sobre o assunto do dia. Já esta mulher muçulmana chega a dizer que o atentado pode chamar a atenção para o problema dos palestinos e resume o que sentiu quando soube do atentado: "Alegria. A primeira coisa, alegria" (sonora sem crédito). Mas o sentimento da maioria é de repúdio ao terrorismo. "Eu acho isso muito ruim. Extremamente terrorista mesmo. O povo que fez também." (Sonora de Bruno Debas, comerciante.)

\footnotetext{
${ }^{155}$ Fala Heleine Heringer, de São Paulo.
} 


\section{Repórter 3 (passagem):}

Representantes no Brasil de entidades islâmicas, incluindo os palestinos, também condenaram com veemência o atentado aos Estados Unidos.

\section{Sonoras:}

"Não se justifica. Nenhum argumento político, nenhuma causa justifica um ato dessa natureza." (Hanna Yousef, secretário-geral da comunidade palestina na América Latina e Caribe)

"Covarde. Não admito isso. Não ajuda nossa causa." (Hassan Emleh, presidente da Federação Palestina no Brasil)

\section{Repórter 3 (off):}

O líder da Juventude Palestina assistiu às imagens dos ataques (imagem do rapaz vendo as notícias pela televisão). Representando trinta mil jovens palestinos e descendentes que vivem no Brasil, diz que nada justifica a ação de grupos terroristas.

Sonora do líder: "Ficamos muito entristecidos e condenamos esses ataques de forma severa. Que sejam condenadas as pessoas que cometeram esses ataques." (Mohamed Salen)

\section{Locutor (cabeça):}

Alem da indignação, o atentado deixou a comunidade judaica de São Paulo preocupada (selo: imagem de São Paulo).

\section{Repórter $4^{156}$ (off):}

O passo normalmente apressado, marca dos judeus moradores de São Paulo, hoje tinha um ritmo mais tenso (imagens de judeus andando nas ruas). Escolas e sinagogas tiveram a segurança reforçada (imagem de seguranças na porta de uma sinagoga).

\section{Repórter 4 (passagem):}

Como medida preventiva, a Federação Israelita de São Paulo determinou que as 54 entidades filiadas suspendessem as atividades no dia de hoje, incluindo aí clubes, hospitais, sinagogas e todas as escolas israelitas do estado de São Paulo. Cuidados de um povo que convive com atos terroristas desde a criação do estado de Israel.

\footnotetext{
${ }^{156}$ Fala Maria Paula, de São Paulo.
} 


\section{Repórter 4 (off):}

No consulado israelense de São Paulo, a polícia na porta acompanhava a saída dos funcionários. O expediente foi suspenso por causa de uma ameaça de bomba no consulado do Rio de Janeiro. (Imagens descritivas.)

\section{Sonora:}

"O consulado no Rio recebeu uma ameaça que o que está passando nos Estados Unidos vai passar também para o consulado no Rio, consulado em São Paulo e embaixada no Brasil." (Medad Medina, cônsul de Israel em São Paulo)

\section{Repórter 4 (off):}

O atentado aos Estados Unidos provocou indignação geral entre os judeus de São Paulo, remetendo a colônia ao conflito no Oriente Médio (outras imagens de judeus andando nas ruas).

\section{Sonoras (sem crédito):}

"Quando existem pessoas que a vida deles, o propósito deles é matar outras pessoas, acabar com vidas, destruir famílias, e o mundo não condena, isso daqui nunca vai chegar a lugar nenhum." (Rapaz judeu)

"Acho que agora virá uma pressão e vai haver então... um processo de paz deve estar chegando. Eu espero, acredito assim." (Mulher judia)

\section{Locutor (cabeça):}

Durante boa parte da manhã a Embratel só conseguiu completar $9 \%$ das ligações para os Estados Unidos. Aflitos, brasileiros que têm parentes morando em cidades americanas passaram o dia pendurados no telefone (selo: aparelho de telefone).

\section{Repórter $5^{157}$ (off):}

A produtora musical Maria Braga viveu horas de muita apreensão hoje pela manhã (imagem da mulher e foto da irmã). Ela é irmã da atriz Sonia Braga que mora a poucas quadras de onde ficavam as torres do WTC em Nova York. A tranqüilidade só veio depois de duas conversas por telefone (imagem da mulher falando ao telefone).

\footnotetext{
${ }^{157}$ Fala Renato Chappot, do Rio de Janeiro.
} 


\section{Sonora de Maria Braga:}

"Ela acordou com o barulho do avião e logo depois o estrondo, que foi a batida do avião. Aí depois ela me ligou da rua dizendo que continuava bem e que estava tudo bem, que estava tranqüilo. Agora estou aguardando que ela ligue novamente para dar notícias, porque só ela me ligando, porque a gente não consegue completar nenhuma ligação para lá."

\section{Repórter 5 (passagem, de uma central telefônica vazia):}

Preocupadas com a situação de familiares, as pessoas aqui no Brasil passaram o dia tentando falar com os Estados Unidos. A Embratel registrou um aumento de quarenta vezes nas chamadas para as cidades americanas. Entre onze horas e meio-dia, o número de ligações internacionais passou de 85 mil para um milhão.

\section{Repórter 5 (off):}

A taxa de chamadas completadas para os Estados Unidos caiu de $65 \%$ para $9 \%$ (imagem de uma central telefônica em funcionamento).

\section{Sonora:}

"Eu não diria que houve um pane. Eu diria que houve um aumento anormal de tráfego na rede que fez com que a taxa de completamento de chamada caísse a um patamar bastante ruim." (Renê Pestre Filho, gerente de operações da Embratel)

\section{Repórter 5 (off):}

No final do dia, diante das edições extras dos jornais cariocas, as pessoas ainda se mostravam perplexas com o que aconteceu (imagens de pessoas vendo os jornais numa banca).

\section{Locutor (cabeça):}

Em Miami, onde vivem milhares de brasileiros, o medo se espalha, mas não foi registrado nenhum incidente ligado ao terrorismo (sem selo). 


\section{Repórter $6^{158}$ (off):}

O clima de tensão se instalou nos Estados Unidos (imagens de policiais nas ruas). Os atentados que destruíram o WTC e atingiram o Pentágono só foram possíveis com o seqüestro de boeings comerciais, o que fez com que, de imediato, o governo americano suspendesse todo tráfego aéreo no país (imagens de aviões e de aeroportos vazios).

\section{Repórter 6 (passagem):}

A comunidade brasileira em Miami está perplexa. $\mathrm{O}$ atentado que atingiu as cidades de Nova York e Washington também fez estragos no sentimento de segurança dos americanos. Aqui no Aeroporto Internacional de Miami todos os vôos foram cancelados e ainda não está prevista a normalização do tráfego aéreo da região.

\section{Repórter 6 (off):}

Com os aeroportos vazios, só restou aos funcionários tentar entender o que se passava (imagens dos funcionários). Como uma parte da telefonia de Nova York ficava justamente nas torres gêmeas, era grande a aflição das famílias que tentavam obter notícias de parentes e amigos residentes nas cidades atingidas (imagens de policiais nas ruas).

\section{Sonoras de brasileiros em Miami:}

"A comunidade brasileira, está todo mundo junto, mas a gente não consegue falar com eles mais, desde às 11 horas agora não se fala mais." (Rosane Melo)

"Eu estou preocupada com minha amiga que foi para Nova York e a gente não tem notícia dela." (Patrícia Costa, estudante)

\section{Repórter 6 (off):}

O cônsul brasileiro em Miami, Lúcio Amorim, não acredita que os atentados cheguem a essa cidade (imagens do consulado).

\section{Sonora do cônsul:}

"No condado de Miami, onde residem alguns milhares de brasileiros, não se registrou nenhum ato terrorista, nenhum incidente que seja do nosso conhecimento."

\footnotetext{
${ }^{158}$ Fala Luiz Afonso, de Miami.
} 


\section{Locutor (nota pé):}

O Itamaraty ainda não tem informações sobre brasileiros feridos no atentado nos Estados Unidos, mas colocou um serviço de atendimento 24 horas para receber ou prestar informações sobre possíveis vítimas brasileiras. Os telefones são (61) 411-6475 ou 411-6476. O telefone do consulado brasileiro em Nova York é (1917) 777-7777.

\section{Locutor (nota):}

O governo americano informou agora há pouco que ainda não tem uma estimativa do número de mortos e feridos nos atentados de hoje. A polícia de Nova York fala em milhares de mortos, talvez dezenas de milhares (selo: Pentágono).

\section{Locutor (cabeça):}

Foi o maior ataque terrorista da história. Aviões comerciais foram seqüestrados e lançados contra o Pentágono em Washington e as torres gêmeas do WTC, em Nova York. Veja novamente como foi a ação terrorista que deixou os Estados Unidos e o mundo em estado de choque (selo: torre em chamas).

\section{Locutor (off repetido, com as mesmas imagens, tudo igualzinho):}

A impressionante ação terrorista começou pela manhã. Num intervalo de apenas 18 minutos dois boeings se chocaram contra as torres do WTC. Uma hora mais tarde o horror dos americanos se transformou em pânico. Um outro avião comercial se espatifou contra o Pentágono, a sede do comando militar dos Estados Unidos, em Washington. Até então, o enorme edifício parecia inexpugnável. A ação dos terroristas foi coordenada e quase perfeita.

Quatro aviões de passageiros foram seqüestrados. Dois deles, que tinham decolado em Boston, foram desviados para Nova York e lançados sobre o WTC. Um outro, que levantou vôo em Washington, foi forçado a dar meia volta e derrubado sobre o Pentágono. O quarto avião partiu de Newark, Nova Jersey, e caiu perto de Pittsburgh, na Pensilvânia. Foi o único aparelho que os terroristas não conseguiram usar como arma de ataque. A ação terrorista lançou os Estados Unidos num ambiente de grande confusão e pânico. Os americanos não conseguiam acreditar no que assistiam, ao vivo, pela televisão. No final da manhã esta era a imagem da América. A estátua da Liberdade, solitária, pequena, coberta pela enorme nuvem de terrorismo. 


\section{Locutor (cabeça):}

$\mathrm{O}$ ataque terrorista nos Estados Unidos foi acompanhado em todo o Brasil. Veja a reportagem de Bianca Vasconcelos (selo: torre em chamas).

\section{Repórter $7^{159}$ (off):}

Por telefone não deu. As linhas estavam congestionadas (imagens de meninas tentando falar ao telefone). Navegar foi preciso para ter notícias. A internet estava sobrecarregada. Os jovens americanos que estudam em São José do Rio Preto, no interior paulista, não conseguiram saber dos pais pela manhã. (Nenhuma sonora, nenhuma explicação.)

Expressão de dor diante de cenas reais (imagem de um homem vendo televisão). "Eu não esperava acordar e ver uma coisa assim." (Sonora de um popular, sem crédito.)

O paraense, mesmo distante, sentiu medo (mais imagens de pessoas vendo televisão). (Entram sonoras de populares: "Eu não sei direito, mas estou com medo." "É pra ficar com medo, né?")

Para essa tragédia, o goiano lançou as respostas que estavam na ponta da língua (outras imagens de pessoas vendo televisão). (Entram sonoras de populares: "Esses ataques são um retorno dessa política neoliberal excludente que os Estados Unidos vêm lançando pelo mundo." "É devido à falta de Deus, né? Acho que o pessoal não tem Deus, a maioria.")

E ainda sobrou para os Estados Unidos (mais pessoas vendo televisão). (Outras sonoras de populares: "Eles devem estar sentindo agora o peso que o cidadão inocente sente. Eles também devem estar sentido, jogando bomba em cima deles lá." "Concentração de poder demais lá nos Estados Unidos está deixando muita gente doida.")

\section{Repórter 7 (passagem):}

Mais de dez horas de vôo, oito mil quilômetros nos separam de Nova York, mas não da tragédia. ( $A$ câmera vai se deslocando da imagem de um telão na avenida Paulista, que exibe uma imagem das torres sob fumaça, até a repórter falando.) Mesmo de longe, quem acompanhou sabe que vai ser difícil não se lembrar desse atentado daqui pra frente.

\footnotetext{
${ }^{159}$ A repórter fala de São Paulo.
} 


\section{Sonoras de populares:}

"O mundo vai ser outro a partir de hoje. Eu tenho medo do que vai vir."

"Pode até vir uma terceira guerra mundial com essa brincadeira toda, envolvendo milhares de seres humanos que não têm nada a ver com essas políticas baratas, vamos dizer assim."

\section{Locutor (comentário):}

Nada é impossível, mas terceira guerra mundial contra quem? Ninguém sabe quem fez o atentado. Se for algum estado, se for algum país, talvez. Nada indica que seja um estado organizado, um país, o autor ou o organizador ou o realizador desse atentado, portanto nada justifica um ataque contra uma população civil. Terrorismo é um horror e precisa ser banido da face da terra.

\section{Locutor (cabeça):}

O presidente Fernando Henrique Cardoso enviou uma carta ao presidente dos Estados Unidos, George W. Bush, condenando com veemência o terrorismo. Fernando Henrique prevê possíveis turbulências na economia brasileira, mas disse que o governo já está agindo (selo: imagem de Fernando Henrique e da bandeira do Brasil).

\section{Repórter $8^{160}$ (off):}

A perplexidade do presidente Fernando Henrique Cardoso diante das cenas do atentado nos Estados Unidos resumiu o sentimento que tomou conta das autoridades hoje em Brasília, no governo e no congresso (imagem de FHC vendo as notícias pela televisão). Fernando Henrique cancelou toda a agenda de compromissos e mandou convocar o conselho de defesa nacional (imagens de FHC reunido com o conselho).

\section{Repórter 8 (passagem):}

Com a ajuda de ministros e auxiliares, o presidente tenta elaborar um quadro dos possíveis desdobramentos da crise e se declarou chocado diante das imagens do atentado. Eles perderam mais de cem mil no Vietnã e hoje podem ter perdido a metade disso. É uma guerra, disse o presidente. Mais tarde, perguntado se temia pela paz mundial, o presidente declarou: Isso não. (Não dá para saber se o que ela fala são "aspas".)

\footnotetext{
${ }^{160}$ Fala Christina Lemos, de Brasília.
} 


\section{Repórter 8 (off):}

Nesta carta ao presidente George Bush, Fernando Henrique fala da indignação e da tristeza dos brasileiros diante das vítimas perdidas no atentado e condena duramente o terrorismo. (Imagem da carta, com destaque para a assinatura do presidente.) O gesto foi repetido pelo Ministério das Relações Exteriores (imagem da fachada do Itamaraty) e pelo ministro da Defesa, Geraldo Quintão, para quem os países têm de rever seus sistemas de defesa (imagem do ministro). No Itamaraty, pressão por informações sobre possíveis vítimas brasileiras. Os diplomatas se mobilizam, mas enfrentam barreiras provocadas pelo próprio atentado (imagem de um embaixador falando).

\section{Sonora:}

"Não havia até aquele momento, nem em Washington, nem em Nova York, nenhuma notícia de que houvesse vítimas de nacionalidade brasileira." (Embaixador Gilberto Velloso, subsecretáriogeral do Serviço Exterior)

\section{Repórter 8 (off):}

No pronunciamento feito no final desta tarde, a expressão e a voz do presidente tinham o peso da preocupação. Fernando Henrique declarou que pretende falar com o presidente Bush ainda hoje e deixou claro: teme pelos efeitos da crise sobre a economia brasileira. (Durante o off, imagem de FHC discursando.)

\section{Trecho da fala de FHC:}

"Ainda esta manhã o governo determinou, através do Banco Central, uma intervenção para acalmar a situação financeira, posto que não há nenhuma razão para uma preocupação maior nesse momento."

\section{Locutor (comentário, em close):}

Olha, a economia só pode ser atingida pra valer se houver conseqüências, se houver fatos novos, se houver uma retaliação, um tipo de guerra, o que é absolutamente improvável a essa altura dos acontecimentos. Quando se fala em terceira guerra mundial - durante o dia hoje se ouviu falar muito nisso - não se sabe, não se leva em consideração que todas as grandes potências, antigas inimigas na Guerra Fria, por exemplo a antiga União Soviética, a Rússia, estão juntas nessa história do combate ao terrorismo, inclusive a China. 
Não há razão para uma terceira guerra mundial. Não há nada neste momento em disputa, não há mercado, não há território, nada, nada, apenas conflitos regionais, pequenos e grandes conflitos regionais, nada que possa envolver as grandes potências atômicas. Pelo contrário, tudo converge, todas elas estão atravessando momentos difíceis, inclusive a China, que também, apesar de ter progredido muito, começa a sentir os efeitos da retração do comércio e das exportações e importações em todo o mundo. Por isso ninguém pode imaginar, nesta altura dos acontecimentos, que, finda a Guerra Fria, tenhamos uma terceira guerra mundial.

O que vai haver, no momento em que os americanos descobrirem exatamente quem são os autores desses atentados, vai ser uma retaliação fantástica, mesmo se os autores dos atentados forem de dentro dos Estados Unidos, terroristas americanos, mesmo assim o exemplo do que pode acontecer com os terroristas já foi demonstrado. Isso vai determinar uma guerra de extermínio contra o terror no mundo inteiro, porque extermínio, porque violência é a única linguagem que essa gente entende. Não há maneira, não há possibilidade de conviver, nem de negociar com o terrorismo.

\section{Locutor (passagem de bloco):}

Veja a seguir. Assassinado a tiros o prefeito de Campinas, Toninho do PT.

E ainda nesta edição, mais informações sobre o ataque terrorista nos Estados Unidos (sempre sem imagens).

\section{Bloco 4}

\section{Locutor (cabeça):}

O metrô e os ônibus voltaram a funcionar agora à noite em Nova York, mas os horários foram espaçados por razões de segurança. Os ataques de hoje mudaram a tradicional e conhecida paisagem da cidade. As torres gêmeas do WTC desapareceram em duas horas (selo: torre em chamas).

\section{Locutor (off repetido, com as mesmas imagens, tudo igualzinho):}

O terror em Nova York começou pouco depois das nove horas da manhã. Um avião comercial atingiu a torre norte do WTC. O prédio começou a pegar fogo. Dezoito minutos depois, quando as câmeras de televisão mostravam o incêndio e ainda não havia confirmação do que realmente 
havia acontecido, um segundo avião se chocou com a outra torre. O caos e o cenário de guerra se espalharam pela ilha de Manhattan, o distrito financeiro mais poderoso do mundo. (Com as mesmas imagens da CNN.) As testemunhas contavam horrorizadas que viram muitas pessoas saltando do alto dos prédios em chamas. Os hospitais começaram a receber centenas de pessoas feridas e intoxicadas pela fumaça. Cerca de duas horas depois a primeira torre desabou. (Imagens sem narração por alguns segundos.)

O prefeito de Nova York, Rudolf Giuliani, pediu para a população permanecer em casa e ordenou que a região do sul da ilha fosse esvaziada para facilitar o transporte das vítimas. Todas as pontes e túneis de acesso a Manhattan foram interditados. O metrô, que tinha estação no subsolo dos prédios, deixou de circular em toda a linha. Todos os prédios públicos foram esvaziados, assim como a sede da ONU. Meia hora depois a segunda torre foi ao chão. Em pouco tempo, só havia destroços das duas torres gêmeas, com 417 metros de altura, 110 andares e 99 elevadores cada uma. O WTC era o quinto prédio mais alto do mundo. Por ali passavam diariamente 50 mil funcionários, de 600 escritórios, e 70 mil turistas. Um primeiro balanço do número de vítimas só deverá sair amanhã. (Mesmas imagens.)

\section{Locutor (nota repetida):}

O WTC foi construído de forma a desabar para dentro no caso de um grande desastre como o que aconteceu hoje. No final da tarde o terceiro bloco do complexo desabou (selo: torre em chamas).

\section{Locutor (off repetido):}

Veja o desabamento à direita do vídeo. Este bloco, bem menor do que as torres gêmeas, é conhecido como anexo 7 do WTC. O desabamento foi resultado da queda das duas torres e do incêndio que tomou conta de todo o complexo. O anexo 7 tem 47 andares e ficou em chamas durante todo o dia. (Com as mesmas imagens da CNN, repetidas duas vezes.)

\section{Locutor (cabeça):}

Agora há pouco grupos guerrilheiros do norte do Afeganistão se responsabilizaram pelos ataques à capital, Cabul (selo: bandeira do Afeganistão). 


\section{Locutor (off repetido, com as mesmas imagens da CNN):}

No início da noite, horário brasileiro, a capital do Afeganistão foi sacudida por várias explosões. Já era madrugada de quarta-feira no Afeganistão quando as explosões começaram. Os clarões podiam ser vistos ao longe. As primeiras informações apontavam para uma retaliação dos Estados Unidos, já que o Afeganistão abriga o líder terrorista Osama Bin Laden, mas o governo americano negou qualquer envolvimento.

\section{Trecho novo do off:}

Depois de assumir a autoria dos atentados, os guerrilheiros afegãos declararam que vão realizar novos ataques de surpresa no país. (Com as mesmas imagens da CNN: mísseis cortando o céu de Cabul e explosões.)

\section{Locutor (cabeça):}

O secretário americano de Defesa, Donald Rumsfeld, fez um pronunciamento agora há pouco (selo: Pentágono).

\section{Locutor (off):}

Rumsfeld afirmou que o Pentágono está funcionando agora e vai trabalhar também amanhã. Rumsfeld disse que ainda é impossível fazer qualquer previsão sobre números. O general Shelton, chefe do estado maior conjunto das forças armadas americanas qualificou os ataques como atos bárbaros de terrorismo e afirmou que o exército americano está pronto para agir. (Durante o off, imagem do secretário falando.)

\section{Locutor (nota):}

O presidente Fernando Henrique deve reunir amanhã todos os líderes de partidos, inclusive os de oposição, para discutir a crise provocada pelos ataques terroristas aos Estados Unidos. A informação é do presidente da Câmara, o deputado Aécio Neves, que participou da reunião do conselho de defesa nacional. Segundo Aécio, a Aeronáutica decidiu franquear o espaço aéreo brasileiro para receber vôos desviados dos Estados Unidos, mas em estado de alerta. Daqui a pouco, mais notícias sobre o terrorismo nos Estados Unidos. 


\section{Entram outras matérias:}

Assassinato do prefeito de Campinas, Toninho do PT; depoimento de Paulo Maluf à CPI da dívida pública; adiamento do relatório com denúncias contra o senador Jader Barbalho.

\section{Locutor (cabeça):}

O secretário de Justiça dos Estados Unidos, John Ashcroft, afirma que os seqüestradores de um dos aviões lançados sobre o WTC estavam armados com facas (selo: torre em chamas).

\section{Locutor (off):}

Em entrevista agora há pouco, em Washington, o secretário de Justiça disse que todos os órgãos do governo americano estão participando das investigações. Ashcroft informou também que as autoridades estão criando um site na internet para receber pistas sobre os atentados e também vão instalar uma central telefônica para dar informações sobre as vítimas. (Durante o off, imagem do secretário falando.)

\section{Locutor (passagem de bloco):}

Veja a seguir. A Otan garante que os responsáveis pelo atentado não sairão ilesos. $E$ as imagens do presidente Bush chegando à Casa Branca (sem imagens).

\section{Bloco 5}

\section{Locutor (cabeça):}

Washington, a capital americana, continua em estado de emergência. O Pentágono, que foi um dos alvos do ataque terrorista de hoje, ainda não informou o número de vítimas no interior do prédio. Veja de novo como foi o ataque ao maior símbolo do poder militar americano (selo: Pentágono).

\section{Locutor (off repetido, com as mesmas imagens, tudo igualzinho):}

O boeing 757 da American Airlines atingiu o Pentágono por volta das nove e meia. O choque provocou uma explosão. Uma parte do prédio pegou fogo e desabou. Uma imensa nuvem de fumaça se formou também na capital americana. A área atingida abrigava o setor de logística do exército. O secretário americano de Defesa, Donald Rumsfeld, estava em outra ala. Vinte mil civis e militares trabalham no complexo de cinco andares, sede do departamento de defesa e 
considerado o prédio mais seguro dos Estados Unidos. Todos os prédios federais de Washington foram esvaziados. Jatos F16 passaram a sobrevoar a cidade. Toda a região foi tomada por carros de bombeiros e ambulâncias. Dezenas de pessoas foram hospitalizadas. O número de vítimas ainda não foi calculado.

\section{Locutor (comentário):}

Você vê que contra o terrorismo não há defesa. O terrorismo é imprevisível e usa recursos muito diferentes dos recursos da guerra. Portanto não adianta proteger contra a guerra, não adianta nenhum projeto de defesa atômica, que ele pode ser facilmente penetrado por terroristas que agem de maneira totalmente diferente do que uma guerra normal, se é que guerra pode ser chamada de normal (selo: torres sob fumaça).

\section{Locutor (cabeça repetida):}

Nos quatro aviões seqüestrados nos Estados Unidos havia um total de 266 pessoas a bordo. Os jatos eram de companhias americanas: dois da American Airlines e dois da United Airlines. Um dos aviões da United caiu em Pittsburgh e há informações, ainda não confirmadas, de que ele teria sido abatido por caças da Força Aérea (mesmo selo).

\section{Locutor (off repetido, com as mesmas imagens, tudo igualzinho):}

O boeing 747 da United Airlines saiu de Newark, em Nova Jersey, com destino a São Francisco, na Califórnia. O aparelho caiu a poucos quilômetros de Pittsburgh, na Pensilvânia. Os destroços ficaram espalhados numa área rural. Havia 58 passageiros a bordo. A polícia informou que um deles conseguiu ligar do celular para o 911, número de chamadas de emergência. $O$ passageiro avisou do seqüestro e pediu ajuda. Há informações não confirmadas de que caças americanos derrubaram o boeing depois que o comandante não atendeu as ordens para aterrissar. Acreditase que o boeing seria usado em mais um atentado.

\section{Locutor (comentário):}

Olha, hoje eu ouvi até gente ilustrada falando em ataque guerrilheiro, se é que esse ataque teve um fundo político. A diferença é simples: o ataque guerrilheiro é contra um quartel, contra uma tropa, contra um exército, nunca contra a população civil. Ataque contra a população civil, como esse ataque realizado hoje nos Estados Unidos, é ataque terrorista. Fomenta a intranqüilidade, fomenta o desequilíbrio. Esse é o objetivo do terrorismo. 


\section{Locutor (cabeça repetida):}

Até o momento nenhuma organização terrorista assumiu a autoria do atentado. $O$ terrorista saudita Osama Bin Laden encabeça a lista de suspeitos (selo: torres sob fumaça).

\section{Locutor (off repetido, com as mesmas imagens, tudo igualzinho):}

Bin Laden é procurado pela Justiça americana, com recompensa de cinco milhões de dólares por sua captura. Ele é acusado de uma série de atentados: uma explosão na garagem no WTC em 1993 e as explosões nas embaixadas americanas no Quênia e na Tanzânia em 1998, que deixaram 257 mortos. Há informações na imprensa árabe de que ele teria anunciado, há três semanas, um ataque sem precedentes aos Estados Unidos. Bin Laden estaria escondido no Afeganistão, sob a proteção do Talibã, a milícia islâmica que controla o país. Hoje os líderes do Talibã negaram o envolvimento de Bin Laden e condenaram os atentados nos Estados Unidos. Outros grupos extremistas islâmicos, como o Jihad, o Hamas, o Hezbollah e a Frente Democrática para a Libertação da Palestina, são hostis aos americanos, mas seus líderes também negaram o envolvimento e condenaram os atentados. Existe ainda a possibilidade de que os terroristas sejam americanos ligados ao grupo de Timothy McVeigh. Ele explodiu um prédio federal em Oklahoma em 1995. Morreram 168 pessoas. McVeigh, que dizia combater o autoritarismo no governo americano, foi executado com uma injeção letal em junho último.

\section{Locutor (comentário):}

A grande pergunta que se faz agora é a seguinte: Será que o ataque já terminou ou será que nas próximas horas, amanhã, teremos surpresas? Essa deve ser a interrogação neste momento que preside a ação do governo americano.

\section{Locutor (nota):}

A Otan, Organização do Tratado do Atlântico Norte, disse que os responsáveis pelo ataque não sairão ilesos. Os embaixadores da aliança militar discutiram o assunto numa reunião extraordinária, em Bruxelas. O secretário-geral George Robertson prometeu aos Estados Unidos total apoio dos aliados, mas disse que a Otan ainda não discutiu uma ação militar de retaliação.

\section{Locutor (cabeça repetida):}

Os principais líderes mundiais reagiram com indignação aos atentados dos Estados Unidos. O presidente da Rússia e o chanceler alemão compararam os atos a uma declaração de guerra ao 
mundo civilizado. O presidente da China, Jiang Zenin, enviou um telegrama de solidariedade ao presidente Bush repudiando os violentos ataques terroristas (selo: torre em chamas).

\section{Locutor (off repetido, com as mesmas imagens, tudo igualzinho):}

O presidente da Rússia, Vladimir Putin, disse que os ataques terroristas ultrapassaram as fronteiras entre os países e são um desafio à humanidade. A mesma reação teve o chefe do governo alemão, Gerard Schoereder. Ele comparou os ataques a uma declaração de guerra a todo o mundo civilizado e afirmou que o povo alemão apóia o povo americano nesta hora difícil. O primeiro-ministro britânico, Tony Blair, convocou os chefes de segurança do país para uma reunião às pressas. Emocionado, disse que esta não é uma batalha entre os Estados Unidos e o terrorismo, mas entre o mundo democrático e o terrorismo. Afirmou ainda que não vai haver descanso enquanto o terrorismo não for varrido do mundo. O presidente da França, Jacques Chirac, reforçou a posição de que é preciso lutar contra o terrorismo. A exemplo de Tony Blair, o primeiro-ministro francês, Leonel Jospin, mobilizou todos os esquemas de segurança para proteger o país de possíveis ataques terroristas.

\section{Locutor (comentário):}

Você vê que as grandes potências têm todas a mesma posição contra o terrorismo, até porque elas podem ser vítimas de terroristas. A França está sendo, a Rússia está sendo, a Alemanha já foi e isso é insuportável num país que queira manter o seu equilíbrio, a sua segurança e a sua segurança em termos de economia.

\section{Locutor (cabeça repetida):}

O ministro de relações exteriores de Israel, Simon Peres, disse que o ataque aos Estados Unidos é uma declaração de guerra. Ele defendeu uma resposta à altura do mal causado pelo terrorismo. Hoje Israel decretou estado de emergência no país e fechou o espaço aéreo para aviões estrangeiros (selo: bandeira de Israel).

\section{Locutor (off repetido, com as mesmas imagens):}

O governo israelense informou que o Aeroporto Internacional Ben Gurion ficará fechado pelo menos por 24 horas para vôos de companhias estrangeiras. O temor do principal aliado dos Estados Unidos no Oriente Médio é também se tornar alvo dos atentados. O ministro da Defesa, Benjamin Ben Eliezer, cancelou a viagem que faria aos Estados Unidos e vai manter o gabinete 
em reunião de emergência. Tanques de Israel ocuparam a cidade de Jenin, na Cisjordânia, sob controle dos palestinos. A medida, segundo o exército, é preventiva, para evitar possíveis ataques de terroristas suicidas.

\section{Locutor (comentário):}

Talvez tenha chegado o momento de as grandes potências intermediarem, até forçando um pouco, uma ação de paz entre israelenses e palestinos.

\section{Locutor (nota):}

Amanhã será dia de luto em Israel em solidariedade ao povo americano. $O$ anúncio foi feito pelo primeiro-ministro, Ariel Sharon, que condenou o terrorismo e se colocou à disposição dos Estados Unidos para ajudar no que for necessário.

\section{Locutor (cabeça repetida):}

Os palestinos se dividem em torno do ataque terrorista nos Estados Unidos. As autoridades negaram participação nos atentados, mas nas ruas a população festejou (selo: bandeira palestina).

\section{Locutor (off repetido, com as mesmas imagens):}

Pedaços de bolo distribuídos de mão em mão na cidade de Nabrus, na Cisjordânia. Muitos palestinos foram às ruas comemorar os ataques suicidas nos Estados Unidos. O clima de festa, com tiros para o alto, chegou até os palestinos refugiados no Líbano. Cenas em contraste com as declarações oficiais. O presidente da autoridade palestina, Yasser Arafat, condenou os atentados e mandou condolências ao povo americano e ao presidente George W. Bush.

\section{Locutor (cabeça):}

Todos os vôos comerciais nos Estados Unidos, domésticos e internacionais, estão suspensos. A medida vale pelo menos até o meio-dia de amanhã. As forças armadas americanas continuam em alerta, mas o governo demorou algumas horas para reagir contra a escalada terrorista (selo: bandeira dos Estados Unidos). 


\section{Locutor (off repetido, com as mesmas imagens, tudo igualzinho):}

Em seu primeiro discurso aos americanos de manhã na Flórida, Bush falou duro, mas ainda pensava numa ação terrorista localizada. Depois do ataque ao Pentágono, o governo americano entrou num ambiente de guerra. O presidente sumiu. Foi levado para uma base militar na Louisiana e depois para uma outra base no Nebrasca. Washington não era mais lugar seguro. A começar pela Casa Branca, os prédios públicos começaram a ser esvaziados na capital e nas principais cidades americanas.

Todos os vôos foram cancelados e os aeroportos, fechados. A Força Aérea tinha ordens de derrubar qualquer avião suspeito. Vôos internacionais foram desviados para o Canadá. Os postos nas fronteiras entraram em alerta máximo. Navios de guerra patrulhavam a costa de Nova York. Por algumas horas, o pânico parecia dominar o país. Os boatos se sucediam. Notícias falsas de atentados e também de que haveria mais quatro aviões no ar controlados por terroristas. No meio da tarde, quando o governo parecia estar tomando pé da situação, Bush reapareceu numa base militar no Nebrasca. Foi quando prometeu caçar e punir os responsáveis pelo maior ataque terrorista da história americana.

\section{Locutor (nota pé):}

O presidente Bush chegou agora à noite a Washington (selo: imagem de Bush). (Daqui em diante a narração é feita em off, com imagens de Bush descendo do avião e caminhando.) Ele desembarcou do Air Force 1, o avião presidencial americano, na base aérea de Andrews. Logo mais deve fazer um pronunciamento oficial pela televisão. Bush passou o dia fora de Washington por medida de segurança e esteve em duas bases aéreas: na Louisiana e no Nebrasca. Nas viagens, o boeing presidencial foi protegido por três caças da Força Aérea Americana.

\section{Locutor $^{161}$ :}

Este foi o Jornal da Record e estas foram as notícias mais importantes do dia.

Ataque terrorista destrói o World Trade Center em Nova York e atinge o Pentágono, em Washington. Há milhares de mortos e feridos.

As tropas americanas estão em alerta no mundo.

Bush promete caçar e punir os responsáveis pela agressão.

\footnotetext{
${ }^{161} \mathrm{O}$ âncora repete o texto que abriu o jornal. Na época, era prática corrente do Jornal da Record fechar a edição lembrando as principais notícias do dia.
} 
Nenhuma organização assume a autoria do atentado. O milionário saudita Bin Laden encabeça a lista de suspeitos.

O primeiro-ministro de Israel diz que o ataque é uma declaração de guerra aos Estados Unidos.

O líder da OLP, Yasser Arafat, condena a ação terrorista, mas palestinos comemoram nas ruas.

Os preços do ouro e do petróleo disparam.

No Brasil, o dólar bate novo recorde e a bolsa despenca.

Fernando Henrique prevê dificuldades na economia brasileira provocadas pela catástrofe.

O prefeito de Campinas, Toninho do PT, é assassinado ao sair de um shopping center.

O PMDB pressiona e adia a leitura do relatório que incrimina Jader.

Exausto, Guga é derrotado e está fora do Brasil Open.

\section{Locutor (despedida):}

Fique agora com o Cidade Alerta, segunda edição, com o Datena.

Boa noite. Muito obrigado por sua atenção. Até amanhã e paz. (O âncora sorri, ao contrário dos locutores do Jornal Nacional.) 


\section{ANEXO 6}

\section{Jornal da Record de 11 de setembro de 2002}

\section{Escalada (sem imagens):}

Boa noite. Este é o Jornal da Record e estas são as notícias mais importantes do dia.

Levante de presos em Bangu 1, no Rio. Beira Mar estaria no comando.

Seis rivais teriam sido mortos e ainda haveria oito reféns.

Após telefonar para Fernando Henrique, a governadora Benedita da Silva autoriza a polícia a reforçar o presídio, mas o impasse continua.

Emocionados e temerosos de novos atentados,

os americanos homenageiam as vítimas de 11 de setembro.

O presidente Bush promete vencer a guerra contra o terrorismo

e vingar os mortos durante os ataques.

Tony Blair convoca o parlamento britânico para discutir uma eventual ação militar contra o Iraque. Uma decisão polêmica pode anular multas de radar registradas a partir de maio.

\section{Bloco 1}

Cobertura da rebelião no presídio Bangu 1, no Rio de Janeiro, e outras notícias.

\section{Locutor (passagem de bloco):}

Veja a seguir. Os americanos se emocionam no primeiro aniversário do maior atentado da história. Bush promete vencer a guerra contra o terror e vingar os mortos. E veja também. Novas informações sobre a rebelião no presídio de Bangu 1, no Rio.

\section{Bloco 2}

\section{Locutor (cabeça):}

Tristeza, medo de novos ataques terroristas e promessas de vingança. Assim foi o primeiro aniversário dos atentados de 11 de setembro nos Estados Unidos. As cerimônias emocionaram os americanos. (O selo que identifica a matéria é a imagem das torres sob fumaça.) 


\section{Locutor (off):}

A principal cerimônia aconteceu em Nova York, no local onde se erguiam as duas torres destruídas nos atentados, e começou às $8 \mathrm{~h} 46$, o exato momento em que a primeira torre foi atingida no ano passado. A emoção foi reforçada pelas gaitas de fole, tradição dos primeiros bombeiros e policiais nova-iorquinos, descendentes de imigrantes irlandeses e escoceses. $\mathrm{O}$ exprefeito Rudolf Giuliani iniciou a leitura dos nomes de todas as 2.801 vítimas do WTC. Milhares de parentes e amigos dos mortos acompanharam em silêncio. Nas ruas de Nova York, os moradores acompanhavam a cerimônia em vários telões. (As imagens são parecidas com as do Jornal Nacional: uma multidão no lugar da cerimônia, pessoas chorando e segurando fotos.)

Em Washington, o presidente comandou a cerimônia no Pentágono, outro alvo do ataque terrorista (imagem da enorme bandeira sobre o Pentágono). Bush prometeu vencer a guerra contra o terror e vingar todos os americanos mortos nos atentados (imagem de Bush falando). $\mathrm{Na}$ Pensilvânia, onde caiu o quarto avião seqüestrado, os toques de sino marcaram a leitura dos nomes das vítimas. Amigos e parentes ergueram um mural com bandeiras, flores e mensagens de pesar. (Imagens das cerimônias, de pessoas chorando e das mesmas placas destacadas no Jornal Nacional.) Bush e sua mulher estiveram no local e depois seguiram para Nova York, onde as homenagens prosseguem ainda na noite de hoje (imagem do casal na cerimônia).

\section{Locutor (cabeça):}

Há um ano, o mundo parava atônito para acompanhar ao vivo o ataque terrorista mais ousado e devastador da história. Os Estados Unidos, maior potência do planeta, foram golpeados em seu próprio território e seus símbolos de poderio financeiro e militar, reduzidos a escombros.

\section{Locutor (off):}

Manhã de 11 de setembro de 2001. A famosa silhueta de Nova York está prestes a mudar para sempre (imagem do WTC antes do ataque). O primeiro impacto foi registrado por um documentarista que estava por acaso nas imediações do WTC. (Entram imagens do choque do primeiro avião e da explosão, imagens não vistas na edição de 2001.) Dezoito minutos mais tarde, o mundo inteiro viu a segunda torre ser atingida. (Entra uma seqüência de imagens: o choque do segundo avião, as torres em chamas, pessoas correndo nas ruas.) Foi o início do mais devastador e ousado ataque terrorista na história dos Estados Unidos. Uma chuva de aviões de passageiros seqüestrados por um obscuro grupo de terroristas suicidas. $\mathrm{O}$ alvo seguinte foi o Pentágono, símbolo do poderio militar americano (imagens da destruição no 
Pentágono). O quarto avião seqüestrado espatifou-se num descampado na Pensilvânia (imagens do local da queda). Foi o único que não atingiu seu objetivo, provavelmente a Casa Branca.

O presidente Bush, há apenas sete meses no poder, foi informado do ataque numa escola primária na Flórida (imagem de Bush recebendo a notícia). Abalado, ele embarcou no avião presidencial e foi levado a uma base militar. O clima era de guerra. Na capital, Washington, a Casa Branca, o Congresso e outros prédios públicos foram esvaziados. A América parecia sem governo, aterrorizada, mas o pior ainda estava por vir. (Entra mais uma seqüência de imagens: pessoas nas janelas, o desabamento das torres, pessoas correndo, muita fumaça.) No alto das torres gêmeas, em Nova York, os acenos desesperados de quem já não tinha como escapar. Foi quando a primeira torre veio abaixo. Mais meia hora e a segunda torre desabou. A estrutura derreteu em meio de toneladas de combustível em chamas. O dia virou noite. Nova York estava mergulhada no caos e na tragédia. Quando a poeira baixou, 2.800 pessoas tinham sido pulverizadas debaixo de um milhão e meio de toneladas de aço e concreto.

O resgate durou sete meses. A identificação dos corpos, com amostras de DNA, continua até hoje. Quando a noite de 11 de setembro chegou, milhares de nova-iorquinos estavam em vigília esperando notícias de familiares e amigos desaparecidos (muitas velas acesas nas ruas, música triste). No ar, a pergunta era: Quem tinha feito aquilo? Quem odiava tanto os Estados Unidos? Feridos e assustados, os americanos choraram seus mortos (imagens de mais pessoas chorando) e os vivos não se sentiam mais seguros na sua pátria, a América (imagens da ilha sob fumaça e da Estátua da Liberdade). (No final do VT, um longo trecho sem narração, sob o som de uma música solene e triste. Na tela, uma arte em que se lê: 11 de setembro - World Trade Center, NY - 2.801 mortos - Pentágono, Washington - 184 mortos - Pensilvânia - 40 mortos.)

\section{Locutor (comentário):}

A barbárie humilhou o gigante americano, barbárie que ceifou milhares de vidas e que só pode ser explicada pelo radicalismo religioso, levado as últimas conseqüências políticas. Depois do atentado, depois da humilhação, o mundo nunca mais foi o mesmo e talvez não o seja. Com uma liderança débil, os Estados Unidos elegeram como sua principal atividade no setor político e internacional o combate ao terrorismo, relegando a plano secundário vários problemas do mundo. O que se espera é que os autores intelectuais dessa barbárie sejam realmente punidos. Não há explicação e não há justificativa. O gigante foi humilhado e não vai sossegar enquanto não for buscar os autores nas suas cavernas e nos seus esconderijos. Entretanto o mundo não pode se calar quando vê que o radicalismo religioso ganha degraus, conquista juventudes, 
sacrifica vidas de um lado e de outro. O mundo precisa caminhar para a paz, o mundo precisa combater, infelizmente, com todos os instrumentos os radicalismos, especialmente aqueles com fundamento religioso, que só encontram explicação na obscuridade, obscuridade que precisa ser iluminada por todos nós.

\section{Locutor (cabeça):}

A segurança é a maior preocupação deste 11 de setembro em várias partes do mundo. Nos Estados Unidos, um navio com suspeita de material radioativo a bordo é detido pela guarda costeira americana no litoral de Nova Jersey.

\section{Locutor (off):}

Sinais de radiação foram detectados quando as autoridades investigavam se havia passageiros clandestinos a bordo do cargueiro com bandeira da Libéria. Novos testes estão sendo feitos. Um avião da North East Airlines fez um pouso de emergência no estado de Arkansas. O piloto considerou suspeitos três passageiros que haviam se trancado no banheiro. Eles foram retirados do avião, sem incidentes. Passageiros de um jato da American Airlines desconfiaram que uma pessoa a bordo tinha uma arma. O avião retornou ao aeroporto de Huston, no Texas. Nenhuma arma foi encontrada. Um prédio de Ohio foi esvaziado depois de cães do esquadrão antibombas reagiram a uma van estacionada. O alerta não foi confirmado. O vice-presidente americano, Dick Cheney, passou o dia num local secreto como medida de segurança em caso de um atentado contra o presidente Bush. As principais cidades da Europa também continuam em alerta. Vinte e oito mil policiais patrulham as ruas de Londres, a capital britânica. A embaixada americana recebe atenção redobrada. Na Alemanha, os aeroportos e possíveis alvos americanos e israelenses receberam reforço. A Itália mobilizou milhares de soldados e policiais para proteger locais considerados sensíveis. (Imagens descritivas durante toda a narração, muitas da CNN.)

\section{Locutor (cabeça):}

Feridos e humilhados, os americanos declararam guerra, mas uma guerra diferente, a um inimigo de face invisível, o terrorismo.

\section{Locutor (off):}

Os Estados Unidos ainda estavam de luto quando os tambores da guerra começaram a tocar (imagem de uma enorme bandeira americana no prédio do Pentágono). No meio das ruínas do 
WTC, o presidente Bush prometeu caçar os responsáveis pelo atentado contra as torres (imagem de Bush falando num megafone, no meio de equipes de resgate). Os dezenove terroristas suicidas foram identificados (fotos dos homens). Os investigadores americanos apontaram como principal suspeito pelo ataque Osama Bin Laden, um saudita de família milionária que colocou sua fortuna e habilidades a serviço do extremismo islâmico (imagens de Bin Laden e, aparentemente, de grupos terroristas em ação). Ele era o líder da Al Qaeda, a base, em árabe, de uma organização terrorista. A Al Qaeda tinha se instalado no Afeganistão, um país pobre, devastado por décadas de guerras, e era o verdadeiro poder atrás do Talibã, o governo afegão, cuja face mais visível era a face invisível das mulheres, obrigadas a se cobrir da cabeça aos pés. (As imagens são descritivas.)

A postura das alianças e os preparativos militares duraram menos de um mês. Uma onda patriótica cobriu os Estados Unidos de bandeiras e símbolos. E no primeiro domingo de outubro, a guerra contra o terrorismo começou (imagens de aviões e de explosões numa cidade não identificada). Mal iniciada a ofensiva, os americanos foram golpeados por um novo ataque terrorista, biológico. Cartas com pó branco, contaminados pela bactéria antraz, chegaram a jornais, redes de TV, Congresso, Casa Branca e outros prédios oficiais. E com elas, mais pânico. Se os aviões de carreira já não eram seguros, o gesto banal de abrir a correspondência podia levar à morte. Dezoito pessoas foram contaminadas e cinco morreram. Os funcionários dos correios foram as grandes vítimas. $\mathrm{O}$ autor das cartas contaminadas não foi descoberto, mas dois meses de bombardeios demoliram o regime do Talibã, no Afeganistão (imagens de tanques e de outras explosões). Procurado vivo ou morto pelos americanos, Bin Laden sumiu nas montanhas e cavernas afegãs (imagem de um cartaz com foto: "Bin Laden - Wanted dead or alive"). Deixou para trás fitas de vídeo em que comemora os atentados e reafirma seu ódio à América.

\section{Locutor (cabeça):}

Já os sobreviventes da tragédia, para eles é impossível esquecer a data que mudou a vida de cada um.

\section{Locutor (off):}

Sobreviver é desafiar o destino. Isso nunca foi tão verdadeiro como na tragédia do WTC. O empresário Tomas Canavan estava no $47^{\circ}$ andar quando o ataque começou (imagem do homem ensangüentado). A duras penas conseguiu descer até o térreo e foi soterrado pelo desabamento 
de uma das torres (mais imagens do desabamento). Milagrosamente sobreviveu (outras imagens do homem ensangüentado). Um ano depois, Canavan é um homem tenta conviver com seus fantasmas (imagens do homem dando entrevista em 2002). Não consegue dormir mais que quatro horas por noite e ainda toma remédios. O guarda de segurança Brian Rives teve menos sorte. Ele estava no hall do WTC quando as portas de um dos elevadores se abriram e uma bola de fogo o lançou na rua através dos vidros. Sofreu queimaduras graves em $40 \%$ do corpo (imagens das cicatrizes no corpo do homem). Nesse momento ordenou a si mesmo: levante e corra. Essa determinação salvou sua vida, mas não foi suficiente para superar seus traumas. Hoje ele admite que tem o coração cheio de ódio.

O bombeiro Mick Ross sente culpa de ser um dos sobreviventes (imagem do homem falando). Foi soterrado pelos escombros das torres, escapou com vida, mas não consegue se esquecer das vítimas, especialmente dos 343 colegas que morreram. Mick conta que quando está ocupado tudo vai bem, mas nas ruas os próprios nova-iorquinos não deixam que ele esqueça a tragédia. Todos dizem "ei, bombeiro, como vai?", "como você sobreviveu?" e o pesadelo sempre está de volta. Pior é o drama das famílias dos mil e setecentos desaparecidos, como Martin Borisersk (imagem da família vendo fotos do rapaz). A mãe dele e as duas irmãs contam que se sentem paradas no tempo, à espera de que os restos mortais de Martin sejam encontrados. Elas contam que outro dia compraram flores para ele, mas não sabiam onde colocá-las, onde levá-las. Dizem que não tinham percebido como a vida era tão boa antes de 11 de setembro.

\section{Seguem-se outras notícias.}

(Na época, Inglaterra e Estados Unidos discutiam uma eventual ação militar no Iraque.) 


\section{ANEXO 7}

\section{Jornal da Record de 11 de setembro de 2003}

\section{Escalada (sem imagens):}

Boa noite. Este é o Jornal da Record e estas são as notícias mais importantes do dia.

No Rio, missa na Candelária em memória ao traficante Uê acaba em confusão.

Estudante encontrado carbonizado tinha sido seqüestrado por um primo em São Paulo.

Proposta de baixar a idade para porte de arma agita o Congresso.

Cai a arrecadação e o Planalto pode arrochar mais ainda o orçamento.

A votação da reforma tributária é adiada mais uma vez por falta de quórum.

Israel decide expulsar Arafat dos territórios palestinos.

Em alerta antiterror, americanos lembram os dois anos do atentado de 11 de setembro. Morre a ministra esfaqueada na Suécia.

\section{Bloco 1}

Diversas notícias. $\mathrm{O}$ assunto entra quase no final do bloco.

\section{Locutor (cabeça):}

Em alerta contra o terrorismo, os Estados Unidos lembram os dois anos dos atentados de 11 de setembro. A principal cerimônia foi em Nova York, no buraco onde se erguiam as torres gêmeas do WTC.

\section{Locutor (off):}

Fotos, fotos, fotos e mais fotos. Para mostrar que eles não foram esquecidos. Hoje milhares de pais, mães, filhos e irmãos se reuniram em Nova York para lembrar pais, mães, filhos e irmãos que morreram há dois anos no maior ataque terrorista da história. (Imagens de pessoas tristes, com fotos das vítimas nas mãos.) Exatamente às 8h46 da manhã todos fizeram um minuto de silêncio para marcar o momento em que o primeiro avião de passageiros atingiu a torre norte do WTC (imagem do choque e da explosão). Em seguida, começou a leitura dos nomes das quase três mil vítimas. Às $9 h 03$, outro minuto de silêncio para lembrar o ataque à torre sul (imagem do segundo choque e da explosão). Um minuto de silêncio também para lembrar os mortos do Pentágono, atingido pelo terceiro avião seqüestrado (imagem do Pentágono em chamas). E silêncio ainda em homenagem aos passageiros que lutaram contra os terroristas e provocaram a 
queda do quarto boeing num bosque da Pensilvânia (imagem do local da queda). Cerimônias em homenagem aos mortos nos atentados também foram realizadas no Pentágono, na Casa Branca e em todos os Estados Unidos. Tudo sob forte esquema de segurança, devido ao temor de um novo ataque terrorista. (Imagens descritivas e o som das gaitas de fole.)

\section{Locutor (cabeça):}

Desde que os terroristas transformaram aviões de passageiros em armas de destruição em massa, a vida jamais voltou ao normal para os americanos. $\mathrm{E}$ talvez nunca mais volte.

\section{Locutor (off):}

Todo um modo de vida desabou junto com essas torres (imagens da queda das torres). Para o resto do mundo, essas imagens já começaram a fazer parte da história, dando lugar a cenas como o bombardeio de Bagdá e a ocupação do Iraque de Saddam Hussein (imagens dos conflitos). Mas para os americanos o pesadelo ainda não terminou, por mais que eles tentem deixar o horror dos atentados para trás (mais imagens dos desabamentos e de pessoas correndo nas ruas). Os nova-iorquinos jamais vão esquecer tudo que viram e o que não conseguem ver hoje, isto é, as torres que sumiram do perfil da cidade (imagens da ilha com e sem as torres). Somente metade das vítimas, 1.523, tiveram seus restos identificados (imagem dos escombros). Nos laboratórios, dezenas de milhares de exames já foram realizados e mesmo assim centenas de famílias ainda não têm o que sepultar, nem mesmo uma amostra de DNA. Todos os dias parentes de desaparecidos rondam o terreno do WTC como se procurassem fantasmas, mas o pior de tudo ainda é o medo, que não vai mais embora (imagem de uma menina se abraçando à mãe).

\section{Locutor (comentário):}

O terrorismo continua vivo e matando. Não faltam radicais, fanáticos religiosos e autoritários para atingir inocentes, civis inocentes no mundo inteiro, sob qualquer pretexto. $O$ ataque de 11 de setembro foi uma ação abominável, embora alguns pretendam justificá-la por razões ideológicas. O terrorismo precisa ser combatido com inteligência e com a força da democracia, democracia que esse mesmo terrorismo busca aniquilar.

\section{Seguem-se outras notícias.}




\section{ANEXO 8}

\section{Jornal da Record de 11 de setembro de 2004}

\section{Escalada:}

Boa noite. Este é o Jornal da Record e estas são as notícias mais importantes do dia.

Pesquisa DataFolha mostra que Serra ultrapassa Marta na disputa pela prefeitura paulistana.

Banco de DNA pode ajudar a encontrar crianças desaparecidas.

Americanos lembram os três anos do maior ataque terrorista da história.

Sobe para trinta e quatro o número de mortos na passagem do furacão Ivan pelo Caribe.

O porto de Santos bate recorde de movimento, mas sofre com a falta de investimentos.

São Paulo e Cruzeiro empatam. Vasco perde de virada para o São Caetano.

Câmera de segurança de um prédio flagra espancamento de um morador de rua em São Paulo.

\section{Bloco 1}

Diversas notícias. O assunto entra quase no final do bloco.

Locutor $^{162}$ (cabeça): Os americanos marcam com cerimônias discretas o terceiro aniversário dos atentados de 11 de setembro.

Locutor (off): Em Nova York, no lugar onde ficava o WTC, pais e avós leram os nomes das 2.749 vítimas (imagens de pessoas chorando). A leitura foi interrompida quatro vezes, cada uma delas por um minuto de silêncio, marcando as horas exatas dos choques dos aviões contra as torres e os dasabamentos (imagens dos ataques). O presidente George W. Bush e o vice, Dick Cheney, lideraram um minuto de silêncio no jardim da Casa Branca. O pronunciamento semanal de rádio do presidente hoje foi transmitido também pela televisão (imagem de Bush falando). Bush, em campanha para reeleição, reafirmou que a guerra contra o terrorismo continua. No cemitério de Arlington, na Virgínia, um minuto de silêncio marcou a hora em que o terceiro avião foi jogado contra o Pentágono, matando 184 pessoas. Na Pensilvânia, a cerimônia foi realizada no local onde caiu o quarto avião, matando as 40 pessoas a bordo. (Mais pessoas chorando.)

Seguem-se outras notícias. (Entre elas a de um atentado a bomba perto da embaixada americana no Iraque, "palco de conflitos entre insurgentes e as forças lideradas pelos EUA".)

\footnotetext{
${ }^{162}$ Essa edição foi apresentada por Salete Lemos.
} 